(1) (9.) 



DEPARTMENT OF COMMERCE AND LABOR

\section{BULLETIN}

OF THE

\section{BUREAU OF FISHERIES}

VOL. XXXI

1911

IN TWO PARTS-PART II

GEORGE M. BOWERS

COMMISSIONER

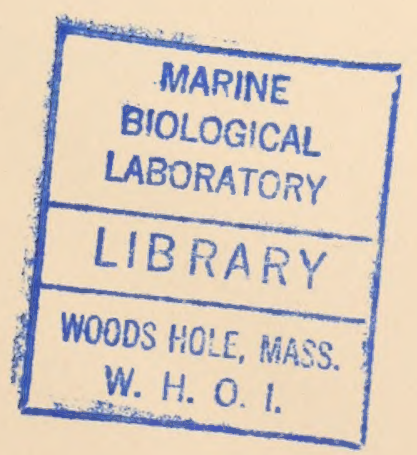



A BIOLOGICAL SURVEY OF THE WATERS OF WOODS HOLE AND VICINITY

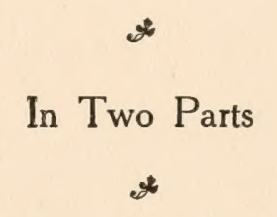

PART II

Section III.-A CATALOGUE OF THE MARINE FAUNA. By Francis B. Sumner, Raymond C. Osburn, and Leon J. Cole

Section IV.-A CATALOGUE OF THE MARINE FLORA. By Bradley M. Davis 



\section{CONTENTS.}

PART II.

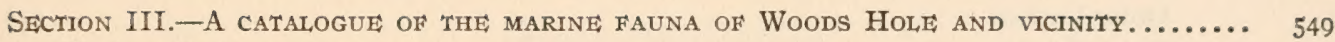

Phylum Protozoa.................................................. 549

Class Rhizopoda. . . . . . . . . . . . . . . . . . . . . . . . . . . . . . . . 549

Subclass Amøbæa . . . . . . . . . . . . . . . . . . . . . . . . . . . . . . . 549

Subclass Foraminifera. . . . . . . . . . . . . . . . . . . . . . . . . . . . . . . . . . . . . . . . . . . . . . . . .

Class Actinopoda . . . . . . . . . . . . . . . . . . . . . . . . . . . . . . .

Class Zoomastigophora. . . . . . . . . . . . . . . . . . . . . . . . . . . . . . . . . . . . . . . . . . . . . .

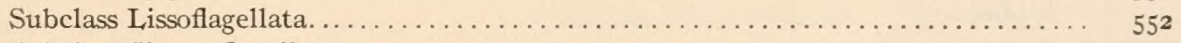

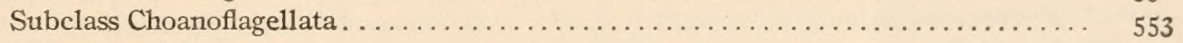

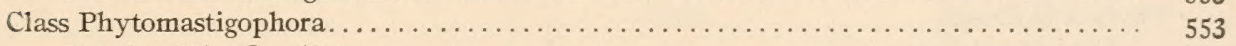

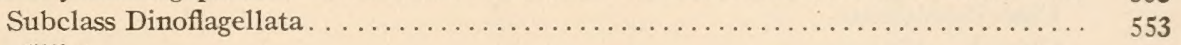

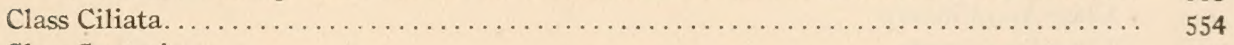

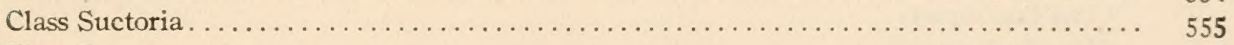

Class Sporozoa . . . . . . . . . . . . . . . . . . . . . . . . . . . . . . . 556

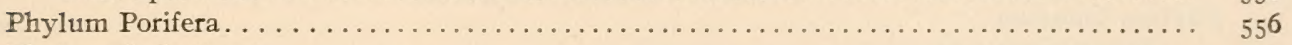

Phylum Colenterata. . . . . . . . . . . . . . . . . . . . . . . . . . . . . . . . . . . . . . . . . . . . . . . . . . . . .

Class Hydrozoa. . . . . . . . . . . . . . . . . . . . . . . . . . . . . . . . . . . . . . . . . . . . . . . . . . . . . . . . . . .

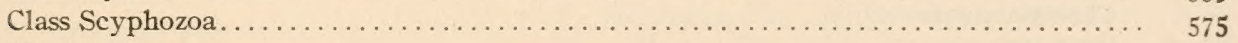

Class Actinozoa . . . . . . . . . . . . . . . . . . . . . . . . . . . . . . . . . . . . . . . . . . . . .

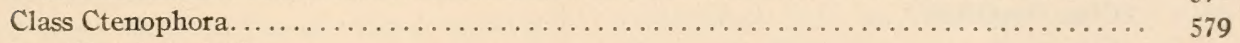

Phylum Platyhelminthes. . . . . . . . . . . . . . . . . . . . . . . . . . . . . . . .

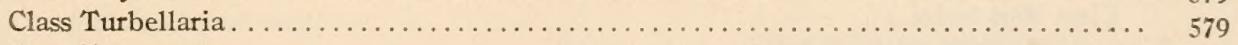

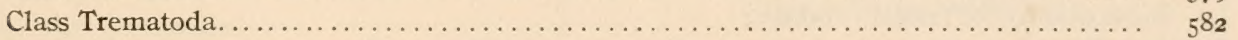

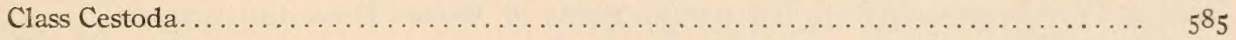

Class Nemertinea . . . . . . . . . . . . . . . . . . . . . . . . . . . . . . . . . 59.

Phylum Nemathelminthes. . . . . . . . . . . . . . . . . . . . . . . . . . . . .

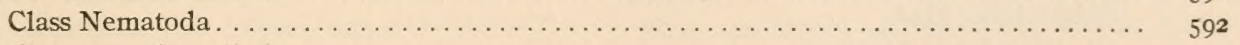

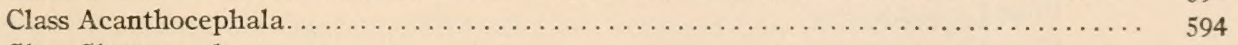

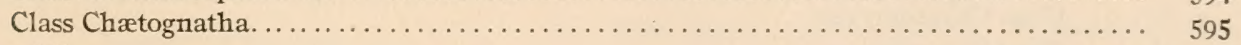

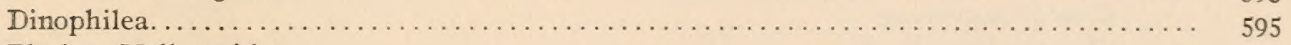

Phylum Molluscoida. . . . . . . . . . . . . . . . . . . . . . . . . . . . . . . . . 595

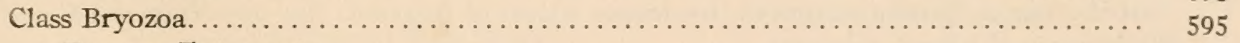

Bryozoa Entoprocta . . . . . . . . . . . . . . . . . . . . . . . . .

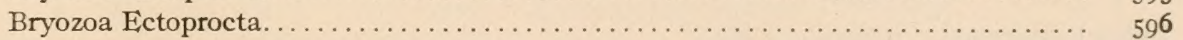

Phylum Echinodermata . . . . . . . . . . . . . . . . . . . . . . . . . . . .

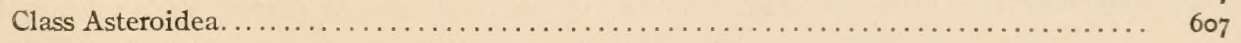

Class Ophiuroidea . . . . . . . . . . . . . . . . . . . . . . . . . . . . . . . . . . .

Class Echinoidea. ........................................

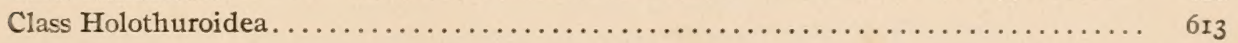


Section III.-A catalogue of the marine fauna of Woods Hole and vicinity-Contd. Page, Phylum Annulata

Class Chætopoda.

Subclass Polychæta

Subclass Oligochæta.

Class Hirudinea.

Sipunculida.

Phylum Arthropoda.

Class Crustacea.

Order Phyllopoda.

Order Ostracoda.

Order Copepoda (free-living) . . . . . . . . . . . . . . . . . . . . . . . . . .

Order Copepoda (parasitic)

Order Cirripedia.

Order Amphipoda

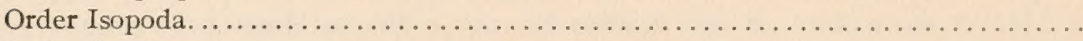

Order Cumacea. .

Order Stomatopoda

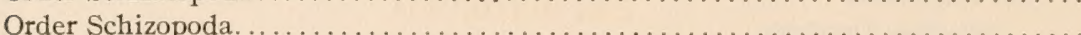

662

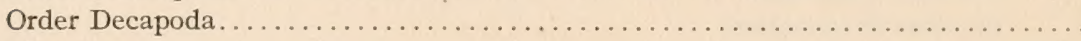

Class Insecta. . . . . . . . . . . . . . . .

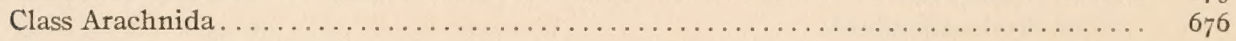

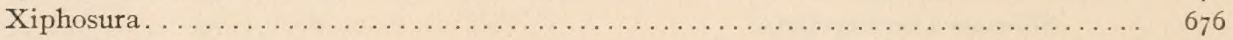

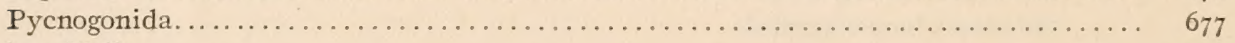

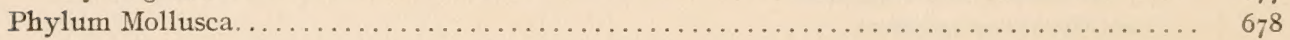

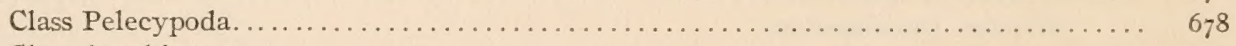

Class Amphineura . . . . . . . . . . . . . . . . . . . . . . . . . . . . 702

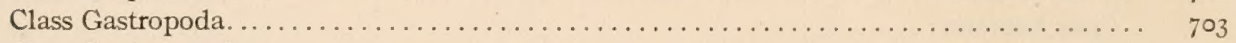

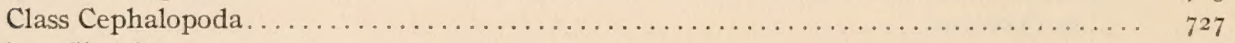

Phylum Chordata . . . . . . . . . . . . . . . . . . . . . . . . . . . . . . 728

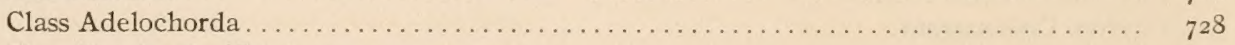

Class Urochorda (Tunicata) . . . . . . . . . . . . . . . . . . . . . . . . 729

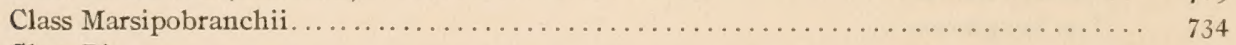

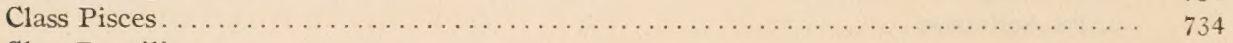

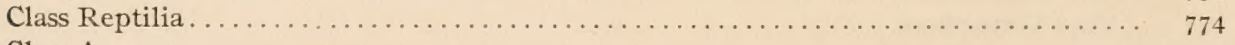

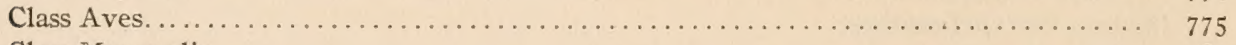

Class Mammalia . . . . . . . . . . . . . . . . . . . . . . . . . . . . . . . $77^{80}$

Bibliography for faunal catalogue $\ldots \ldots \ldots \ldots \ldots \ldots \ldots \ldots \ldots \ldots \ldots \ldots \ldots \ldots \ldots \ldots \ldots \ldots \ldots \ldots \ldots \ldots$

Section IV.-A catalogue of THE marine Flora of Woods Hole and vicinity.

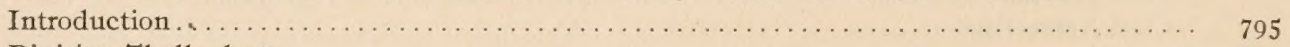

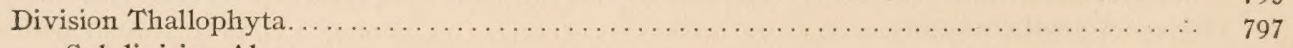

Subdivision Algæ. . . . . . . . . . . . . . . . . . . . . . . $79 \ldots \ldots \ldots \ldots \ldots$

Class Cyanophyceæ.................................. 797

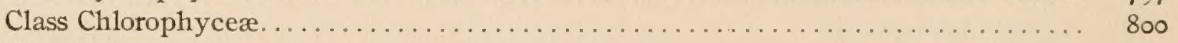

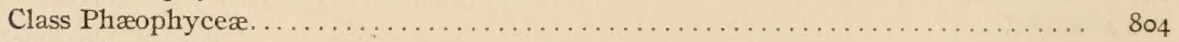

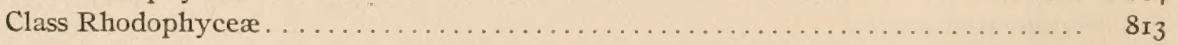

Distribution of Zostera marina in the deeper waters of Buzzards Bay and Vineyard Sound. $\quad 83 \mathrm{r}$

Bibliography for floral catalogue. . . . . . . . . . . . . . $8 \ldots \ldots \ldots \ldots \ldots \ldots \ldots \ldots$

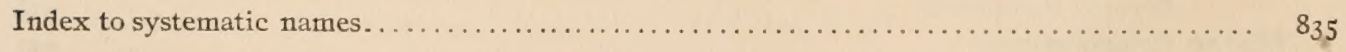




\title{
A BIOLOGICAL SURVEY OF THE WATERS OF WOODS HOLE AND VICINITY.
}

\section{Section III.-A CATALOGUE OF THE MARINE FAUNA OF WOODS HOLE AND VICINITY. ${ }^{a}$}

\author{
BY FRANCIS B. SUMNER, RAYMOND C. OSBURN, and LEON J. COLE.
}

\author{
* \\ Phylum PROTOZOA. \\ Class RHIZOPODA.
}

Subclass AMCEB EAA.

Amcba guttula Dujardin.

Calkins, I902, page 417 .

U. S. Bureau of Fisheries pier, "frequent in decomposing vegetable matter."

Amœba sp. undetermined.

Calkins, I902, page 4I7.
Trichosphorium sieboldi Schneider.

Calkins, I902, page 418 .

U. S. Bureau of Fisheries pier, one specimen taken.

\section{Subclass FORAMINIFERA. $b$}

Family Gromide:

Gromia lagenoides Gruber.

Calkins, I902, page 419.

"Not uncommon about Woods Hole, where it is found upon the branches of various types of algæ."

Family AstrormizIDAE.

Astrorhiza limicola Sandahl.

Cushman, I908, page 22.

Fish Hawk station $768_{3}$ (common); "again in a similar haul from a sandy or slightly muddy bottom in Vineyard Sound, one and one-half miles north of Menemsha Bight in $\mathrm{r}_{3}$ fathoms."

\section{Family Lituolide:}

Reophax dentaliniformis Brady.

Cushman, I908, page 23.

Buzzards Bay at 1907 repetitions of Fish Hawk stations $7649,765 \mathrm{I}$, and $766_{2}(?)$; one specimen each. The bottom at the first station is recorded as "stony," at the second "mud and gravel."
Haplophragmium canariense (d'Orbigny).

Cushman, I908, page 23.

Buzzards Bay at Phalarope station 79, near Nashawena Island, $5^{\mathrm{T} / 2}$ fathoms, mud; also encountered once at Fish Hawk station 7565 (I907 repetition ?).

\section{Family Trochamminide.}

Webbina hemispherica Jones, Parker, \& Brady.

Cushman, I908, page 24.

Dredged at several widely separated points in Vineyard Sound and Buzzards Bay in 4 to 7 fathoms, on various bottoms.

Fish Hawk station 7776 and Phalarope station I36; also 1907 repetitions of 7542 and $76 \mathrm{r}_{2}$.

\section{Family Miliolinid}

Spiroloculina limbata d'Orbigny.

Cushman, I908, page 24.

A single specimen taken near Robinsons Hole, at Phalarope station 85 .

a For the sources of the data included in this catalogue, and the system employed in its compilation, the reader is referred to section I, pp. 13-15, 80-83, and the discussions of the various groups in chapter IV.

$b$ The determinations of all Foraminifera from the Survey dredging were made by Dr. J. A. Cushman. 
Biloculina ringen: (Lamarck). [Chart I.]

Cushman, Igo8, page 24 .

Western half of Vineyard Sound and adjacent points in Buzzards Bay, in 6 to 17 fathoms, on sandy or muddy bottoms; recorded once from near head of Buzzards Bay.

Fish Hawk stations: 768I (few), 7686, 7710, 7725,7727 (common), 7728 (common), 7729 (common), 7730, 773I, 7736. Repeated stations (I907): 7663 (2), 7728 (few).

Phalarope stations: 78 (few), 8 I (few), 85 (few), I5I (few).

\section{Biloculina ringens striatella Cushman.}

Cushman, I908, page 25 (var. nov.)

Often abundant "in the material scraped from the wharf piles."

\section{Biloculina elongata d'Orbigny.}

Cushman, igo8, page 25.

"Specimens of this species were found in considerable numbers among hydroids and scrapings from the piles of the dock at Woods Hole. Occasionally ... met with in the dredgings."

\section{Biloculina tubulosa Costa.}

Cushman, I908, page 25.

Bay shore of Nashawena Island (3 stations); western end of Vineyard Sound (I station); 5 to I3 fathoms, sand and mud.

Fish Hawk station 7710; Phalarope stations: 78 (few), 79 (few), 8r (few).

\section{Miliolina seminulum (Linnæus). [Chart 2.]}

Cushman, I908, page 25.

Abundant and generally distributed in Vineyard Sound; in Buzzards Bay abundant along the eastern shore line, and recorded from scattered stations in the deeper waters. Its apparent rarity at such points may be due, however, to the incompleteness of the search for Foraminifera there. Dredged in 2 to $I 7$ fathoms on bottoms of clear sand or mixtures of sand and mud.

Fish Hawk stations: $7685,7686,7687,7695$, 7704 (common), 7706 (few), 7709, 7710, 77 I, 77 19 (few), 7722 (few), 7725 (common), 7726 (few), 7727 (common), 7728 (few), 7729, 7730, 7731, 7732 (few), 7734 (few), 7735 (few), 7748 (few), 7750 (common), 7755 (few), 7759 (few), 776 I (few), 7767 (few). Supplementary stations (I907): 7542 (few), 7628 (few), 7630 (few), 7639 (few), 7656 (few), $766_{3}$ (common), 7667 (few), 7669 (few), 7728 (common), 773 (few), 776r (common), 7780 (few).
Miliolina seminulum-Continued.

Phalarope stations: 78 (very common), 79 (common), 8o (common), 8I (common), 82 (common), 84 (common), 85 (few), 9I (few), 93 (common), III (common), II3 (common), I25 (few), I32 (few), I34 (few), I38 (few), I45 (few), I47 (few), I49 (few), I5I (few).

Miliolina oblonga (Montagu). [Chart 3.]

Cushman, 1908, page 26.

Vineyard Sound, chiefly at western end; in Buzzards Bay recorded almost entirely from the island shores. Dredged in 2 to $I 7$ fathoms, on bottoms of sand or sandy mud.

Fish Hawk stations: $7685,7686,7687,7688$ (few), 7704 (common), 7710, 7731. Supplementary stations (I907): 7667 (few), 7728, 776 I (few).

Phalarope stations: 78 (very common), 84 (I), 88 (common), 89 (common), 93 (few), 94 (few), I03, I04, II 8 (few), I22 (few), I23 (few), I24 (few), I48 (few).

Miliolina circularis (Bornemann). [Chart 4.]

Cushman, 1908, page 26.

"On the piles of the wharf at Woods Hole it appears in great numbers attached to the stems of hydroids." Dredged by the Survey at scattered stations in Vineyard Sound and along the eastern shore of Buzzards Bay, in 3 to $I_{3}$ fathoms, on bottoms of sand and gravel, attached to hydroids and algæ.

Fish Hawk stations: 7709, 7727 (few), $775 \mathrm{I}$ (few), 7759 (few).

Phalarope stations: 83 (on eel grass), 85 ( 1 ), 87 (common), IO3, III (few), II3 (common), II 8 , I30 (few), $1_{3} 8$ (few), I46 (few).

Miliolina boueana (d'Orbigny).

Cushman, I908, page 26.

Dredged by the Survey at five scattered stations in Vineyard Sound, in 6 to 13 fathoms, on sandy bottom. Also found "in the scrapings from the dock piles at Woods Hole."

Fish Hawk station 768I (few). Supplementary stations (1907): $75^{25}$ (common), 7526 (common), 7542 (common), 7780 (few).

Miliolina venusta (Karrer).

Cushman, I908, page 27.

Dredged by the Survey at a few scattered stations in the western end of Vineyard Sound; recorded twice from Buzzards Bay.

Fish Hawk stations: 7720 (I), 7722 (2), 7724 (common), 7725 (common), 7727 (common), 7728 (common). Supplementary stations (I907): 7628 (few), 776 I (few).

Phalarope station II $3_{3}(\mathrm{I})$. 
Miliolina bicomis (Walker \& Jacob).

Cushman, I908, page 27.

Dredged by the Survey at two stations (Fish Hawk 77 Io and 7722) at the western end of Vineyard Sound; once near West Falmouth Harbor (Phalarope I34); in each case a few specimens.

\section{Family TEXTULARIDEA}

Verneuilina poly'stropha (Reuss).

Cushman, I9o8, page 27.

A single specimen dredged in Vineyard Sound at a 1907 repetition of Fish Hawk station $7565(?)$.

\section{Family BULIMINID臣.}

\section{Bolivina punctata d'Orbigny.}

Cushman, I9o8, page 28.

"A number of specimens . . . were obtained from the surface of old shells of Mytilus edulis attached to the outer piles of the U. S. Fisheries dock at Woods Hole."

\section{Family POLYMORPHINIDAs.}

Polymorphina lactea (Walker \& Jacob). [Chart 5.] Cushman, I908, page 28 .

Frequent at the western end of Vineyard Sound; recorajed likewise from scattered stations throughout Buzzards Bay, both in the adlittoral zone and in deeper waters. Dredged in 2 to Ig fathoms, on bottoms of sand or mud.

Fish Hawk stations: 7679, 7680 (few), $768 \mathrm{I}$ (few), 7682 (few), 7704 (few), 7705 (few), 7724 (common), 7725 (common), 7726 (few), 7727 (few), 7728 (few), 7729. Supplementary stations (1907): 76I2 (few), 7614 (few), 7620 (few), 7621 (few), 7628 (few), 7639 (few), 7649, 765 I (2), 7728 (several).

Phalarope stations: 78 (few), $8 \mathrm{I}$ (few), 82 (few), 93 (I), 94 (few), I33 (few), I38, I42, I47 (few), I 48 (few), I 52 (few).

\section{Polymorphina concava (Williamson).}

Cushman, rgo8, page 28.

Upper half of Buzzards Bay, at Phalarope stations 133 and 148 ; in Vineyard Sound, at a I907 repetition of Fish Hawk station 7525 .

Polymorphina rotundata (Bornemann).

Cushman, I908, page 29.

Vineyard Sound, at Fish Hawk station 7728 (Igo7 repetition?); Buzzards Bay at Phalarope station I $_{4} 6$ (single specimen).
Family RoTALIDAE.

Patellina corrugata Williamson.

Cushman, I908, page 29.

"A single specimen . . . found in material scraped from the surface of a large shell of Mytilus edulis, taken from the outer piles of the dock at Woods Hole, July 19, r905." Fiurther search revealed no other specimens.

Discorbina rosacea (d'Orbigny). [Chart 6.]

Cushman, I908, page 30.

Common and generally distributed, occurring on hydroids growing upon piles, etc., as well as on those upon the bottom in deeper waters. "Anything that is stationary in the water for any length of time is sure to have its share of the shells of this species." Recorded from a number of scattered stations in Vineyard Sound and along the shore line of Buzzards Bay in 3 to $I_{3}$ fathoms; also at Crab Ledge in 16 to $I 9$ fathoms.

Fish Hawk stations: 7606 (abundant), 7607 (abundant), 7608 (abundant), 7680 (few), 7728, $7729,7730,7731,776$ I (few).

Phalarope stations: 8,85 (few), 87 (I), 9x (few), I03, II8 (few).

Discorbina sp. undetermined (perhaps the above). Found by Peck ( 1894 ) in food of menhaden.

Truncatulina lobatula (Walker \& Jacob).

Calkins, I902, page 420; Cushman, I908, page 30.

"Found frequently among the algæ at Woods Hole. "-Calkins. Recorded from four of the survey dredging stations at the lower end of Buzzards Bay and the adjacent portion of the Sound, in 5 to $x 7$ fathoms.

Fish Hawk station 7685; Phalarope stations: 78 (common), 79 (common), 8r (common).

Truncatulina rosea (d'Orbigny).

Cushman, I908, page 30.

"A single specimen . . . from material . . scraped . . from the piles of the dock at Woods Hole," July I9, I905.

Pulvinulina lateralis (Terquem). [Chart 7.]

Cushman, I908, page 30.

Dredged at numerous stations throughout the length of Vineyard Sound, at 4 to $I_{3}$ fathoms, chiefly on sandy bottoms; recorded also from the lower end of the Bay.

Fish Hawk stations: 768I (common), 7704 (few), 7706 (few), 7710,7719 (common), 7720 (few), 7722 (few), 7724 (few), 7727 (common), 7734 (few), 7735 (few), 7736, 7751, 7755 (few), 7759 (few), 7767 (few). Supplementary stations: 7525 (common), 7592 (few), 7667 (few), 7731 (I worn), 776 I (few).

Phalarope stations: 78 (I), III (common). 
Pulvinulina tumida Brady.

Cushman, 1908, page $3 \mathrm{I}$.

"A few specimens, apparently belonging to this species, were obtained from scrapings from the dock at Woods Hole, " July I9, Ig05.

\section{Rotalia beccarii (Linnæus). [Chart 8.]}

Cushman, I908, page $3 \mathrm{I}$.

"Probably the most abundant of the Foraminifera of the region."-Cushman. Abundant and apparently of pretty general distribution both in Vineyard Sound and Buzzards Bay. Dredged in 2 to to I9 fathoms, sand and mud.-Survey.

Fish Hawk stations: 7679 (common), 7680 (common), 7682 (few), $7685,7686,7687,7688$ (few), 7704 (common), 7707, 7709, 7710, 7719, 7722 (few), 7724 (common), 7725 (common), 7726 (common), 7727 (common), 7729 (common), 7730, 773I, 7734 (few), 7735 (few), 7736, 775 I (few), 776 I (common), 7767 (few). Supplementary stations (I907): 7542 (common), $75^{65}$ (common), $75^{81}$ (few), 7592 (few), 7620 (few), 7630 (few), 7639 (few), 7643 (few), 7648 (few), 7649 (common), 7652 (few), 7656 (few), 7661 (common), 7662 (r), 7663 (abundant), 7667 (few), 7668, 7669 (few), 7728 (abundant), 773 I (few), 776I (few).

Phalarope stations: 78 (few), 79 (few) 80 (few), 82 (common), 84 (common), 85 (common), 9I (few), 93 (few), 94 (few), I03, IIr (common), II3 (common), II4 (common), I 8 (few), II9 (few), I23 (few), I24 (few), I25 (few).
FAMILY POLYSTOMELLIDAE.

Polystomella striatopunctata (Fichtel \& Moll). [Chart 9.]

Cushman, I908, page $3 \mathbf{I}$.

Recorded from numerous stations in the western end of Vireyard Sound and throughout the length of Buzzards Bay; dredged in 2 to $I 7$ fathoms, sand and mud.

Fish Hawk stations: 7680 (common), 768 (common), $7685,7687,7705$ (few), 7706 (few), 7707 (common), 7710, 7719 (few), 7720 (common), 7725 (common), 7729 (common), 773I, 7734 (few), 776I. (common). Supplementary stations (r907): $75^{6} 5$ (common), 7612 (few), 7620 (few), 7621 (few), 7643 (common), 7648 (few), 7649 (common), $765 \mathrm{x}$ (common), $765^{2}$ (few), 7654 (common), 766r (common), 7662 (abundant), 7663 (common), 7667 (few), 7668 (few), 7669 (few), 7728 (common), 773 I (few).

Phalarope stations: 78 (common), 80 (few), 84 (common), 85 (common), 87 (few), 93 (common), 94 (common), I30 (few), I38 (few), I 43 , I 47 (few), I52 (few).

\section{Polystomella crispa (Linnæus).}

Cushman, I908, page 32 .

Recorded from a few stations in both Bay and Sound.

Fish Hawk stations: 7680 (few), 7686 (few), also I907 repetitions of stations $76 \mathrm{I}_{4}, 7639,7643$ (common), and 7648 .

Phalarope station 93 (I).

\section{Class ACTINOPODA.}

Subclass HELIOZOA.

Actinophrys sol Ehrenberg, variety.

Calkins, I902, page 420 .

Woods Hole, a single specimen (determined with doubt).

\section{Heterophrys myriapoda Archer.}

Calkins, 1902, page 421 .

"Common among algæ. This form was probably meant by Peck, I895, when he figured 'a heliozoon.',

\section{Class ZOOMASTIGOPHORA.}

\section{Subclass LISSOFLAGELLATA.}

\section{Family RHIZOMASTIGIDAs.}

\section{Mastigamoba simplex Calkins}

Calkins, I902, page 422 (sp. nov.).

U. S. Bureau of Fisheries pier, in decaying algæ; seen several times.

\section{Family Codonacides.}

\section{Codonoca gracilis Calkins.}

Calkins, I902, page 423 (sp. nov.).

U. S. Bureau of Fisheries pier.
Family HETEROMONADIDE.

Monas sp. undetermined.

Calkins, I902, page 423 .

U. S. Bureau of Fisheries pier, attached by a thread of protoplasm to alga; only one specimen found.

$$
\text { Family BODONIDAs. }
$$

Bodo globosus Stein.

Calkins, I902, page 425 .

U. S. Bureau of Fisheries pier, common. 
Bodo caudatus (Dujardin).

Calkins, I902, page 425 .

U.S. Bureau of Fisheries pier, common. "This species was seen by Peck, I905, and described as a small flagellate."

Oxyrrhis marina Dujardin.

Calkins, I902, page 425 .

U. S. Bureau of Fisheries pier.

Family AstasIrde.

Astasia contorta Dujardin.

Calkins, I902, page 426 .

U.S. Bureau of Fisheries picr, "common in decaying algæ."

Subclass CHOANOFLAGELLATA.

\section{Monosiga ovata Kent.}

Calkins, I902, page 424 .

U. S. Bureau of Fisheries pier. This species inhabits both fresh and salt water.

Monosiga fusiformis Kent.

Calkins, I902, page 424 .

U. S. Bureau of Fisheries pier. This species inhabits both fresh and salt water.

\section{Class PHYTOMASTIGOPHORA.}

Subclass DINOFLAGELI,ATA.
Exuvialla lima (Ehrenberg).

Calkins, Igo2, page 428 .

U. S. Bureau of Fisheries pier.

Exuvialla marina Cienkowsky.

Calkins, I902, page 429 .

U. S. Bureau of Fisheries pier.

Exuviclla sp. undetermined.

Peck, r8g6.

Buzzards Bay in plankton.

\section{Family PERIDINIIDE.}

Gymnodinium gracile spherica Calkins.

Calkins, I902, page 429 .

U. S. Bureau of Fisheries pier, common.

Glenodinium compressa Calkins.

Calkins, rgo2, page 430 (sp. nov.).

U.S. Bureau of Fisheries pier, not uncommon.

Glenodinium cinctum Ehrenberg.

Peck, I894; Calkins, I902, page 430.

U. S. Bureau of Fisheries pier.-Calkins. Peck figures a "Glenodinium sp.," which he refers to as being abundant in the food of the menhaden. Dr. Calkins concludes from Peck's figure that G. cinctum was the form observed.
Family PERANEMIDz.

Anisonema vitrea (Dujardin).

Calkins, I902, page 426 .

"Quite common in decaying algæ at Woods Hole."

\section{(Assigned to no family.)}

Distephanus speculum Stöhr.

Calkins, 1902, page 427 .

U.S. Bureau of Fisheries pier, a single specimen taken in tow in the evening.

\section{Calkins, I902, page 424}

U. S. Bureau of Fisheries, on red algæ; a few individuals (no colonies).
Peridinium digitale Pouchet.
Peck, I896 (figured by Peck as "P. divergens," Dr. Calkins states); Calkins, I902, page 43r.

U.S. Bureau of Fisheries pier, common.-Calkins.

Peridium divergens Ehrenberg.

Peck, I896; Calkins, I902, page 43I.

U. S. Bureau of Fisheries pier, common.-Calkins. Peck listed and figured "Peridinium divergens " from plankton of Buzzards Bay, but Dr. Calkins believes that Peck really referred to $P$. digitale.

Peridinium sp. sp.

Peck, I894 and I896, refers to "Peridinium furca" and to various undetermined members of this genus as constituting an important constituent of the food of the menhaden.

Ceratium fusus (Ehrenberg).

Peck, I894 and I896; Calkins, I902, page 432.

Buzzards Bay; abundant in plankton and a frequent constituent of food of menhaden.-Peck. U. S. Bureau of Fisheries pier, common in tow and in algæ.-Calkins.

Ceratium tripos (Müller).

Peck, I894; Calkins, I902, page 432.

Found in food of menhaden.-Peck. U. S. Bureau of Fisheries pier, common in tow and in algæ.-Calkins. 


\section{Family Dinophysides.}

Amphidinium operculatum Claparède \& Iachmann.

Calkins, 1902 , page $43^{2}$.

"Very common about Woods Hole."

\section{Class CILIATA.}

\section{Family ENCHELINIDEE.}

Lacrymaria lagenula Claparède \& Lachmann.

Calkins, I902, page 433 .

U.S. Bureau of Fisheries pier, in decaying algæ.

Lacrymaria coronata Claparède \& Lachmann.

Calkins, I902, page 434 .

U. S. Bureau of Fisheries pier.

Trachelocerca phœnicopterus Cohn.

Calkins, 1902, page 435 .

U. S. Bureau of Fisheries pier.

Mesodinium cinctum Calkins.

Calkins, I9o2, page 436 (sp. nov.).

U.S. Bureau of Fisheries pier, not uncommon.

Mesodinium sp.

Peck, I896; Calkins, Igo2, page $45^{8}$.

Peck so records one species, but Calkins, from Peck's own figures, concludes that this was Aspidisca hexeris.

Tiarina fusus (Claparède \& Lachmann).

Calkins, I902, page 437 .

U. S. Bureau of Fisheries pier.

Family TracheliNide.

Loxophyllum setigerum Quennerstedt.

Calkins I902, page 438 (Loxophyllum setigerum, var. armatum).

U. S. Bureau of Fisheries pier

Lionotus fasciola (Ehrenberg).

Calkins, I902, page 438 .

U. S. Bureau of Fisheries pier.

\section{Family ChlamydodontIDA.}

Nassula notata Müller.

Calkins, I902, page 440 (Nassula microstoma).

U. S. Bureau of Fisheries pier.

Chilodon cucullulus (Müller).

Calkins, I902, page 44I.

U. S. Bureau of Fisheries pier, rare.

\section{Chilodon sp.}

Peck, 1896.

Dysteria lanceolata Claparède \& Lachmann.

Calkins, 1902 , page $44 \mathrm{I}$.

U. S. Bureau of Fisheries pier.
Dinophysis sp.

Peck, 1894 and 1896.

Buzzards Bay in plankton; a common constituent of the food of the menhaden.
Frontonia leucas Ehrenberg.

Calkins, I902, page $44^{2}$.

U. S. Bureau of Fisheries pier.

Colpidium colpoda (Ehrenberg).

Calkins, I902, page 443 .

U. S. Bureau of Fisheries pier, common. This form is regarded by Dr. Calkins as specifically the same as that found in fresh water.

Uronema marina Dujardin.

Calkins, I902, page 444 .

U. S. Bureau of Fisheries pier, "common in decomposing algae."

\section{Family PléRONEMIDAs.}

Pleuronema chrysalis (Ehrenberg).

Calkins, r902, page 444 .

U.S. Bureau of Fisheries pier, not very common. Occurs both in fresh and salt water.

Pleuronema setigera Calkins.

Calkins, Igo2, page 445 (sp. nov.).

U. S. Bureau of Fisheries pier, "in decaying algæ."

Lembus elongatus Claparède \& Lachmann.

Caikins, 1902, page 446 (Lembus infusonium).

U. S. Bureau of Fisheries pier, "common in old infusions of algæ, especially after decomposition is well advanced."

Lembus pusillus Quennerstedt.

Calkins, 1902, page 446.

U. S. Bureau of Fisheries pier. "Habitat similar to that of $L$. infusionum, in zooglœa masses."

\section{Family Opalinidas.}

Anoplophrya branchiarum Stein.

Calkins, I902, page 447 .

U. S. Bureau of Fisheries pier, one specimen "found free swimming among some algæ." The species is "parasitic in the digestive tract of various annelids."

\section{Family BURSARIDAE.}

Condylostoma patens (Müller).

Calkins, I902, page 449.

U. S. Bureau of Fisheries pier, very common. 


\section{Family STENTORIDE.}

Strombidium caudatum Fromentel.

Calkins, I902, page 450 .

U. S. Bureau of Fisheries pier, common in decaying vegetable matter.

\section{Family TINTINNID死.}

Tintinnus sp. undetermined.

A species which was referred to this genus was found by Peck (1894) to be abundant in the plankton and in the food of the menhaden.

Tintinnopsis beroidea plagiostoma Daday.

Calkins, r902, page $45 \mathrm{I}$.

U. S. Bureau of Fisheries pier.

Tintinnopsis beroidea compressa Daday.

Calkins, I902, page 45 I.

U. S. Bureau of Fisheries pier.

Tintinnopsis davidoffi Daday.

Calkins, I902, page $45 \mathrm{I}$.

U. S. Bureau of Fisheries pier.

Codonella sp. undetermined.

Peck, I894 and I896.

Buzzards Bay in plankton; abundant in food of menhaden.

\section{Family PERITROMIDAE.}

\section{Peritromus emma Stein.}

Calkins, I902, page $45^{2}$.

U. S. Bureau of Fisheries pier.

\section{Family OXYTRICHID王.}

Epiclintes retractilis Claparède \& Lachmann.

Calkins, r902, page 453 (Epiclintes radiosa).

U. S. Bureau of Fisheries pier.

Amphisia kessleri (Wrzesniowski).

Calkins, 1902, page 454.

U. S. Bureau of Fisheries pier.

Family Euplotrde:

Euplotes charon Ehrenberg.

Calkins, I902, page 455 .

U. S. Bureau of Fisheries pier. Occurs in both fresh and salt water.

Euplotes harpa Stein.

Calkins, I902, page 455 .

U. S. Bureau of Fisheries pier.
Diophrys appendiculatus (Stein).

Calkins, I902, page $45^{6}$.

U. S. Bureau of Fisheries pier.

Uronychia transfuga Stein.

Calkins, I902, page 457 (Uronychia setigera).

"Very common in the Woods Hole waters."

Aspidisca hexeris Quennerstedt.

Peck, r895. Calkins, r902, page $45^{8}$.

"Incorrectly mentioned as Mesodinium sp. by Peck."

U. S. Bureau of Fisheries pier.

Aspidisca polystyla Stein.

Calkins, rgo2, page $45^{8}$.

U. S. Bureau of Fisheries pier.

Family LICHNOPHORIDA.

Lichnophora auerbachii Cohn.

Calkins, x902, page 459 (Lichnophora macfarlandi). Woods Hole, "on the egg capsules of Crepidula plana; also reported upon annelids."

Family VORTICELLID王.

Vorticella patsllina Müller.

Calkins, I902, page 461 .

U. S. Bureau of Fisheries pier.

Vorticella marina Greeff.

Calkins, I902, page $46 \mathrm{r}$.

U. S. Bureau of Fisheries pier, common, growing "in small social groups."

Zoothamnium elegans D'Udekem.

Calkins, 1902 , page $46 \mathrm{r}$.

U. S. Bureau of Fisheries pier.

Cothurnia ingenita Müller.

Calkins, 1902, page 462 (Cothurnia crystallina). U. S. Bureau of Fisheries pier. Inhabits both fresh and salt water.

Cothurnia imberbis curvula Entz.

Calkins, I902, page 462 .

U. S. Bureau of Fisheries pier, on red algæ. Inhabits both fresh and salt water.

Cothurnia innata Müller.

Calkins, I902, page 463 (Cothurnia nodosa).

U. S. Bureau of Fisheries pier. Dr. Calkins believes that $C$. longipes Kellicott, described from Woods Hole, is only a long-stemmed variety of this species.

\section{Class SUCTORIA.}

\section{Family PODOPHRYIDA.}

\section{Podophrya gracilis Calkins.}

Calkins, Igo2, page $46_{3}$ (sp. nov.).

U.S. Bureau of Fisheries pier, "only one specimen seen."
Ephelota coronata Wright.

Calkins, rgo2, page 464 .

"One of the commonest of the Suctoria found at Woods Hole. It is usually present on Campanularian hydroids, but may be found on algx and Bryozoa." 
Family AcINETID E.

Acineta divisa Fraipont.

Calkins, I902, p. 465 .

"Common on Bryozoa at Woods Hole."

Acineta tuberosa Ehrenberg.

Calkins, I902, page 465 .

U. S. Bureau of Fisheries pier.
Family DENDROSOMIDA.

Trichophrya salparum Entz.

Calkins, I902, page 466 .

Woods Hole. "This species was found by Dr. $\mathrm{G}$. Hunter on the branchial bars of the Ascidian Molgula manhattensis, where great numbers of them are often parasitic."

\section{Class SPOROZOA.}

\section{Family Polycystidez.}

Gregarina gigantea Van Beneden.

Herrick, I895, page 122.

Host, the lobster. Not specifically recorded for this region.

\section{Family MyxовоLID瓜}

Myxobolus lintoni Gurley.

Linton, 1891; 1900, page 277; 1901, p. 442. Gurley, I893, page 414 (sp. nov.); I894, page 238 .

Host, Cyprinodon variegatus, upon which it occasionally gives rise to wartlike excrescences.-Linton, Gurley.

\section{Sporozoa undetermined.}

Dr. Linton (MS. notes) records undetermined monocystid gregarines from the spiral valve of the mackerel shark (Isurus dekayi), and undetermined Myxosporidia from the eel ( $A n$ guilla chrysypa), the menhaden (Brevoortia tyrannus), the squeteague (Cynoscion regalis), the halibut (Hippoglossus hippoglossus), the silverside (Menidia menidia notata), the smelt (Osmerus mordax), and the mackerel (Scomber scombrus). Mr. C. W. Hahn and others have likewise found Myxosporidia in local fishes of a number of species, but the results of their. work are not yet available.

\section{Phylum PORIFERA. ${ }^{a}$}

\section{Family Asconides.}

Ascortis fragilis Haeckel.

Verrill and Smith, I873, p. 74I.

Vineyard Sound.-Verrill. Western end of Vineyard Sound, at two stations* (Fish Hawk 7720 and Phalarope 32 ); 5 to 13 fathoms.

\section{Leucosolenia sp.}

Verrill and Smith, 1873, p. 74I, 39I (Leucosolenia botryoides?).

Verrill doubtfully identified a species found in this region and said to be very common on piles. Specimens which were provisionally assigned to this genus by the collectors were taken at several dredging stations.

\section{Family SyconIDE.}

\section{? Grantia ciliata (Fabricius) [Chart Io.]}

Verrill and Smith, I873, p. 740, 330, etc. ("Probably the same as the Grantia ciliata of Europe." )

"Vineyard Sound, not uncommon."-Verrill. Vineyard Sound, particularly at the eastern and western extremities; scattered stations along the eastern shore of Buzzards
? Grantia ciliata-Continued.

Bay and near its mouth; dredged in I to I9 fathoms on non-muddy bottoms.-Survey. Grantia is found most abundantly, however, on the piles of piers, in which situations it is common in Woods Hole Harbor and is doubtless of very general distribution throughout the region.

Fish Hawk stations: $b$ 753 I bis (few), 76 Io, 7630 (r), 7666 (few clusters), 7670 (few), 7672 , 7676 (on an alga), 7689 (few), 7703 (few), 7732 (several), 7742 (several), 7743 (several), 7746 (few), 7749 (many), 7750 (very many), $775^{2}$ (few), 7755 (few), $775^{8}$ (few), 7769 (I), 7772 (I), 7773 (several). Supplementary station (1909): $767 \mathrm{r}$.

Phalarope and Blue Wing stations: $b$ I (many), 8 (many), 22 (several), 24 (few), 32 (several), 33 (few), 34 (common), 36 (few), 37 (few), 44 (many), 45 (many), 46, 47 (few small), 49 (few), 5I (several), 56 (few), 57 (few), 58 (common), 60 (several), 62 (I), 63 (few), I I6, I2 I (few), I30 (few), I45 (few). Supplementary stations (Ig09): 83, I3 1 . 


\section{Family Clionidat.}

\section{Cliona celata Grant. [Chart II.]}

Desor, 1848, p. 68 (Spongia sulphurea). Verrill and Smith, I873, p. $744,42 \mathrm{I}$, etc. (Cliona sulphurea).

Abundant and of pretty general distribution throughout Vineyard Sound and Buzzards Bay. Dredged by the Survey in 2 to 19 fathoms, on every sort of bottom. Sometimes taken in sufficient quantity to fill the dredge. Regarding the life history of this species Verrill writes: "The sponge commences as a boring species, on various dead shells, and as it grows it penetrates the shells in every direction, forming irregular holes and galleries, which continue to grow larger as more of the substance of the shell is absorbed, until the shells are reduced to a completely honeycombed, brittle mass, or a mere skeleton; finally the sponge begins to protrude from the surface."

Fish Hawk stations: $75^{22}$ (abundant), $75^{22}$ bis (many masses), 7523 bis (few masses), 7524 bis (few pieces), $75^{2} 5$ (very abundant), $75^{26}$ (great masses), $75^{27}$ (few); 7528 (few), $75^{29}$ (few), 7530 (few), 7530 bis (little), 753 I bis (many), 7532 (abundant), 7532 bis (few), 7533 (small piece), 7533 bis (few masses), 7534 bis (I small piece), 7535 bis (several masses), 7536 (several masses), 7536 bis (several masses), 7537 (many masses), 7537 bis (several masses), 7538 bis (very much), 7539 (several masses), 7540 (few pieces), $754 \mathrm{I}$ (many), $754 \mathrm{I}$ bis (little), 7542 bis (little), 7544 (few masses), 7544 bis (small fragments), 7547 (dredge fuli), 7547 bis (2 masses), 7548 (many), 7550 bis (much), 7553 (few large pieces), 7554 bis (few), $755^{8}$ (many pieces), 7560 (several pieces), $756 \mathrm{I}$ (few masses), $75^{6} 5$ bis (considerable), 7570 (few pieces), 7572 (much), $75^{8} 7$ (several large pieces), 7594 (many masses), 7595 (few pieces), 7610 ( 1 mass), 7612 (I small), 76I3 (many large masses), 7614 (few small), 76I5 (many masses), 76I6 (very young, on Venus shell), 76I8 (2 large), 76I9 (several masses), 7620 (abundant), 7624 (few colonies), 7625 (few masses), 7627 (few small), 7628 (young, on shell of Crepidula fornicata), 7629 (few masses), 7630 (few small masses), 763I (several masses), $76_{32}$ (few masses), $76_{33}$ (few masses), 7634 (few masses), 7635 (few masses), 7639 (several large masses), 7640 (I small mass), 7645 (several masses), 7646 (few small colonies), 7648 (several colonies), 7659 (few masses), 7660 (few masses), 7666 (few masses)
Cliona celata-Continued. 7670 (much), 767 I (many masses), 7672 (few masses), 7675 (several large colonies), 7689 (few small masses), 7690 (several large masses), 7692 (several large masses), 7693 ( 1 ), 7706 (I mass), 7720 (I mass), 772 I, 7730 (much), 7732 (little), 7738 (very much), 7742 (few small pieces), 7743 (several large pieces), 7745 (much), 7746 (very little), 7747 (very little), 7748 (little), 7749 (little), 7750 (little), $775^{\mathrm{I}}$ (little), 7754 (much), 7755 (little), 7757 (I large mass), $775^{8}$ (very much), 7759 (litgle), 7763 (x mass), 7768 (little), 7770 (little), 7772 (little), 7775 (little), 778 I (in Busycon shell), 7782 (several masses). Supplementary stations (I909): $7624,7627,7629,7634,7643,7645$, $7648,7653,7659,7660,7670,7671,7672$.

Phalarope and Blue Wing stations: I (several small masses), 2 (many), 3 (abundant), 5 (few masses), 7 (abundant), 8 (I piece), 9 (many pieces), Io (abundant), II (very abundant), I2 (very abundant), I3 (abundant), I4 (little), I5 (abundant), I6 (few), 20 (few), 24 (few), 27 (2), 28 ( 2 masses), 30 (I mass), 32 (small mass), 36 (several large masses), 37 (small masses), 44 (very small pieces), 53 (I mass), 60 (I), 62 (I mass), 63 (abundant), 65 (many masses), 66 (several), 69 (few masses), 74 (many), 77 many), 8o (several bunches), 8r (several masses), 82 (few), 83 (2 pieces), 85,95 , roo (much), I08, I09, II3, II4 (many), II5 (much), II7 (common), I22 (few), I24 (few), I28 (I piece), I3I '(rocks covered), I34 (common), $I_{37}$ (masses), I 38 (several masses), I40 (many), I4I (common), I44 (few), I45 (several), I46 (common), I47 (common), I48 (common), I 49 (common), I50 (I mass), I52 (I), I55 (young). Supplementary stations (Ig09): 83 , I 3 I, I46.

\section{Family PolymastIIDE}

Polymastia robusta Bowerbank.

Verrill and Smith, I873, p. 744, 497 (identified with doubt).

"Off Gay Head, I8 to 20 fathoms," rocky bottom.-Verrill. Dredged by the Survey at the western end of Vineyard Sound and the lower end of Buzzards Bay, in 7 to I2 fathoms, on bottoms of gravel and stones (4 stations); at Crab Ledge ( 5 stations).

Fish Hawk stations: 7595 (several large masses), 7603 (several pieces)* $^{*} 7604$ (I small piece), 7605 (I small piece), 7606 (several pieces), 7607 (several pieces); also at a 1907 repetition of station 7722 , and at $\mathrm{I} 909$ repetitions of stations 7660 and 7670 . 


\section{Family SUBERITID死.}

Suberites compacta Verrill.

Verrill and Smith, 1873, p. 744, 503 (sp. nov.). "Off Marthas Vineyard, to fathoms, sandy; Nantucket"; also on beach at Edgartown.Verrill. Irarge dried masses of this sponge found in abundance upon the beach at the south shore of Nantucket.--Sumner.

\section{Family TETHYTDE.}

\section{Tethya gravida Hyatt.}

Hyatt, I877, p. 34, footnote (sp. nov.); I878, p. I668, fig. only (here spelled "Tethya gravata"').

Buzzards Bay.-Hyatt. Dredged by the Survey at seven stations in the vicinity of North Falmouth; 3 to 6 fathoms, on various bottoms. Reported by Mr. Gray from Bird Island Light, a point not far distant from the Survey stations where Tethya was taken.

Phalarope stations: I4I (several), I43 (I small), I44 (I), I46 (several), I47 (I), I48 (several). Also at $\mathrm{I} 909$ repetitions of Fish Hawk station 7634 and Phalarope station I46.

\section{Family HOMORRHAPHDAE.}

\section{Halichondria panicea (Pallas).}

Verrill, 1873, p. 743,498 (referred to in one place as "Tedania").

Off Gay Head.-Verrill. "One of the most abundant species of this [Woods Hole?] region [which] forms very irregularly shaped, uneven, pale yellow masses, attached to the stems and fronds of Phyllophora and other small algæ, and often, as it grows larger, spreading over, entirely covering and destroying the algæ." Specimens assigned to this species by Dr. Cushman were dredged at Crab Ledge and at the western end of Vineyard Sound; 6 to 25 fathoms, on gravelly and sandy bottoms.-Survey.

Fish Hawk stations*: $75^{82}$ (I large mass), $75^{89}$ (I large piece), 759 I (2 small clumps attached to algx), 7605, 7606, 7607, 7608 (large mass), 7609 (several pieces), 7722 .

Phalarope stations*: 34,63 .

\section{Halichondria caduca Bowerbank.}

Specimens thus identified by Dr. Cushman were taken at Phalarope stations 24 (Vineyard Sound), and II2, I23, I30, and I37 (Buzzards Bay).
Halichondria sp. sp.

Verrill, 1873, p. 743,334 , lists several undetermined species of this genus, two of which ("species b" and "species c") were taken within this region. Specimens of whose specific identity we can not be certain were taken in Vineyard Sound at Phalarope and Blue Wing stations $25,32,33,36,45,46,49$, $5^{1}, 56,57,5^{8}, 60$, and 64; and in Buzzards Bay at Fish Hawk station 7639 .

\section{? Reniera sp. sp.}

Verrill and Smith, 1873, p. 743,334 .

Two undetermined species, " $a$ " and " $b$," are listed by Verrill from Vineyard Sound, I (3) to ro fathoms.

Chalina arbuscula Verrill.

Verrill and Smith, I873, p. 742, 39I (sp. nov.).

"Vineyard Sound, I to 8 fathoms", very common.-Verrill.

Chalina oculata (Pallas).

Verrill and Smith, I873, p. 742, 409, etc.

"Off Gay Head, 4 to I5 fathoms", "in the outside cold waters." - Verrill.

Chalina sp. undet. [Chart I2.]

Dr. Cushman believes that a confusion exists in Verrill's descriptions of the two foregoing species. It is therefore necessary to enter as undetermined all the Chalinas taken during the Survey dredging. Members of the genus are recorded from scattered stations throughout Vineyard Sound and at the lower end of Buzzards Bay, in 6 to 17 fathoms, on various bottoms. Dried specimens, often of large size, are to be found in abundance upon the beach at Cuttyhunk Island and elsewhere. Mr. Gray has collected living specimens of what have commonly been regarded as Chalina arbuscula at Nobska Point and on Red Ledge, in Woods Hole Harbor. They are likewise known to occur on the Bureau of Fisheries pier at Woods Hole.

Specimens from the following points were originally identified by Dr. Cushman as $C$. arbuscula: Fish Hawk stations $755^{\circ}$ bis (several large), 7666 (I colony), 7670 ( 1 colony), 7671, 7674 (I mass), 7675 ( 1 large colony); Phalarope station II (several colonies). Specimens from the following points were originally identified as C. oculata: Fish Hawk stations: 7524 bis, 7533 bis (2), 7536 bis (I), 7593 (I cluster), 7702 (I clump), 7728; Phalarope stations: II, 78 (I piece), 8 I (I piece). 


\section{Family DESMacidonidz:}

\section{Esperella modesta Lambe.}

A specimen thus identified by Dr. Cushman was taken in Buzzards Bay, near Cuttyhunk, at Fish Hawk station 767 I ( 9 fathoms, stones and muddy sand).

?Esperella fibrexilis Wilson.

Wilson (I89I, p. 5II) refers to "Esperella fibrexilis (n. sp.)" as "abundant near Woods Hole, Mass.," but no description is offered nor cited and the authors are not aware that any such has been published.

Esperella sp. undet.

A sponge referred to this genus by Dr. Cushman was found in some numbers by Dr. Osburn on the New York Yacht Club pier at Vineyard Haven July 3 I, Ig06. It was much excavated by a tube-dwelling amphipod.

Desmacidon palmata (Johnston).

Crab Ledge, at 6 stations; extreme western end of Vineyard Sound: I station. Dredged in $I x$ to 20 fathoms, sand, gravel, and stones. Some of these were large specimens and they were of a dark-red color when fresh.

Fish Hawk stations: 7603 (many)*, 7604 (I small piece), 7605 (several), 7606 (many), 7607 (many), 7608 (few pieces), $7722^{*}$.

2Isodictya sp.

Verrill $(\mathrm{I} 873, \mathrm{p} .742)$ thus lists a sponge washed ashore after storms in winter at Nantucket, Vineyard Sound, and elsewhere. It is said by him to resemble "Isodictya palmata Bowerbank," i. e., the Desmacidon palmata listed above.

Sponges undetermined.

Fish Hawk stations: 7524 (abundant; gray, incrusting), $75^{24}$ bis, $75^{25}$ bis, $75^{26}$ (3), 7530 bis, 7603 (I piece, several inches long), 7605 (I piece), 7606 ( $\mathrm{I}$, in appearance like Grantia), 7616, 7630, $7653,7690,7783$.

Phalarope stations: $56,74, \mathrm{I}_{3} \mathrm{O}, \mathrm{I} 37, \mathrm{I41}, \mathrm{I} 45$ (common), ${ }_{5} 8$ (large brown mass).

\section{Phylum COELENTERATA. ${ }^{a}$ Class HYDROZOA.}

\section{Family CLAVIDE.}

Clava leptostyla Agassiz.

Verrill and Smith, 1873, p. 734,328 , etc.; Bumpus, 1898 , p. 487 ; Bumpus, 1898 b, p. 857 ; Hargitt, I90I, p. 305; Nutting, I90I, p. 327.

Woods Hole, on piles of Bureau of Fisheries pier; also from rockweed in "the Hole." Bumpus. Woods Hole, Hadley Harbor, etc.Hargitt. "Rocks near the Hole."-Nutting.
Myxilla sp.

Specimens referred to this genus by Dr. Cushman were dredged along the western shore of Buzzards Bay (Phalarope stations $137, \mathrm{r} 4 \mathrm{I}$ ), in 4 fathoms, sand and gravel.

Microciona prolifera (Ellis \& Solander.) [Chart 13.] Verrill and Smith, 1873, p. 741, 409, etc.

Vineyard Sound.--Verrill. Scattered stations throughout Vineyard Sound and Buzzards Bay, particularly in the upper half of the latter, and at the mouth of Wareham River, where large colonies thrive; dredged in 2 to $I_{3}$ fathoms, on all sorts of bottoms. - Survey. Regarding the life history of this sponge Verrill writes: "This species, when young, forms broad, thin, bright red incrustations over the surfaces of stones and shells . . . at a later period, rises up into irregular lobes and tubercular prominences, which eventually become elongated and subdivided into slender branches . . ."

Fish Hawk stations: $75^{21}$ bis (incrusting rock)*, 7543 (incrusting broken Echinarachnius)*, 7619 (?), 7620 (?), 7629 (? several large masses), $763 \mathrm{I}$ (?), 7633 (?), 7648 (? few masses, incrusting), 7663 (?), $7680^{*}, 773^{*}, 7734^{*}, 7736^{*}, 7768^{*}, 7777$, 7780, 778I (incrusting Busycon shell), 7783 . Supplementary stations (Igog): 7648, 7653 , $7659,7671,7672$.

Phalarope stations: 60 (?), ${ }_{3} 6$ (few colonies), ${ }_{3} 8$ (many), I42 (I colony)*, I49*, I5I (dead), I55 (on several shells)*, ${ }_{5} 6^{*},{ }_{5} 8$ (many, large and

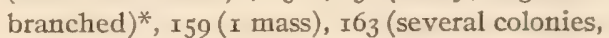
one on the back of Libinia), I65 (few), I67 (abundant on shells). Supplementary stations (1909): 79,165 .

$a$ Specimens from points designated by an asterisk $(*)$ were identified by Prof. C. W. Hargitt. Specimens from points designated by the dagger $(\dagger)$ were identified by Prof. C. C. Nutting. I6269 - Bull. 3 I, pt $2-\mathrm{I}_{3} \longrightarrow 2$ 
Cordylophora lacustris Allman.

Verrill and Smith, I873, p. 734 (Cordylophora, species undetermined); Nutting, I9oI, p. 327 ; Hargitt, r908, p. 99.

"Found in a fresh-water pond near the [Nobska] bathing beach by A. D. Morrill."-Nutting. Taken by Hargitt "in several similar ponds in the region and near Falmouth, and in fresh or brackish ponds on Marthas Vineyard." Collected by Dr. Congdon at Tashmoo Pond, Great Pond, and Weweantic River, and by Mr. Edwards at Fresh Pond (Falmouth) and Oyster Pond.

"The reproductive season seems to be chiefly in spring or early summer, and sparingly in July. Colonies have been found later, September or October, but with no signs of gonophores."-Hargitt.

\section{Family CORYNIDAs.}

Syncoryne mirabilis Agassiz.

Verrill and Smith, 1873, p. 735 (Coryne mirabilis); Fewkes, I88I, p. I4I (Sarsia mirabilis); Bumpus, 1898 , p. 487 (Coryne); Mead, r898, p. 704 (Coryne); Nutting, I901, p. 328, 372; Hargitt, I902a, p. 552; 1904, p. 30; Mayer, IgIo, p. 53 (Sarsia tubulosa, var. mirabilis).

"Marthas Vineyard to Greenland."-Verrill. Hydroids on Bureau of Fisheries pier, at Woods Hole--Bumpus, Mead. Waquoit.Edwards, cited by Nutting. Rocks in Woods Hole Passage.-G. M. Gray. Medusæ reported locally by various observers.

"Breeding hydroids" in March.-Bumpus. In April (1898), according to Mead, the hydroids "occurred in colonies that could be measured by the square yard;" these disintegrated later. Dr. A. G. Mayer found the medusa to be common in Woods Hole Harbor on March 4 (I908); while Dr. Mead and Mr. G. T. Hargitt report its occurrence during April. According to Mr. Edwards's towing records it is commonest during April and May, though taken occasionally in other months. The seasonal range is stated by Dr. C. W. Hargitt as extending from February to May.

Syncoryne producta Hargitt.

Hargitt, I902a, p. 550 (Coryne producta, sp. nov.); Hargitt, 1904, p. 30; Mayer, 1910, p. 63 (Sarsia hargitti).

Woods Hole: A single medusa taken in tow, August I0, I90x.
2Corynitis agassizii McCrady.

Bumpus, I898b, p. 857 ; Murbach, I898, p. 354 ; Nutting, I90I, p. 329, 372; Hargitt, I904, p. 42; I908, p. I00; Mayer, I910, p. 72.

Murbach reported the occurrence of "Corynitis agassizii" upon floating sargassum from Vineyard Sound. Hargitt has shown, however, that these observations refer to an entirely different species, Gemmaria gemmosa McCrady, which Murbach endeavored to identify with Corynitis agassizii. Dr. Hargitt knows of no authentic records of the occurrence of the latter species at or near Woods Hole. The reader is referred to the conflicting statements of Hargitt, Murbach, and Mayer in the papers cited.

\section{Family Cladocorynidas.}

Cladocoryne floccosa sargassensis Hargitt.

Hargitt, I909, p. 369 (var. nov.).

A form thus designated by Dr. Hargitt was taken on floating sargassum in Vineyard Sound during the summer of 1907 .

\section{Family CODONIDAE.}

Dipurena strangulata McCrady.

L. Agassiz, I862, p. 34I (Dipurena conica); A. Agassiz, I865, p. I8I (Dipurena conica); Verrill and Smith, I873, p. 735, 455 (Dipurena conica); Fewkes, I88r, p. I55 (Dipurena strangulata); Nutting, 1901, p. 373 (Dipurena conica); Hargitt, Igorb, p. 578 (Dipurena conica); I902a, p. 554 (Dipurena conica and $D$. strangulata); 1904, p. 30 (D. strangulata, p. 3т (D. conica); Mayer, I9Io, p. 76 (Slabberia strangulata).

Buzzards Bay, at Naushon Island, in July.A. Agassiz. Newport.-Fewkes. Woods Hole and vicinity, in midsummer, common.Hargitt.

J. P. McMurrich (in Marine Biological Laboratory card catalogue) records having obtained ova on August 7 ( 1893 ).

Of the "Dipurena conica" of A. Agassiz, Hargitt writes: "It seems altogether probable ... that we have here simply a varietal form, which would hardly justify specific separation, and should probably be included under the above species." 


\section{? Dipurella clavata Hargitt. $a$}

Hargitt, rgo2, p. 19 (sp. nov.); Hargitt, r9o4, p. 3I; Mayer, I9ro, p. 76 (Slabberia strangulata, immature).

A single specimen taken in Great Harbor, August I6, I902.

Ectopleura ochracea Agassiz.

L. Agassiz, I862, p. 343 ; A. Agassiz, I865, p. I9I; Verrill and Smith, I873, p. 735, 455; Fewkes, 1882 , p. 295; Nutting, I9or, p. 373; Hargitt, I902a, p. 554; Hargitt, I904, p. 32; Mayer, I9Io, p. 69 (Ectopleura dumortieri).

Buzzards Bay, at Naushon Island.-A. Agassiz. Newport; Woods Hole.-Nutting. Woods Hole and vicinity, "taken mostly in the evening tow."-Hargitt. A common species locally, occurring from June to September.

Ectopleura prolifica Hargitt.

Hargitt, I908, p. 106 (sp. nov.).

Described by Hargitt from a specimen found upon a small spider crab, dredged of Gay Head, July I5, I907. Taken several times during summer of 1908 , and in considerable numbers, both in Vineyard Sound and on the piles of the Bureau of Fisheries pier at Woods Hole.

Hydrichthys mirus Fewkes.

Fewkes, I888, p. 224 (sp. nov.); Nutting, I9or, p. 374; Hargitt, I904, p. 32; Mayer, I91o, p. 67 .

A large cluster found growing upon the side of a pilot-fish (Seriola zonata) taken at Newport in August, I887; not observed at any other time. Fewkes thought it likely that this hydroid was a parasite. Thousands of medusæ were liberated while the animals were under observation.

\section{Family PENNARIDAE.}

Pennaria tiarella McCrady. [Chart 14.]

A. Agassiz, I865, p. 187; Verrill and Smith, I873, p. 735,327 ; Bumpus, I $898 \mathrm{~b}$, p. 858 ; Hargitt, I900, p. 387-406; Nutting, r9or, p. 337, 374; Hargitt, I90I, p. 3II; I902a, p. 554; I904, p. 32; Mayer, I9ro, p. 25.

Dredged by the survey throughout the length of Vineyard Sound, at depths of I to I 5 fathoms on non-muddy bottoms; recorded but twice in the Buzzards Bay dredgings, though probably of more general occurrence as a
Pennaria tiarella-Continued.

littoral species. Pennaria has a wide range of habitat. It is perhaps most readily collected from piles, but is found upon all sorts of objects whether fixed or free. In midsummer it occurs in abundance on floating eel grass. Dr. Hargitt believes that the attachment to eel grass represents a later seasonal phase in the life of Pennaria, and that it is to be regarded as an adaptation for distribution. The medusæ are especially abundant in the latter part of the summer.

Fish Hawk stations: $75^{2 I}$ bis (? many), 7523 bis (? few colonies), 7524 (many) †, 7525 (abundant, large bunches), $75^{2} 5$ bis (? many), $75^{26}$ (many), 753 I bis*, 7537, 7540 (dead), 7542 (numerous), 7553 bis*, 7557, 7572 (many), $75^{82}, 75^{89}$ (small tuft), 7594 (small piece, dead), 7676 (sexually mature)*, 768x*, 7688*, $7703^{*}, 7709^{*}, 7717^{*}, 7718^{*}, 7721^{*}, 7725^{*}, 7726 *$, $7730^{*}, 7733^{*}, 7741^{*}, 7742^{*}, 7743^{*}, 7745^{*}$, $7746^{*}, 7749^{*}, 775^{*}, 775^{*}, 7759^{*}, 7760^{*}, 776 \mathrm{I}^{*}$, $7763^{*}, 7764^{*}, 7779 *$. Supplementary stations (I909): 7653,7659 .

Phalarope and Blue Wing stations: $1 *, 30 *, 44^{*}$, $5^{*}, 63^{*}, 7 I^{*}, 73^{*}$, III*, I2I*.

Euphysa virgulata Agassiz.

Nutting, I901, p. 370; Hargitt, I904, p. 33; Mayer, I9г, p. 35 (Steenstrupia virgulata "=(?) S. aurata Forbes").

Woods Hole.-Hargitt.

\section{Family Hyвocodonidz:}

\section{Hybocodon prolifer Agassiz.}

Verrill and Smith, 1873 , p. 736, 328; Nutting, I90I, p. 34I, 370; Hargitt, I902a, p. 552; Hargitt, I904, p. 33; Mayer, I910, p. 38 .

Vineyard Sound.-Verrill. Woods Hole (medusæ only).-Nutting. The medusæ of this species have been taken locally by Mr. Edwards during nearly every month of the year, but they appear from his records to be most abundant in April. Dr. Mayer found them in abundance in Woods Hole Harbor on March 4 (I907), while Dr. Hargitt records their capture off Crab Ledge in July and August. So far as we know the polyp phase has not been definitely recorded for local waters, but the constant occurrence of the medusa warrants the belief that the hydroid likewise occurs. 


\section{Family CORYMORPIIDA.}

Corymorpha pendula Agassiz.

Verrill and Smith, I873, p. 736, 5ro; Nutting, I9oI, p. 337, 370; Hargitt, I90Ib, p. 580; I902a, p. 549 ; 1904 , p. 34 (Hybocodon pendula); Mayer, Igro, p. 4I (Hybocodon pendula).

Sandy bottom in rather deep waters in Vineyard Sound and Muskeget Channel and off Chatham and Nantucket.-Hargitt. Dr. Hargitt has found medusæ which are believed to belong to this species, but thus far their derivation from the polyp form has not been demonstrated by actual observation.

\section{Family TIARIDE.}

Protiara haeckeli Hargitt.

Hargitt, I902, p. I7 (sp. nov.); I904, p. 34; Mayer, 19ro, p. Io6 (Protiara borealis).

"Off Gay Head and No Mans Land, Vineyard Sound. Several specimens were taken on two occasions during the summer (July and August) in the same general region. "--Hargitt.

Stomotoca apicata (McCrady).

A. Agassiz, r865, p. x68; Verrill and Smith, 1873 , p. 734,455 (no local records); Fewkes, I88I, p. I5I (Dinematella cavosa); p. I $_{52}$ (Stomotoca apicata); Mayer, I900, p. 3; Nutting, r901, p. 37 ; Hargitt, I904, p. 35; Mayer, I9Io, p. Iog (Stomotoca dinema).

Newport.-A. Agassiz, Mayer, Nutting. July, August, and September.

Stomotoca rugosa Mayer.

Mayer, I900, p. 4 (sp. nov.); Hargitt, Igorb, p. 581; r904, p. 35; Mayer, I9Io, p. II2.

Common at Newport.-Mayer. According to Brooks, this is the medusa of Perigonimus minutus Allman.

Turris vesicaria A. Agassiz.

Nutting, I901, p. 375; Hargitt, I904, p. 36; Mayer, I910, p. I26.

Medusa at Woods Hole, collected by V. N. Edwards.-Nutting. This species has not been taken by Hargitt.

Turris episcopalis (Forbes).

Fewkes, I881, p. r47; Hargitt, 1904, p. 36; Mayer, r91o, p. I26 (Turris vesicaria).

Newport.-Fewkes.

Turritopsis nutricula McCrady.

L. Agassiz, I862; A. Agassiz, I865, p. x67; Verrill and Smith, I873, p. 734, 454; Fewkes, I88I; p. I49 (Modeeria multitentacula); p. I53 (Turritopsis nutricula); Nutting, I9or, p. 375; Hargitt, I904, p. 37; Mayer, IgIo, p. I43.
Turritopsis nutricula-Continued.

Medusa at Naushon.-A. Agassiz. Woods Hole.Nutting, Hargitt. Recorded by Agassiz for July and September. Specimens believed to belong to this species have been taken by Mr. Edwards in March and August.

\section{Family BougaINVILLIIDEE.}

Podocoryne fulgurans (Agassiz).

A. Agassiz, I865, p. I63 (Dysmorphosa fulgurans); Verrill and Smith, 1873, p. 734, 448, etc. (Dysmorphosa fulgurans); Nutting, I9or, p. 374 (Dysmorphosa fulgurans); Hargitt, I904, p. $3^{8}$ (Dysmorphosa fulgurans); Mayer, I9ro, p. 139 .

Buzzards Bay, at Naushon.-Agassiz. Throughout the Woods Hole region, during the summer.-Nutting, Hargitt.

Podocoryne carnea Sars.

Bumpus, I898b; Hargitt, I902a, p. 554; I904, p. 38 ; Mayer, I910, p. I36.

Vineyard Sound; Tarpaulin Cove.-Hargitt. Buzzards Bay, at Igog repetitions of Fish Hawk stations $7618^{*}, 7648^{*}$, and $7653^{*}$ in each case on shells occupied by hermit crabs.Survey. Hydroid phase chiefly on the shells of hermit crabs. Medusæ fairly common locally.

"Breeding" during August.-Bumpus, citing Murbach.

\section{Hydractinia echinata Fleming. ${ }^{a}$ [Chart ${ }_{5}$.]}

A. Agassiz, 1865 , p. I98 (Hydractinia polyclina); Verrill and Smith, 1873, p. 736,328 , etc. $(H y$ dractinia polyclina); Bumpus, $\mathrm{r} 898 \mathrm{~b}$, p. $85^{8}$ (Hydractinia (Echinata) polyclina); Nutting, IgoI, p. 335 (Hydractinia polyclina); Hargitt, I908, p. 97 .

Generally present in local waters; distribution in large degree coextensive with that of the hermit crabs, on whose shells it dwells, though this species appears to be nearly or quite lacking in the central portions of Buzzards Bay. Recorded from all of the Crab Ledge stations. Dredged on every sort of bottom. In the great majority of cases Hydractinia is found upon shells occupied by hermit crabs, though its presence has been noted in the following situations by various local observers: rocks (Verrill); rock-weed and Limulus (Bumpus); piles of piers (Nutting, Osburn, Hargitt); maxillipeds of lobster, chela of $a$ This species, according to Agassiz and Nutting, is quite distinct from the H. echinata of Europe. Leidy, McCrady and Hargitt hold otherwise. 
Hydractinia echinata-Continued,

Cancer irroratus, stems of rock-weed, carapace and legs of Limulus (Hargitt). During the survey dredging it was found upon two sticks of wood brought up from the bottom near Menemsha Bight, also from the shell of a living Buccinum undatum. Regarding an interesting mass of these organisms found at Vineyard Haven, in August, 1906, Dr. Osbum has furnished the following notes: "One old pile, broken off just at low water, was entirely incrusted, almost to the exclusion of all else, with a colony of Hydractinia polyclina . . The colony extended from just below low water to over a fathom's depth and covered many square feet." The following is probably a very incomplete list of stations at which this species was dredged:

Fish Hawk stations: $7523,7526,7532,7537$, $7542,7554,7559,7560,7561,7563,7567,7570$, $7574,7576,75^{82}, 75^{8} 3,7592,7596,7603,7604$, $7605,7606,7607,7608,7609,7664,7676,7677$, $7678,7680,7681,7682,7683,7698,7699$, 7701, 7702, 7703, 7706, 7707, 7708, 7718, $7719,7720,7722,7726,7727,7730,7731$, $7734,7736,7740,7753,7761,7762,7764$, $7766,7767,7769, \quad 7770, \quad 7772,7773,7776$, $7777,7778,7779,7780,7781,7782,7783$. Supplementary station (I909): 7636 .

Phalarope stations: $59,60,62,64,71,72,73$, $\delta_{3}, 90,107,108$, I09, IIO, III, II 3, II 8, I 22, $I_{29}, I_{30}, I_{32}, I_{33}, I_{35}, I_{3} 6, I_{40}, I_{42}, I_{45}$, $I_{47}, I_{48}, I_{49}, I_{50}, I_{5} I_{1} I_{53}, I_{54}, I_{5} 8, I_{60}$, I6I, I64, I65, I66, I67. Supplementary stations (I909): $83, \mathbf{I}_{4} 6$.

"Breeds" during July and August.-Bumpus.

\section{Lizzia grata Agassiz.}

Fewkes, I88I, p. I42; Bumpus, I8g8b; Nutting, I9di, p. 376; Hargitt, I902a, p. 552; I904, p. 39; Mayer, I910, p. 179 (Rathkea octopunctata var. grata).

Medusa at Newport.-Fewkes. Woods Hole Harbor and Eel Pond, April to August.-C. W. Hargitt. Dr. Mayer reported this species as common in Woods Hole Harbor, March 4, 1907, while Mr. G. T. Hargitt found it in abundance from April 5 to II, Ig08. According to Mr. Edwards's towing records, it is most common in April, though taken from February to August and occasionally at other times.
Bougainvillia carolinensis (McCrady).

A. Agassiz, 1865, p. ${ }_{56} 6$ (Margelis carolinenis); Verrill and Smith, I873, p. 733,408 , etc. (Margelis carolinensis.); Bumpus, $1898 \mathrm{~b}, \mathrm{p}$. 858 (Margelis carolinenses); Nutting, r.gor, p. 330, 376; Hargitt, 1902a, p. 554; 1904, p. 39; Mayer, I9io, p. I65.

Hydroids generally distributed in shallower waters upon piles, rock-weed and floating timber; not recorded in the Survey dredging. Medusa common in summer, occurring during August and September (Verrill); as early as June (Hargitt). Mr. G. T. Hargitt found a few specimens early in April (Ig08) which he referred to this species.

Bougainvillia superciliaris Agassiz.

A. Agassiz, I865, P. I53; Verrill and Smith, I 873 , p. 733, 328, etc.; Nutting, rgor, p. 330, 376; Hargitt, I902, p. 13; 1904, p. 40; Mayer, I910, p. I62.

Newport.-A. Agassiz. Woods Hole (medusa only).-Nutting. Medusæ taken in April, May, and June (Verrill); August II, I899 (Nutting); "June to September" (Hargitt).

Bougainvillia autumnalis Hartlaub.

Mayer, Igoo, p. 5 (Bougainvillia gibbsi); Hargitt, r904, p. 40 (Bougainvillia gibbsi); Mayer, IgIO, p. I69.

Medusa taken at Newport, from July to October.-Mayer.

Calyptospadix cerulea Clarke.

Hargitt, 1909, p. 37 I.

Woods Hole Harbor; found by Dr. Hargitt, growing on the bottom of the steamer Fish Hawk, also on piles of Fisheries pier, August, 1908. Wareham, on bridge, August, I908; "fine colonies" collected by V. N. Edwards, identified by C. W. Hargitt. During following summer no specimens were taken in Woods Hole Harbor, but "luxurious colonies" were again taken at Wareham.

Dr. Hargitt believes that this species has but recently established itself in the region.

Willia ornata McCrady.

L. Agassiz, I862, p. 346; A. Agassiz, I865, p. I7I; Verrill and Smith, I873, p. 735, 455; Fewkes, I882, p. 299; Nutting, rgor, p. 377; Hargitt, I902a, p. 554; 1904, p. 40; Mayer, I9Io, p. I89 (Proboscidactyla onnata).

Buzzards Bay, at Naushon, the last part of September-A. Agassiz. Great Harbor and Eel Pond; "more or less common at irregular intervals"; medusæ of all sizes and stages found during the summer.-Hargitt. 
Nemopsis bachei Agassiz.

A. Agassiz, 1865, p. I49; Verrill and Smith, I873, p. 733, 454; Nutting, I90r, p. 375; Hargitt, I902, p. I4; I902a, p. 554; I904, p. 4x; Mayer, I9Io, p. I73.

Medusæ reported from Nantucket, Vineyard Haven, Vineyard Sound, Buzzards Bay, and Newport. Common in September.-A. Agassiz. Observed from June to September.Verrill, Hargitt, Nutting.

Stylactis hooperi Sigerfoos.

Nutting, I9or, p. 335, 374; Hargitt, I904, p. $4 \mathrm{I}$; Mayer, I9Io, p. 150.

"Found growing on a live gastropod Ilyanassa. Collected near Woods Hole by Mr. Waldron."-Nutting.

\section{Family EUDENDRIDA.}

\section{Eudendrium ramosum (Linnæus). [Chart I6.]}

A. Agassiz, I865, p. I59 (not listed for this region); Verrill and Smith, I873, p. 734, 408, etc.; Nutting, r9or, p. 332; Bumpus, I898b, p. 857 ; Hargitt, r908, p. 95.

"Off Gay Head, 8 to 20 fathoms."-Verrill. Abundant and of general distribution throughout Vineyard Sound and Buzzards Bay, being one of the few hydroids dredged with great frequency in the latter; taken in 2 to 19 fathoms, on every sort of bottom.-Survey. Likewise abundant on piles and frequent in shallower waters than those reached by the dredge.

Fish Hawk stations: $75^{21}$ (few), $75^{2} \mathrm{I}$ bis*, $75^{2} 3$, $75^{2} 5$ bis*, 7527 (few tufts), $753^{2}$ (few), 7534, 7535,7535 bis*, 7537 (abundant), 7540, 7542 bis (few colonies), 7543 (many), 7543 bis, 7544 , 7545 (stolons), 7545 bis*, 7546 (dead branch)*, 7546 bis*, 7549,7549 bis*, 7550,7550 bis (few), $755^{\mathrm{x}}, 755^{\mathrm{I}}$ bis (much), 7552, $755^{2}$ bis (few), 7553 , $755^{6}$ bis (few), 7557 (large branch), $755^{8}$ (large branch living), 7559 (living), 756I (many clusters living), $75^{62}$ (many living), $75^{63}$ (many living), 7568 (small bunch), 7570, $757^{2}$ (much), 7575 (much), 7576, 7577 (several colonies), 7578 (on Mytilus), 7579 (few living), 7598 (dead), $7605^{*}, 7607^{*}, 76$ I 2 (? fragment) ${ }^{*}$, 7618 (? fragments) ${ }^{*}, 7619,7624$ (few dead stems), 7625 (few dead colonies), 7627 (few colonies), $76_{3}$ I ( I small colony), $76_{33}$ (I colony), $76_{37}$ (few stems), 7642 (few dead stems), 7645 (I colony), 7659 (few colonies), 7662 (? old fragments)*, $7663^{*}, 7666^{*}, 7670$ (few colonies), $7690^{*}, 7702^{*}, 7724^{*}, 774 \mathrm{I}$ (little)* $7744^{*}, 7746^{*}, 7749^{*}, 775^{*}, 7755^{*}$, $7759^{*}, 778^{*}, 7781^{*}, 7782^{*}, 7783^{*}$. Supplementary stations* (I906): $75^{2} 5,7537,7545$;
Eudendrium ramosum-Continued.

(I907): 7526, 7538, 7549; (I909): 7622 (fragment), 7643 (fragments), $76_{53}$ (living), $76_{57}$ (dead stems), 7660 (living and dead), 7668 (living, with gonads), 7670 (? fragments), 767 I (fragments).

Phalarope stations: I $3^{*}, I_{4}(?)^{*}, 37,5^{*}, 68$, $69^{*}, 82$, III $^{*}$, I60 (? dead stems)*, I6 6 (I bunch)*.

Concerning reproduction Bumpus records: "Colonies of Eudendrium, probably E. ramosum, were taken in a very imperfect condition June I7 [I908], apparently just beginning from old stolons * * * The earliestsigns of development of eggs occurred during the first week of July. The latest were recorded by Dr. Murbach, on September I5."

After speaking of the slight mention made of Eudendrium ramosum in the earlier accounts of our local fauna, Hargitt comments: "Can it be possible that this species is a recent comer into this region, or has it become more prolific and abundant of recent years, or was its earlier presence simply overlooked by naturalists?"

Eudendrium dispar Agassiz. [Chart 17.]

A. Agassiz, I865, p. I59; Verrill and Smith, I873, p. 734, 408; Hargitt, I901, p. 309; г008, p. 96; Nutting, Igor, p. 332 .

Naushon.-A. Agassiz. Vineyard Sound.-Verrill. Apparently no local specimens were assigned to this species by Nutting. Specimens thus identified by Dr. Hargitt were dredged rather frequently by the survey in Vineyard Sound, almost exclusively in the western half, in 8 to Ig fathoms, for the most part on bottoms of sand and gravel. Taken also at Great Round Shoal, off Nantucket, July 23, 1908*. There are no Survey records for Buzzards Bay. Hargitt's statements (r9o8, p. 96,97$)$ to the effect that this species "seems to be more common in Buzzards Bay," and that it "has not been taken on the average once per year during this period [i. e., I5 years]" were based upon a misunderstanding as to the source of certain specimens which were examined by him.

Fish Hawk stations*: 7523 bis, 7567 (several clusters) $a, 7678$ (sexually mature), 7682 (male and female), 7689,7697 (male and female), 7698 (female), 7699 (male and female), 7700 (female), 7701, 7706, 7725, 7727, 7730, 7734, $7735,7736,7739,7745$ (? fragments). Supplementary stations* (rgo6): 7567 (twice repeated) 7723. Phalarope station $58^{*}$. 


\section{Eudendrium carneum Clarke.}

Nutting, r9or, p. 333; Hargitt, 1908, p. 97.

A specimen found in United States Fish Commission collection at Woods Hole, dated December 17,1888 , locality not stated.-Nutting. Recorded by Hargitt from the following points: Piles of New York Yacht Club pier at Vineyard Haven (collected by R. C. Osburn); off Naushon, on Fucus off Gay Head (1906 and ? I907).

\section{Eudendrium tenue A. Agassiz.}

A. Agassiz, 1865, p. 160; Verrill and Smith, 1873, p. 734; Nutting, I90x, p. 333; Hargitt, I908, p. 97 .

Buzzards Bay at Naushon.-A. Agassiz. Vineyard Haven, at New York Yacht Club pier, August, 1906. (Collected by R. C. Osburn; identified by C. W. Hargitt.)

\section{Eudendrium capillare Alder.}

Hargitt, rgor, p. 3 10; I908, p. 97; Nutting, rgor, p. 334 .

"Newport, R. I., in shallow water."-Nutting. Great Harbor, Woods Hole--Hargitt. A specimen doubtfully assigned to this species by Dr. Hargitt was dredged near Quicks Hole, at Phalarope station 82 ; others recorded from Buzzards Bay, at 1909 repetitions of Fish Hawk stations 7670 (? fragmeilts) and 7672 .

\section{Eudendrium album Nutting.}

Nutting, I901, p. 334; Hargitt, I901, p. 3 I0; I908, p. 97 .

"Found on floating seaweed ... in ... tow at Woods Hole; also on United States Fish Commission wharf."-Nutting. Specimens thus identified by Dr. Hargitt were taken at Fish Hawk stations (repeated): $75^{23}$ (I906) and 7776 (I907).

\section{Eudendrium sp. undet.}

Fish Hawk stations: $75^{2} 3$ bis, $7539,754 \mathrm{I}$ bis, 7554 bis, $7555,75^{64}, 75^{64}$ bis, $75^{81}, 75^{82}, 75^{83}, 75^{84}$, $7592,7596,7599,7604,7680,7681,7768,7769$, $7770,7772,7773,7777$.

Phalarope and Blue Wing stations: I5, 5I, I08.

\section{Family CladoNEMIDAE.}

\section{Gemmaria cladophora Agassiz:}

Nutting, I90I, p. 37 r; Hargitt, I904, p. 42 ; Mayer, I9ro, p. 90 Zanclea cladophora).

"Collected at Woods Hole, August, I899." Nutting. Woods Hole (? independent record).-Hargitt.
Gemmaria gemmosa McCrady.

A. Agassiz, I865, p. 184; Verrill and Smith, I873. p. 735, 455; Fewkes, I881, p. I50; Murbach, 1898, p. 354; Nutting, 190r, p. 329, 372; Hargitt, I904, p. 42; 1908, p. I00; Mayer, I910, p. 88 (Zanclea gemmosa).

"Buzzards Bay, Naushon."-A. Agassiz. Newport, in September-Fewkes. Polyp colonies recorded by Murbach for Woods Hole, under name of "Corynitis agassizii McCrady." Since these liberated medusx which were identified as Gemmaria gemmosa, Murbach concluded that Corynitis agassizii and Gemmaria gemmosa were merely different phases in the life history of the same organism. Nutting accepted this view, but Hargitt rejects it, believing Murbach to have been mistaken in his identification of the polyp form.

\section{Family TUBULARIIDAE.}

Tubularia couthouyi Agassiz [Chart I8.]

Bumpus, I898, p. 489; I898a, p. 6r; Hargitt, I9or, p. 3 I 3 ; Nutting, I90r, p. 338.

Quicks Hole and off Nobska Point.-G. M. Gray, cited by Nutting. Vineyard Sound, common, chiefly in the eastern half; mouth of Buzzards Bay; dredged in 2 to 19 fathoms, mainlyon mudfree bottoms, and particularly among stones and gravel.-Survey. The specimens taken in the inner waters during the summer months are all, or nearly all, empty perisarcs, or ones in which the coenosarc is dormant. Living hydranths, loaded with ripe gonophores, were reported by Dr. Bumpus during March ( 1898 ), and Mr. Gray states that he has taken living specimens from January till April. Offshore, in 29 fathoms, living hydranths were dredged by the Fish Hawk in August, 1905, and at Crab Ledge small ones were met with July 2 I, I908, and August I2, I909. Nutting writes: "A number of beautiful specimens were sent me by Dr. Mead, of Brown University, who had them growing in a submerged flatboat at Providence, R. I. [season not stated]." Mr. Gray reports that he found considerable num. bers of this species growing upon the carapace of a living Limulus. Those dredged are generally attached to stones or shells. (Is Nutting justified in his statement that this species is usually found in brackish water?).

Fish Hawk stations: $75^{22}$ bis (I tube), $75^{28}$ (many tubes), 7529 (I stem), 753 I (2 stems), 7532 bis (many stems), 7533 bis (few stems), 7534 (few tubes)*, 7537 (few), 7538 (very abundant), 7538 bis (few), 7539 (few), 7544 
Tubularia couthouyi-Continued.

(numerous), 7549 bis (few), $755^{\circ}$ bis (few), 7554 bis ( $\mathrm{x}$ ), 7555,7564 ( 1 tube), 7579 ( $\mathrm{x}$ perisarc), 7588 (many stalks), 7593 (several tubes), 7595 (many tubes), 7664 (few), $766_{5}$ (few), 7666 (few), 7670 (few), 767 x (few), 7672 (several), 7673 (several), 7674, 7682 (stems), 7686 (? I tube), 7697 (few tubes), 7698 (I), 770 oI (stems), 7722 (I), 7732 (few), 7737 (several), 7738 (stems), 7753 (many): Supplementary stations (1907): $753^{*}$; (1909): $7670,7671,7672$.

Phalarope and Blue Wing stations: $x$ (I tube), 2 (several tubes), 5 ( 2 tubes), 6 (several stems), 7 (several tubes), 8 (several), 9 (numbers), Io (few), II (few), $x_{3}$ (common), I4 (few), I5 (few tubes), I7 (I tube on "Busycon shell), 20 (I tube), 28 (I stem), 82 (stems), II3, II4 (many tubes).

Tubularia larynx Ellis \& Solander.

Nutting, Igor, p. 339 .

"A number of specimens secured growing on Eudendrium dispar and on seaweed at U. S. Fish Commission station 7060, Muskeget Life-Saving station bearing N. by E. I/2 E. $4 \frac{T}{2}$ miles. Depth, 5 fathoms."

Tubularia spectabilis (Agassiz).

Nutting, rgor, p. 339.

"Found on rocks at end of Newport Island. At Woods Hole, locality not given." A specimen doubtfully referred by Dr. Hargitt to this species was taken in 1907 at a repetition of Fish Hawk station $75^{26}$.

Tubuiaria tenella (Agassiz).

Verrill and Smith, 1873 , p. 736, 407, etc. (Thamnocnidia tenella); Nutting, I901, p. 339.

"Vineyard Sound, 6 to Io fathoms."-Verrill. Crab Ledge, abundant, growing attached to sponge and to Boltenia stems; Woods Hole passage-Survey. Off Gay Head, August, I906.-Hargitt.

Fish Hawk stations: $7603 \dagger$ (abundant), 7604 , 7605 (very abundant).

Phalarope stations: $\mathrm{I}_{5}(\text { ? })^{*}$, I2 $_{2},{ }^{*}$.

Tubularia crocea (Agassiz). [Chart I9]

Verrill and Smith, 1873, p. 736,390 , etc. (Parypha crocea); Bumpus, I898, p. 858 (Parypha); Nutting, rgor, p. 340.

Dredged in abundance throughout the length of Vineyard Sound; Bay records few and restricted to the lower half; common at Crab Ledge; taken in 2 to 25 fathoms on quite various bottoms.-Survey. Abundant, also, on piles of piers, floating timbers, etc., at Woods Hole and elsewhere, and sometimes on Fucus;
Tubularia crocea-Continued.

it often flourishes in water which is somewhat brackish.

Fish Hawk stations: $75^{2 \mathrm{I}}$ (few tubes) ${ }^{*} \uparrow, 75^{2} \mathrm{I}$ bis (several clusters) $^{*}, 75^{22}$ (several tubes), $75^{22}$ bis*, $75^{23}$ bis*, $75^{2} 5$ bis*, $75^{28}$ (few stems), 753 I (bunch of stems), 7532 (few tubes), 7532 bis, 7533 (few tubes), 7535 (few tubes), 7536 bis (many living), 7538 (numerous perisarcs), 7538 bis*, 7539 (few bunches of perisares), 7540 (few perisarcs, some forming part of Diopatra tube), 7543 bis (? few colonies), 7546 (I living cluster), 7547 bis (? I colony), 755I (many living), 7553 (x cluster of tubes), 7554 (I cluster tubes), 7557 (several tufts, living), 7560 (few clusters living), $756 \mathrm{r}$ (few clusters living), 7564 (few tubes), 7566 (I cluster living), 7572 (I cluster), 7573 (few clusters, tubes), $75^{82}$ (I cluster tubes), 7603*, 7604, 7605*, 7607*†, $7608 \uparrow$ (abundant, growing on Balanus), $7609 \%, 7653$ (I bunch), 7656 (few colonies), 7689, 7690, 7692, 7697 (4 stems), 7701, 7702, 7703, 7704 (I hydranth), 7721, 7722 (fragments), 7723, 7725 , 7732 (fragments), 7733, 7739, 7745, 7753 (? fragments) ${ }^{*}, 7755^{*}$. Supplementary stations* (I907): 7521, 7538; (I909): 7653, 7660.

Phalarope and Blue Wing stations: 3 (2 large living bunches), 4 (few living), 7 (few clusters), 8 (few), 9 (many), Io (common, living), I I (few), I2 (tubes), I3 (few colonies)*, I4 (few), I5 (abundant, living), I6 (abundant, living), $2 I$ (common), 22 (ferr), 23 (few), 24 (very abundant), 26 (abundant), 27 (very abundant, living), 29 (few), 30 (few), 36 (few tubes), 39 (few tubes), 52 (few tubes), 60 (many tubes), 63 (few), 66 (several), 73 (few), 82 (few tubes), 83 (tubes), 86, II3, II4 (few), II8 (tubes), I2I (tubes).

In midsummer, in the warmer waters of the harbor, the hydranths of this species disappear by a normal process of autotomy. On the local pier, for example, living hydranths begin to be scarce about the third week in July.-Max Morse and A. J. Goldfarb. Later, they reappear in these same places, being found during the latter part of October-Morse. In somewhat cooler waters, $T$. crocea may remain in an active condition throughout the entire summer, such specimens having not infrequently been recorded during the survey dredging in Vineyard Sound, between July 6 and August 2I. Dr. Morse informs us that they may likewise be found in small numbers in Woods Hole passage, throughout the summer months.

"Breeding" hydroids found in March.-Bumpus. Reproduces in June and July.-Hargitt. 
Tubularia parasilica Hargitt. $\alpha$

Hargitt 1902 a, p. 550 (sp. nov.).

Found (parasitic?) upon the base of Corymorpha pendula, dredged in Muskeget Channel; August, I900.

Hypolytus peregrinus Murbach.

Murbach, I898, p. $34 \mathrm{I}$ (sp. nov.); Bumpus, 1898b; Nutting, I90I, p. 340; Hargitt, I90Ia, p. 315 .

Described by Dr. Murbach from specimens taken in the Eel Pond, during the summer of 1895 , and since then found on a number of occasions in the same locality. This is a free living, solitary form, capable of temporary attachment to eelgrass, etc. Only a hydroid generation occurs, which becomes sexually mature in August.

\section{Family Thaumantuda.}

Laodicea calcarata Agassiz.

L. Agassiz, I862, p. 350; A. Agassiz, I865, p. I22 (Lafoca calcarata); Verrill and Smith, I873, p. 729, 334, etc. (Lafoca calcurata); Nutting, I901, p. 353, $37^{8}$ (Hebella calcarata) Hargitt, I902, P. I4 (Lafoea calcarata); I902a, p. 554; (Lafca calcarata) Hargitt, I904, p. 43; Mayer, I9to, p. 201 (Laodicea cruciata).

Buzzards Bay, at Naushon.-A. Agassiz. " $\mathrm{Hy}$ drarium abundant on floating Zostera and algæe in Vineyard Sound, creeping over Sertularia cornicina; also at low water, and in 6 to 8 fathoms on Phyllophora.' - Verrill. Medusæ in tow at Woods Hole during July and August common.-Hargitt. Taken likewise in September, according to Verrill.

Staurostoma laciniata (Agassiz).

Hargitt, I902a, p. 553 (Staurophora laciniata); Hargitt, I904, p. 43; Mayer, I9ro, p. 29 I (Staurophora mertensii).

"Very common at times at Woods Hole and in adjacent waters."-Hargitt. Taken in May by G. M. Gray and H. M. Smith.

Melicertum campanula Agassiz.

Nutting, I90I, p. 382 ; Hargitt, I904, p. 44; Mayer, I910, p. 207.

Medusa taken at Woods Hole by V. N. Edwards.Nutting. Dr. Hargitt has not found the species here.

Orchistoma tentaculata Mayer.

Mayer, I900, p. 8 (sp. nov.); Nutting, rgor, p. 377; Hargitt, I904, p. 44; Mayer, rgro, p. 212 . ewport, one immature specimen (medusa) taken August I8, 1896.-Mayer.

\section{Family Eucopids:}

Eutima mira McCrady.

Nutting, I901, p. 378; Hargitt, 1904, p. 45; Mayer, I9Io, p. 295 .

Woods Hole.-Nutting. "Very common at Woods Hole and in Vineyard Sound during August."-Hargitt.

2Eutima limpida Agassiz.

L. Agassiz, 1862, p. 363; A. Agassiz, I865, p. Ir6; Verrill and Smith, 1873, p. 729, 454; Nutting, I90I, p. 377; Hargitt, I902a, p. 554; I904, p. 46; I908, p. IIr; Mayer, I9ro, p. 295 (Eutima mira).

"Buzzards Bay during September."-A. Agassiz. F. R. Lillie (Marine Biological Laboratory card catalogue) records having taken this species August 8 and 9, I893. Reported by Hargitt (I902) as fairly common locally, though this statement is later corrected, the earlier opinion having been based upon immature specimens of E. mira. Dr. Hargitt now states that he has never known such a species to be taken in local waters, and believes it to be "probably at most but a regional variety of E. mira."

Eucheilota ventricularis McCrady.

L. Agassiz, I862, p. 353; A. Agassiz, 1865, p. 74; Verrill and Smith, 1873, p. 725, 454; Fervkes, I88I, p. I59; Nutting, I90I, p. 379 Hargitt, Ig02 a, p. 554; Hargitt, I904, p: 46; Mayer, I910, p. 282 .

Medusæ believed to be the young of this species "exceedingly common at Naushon."-A. Agassiz. Newport.-Fewkes. "Fairly common in the waters adjacent to Woods Hole;" taken in August.-Hargitt.

Eucheilota duodecimalis Agassiz.

L. Agassiz, 1862, p. 353; A. Agassiz, r865, p. 75; Verrill and Smith, 1873, p. 725, 454; Fewkes, I882, p. 297 (Phialium duodecimale); Nutting, I90I, p. 378; Hargitt, I902a, p. 554; I904, p. 46; Mayer, I9ro, p. 283.

Buzzards Bay at Naushon.-A. Agassiz. Newport, Woods Hole.-Nutting. Woods Hole, Hargitt. Recorded for July and August.

Tima formosa Agassiz.

Verrill and Smith, 1873 , p. 729,448 , etc.; Fewkes, I88r, p. I57; Nutting, I901, p. 379; Hargitt, I902a, p. 553; I904, p. 47; Mayer, I9I0, p. 317.

"Vineyard Sound, February and April." - Verrill. "Very abundant at Newport, in May."Fewkes. Woods Hole.-F. M. Walmsley, cited by Nutting. "Rather general through- 
Tima formosa-Continued.

out the region." - Hargitt. According to Mr. Edwards's extensive towing records, this species is most abundant locally in April and May, though taken as early as February, and again in August and September.

Tiaropsis diademata Agassiz.

Verrill and Smith, I873, p. 725,454 , etc.; Mead, I898, p. 704; Nutting, r901, p. 38r; Hargitt, I902a, p. 552; I904, p. 49; Mayer, I91o, p. $25^{8}$.

"Woods Hole; April I7 (V. N. Edwards)."Verrill. "Taken frequently,' April, I908.Mead. "Occasionally taken at Woods Hole, March to May."-Hargitt. March 4, 1907, a few young.-A. G. Mayer.

\section{Oceania languida Agassiz.}

I. Agassiz, 1862, p. $35^{2}$; A. Agassiz, 1865, p. 70; Verrill and Smith, 1873 , p. 725, 454; Hargitt, I902, p. I3; 1904, p. 50; Mayer, I9Io, p. 269 (Phialidium languidum).

Naushon, in September--A. Agassiz. Buzzards Bay; common in Vineyard Sound.Verrill. "Very abundant in the Woods Hole region, . . . June to September.'-Hargitt.

\section{Oceania singularis Mayer.}

Mayer, I900, p. 7 (sp. nov.); Nutting, I90I, p. 380; Hargitt, I904, p. 50; Mayer, I910, p. 273 (Phialidium singularis).

A single specimen taken at Newport, August 22, 1806 .

Epenthesis folleata McCrady.

Fewkes, 1882, p. 298; Nutting, I90r, p. 38r ; Hargitt, I902, p. I3; I902a, p. 554; I904, p. 50; Mayer, I91o, p. 264 (Clytia folleata).

Newport.-Fewkes. "Common in Vineyard Sound, Woods Hole, etc., from July to September." -Hargitt. According to Mr. Edwards's towing records, this medusa has been taken locally from February to December, being most common in May.

\section{Family CAMPANULARIIDE.}

\section{Clytia bicophora Agassiz.}

A. Agassiz, 1865, p. 78 ; Verrill and Smith, I873, p. 725,408 , etc. (Clytia johnstoni); Bumpus, r898b, p. 857; Nutting, I9or, p. 343, 379; Hargitt, I904, p. 46; Mayer, rgro, p. 262 (Clytia volubilis).

Vineyard Sound.-L. Agassiz. Naushon.-I. and A. Agassiz. "Buzzards Bay; Vineyard Sound, I to 14 fathoms, common," attached to larger hydroids and algæ--Verrill. "Found on the stems of Tubularia crocea ... on the
Clytia bicophora-Continued.

piles of the United States Fish Commission dock at Woods Hole. '-Nutting. Hydroid colonies found locally on Fucus or among other hydroids, shells, etc. Medusa "frequent in the tow at Woods Hole,' in summer.--Hargitt.

Nutting regards this species as quite distinct from $C$. johnstoni Alder, with which it has been placed by Hincks and by Verrill.

Clytia cylindrica Agassiz.

L. Agassiz, I862, p. 354 (Platypyxis cylindrica); A. Agassiz, 1865, p. 80 (Platypyxis cylindrica); Verrill and Smith, r873, p. 726, 408, etc. (Platypyxis cylindrica); Nutting, I901, p. 343; Hargitt, I909, p. 374 .

Buzzards Bay, at Naushon.-A. Agassiz. "Vineyard Sound; off Buzzards Bay, 25 fathoms." Verrill. Buzzards Bay, at 1909 repetition of Fish Hawk station $7653 . *$-Survey.

Clytia noliformis (McCrady).

Nutting, Ig01, p. 343, 379; Hargitt, I904, p. 47. Dr. Nutting regards the occurrence of this species at Woods Hole as doubtful. According to Dr. Hargitt, however, the medusa is not uncommon locally.

Clytia grayi Nutting.

Nutting, Igor, p. 344 (sp. nov.).

Nutting's record refers to specimens dredged by the Fish Hawk south of Marthas Vineyard in 3 fathoms; thus not strictly within the region. Likewise taken off Crab Ledge.-Hargitt.

Clytia volubilis Lamouroux.

Hargitt, I909, p. 373 .

Neighborhood of Woods Hole, on floating masses of sargassum.

Campanularia poterium (Agassiz).

Verrill and Smith, 1873, p. 726, 408, etc. (Orthopyxis caliculata); Nutting, rgor, p. 344 .

"Off Gay Head and in Vineyard Sound, 4 to $\mathrm{r}_{5}$ fathoms."-Verrill. Off Nantucket, in 23 fathoms.-Nutting.

Campanularia hincksii Alder.

Nutting, I9or, p. 345 .

"A specimen was secured from a depth of ${ }^{5}$ fathoms near Newport, R. I."

Campanularia volubilis (I,innæus).

Verrill and Smith, 1873, p. 726,408 , etc.; Nutting, Igor; p. 345 .

"Vineyard Sound to Greenland,"-Verrill. "Found growing on Sertularella tricuspidata on specimens in the U. S. Fish Commission collection; supposed to be from rather deep water."-Nutting. 
Campanularia minuta Nutting.

Nutting, I9or, p. 345 (sp. nov.).

"Parasitic on Obelia commissuralis from the piles of the wharf at New Bedford. Collected by Mr. Vinal Edwards."--Nutting.

Campanularia edwardsi Nutting.

Nutting, I90r, p. 346 (sp. nov.).

The type specimen was found on the piles of the U. S. F. C. dock at Woods Hole."

Campanularia neglecta (Alder).

Nutting, Igor, p. 346.

Woods Hole. Said to occur "in shallow water, on stones, shells, and other hydroids."

Campanularia verticillata (Linnæus).

Nutting, I9or, p. 347 (not listed for strictly local waters); Hargitt, I908, p. II2.

A specimen thus identified by Prof. Nutting was dredged by the survey at Crab Ledge (Fish Hawk station 7609) in I903. Prof. Hargitt thus identifies specimens found upon a valve of Modiolus taken by Mr. Edwards off Sankaty Light, at a depth of 25 fathoms.

Campanularia amphora (Agassiz).

A. Agassiz, 1865, p. 93 (Laomedea amphora); Verrill and Smith, I873, p. 727, 327 (Campanularia flexuosa); Bumpus, I898, p. 858 (Laomedea amphora); Nutting, I90I, p. 347.

Naushon.-A. Agassiz. On Fucus, with ripe gonophores, June 2, I89o-J. P. McMurrich, in Marine Biological Laboratory card catalogue. "Common in shallow water in the Woods Hole region." -Nutting.

Verrill confuses this species with $C$. flexuosa Hincks, and includes both species under C. flexuosa.

?Campanularia angulata Hincks.

Nutting, rgor, p. 347 .

Woods Hole region (specimens identified doubtfully by C. C. Nutting).

Campanularia calceolifera Hincks.

Verrill, I875, p. 42; Nutting, I90I, p. 348.

United States Bureau of Fisheries pier at Woods Hole--Verrill, Nutting.

Campanularia flexuosa (Hincks).

Verrill and Smith, 1873 , p. 726, 327, etc.; Nutting, I90r, p. 348 .

Vineyard Sound, off Gay Head.-Verrill. (By Verrill C. amphora (Agassiz) was also included under this species). "One of the most abundant species at Woods Hole," occurring "on floating seaweed and on rocks and timbers in shallow water."-Nutting. Vineyard Haven. (Collected by Osburn, identified by Hargitt.)
Obelia flabellata (Hincks).

Verrill and Smith, I873, p. 728, 390, etc.; Nutting, I90I, p. 350; Hargitt, I902, p. I4; I908, p. I09; Mayer, I910, p. 249 (Obelia plana).

Woods Hole, on old wreck, in the passage.Verrill. "Collected by Mr. George M. Gray at Woods Hole in April, 1906, and in the aquarium numerous medusæ were liberated."'-Hargitt.

Obelia commissuralis McCrady.

L. Agassiz, 1862, p. 35r; A. Agassiz, 1865, p. 9r; Verrill and Smith, I873, p. 728, 327, etc.; Nutting, I90r, p. 350,380 ; Hargitt, 1904, p. 48; Mayer, I9Io, p. 244.

Hydroids common and of general distribution in shallow waters locally, being found on rocks, piles, or seaweed. In the Survey dredging recorded only from Fish Hawk stations $7678^{*}$, $7680^{*}$, and $7707^{*}$. Medusæ taken in abundance occurring from July to September.

Obelia diaphana (Agassiz).

I. Agassiz, 1862, p. 352 (Eucope diaphana); A. Agassiz, 1865 , p. 83 (do.); Verrill and Smith, I873, p. 727,327 , etc.; Hargitt, I904, p. 48; Mayer, Igro, p. 249 (Obelia geniculata).

Hydroids reported as abundant in local waters, on Fucus, etc.; medusæ likewise common, being referred to by A. Agassiz as "by far the most common of our jellyfishes." According to this writer, the medusæ occur from March to November.

Obelia dichotoma (Linnæus).

Verrill and Smith, I873, p. 728, 407, etc.; Nutting, I90I, p. 350; Mayer, I910, p. 246.

"Vineyard Sound, northward; . . . . off Gay Head, 8 to ro fathoms, on ascidians."-Verrill.

Nutting thinks it likely that this is the same species as Eucope pyriformis A. Agassiz.

Obelia geniculata (Linnæus). [Chart 20.]

Verrill and Smith, 1873, p. 727, 407, etc.; Nutting, I9or, p. 35r, 380; Hargitt, I902, p. I4; Mayer, I9Io, p. 249.

Dredged by the Survey throughout Vineyard Sound, and occasionally in the lower half of Buzzards Bay, occurring at I to 16 fathoms, on various bottoms, generally growing on Laminaria or other seaweeds; taken most abundantly at the western end of the Sound. This species is likewise common on piles and floating timbers, and is occasionally found growing in profusion on other animals, such as Lepas, the sargasso crabs, and even the sea horse (Hippocampus). The medusæ occur during the summer. 
Obelia geniculata-Continued.

Fish Hawk stations: $75^{2} 5$ bis, 7532 bis, 7535 bis*, 7543 bis, $7548^{*}, 755^{\mathrm{I}}, 7557,7560,7575,7579$, $75^{82}, 75^{8} 3,75^{85}, 75^{89}, 7592,7593,7595,7610$, $7637,7642,7656(?)^{*}, 7662,7664,7667,7671^{*}$, $7678^{*}, 7679(?)^{*}, 7701(?)^{*}, 7702(?)^{*}, 7703^{*}$, $7704^{*}, 7706^{*}, 7709(?)^{*}, 7718^{*}, 7720^{*}, 7722^{*}$, $7723^{*}, 7726(?)^{*}, 7730(?)^{*}, 7731(?)^{*}, 7739^{*}$, $7755^{*}, 7767^{*}$. Supplementary stations: Approximate repetitions in 1907 of stations $752 \mathrm{I}$, $75^{8} \mathrm{I}, 773$ I (?), 7739.

Phalarope and Blue Wing stations: $17,24(\text { ? })^{*}$, 28 (?), 29 (?), $32^{*}, 33,34,44^{*}, 47^{*}, 51^{*}, 57$, $58^{*}$, I I $4^{*}$, I I $8^{*}$.

\section{Obelia gelatinosa (Pallas).}

Verrill and Smith, I873, p. 728, 39r, etc. Nutting, I90I, pp. 35r, 380; Hargitt, I904, p. 48; Mayer, I9ro, p. 244.

Listed by Nutting and Hargitt for the region. According to Verrill, this species is sometimes found in waters which are quite brackish, while Nutting states that it may grow between tides.

\section{Obelia pyriformis (A. Agassiz).}

Verrill and Smith, 1873, p. 727,390 , etc.; Hargitt, I904, p. 49; Mayer, I910, p. 247.

"Very abundant on piles of wharves, etc., at Woods Hole."-Verrill. Hargitt records the medusæ locally. Nutting thinks it likely that this species is identical with Obelia dichotoma (Linnæus).

\section{Obelia bicuspidata Clarke.}

Nutting, I9or, p. 35r; Mayer, I9ro, p. 254 (Obclia bidentata).

"Near Woods Hole, I9 fathoms."-Nutting. Vineyard Haven.-Hargitt.

Obelia longissima (Pallas).

Verrill and Smith, $x 873$, p. 728 ; Nutting, I90I, p. 35r, 379; Mayer, r9ro, p. 255.

Gay Head.-Verrill. Woods Hole-Nutting.

\section{Obelia bidentata Clarke.}

Nutting, Igor, p. $35^{\mathrm{r}}$ (not recorded locally); Mayer, I9ro, p. 254.

Vineyard Haven.-Hargitt.

\section{Obelia congdoni Hargitt.}

Hargitt, I909, p. 375 (sp. nov.)

Vicinity of Woods Hole, on floating sargassum, taken during the summers of 1907 and 1908 .
"Obelia polygena Verrill" (said to be equivalent to Eucope polygena A. Agassiz) and "Obelia divaricata Verrill"' (=Laomedea divaricata $\mathrm{McCrady})$ are likewise listed by Verrill and Smith ( 1873, p. 727 ), the former species being recorded as taken "off Gay Head, 4 to 5 fathoms, not common," the latter "found on floating algæ in Vineyard Sound." The identity of the species here referred to is not certain.

Obelia sp. undet.

Unidentified specimens belonging to this genus, but probably referable to one or more of the above species, are recorded for Fish Hawk station 7676 and Blue Wing stations $2 x$ and 23.

Gonothyrce loveni Allman.

Nutting, rgor, p. $35^{2}$; Hargitt, rgora, p. 386.

Woods Hole, "on fucus and other algæ, rocks, etc.;"' taken off Nantucket in June, I906, by Mr. Edwards.-Hargitt.

\section{Family LAFGIDAE.}

Lafoca dumosa Fleming.

Nutting, r9or, p. 355 .

Nantucket Shoals, growing on other hydroids. Verrill, cited by Nutting.

Lafoca gracillima (Alder).

Nutting, I901, p. 356; Hargitt, I908, p. II3.

"Although not specifically reported from the Woods Hole region, it doubcless occurs there, as its distribution is much like that of $L$. dumosa." -Nutting. Prof. Hargitt found specimens which he thinks were probably referable to this species upon a shell dredged off Sankaty Light at a depth of 25 fathoms.

Hebella pygmaa Hincks.

Nutting, I90r, p. 353 .

"Found on a polyzoon off Nantucket; Sankaty Light, east by south; depth, 24 fathoms (Vinal Edwards)."

Hebella sp. undet.

A minute species taken at Crab Ledge.-Hargitt.

\section{Family HydroceratiNID无.}

Keratosum complexum Hargitt.

Hargitt, r909, p. 379 (sp. nov.); Hargitt, I9II, p. $\mathrm{I}_{7}$.

Crab Ledge, summers of 1903 and rgog. Superficially, this species bears considerable resemblance to a branching sponge, and was at first regarded as such. All of the specimens which have been examined by Dr. Hargitt appear to be in a state of degeneration, perhaps of xstivation, "no hydranths or similar organs being distinguishable." 


\section{Family Campanulinide.}

Lovenella grandis Nutting.

Nutting, I90I, p. 354 (n. sp.); Hargitt, r908, p. 112 .

Newport Harbor, off Castle Hill.-Nutting. Kopeecon Point, at Phalarope station 66.* Survey.

Opercularella pumila Clarke.

Hargitt, I909, p. 375 .

A few specimens were dredged by the Survey in Vineyard Sound, off Naushon, in March, I908, which Dr. Hargitt regards as identical with Clarke's species above named. This is the first record of occurrence since the original description.

Calycella syringa (Liunæus).

Nutting, I90r, p. 355; Hargitt, I909, p. 376.

Found abundantly in the Woods Hole region, "growing over all sorts of plant-like marine organisms, especially other hydroids. "-Nutting. Seasonally abundant, according to Hargitt. "Rather uncommon during the midsummer season," and then apparently not reproducing sexually. In early spring, "it seems much more abundant and immense colonies with prolific crops of gonangia are not rare." Crab Ledge and off Sankaty Head.Hargitt. Tarpaulin Cove, March, I908. (Dredged by Sumner, identified by Hargitt.)

Calycella nuttingi Hargitt.

Hargitt, I909, p. 378 (sp. nov.).

Woods Hole; fishing grounds off Sankaty. A very minute species, found first upon Bugula turrita, and in general "found only associated with other hydroids, or similar organisms, e. g., Bryozoa."

\section{Family ÆQUOREIDAE.}

?Stomobrachium tentaculatum Agassiz.

Hargitt, I904, p. 5I; Mayer, I910, p. 322.

"I have occasionally taken at Woods Hole what may have been fragments of ... this medusa."-Hargitt.

Rhegmatodes tenuis Agassiz.

L. Agassiz, I862, p. 36r; A. Agassiz, 1865, p. 95; Verrill and Smith, 1873 , p. 729, 454; Nutting, I90I, p. 383 ; Hargitt, I902a, p. 553; I904, p. 52; I908, p. II2; Mayer, IgIo, p. 332 (Equorea tenuis).

Recorded for local waters by a number of writers. The species is one of decidedly variable frequency, "occurring at very irregular periods,
Rhegmatodes tenuis-Continued.

and a very erratic manner." At times it is abundant, while a number of years may elapse without its being observed at all. (See particularly Hargitt, I908.)

Ova shed early in morning, August 15, I893.-J. P. McMurrich, in Marine Biological laboratory card catalogue.

Equorea albida Agassiz.

L. Agassiz, I862, p. 359; A. Agassiz, I865, p. I10; Verrill and Smith, 1873, p. 729, 454; Nutting, IgOI, p. 382; Hargitt, Igorb, p. 592; I g04, p. 52; Mayer, r9io, p. 33I.

Recorded for local waters by A. Agassiz and by Hargitt. According to the latter author, this medusa is "not uncommon ... during late summer and autumn."

Zygodacty'la grœnlandica (Peron \& Lesucur).

A. Agassiz, 1865, p. I03; Verrill and Smith, 1873, p. 729, 449, etc.; Fewkes, 1881, p. 156; Nutting, I90r, p. 382 ; Hargitt, I904, p. 52 ; Mayer, I gro, p. 335 .

Recorded for local waters by various observers, who report its occurrence from June to September. Verrill refers to this species as common, Hargitt as occasional.

\section{Family HALECIIDA.}

Halecium halecinum (Linnæus). [Chart 2I.]

Nutting, Igor, p. 357 .

"Abundant throughout the Woods Hole region, growing on shells, stones, etc., in shallow water."-Nutting. Dredged by the survey with considerable frequency throughout the length of Vineyard Sound, and at scattered stations throughout Buzzards Bay; occurring in 3 to 16 fathoms, on quite various bottoms.

Fish Hawk stations: $752 \mathrm{I}$ bis*, $754 \mathrm{I}$ bis*, $755 \mathrm{I}$ (many, branches) $\uparrow, 7554$ bis, 7563 bis*, 7569 bis*, 7576 (on Arca pexata shell) †*, 7592 (large tuft on Mytilus shell) $,, 7610^{*}, 1612(?)^{*}, 7613^{*}$, $7625(?)^{*}, 7636^{*}, 7676^{*}, 7678^{*}, 7679^{*}, 7680$ (mature female)*, 768I (male)* $7682^{*}, 7687$ (fragment) $^{*}, 7697^{*}, 7698^{*}, 7699^{*}, 7700^{*}, 7701^{*}$, $7706^{*}, 7708^{*}, 7717^{*}, 7720^{*}, 7724^{*}, 7727^{*}, 7228^{*}$, $7730^{*}, 773$ I (poor specimen)*, 7734 (fragments)*, $7735^{*}, 7736^{*}, 7737(?)^{*}, 7738(?)^{*}, 774 \mathrm{I}(?)^{*}$, $775^{*}, 772^{*}, 7766^{*}, 7777^{*}, 7780^{*}, 7782^{*}$. Supplementary stations* (I906): 7723; (I907): $75^{2} 6$, $7549,7592,7776,7780$; (I909): 7618 (? dead stems), 7638 (living), 7659 (attached), 7660 (fragments), 7672 (living, with gonads).

Phalarope stations*: I5, 68, 81, 82, II 3, II 4, II 5 , I 8 , I50 (common), I62, I66, I67 (on Spisula shell). 
Halecium articulosum Clarke.

Nutting, I901, p. 357 (not recorded for the region as here defined); Hargitt, I,08, p. I06.

Off Gay Head, July I5, I907, on carapace of a small spider crab.-Hargitt.

Halecium tenellum Hincks.

Nutting, r9or, p. 357 .

Woods Hole.-Nutting. Crab Ledge, rgo8.Hargitt.

Halecium beani (Johnston).

Nutting, I9or, p. $35^{8}$.

"Found growing on bivalve shells at Woods Hole."

\section{Halecium gracile Verrill.}

Verrill and Smith, I873, p. 729, 328, etc. (sp. nov.); Nutting, rgor, p. 358 .

Buzzards Bay and Vineyard Sound.-Verrill. Said to be "frequently found growing in profusion on the under side of stones, in tide pools, and attached to oysters, dead shells, etc., in shallow waters, both in the sounds and estuaries." Also said to occur on piles and floating timbers.

Halecium sp. undet.

Fish Hawk stations: $76 \mathrm{r} 5,7675,777 \mathrm{r}, 7778,778 \mathrm{I}$. (Specimens too poor to be determined specifically.)

\section{Family SERTULARIID}

\section{Sertularia pumila Linnæus.}

A. Agassiz, I865, p. I4I (Dynamena pumila), Verrill and Smith, I873, p. 732, 327, etc.; Nutting, I9or, p. 359 ; r904, p. 5 I.

Nantucket.-L. Agassiz. Vineyard Sound.Verrill. Generally distributed in the shallow waters of the region, occurring on Fucus and other seaweeds and on piles. Dredged by the Survey, on a few occasions, in Vineyard Sound, at depths of 4 to 12 fathoms.

Fish Hawk stations: 7535 bis*, 7750*, 7767*, 777 I*. Supplementary stations: 755 I (I907), $776_{3}$ (1907).

Phalarope station $63 *$.

Sertularia versluysi Nutting.

Nutting, 1904, p. 53; Hargitt, I908, p. II2.

Prof. Nutting records this species as occurring upon gulf weed, but not specifically for this locality. Prof. Hargitt has found it on some floating sargassum, collected by Mr. Edwards in Vineyard Sound, August 30, I906.

Sertularia gracilis Hincks.

Verrill, I875, p. 43; Nutting, I904, p. 57.

Taken on sargassum at Hyannis.-Verrill. A specimen in the National Museum from Naushon.-Nutting.
Sertularia cornicina (McCrady).

Verrill and Smith, I873, p. 733 , 408, etc.; Nutting, I901, p. 359 (Sertularia comicina); p. 360 (S. complexa); rgo., p. $5^{8}$.

"Not uncommon in Vineyard Sound, I to 8 fathoms, often on Halccium gracile; also on floating Zostera, etc., and covered with Lafoca calcarata."-Verrill. "Found . . . growing in great quantities over seaweed dredged from the bottom near Nobska Point."-Nutting.

Not to be distinguished from S., complexa Clarke.-Nutting.

Thuiaria thuja (Linnæus).

Nutting, I901, p. $364 ;$ I904, p. 62.

Off Nantucket. (Collected by V. N. Edwards; identified by Nutting).

Thuiaria argenta (E1lis \& Solander). [Chart 22.]

Verrill and Smith, I873, p. 732 , 408, etc. (Sertularia argentea); Bumpus, 1898 , p. 480 (Sertularia argentea); G. M. Gray, in "Biological Notes, No. I," I900 (Sertularia argentca); Nutting, I90I, p. 363; I904, p. 7 I; Sumner, r9Io, fig. 9 .

Abundant in Vineyard Sound, particularly in the eastern half; in Buzzards Bay, scarce and chiefly restricted to the lower half; dredged in I to 20 fathoms, predominantly on gravelly or stony bottoms devoid of mud.-Survey. Collected on piles at Vineyard Haven.*

Fish Hawk stations: $75^{2} \mathrm{I}^{*}, 75^{21}$ bis (many), $75^{22}$ bis (many clusters), $75^{23}$ (many)*, $75^{2} 3$ bis*, $75^{24}$ (small branch)*, $75^{24}$ bis (many clusters), 7525 bis (abundant on stones)*, 7527 (I branch)†, 7530 bis*, 7533 bis (many on stones), 7534 (many stems on stones), 7534 bis (very abundant), 7535 bis*, 7539 bis*, 754r (numerous), 7545 (on stones)*, 7545 bis*, 7547 (few stems on Spisula shells) $\dagger, 7549 *$, 7550*, 7558 (on Venus shells)*, 7562, 7563, 7572, 7608*, $7615^{*}, 7663^{*}, 7682,7689$ (fragments), 7722 (fragments), 7724, 7725*, 7732, 7733, 7734, 7737, $7738,7739,7741,7744^{*}, 7747^{*}, 772^{*}, 7753^{*}$, $7755^{*}, 7756$ (fragments)*, 7763*, 7766*, $7767^{*}$, $7768^{*}, 7769^{*}, 7770^{*}, 7772 *, 7773^{*}, 7775^{*}$.

Supplementary stations (I906): $75^{22}, 775^{2}$, (1907):* 7521, 7538, 7549, 755 I, 7581, 7763, 7766, $7770,7775,7776,7780,7783$; (r909): 7653 (fragments), 7657 (dead stems), 7660 (fragments), 7668 (fragments), 7672 (fragments).

Phalarope and Blue Wing stations*: I (few), 2, $4, I_{3}, 5$ I, 83, IOS, I I 4, II 5 .

Apparently for the most part empty perisarcs are to be found during the summer months. Mr. Gray states that living specimens are taken from early winter till April, and that ripe gonophores are present in March and April. Bumpus likewise records the taking of these hydroids, "laden with eggs," in March. 
Thuiaria cupressina (Linnæus).

Verrill and Smith, 1873 , p. 732,408 , etc. (Sertularia cupressina); Nutting, I901, p. 364; 1904, p. 72 .

"Vineyard Sound, not common.-Verrill. "E. by S. Sankaty Light, 25 fathoms." -Nutting. Vineyard Sound(?); Buzzards Bay(?); Crab Ledge(?).-Survey.

Owing to differences of opinion between our authorities as to the identity of specimens submitted to them, the Survey records for this species must be entered as doubtful. Specimens from the following stations were identified by Prof. Nutting as Thuiaria cupressina: $7537,7581,7603,7605,7607$. The same specimens, from the first, third, and fourth of the foregoing stations, were assigned by Prof. Hargitt to $T$. argentca, while the latter writer doubtfully agrees with Prof. Nutting in the case of the specimen from $758 \mathrm{I}$, and likewise identifies as $T$. cupressina a specimen from station $76 \mathrm{I}_{2}$.

Pasythea nodosa Hargitt.

Hargitt, 1908, p. II4 (sp. nov.).

Taken from gulfweed collected in local waters.

Sertularella gayi (Lamouroux).

Nutting, I90r, p. 363; I904, p. 78 .

"E. by S., Sankaty Light, Nantucket, 25 fathoms." -Nutting. Crab Ledge at Fish Hawk station $7609 \dagger$.

Sertularella polyzonias (Linnæus).

Nutting, rgor, p. 362 ; I904, p. 90.

Not recorded by Nutting for the region as here defined. Dr. Hargitt thus identifies a specimen taken by Mr. Edwards off Nantucket.

Sertularella tricuspidata (Alder).

Nutting, Igor, p. 362; I904, p. I00.

“E. by S., Sankaty Light, 25 fathoms." -Nutting. Crab Ledge, in 16 to Ig fathoms, gravel and stones.-Survey. Off Nantucket, June, Igo6. (Collected by Edwards, identified by Hargitt.)

Fish Hawk stations: $7604 \uparrow, 7606 \uparrow, 7607 \uparrow$.

Diphasia fallax (Johnston).

Nutting, I90r, p. 36r; I904, p. ro9.

"E. by S., Sankaty, Nantucket, 23 fathoms, V. N. E." -Nutting.

Abietinaria abietina (Linnæus).

Nutting, I9ог, p. 362 (Sertularella abietina), I904, p. II 4 .

"E. by S. Sankaty Light, 20 fathoms."-Nutting.

Off Nantucket, June, I906. (Collected by Edwards, identified by Hargitt.)
Hydrallmania falcata (Linnæus).

Verrill and Smith, r873, p. 733,408 , etc.; Nutting, I901, p. 364; I904, p. 124.

"Vineyard Sound, and off Gay Head, 6 to 20 fathoms." - Verrill. "Common in rather deep water throughout the Woods Hole region." Nutting. Western part of Vineyard Sound, in 7 to $\mathrm{I}_{3}$ fathoms, on sandy bottoms. - Survey.

Fisin Hawk stations*: 7679, 7703, 7706, 7709, $7717,7724,7736$.

\section{Family Plumularidde.}

Antennularia antennina (Linnæus).

Verrill and Smith, 1873 , p. 730,497 , etc.; Nutting, I900, p. 69; I901, p. 367.

"Off Gay Head, 8 fathoms."-Verrill. "Off Gay Head, I $81 / 2$ fathoms. Newport Harbor; Woods Hole (George Gray)." -Nutting.

? Antennularia americana Nutting.

Nutting, r900, p. 69; I90I, p. 368.

"Off Marthas Vineyard, Albatross. Waters of Rhode Island."-Nutting. These records doubtfully warrant the inclusion of this species in the present list.

Monostachas quadridens (McCrady).

Nutting, x900, p. 75; I90r, p. 365; Hargitt, I9ora, p. 394 .

"Dredged by the Albatross near Marthas Vineyard. Depth 22 fathoms." -Nutting.

Schizotricha tenella (Verrill). [Chart 23.]

Verrill and Smith, 1873, p. 731, 407 (Plumularia tenella, sp. nov.); Nutting, I900, p. 80; I901, p. 365; Hargitt, I9ora, p. 394.

"Off Gay Head, 8 to Io fathoms, among ascidians; Vineyard Sound, 8 fathoms."-Verrill. "Found abundantly on the piles of the wharves at Woods Hole and Vineyard Haven." -Nutting. Eastern third of Vineyard Sound, 8 to $I_{3}$ fathoms, gravelly bottom; Buzzards Bay, at two stations, one of these being at the head: in both cases fragments.-Survey.

Fish Hawk stations: $75^{2} 6$ (small piece, associated with Pennaria) $\dagger, 753^{8}$ bis*, $7742^{*}, 7745^{*}$, $7748^{*}, 7754^{*}, 7755^{*}, 7763^{*}$; also at a roo repetition of station $7538^{*}$, and at 1909 repetitions of stations 7634 and 7660 .

Aglaophenia minuta Fewkes.

Nutting, I900, p. 96 (not listed for this region); Hargitt, I908, p. rog.

From floating sargassum in Vineyard Sound, August 30, 1906, again in 1908.-Hargitt. 
?Aglaophenia struthionoides (Murray).

Verrill and Smith, 1873, p. 730 (Aglaophenia arborea); Nutting, 1900, p. I02.

"Shoals of Nantucket, ro miles east of Sancati Head, I4 fathoms." -Desor, cited by Verrill. Prof. Verrill now thinks that this species was recorded through an error, probably caused by mixing labels, as the species has not been taken otherwise except on the Pacific coast (see Nutting, I900).

\section{Family PETASID}

Gonionemus murbachii Perkins.

Murbach, I895 (Gonionemus sp.); Thompson, 1898 (Gonionemus); Nutting, rgor, p. 382 (Gonionemus vertens); Mayer, Igor, p. 5 (Gonionemus murbachii, nom. nov.) ${ }^{a}$; Perkins, I902 (Gonionema murbachii); Hargitt, I904, p. 53; Mayer, I9Io, p. 343, 497.

Abundant at Woods Hole, particularly in the Eel Pond. Recorded also from Vineyard Sound and Hadley Harbor, by Murbach; from Vineyard Haven, by Hargitt, and from Muskeget Island, by R. L. Baird. Perkins calls attention to the fact that this now abundant species was first taken in I894. Its more familiar habitat is among eelgrass, to which it clings by its tentacles.

Sexual season from July to October.-Murbach. Period of maximum sexual activity from the middle of July to the middle of August; eggs extruded at dusk.-Perkins. It has been shown by Perkins that an inconspicuous hydroid phase occurs in the life history of this species, during which asexual multiplication by budding occurs.

Locally this medusa has been an important object of experimental research. It survives transportation, and Dr. Perkins has kept specimens alive for six months in aquarium jars.

\section{Family TRACHYNEMIDAE.}

\section{Rhopalonema typicum (Maas).}

Hargitt, I904, p. 54; Mayer, I91o, p. 378 (Rhopalonema velatum).

"Fragments taken in the tow in Vineyard Sound."-Hargitt.

\section{Family Aglaurid F, $_{\text {. }}$}

\section{Aglantha digitalis (Müller).}

Verrill and Smith, 873, p. 725, 454 (Trachynema digitale); Fievkes, I88I, p. I60 (Trachynema
Aglantha digitalis - Continued.

digitale); Nutting, I9or, p. $38 \mathrm{I}$ (Trachynema digitale); Hargitt, Igo2a, p. 553 (Trachynema digitale); Hargitt, 1904, p. 55 (Aglantha digitalis); Mayer, I9ro, p. 402 (Aglantha digitale).

"Woods Hole, July I, young specimens." Verrill. Woods Hole, March to May,-C. W. Hargitt. Mr. G. T. Hargitt found sexually mature specimens in abundance, from April 5 to II, I9O8.

Aglantha conica Hargitt.

Hargitt, I902, p. 2 (sp. nov.); I904, p. 56; Ig08, p. III.

Off Nantucket and off Chatham, in August, r902; Woods Hole, April 25 to 30 , I906; taken towing in $I 2$ to 20 fathoms, likewise at surface.-Hargitt.

\section{Family GerRYoNID瓜.}

Liriope scutigera McCrady.

Fewkes, I88I, p. I62; Hargitt, I904, p. 56; Mayer, I9Io, p. 421.

Newport.-Fewkes.

Glossocodon tenuirostris (Agassiz).

Mayer, I900, p. 165; Hargitt, I904, p. 57 ; Mayer, I910, p. 42 (Liriope scutigera).

Occasional at Newport.-Mayer.

\section{Family Cunanthidas.}

Cunina discoides Fewkes.

Fewkes, I88I, p. I6r; Hargitt, I904, p. 57.

Occasional at Newport.-Fewkes.

\section{Family PORPITID Es.}

\section{Porpita linnceana Lesson.}

Fewkes, I880, p. I40; Hargitt, I904, p. 59.

"Occasionally taken at Woods Hole, Vineyard Sound, Newport, R. I., etc."-Hargitt. Fewkes notes having received "a dried specimen [of 'Porpita'] preserved on paper after the manner of a plant, taken by a sailor not far from Nantucket."

\section{Family VELELLIDAE.}

Velella mutica Bosc.

Verrill and Smith, 1873, p. 737 , 455; Hargitt, I904, p. 59.

"Coming northward in the Gulf Stream as far as Nantucket:" recorded for August.-Verrill. "Occasionally taken in Vineyard Sound, Buzzards Bay, and off Newport."'-Hargitt.

$a$ The species was only named in this paper, in a footnote. No description was given. Mayer (rgro) now credits the first real description to Perkins. 
Family MoNophyid

Spheronectes gracilis (Claus).

Fewkes, r88r, p. I43; Hargitt, r904, p. 6r.

Newport.-Fewkes.

\section{Family DipHYide.}

Diphyes bipartita Costa.

Hargitt, rgo., p. 59.

Often taken at Newport.-Mayer. "Not infrequently drifts into the bays of the region from the Gulf Stream."-Hargitt.

Diphyopsis campanulifera Eschscholtz.

Hargitt, I904, p. 60 .

"Frequently taken in the deeper tows, particularly south of Marthas Vineyard and in the region of Nantucket.'

\section{Family AgALMID我.}

Cupulita cara Agassiz).

A. Agassiz, 1865, p. 200 (Nanomia cara); Fewkes, I88r, p. I63 (Agalma elegans); Hargitt, rgo.4, p. 60.

Newport.-A. Agassiz.

\section{Family ANTHOPHYSIDE:}

? Anthophysa formosa (Fiewkes).

Hargitt, 1904, p. 60.

A single specimen taken "south of Marthas Vineyard " in the summer of $\mathrm{I} 9 \mathrm{O}_{2}$ (beyond limits of region?).

\section{Family Puryalides.}

Physalia pelagica Bosc.-Portuguese man-of-war.

A. Agassiz, 1865, p. 214 (Physalia arethusa); Verrill and Smith, I873, p. 737,450 ; Hargitt, I904, p. $25,6 \mathrm{r}$.

Taken nearly every summer in Vineyard Sound, sometinnes in considerable numbers; occasionally drifting into Woods Hole Harbor. On July 7, I904, Mr. John J. Veeder collected 78 specimens in the Sound. During some summers, on the contrary, none are observed. It is probable that the abundance of this species varies directly with the quantity of material which is blown to our shores from the Gulf Stream. Physalia has been observed locally in July, August, and September.

\section{Class SCYPHOZOA.}

\section{Family Charyedeidat.}

Charybdea verrucosa Hargitt.

Hargitt, I902 a, p. 559, 560 (sp. nov.); Hargitt, 1904, p. 65.

Great Harbor, Woods Hole; North Falmouth; several specimens, August I3 and I4, rgor.

\section{Family EPHYRIDA.}

\section{? Bathyluca solaris Mayer.a}

Mayer, I900, p. 2 (sp. nov.); Hargitt, I904, p. 66. Narragansett Bay; a single specimen found July 27, I896. Latter "much torn and battered ... may prove to be a deep-sea form." -Mayer.

\section{Family UlMarida:}

\section{A urelia flavidula Peron \& Lesueur.}

Verrill and Smith, 1873, p. 723,449 , etc.; Fewkes, I88I, p. I72; Bumpus, I898, p. 487 ; Hargitt, I904, p. 67; Mayer, I910, p. 623 ( $A$ urellia aurita).

Common throughout local waters during spring and summer. Young stages recorded by several observers as early as March; adults found as late as September. According to Mr. Edwards, Aurelia appears in the tow most frequently in May. Dr. Hargitt thinks it likely

a Mayer (1910, p. 585) now thinks that the type of this species (?) was probably a "damaged and regenerating specimen" of Dactylometra quinquecirro.
Aurelia flavidula-Continued.

that sexual reproduction occurs in summer, the resulting scyphistoma larvæ remaining in that condition till the following spring, when ephyræ are produced.

\section{Family CyaneIde.}

Cyanea arctica Peron \& Lesueur.

A. Agassiz, 1865, p. 44 (Cyanea arctica), p. 46 (Cyanea fulva) - Verrill and Smith, 1873, p. 723 , 449, etc.; Fewkes, I881, p. I66; Bumpus, I898, p. 487; I898a; Mead, I898, p. 705; Hargitt, r904, p. 68; Mayer, I9Io, p. 597 (C janea capillata, var. arctica).

Very common throughout the region during the spring and summer. Both Mr. Edwards and Mr. Gray report the occurrence of this species from March till September. About a dozen specimens, several inches in diameter, were taken in a fyke net by Mr. Edwards, February 28, 1908. Ripe eggs reported by Bumpus in May and early June, by Hargitt in July. The early stages may readily be reared in aquaria. Verrill and Mead note the occurrence of ephyræ in April. I $6269^{\circ}$ Bull. $3 \mathrm{I}, \mathrm{pt} 2-13-3$ 


\section{Family PELAGIDAE.}

Dactylometra quinquecirra (Desor).

A. Agassiz, 1865 , p. 48; Verrill and Smith, I873, p. 724, 449, etc.; Fewkes, I881, p. 173; 1882, p. 293; Hargitt, I904, p. 69; Mayer, I910, p. $5^{85}$.

Common in local waters throughout the summer. Reported as early as May (Edwards), as late as October (Gray).
Pelagia cyanella Peron \& Lesueur.

Hargitt, I904, p. 7o; Mayer, I9ro, p. 574.

"Southward from Marthas Vineyard in the region of the Gulf Stream;" 2 specimens. Dr. Hargitt believes this species should be retained in the local list.

\section{Class ACTINOZOA.}

\section{Family ALCyonIrdeE.}

\section{Alcyonium carneum Agassiz. [Chart 24.]}

Verrill and Smith, 1873, p. 737,497 , etc.; Sumner, rgio, fig. I4.

"Off Cuttyhunk Island, Io to I 5 fathons; off Gay Head, 8 to Io fathoms." - Verrill. Western end of Vineyard Sound and mouth of Buzzards Bay; Crab Ledge; dredged in 7 to ig fathoms, most commonly on gravelly or stony bottoms. Survey.

Fish Hawk stations: 7572 (many pieces), $75^{82}$ (I piece), $75^{87}$ (few small pieces), 7588 ( 2 small pieces), 7595 (few pieces), 7603 (few small pieces) †, 7605 (I small piece), 7606 (I piece) $†$, 7670 ( 1 clump), 7689 (few pieces), 7690, 7704 (i large clump), 77 18 (I clump), 7719 ( I clump), 7721 (considerable quantities). Supplementary station (I909): 7670 .

Phalarope stations: 36 (few pieces), 60 (several).

\section{Family GorgoNIIDAE.}

\section{? Pterogorgia gracilis Verrill.}

A fragment of a gorgonid believed at the time to have been taken in Vineyard Sound at Fish Hawk station 7568 has been assigned to this species by Prof. Nutting. It seems very probable that the specimen came from waters far beyond the limits of the region, having, perhaps, become entangled in the meshes of the dredge net during some earlier collecting trip.

\section{Family CeRIANTHIDAs.}

\section{Cerianthus americanus Verrill.}

Mr. G. M. Gray reports the rare occurrence of a Cerianthus in the Eel Pond, just inside the outlet; also just outside the latter; once at Ram Island. Dr. Hargitt, who has examined specimens taken locally, informs us that they are to be assigned to the species here named.
Family ZOANTHDAE.

Epizoanthus americanus Verrill.

Verrill and Smith, 1873, p. 740, 5 ro.

Deeper waters off shore. Dredged by the Fish Hawk south of Marthas Vineyard in 28 and 29 fathoms. Not taken in the Sound or Bay, and not strictly to be included in the fauna of this region. Commonly found upon the shells of hermit crabs, though Verrill records its occurrence on rocks.

\section{Family EdwardSIIDE.}

Edwardsia elegans Verrill.

West Falmouth.-Hargitt. Ram Island.-Gray. According to Mr. Gray, this anemone is fairly common in suitable localities, living in the sand at the roots of eelgrass, where it may be taken by digging.

Edwardsia farinacea Verrill.

Verrill and Smith, I873, p. 739, 45I.

"On the soft muddy bottom off Gay Head, in 19 fathoms," one specimen.

Edwardsia leidyi Verrill.

A. Agassiz, I865, p. 23 (here mentioned as an unknown "worm"); Verrill and Smith, I873, p. 457 (citing Agassiz) Verrill, $x 898$ (sp. nov.).

Woods Hole and adjacent waters, of very varia. ble abundance. The young is parasitic in the ctenophore, Mnemiopsis leidyi; it is believed by Verrill and others that the animal becomes free living in later life, but its history is not known at present. On November I3, I907, the ctenophores, with their contained parasites, were so numerous in Buzzards Bay that the latter organisms were at times very conspicuous as one looked down from the deck of the Phalarope.-Sumner. On the other liand, the Edwardsia is not always common when Mnemiopsis is present in abundance. 
Edzardsia lineata Verrill.

Verrill and Smith, 1873, p. 739, 497, etc. (sp. nov.).

"Vineyard Sound and off Gay Head, 6 to I2 fathoms, among ascidians, annelid tubes, etc., abundant."-Verrill. This species at present is certainly not generally distributed nor very common in local waters. It has not been recorded from the survey dredgings.

\section{Family ILYANTHIDE.}

Eloactis producta (Stimpson).

Verrill and Smith, 1873, p. 738,330 , etc. (Halocampa producta).

Naushon; Marthas Vineyard; Nantucket.-Verrill. Katama Bay ("North Pond"), abundant August 14, 1906.-Osburn. West Falmouth, North Falmouth, Hadley Harbor, Kettle Cove.-G. M. Gray. Muskeget Island. This is a burrowing species, which conceals itself in gravel or sand, only the distal end protruding from the surface.

\section{Family ANTHEIDEs.}

\section{Anemonia sargassensis Hargitt.}

Hargitt, I908, p. I I7 (sp. nov.).

Vineyard Sound on floating sargassum. Recorded on October 15 and 16, 1905, and August 30, I906. From its abundance on some of these dates, it seems likely that the species may have been present on many others.

\section{Family SAGARTHDE:}

\section{Cylista leucolena (Verrill).}

Verrill and Smith, I873, p. 738,329 , etc. (Sagartia leucolena).

Buzzards Bay and Vineyard Sound.-Verrill. Vineyard Haven at New York Yacht Club pier; Nobska Point, * on rocks, below low water. A common species, having a littoral habitat.

Sagartia lucice Verrill.

Verrill, I898, p. 493 (sp. nov.); Parker, I902, p. 49 r.

This species is now the most abundant actinian of the region and is of general occurrence littorally, growing on stones, living mussels, rock-weed, etc., often in great profusion. It is, however, a very recent immigrant, having been first observed at Woods Hole by W. R. Coe in 1898. S. lucice was naticed for the
Sagartia lucic-Continued.

first time by Prof. Verrill at New Haver in 1892 , and is believed by him to have been introduced into that region upon oysters, which are annually brought from the South and planted in Long Island Sound. According to Parker, the species migrated eastward from New Haven and northward to Salem, Mass., within a period of Io years.

Sagartia modesta Verrill.

Verrill and Smith, I873, p. 738, 330, etc.

"Naushon Island; low water, buried in sand or gravel."-Verrill. Local bathing beach, on Buzzards Bay, between tides or at low water.Hargitt. An uncommon species locally.

Metridium dianthus (E11is). [Chart 25.]

Verrill and Smith, I873, p. 738, 329 (M. marginatum); Mead, I898, p. 705 (M. marginatum).

As a littoral species, common and widely distributed in local waters, occurring on stones, piles, etc., at or below low-water mark. Dredged by the Survey at scattered stations throughout the length of Vineyard Sound; several stations at Crab Ledge; none in Buzzards Bay; 4 to 25 fathoms, on mud-free bottoms.

Fish Hawk stations: 7521 bis (I), 7526 (I), 7532 (I), 7544 (I), $755^{8}$ (I), 7560 (2 large), 7565 (I), $7572(2), 7588(2), 7595$ (I), 7603 (several small), 7605 (3 large), 7606,7608 (6 large), 7609 (I small), 7693 (3), 772I (very many), $7725,774^{2}$ (I), 7743 (I).

Phalarope station: 77 (I).

The reproductive period of this anemone appears to occur during the summer. Dr. Mead notes that Metridium "was found to be full of eggs, apparently nearly mature," on April i8 (I898), while Dr. F. R. Lillie (Marine Biological Laboratory card catalogue) records the presence of ova and sperm on June 20 ( 1889 ).

\section{Family Tralinde.}

Tealia crassicornis (Müller).

Crab Ledge.-Hargitt. Vineyard Sound?Sumner. A specimen, believed to be of this species, from the last-mentioned place, was taken in the vicinity of Gay Head by the Fish Hawk in August, 190\%. Unfortunately it was devoured by hermit crabs before it could be carefully examined. 


\section{Family Astrendi.}

\section{Astrangia dance Agassiz. [Chart 26.]}

Verrill and Smith, 1873 , p. 740,330 , etc.

Abundant and generally distributed throughout the greater part of Vineyard Sound and Buzzards Bay, though scarce or lacking over a considerable area at the outer end of the Sound; dredged in 2 to ig fathoms, on all sorts of bottoms.-Survey. Likewise frequent on piles of Bureau of Fisheries pier in Woods Hole Harbor, and doubtless in similar places elsewhere.

Fish Hawk stations: $75^{22}$ (many living), $75^{22}$ bis (many living and dead), $75^{23}$ (few), $75^{23}$ bis (many living), 7527 (few), 7530 bis (few living colonies), 753 I bis (I living colony), 7532 (several), 7533 (few), 7534 (few), 7534 bis (few living), 7535 (few), 7535 bis (few living), 7537 (many), 7538,7538 bis (several living colonies), 7539 (numerous), 7539 bis ( $\mathrm{r}$ small colony), 7543 (I dead piece), 7544 (few dead), 7545 (many), 7545 bis (several), 7546 (few living), 7546 bis (several dead colonies), 7547 (few), 7547 bis (few dead colonies), 7549 (many), 7549 bis (several living colonies), $755^{\circ}$ (few dead), $755^{\mathrm{I}}$ (few dead), 7554 (several dead pieces), 7556 bis ( 2 dead colonies), 756 I (I dead colony), 7563 (few dead), $75_{65}$ bis ( I small living colony), 7567 (I dead piece), $757^{2}$ (many living), 7574 (I dead piece), 7587 ( d dead piece), 7595 ( $\mathrm{r}$ living), $76 \mathrm{I} 2$ ( $\mathrm{I}$ living colony), $76 \mathrm{I}_{3}$ (several living colonies), $76 \mathrm{r}_{4}$ ( 2 dead colonies), $76 \mathrm{I}_{5}$ (several small dead pieces), 76r9 ( I small dead colony), 7620 (pieces on Cliona); 762I (few small dead colonies), 7624 (few small dead colonies), 7626 (several colonies), 7627 (I dead colony), 7628 (few small pieces), 7630 (few small dead colonies), 763 I (small dead pieces), 7632 (few clumps), 7639 ( $\mathrm{r}$ living colony, few dead), 7640 (I small dead colony), 7643 (2 small dead colonies), 7644 (few dead colonies), 7645 ( I small dead colony), 7648 (few small dead colonies), 7655 (very little), 7659 (2 small dead colonies), 7660 (numerous colonies, dead and living), 7665 ( 1 small dead piece), 7666 (few dead pieces), 7670 (few small colonies, living and dead), $767 \mathrm{I}$ (few dead colonies), 7672 ( 1 small living mass), 7673 (considerable living), 7689 ( $I$ small living piece), 7694 (I small dead picce), 7703 (I small dead colony), 7732 (much, living and dead), 7734 (I small
Astrangia dana-Continued.

dead colony), 7737 (several living colonies), $773^{8}$ (several small living colonies), 7746 (I living colony), 7747 (little), 7748 (I living colony), 7753 (several colonies, living and dead), 7754 (little living), 7755 (few small living), 7756 (many living colonies), 7764 ( 1 dead colony), 7767 (very little, dead), 7768 (I small living colony), 7769 (little dead), 7770 (many small living colonies), 777 I ( $\mathrm{I}$ dead colony), 7772 ( I dead colony), 7773 (several living colonies), 7774 (few colonies), 7775 (many small living colonies) 7776 (few small dead coloniés), 7777 (little), 7778 (few small living colonies), 7780 (little), 778 I ( I dead colony and I small living), 7783 (very little living). Supplementary stations (Igog): 7624 (several living colonies), 7629 ( $\mathrm{r}$ dead), 7648 (several living colonies), 7657 ( 2 small living), 7659 (several living colonies), 7660 (several living and dead), 7668 (I dead colony), 7670 (several living), 7672 (I dead colony).

Phalarope and Blue Wing stations: 2 (few living), 3 (several dead), 5 (many living and dead), 6 (many living and dead), 7 (many living on shells), 9 (living), ro (pieces), I I (common), I2 (few), I3 (considerable quantity), I4 (few), I5 (common), I6 (2 pieces), 20 (few), 2 I (few), 22 (few), 24 (few), 25 (few), 27 (few dead), 28 (few), 35 (I dead colony), 36 (few living), 39 ( 1 dead piece), 65 ( 2 dead), 66 ( 1 dead), 69 ( 1 small mass), 80, 8 I ( $\mathrm{I}$ living, pieces), 83 (several small), 84, 85 (living), 86, 87, 91, 92, 96, го8, I IO, I $x_{3}, I_{4}$ (few), II 7 (dead and I living), I 20 (dead), I2I (dead), I27 (dead), I2S (living), I3 I, x32, I34 (few colonies), I38 ( 1 living colony), I40 (few), I4I (few living and dead), I 44 ( I dead colony), I45 (few living), I48 (several living), I5o (many), I 53 (I dead colony), I65 (few dead), I66 (? small dead), r67 ( 1 living colony). Supplementary stations (I909): 83 ( 1 dead), I3I (I living).

\section{Family ORBICELLID E.}

? Orbicella acropora (Linnxus).a

Four large water-worn pieces, which have been referred to this species by Dr. Hargitt, were found along the beach north of Nobska Point, at considerable distances from one another. It is quite unlikely that this coral lives in these waters, but the record is worth entering. It may have been used as ballast by some vessel. 
Class CTENOPHORA.

Family MERTENSIIDA.

Mertensia ovum (Fabricius).

Hargitt, I904, p. 7 .

"Only rarely taken at Woods Hole."

Family PLEUROBRACHIDAs.

Pleurobrachia pileus (Fabricius).

Verrill and Smith, 1873, p. 722,444 , etc. (Pleurobrachia rhododactyla); Bumpus, $\mathrm{i} 898$; Hargitt, I904, p. 7 I.

Vineyard Sound, Woods Hole Harbor, etc.; sometimes abundant. This species has been reported by various local observers for every month in the year. According to Mr. Edwards's towing records it has been taken most frequently in April.

With eggs, May, I89o- - J. P. McMurrich, in Marine Biological Labora ory card catalogue.

\section{Family LESUEURIDAE.}

\section{Lesueuria hyboptera Agassiz.}

A. Agassiz, 1865, p. 23; Verrill and Smith, 1873, p. 722,454 ; Hargitt, I904, p. 72 .

Newport.-Agassiz. Woods Hole-Hargitt. Recorded for September by Verrill, for December and January (?) by Hargitt.

\section{Family BOLINIDAE.}

\section{Bolina alata Agassiz.}

A. Agassiz, 1865 , p. I 5 (no definite local records); Verrill, 1875 , p. 42 ; Hargitt, I904, p. 72.

Newport.-Agassiz, cited by Verrill. "Seldom found at Woods Hole." - Hargitt.

\section{Family MNEMIDA:}

Mnemiapsis leidyi Agassiz.

A. Agassiz, I865, p. 20; Verrill and Smith, 1873, p. 722,449 ; Fewkes, I881, p. I73; 1882, p. 29I; Bumpus, 1898; Hargitt, 1904, p. 72.

Scarce to very abundant throughout the waters of the region. Recorded by various local observers for every month of the year. According to Mr. Edwwards's towing records Mnemiopsis has been taken most frequently in September and December. 'This ctenophore is of very' irregular occurrence. During some summers it is enormously abundant everywhere in local waters, but in other summers (e. g., that of I904) it may not be observed at all. Periods of extreme abundance may likewise occur in winter. (See note under Edwardsia leidyi, p. 576$.

\section{Family CESTIDE.}

Cestus veneris Lesueur.

Verrill and Smith, 1873, p. 723; Hargitt, 1904, p. 73.

Fragments of a single specimen taken at Newport.-Hargitt, citing A. Agassiz.

$$
\text { Family BEROIDE. }
$$

Beroë ovata Bosc.

Hargitt, I904, p. 73.

"Common at Woods Hole in rgor, though seldom taken in any considerable numbers."

Beroë cucumis Fabricius.

Verrill and Smith, 1873, p. 723,454 , etc. (Idyia roseola); Hargitt, 1904, p. 73 .

"Off Gay Head, not common"; taken in September.-Verrill. Off Crab Ledge in I902.Hargitt.

\section{Phylum PLATYHELMINTHES.}

\section{Class TURBELLARIA.}

Family PLANOCFíRID:

Stylochus zebra Verrill.

Verrill, I892b, p. 463 .

Great Harbor; on piles, and on shore, at low-water mark; likewise dredged in Io to 12 fathomsVerrill. Tarpaulin Cove-Curtis. This species sometimes lives commensally, within the shell occupied by a hermit crab.-Verrill, W. C. Curtis (MS.).
Eustylochus ellipticus (Girard).

Verrill and Smith, I873, p. 632, 325 (Stylochopsis littoralis); Verrill, I892b, p. 463 .

Woods Hole, Vineyard Sound, Newport; common in shallow water and between tides, under stones and in tide pools, likewise on piles.Verrill.

Large clusters of eggs were found July I2. 
Planocera inquilina Wheeler.

Wheeler, r894a, p. 195-20r (sp. nov.); Verrill, I895, p. 534.

Wheeler writes: "In all I have opened about 100 adult specimens of Sycotypus [Busycon canaliculatum], and in the branchial chamber of nearly every individual from one to six of the Planoceræ were found."

Planocera nebulosa Girard.

Verrill and Smith, I873, p. 632, 325; Verrill, r $892 \mathrm{~b}, \mathrm{p} .472$.

Woods Hole, in 1886, under stones near lowwater mark; not common; most specimens immature. Sometimes found living in the burrows occupied by Cercbratulus lacteus.Coe.

\section{Imogine oculifera Girard.}

Verrill I892b, p. 475 .

Quisset Harbor, September 4, I882, on sandy bottom in 4 or 5 fathoms of water.

\section{Family LEPTOPLANIDAE.}

\section{Leptoplana variabili; (Girard).}

Verrill, r892b, p. 480 .

Vineyard Sound, off Cuttyhunk, on telegraph cable.

\section{Trigonoporus folium Verrill.}

Verrill and Smith, 1873, p. 632, 487 (Leptoplana folium, sp. nov.); Verrill, 1892b, p. 487 .

Off Buzzards Bay, in 25 fathoms; off Gay Head, in I8 fathoms; outer rocky shores, creeping on the under surface of stones.

Discocelis mutabilis Verrill.

Verrill, r892b, p. 493.

Young specimens, believed to belong to this species, taken at Woods Hole in the tow net.

\section{Family EURYLEPTIDE.}

Eurylepta maculosa Verrill.

Verrill, r892b, p. 495 (sp. nov.).

Woods Hole, on piles, July I4, I88r; in mud, August 2, 1882; Naushon Id., at low-water mark, among algæ, August 20, I887.

\section{Family Prothiostomides.}

Prothiostomum gracile Girard.

Verrill, r892b, p. 496 .

Woods Hole, July 25, I886.

\section{Family BDELLOURIDE.}

Bdelloura candida Girard.

Verrill and Smith, I873, p. 634, 460; Verrill, 1892 b, p. 499; Wheeler, I894.

Very common on the gill plates and on the legs of Limulus polyphemus.

Egg capsules often found in considerable numbers on gills of host. Eiggs laid throughout the summer and as late as October.-Verrill.

Bdelloura propinqua Wheeler.

Wheeler, 1894; Verrill, 1895, p. 534.

Found on the basal portions of the gill lamellæ of Limulus polyphemus.

Eggs laid in elongated capsules, attached by stalks to the host.-W. C. Curtis, MS.

Syncolidium pellucidum Wheeler.

Wheeler, 1894, p. 167-194 (sp. nov.); Verrill, r895, p. 534 .

Occurs on the gills of Limulus polyphemus.

Elongated egg capsules are deposited during the summer upon the gill lamellæ of the host, near their edge.-Wheeler, Curtis.

\section{Family Planaritde}

Procerodes warrenii (Girard).

Verrill and Smith, 1873, p. 633 (Fovia Warrenii and Planaria grisea); Verrill, 1892b, p. 504 (Fovia affinis); Wilhemi, I908, p. 4.

Specimens believed to be of this species found by Verrill at Woods Hole, among eelgrass. "Woods Hole and neighborhood ... summer, 1907."-Wilhelmi.

Procerodes wheatlandi Girard.

Verrill and Smith, 1873, p. 633; Verrill, $x 802$ b, p. 506 (Procerodes ulvce): Wilhelmi, I908, p. 3 .

Newport, Woods Hole; "found near low-water mark under stones, and in tide pools, among algæ."-Verrill. Cuttyhunk, Newport, Buzzards Bay.-Wilhelmi.

\section{Family Convolutidas.}

A phanostoma diversicolor Oersted.

Verrill, I892 b, p. 509; Graff, I9II, p. 326.

Newport, July 29, r880, among algæ at low-water mark.-Verrill. Fairly common on Ulva in Eel Pond and Little Harbor.-Graff.

A phanostoma aurantiacum Verrill.

Verrill, I 892 b, p. 509 (sp. nov.).

Newport, July 29, 1880, among algæ at low-water mark (only provisionally referred to this genus). 
Polychorus caudatus Mark.

Mark, I892 p. 298; Verrill, I892b, p. 5Ir; Gardiner, I895, p. I55; Bumpus, I898 b, p. 856 : Graff, I9II, p. 326 .

Woods Hole Harbor, Hadley Harbor.-Mark. Newport, Woods Hole; found "especially in sheltered harbors, adhering to eelgrass (Zostera) and creeping over the vegetable débris, shells, etc., on the bottom in shallow water, where it is often extremely abundant." Verrill. "Northwest Gutter," near Hadley Harbor.-Gardiner. On Ulva in Little Harbor
Polychorus caudatus-Continued. and eelgrass in front of Breakwater Hotel.Graff.

Mark records finding egg-capsules of this species on dead shells and stones in Woods Hole Harbor. J. P. McMurrich (in Marine Biological Laboratory card catalogue) notes their presence on Pecten shells, July I5 (I890). E. G. Gardiner (cited by Bumpus) found the eggs from June 6 to August 25, and noted that "the eggs are deposited at night in transparent gelatinous capsules."

The paper of Graff (I9II), recording a considerable number of turbellarians, many of them new to science, which were taken at Woods Hole and vicinity, appeared too late to allow of our including Graff's list except as an appendix to our own. These added species are accordingly arranged serially, without relation to those previously listed. One of them, Grafflla gemellipara, had been described by Dr. Linton in I9Io.

Anaperus gardineri Graff.

I9II, p. 327 (sp. nov.).

In beds of Ulva and eel-grass, burrowing in the sand; taken with Polychorus caudatus, but far less common.

Childia spinosa Graff.

I9II, p. 34I (sp. nov.).

Juniper(Butlers) Point, in $1 / 3$ to I fathom of water, on Laminaria; Little Harbor, at ebb tide, on Ulva; about a dozen specimens taken.

Stenostomum coluber Leydig.

I9I I, p. 348.

Doubtfully identified by Graff among material taken by Child and Wilhelmi from a brackish pond at Falmouth, under stones.

Microstomum davenporti Graff.

I 1 I , p. 349 (sp. nov.).

Eel Pond and breakwater, on Ulva.

Prorhynchus stagnalis Schultze.

I9II, p. 35 I.

Brackish ponds at Falmouth, under stones; a number taken by Graff.

Graffilla gemellipara Linton.

Linton, I9Iо, p. 37 I (sp. nov.); Graff, IgIr, p. 35I; Patterson, I912, p. I73.

Discovered by Linton at Woods Hole, in the ribbed mussel Modiolus demissus, from the gills of which the parasites were washed. According to Linton, this species is especially numerous in mussels exposed to rather free tidal currents, being absent from those taken in confined coves. Patterson finds evidence that the parasite inhabits the kidneys of the host, rather than the gills. He has taken it in abundance during the latter part of June and the latter part of August, finding it to be rare in the intermediate period.

\section{Dalyellia dodgei Graff.}

I9I I, p. 354 (sp. nov.).

This and the two following species were taken by Graff in the brackish pond behind the Episcopal Church at Falmouth.

Dalyellia rossi Graff.

IgrI, p. 359 (sp. nov.).

Dalyellia mohicana Graff. IgII, p. 362 (sp. nov.).

Proxenetes modestus Graff. I9II, p. 374 (sp: nov.). Eel Pond, 5 specimens found by Graff.

Promesostoma marmoratum nudum Graff. I9II, p. 375 (var. nov.). Woods Hole, on Ulva, 3 specimens.

Trigonostomum marki Graff. Igr I, p. 380 (sp. nov.).

Little Harbor, on Ulva; Red Ledge, among Zostera; several specimens.

Woodsholia lilliei Graff.

IgI I, p. 38 I (sp. nov.).

Woods Hole, very common, being taken in Eel Pond, Little Harbor, Grassy Island, and Red Ledge, on Zostera.

Phonorhynchus helgolandicus (Meczn.).

IgrI, p. 385 .

Eel Pond, Grassy Island, Red Ledge, Juniper (Butlers) Point; one of the commonest species.

Gyratrix hermaphroditus maculata Graff.

I9I., p. 388 (var. nov.).

Woods Hole, in salt marsh near Gardiner cottage. 
Plagiostomum stellatum Graff.

I II, p. 393 (sp. nov.).

Eel Pond, Red Ledge, and Grassy Island, fairly abundant on Zostera.

Plagiostomum morgani Graff.

I9II, p. 395 (sp. nov.).

Found by Graff at Eel Pond and Juniper (Butlers Point.)

Plagiostomum wilsoni Graff.

I9II, p. 396 (sp. nov.).

Grassy Island and Little Harbor, on Ulva; one of the commonest species.

Plagiostomum whitmani Graff. I9II, p. 397 (sp. nov.).

Little Harbor, on Ulva, Io specimens.
Monoophorum triste Graff.

IgII, p. 4 OI (sp. nov.).

Grassy Island and Juniper (Butlers) Point, 3 specimens.

Monocelis fusca Oersted.

I9I I, p. 408 .

Eel Pond, especially under bridge.

Monocelis wilhelmii Graff.

IgII, p. 4Io (sp. nov.).

Red Ledge, collected by Dr. Wilhelmi.

Myrmeciplana elegans Graff.

IgII, p. 4 I0 (sp. nov.).

Falmouth, in brackish water, collected by Dr. Wilhelmi.

\section{Class TREMATODA.}

Dactylocotyle denticulatum (Olsson).

Linton, 1900, p. 286 (Octobothrium denticulatum); Linton, I90I, p. 4I4, 474 .

From gills of Pollachius virens (locality not stated).

Dermocystis ctenolabri Stafford.

Ryder, I884, p. 37; Linton, I900, p. 28I, 296; I9or, p. 462,463 . (By both writers referred to as an unidentified trematode).

Immature stages encysted in the skin of the cunner (Tautogolabrus adspersus) and the tautog (Tautoga onitis), often in such numbers as to give the fish a spotted appearance. The adult has been found in abundance by Dr. Linton in the intestine of a loon (Gavia immer) captured at Woods Hole in I9II.

Diclidophora affinis Linton.

Linton, r898, p. 5 II (Octoplenum affine, sp. nov.); Linton, I901, p. 4r4, 482 .

From mouth of Paralichthys dentatus.

Dionchus agassizi Goto.

Goto, I900, p. 286 (sp. nov.).

From the gills of Remora brachyptera, Newport.

Diplostomum sp.

Linton, I90I, p. 4I5, 442, $47 \mathrm{I}$.

Undetermined species, referable to this genus, found in liver of Fundulus heteroclitus (cysts), and in intestine of Prionotus carolinus.

Distomum appendiculatum Rudolphi.

Linton, I900, p. 289; Linton, I90r, p. 415, etc.

Hosts: Achirus fasciatus (intestine), Anchovia brownii, Brevoortia tyrannus (intestine), Clupanodon pseudohispanicus, Clupea harengus (intestine), Cynoscion regalis (intestine), Decapterus macarellus (intestine), Microgadus tomcod (intestine), Myoxocephalus aneus (intestine),
Distomum appendiculatum-Continued.

Paralichthys dentatus (intestine), Pomolobus mediocris (stomach and pylorus), Pomolobus pseudoharengus, Prionotus carolinus (intestine), Pseudopleuronectes americanus (intestine), Scomber scombrus, Stenotomus chrysops, Trachurops crumenophthalmus, Urophycis chuss (intestine).

Distomum areolatum Rudolphi.

Linton, 1900, p. 293; Linton, I901, p. 4I5, etc. Hosts: Menticirrhus saxatilis, Morone americana (intestine), Pseudopleuronectes americanus, Tautogolabrus adspersus (intestine). Common.

Distomum bothryophoron Olsson.

Linton, rgor, p. 415, etc.

Hosts: Clupea harengus, Pomolobus pseudoharengus.

Distomum clavatum Rudolphi.

Linton, I898, p. 539; Linton, I90I, p. 4r5, etc.

Hosts: Thunnus thynnus, Xiphias gladius (stomach).

Distomum contortum Rudolphi.

Linton, I898, p. 528; Linton, rgor, p. 4I5, 466 .

From intestine of Mola mola.

Distomum dentatum Linton.

Linton, I900, p. 294 (sp. nov.); Linton, I90r, p. $4 \mathrm{I} 5,483$.

From intestine of Paralichthy's dentatus (few).

Distomum fenestratum Linton.

From Brevoortia tyrannus.

Distomum fœcundum Linton.

Linton, I900, p. 289 (sp. nov.); Linton, I90r, p. 415,472 .

From intestine of Lopholatilus chamcleonticeps, one specimen. 
Distomum foliatum Linton.

Linton, I898, p. 532 (sp. nov.); Linton, I90I, p. $4 \times 5,466$.

From intestine of Mola mola.

Distomum fragile Linton.

Linton, I900, p. 295 (sp. 110V.); I.inton, I90I, p. 415,466 .

From intestine of Mola mola, several.

Distomum globiporum Rudolpli.

Linton, 190I, p. 415, 486 .

Hosts: Centropristes striatus, Menticirrhus saxatilis, Pseudopleuronectes americanus (intestine).

Distomum grandiporum Rudolphi.

Linton, I898, p. 520; Linton, I90r, p. 4I5, etc.

Hosts: Anguilla chrysypa (stomach), Paralichthy's dentatus, Pseudopleuronectes americanus (intestine).

\section{Distomum gulosum Linton.}

Linton, Igor, p. 4I 5, 454 (sp. nov.).

Hosts: Poronotus triacanthus, Scomber scombrus.

Distomum hispidum Abilgaard.

Linton, Igor, p. 415,478 .

From intestine of Urophycis tenuis.

Distomum lageniforme Linton.

Linton, I898, p. 524 (sp. nov.); Linton, I9oI, p. 4 I 5,473 .

From intestine of Remora remora.

Distomum macrocotyle Diesing.

Linton, 1898 , p. 522; Linton, I9OI, p. 415 , etc.

Hosts: Mola mola (intestine); Myliobatis freminvillci (stomach).

Distomum monticellii Linton.

Linton, I898, p. 5 I8 (sp. nov.); Linton, I9OI, p. 415, etc.

Hosts: Cynoscion regalis, Gymnosarda alleterata, Paralichthys dentatus (intestine), Pomatomus saltatrix (intestine), Remora remora (intestine).

Distomum nigrescens Olsson.

From Lophius piscatorius.-Linton, MS.

- Distomum nigroflavum Rudolphi.

Linton, I898, p. 530; Linton, I90I, p. 415, 466. From intestine of Mola mola.

Distomum nitens Linton.

Linton, I898, p. 534 (sp. nov.); Linton, Igor, p. $4 \mathrm{I} 5,443$.

From intestine of $T y$ losurus acus.
Distomum ocreatum (Molin).

Linton, I898, p. 514; Linton, I900, p. 288; Lintol1, I9OI, P. 4I5, etc.

Hosts: Anguilla chrysypa, Clupca harengus, Gadis callarias, Lopholatilus chamaleonticeps (intestine), Merluccius bilinearis (intestine), Microgadus tomcod, Pollachius virens (stomach), Pomatomus saltatxix (intestine), Uroplyocis chuss (intestine).

Distomum pallens Rudolphi.

Linton, 1898, p. 526; Linton, I90I, p. 415, 464. From intestine of Alutera schocpfii.

Distomum polyorchis Stossich.

Linton, I90I, p. 4I5, 460.

From intestine of Cynoscion regalis.

Distomum pudens Linton.

Lintor, r900, p. 290 (sp. nov.); Linton, I90I, p. 4 I 5,482 .

Host: Paralichthys dentatus (a large number taken).

Distomum pyriforme Linton.

Linton, I900, p. 292 (sp. nov.); Linton, I90I, p. 415 , etc.

Hosts: Cynoscion regalis (intestine), Menticirrhus saxatilis (intestine), Palinurichthy's perciformis (intestine and pyloric cœca, enormous numbers), Sarda sarda.

? Distomum rachion Cobbold.

Linton, I898, p. 538; Linton, I9or, p. 4I5, 476 .

Hosts: Gadus callarias, Melanogrammus aglefinus.

Distomum simplex Rudolphi.

Linton, I898, p. 525; Linton, I90r, p. 4I5, etc. Hosts: Gastcrosteus aculcatus, Hemitripterus americanus (intestine), Leplocephalus conger, Li=。 manda ferruginea (intestine), Microgadus tomcod (intestine).

Distomum tenue Linton.

Linton, I898, p. 535 (sp. nov.); Linton, Igor, p. 4 I 5 , etc.

Hosts: Roccus lineatus, Opsanus tau (intestine).

Distomum tenue tenuissime Linton.

Linton, r898, p. 536; Linton, I9or, p. 415, $45^{6}$.

From peritoneum of Morone americana.

Distomum tornatum Rudolphi.

Linton, 1898 , p. 513 (Distomum tornatum), p. 5 I5 (D. rufoviride); Linton, Igor, p. 4I5, etc.

Hosts: Coryphana hippurus, a Fundulus heteroclitus, Roccus lincatus (intestine), Mcnidia menidia notata, Opsanus tau. a From the Gulf Stream, and thus not strictly within the region comprised in the present feport. 
Distomum valdeinflatum Stossich.

Linton, 1898, p. 527; Linton, I90r, p. 416, etc.

Hosts: Alutera schoepfi (capsules in peritoneum) Menidia menidia notata (cysts in liver and body cavity), Opsanus tau, Spheroides maculatus.

Distomum veliporum Creplin.

Linton, I\$98, p. 52I; Linton, I90I, p. 4I6, 43 I. From stomach of Raja lavis.

Distomum vibex Linton.

Linton, I900, p. 29 I (sp. nov.); Linton, I90I p. 416,464 .

From Balistes vetula and Spheroides maculatus (intestine and pharynx).

Distomum vitellosum Linton.

Linton, I900, p. 290 (sp. nov.); Linton, I90r, p. 4 I6, etc.

Hosts: Anguilla chry'sypa, Brevoortia tyrannus, Clupea harengus, Cynoscion regalis (intestine), Decapterus macarellus, Leptocephalus conger (intestine), Limanda ferruginea (intestine), Lophopsetta maculata, Menticirrhus saxatilis (intestine), Merluccius bilinearis (intestine), Microgadus tomcod, Morone americana, Paralichthys dentatus (intestine), Paralichthy's oblongus, Pomatomus saltatrix (alimentary canal), Pomolobus pseudoharengus, Prionotus carolinus, Pseudopleuronectes americanus (intestine), Sarda sarda (intestine), Scomber scombrus, Spheroides maculatus (intestine), Stenotomus chrysops, Tautoga onitis, Tautogolabrus adspersus (intestine).

Distomum, sp. sp. (unidentified).

Species referable to this genus, but not determinable owing to immaturity or other reasons, were found by Dr. Linton in the following hosts: Achirus fasciatus, Alutera schoepfi, Anchovia brownii, Anguilla chrysypa, Brevoortia tyrannus, Carangus crysos, Enchelyopus cimbrius (intestine), Fundulus heteroclitus (intestine), Gadus callarias (encysted under skin), Gasterosteus aculeatus, Lagocephalus lavigatus (intestine), Limanda ferruginea (intestine), Melanogrammus aglefinus, Menidia menidia notata, Menticirrhus saxatilis (intestine), Microgadus tomcod (encysted under skin), Morone americana (encysted ova in liver), Myoxocephalus aeneus, Myoxocephalus octodecimspinosus, Opsanus tau (intestine), Palinurichthys perciformis, Paralichthy's dentatus, Paralichthys oblongus, Pomatomus saltatrix, Poronotus triacanthus, Prionotus carolinus (intestine), Prionotus strigatus, Pseudopleuronectes americanus (on viscera and in intestinal walls), Pterophryne histrio, Scomberomorus maculatus (cysts in intestinal wall), Seriola lalandi, Stenotomus chrysops, Tautoga onitis, Tautogolabrus adspersus, Trichiurus lepturus.
Epibdella bumpusii Linton.

Linton, I900, p. 286 (sp. nov.); Linton, I90r, p. 414,433 .

An external parasite on Dasyatis centrura.

See Linton, 1900, p. 287 , for an interesting account of egg formation in this species.

Epibdella hippoglossi Müller.

From Hippoglossus hippoglossus.

Gasterostomum arcuatum Linton.

Linton, I900, p. 297 (sp. nov.); Linton, I90I, p. 4 I6, etc.

Hosts: Brevoortia tyrannus, Carcharhinus obscurus (spiral valve), Sarda sarda (pylorus, stomach, intestine, pyloric cœea).

Gasterostomum ovatum Linton.

Linton, 1898, p. $54 \mathrm{I}$ (Monostomum orbiculare); Linton, I900, p. 297 (Gasterostomum ovatum, sp. nov.); Linton, r9or, p. 416, 457.

From intestine of Lobotes surinamensis.

Gasterostomum sp.

Linton, I90I, p. 4I6, 442, 447.

Undetermined species referable to this genus were taken from Menidia menidia notata, Scomberomorus maculatus (intestine, common), Seriola lalandi, and from Tylosurus marinus.

? Hexacotyle thynni (De la Roche).

Linton, rgor, p. 414, 446.

One specimen taken from mouth of Sarda sarda, August 7, I900.

Microcotyle hiatula Goto.

Goto, 1900, p. 28I (sp. nov.).

From gills of Tauioga onitis, Newport.

Microcotyle longicauda Goto.

Goto, I900, p. 282 (sp. nov.).

From gills of Cynoscion regalis, Newport.

Microcotyle pomatomi Goto.

Goto, I900, p. 279 (sp. nov.).

From gills of Pomatomus saltatrix, Newport.

Microcotyle stenotomi Goto.

Goto, I900, p. 279 (sp. nov.).

From gills of Stenotomus chrysops, Newport.

Microcotyle sp.

Linton, Igor, p. 4I 4, 45I.

Hosts: Cynoscion regalis, Pomatomus saltatrix (extemal), Poronotus triacanthus, Tylosurus marinus.

Monostomum vinal-edwardsii I,inton.

Linton, I9or, p. 4r6, 470 (sp. nov.).

Internal parasite of Opsanus tau, numerous.

Monostomum sp.

Linton, I90I, p. 4I6, 439.

Hosts: Pomolobus pseudoharengus, Poronotus triacanthus. 
Nematobothrium, sp. undet.

From gills of Sarda sarda.

Nitzschia clongata (Nitzsch).

Linton, I898, p. 508 (Nitzschia elegans); Linton, I90I, p. 4I 4,435 .

Found under the opercles and gills of Acipenser sturio.

Nitzschia papillosa Linton.

Linton, r898, p. 508 (sp. nov.); Linton, I90I, p. 4 I 4,476 .

From gills of Gadus callarias.

Octocotyle major Goto.

Goto, I900, p. 274 (sp. nov.=O. scombri (Kuhn), pars).

From mackerel, off Newport.
Tristomum coccineum (Cuvier)

Linton, I898a, p. 509; Linton, I90r, p. 4I4, 448.

From gills of Xiphias gladius.

Tristomum lave Verrill.

Linton, I808a, p. 509; Linton, I90I, p. 4I4, 445. From gills of Gymnosarda pelamy's. This fish was taken "south of Marthas Vineyard" Aug. I8, I886 (perhaps not within the limits of the region).

Tristomum mola Blanchard.

Linton, 1898a, p. 5 Io (Tristomum rudolphianum); Linton, Igor, p. 414, 466.

From skin and gills of Mola mola.

Tristomum papillosum Diesing.

From Xiphias gladius.

\section{Class CESTODA.}

Acanthobothrium coronatum (Rudolphi).

Linton, I9or, p. 4II, 43 r.

From intestinal wall of Raja lavis.

Acanthobothrium paulum Linton.

Linton, I89o, p. 816 (sp. nov.); Linton, I90I, p. 4 II , etc.

Hosts: Dasyatis centrura (spiral valve), Myliobatis freminvillei, Raja eglanteria.

Anthobothrium laciniatum Linton.

Linton, I89o, p. 754 (sp. nov.); Linton, I897a, p. 439; Linton, I9or, p. 4 II, etc.

Hosts: Prionace glauca, Carcharhinus milberti (spiral valve), Carcharhinus obscurus (spiral valve), Isurus dekayi (spiral valve), Raja eglanteria, Sphyrna zygena (spiral valve).

Anthobothrium pulvinatum Linton.

Linton, 1890 , p. 759 (sp. nov.); Linton, $1897 \mathrm{a}$, p. 439; Linton, I90I, p. 4II, $43^{2}$.

From spiral valve of Dasyatis centrura.

Anthocephalum gracile Linton.

Linton, IS90, p. 794 (sp. nov.); Linton, Igor, p. 4II, 433 .

From spiral valve of Dasyatis centrura.

Calliobothrium eschrichtii Beneden.

Linton, I89o, p. 812; Linton, I897a, p. 447; Linton, I90I, p. 4 II, 425 .

From spiral valve of Mustelus canis (very rare).

Calliobothrium verticillatum (Rudolphi).

Linton, I889, p. 476; Linton, I89o, p. 81o; Linton, I897a, p. 447; Linton, I90r, p. 4II, 425.

From spiral valve of Mustelus canis (abundant) also recorded from Squalus acanthias.

Calyptrobothrium minus Linton.

Linton, I907a, p. 279 (sp. nov.).

From intestine of Tetronarce occidentalis.
Calyptrobothrium occidentale Linton.

Linton, I900, p. 298 (sp. nov.: at this time not distinguished from $C$. minus, described later); Linton, I901, p. 4II, 432; Linton, I907a, p. 276.

From spiral valve of Tetronarce occidentalis.

Crossobothrium angustum Linton.

Linton, I889, p. 468 (Orygmatobothrium angustum, sp. nov.); Linton, 1897 , p. 796 (O. angustum); Linton, I897a, p. 443 (О. angustum); Linton, I9OI, p. 4II, etc.

Hosts: Carcharhinus milberti (spiral valve), Carcharhinus obscurus (spiral valve), Carcharias littoralis, Galeocerdo tigrinus, Prionace glauca.

Crossobothrium laciniatum Linton.

Linton, I889, p. 470 (sp. nov.); Linton, I89o, p. 799; Linton, I897a, p. 445; Linton, I90r, p. $4 \mathrm{II}, 429$.

From stomach and intestine of Carcharias littoralis (very abundant).

Dibothrium alutera Linton.

Linton, I889, p. $45^{8}$ (sp. nov.); Linton, I9or, p. $4 \pi \mathrm{I}, 464$.

From intestine of Alutera schoepfi; 104 specimens taken from a single fish.

Dibothrium angustatum (Rudolphi).

Linton, I9or, p. 4II, etc.

Hosts: Merluccius bilinearis (intestine), Poronotus triacanthus.

Dibothrium crassiceps (Rudolphi).

Linton, Igor, p. $4 \mathrm{Ir}$, etc.

Hosts: Anguilla chrysypa, Hippoglossus hippuglossus, Merluccius bilinearis (intestine), Pomatomus saltatrix.

Dibothrium ligula Donnadieu.

Linton, I9OI, p. 4II, 44I.

Host: Osmerus mordax. 
Dibothrium manubriforme Linton.

Linton, r889, p. $45^{6}$ (sp. nov.); Linton, I89o, p. 728; Linton, I897a, p. 429; Linton, I90I, P. 4 II , etc.

Hosts: Istiophorus nigricans (intestine), Tetrapterus imperator (intestine).

Dibothrium microcephalum (Rudolphi).

Linton, 189o, p. 736; Linton, I90I, P. 4II, 465.

From intestine of Mola mola (common).

Dibothrium plicatum (Rudolphi).

Linton, 1890 , p. 746; Linton, 1897a, p. 430; Linton, Igor, p. 412, 448.

From intestine of Xiphias gladius.

Dibothrium punctatum (Rudolphi).

Linton, I89o, p. 73I; Linton, I897a, p. 430; Linton, I90I, P. $4 \mathrm{II}$, etc.

Hosts: Decapterus punctatus, Hemitripterus americanus, Hippoglossushippoglossus, Limanda ferruginea (intestine), Lophopsetta maculata (intestine), Myoxocephalus aneus, Myoxocephalus octodecimspinosus, Palinurichthys perciformis, Paralichthys dentatus, Paralichthys oblongus (intestine), Pseudopleuronectes americanus, Scomber scombrus (intestine), Trachurops crumenophthalmus, Urophycis chuss.

Dibothrium restiforme Linton.

Linton, I89o, p. 722 (sp. nov.); Linton, I9or, p. 4 II, 443 .

From intestine of Tylosurus acus.

Dibothrium rugosum (Rudolphi).

Linton, I890, p. 750; Linton, I897a, p. 431; Linton, I90I, p. 4I2, 476 .

Hosts: Gadus callarias (pyloric cœca), Melanogrammus aglefinus, Microgadus tomcod, Urophycis tenuis.

\section{Dibothrium sp.}

Linton, 1901, p. 412 , etc.

Undetermined species of this genus found in spiral valve of Mustelus canis, and larvæ in Alutera schoepfi, Carangus crysos, Gasterosteus aculeatus, Lagocephalus lavigatus, Lophius piscatorius, Myoxocephalus aneus, Scomber scombrus (intestine), Seriola lalandi, Spheroides maculatus.

Dinabothrium septaria Beneden.

Host: Carcharodon carcharias,-Linton, MS.

Discocephalum pileatum Linton.

Linton, I89o, p. $78 \mathrm{I}$ (sp. nov.); Linton, I90I, p. 412,427 .

From spiral valve of Carcharhinus obscurus.
Echeneibothrium variabile Beneden.

Linton, I889, p. 460; Linton, I890, p. 766;

Linton, I897a, p. 440; Linton, 1901, p. 412, 43I.

From spiral valve of Raja erinacea, Raja lavis, Raja ocellata.

Echeneibothrium sp.

Linton, I90r, p. 412, etc.

Hosts: Myliobatis freminvillei (spiral valve), Rhinoptera bonasus (spiral valve).

Lecanicephalum peltatum Linton.

Linton, I89o, p. 802 (sp. nov.); Linton, I9oI, p. 4 I2 433

From spiral valve of Dasyatis centrura.

Ligula sp. larva.

Linton, 1897 , p. 788; Linton, I9OI, p. 4I2, 465, (Ligula chylomycteri).

From spleen of Chilomycterus schœpfi.

Monorygma sp.

Linton, I90r, p. 412 , etc.

Hosts: Carcharhinus milberti, Galeocerdo tigrinus, Isurus dekayi (all in spiral valve), Raja levis, Squalus acanthias.

Onchobothrium uncinatum (Rudolphi).

Linton, I897a, p. 446; Linton, I9or, p. 4I2, 433.

From spiral valve of Dasyatis centrura.

Orygmatobothrium crenulatum Linton.

Linton, I897a, p. 444 (sp. nov.); Linton, I90I, p. 412, 433 .

From spiral valve of Dasyatis centrura.

Orygmatobothrium paulum Linton.

Linton, 1897a, p. 444 (sp. nov.); Linton, I90r, p. 412,426 .

From spiral valve of Galeocerdo tigrinus.

Otobothrizon crenacolle Linton.

Linton, I89o, p. 350 (sp. nov.); Linton, I9or, p. 4I2, 428; Linton, I907, p. II 3 et seq.

Adult worms abundant in the spiral valve of Sphyrna zygana; cysts abundant in the flesh of Poronotus triacanthus; have likewise been found encysted in the viscera of the following fishes taken in local waters: Alutera schoepfi, Carcharhinus obscurus, Cynoscion regalis, Fundulus heteroclitus, Mustelus canis, Paralichthys dentatus, Sarda sarda, Trichiurus lepturus, Xiphias gladius.

Ctobothrium dipsacum Linton.

Linton, i 897 , p. 806 (sp. nov.); Linton, Igor, p. 412,451 .

Host: Pomatomus saltatrix. 
Paratenia medusia Linton.

Linton, 1890, p. 862 (sp. nov.); Linton, I897a, p. 440; Linton, I901, p. 412, 433.

From spiral valve of Dasyatis centrura.

Phoreiobothrium lasium Linton.

Linton, r889, p. 474 (sp. nov.); Linton, r89o, p. 819; Linton, r897a, p. 447; Linton, rogr, p. 412 , etc.

Hosts: Carcharhinus milberti, Carcharhinus obscurus (spiral valve), Sphyrna zygana (spiral valve).

Phoreiobothrium triloculatum Linton.

Linton, I90I, p. 412, 427 (sp. nov.).

From spiral valve of Carcharhinus obscurus.

Phyllobothrium foliatum Linton.

Linton, I89o, p. 787 (sp. nov.); Linton, I897a, P 443; Linton, I90I, p. 4I2, 433.

Hosts: Dasyatis centrura (spiral valve): Raja lavis.

Phyllobothrium loliginis Leidy.

Linton, 1897 , p. 792 .

Adults from stomach of the squid (Ommastrephes illecebrosus), taken at Provincetown. Immature specimens of this species have been found in the stomachs of the following hosts, not yet having been affected by the digestive fluids: Hemitripterus americanus, Mustelus canis, Paralichthys dentatus, Paralichthys oblongus, Raja lavis, Raja ocellata, Spheroides maculatus, Squalus acanthias, Urophycis chuss, Urophycis tenuis, Xiphias gladius.

Phyllobothrium, sp. undetermined.

Linton, Igor, p. 412, 474 .

Hosts: Carcharodon carcharias, Isurus dekayi, Merluccius bilinearis (intestine).

Platybothrium cervinum Linton.

Linton, I89o, p. 820 (sp. nov.); Linton, I9oI, p. 412,427 .

From spiral valve of Carcharhinus obscurus.

Platybothrium parvum Linton.

Linton, I90I, p. 4I2, etc. (sp. nov.).

Hosts: Carcharhinus milberti (spiral valve), Isurnes dekayi (spiral valve), Sphyrna zygana (spiral valve).

Rhinebothrium cancellatum Linton.

Linton, I89o, p. 77 I (sp. nov.); Linton, Igor, p. 412 , etc.

Hosts: Dasyatis centrura (spiral valve), Rhinoptera bonasus (spiral valve).

Rhinebothrium flexile Linton.

Linton, I89o, p. 768 (sp. nov.); Linton, I9or, p. 412,433 .

From spiral valve of Dasjatis centrura.
Rhinebothrium longicolle Linton.

Linton, I89o, p. 775 (sp. nov.); Linton, I897a, p. 44I; Linton, rgor, p. 4r2, 433 .

Hosts: Myliobatis freminvillei (spiral valve), Rhynoptera bonasus.

Rhinebothrium minimum (Beneden).

Linton, I897a, p. 44r; Linton, r9or, p. 4I2, 43 r.

From spi:al valve of Raja eglanteria and Raja lavis.

Rhynchobothrium agile Linton.

Linton, I897a, p. 45 I (sp. nov.); Linton; rgor, p. 412 , etc.

Hosts: Myliobatis freminvillei (spiral valve), Rhinoptera bonasus (spiral valve).

Rhynchobothrium attenuatum (Rudolphi).

Linton, I897, p. 805; Linton, I90I, p. 412, 448.

From peritoneum of Xiphias gladius.

Rhynchobothrium brevispine Linton.

Linton, I897a, p. $45^{\circ}$ (sp. nov.); Linton, 190r, p. 412,434 .

From spiral valve of a small ray (probably Rhynoptera bonasus).

Rhynchobothrium bulbifer Linton.

Linton, I889, p. 486 ( $R$. tenuicolle); Linton, I89o, p. 825 (R. bulbifer, sp. nov.); Linton, I897, p. 793; Linton, I897a, p. 448; Linton, IgOI, p. 4I 2 , etc.

Adults common in spiral valve of Mustelus canis; cysts in viscera of following species: Aluiera schocpfi, Ammodytes americanus, Anguilla chrysypa, Cynoscion regalis, Elops saurus, Gadus callarias, Gymnosarda alleterata, Menidia menidia notata, Menticirrhus saxatilis, Merluccius bilinearis, Microgadus tomcod, Myoxocephalus aneus, Paralichthys dentatus, Pomatomus saltatrix, Poronotus triacanthus, Raja erinacea, Sarda sarda, Scomber scombrus (muscles of back), Scomberomorus maculatus, Spheroides maculatus, Squalus acanthias, Tetronarce occidentalis, Urophycis chuss.

Rhynchobothrium heterospine Linton.

Linton, I89o, p. 839 (sp. nov.); Linton, 1897, p. 799; Linton, I9o1, p. 412 , etc.

Adults in spiral valve of Mustelus canis and Squalus acanthias; cysts in viscera of Anguilla chrysypa, Paralichthy's dentatus, and Syngnathus fuscus.

Rhynchobothrium hispidum Linton.

Linton, r89o, p. 833 (sp. nov.); Linton, I9or, p. 4I2, 433 .

Cysts from Tautoga onitis; adults from spiral valve of Dasyatis centrura. 
Rhynchobothrium imparispine Linton.

Linton, 1890, p. 840 (sp. nov.); Linton, I 897 , p. 799; Linton, $1897 a$, p. 450; Linton, I90r, p. 4 I 2 , etc.

Adult worms in following species: Dasyatis centrura, Myliobatis freminvillei, Raja eglanteria, Raja erinacea (spiral valve), Raja lavis (spiral valve), Raja ocellata, Squalus acanthias. Cysts and larvæ in the following species: Ammodytes americanus, Anguilla chrysypa, Centropristes striatus (in viscera), Clupea harengus (stomach wall), Gadus callarias (peritoneum), Hemitripterus americanus, Leptocephalus conger (serous coat of intestine), Limanda ferruginea (in viscera), Lophius piscatorius, Lophopsetta maculata, Melanogrammus aglefinus (peritoneum), Menidia menidia notata, Merluccius bilinearis, Microgadus tomcod (in viscera), Myoxocephalus aneus, Myoxocephalus octodecimspinosus, Osmerus mordax, Paralichthys dentatus (in viscera), Pollachius virens, Pomolobus pseudoharengus, Prionotus strigatus, Pseudopleuronectes americanus, Raja erinacea, Sarda sarda, Scomber scombrus, Stenotomus chrysops (in viscera), Tautogolabrus adspersus, Tetronarce occidentalis (intestinal wall), Urophycis chuss, Urophycis tenuis, Xiphias gladius.

Rhynchobothrium lomentaceum Diesing.

Linton, 1890, p. 845; Linton, I901, p. 412, 425. From spiral valve of Mustelus canis.

Rhynchobothrium longicorne Linton.

Linton, 1890 , p. 847 (sp. nov.); Lintorl, I 897 , p. 450; Linton, I90I, p. 412, 429.

From spiral valve of Carcharias littoralis.

Rhynchobothrium longispine Linton.

Linton, I89o, p. 835 (sp. nov.); Linton, I9or, p. 4 I 3,433 .

Adults from spiral valve of Dasyatis centrura; cysts from the following hosts: Menticirrhus saxatilis, Paralichthys dentatus, Poronotus triacanthus, Prionotus strigatus, Scomberomorus maculatus, Stenotomus chrysops, Urophycis chuss.

Rhynchobothrium speciosum Linton.

Linton, r897, p. 80 I (sp. nov.); Linton, I9or, p. $4 \mathrm{I} 3$, etc.

Adults from Carcharhinus obscurus; cysts in the viscera of the following hosts: Chatodipterus faber, Cynoscion regalis, Lophius piscatorius, Paralichthys dentatus, Pomatomus saltatrix, Remora remora, Roccus lineatus, Scomber scombrus, Scomberomorus maculatus, Stenotomus chrysops, Trichiurus lepturus, Tylosurus acus.

\section{Rhynchobothrium tenuispine Linton.}

Linton, r89o, p. 837 (sp. nov.); Linton, r897a, p. 448 ; Linton, I9OI, p. 4 I3, etc.

Hosts: Carcharhinus milberti (spiral valve), Dasyatis centrura (spiral valve), Raja erinacea.

Rhynchobothrium tumidulum Linton.

Linton, 1890, p. 829 (sp. nov.); Linton, $1897 \mathrm{a}$, p. 448; Linton, I90I, p. $4 \mathrm{I} 3$, etc.

Adults found in spiral valve of Carcharhinus obscurus, Mustelus canis, and Raja erinacea; scolices in intestine of Opsanus tau; cysts in Spheroides maculatus.

Rhynchobothrium wageneri Linton.

Linton, I 890, p. 843 (sp. nov.); Linton, I90I, p. 413,433 .

From spiral valve of Dasyatis centrura.

Rhynchobothrium, sp. undet.

Cysts from the following hosts: Cynoscion regalis, Lophius piscatorius, Pseudopleuronectes americanus, Seriola lalandi, Spheroides maculatus.

Scolex polymorphus Rudolphi.

Linton, I90I, p. 4I3, etc.

Hosts: Anchovia argyrophanus, Anchovia brownii (larvæ in intestine), Anguilla chrysypa, Brevoortia tyrannus (intestine, larvæ), Centropristes striatus (free in intestine), Clupea harengus (intestine, larvæ), Cynoscion regalis (free in gall bladder and cystic duct), Decapterus macarellus (free in intestine), Decapterus punctatus, Etrumeus teres, Fundulus heteroclitus (intestine, larvæ), Hippoglossus hippoglossus, Lagocephalus lceigatus (intestine, abundant), Leptocephalus conger (intestine, larvæ), Limanda ferruginea (intestine), Lophius piscatorius (free in intestine, larvæ), Lopholatilus chamcleonticeps (free in intestine), Melanogrammus aglefinus, Menticirrhus saxatilis (intestine), Merluccius bilinearis (free in intestine), Microgadus tomcod (free in intestine), Opsanus tau, Palinurichthys perciformis (alimentary tract), Paralichthys dentatus (cystic duct and free in, intestine), Paralichthy's oblongus (intestine), Pomatomus saltatrix (larva in intestine), Pomolobus mediocris (larva in intestine), Pomolobus pseudoharengus (larvæ in intestine), Poronotus triacanthus (free in intestine), Raja lavis, Sarda sarda (larvæ free in intestine, rare), Scomber scombrus (larvæ free in intestine), Spheroides maculatus (free in intestine), Stenotomus chrysops (free in intestine), Tautoga onitis, Trichiurus lepturus, Tylosurus marinus (larvæ in intestine), Urophycis chuss, Xiphias gladius. 
Spongiobothrium variabile Linton.

Linton, I889, p. 462 (sp. nov.); Linton, I890, p. 778 ; Linton, 1897 a, p. 442 ; Linton, 1901, p. $4 \mathrm{I} 3,433$.

From spiral valve of Dasyatis centrura

Synbothrium filicolle Linton.

Linton, I89o, p. 86I (Syndesmobothrium filicolle, sp. nov.); Linton, I897, p. 815; Linton, I90r, p. $4 \mathrm{I}_{3}$, etc.

Scolex in spiral valve of Dasyatis centrura; cysts in viscera of following species: Brevoortia tyrannus, Carcharhinus obscurus, Cynoscion regalis, Galeocerdo tigrinus, Lobotes surinamensis, Mustelus canis, Paralichthy's dentatus Pomatomus saltatrix, Scomberomorus cavalla, Scomberomorus maculatus, Scomberomorus regalis, Seriola dumerili.

Trenia chamissonii Linton.

Linton, I905 (sp. nov.).

About 25 cysts found in mesentery of a "skunk porpoise" (Lagenorhynchus acutus) captured at Menemsha Bight, October 7, Igor.

Tania dilatata Linton.

Linton, I889, p. 488 (sp. nov.); Linton, I897a, p. 425 ; Linton, I90r, p. 4I4, 435 .

From intestine of Anguilla chrysypa.

Tania sp.

Linton, I90I, p. 4I4, 428, 435 .

Undetermined worms referred to this genus found in Anguilla chrysypa, Fundulus diaphanus, and in Sphyrna zygana (mucous membrane of intestine).

Tetrarhynchus bicolor (Bartels).

Linton, I90I, p. 4I4, etc.

Adult taken once in Carcharhinus obscurus; cysts and scolices found in the following hosts: Carcharinus obscurus, Coryphana hippurus (peritoneum), Galeocerdo tigrinus (stomach), Paralichthys dentalus (alimentary canal), Sarda sarda, Xiphias gladius (peritoneum and mesentery).

Tetrarhynchus bisulcatus Linton.

Linton, I889, p. 479 (Rhynchobothrium bisulcatum, sp. nov.); Linton, r89o, p. 857; Linton, I897, p. 81o; Linton, I897a, p. 452; Linton, I90I, p. 4I4, etc.

Adults very abundant in the pylorus and intestine of Carcharhinus obscurus; cysts and scolices in the viscera of the following species: Cynoscion regalis, Decapterus macarellus, Lophius piscatorius, Lopholatilus chamaleonticeps, Paralichthy's dentatus, Paralichthy's oblongus, Pomatomus saltatrix, Poronotus triacanthus, Prionotus carolinus, Prionotus
Tetrarhynchus bisculcatus-Continued.

strigatus, Pseudopleuronectes americanus, Scomber scombrus, Seriola zonata, Spheroides maculatus, Stenotomus chrysops, Tetronarce occidentalis, Urophycis chuss, Xiphias gladius.

Tetrarhynchus elongatus (Wagener).

Linton, 1897 , p. 8I2; Linton, I90I, p. 4I4, 466.

From liver of Mola mola (common).

Tetrarchynchus erinaceus Beneden.

Linton, I897, p. 8II; Linton, I90I, p. 4I4, etc.

Cysts in viscera of $C y$ noscion regalis, Pomatomus saltatrix and Poronotus triacanthus.

Tetrarhynchus lintoni Vaullegeard.

Linton, 1890, p. 853 (T. tenue, sp. nov.); Linton, I897a, p. 452; Linton, I9or, p. 4I 4,433 (T. tenuis).

Spiral valve of Dasyatis centrura.

Tetrarhynchus robustus Linton.

Linton, I89o, p. 855 (sp. nov.); Linton, r897a, p. $45^{2}$; Linton, I9or, p. 414, etc.

Adults from Carcharhinus obscurus, Dasyatis centrura (stomach and pylorus), Isurus dekayi (scolex in spiral valve), Myliobatis freminvillei, Raja lavis, Rhinoptera bonasus; cysts from Paralichthys dentatus.

Tetrarhynchus sp.

Linton, I9or, p. 4I4, etc.

"Cysts too immature for identification or not yet identified" recorded for the following hosts: Carcharinus obscurus, Chetodipterus faber, Dasyatis centrura, Lophius piscatorius, Mustelus canis, Pomolobus mediocris, Poronotus triacanthus, Pseudopleuronectes americanus, Raja erinacea, Sarda sarda, Scomberomorus regalis, Spheroides maculatus, Sphyrna zygena, Terapterus imperator.

Thysanocephalum crispum Linton.

Linton, I889, p. 464 (Phyllobothrium thysanocephalum, sp. nov.); Linton, I890, p. 823; Linton, 189ra, p. 543; Linton, I897a, p. 448; Linton, I90I, p. 4I4, 426 .

From spiral valve of Galeocerdo tigrinus.

Thysanoccphalum ridiculum Linton.

Linton, r9or, p. 4I4, 430 (sp. nov.).

From spiral valve of Isurus dekayi.

Trilocularia gracilis Olsson.

Adult from Squalus acanthias.-Linton, MS.

Tylocephalum pingue Linton.

Linton, ISgo, p. 806 (sp. nov.); Linton, I9or, p. 4I $4,434$.

From spiral valve of Rhinoptera bonasus.

Cestode, undetermined (belonging to a new genus allied to Ligula).

From Liparis liparis. 


\section{Class NEMERTINEA. $a$}

Family CARINELLIDE:

Carinella pellucida Coe.

Vineyard Sound, Buzzards Bay, Woods Hole, Juniper Point, Nobska Point; under stones and among algæ low water to 8 fathoms.-.-Coe. Ripe sexual products at Woods Hole in July.

Family Carinomida.

Carinoma tremaphoros Thompson.

Breakwater (Buzzards Bay side), Great Pond, Falmouth; low water to I fathom, in sandy localities.-Coe.

Sexually mature in September.

Family CEPHaLOTRICHIDAs.

Cephalothrix linearis (Rathke).

Verrill, I892, p. 442; Coe, 1899.

Newport, Woods Hole.-Verrill. Woods Hole, Juniper Point, Penzance (Buzzards Bay side), Naushon Id.; not abundant; found under stones and hard clay, and in gravel and mud.Coe. Verrill states that it "often occurs gregariously, many individuals being intricately coiled up in a mass."

Sexual products mature at Woods Hole in August; eggs can be artificially fertilized.Coe.

\section{Family TANIOSOMDE.}

\section{Parapolia aurantiaca Coe.}

Coe, r895, p. 5 I8 (sp. nov.); I899.

Shore of Devils Foot Island; in Woods Hole Harbor; two specimens found in sand at low-water mark, August, 1894. The sexual products were then mature.

Zy'geupolia rubens (Coe).

Coe, I895, p. 52I (Valencinia rubens, sp. nov.); I899 (Valencinia rubens).

Near "Gut of Canso," in Woods Hole Harbor, Bay shore of Penzance, Quisset Harbor; fairly common near low-water mark, several inches in the sand, occasionally under stones.-Coe.

\section{Family LINEIDA.}

\section{Lineus viridis (Fabricius).}

Verrill and Smith, 1873, p. 628 (Nemertes viridis); Verrill, 1879, p. $185 ; 1892$, p. 418 ; Coe, 1899.

Buzzards Bay and Vineyard Sound (very common), Woods Hole, Newport; under stones between tides, and in shallow water on rocky bottoms.-Verrill. Eel Pond, Great Harbor, Juniper Point, Little Harbor, Bay side of Penzance, Hadley Harbor; common under stones at low water.-Coe.

Sexually mature in June; eggs laid under stones at low water; may be artificially fertilized.-Coe.
Lineus viridis sanguineus (Rathke)

Associated with Lineus viridis, not uncommon.Coe.

Lineus socialis (Leidy).

Verrill and Smith, I873, p. 628, 324, $392(\mathrm{Ne}$ mertes socialis); Verrill, 1879, p. 185 (Lineus communis); Verrill, I892, p. 424 ; Coe, 1899.

Vineyard Sound; "in great abundance under stones from mid-tide to near high-water mark" ; very gregarious.-Verrill. Eiel Pond, Little Harbor, Great Harbor, Hadley Harbor; in eelgrass and under stones; not common.--Coe.

Eggs mature in midwinter at New Haven.-Coe.

Lineus bicolor Verrill.

Verrill, I892, p. 426 (sp. nov.); Coe, I899.

Vineyard Sound, common; "usually taken on shelly or stony bottoms, among algæ, ascidians, and hydroids."-Verrill. Nobska, Tarpaulin Cove, and westward; 3 to 5 fathoms.-Coe. Buzzards Bay, near Cuttyhunk, at Phalarope station ro3; 5 fathoms, mud.*

Local specimens taken in July, I898, contained mature sexual products.-Coe.

Micrura leidyz (Verrill).

Verrill and Smith, I873, p. 630, 324 (Meckelia rosea); Verrill, r892, p. 436 (Cerebratulus leidyi); Coe, I899 (Cerebratulus leidyi).

Vineyard Sound, Woods Hole, Newport, very common, burrowing in sand near low-water mark, occasionally under stones.-Verrill. Uncatena Gutter, bay shore of Penzance.-J. P. McMurrich, in Marine Biological Laboratory card catalogue. Great Harbor, Bay side of Penzance, Naushon, Quisset, Falmouth.Coe.

Fish Hawk stations $75^{2}$ I * (Vineyard Sound) and 7647 * (Buzzards Bay); 6 to Io fathoms, sand and mud.-Survey.

Breeds commonly at Woods Hole in July and early August, sometimes earlier than July; eggs may be artificially fertilized.-Coe.

Micrura caca Verrill.

Verrill, I892, p. 53 I (sp. nov.; not listed for this region); Coe, I899.

Vineyard Sound, Bay shore of Penzance, Great Harbor, Naushon, Quisset Harbor; in sand between tides.-Coe.

Sexual products mature at Woods Hole in August; eggs can be artificially fertilized, and reared to the pilidium stage.-Coe. 
Micrura afinis (Girard).

Verrill, 1879, p. 186 (not listed for this region); 1892, p. 428 .

South of Cape Cod and off Nantucket and Marthas Vineyard; I2 to 50 fathoms.-Verrill. Marthas Vineyard and northward.-Coe.

Cercbratulus lacteus (Leidy).

Verrill and Smith, 1873, p. $630,324,349,350$ (Meckelia lactea and $M$. ingens); Verrill, I892, p. 433; Coe, 1899 .

Buzzards Bay and Vineyard Sound; "common, burrowing both in sand and mud at and above low-water mark and in shallow water down to several fathoms in depth."-Verrill. Naushon, Hadley Harbor, Great and Little Harbors (Woods Hole), Penzance (Buzzards Bay side), Falmouth, Quisset.-Coe.

Fish Hawk station *: 7556 (several dead pieces), 7640 (? posterior portion only), 7647 (? midportion only), 7652 (? posterior end only), 7659 .

Eggs ripe at New Haven during March, April, and May; in Maine this species breeds in July; eggs can be artificially fertilized and embryos easily reared to pilidium. In recent years the eggs of this form have been extensively used in experimental embryology.

\section{Cerebratulus marginatus Renier.}

Verrill, r892, p. 438 (Cerebratulus fuscus).

"South of Cape Cod it occurs in I5 to 45 fathoms on bottoms of sand and mud in the cold areas swept by the arctic current, as off Gay Head in I9 fathoms."'-Verrill. Gay Head, under stones, between tides.-Coe. Buzzards Bay, at Fish Hawk station 7658 ; 9 fathoms, mud*.

Cerebratulus luridus Verrill.

Verrill and Smith, 1873, p. 630, 502, 508 (Meckelia lurida, sp. nov.); Verrill, I892, p. 440; Coe, I899.

Off Gay Head, I9 fathoms, soft mud; off Buzzards Bay, 25 fathoms.-Verrill. Loiver half of Buzzards Bay, in 6 to ${ }_{3} 3$ fathoms, on muddy bottoms.-Survey.

Fish Hawk stations: $763^{*}, 7642^{*} a, 7643^{*} a$, $7647^{*}, 7654^{*}, 7655^{*}, 768^{*}, 766$ I (?), 7662 (?), 7669 (?).

Apparently ripe eggs in Cape Cod Bay in August.-Verrill, cited by Coe.
Family CARCINONEMERTIDEA.

Carcinonemertes carcinophila (Kölliker).

Coe, I902, p. 44I.

Nobska Point, Katama Bay, Menemsha Bight.

"Parasitic on the gills of various species of crabs when young, migrating to the egg masses of the crab at the approach of sexual maturity." Locally, reported only from the "lady crab" (Ovalipes ocellatus). In the case of a large number of crabs of this species examined by Dr. Coe during July and August of various years the parasites were found on the gills of about ro per cent of the female crabs, but none were found on the males.

\section{Family AMPHIPORIDE.}

Zygonemertes virescens (Verrill).

Verrill, 1879, p. 183 (Amphiporus virescens, sp. nov.); 1892 , p. 400 (Amphiporus virescens); Coe, 1899 (Amphiporus virescens).

Woods Hole, Newport; "common in shallow water among hydroids and ascidians, and on the piles of wharves, between tides." - Verrill. Piles of United States Bureau of Fisheries pier, Woods Hole steamboat landing, Little Harbor.-Coe.

Eggs mature at Woods Hole in July and August.Coe.

Amphiporus ochraceus Verrill.

Verrill and Smith, 1873, p. 630, 325 (Cosmocephala ochracea, sp. nov.); Verrill, I892, p. 396; Coe, I899.

Woods Hole, Vineyard Sound; common between tides, in tide pools, and under stones, creeping among algæ, hydroids, etc., or in dead tubes of serpula; on piles of wharves; likewise dredged in 2 to 20 fathoms, on stony or shelly bottoms.Verrill. Woods Hole Harbor, at railroad wharf and Juniper Point, Nobska Point, Penzance (Bay shore), Eel Pond; common among eelgrass.-Coe. Buzzards Bay, shore of Nashawena, at Phalarope station 78 , in 5 to 6 fathoms, sand and mud*.

Dr. Coe reports that in the vicinity of New Haven the eggs are laid during May and June; in one case as early as January.

${ }^{a}$ Uncertain whether presen at one or both of these stations.

I6269 - Bull. 3 I, pt $2-13-4$ 
?Amphiporus glutinosus Verrill.a

Verrill and Smith, 1873, p. 631, 324, 382 (Polina glutinosa, sp. nov.); Verrill, I892, p. 397; Montgomery, I897, p. 9.

Woods Hole, Vineyard Sound; low water to 6 fathoms, usually among hydroids and bryozoa.-Verrill. Abundant in Eel Pond.T. H. Montgomery.

Amphiporus cruentatus Verrill.

Verrill, I879, p. I84 (sp. nov.); I892, p. 399.

Vineyard Sound, 4 to Io fathoms; off Newport, 3 to 8 fathoms.-Verrill. Off Nobska Point, common among dead shells of Spisula; Tarpaulin Cove.-Coe.

Amphiporus bioculatus McIntosh.

Verrill, I892, p. 402 (determination doubtful).

Vineyard Sound, I to to fathoms, not uncommon.-Verrill. Vineyard Sound, I to 20 fathoms.-Coe.

Family Tetrastematide:

Tetrastemma candidum (Fabricius).

Coe, 1899.

Great Harbor, Little Harbor; on piles, between tides; not common.-Coe.

Sexually mature at Woods Hole in July and August.

Tetrastemma vittatum Verrill.

Verrill, I892, p. 4II.

Vineyard Sound, Woods Hole; in mud.-Verrill. Little Harbor, Eel Pond; muddy bottoms and eelgrass, down to 25 fathoms.-Coe.

Nemertean, family and species undetermined. Blue Wing station 44 .

\section{Phylum NEMATHELMINTHES.}

\section{Class NEMATODA.}

Acanthocheilus nidifex Linton.

Linton, 1900, p. 303 (sp. nov.); Linton, I90I, p. 410,426 .

Host: Galeocerdo tigrinus, in pits or nests formed by the worm bnrowing into the mucous membrane of stomach, rare.

Acanthocheilus sp.

Linton, I901, p. $410,428$.

From Carcharias littoralis (stomach) and Raja ocellata.

? Agamonema capsularia Diesing.

Linton, I90I, p. 4 ro, etc.

Immature specimens from Anguilla chrysypa, Clupea harengus and Scomber scombrus.

? Agamonema papilligerus Diesing.

Linton, Igor, p. 410, 444.

Host: Scomber scombrus.

? Ascaris acanthocaudata Cobbold.

Linton, r901, p. 410, 476.

Host: Melanogrammus aglefinus.
Tetrastemma elegans Verrill.

Verrill, I892, p. 406.

Woods Hole, on piles of wharf.-Verrill. Vineyard Sound, Great Harbor, Little Harbor; on piles; not common.-Coe.

Tetrastemma vermiculus (Quatrefages).

Verrill, r892, p. 407; Coe, I899.

Little Harbor, on piles and in mud.-Verrill. Great Harbor, Hadley Harbor, Vineyard Sound, on all kinds of bottoms.-Coe.

Ripe ova in August.-Coe.

Tetrastemma dorsale (Abildgaard).

Little Harbor and Hadley Harbor; common on piles.-Coe.

Sexually mature in August.

Family MaL,ACOBDELLIDA:.

Malacobdella grossa Müller).

Verrill and Smith, I873, p. 625,458 (Malacobdella obesa; listed among the leeches); Verrill, r892, p. 444 (Malacobdella obesa).

Parasitic on Mya, Venus, and Cyprina; rare. "Has apparently decreased in numbers in recent years, for an examination of thousands of lamellibranchs in the Woods Hole region during each summer for more than five years has not revealed a single specimen."'-Coe.

Ascaris adunca Rudolphi.

Host: Alosa sapidissima.-Linton.

Ascaris brevicapitata Linton.

Linton, Igor, p. 410, 425 (sp. nov.).

From stomach of Galcocerdo tigrinus (very rare).

Ascaris capsularia Rudolphi.

Linton, I90I, p. 410, etc.

Hosts: Gadus callarias; Scomber scombrus.

Ascaris clavata Rudolohi.

Linton, I900, p. 302 ; Linton, I90I, p. 410 , etc.

Hosts: Gadus callarias, Hippoglossus hippoglossus, Melanogrammus aglefinus, Merluccius bilinearis, Microgadus tomcod, Myoxocephalus aneus, Myoxocephalus octodecimspinosus, Pollachius virens, Pomolobus mediocris (?), Raja crinacea, Scomber scombrus, Scomberomorus maculatus, Squalus acanthias. 
Ascaris habcna Linton.

Linton, I900, p. 302 (sp. nov.); Linton, I90I, p. $410,468$.

Hosts: Gadus callarias, Lophopsetta maculata, Myoxocephalus aneus, Myoxocephalus octodecimspinosus, Opsanus tau (stomach and intestine, common), Palinurichthys perciformis, Pomolobus mediocris, Prionotus carolinus, Pseudopleuronectes americanus, Scomberomorus, maculatus, Spheroides maculatus, Urophycis chuss, Urophycis tenuis.

Ascaris increscens Molin.

Linton, I90I, P. 4Io, etc.

Hosts: Coryphena hippurus (stomach); Lophius piscatorius.

Ascaris incurva Rudolphi.

Linton, Igor, p. 410, etc.

Hosts: Hippoglossoides platessoides (rectum, rare), Scriola zonata (stomach), Scomberomorus maculatus (intestine, rare), Seriola lalandi, Tetrapterus imperator (intestine and rectum, rare), Xiphias gladius (stomach, common)

Ascaris inquies Linton.

Linton, I901, p. $410,45^{2}$ (sp. nov.).

From stomach of Rachycentron canadus (many).

Ascaris neglecta Leidy.

Linton, I90I, p. 410, 465 .

From intestine of Chilomycterus schœpfi.

? Ascaris rigida $\mathrm{Rudolphi}$.

Linton, I90I, P. 410, 488 .

Host: Lophius piscatorius.

Ascaris rotundata Rudolphi.

Linton, I90I, p. 410, etc.

Hosts: Raja eqlanteria; Raja erinacea (stomach and intestine), Raja lcevis, Raja ocellata.

Ascaris sp.

Linton, I90I, p. 4ro, etc.

Unidentified (for the most part immature) worms referred to this genus are recorded for the following hosts: Alosa sapidissima, Brosmius brosme, Carcharias littoralis, Clupea harengus, Dasyatis centrura, Hemitripterus americanus, Lagocephalus lavigatus, Macrourus bairdii, Menticirrhus saxatilis, Microgadus tomcod, Mustelus canis (peritoneal capsules), Myoxocephalus aneus, Osmerus mordax, Paralichthys dentatus (intestine), Pomolobus mediocris (stomach), Pscudopleuronectes americanus, Roccus lineatus, Sarda sarda (stomach), Scomber scombrus, Stenotomus chrysops, Tylosurus acus, Urophycis tenuis.
Dacnitis hians Dujardin.

Linton, I901, p. $410,436$.

From intestime of Leptocephalus conger.

Dacnitis sphcerocephala Dujardin.

Linton, rgor, p. 410, 435 .

From intestine of Acipenser sturio.

Filaria rubra L,eidy.

Linton, I90I, p. 4ro, etc.

Hosts: Centropristes striatus (under skin), Roccus lineatus (from flesh).

Filaria, sp. undet.

Host: Menidia menidia notata.-Linton.

Heterakis foveolata (Rudolphi).

Linton, Igor, p. 410, etc. (Cucullanus globosus).

Hosts: Carangus crysos, Gadus callarias, Hippoglossus hippoglossus, Lophius piscatorius (intestine), Melanogrammus aglefinus, Pomolobus astivalis, Urophycis chuss.

Heterakis, sp. undet.

Linton, I90I, P. 410, 44I, 453 (Cucullanus, sp.).

Hosts: Fundulus diaphanus, Fundulus heteroclitus, Fundulus majalis, Morone americana, Poronotus triacanthus.

Ichthyonema globiceps (Rudolphi).

Linton, I90I, p. 410 , etc.

Hosts: Lobotes surinamenus (peritoneum), Pomatomus saltatrix (ovaries), Scomberomorus maculalus (ovary, rare), Tarpon atlanticus.

? Ichthyonema sanguineum (Rudolphi).

Linton, 1900, p. 304; Linton, I901, p. $410,482$.

From mouth of Paralichthy's dentatus.

Ichthyonema sp.

Linton, I90r, p. 410, 428, etc.

Undetermined worms referred to this genus were found in Chatodipterus faber (abdominal cavity), Hippoglossoides platessoides (intestine), Microgadus tomcod, Poronotus triacanthus, Pseudopleuronectes americanus, Roccus lineatus, Sarda sarda (beneath skin in gill cavity), Sphyrna zygana (liver), Urophycis tenuis.

Lecanocephalus annulatus (Molin).

Linton, 1901, p. 410, 455 .

Hosts: Anguilla chrysypa, Morone americana, Palinurichthys perciformis, Poronotus triacanthus, Roccus lineatus (peritoneum, very rare). 
Nectonema agile Verrill.

Verrill and Smith, I873, p. 453 (a "slender round worm"); Verrill, I879, p. I87 (Nectonema agilis, sp. nov.; assigned doubtfully to the Nematoda); Ward, I892; Bumpus, I898b.

Vineyard Sound.-Verrill, F. R. Lillie. Woods Hole.-Woodworth, Andrews. Newport.-A. Agassiz, Fewkes.

Swims actively at the surface in the evening in June and July. Ward regards the body structure as indicating that this worm is a parasite during its larval life.
Pontonema marinum Leidy.

Verrill and Smith, 1873, p. 634,325 , etc.

Vineyard Sound, "very abundarit from above low-water mark to ro fathoms;" rocky shores, beneath stones, among algæ, hydroids, etc.; adults taken in surface tow, in February.

Pontonema vacillatum Leidy.

Verrill and Smith, I873, p. $634,326$.

Occurrence similar to that of $P$. marinum.

Spiroptera pectinifer Linton.

Linton, I9OI, p. 4 II, 427 (sp. nov.).

From stomach of Sphyrna zy'gana.

\section{Class ACANTHOCEPHALA.}

Echinorhynchus acus Rudolphi.

Linton, 1889, p. 492; Linton, I89I, p. 525; Linton, Ig0I, p. 409 , etc.

Hosts: Alosa sapidissima, Carcharias littoralis (spiral valve), Cynoscion regalis, Enchelyopus cimbrius (intestine), Fundulus diaphanus, Fundulus heteroclitus, Gadus callarias, Hemitripterus americanus, Hippoglossus hippoglossus, Leptocephalus conger (intestine), Limanda ferruginea (intestine), Lophius piscatorizs (intestine), Lophopsetta maculata, Macrourus bairdii, Melanogrammus aglefinus, Merluccius bilinearis (intestine), Microgradus tomcod, Mola mola (gills), Myoxocephalus aneus, Myoxocephalus octodecimspinosus, Opsanus tau (intestine), Paralichthys dentatus (intestine), Paralichthys oblongus (intestine), Pholis gunnellus, Pollachius virens, Pomolobus astivalis, Pomolobus mediocris, Pomolobus pseudoharengus, Poronotus triacanthus, Prionotus carolinus, Prionotus strigatus, Pseudopleuronectes americanus (intestine), Raja eglanteria, Roccus lineatus, Scomber scombrus, Spheroides maculatus (pharynx), Stenotomus chrysops (viscera), Tautoga onitis, Trichiurus lepturus, Urophycis chuss (intestine), Urophycis tenuis.

Echinorhynchus claveceps Zeder.

Linton, I889, p. 490 (Echinorhynchus agilis); Linton, I89r, p. 534 (E. agilis); Linton, I9or, p. 409 , etc. (E. agilis).

Hosts: Anguilla chrysypa (intestine), Carcharhinus obscurus (spiral valve), Fundulus heteroclitus, Morone americana (intestine), Opsanus tau, Tylosurus marinus (intestine).

Echinorhynchus attenuatus Linton.

Linton, I89r, p. 529 (sp. nov.); Linton, r900, p. 409,435 .

Host: Acipenser brevirostrum (=sturio).
Echinorhynchus carcharia Linton.

Linton, I\$9r, p. 536 (sp. nov.); Linton, rgor, p. 409,428 .

Host: Carcharias littoralis.

Echinorhynchus fusiformis Zeder.

Linton, I901, p. 409, 468.

Host: Opsanus tau (intestine).

Echinorhynchus globulosus Rudolphi.

Linton, I90I, p. 409, 435 .

Hosts: Acipenser rubicundus, Anguilla chrysypa.

Echinorhynchus lateralis Molin.

Linton, I89I, p. 533 (Echinorhynchus incrassatus); Linton, I901, p. 409, etc. (E. incrassatus).

Hosts: Lophius piscatorius, Paralichthys dentatus, Pomatomus saltatrix, (in each case from peritoneum).

Echinorhynchus pristis Rudolphi.

Linton, I89I, p. 530; Linton, rgor, p. 409, etc.

Hosts: Carangus crysos, Cynoscion regalis (viscera), Lobotes surinamensis (intestine), Lophius piscatorius, Palinurichthys perciformis (intestine), Tylosurus acus.

Linton (I89I, p. 53I) lists a variety tenuicornis, which he found in "Tylosurus caribbaus" (doubtless acus or marinus), and in Lobotes surinamensis.

Echinorhynchus proteus Westrumb.

Linton, I889, p. 496; Linton, I89I, p. 537; Linton, I9or, p. 409, etc.

Hosts: Archosargus probatocephalus (peritoneum), Carangus hippos, Centropristes striatus, Cynoscion regalis (intestine), Merluccius bilinearis, Paralichthys dentalus (mesentery), $\mathrm{Po}$ matomus saltatrix (intestine, usually with head perforating the wall), Roccus lineatus (always present in rectum). 
Echinorhynchus sagitlifer Linton.

Linton, I889, p. 493 (sp. nov.), Linton, I891, p. 535 ; Linton, I901, P. 4.09 , etc.

Hosts: Centropristes striatus (peritoneum), Cynoscion regalis (viscera), Paralichthy's dentalus (viscera), Pomatomus saltatrix (peritoneum), Raja erinacea, Rhombus triacanthus (viscera), Stenotomus chry'sops.

Echinorhynchus aurantiacus Risso.

Linton, r89r, p. 535 (Echinorhynchus serrani, sp. nov.); Linton, Igor, p. 409,456 (E. serrani).

From peritoneum of Centropristes striatus.
Echinorhynchus thecatus Linton.

Linton, 189r, p. 528 (sp. nov.); Linton, Igor, J). 409,456 .

Host: Morone americana.

Echinorhynchus, sp. undet. Linton, I90I, p. 409, 47 I (and MS.).

Undetermined representatives of this genus were found in Centropristes siriatus, Lophius piscatorius, Lopholatilus chamaleonticeps (two occasions), Morone anericana, Thunnus thynnus.

\section{Class CHAETOGNATHA.}

Sagitta elegans Verrill.

Verrill and Smith, 1873, p. 626,440 , etc. (sp. nov.).

"Woods Hole and Vineyard Sound, at surface, July r; off Gay Head, among Salpce, September $8 . "$

\section{Sagitta sp.}

Verrill and Smith, r873, p. 440, 453.

An undetermined species, larger and stouter than $S$. elegans, reported by Verrill as taken in large numbers at Woods Hole by V. N. Edwards in January and February.

\section{Sagitta sp.}

One or more species of Sagitia (undetermined: doubtless including those listed by Verrill) are a conspicuous feature of the local plankton during the winter and spring. According to Mr. Edwards's towing records, they are present in greatest abundance during December and January, but are recorded from October till July.

\section{DINOPHILEA. (Incertæ sedis.)}

Family DINOPHILIDA:

\section{Dinophilus gardineri Moore.}

Anne Moore, I900, p. I5 (sp. nov.).

Woods Hole, in an artificial pond of brackish water, May, 1898 and 1899.

Dinophilus pygmaus Verrill.

Verrill, I892a, p. 457 (sp. nov.).
Dinophilus pygmceus-Continued.

Woods Hole, on piles of a wharf, Aug. 1o, 1883 .

Dinophilus simplex Verrill.

Verrill, x8g2a, p. 458 (sp. nov.).

Newport, August, I880.

\section{Phylum MOLLUSCOIDA.}

\section{Class BRYOZOA.}

\section{BRYOZOA ENTOPROCTA.}

Family Loxosomide.

\section{Loxosoma davenporti Nickerson.}

Nickerson, r898, p. 220 (sp. nov.); I899, p. 366 ; Igor, p. 35I; Osburn, I9I2, p. 212.

Cotuit Harbor, in tubes of sand, I foot deep; locally common.

Loxosoma minuta Osburn.

Osburn, I9I2, p. 212 (sp. nov.).

"Found on Phascolcon strombi (=Phascolosoma comentarium) in the Woods Hole region, and on Phascolosoma eremita at the Isles of Shoals, often in considerable numbers among the tubercles of the skin."

\section{Family PEDICELLINIDAE.}

Pedicellina cernua Pallas.

Verrill and Smith, I873, p. 707, 405, etc. (Pedicellina Americana); Osburn, I9I2, P. 2 I3. $_{3}$

New Haven to Vineyard Sound.--Verrill. New Bedford Harbor, on piles, very common, growing intermixed with Bowerbankia gracilis; Nobska Point, in shallow water; Vineyard Sound, off Vineyard Haven, 7 fathoms; Crab Ledge, in 18 fathoms. A form which may be a different species occurs on the piles at New Bedford. This bears a varying number of blunt spines on the head. 
Barentsia major Hincks.

Osburn, I912, p. 213.

Occasional throughout the waters of the region, growing on shells and stones. Dredged by the Survey almost wholly in Buzzards Bay, in 3 to $I_{3}$ fathoms, on various sorts of bottom. Off Gay Head, on leg of spider crab; piles at Nantucket, on Chondrus crispus.

Fish Hawk stations: $7611,7645,7709$. Supplementary station (rgog): 7659 .

Phalarope stations: $135,165,167$. Supplementary station (Ig09): I46 (I).

Barentsia discreta (Busk).

Osburn, I9I2, p. 2 I $_{4}$.

A colony of several dozen individuals that seem to belong to this species was taken by the sur-
Barentsic discreta-Continued.

vey in the eastern part of Vineyard Sound, at Fish Hawk station 7777 , in $5 \frac{1}{2}$ fathoms, growing on a shell fragment, and again off the eastern end of Naushon Island, in I f fathoms, growing on a pebble. Taken in 1909 at two repeated stations $(7660$ and 7668$)$ in the lower end of Buzzards Bay, 6 to ro fathoms.

The species has heretofore been known only from the type locality, Tristan da Cunha, in the middle of the South Atlantic Ocean, where it was dredged in 100 to 150 fathoms, off Nightingale Island.-Busk (Challenger Report. There listed as Ascopodaria discreta n. sp.).

\section{BRYOZOA ECTOPROCTA.}

\section{Family CRISIIDF.}

\section{Crisia eburnea (Linnæus). [Chart 27.]}

Verrill and Smith, I873, p. 707,3II, etc.; Osburn, I9I2, p. 2 I5.

Vineyard Sound, common.-Verrill. Abundant and universally distributed in Vineyard Sound; common in many parts of Buzzards Bay. Dredged by the Survey in $I$ to I7 fathoms on all sorts of bottom. Recorded also from shores and piles of wharves in nearly every part of the region.

Fish Hawk stations: $75^{2} \mathrm{I}$ bis (scarce), $75^{23}$ (few small pieces), $75^{24}$ bis, $75^{26}$ (few very small pieces on stem of dead Pennaria (?)), $753 \mathrm{I}$ bis (much), 7532 bis (few colonies), 7533 bis (many tufts), 7535 (small piece), 7536 (abundant on algæ), 7537 (small cluster), 7537 bis (few), 7538 (several large tufts), 7539 (abundant), 7543 bis (few colonies), $755^{\circ}$ (small tufts on Eudendrium and algæ), $755^{\circ}$ bis (little), $755^{2}$ bis (I colony), 7553 (small tufts on Eudendrium and algæ), 7553 bis (few colonies), 7557 (considerable tuft on Pennaria and Chondrus), 7560 (on Chondrus crispus; abundant on Pennaria), 7562 (on Chondrus crispus; few small tufts on Eudendrium), $75^{6} 3$ bis, 7564 bis (considerable), 7565 bis (several colonies), 7569 bis, $757^{2}$ (small cluster on algæ), $75^{82}$ (few tufts on Laminaria and Chondrus), $75^{8} 3$ (many on Laminaria and Chondrus), $75^{8} 7$ (abundant on algæ) (?), $75^{88}$ (very abundant on algæ) (?), 759I (abundant), 7592 (on Chondrus), 7593, 7594, 7597, 76II (few clusters), 7612, 7613, 76r4, 76 I $_{5}, 76$ I9 $_{9} 76_{30}, 76_{3} 6,76_{39}$ ( I colony), 7640,
Crisia eburnea-Continued.

7643 (I colony), 7644 (few colonies), 7645, 7653 (few clusters), 7659 (few masses), 7660 , 7661,7663 (few), 7664, 7666, 7671, 7672 (few), 7673,7675 (few colonies), 7678,7679 (little with Bugula), $7680,768 \mathrm{I}, 7685,7689,7690$ (with algæ), 7692 (little), 7693, 7697, 7699 (little), 7700, 7701, 7702, 7703, 7717, 7718, $7720,7721,7723,7724,7725,7729,7731,7732$ (little), 7733, 7734, 7735 (much), 7738, 7739 (little), 7740, 7741, 7742 (little), 7743 (little), 7744 (little), 7745 (little), 7746 (little), 7749 (much), $775^{\circ}$ (much), 775 I (little), $775^{2}$ (little), 7753 (?), 7754 (much), 7755 (little), 7757 (little), $7760,7763,7764$ (very much), 7765 (much), 7766 (little), 7767 (much), 7768 (much), 7769 (much), 7771, 7772 (much), 7774, 7775 (much), $7778,778 \mathrm{r}, 7782$ (little) 7783 . Supplementary stations (I906): $7525,7537,7567$, $7709,77^{23}$; (1907): 7526, 7538, 7551, 7581, 7761, 7763,$7780 ;(1909): 7634,7643,7645,7659,7660$, $7668,7670,7671,7672$.

Phalarope and Blue Wing stations: I (much), 2 (relatively few), 3 (many), 4 (few), 5 (few tufts), 7 (many), 8 (very abundant), 9 (common, several colonies), Io (few), II (rare), I2 (few), I5 (common), I6 (common), 20 (common), 2 I (common), 22 (abundant), 23 (few), 24 (abundant), 25 (abundant), 30 (few), 32 (abundant), 33 (few), 34 (abundant), 36 (common), 37 (few), 39 (small colony), 44 (abundant), 45, 46 (very common), 48 (few), 49 (common), 5I (common), 55 (few), $5^{6}$ (many), 57 (many), $5^{8}$ (abundant), 60 (much), 62 (few), 63 (few), 64 (few colonies), 65 (abundant on Laminaria), 66 (several), 
Crisia eburnea-Continued.

67 (many), 68 (few), 69 (several), 73 (few), 74 (few), 75 (few colonies), 76 (few), 77 (few), 79 (common), 83 (few), 85, 87, roo (common), IO7 (few), IO8, III, II2, II3, II4, II6, II 7, I2I, I22 (few.), I23 (few), I24 (few), I3O (few), I3I (common), I34 (common), I35 (very abundant), I36 (few), I37 (common), I4I (common), I44 (few), I45 (few), I46 (few), I 50 (common), I60 (few), I63 (very abundant).

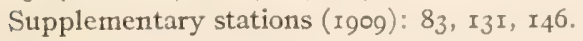

Crisia cribraria Stimpson.

Osburn, I9I2, p. 2 I5.

Found only in the colder waters, at outlying points. Taken at Crab Ledge, in 18 fathoms.

?Crisia denticulata (Lamarck).

Osburn, I9I2, p. 216.

Doubtful specimens taken in the outer waters of the Woods Hole region.

\section{Family TUBULIPORID死.}

\section{Tubulipora liliacea (Pallas). [Chart 28.]}

Verrill and Smith, I873, p. 708, 405, etc. (Tubulipora flabellaris); Osburn, I912, p.217.

Vineyard Sound.-Verrill. Occasional throughout Vineyard Sound and the lower half of Buzzards Bay; dredged in 3 to I $_{5}$ fathoms, on sand, gravel, and stones, usually attached to algæ, occasionally on shells.-Survey. Also found in piles.

Fish Hawk stations: 7560 (on Chondrus crispus), $75^{82}$ (on Chondrus crispus), 7724, 7725, 7753 (?), 7764, 7771. Supplementary stations (I909): $7643,7659,7660$.

Phalarope and Blue Wing stations: $22,37,87$.

Tubulipora atlantica (Johnston).

Osburn, I912, p. 217 .

Crab Ledge, August 12, Igog, several welldeveloped colonies with ovicells attached to rocks and shells.

Tubulipora flabellaris (Fabricius).

Osbuin, I9I2, p. 218.

Crab Ledge, off Sankaty Head, Great Round Shoal; taken only in outside waters of the region.

\section{Stomatopora diastoporoides (Norman).}

Osburn, 1912, p. 218.

A few specimens taken by the Survey at Crab Ledge upon pebbles.

\section{Family LICIENOPORIDAE.}

Lichenopora verntcaria (Fabricius).

Verrill and Smith, 1873, p. 707, 405. (Diastopora patina); Osburn, I912, p. 219.

Vineyard Sound, off Vineyard Haven.-Verrill. Nobska Point, in shallow water, along shore; Muskeget Channel, 7 fathoms; Crab Ledge, common; Sankaty Head, E. S. E. I3 fathoms; Robinsons Hole, at Phalarope station 22; near Gay Head, at Fish Hawk station 7730.

Found on hydroids, on other Bryozoa, shells and algæ.

\section{Family ETErDA:}

Etea anguina (Linnxus). [Chart 29.]

Verrill and Smith, I873, p. 710, 405; Osburn, IgI2, p. 220.

Vineyard Sound,-Verrill. Abundant and generally distributed in Vineyard Sound and Buzzards Bay; dredged in I to I 9 fathoms, on every sort of bottom, creeping over hydroids, algæ and Bryozoa, occasionally on shells and pebbles.-Survey. Recorded for Woods Hole, on Bureau of Fisheries pier; Vineyard Haven; Katama Bay, on piles of wharf; Nantucket Harbor, on piles; Nantucket cable; on weed floating in Vineyard Sound; Fort Phœnix (New Bedford Harbor); Round Hill Point.

Fish Hawk stations: 7524 bis, 7533 bis, 7545 bis, 7547 bis, 7559 (on Eudendrium), 7563 bis, 7564 bis, 7593, 76II, 76I2, 76I4, 76I5, 76I6, 76I9, $7622,76_{30}, 76_{3} 6,76_{39}, 7640,76_{43}, 76_{44}, 76_{45}$, $7656,7659,7660,7664,7666,7667,7670,7671$, $7676,7678,7679,7681,7689,7692,7697,7699$, $7700,7702,7703,7706,7707,7724,7729,7730$, $7731,7734,7735,7739,7740,7741,7742,7743$, $7744,7745,775$ I, 7754, 7759, 7760, $776_{3}, 7,50$, $7774,7775,7778,7779,7780,7781,7782,7-33$. Supplementary stations (I906): $7567,7633,7705$, 7709, 7723; (1907): 758x, 7718, 7731, 7739, 776́1, 7780,7783 ; (I909): $7627,7634,7643,7659,7660$, $7668,7670,7671$.

Phalarope and Blue Wing stations: $I, 5,7,8$, I5, I6, 20, 32, 45, 5I, 57, 64, 65, 74, 83, 87, 9I, I08, III, II3, II4, II6, II7, II8, I34, I4I, I59 (common on Bugula), I6o (few), I63 (abundant). Supplementary stations (I909): 83, I3 r.

\section{Family EUCRATEIDF.}

Eucratea chelata (Linnæus).

Verrill and Smith, I873, p. 710, 405; Osburn, I9I2, P. 221 .

"Off Gay Head, Io fathoms, on hydroids and ascidians."-Verrill. Not noted in Survey dredgings, but taken on piles of a wharf at Vineyard Haven in some numbers, growing on Amathia dichotoma. 
Gemellaria loricata (Linnæus).

Verrill and Smith, I873, p. 747; Osburn, I9I2, p. 221 .

Nantucket.-Verrill. Well distributed in the outer waters of the region.-Survey. Crab Ledge, very abundant; off Sankaty Head, ESE., in I3 fathoms; ESE., in 20 fathoms; E. by S. in 24 fathoms; off No Mans Land, abundant.

Verrill states that the Nantucket specimens "differ somewhat from the ordinary form." Dr. Osbum thinks that this statement refers to the variety americana Lamouroux, which is common at Crab Ledge.

Scruparia clavata Hincks.

Osburn, I9I2, p. 22 I.

Crab Ledge, in 18 fathoms, several colonies growing on Gemellaria loricata; Great Round Shoal fishing ground, 8 fathoms, on Bugula murrayana.

\section{Family CELLULARIIDAt.}

\section{Cellularia peachii Busk.}

Osburn, I912, p. 223.

Great Round Shoal fishing ground, 8 fathoms, a few fragments on Bugula murrayana. Not previously recorded south of the St. Lawrence.

Menipea ternata (Solander).

Verrill and Smith, r873, p. 7 II, 496 (Cellularia ternata?); Osburn, I912, p. 222.

Off Gay Head, "a species of Cellularia, allied to ternata."-Verrill. Dredged by the Survey only in the outer waters of the region, on rocky and shelly bottoms. Taken a half mile SW. of Gay Head; in Muskeget Channel, 7 fathoms; Sankaty Head, E. by S., 24 fathoms, very abundant; ESE., in 20 fathoms, common; Crab Ledge.

Scrupocellaria scabra (Van Beneden).

Osburn, I9I2, p. 223.

Woods Hole harbor, in drift; Crab Ledge, on a few shells.

Caberea ellisii (Fleming).

Verrill and Smith, I873, p. 7II, 420; Osburn, Ig12, p. 222 .

Mouth of Vineyard Sound, off Gay Head, 8 to 12 fathoms; off Buzzards Bay, 25 fathoms.-Verrill. Crab Ledge; off Sankaty Head, E. by S., 24 fathoms, very abundant, ESE., I3 fathoms, abundant; ESE., 20 fathoms, common; Great Round Shoal fishing ground, 8 fathoms, common.-Survey.
Family BICELLARIDAE.

Bicellaria ciliata (Linnæus). [Chart 30.]

Osbum, I9I2, p. 224.

Occasional stations throughout Vineyard Sound, taken a few times at the mouth of Buzzards Bay; dredged in 7 to 15 fathoms, on sand, gravel, and shells. Also recorded from piles at Woods Hole, Vineyard Haven, and Nantucket.

Fish Hawk stations: $75^{24}$ bis, 7564 bis, 7699 , $7702,7706,7729,7730,7733,7741,7742,7744$, 7745. Supplementary stations (1906): 7567; (I907): $7780 ;$ (I909): 7660, 7668, 767 I.

Phalarope stations: 5,68 .

Bugula turrita (Desor). [Chart 3r.]

Desor, I848, p. 66 (Cellularia turrita, sp. nov.); Verrill and Smith, I873, p. 7I2, 3II, etc.; Osburn, I9I2, p. 225 .

Abundant and almost universally distributed in Buzzards Bay and Vineyard Sound; not recorded from Crab Ledge or other outlying points; dredged by the Survey in I to I9 fathoms, on all kinds of bottom, as well as collected at very numerous points along shores, on piles, etc.; frequently found attached to floating eelgrass.

Fish Hawk stations: $75^{23}, 75^{23}$ bis, $75^{24}$ bis, $75^{2} 8$ (few), 7530 bis (much), 753 I bis (much), 7532 bis (few clusters), 7533 bis, 7534 (abundant), 7535,7535 bis (few), 7536 (abundant), 7538 (?), 7538 bis (very much), 7539 bis (few colonies), 754 I bis (many), 7542, 7542 bis (several colonies), 7543 bis (?), 7544 (abundant), 7545 bis, 7546 (2 large clusters), 7547 bis, 7548 (many clusters), 7549 bis (few), $755^{\circ}$ bis. (much), 755 (abundant), 755 I bis (several colonies), $755^{2}$ bis (many colonies), 7553 (abundant), 7553 bis (very much), 7554 (many), 7554 bis (little), 7557 (many), 7558, $7559,7560,756 \mathrm{x}$ (many), 7562, 7562 bis (few colonies), 7563 (many), 7563 bis (few colonies), 7564 (many), 7564 bis (considerable), $75^{6} 5$ (many), $75^{6} 5$ bis (considerable), 7568 , 7569 bis ( 1 colony), 7570 (few), $757^{2}$ (many pieces), 7574,7575 (few), 7576 (several colonies), 7577 (few), 7578 (several colonies), $75^{80}$ (few), 758I (many colonies), $75^{82}$ (several clusters), $75^{84}$ (abundant), 7585, $75^{87}$ (many clusters), $75^{88}$ (abundant), 7589 (abundant), 7590 (few pieces), 7591 (many), 7592 (few), 7593, 7594 (several clusters), 7595 (many), 7596,7598 (few), 7599, 7610, 76r1, 7612, 7613, 
Bugula turrita-Continued.

$7615,7616,7617,7618,7619,7620(?), 7622$, $7627,7630,7637,7638(?), 7639,7640,7641$ (?), $7643,7644,7645,7646,7656,7659,7660$, $7661,7662(?), 7664,7666,7667,7670,7671$, $7672,7673,7675,7676,7678,7679$ (abundant), 7680 (several clusters), 7681, 7682 (few), 7688 , $7689,7690,7692,7697,7698,7699,7700,7702$, $7703,7706,7707,7708$ (abundant), 7709, 7710, $7717,7718,7719,7720,7721,7724,7725,772 \%$, $7728,7729,7730,7731,7732,7733,7734,7735$, $7736,7738,7739,7740,7741,7742$ (much), 7743 (little), 7744 (much), 7745, 7749 (much), $775^{\circ}$ (little), $775^{\text {I }}$ (little), 7754 (little), 7755 (little), 7759 (little), 7760 (little), 776 I (little), 7763 (little), $7768,7769,7778,7779$ (little), 7780 (little), 7781,7782 (little), 7783 (little). Supplementary stations (I906): 7525, 7537 , $7567,7633,7723 ;(1907): 7526,7538,7542,7551$, $75^{81}, 7718,7728,7731,7739,7761,7763,7776$, 7780 ; (rgog): $7627,7634,7636,7643,7653$, $7659,7660,7668,7670,7671,7672$.

Phalarope and Blue Wing stations: $\mathrm{I}, 2$ (few pieces), 3, 5 (few pieces), 6 (many pieces), 7 (many pieces), 8 (few), 9 (f $\mathrm{fw}$ ), I2 (few pieces), I5, I6, (many), 22 (common), 23 (few), 24 (common), 32 (few), 35 (I colony), 36 (common), 39 (abundant), 45 (much), 46 (much), 50 (small amount), 5I, 52 (many), 53 (many), 55 (few), $5^{8}$ (common), 59 (common), 60 (few), 6r (?), 62 (many), 63 (many), 64 (much), 65 (many), 66 (many), 67 (many), 68 (many), 69 (several colonies), 73 (abundant), 74 (many), 75 (few colonies), 76 (few), 77 (few), 8I (I colony), 82 (common), 83 (small masses), 85, 103, 105 (living), I08, I10, III (few), II2, II3, II4, II6 (large quantities), II7 (many), II8 (common), I2I (common), I22 (few), I23 (few); I24 (few), I28 (common), I29 (common), I30 (abundant), I3 I (common), I34 (common), I36 (common), I37 (abundant), I38 (common), I39, I40 (few colonies), I4I (common), I42 (common), I 44 common), I 46 (few), I 47 (few), $x_{4} 8$ (common), I $_{50}$ (common), I 5 , I 52 (few), I 54, I58, I59 (several clusters), I60 (several worn colonies), $16_{3}$ (very abundant), I64 (few), I67 ( I old colony). Supplementary stations (I909): 79, 83, I3I, I46.

? Bugula avicularia (Linnæus).

Verrill, I879, p. I89; Osburn, I9I2, p. 226.

Listed by Verrill as occurring from "Long Island Sound to Spitzbergen," but not noted by the Survey.
Bugula gracilis uncinata Hincks.

Osburn, I912, p. 224.

Vineyard Sound, at both ends (several records); dredged in 5 to ro fathoms, on bottoms of sand and gravel; Mattapoisett Harbor; Nobska Beach, in drift material; shore of No Mans Land; floating in Vineyard Sound; Round Hill Point; Fort Phoenix; Nantucket cable.

Fish Hawk stations: $7755,7775,7777$. Supplementary stations (1906): 7723 (1907): 7776 .

Phalarope stations: 6 , I6r.

Bugula cucullifera Osburn.

Osburn, I9I2, p. 225 (nom. nov.).

A few small colonies taken at Crab Ledge, August I2, I909.

Bugula flabellata Thompson.

Verrill and Smith, I873, p. 7Ir, 389; Verrill, I379, p. 179 (Bugula flustroides); Davenport, I $80 \mathrm{r}$, p. 46; Osburn, I9I2, p. 225.

Vincyard Sound, 6 to 8 fathoms; on piles 11 Woods Hole Harbor.-Verrill. Identified from only two dredging stations of the Survey (Phalarope stations 24 and 60), though perhaps frequently overlooked; collected, likewise, at Woods Hole, from Bureau of Fisheries pier; Vineyard Haven, Edgartown, Katama Bay, Nantucket Harbor; in all cases on piles of piers.

Bugula murrayana (Johnston).

Verrill and Smith, I873, p. 7 II, 496; Osburn, I912, p. 226.

Off Gay Head, ro to 20 fathoms.-Verrill. Crab Ledge; abundant off Sankaty Head, E. by S., 24 fathoms, common; ESE., I3 fathoms, abundant; ESE., 20 fathoms, abundant; Great Round Shoal fishing ground, 8 fathoms, on shells and pebbles.-Survey.

Family MEMBRANIPORIDAs.

Membranipora cymbaformis Hincks.

Osburn, I912, p. 230.

Taken at Crab Ledge in $\mathrm{I}_{4}$ to 20 fathoms and off Sankaty ESE., $I_{3}$ to 20 fathoms; not uncommon, incrusting the stems of hydroids and of other Bryozoa.

Membranipora pilosa (Linnæus). [Chart 32.]

Verrill and Smith, 1873, p. 712, 406; Osburn, Igr2, p. 228.

Vineyard Sound.-Verrill. Common throughout both Vineyard Sound and Buzzards Bay; especially abundant at Gay Head and Devils Bridge; dredged in $\mathrm{I}$ to $\mathrm{I} 7$ fathoms, sand and 
Membranipora pilosa-Continued.

gravel.-Survey. Recorded also from Woods Hole Harbor, on piles; Nobska Beach; Vineyard Haven, on piles; Lagoon Pond, on piles; Nantucket Harbor, on piles; Great Round Shoal fishing ground, 8 fathoms, on shells; Cedar Tree Neck; No Mans Land, shoie; surface of Vineyard Sound, on floating weed; Great Pond; Scraggy Neck.

Fish Hawk station: 7533 bis, 7536 (on alya), 7557 (on cel grass), 7559 ? (on cel grass), 7560 (on Chondrus .crispus), $75^{62}$ (on Chondrus crispus), 7567 (on alga), 7574 (many patches), 7579 (?) (on Laminaria), 758 I (on alga), 7582 ? (abundant on Laminaria and on Chondrus crispus), 7584 (on Chondrus crispus), 7585 ? (on Laminaria), $75^{87}$ (abundant on algæ), 7589 ? (abundant on Laminaria), 7592 ? (on Laminaria), 761 $1,761_{4}, 761_{5}, 7619,7630,7636,7639$, $7656,7659,7667,7678$ (on Polynices shell), 7685, $7701,7706,7708,7710,7718,7720,7721,7722$, $7723,7724,7728,7739,7764$. Supplementary stations (r906): 7723; (1907): 7581, 773 I, 7739, 7761,7783 ; (I909): 7659 .

Phalarope and Blue Wing station: $1,2,3,16,32$, $36,44,45,46,47,5^{1}, 5^{6}, 57,5^{8}, 64,67,74,82$, $8_{3}, 87,9 I$, III, II6, II7. Supplementary station (Ig09): 83 .

\section{Membranipora craticula Alder.}

Osburn, I9I2, p. 229.

Great Round Shoal fishing ground, in 8 fathoms, on shells and on Bugula murrayana. Also from Crab I,edge, Muskeget Channel, No Mans Land and Nantucket Shoals.

\section{Membranipora lineata (Linnæus).}

Verrill and Smith, I873, p. 712, 406, etc.; Osburn, I912, p. 228.

Vincyard Sound.-Verrill. Large colony, growing on Laminaria, taken at Devils Bridge (Blue Wing station 46 ), in 2 to $3 \frac{T}{2}$ fathoms, sandy bottom. Also dredged at Crab Ledge, in Is fathoms, and collected at Woods Hole Harbor on Fucus, Vincyard Haven and Nantucket on piles; not common.

\section{Membranipora unicornis (Fleming).}

Osburn, 1912, p. 230.

Dredged at the Great Round Shoal fishing ground in 8 fathoms, several fine colonies incrusting shells.
Membranipora monostachy's Busk. [Chart 33.]

Osburn, I912, p. $27 \%$.

Vineyard Sound at scattered stations throughout its length; Buzzards Bay, at a few widely separated points; dredged by the Survey in 3 to I9 fathoms, chiefly on sandy bottoms; growing upon shells, rarely upon alga, the egg cases of skates, or the carapace of Limulus. Recorded, also, from Muskeget Channel and Great Round Shoal, from among drift on the shore of No Mans Land, and from Woods Hole Harbor and Nantucket, on piles.

Fish Hawk stations: $753^{2}$ bis, 7533 bis, $755^{8}$ (on mussel shell), $7680,7683,7697,7709,7722$ $7727,7777,7779$. Supplementary stations (I907): 7538; (1909); 7659, 7660, 7671.

Phalarope stations: 3,164 . Supplementary stations (I909): $\delta_{3}, I_{4} 6$.

Membranipora lacroixii (Adouin).

Osburn, I9I2, p. 227.

A fine colony, 6 inches in diameter, found by Mr. E. D. Congdon in the estuary of the IVeweantic River, incrusting a stone, collected at low tide. This species not previously recorded for the American coast south of the St. I,awrence River.

Membranipora tenuis Desor. [Chart 34.]

Desor, r848, p. 66 (sp. nov.); Verrill and Smith, I873, p. 712, 420; Osburn, I9I2, p. 23 .

Muskeget Channe1.-Desor. Vineyard Sound.Verrill. Common throughout Vineyard Sound; taken at frequent stations in the Bay, though apparently lacking in the central parts; recorded, also, from Muskeget Channel, in 7 fathoms, and Great Round Shoal fishing ground, in 8 fathoms. Stones and shells bearing this species dredged in 2 to $\mathrm{Ig}$ fathoms, on various bottoms.-Survey.

Fish Hawk stations: 7532 bis, 7533 bis, 7543 (on shell of Modiolus), 7545 bis, 7547 bis, 7659 , 7666,7678 (on Polynices shell), 7679, 7680, 7682 . $7686,7698,7699,7700,7703,7706,7707,7708$, $7709,7717,7720,7722,7727,7730,7731,7734$, $7735,7740,7741,7749,7755,7759,7760,7766$, $7767,7768,7769,7774,7775,7776,7777,7780$, $7781,7782,7783$. Supplementary stations (1906): 7525; 7723, 773I; (I907): 752I, 7526, $753^{8}, 7542,7543,7549,75^{8} \mathrm{x}, 7718,7766,7770$, $7775,7776,7780 ;($ I909): $7624,7629,7634,7636$, $7653,7659,7670,7671,7672$.

Phalarope stations: $2,6, I_{5}, 24,68,83$, I09, I50, $I_{52}, I_{3}$ (common), I6 5 (few), I67 (few). Supplementary station (1909): 83 . 
Membranipora flemingii Busk. [Chart 35.]

Osburn, I9I2, p. 23 I.

Taken by the Survey at scattered stations throughout Vineyard Sound, incrusting shells, stones, and occasionally algx, at depths of from 3 to 19 fathoms. Common at Muskeget Channel, in 7 fathoms; Crab Ledge, in $I_{4}$ to 20 fathoms; off Sankaty Head, ESE., I3 to 20 fathoms (V. N. Edwards, col.).

Fish Hawk stations: 7533 bis, 7538, 7544 bis, $7683,7723,7726,7748,7768,7770,7775,7776$. Blue Wing station 46.

Membranipora aurita Hincks. [Chart $\left.{ }_{3} 6.\right]$

Osburn, rare, p. 230.

Taken by the Survey at a few stations in Vineyard Sound, near both ends; also in lower half of Buzzards Bay; dredged in 7 to $I_{5}$ fathoms, on bottoms of clear or muddy sand and gravel; mainly incrusting shells and algx. Also taken in Muskeget Channel, 7 fathoms, Great Round Shoal and Crab Ledge.

Fish Hawk stations: 7525,7533 bis, 7723,7725 , $7749,7768,7770,7776$. Supplementary stations (r9o9): $7636,7643,7653,7657,7659,7660$, 7672 .

Phalaropestations (supplementary, I909): 83, I3I.

Membranipora tehuelcha (d'Orbigny).

Osbum, I912, p. 23 I.

Common in Vineyard Sound, incrusting floating gulfweed; No Mans Land, on stranded gulfweed. The only member of the genus noted upon gulfweed locally.

Membranipora arctica (d'Orbigny).

Osburn, I912, p. 229.

Crab Ledge, July 23,1907 , in I6 fathoms, two small colonies on shells; August I2, I909, common on stones and shells.

Membranipora arctica armifera (Hincks).

Osburn, I9I2, p. 229.

Crab Ledge, in 16 fathoms, one colony on shell; August r2, 1909 , several colonies on shells and stones.

\section{Family CrIBRILINIDAs.}

Cribrilina punctata (Hassall). [Chart 37.]

Verrill and Smith, 1873, p. 7r3, 403 (Escharipora punctata); Osburn, I9I2, p. 232.

Vineyard Sound, common.-Verrill. Taken by the Survey at scattered stations throughout Vineyard Sound, on stones and shells, but
Cribrilina punctata-Continued.

never abundant. Common, however, at various outlying points, c. g., Crab Ledge; off Sankaty Head, ESE., I 3 to 20 fathoms (V. N. Edwards, col.); Muskeget Channel, 7 fathoms; Great Round Shoal fishing ground, 8 fathoms; a half mile SW. of Gay Head.

Fish Hawk stations: $75^{22}, 7538$ bis, 7544 bis, 7549 bis, $75^{82}, 75^{8} 5,7717,7723,7726,7748$, 7768 .

Blue Wing station 46.

Cribrilina annulata (Fabricius).

Osburn, 1912, p. 232.

Crab Ledge in I8 fathoms, July 22, 1907, a small colony; August I2, I909, several colonies; Nantucket Shoals.

Family PORINIDA.

Porina tubulosa (Norman).

Osburn, I9I2, p. 233.

Muskeget Channel, July 22, 1907, rare on shells; Crab Ledge, July 23, 1907, and August I2, I909, rare on stones and shells; Nantucket Shoals.

\section{Family MICROPORELLIDIE.}

Microporella ciliata (Pallas).

Osburn, I912, p. 233.

Taken $1 / 2$ mile SW. of Gay Head (a number of colonies, on shells of Pecten magellanicus); eastern end of Vineyard Sound, at Fish Hawk station 7766 (one good-sized colony on a pebble); off Gay Head, at Blue IVing station 46 (several colonies on shells of Pecten magellanicus); western shore of Buzzards Bay, at Phalarope station 167 (a few small colonies on shells of various sorts). Likewise taken at Crab Ledge, in I4 to 20 fathoms, on shells and pebbles, at Great Round Shoal fishing ground, in 8 fathoms, on shells, and at Nantucket Shoals. Never taken in large numbers.

Microporella ciliata stellata (Verrill).

Osburn, 1912, p. 234.

Taken in eastern end of Vineyard Sound at Fish Hawk stations $75^{2} \mathrm{I}$ and 7766 ; likewise at Crab Ledge, on stones and shells; common; off Sankaty Head, ESE., I3 to 20 fathoms (V. N. Edwards, col.), common; Muskeget Channel, in 7 fathoms, scarce; Great Round Shoal fishing ground, 8 fathoms, common; Nantucket Shoals. 


\section{Family MYrIOzOIDAE.}

Schizoporella unicornis (Johnston). [Chart 38.] Verrill and Smith, I873, p. 713,312 , etc. (Escharella variabilis); Verrill, I875a, p. 4 I (Hippothoa reversa), a Osburn, I9I2, p. 236 .

Buzzards Bay, Vineyard Sound, Nantucket Harbor, off Gay Head.-Verrill. Abundant and almost universally distributed in Vineyard Sound; perhaps equally general in Buzzards Bay. Dredged by the Survey in $I / 2$ to I 9 fathoms, on every sort of bottom. Recorded, also, from shores and wharves, throughout the entire region. This species may either incrust stones, shells, etc., in fiat sheets, gradually building up thick masses; or it may occasionally form wavy ridges, projecting freely from the stems of algæ and hydroids. Particularly beautiful specimens have been taken by us, growing on Tubularia couthouyi.

Fish Hawk stations: 7523 (?), 7524 bis, $75^{2} 5$ bis, $75^{26}$ (several masses on stem of dead hydroid), 7530 bis, 753 I (on Crepidula), 7532 (?), 7533 bis (?), 7535, 7536 (abundant), 7537 (on Thuiaria), 7538 (on Tubularia couthouyi), 7538 bis, 7539 (many-layered mass), $754 \mathrm{I}$ bis (?), 7543 (on shell of Modiolus), 7543 bis, 7546 bis, 7549 bis, $755^{\circ}$ bis, $755^{I}$ (on Clidiophora), $755^{\mathrm{I}}$ bis (?), $755^{2}$ bis, 7553,7554 bis (?), 7558 (on mussel shell), 7559 (on Eudendrium), 7560 (common, pink or orange when fresh), 7562 (un mussel shell), $75^{6} 3$ (?), 7564 (?) (manylayered mass), 7564 bis, 7565 bis, 7567 (?) (many-layered mass), 7572 (?) (few on algæ), 7577 (?) (on Mytilus shell), 758I (on algx), 7586 (?), $75^{87}$ (many pieces, attached to Chondrus crispus and other algæ; pink and coral-like in appearance), $75^{88}$ (many pieces, attached to Chondrus crispus and other algæ; pink and coral-like in appearance), 7593 (many pieces, pink and coral-like), 7594 (?), 7595 (many pieces, pink, coral-like form), 7596 (few), $76 \mathrm{Ir}$, $7612,7615,7618,7619,7622,7625,7626,7627$, $7628,76_{32}, 76_{33}, 76_{35}, 76_{3} 6,76_{39}, 7640,76_{44}$, $7645,7646,7648,7655,7656,7659,7660,7664$, $7666,7670,767 x, 7672,7674,7675,7676,7678$, $7679,7680,7682,7686,7688,7689,7690,7692$, $7693,7697,7698,7699,7700,7701,7702,7703$, $7704,7706,7707,7708,7717,7722,7724,7727$, 7730, 7731, 7732, 7738, 7739, 7740, 7741, 7742, $7743,7744,7745,7746,7747,7749,7751,7753$ (?),
Schizoporella unicornis-Continued.

$7755,7756,7757,775^{8}, 7759,7760,7763,7764$, $7765,7766,7767,7768,7769,7770,7772,7773$, $7774,7775,7776,7777,7778,7779,7780,7781$, 7782,7783 . Supplementary stations (I906): $75^{2} 5,75^{27}, 7537,7567,7633,7745$; (1907): $75^{2} \mathrm{I}, 75^{26}, 7530,7538,7543,7549,755^{1}, 75^{8 \mathrm{I}}$, $7718,7731,7739,7761,7763,7766,7770,7775$, $7776,7780,7783$; (I909): $7624,7629,7636,7643$, $7645,7648,7653,7659,7660,7668,7670,7671$, 7672 .

Phalarope and Blue Wing stations: $1,2,3,5,6$, 7 , I5, I6, 20, 22, 24, 30, 32, 36, 37, 44, 45, 46, $51,56,57,58,60,63,64,67,68,74,76,83,85$, $87,91,96,108,109$, III, II3, II6, II 7 , II 8 , I34, I37, I4 I, I44, I50, I52, I56, I60 (few), I63 (abundant), I64 (common), I65 (few), I66 (few), I67 (abundant). Supplementary stations (1909): 79, 83, I6 5 .

Schizoporella biaperta (Michelin). [Chart 39.]

Verrill, I875a, p. 4I (Hippothoa biaperta); Osburn, 1912, p. 237 .

Vineyard Sound, abundant.-Verrill. Taken by the Survey at scattered stations throughout Vineyard Sound and Buzzards Bay; recorded also from Crab Ledge, Great Round Shoal, Muskeget Channel, No Mans Land (drift), and the Nantucket cable. Dredged in 3 to $I_{5}$ fathoms, on various bottoms, growing on shells and stones.

Fish Hawk stations: 7533 bis, 7544 bis, 7562 , $7706,7723,7766,7770,7775,7776$. Supplementary stations (I909): $7624,7629,7643,7645$, $7648,7660,7668,7670,7671,7672$.

Phalarope and Blue Wing stations: $46,163,167$. Supplementary stations (rgog): $83, \mathrm{I}_{3} \mathrm{I}, \mathrm{I}_{4} 6$.

Schizoporella auriculata (Hassall).

Osburn, I9I2, p. 237.

Crab Ledge, July 23, 1907 , in 17 fathoins, and at Great Round Shoal fishing ground, on the same date, in 8 fathoms (both times in small numbers); Crab Ledge, August 12, I909, several colonies; Nantucket Shoals.

Schizoporella sinuosa (Busk).

Osburn, I9r2, p. 238.

Crab Ledge, August I2, I909, numerous colonies on stones.

a Verrill described as a new species ( $1875, \mathrm{p} .4 \mathrm{I})$ a form of $S$. unicornis in which the position of the avicularum was reversed; i. e., pointing backward instead of forward. Dr. Osburn states that he has found colonics with the avicularia pointing in both directions and also exhibiting all sorts of intermediate positions. As no other distinguishing characters have been given, he regards reversa as a synonym of unicornzs. 
Hippothoa hyalina (Linnæus). [Chart 40.]

Verrill and Smith, I873, p. 7I3, 405, etc. (Mollia hyalina); Osburn, 1912, p. 235 .

Buzzards Bay and Vineyard Sound, abundant.Verrill. Taken by the Survey in various parts of Vineyard Sound; less frequently in Buzzards Bay and mainly at inshore stations; abundant at Devils Bridge. Dredged in I to I 7 fathoms, on every sort of bottom, occurring for the most part on algx, but occasionally on hydroids, Bryozoa, shells, etc. Recorded, also, for Crab Ledge; Nantucket, in harbor, and at south shore; Great Round Shoal fishing ground, 8 fathoms (very abundant on stems of hydroids); likewise from various shores and wharves in the region, and from the Nantucket cable; abundant on floating weed in Vineyard Sound.

Fish Hawk stations: 7560, 7562 (on Chondrus crispus), $75^{81}$ (on alga), $75^{82}$ (on Chondrus crispus), 7587, 7613, 7659, 7685, 7721, 7724, 7727 , 7771. Supplementary stations (1906): 7723 ; (1907): 7526, 758ז, 7783; (1909): 7627 , 7671 .

Phalarope and Blue Wing stations: $20,24,30,44$, $45,46,47,5 \mathrm{I}, 56,57,63,64,67,83$, 9I, III, I63 (few). Supplementary station (I909): 83 .

\section{Hippothoa divaricata Lamouroux.}

Osburn, I9r2, p. 235.

Vineyard Sound, near both ends, at Fish Hawk stations 7526 and 7723 (Igo6 repetition); likewise at Crab Ledge in I8 fathoms. In all of these cases only small colonies of a few cells were noted.

\section{Cellepora americana Osburn. [Chart 44.]}

Verrill and Smith, IS73, p. 7I4, 3I2, etc. (Cellepora ramulosa); Osburn, I912, p. $23^{8}$ (sp. nov.).

Buzzards Bay and Vineyard Sound.-Verrill. Abundant throughout the Sound; scarce in the Bay; dredged in I to Is fathoms, on very various bottoms, commonly attached to hydroids, algæ, or Bugula.-Survey. Also in drift on the shores of No Mans Land and Nantucket.
Cellepora americana-Continued.

Fish Hawk stations: 7523(?), 7532 (many on Eudendrium), 7533 bis, 7534,7538 bis, 7540 (few small masses on stems of Eudendrium), 7547 bis, $755 \circ, 7557$ (abundant on Eudendrium), 7559,7560 (on Bugula turrita), 7562 (abundant), 7564 bis, 7570,7572 (on Eudendrium and Pennaria), 7574, 7576, 7579 (abundant), 758r, 759 I (abundant on Bugula), 7594 (very abundant), 7595 (many), 7598, 7616, 7618, 7656, 7660, $7679,7680,7681,7682,7689,7693,7699,7700$, $7701,7704,7706,7707,7709,7718,7719,7724$, $7725,7730,7731,7732,7733,7734,7739,7741$, $7742,7744,7753(?), 7768,7769,7774,7775$, 7781. Supplementary stations (1906): 7537 , $7567,7723,7745$; (I907): 7526, 7538, 7549, $755 \mathrm{I}, 75^{81} \mathrm{I} 773 \mathrm{I}, 7739,7775,7780$; (1909): $7618,7638,7643,7659,7650,7668,7670,7671$, 7672 .

Phalarope and Blue Wing stations: $5,6,7$ (few pieces)?, $8,46,5 \mathrm{I}, \mathrm{II} 3, \mathrm{I} 60$

Cellepora canaliculata Busk.

Osburn, I912, p. 239.

Crab Ledge, August I2, I9०9, one large branched colony, and two of the ordinary pisiform type.

\section{Family ESCHARIDE.}

Lepralia americana Verrill. a

Verrill and Smith, 1873, p. $7 \mathrm{I}_{3}, 420$ (? Lepralia pallasiana); Verrill, I875, p. 415, pl. VII, fig. 4; Davenport, I89r, p. 47 (Lepralia pallasiana); Osburn, I9I2, p. 24 I.

Unequivocal records for this species as follows: Western end of Vineyard Sound, at Fish Hawk station 7719; Buzzards Bay at I909 repetitions of Fish Hawk stations $7657,7668,7671,7672$, and of Phalarope station I65; Woods Hole Harbor, on piles; Nantucket Harbor, on piles; Muskeget Channel, 7 fathoms; Great Round Shoal fishing ground, 8 fathoms; Crab Ledge. (For other possible records see below.)

\section{Lepralia pallasiana (Moll). 6}

Leidy, 1855 , p. 9, fig. 23 (Escharina pediostoma); Osburn, I912, p. 240.

$a$ This species and the following were undoubtedly confused by Verrill, probably in the Vineyard Sound report, and certainly in his later papers, in which he refers only to L. americana after his description of that species. In the 1875 paper, for example, figure 4 can be identified with certainty as L. americana; but figure 5 of the same plate, which is without doubt $L$. pallasiana Moll, is referred to as representing "the same without ootheca" as figure 4. The present authors followed Verrill in their earlier records for this report, and the two species were thus confused. Hence, unfortunately, it is impossible to present the distribution of these forms separately. The resulting combined records are given below. A few unequivocal records for each species are likewise presented, however.

$b$ Concerning the confusion of this with the preceding species, see above. Leidy undoubtedly figured this species, recording it from Beesleys Point, N. J. Dr. Osburn has found it in the drift on the north shore of Cape Cod; likewise in Vineyard Sound, where it is not uncommon, ranging from the low-water mark to the deepest parts. 
Lepralia pallasiana-Continued.

Independent records for this species: Buzzards Bay at repetitions (1909) of Fish Hawk stations 7645,7648 , and $767 x$, and of Phalarope station 83; Woods Hole Harbor, on piles; West Falmouth Harbor, shallow water; New Bedford, on piles; Cedar Tree Neck, along shore; Vineyard Haven, on piles; Muskeget Channel, 5 fathoms; Nantucket Harbor, on piles; Great Round Shoal fishing ground, 8 fathoms; Crab Ledge, I4 to 20 fathoms (?). Locally, this is believed to be predominantly a shallow water form.

Lepralia americana and L. pallasiana (combined records). [Chart $4 \mathrm{r}$.]

Fish Hawk stations: 7557 (on eel grass), 7560 (on Chondrus crispus), 7587, 76ェ $, 7614,7619,7656$, $7664,7678,7681,7690,7692,7700,7701,7727$, $7743,7766,7783$. Supplementary stations: $75^{25}$ (I906), $75^{26}$ (I907), 7537 (I906), 758I (I907), 77 I 8 (I907), 7723 (I906), 773I (I907), 7739 (I907), 7780 (I907).

Phalarope and Blue Wing stations: $24,36,45$, $5^{1}, 58,63,68,76,82,83$, I1 8, I 59 (x small colony).

Lepralia pertusa (Essper). [Chart 42.]

Verrill, 1879, p. I93 (Escharina porosa); $a$ Osburn, r9I2, p. $24 \mathrm{I}$.

Vineyard Sound, 8 to I2 fathoms, common.Verrill. Scattered stations in Vineyard Sound and Buzzards Bay; 3 to I $_{5}$ fathoms, growing on shells and less commonly on pebbles.Survey. Also recorded from Crab Ledge and Great Round Shoal.

Fish Hawk stations: 7522,7533 bis, 7538,7544 bis, $7549,7717,7723,7726,7739,7770,7775$, 7776. Supplementary stations (I909): 7624, $7629,7643,7648,7659,7660,7668,7670,767$ I, 7672 .

Phalarope and Blue Wing stations: $46,16_{3}, 167$. Supplementary stations (I909): 83, I3I.

\section{Lepralia serrata Osburn.}

Osburn, I912, p. 242 (sp. nov.).

Recorded from a few scattered stations in Vineyard Sound and Buzzards Bay, 6 to 15 fathoms; Muskeget Channel, in 7 fathoms; Crab Ledge, in $\mathrm{I}_{4}$ to 20 fathoms; Great Round Shoal fishing ground in 8 fathoms. This species grows on shells, forming at first a rather smooth and later a very rough incrustation.

Fish Hawk stations: $75^{21}$, 7546 bis, 7549, 7726 . Supplementary stations (I909): 7636, 7668 , Phalarope 83.
Mucronella peachii (Johnston).

Verrill and Smith, I873, p. 714, 496 (? Discopora coccinea); Osburn, I9I2, p. 243.

Vineyard Sound and Quicks Hole, very abundant.-Verrill. Dredged by the Survey at scattered stations throughout Vineyard Sound; likewise taken at Crab Ledge, off Sankaty Head, at Great Round Shoal and in Muskeget Channel. For the most part this species occurs incrusting stones and shells, occasionally on algæ.

Fish Hawk stations: $753^{8}, 7546$ bis, 7697,7723 , $7748,7770,7775$.

Blue Wing station 46 .

Mucronella ventricosa (Hassall).

Osburn, I9I2, p. 243.

"Taken rather rarely at Crab Ledge, growing on stones and shells, at I4 to 20 fathoms."

Mucronella pavonella (Alder).

Osburn, I9I2, p. 243.

Several colonies incrusting hydroid stems and stones at Crab Ledge, August I2, I909. Also on shell of Modiolus modiolus, in U.S. National Museum, labeled "Vineyard Sound, I875, station 4708."

Smittia trispinosa (Johnston).

Osburn, I9I2, p. 246.

A number of colonies taken at Crab Ledge, August 12, I909, on stones; also recorded from Buzzards Bay, near Penikese Island, at Fish Hawk station 7672 .

Smittia trispinosa nitida (Verrill). [Chart 43.]

Verrill, I875, p. 4I5 (Discopora nitida, sp. nov.); Verrill, I879, p. 195 (Mucronella nitida); Osburn, x912, p. 246.

Vineyard Sound.-Verrill. Abundant and almost universally distributed in Vineyard Sound; common, though perhaps less general, in Buzzards Bay. Dredged by the Survey at all depths and on every kind of bottom throughout the region, incrusting shells and stones. Recorded, also, from Woods Hole Harbor, on piles; Great Pond; Nobska Point and beach; shore of No Mans Land.

Fish Hawk stations: $75^{22}$ (?), $75^{23}, 75^{24}$ bis, 7525 bis, 7528 (?) (on stones), 7530 bis, 7533 bis, 7534,7535 (on shells and stones), 7536 bis, 7537 (?) (on stones), 7538 bis, 7539 (?) (on stone), $754 \mathrm{I}$ (?) (on stone), $754 \mathrm{I}$ bis (?), 7543 (on shell of Modiolus), 7544 bis, 7545 bis, 7546 bis, 7547 bis, 7549 bis, $755^{\circ}$ (on Thuiaria and Eudendrium), $755^{\mathrm{I}}$ (on Clidiophora), $755^{\mathrm{I}}$ bis (?), $755^{2}$ (?) (on mussel shell and on stone), 7554 bis (?), 
Smittia trispinosa nitida-Continued.

$755^{8}, 756$ I (?) (on mussel shell), 7562 (on mussel shell and on Chondrus crispus), $75^{6} 3$ bis, 7564 bis, 7565 bis, 7576 (on Crepidula shell), $75^{82}$ (on Chondrus crispus), $75^{86}$ (?), $75^{87}$ (on algæ), $76 \mathrm{II}, 76 \mathrm{I}_{2}, 76 \mathrm{I}_{3}, 76 \mathrm{I4}_{4}, 76 \mathrm{I}_{5}, 7622,7628$, $7629,7630,7632,7634,7635,7637,7639,7640$, $7644,7648,7650,7660,7664,7666,7671,7672$, $7673,7675,7683,7690,7692,7693,7694,7698$, $7699,7708,7717,7727,7729,7730,7732,7733$, $7735,7738,7739,7740,7741,7742,7744,7745$, $7746,7748,7751,7753$ (?), 7754, 7755, 7756, $7760,7765,7766,7767,7768,7769,7770,7771$, $7772,7773,7774,7775,7776,7777,7778,7780$, $7781,7782,7783$. Supplementary stations (1906): 7525, 7537, 7567, 7633, 7709, 7723, 7745,7748 ; (I907): 752I, 7526, 7530, 7538, $7542,7543,7549,755 \mathrm{I}, 75^{8} \mathrm{I}, 773 \mathrm{I}, 7739,776 \mathrm{I}$, $7763,7766,7770,7775,7776,7780$; (I909): $7624,7629,7643,7645,7648,7659,7660,7668$, $7670,7671,7672$.

Phalarope and Blue Wing stations: $1,2,3,5,6$, $7,8,15,16,20,24,30,32,36,37,44,45,56$, $58,63,64,65,68,74,76,83,85,87,91,92,96$, I00, III, II3, II4, II6, II $7, I_{34}, I_{35}, I_{37}, I_{44}$, I 45, I 47 (abundant), I48 ? (abundant on shells), I.49? (abundant on shells), I50, I53 (?), I56, I58, I60 (few), I63 (abundant), I64 (common), I66, I67 (abundant). Supplementary stations (I909): $83, I_{3}$ I, I46.

Smittia porifera (Smitt).

Osburn, I9I2, p. 245.

Taken with some frequency at Crab Ledge, in I 7 fathoms, and at Great Round Shoal fishing ground, on shells and on the stems of hydroids and Boltenia.

Porella propinqua (Smitt).

Osburn, IgI2, p. 248.

Crab Ledge, and off Sankaty Head, not uncommon on shells and hydroid stems.

Porella acutirostris Smitt.

Osburn, Igr2, p. 248.

Taken by the Survey on various occasions at Crab Ledge and at Great Round Shoal fishing ground, incrusting shells and pebbles; common.

Porella concinna (Busk).

Osburn, Igr2, p. 247 .

Crab Ledge, incrusting stones and shells, I4 to 20 fathoms; not common.
Porella proboscidea Hincks.

Osbum, I912, p. 249.

Taken in abundance at Crab Ledge, Great Round Shoal, and off Sankaty Head ESE., in 23 fathoms; also at Nantucket Shoals.

Rhamphostomella bilaminata (Hincks).

? Verrill and Smith, 1873, p. 714, 419 (Cellepora scabra ${ }^{a}$; Osburn, I912, p. 244.

Vineyard Sound and Quicks Hole.?-Verrill. Taken by the Survey at several points in Vineyard Sound and Buzzards Bay; common at Crab Ledge, in $I_{4}$ to 2 I fathoms, on hydroid stems; Great Round Shoal fishing ground, in 8 fathoms.

Fish Hawk stations: 7743, 7745; Phalarope station I.

Rhamphostomella costata Lorenz.

Osburn, 1912, p. 244.

Thus far only recorded from two outlying points, Crab Ledge (common) and Great Round Shoal (scarce), in company with the preceding species.

Rhamphostomella ovata (Smitt).

Osburn, I9I2, p. 245.

Vineyard Sound, I875, one well-developed colony on shell of Modiolus modiolus; Crab Ledge, August 12, 1909, a few small colonies.

\section{Family FLUSTRELLIDEA.}

Flustrella hispida (Fabricius).

Verrill and Smith, I873, p. 708, 312, etc. (Alcyonidium hispidum); Davenport, I8gr, p. 49; Osburn, I912, p. 250.

Woods Hole Harbor, on Ascophyllum beds, abundant; Tarpaulin Cove; Cedar Tree Neck; Robinsons Hole. Locally very abundant, incrusting Fucus and Ascophyllum, at low water mark; less commonly found upon rocks, or other objects; not recorded, however, from dredging stations.

\section{Family ALCYONIDIDA.}

Alcyonidium verrilli Osburn.

Verrill, I872, p. 289 (Alcyonidium ramosum); Verrill and Smith, I873, p. 708, 404, etc. (Alcyonidium ramosum); Osburn, Igr2, p. 252 (nom. nov.).

Eastward to Vineyard Sound, "often very abundant, attached to rocks in shallow water." -Verrill. This species is rare in the waters dredged by the survey, having been taken in only one locality, Phalarope station 37, at Sow and Pigs Reef, where two small specimens were found.

a The Cellepora scabra of Smitt has been separated into several species, of which two are herewith recorded. While it is jmpossible to identify Verrill's record with certainty, it seems probable that he referred to the present species, rather than to the following. which is less common and has not been taken in the inner waters of the Sound. 
? Alcyonidium hirsutum (Fleming).

Verrill and Smith, I873, p. 708, 404, etc.; Osbum, 1912, p. $25^{2}$.

Vineyard Sound.-Verrill. This species has not been identified in the Survey dredgings. According to Verrill, it is found "living under the same circumstances as the last [A. hispi$d u m]$, and sometimes associated with it, both above and below low-water mark."

?Alcyonidium gelatinosum (Linnæus)

Verrill and Smith, I873, p. 709, 496; OsburnI912, p. $25^{2}$.

"A few small specimens, apparently belonging to this species, were dredged in the deeper parts of Vineyard Sound," on red algæ.-Verrill. Not identified in the survey dredgings,

Alcyonidium parasiticum (Fleming).

Verrill and Smith, I873, p. 708, 404; Osburn, I912, p. 25 I.

Vineyard Sound, on rocky bottoms, at depths of a few fathoms, "forming thin crusts on algæ and hydroids, which generally become coated with a layer of fine sand or dirt." - Verrill. Crab Ledge, August I2, I909; several colonies on hydroids; recorded also from two uncharted stations $(7784$ and 7785$)$, which, strictly speaking, lie outside of the limits of the region treated in the present report (off No Mans Land, S. by W., 29 fathoms).

Alcyonidium mytili Dalyell.

Verrill, 1879, p. I88 (Alcyonidium rubrum); Osburn, I912, p. 25 I.

"Long Island Sound to Nova Scotia, common all along the coast."--Verrill. Dredged by the Survey at the western end of Vineyard Sound, 13 to 16 fathoms; also near the entrance of Woods Hole passage; one good-sized colony taken at Great Round Shoal fishing ground, in 8 fathoms, on a shell. Likewise found in abundance, incrusting barnacles on piles in New Bedford Harbor, and not infrequently occurring on the legs and carapace of Libinia, occasionally even in the branchial chamber.

\section{Family Cylindraicides:}

Anguinella palmata Van Beneden.

Osburn, I912, p. 253.

Two colonies taken July 20 , I909, at a repetition of Fish Hawk station 7659 in Buzzards Bay. Previously recorded from this coast only at Charleston, S. C.
Family VesICULARIIDE.

Amathia dichotoma (Verrill).

Verrill and Smith, 1873, p. 709, 389, etc. (Vesicularia dichotoma, sp. nov.); Osburn, I9r2, p. 254.

Survey records: Woods Hole Harbor, Katama Bay, Edgartown, Nantucket Harbor; in each case growing on piles; not taken during the dredgings. Verrill gives no specific local records for this region, but notes that it is a very common species, growing under a considerable variety of conditions.

Bowerbankia gracilis Leidy. [Chart 45.]

Verrill and Smith, 1873, p. 709, 389 (Vesicularia gracilis); Osburn, I912, p. 253.

Vineyard Sound.-Verrill. Occasional records for Vineyard Sound and Buzzards Bay; dredged by the Survey in 4 to $I_{5}$ fathoms, on various bottoms. Recorded also from the piles of piers at New Bedford (abundant); Round Hill Point; Woods Hole; Vineyard Haven and Nantucket.

Fish Hawk stations: 7533 bis, 76 ro, $76 \mathrm{r}_{3}, 76 \mathrm{rg}$, $7644,7702,7735$; also 'I906 repetitions of 7567,7709 , and 7723 .

Phalarope stations: 7,65 .

Bowerbankia gracilis caudata (Hincks).

Osburn, I9I2, p. 254.

Dredged by the Survey both in Vineyard Sound and Buzzards Bay, at Fish Hawk stations 7613,7626 , and 7760 ; also at 1906 repetitions of stations 7567 and 7723 . Recorded, likewise, from New Bedford, on piles, sometimes completely covering hydroids and algæ; Woods Hole, on United States Bureau of Fisheries pier; West Falmouth Harbor; Vineyard Haven; Nantucket Harbor.

?Vesicularia familiaris (Gros).

Verrill and Smith, I875, p. 710, 487 (Farrella familiaris); Osburn, I9I2, p. 255.

Vineyard Sound.-Verrill. Not noted in the Survey dredgings.

\section{Family VALKERIDE.}

\section{Valkeria uva (Linnæus).a}

Verrill and Smith, I873, p. 709, 389, etc. (Vesicularia cuscata); Osburn, I912, p. 255.

Vineyard Sound, "found on hydroids attached to floating eelgrass, . . . also dredged in 6 to 8 fathoms, on algæ, Sertularia argentea, and other hydroids. "-Verrill. Not recorded in the Survey collection.

$a$ Miss Jelly (Syn. Catalogue of Marine Bryozoa, p. 267-269) gives Vesicularia cuscata Linnæus as synonymous with Valkeria wva. The genus Valkeria is distinguished from Vesicularia by the absence of a gizzard. Since, however, none of the species taken by the Survey, which could, by any possibility, fall within this genus, have been found to be destitute of a gizzard, it seems probabie, either that Verrill was wrong in placing the Vineyard Sound specimens in Vesicularia cuscata, or else that Miss Jelly is in error in her synonymy. To allow, nevertheless, for the possibility of the species having been overlooked by us, we will include Verrill's statement. as above. 


\section{Family TRITICELLIDA.}

Hippuraria armata (Verrill). [Chart 46.]

Verrill and Smith, I873, p. 7 ro, 405 (Vesicularia armata, sp. nov.); Osburn, I912, p. 256.

Vineyard Sound.-Verrill. Scattered stations throughout Vineyard Sound and Buzzards Bay; dredg $d$ by the Survey in 4 to 15 fathoms, on various bottoms. Likewise recorded by us from the piles of wharves at New Bedford (abundant), Woods Hole, Edgartown, Katama Bay, and Nantucket; also from Fort Phœnix. Verrill records this species from floating seaweed.
Hippuraria armata-Continued.

Fish Hawk stations: 7533 bis, $7611,7613,7619$, $7639,7645,7690,7730,7732,7742,7744,7766$. Supplementary stations (I906): 7525, 7633, 7708; (1929): 7659, 7660, 7668.

Phalarope stations: 5, 6, I5.

Hippuraria elongata Osbum.

Osburn, I9r2, p. 256 (sp. nov.).

Buzzards Bay, Vineyard Sound, and Woods Hole Harbor, in the branchial chamber of the blue crab (Callinectes sapidus) and of the spider crabs (Libinia), growing on the walls of the chamber and spreading over the gills; also on the back of Pinnixa. Taken several times locally.

Bryozoa, undetermined.

Fish Hawk stations: $7521,75^{21}$ bis, $75^{22}$ bis, $75^{26}, 75^{28}, 7532,7534$ bis, 7535 bis, 7537 bis, 7538 , $7539,754 \mathrm{I}$ bis, $7542,7549,755^{\circ}$ bis, $755 \mathrm{r}, 7553,7553$ bis, $7554,755^{6}, 7559,7560,7562$ bis, $7567,75^{69}$, $7572,7575,757^{8}, 7579,75^{81}, 75^{8}, 75^{84}, 75^{86}, 75^{88}, 75^{89}, 7591,7592,7596,7603,7604,7605,7606$, $7607,7608,7609,7726,7737,775^{2}$.

Phalarope stations: $13,25,66,75,77,85$, II $5,123, x_{5} 6, x_{57}$.

\section{Phylum ECHINODERMATA. ${ }^{a}$}

\section{Class ASTEROIDEA.}

\section{Family SOLASTERIDAE.}

Solaster endeca (Linnæus). Sun star.

Clark, 1904, p. 556; 1905, p. r.

Just enters the region at its northern limit; not uncommon at Crab Ledge-Clark. Fish Hawk station 7608 , at Crab Ledge, in 20 fathoms, sand and gravel, I specimen, $3 \frac{1}{4}$ inches in diameter.-Survey.

\section{Family ECHINASTERIDAE.}

Henricia sanguinolenta (Müller). Red starfish. [Chart 47.

Verrill and Smith, 1873, p. 7 I9, 407, etc. (Cribrella sanguinolenta); Verrill, I895, p. 205 (Cribrella sanguinolenta); Mead, 1898, p. 703 (Cribrella sanguinolenta); Clark, I904, p. 555 (Cribrella sanguinolenta); 1905, p. 3 (Cribrella sanguinolenta).

Woods Hole Harbor; Vineyard Sound, more common in the eastern half; in Buzzards Bay, rare and restricted to inshore stations and to its mouth; common at Crab Ledge; dredged in 2 to I9 fathoms, particularly on bottoms of gravel or stones. This species is said by Verrill to reside particularly in the outer cold waters.-Survey.
Henricia sanguinolenta-Continued.

Fish Hawk stations: $75^{22}$ (several), $75^{22}$ bis (many small), $75^{23}(3), 75^{2} 3$ bis (few small), $75^{24}$ bis (I small), $75^{25}$ bis (I small), $75^{26}$ (several), 7528 (few), 7529 (few), 7530 bis (several), 753 I bis (few), 7532 (few), 7534 (many), 7534 bis (several small), 7535 (few), 7535 bis (several small), 7536 (several very small), 7537 (few), 7537 bis (several small), $753^{8}, 7539$ (few), 754I (several), 7545 (many), 7546 (few), 7547 (many), 7547 bis (several small), 7548 ( I), 755 I (few), 7553 bis (2), $755^{8}$ (many), 7560 (several), 756 I (few), 7562 (few), 7572 (few), 7588 (I), 7593 (2), 7594 (few very large), 7595 (ferv), 7604 (I large), 7605, 7606 (many), 7607 (several), 7608 (few), 7630 ( I), 7639 (I), 7666 (I), 7670 (many), 767 I (several), 7672 (several), 7676 (I), 7680 (I), 7688 (2), 7689 (several), 7690 (I), 7698 (I), 772 I (few), 7730 (r large), 773 I (I), 7738 (2), $774 \mathrm{I}$ (I), 7742 (4), 7743 (2), 7744 (several), 7746 (x small), 7748 (I), 7757 (several), $775^{8}$ (many), 7759 (several), 7763 (few), 7764 (common), 7770 (I), 777 I (2), 7774 (I). Supplementary station (rgo9): 7672 . Phalarope and Blue Wing stations: I (few very small), 3 (I), 5 (several), 6 (few small), 7 
Henricia sanguinolenta - Continued.

(several), 8 (few), I I (2), I2 (2), I3 (3), I5 (few), I6 (few), 20 (2), 22 ( ), 24 (few), 25 (few), 27 (2), 28 (2), 30 (few), 32 (3 very small), 34 (3), 35 (I small), 36 (3), 44 (2), 45 (2), 52 (2), 56 (I), 57 (few), 60 (I), 62 (I), 63 (I), 64 (I), 65 (I), 67 (I), 69 (2), 74 (I), 77 (many), 83 (I small), $85,86,87$ (small), I08, II2, II5 (several large and small), 128 (2), I34 (I).

The eggs are deposited around the mouth and retained by the mother until the young starfishes are able to take care of themselves.Verrill. Larvæ taken in the tow net May ro.Bumpus. Breeds in the early spring.-Clark.

\section{Family ASTERID尼.}

\section{Asterias austera Verrill.}

Clark, I904, p. 555; 1905, p. 3.

Common at Crab Ledge in 17 to 35 fathoms. Clark. Dredged by the Survey in 17 to 25 fathoms, on bottoms of gravel and stones.

Fish Hawk stations (all at Crab Ledge): $7603^{*}$ (one, 2 inches diameter), 7605 (one, $3 / 4$-inch specimen), 7606 (5), 7607 (one, $3 / 4$-inch), $7608^{*}$ (one, 2-inch), 7609* (one).

Asterias forbesi (Desor). Common starfish (in this region). [Chart 48.]

Verrill and Smith, 1873, p. 718, 326, etc. (listed both as Asterias arenicola and $A$. forbesi, though the authors recognize that the two are probably identical); Verrill, I895a, p. 206; Mead, I900, p. 203; Clark, I904, p. 552; 1905, p. 4; Sumner, I9Io, fig. 20.

Abundant and of general distribution throughout the region, from the adlittoral zone to the greatest depths of the Bay and Sound. Dredged by the Survey in 2 to 19 fathoms, on all kinds of bottom. The abundance of the starfish is subject to great fiuctuations from year to year, its presence or absence on a given spot being frequently determined by the presence or absence of mussel beds.

Fish Hawk stations: $752 \mathrm{I}$ bis (2), $75^{22}$ (several), $75^{22}$ bis (I small), $75^{23}(2), 75^{23}$ bis (several small), $75^{2} 5$ bis (few), $75^{26}$ (several), $75^{27}$ (few), $75^{28}$ (few), 7530 (several), 7530 bis (few), 753 I (I small), 753 I bis (few small), 7532 (few small), 7532 bis (I), 7533 bis ( $\mathrm{x}$ large, several small), 7534 (few), 7535 (several), 7535 bis (several small), 7536 (few), 7537 (many), 7538 (few), 7539 (few), 754I (few), 7543 (I), 7544 (few small), 7545 (few small), 7546 (few small), 7547 (few small), 7547 bis (2 small), 7548 (few small), 7549 (few small), 7549 bis (I), $755^{\circ}$ (many), 755 bis (4 large), $755^{2}$ (few small), 7553 bis (2), 7554 (I small), 7554 bis (2), 7555
Asterias forbesi-Continued.

(several), 7556 (many), 7557 (I), $755^{8}$ (few), 7559 (I), 7560 (I), 756r (few), $75^{64}$ (many), $75^{64}$ bis (I large), $75^{6} 5$ (few), 7566 (x), 7570 (4), 757 I (several), 7579 (many), 7580 (I), $75^{8}$ I (2), 7592 (many), 7593 (? few), 7594 (? few), 7595 (few), 7596 (r), 7608 (few), 76ro (2 small), $76 \mathrm{I} 2$ (I), 76г5 (many small), 7616 (several), 7619 (several small), 7620 (several small), 7621 (several), 7624 (few), 7625 (several), 7626 (I), 7628 (I), $76_{33}(\mathrm{I}), 76_{3} 8$ (several), $76_{44}(\mathrm{I}), 7653$ (2), 7654 (several), 7660 (few), 766 I (several), 7663 (2), 767 I (many), 7672 (few), 7673 ( 15 ), 7675 (3), 7676 (I), 7678 (I), 7680 (2), 768 I (few), 7682 (several), 7687 (I), 7697 (I small), 7699 (I), 7700 (large number), 770 or (several), 7702 (I), 7703 (I), 7704 (I small), 7706 (few), 7707 (few), 7708 (few), 7709 (many), 77 10 (2), 77 I 7 (1), 77 I8 (? young), 77 I (few), 7720 (few), 7721 (few), 7723 (several), 7725 ( 2 small), 7726 (several), 7727 (I), 7728 (2), 7729 (I), 7730 (I small), 773 I (I small), 7732 (several), 7733 (4 large), 7734 (I), 7736(I), 7740 (2),7744(2),775x (2), 7752 (I), 7753 (I small), 7759 (many), 7760 (several), 7762 (several), 7766 (many small), 7767 (several small), 7769 (few small), 7770 (several small), 7772 (2 small), 7773 (I small), 7774 (few small), 7775 (I large), 7776 (many large and medium), 7777 (many), 7778 (common), 7779 (2), 7780 (very many, large), $778 \mathrm{r}$ (many large), $778_{2}$ (several), $778_{3}$ (very many, large and inedium sized). Supplementary stations (1909): $7618,7624,7643,7659,7671$.

Phalarope and Blue Wing stations: I (few), 2 (several), 3 (few), 4 (I large), 8 (I), II (I), I2 (I), I 5 (2), 18 (I), 22 (2), 26 (I), 27 (3), $5^{2}$ (several), 53 (I piece), 59 (I), 6 I (I), 62 (several), 63 (few), 64 (few), 70 (several), 7 I (several), 72 (several), 76 (I), $77(2), 79$ (I), 80 (few), 8I (few small), 82 (several), 85 (I small), 87 (small), 89,98 , I00 (I small), I07 (I small), III, II3, I 4 (few small), II6, I 8 (several), i I9 (I small), I20 (2), I2 I (several), I22 (I small), I27 (2), I30, I3I (few small), I32 (several), I34 (small), I35 (many), I37 (I), I3S (I), I4I (I), I42 (I), I 45 (common), I47 (I), I48 (2), I49 (several), I 50 (several), I58 (I), I6I (several small), I6 3 (I small), I64 (I), I67 (2). Supplementary station (1909): 83 .

The height of the spawning season is reported by Mead to occur during the latter half of June in Narragansett Bay, though individuals with apparently ripe sexual products were found during the rest of the summer. The young are abundant in the Eel Pond during the latter part of the summer. 
Asterias forbesi-Continued.

Food: Oysters, clams, mussels, barnacles, various kinds of gasteropods, worms, and crustacea; occasionally smaller starfishes of their own species.-Mead. The starfish is of great economic interest as one of the most destructive enemies of the oyster.

Asterias tenera Stimpson.

Verrill and Smith, I873, p. 7 I9 (Leptasterias compta); Verrill, 1895a, p. 209 (Leptasterias compta), p. 2 IO (L. tenera); Clark, I904, p. 554 ; 1905, p. 4 .

Abundant in the cold areas south of Rhode Island and Marthas Vineyard, in 20 to 50 fathoms.-Verrill. Very common off Sankaty Head.-Clark. Fish Hawk station $7609^{*}$, at Crab Ledge in 25 fathoms.-Survey. Said to be without metamorphosis, the young being cared for by the mother, to which they are attached.-Clark.

Asterias vulgaris Verrill. Northern starfish; purple starfish. [Chart 49.]

Verrill and Smith, 1873, p. 718, 389, etc.; Verrill, I895a, p. 207; Mead, I900, p. 203-224; Clark, I904, p. 553; I905, p. 4; Sumner, I910, fig. $2 \mathrm{I}$.

Near entrance of Vineyard Sound and off Gay Head.-Verrill. Woods Hole Harbor, occasional; Gay Head; Cuttyhunk; Crab Ledge; vey in Vineyard Sound, chiefly western half; Crab Ledge (common); rare in Buzzards Bay and probably restricted to the lower end; 3 to 25 fathoms, on bottoms of sand, gravel, stones, or shells; not common in mud. At Gay Head they have been taken from piles.

Fish Hawk stations: 7537 bis (I large, several small), 754I (I), 7545 (I medium sized), 7546 Sankaty Head.-Clark. Dredged by the Sur-

Asterias vulgaris-Continued.

bis (I large), 7547 ( $\mathrm{I}), 7547$ bis ( $\mathrm{r}$ large), $755^{2}$ bis (2), 7553 (several), $755^{6}(\mathrm{few}), 7557$ (I) $755^{8}$ (many), 756I (several), 7562 (several), 7564 (abundant), 7567 (few, very small), 7569 (I small), 7570 (I), 7572 (2), 7579 (few), 758I (about ro), $75^{82}$ (few), $75^{8} 3$ (few), $75^{84}$ (few), $75^{8} 5$ (2), $75^{86}$ (r), 7588 (I small), 759 I (I), 7592 (many), 7593 (few), 7594* (few), 7595 (few), 7596 (several), 7599 (many), 7600 (few), 7601 (I), 7602 (I), 7603 (few), 7604 (2), 7605,7606 (few), 7607 (I small), 7608 (several), $7609^{*}$ (few), 7627 (? I), 7638 (? several), 7645 (? I), 7648 (? 2 small), 7657 (? I large), 7670 (several large), 7671 (4), 7672 (I), 7676 (4), 7678 (perhaps 80 , mostly large), 7679 (several), 7680 (several), 768I (many), 7686 (2), 7689 (several small), 7690 (small), 7699 (2), 7700 (many), 770 (many), 7702 (many), 7703 (few), 7706 (many), 7707 (few), 7708 (few), 7709 (many), 7717 (few), 7719 (few), 7720 (few), 7721 (few), 7722 (few), 7723 (I), 7724 (several, medium sized), 7725 (I), 7726 (several), 7727 (3), 7728 (I large, several small), 7730 (2), 773 I (6), 7732 (I large), 7733 (2 large, living), 7734 (I), 7735 (r), 7736 (several), 7737 (I small), 774I (3). Supplementary station (Igog): 7672 (several small).

Phalarope and Blue Wing stations: 5 (I), 27 (I adult), 32 (I very small), 35 (I small), 44 (sev. eral large and small), 45 (2), 46 (2), 52 (several), 55 (I), 56 (I), 57 (several), 58 (many small), 59 (few), 64 (few), 65 (I small), 77 (I), 83 (I small), 86 (2 small), 87 (several), III (small), II6. Supplementary station (I909): 83 .

Young taken in August at Gay Head and other points.-Clark.

\section{Class OPHIUROIDEA.}

\section{Family OPHURIDE.}

Ophioderma brevispina (Say).

Verrill and Smith, 1873, p. 719,363 , etc. (Ophiura olivacea); Bumpus, $1898 \mathrm{~b}$, p. 857 (Ophiura brevispina) Clark, 1904, p. 558; 1905, p. 5 (Ophiura brevispina).

Woods Hole, Buzzards Bay, Vineyard Sound, not common; found among eelgrass on sandy shores, especially in tide pools, in sheltered localities.-Verrill. North Falmouth Harbor, Marion, New Bedford; Buzzards Bay, the northern limit.-Clark. West Falmouth; a fragment from Hadiey Harbor.-G. M. Gray.
Ophioderma brevispina-Continued.

Fish Hawk stations: 7644 (? r arm), 7650 (2 arms, identified by W. L. Sperry).

Begins to breed the second week in July.Grave, cited by Bumpus.

\section{Family OPHIOLEPIDIDAE.}

Ophiura robusta (Ayres).

Clark, I904, p. 558; 1905, p. 5 (Ophioglypha robusta).

A northern form, just entering the region; taken at Crab Ledge, 17 fathoms. 


\section{Family AMPHIURIDE.}

Ophiopholis aculeata (Linnæus).

Verrill and Smith, I873, p. 7I9, 400, etc.; Clark, I904, p. 559; I905, p. 6.

Off Gay Head, 6 to 8 fathoms, rare--Verrili. According to H. L. Clark (I9O4), this species is "regarded as a rarity south of Cape Cod;" he at one time expressed the belief that "the reported cases of its occurrence in Vineyard Sound are almost certainly cases of mistaken identification." Recorded from six of the seven Survey stations at Crab Ledge; likewise from at least one station in Vineyard Sound (probably Fish Hawk station 7570), a specimen from which was thus identified by Dr. Clark. Another undoubted specimen of the same species was dredged by the Marine Biological Laboratory steamer Cayadetta at the mouth of Vineyard Sound in September, Igog.

Fish Hawk stations: 7603 (3, the largest 4 or 5 inches in diameter)* ${ }^{*}, 7605,7606$ (several small), 7607 (several small), 7608 (many small)*, $7609(4)^{*}$; also at 7570 ? (see above) and perhaps from other stations in Vineyard Sound $a$

Reported by both Verrill and Clark as being eaten in large numbers by cod.

Amphipholis squamata (Delle Chiaje). [Chart 50.] Verrill and Smith, 1873 , p. 720,420 , etc. (Amphipholis elegans); Clark, I904, p. 559; I905, p. 6.

Vineyard Sound, occasional.-Verrill. Vineyard Sound, common, especially just east of Nobska; Ram Island, Eel Pond, Crab Ledge, Sankaty Head; rocky or shelly bottom, generally in cavities and interstices; "the commonest and most widely distributed of the ophiurans in the Woods Hole region." - Clark. Fairly frequent throughout Vineyard Sound; Buzzards Bay, at a number of stations; dredged in 4 to 15 fathoms, on various bottoms.-Sur-
Amphipholis squamata-Continued.

vey. Hadley Harbor, on side toward Vineyard Sound; head of Great Harbor, Woods Hole.-G. M. Gray.

Fish Hawk stations: $b \quad 75^{2} \mathrm{I}$ bis (?)*, 7537 bis (several small)*, 7538 bis*, 7560 (I small)*, 7564 ( $x$, I inch across)*, 757 I (r), 758 I (2), 7628 ( I), 7672, 7674 (about 10), 7699*, 7703*, 7707*, 7730*, $7743^{*}, 7744^{*}, 7780$ (?)*; Supplementary stations (1907): $7780(\mathrm{I}) * ;(\mathrm{rg09}): 767 \mathrm{r}(\mathrm{I})$.

Phalarope stations: $b 55(2), 116 *$, 118 .

Viviparous. In July and August the adults nearly always contain eggs and young.Clark.

Amphioplus abdita (Verrill).

Verrill and Smith, I873, p. 720, 433 (Amphiura abdita); Clark, 1908; Sumner, I908, p. 3 I9.

Near Nobska Point and western shore of Buzzards Bay. One arm taken at each of the following stations: Fish Hawk 7776* (repetition made Aug. 6, 1907), Phalarope stations $163^{*}$ and I67*.-Survey. Ram Island*, Aug., I907 (collected by G. M. Gray). Not listed by Verrill for any point within this region. According to the latter author this brittle star "buries itself deeply beneath the surface of the soft mud, and projects one or more of the long arms partially above the surface of the mud;" hence it is seldom dredged entire.

\section{Family Gorgonocephalid E.}

Gorgonocephalus agassizii(Stimpson). Basket-fish, "spider."

Verrill and Smith, 1873, p. 722 (Astrophyton agassizii): Clark, 1904, p. 56r; 1905, p. 7 .

"First described from a specimen obtained 'not far from the shoals of Nantucket,' by Governor John Winthrop, in 1670 and $1671 \ldots$ under the name of 'basket fish 'or 'net fish.' "Verrill. Crab Ledge.-Verrill, after $V$. N. Edwards; H. L. Clark; Survey.

Ophiuroids, unidentified (probably for the most part Amphipholis squamata).

Fish Hawk stations: 7532 (I), 7536 (I), 7547 (I), $755^{2}$ (I, very small), 7564 (I small), 7568 (I), 7573

(I small), 7582 (I), 7599 (several), 76r5 (I small), 7633 (I arm), c 7657 ( $\mathrm{I}$ arm), 7660 (I arm).

Supplementary station (1909): 7643 ( 1 arm).

Phalarope stations: I (I), 2 (I), 3, 8, 9 (fragment), 26, 28, 29, 8I, I Io (I), I 32, I 46 (2).

\footnotetext{
$a$ Specimens from stations 7605,7606 , and 7607 (Crab Ledge) were identified in the field, but not saved for later examination. Hence the identity of these is somewhat doubtiul, but not that of those from the other stations. Owing to a coniusion of the records, we are not certain from which of the Vineyard Sound stations the single undoubted Survey specimen ame. Some others, which were listed in the field under this name, were later found to be referable to the next species.

$b$ Here, also, probably belong most of the specimens listed as "Ophiuroids, unidentified."

$c$ Perhaps Amphioplus abdita (Verrill).-H. L. Clark.
} 


\section{Class ECHINOIDEA.}

\section{Family StrongyLOCENTROTIDE.}

Strongylocentrotus droebachiensis (Müller). Green sea urchin. [Chart $5^{1}$.]

Verrill and Smith, I873, p. 716, 326, etc; Clark, I904, p. 563; 1905, p. 7 ; Sumner, I910, fig. I9. Mouth of Vineyard Sound and off Gay Head; off West Chop.-Verrill. Crab Ledge, common; off Sankaty Head, abundant.-Clark. Common in Vineyard Sound, chiefly near western end; appears to be absent from Buzzards Bay, except near mouth; dredged on all sorts of bottoms except muddy ones, chiefly at depths of to fathoms or more.-Survey. Likewise taken at low water, according to Verrill, on the outer, rocky shores.

Fish Hawk stations: 7525 bis ( 2 very small), $753 \mathrm{I}$ bis (I small), 7534 bis (I small, living), 7536 (I small), 7537 bis (I small), 7545 (I small), 7547 (I small), $755^{6}$ (I), $755^{6}$ bis (? I shell), $75^{61}$ (several), $75^{64}$ ( 2 large), $75^{82}$ (several), $75^{8} 5$ (I large), 7592 (I large), 7593 (I small), 7603 (2 small), 7604 (several very small), 7605 (2 small), 7606 (many small), 7607 (several small), 7608 (few small), 7609 (I small), 7663 (I), 7678 (I living), 7679 (I spine), 7680 (I large living, and fragments), 768I (many), 7695 (few spines), 7696 (spines and fragments), 7699 (few spines), 7700 (few spines), 7701 (few spines), 7702 (I living), 7703 (few spines), 7704 ( 1 spine), 7705 (few spines), 7706 (I small living), 77 I8 (I small), 77 I9 (few spines), 7720 ( 1 large living and spines), 7723 (I), $775^{2}$ (I spine).

Phalarope stations: 25 ( 2 small), 32 (I living), 34 ( 1 living), $5^{2}$ (several living), $5^{8}$ (spines), 59 (few small), I 6 ( 1 living).

Food: Diatoms and other small algx; also dead fishes.--Verrill.

\section{Family ARBacmdat.}

Arbacia punctuiata (Lamarck). Common sea urchin; purple sea urchin. [Chart 52.]

Verrill and Smith, I 873, p. 7 I 7,326 , etc.; Clark, I904, p. 563 ; r905, p. 8; Bumpus, $189 S$ b; Sumner, I010, fig. I8.

In Vineyard Sound generally distributed, except at western end; in Buzzards Bay chiefly confined to inshore stations, particularly along the eastern shore; living specimens dredged in 2 to I7 fathoms, on bottoms of sand, gravel, and stones; spines and fragments more generally distributed.-Survey. Found, likewise, clinging to submerged rocks along shore. Formerly fairly frequent in Woods Hole Harbor, even
Arbacia punctulata-Continued. within the "basin" of the local pier. In its occurrence this species is scarce to abundant, being subject to marked fluctuations from year to year. Abundant in 1903, as dredging records show; living specimens very scarce during the following summer, though spines and fragments were frequently taken. (It is of importance to note in this connection that the winter of $1903-4$ was an exceptionally severe one; see p. II4-II6.) Dr. J. F. McClendon, who collected large numbers of Arbacia for biochemical studies during the summer of I908, reports that the greatest numbers were taken southwest of the spar buoy lying nearest to the lighthouse at Tarpaulin Cove, in water of 12 to 15 fathoms depth. They were collected most successfully by means of tangles, a bucketful being sometimes taken at once.

Fish Hawk stations: $75^{21}$ bis (fragments and spines), $75^{22}$ (many living), $75^{23}$ (several living), $75^{23}$ bis (I spine), $75^{24}$ (very abundant, living), $75^{26}$ (2), $75^{29}$ (few), 7530 (abundant), $753 \mathrm{I}$ (I dead), $753 \mathrm{I}$ bis (few fragments), $753^{2}$ (many), $753^{2}$ bis (few spines), 7533 (few, many spines), 7533 bis (I small, living), 7534 (numerous), 7534 bis (ferv spines), 7535 (few shells, many spines), 7535 bis (many spines), 7536 bis (many spines), 7537 (many, rather small), $7538,753^{8}$ bis (spines and fragments), 7539 (few), 7540 (few), 754I (few), 754I bis (many spines), $754^{2}$ bis (several spines), 7543 (fragment), 7545 (numerous, living), 7545 bis (fragment of shell and many spines), 7546 (few living), 7546 bis (spines), 7547 bis (several living and fragments), 7549 (many living), 7549 bis (few fragments and spines), $755^{\circ}$ (fragments), $755^{\circ}$ bis (few spines), $755^{\mathrm{I}}$ (few living), $755^{\text {I }}$ bis (I living, several fragments), $755^{2}$ (few), $755^{2}$ bis (few spines), 7553 bis (few spines), 7554 (I small, dead), 7555 (numerous), $755^{6}$ (few), $755^{6}$ bis (many fragments and spines), 7557 ( $\mathrm{I}$ shell), $755^{8}$ (many living), 7559 (few living), $756 \mathrm{r}$ (about two bushels), 7562 (few living), $75^{6} 3$ (many living), $75^{6} 3$ bis (spines and fragments), $75^{64}$ (many living), 7564 bis (many spines), 7566 (many spines), 7567 (many spines), 7568 (many spines), 7569 bis (spines), $757 \mathrm{I}$ (I), 7572 (few), 7575 (few spines), 7576 (few spines), 7577 (few spines), 7578 (few spines), 7579 (few spines), 7580 (few spines), 7597 (few spines), 7621 (I small), 7624 (spines), 7628 (I small), $763 x$ (few spines), 7639 (few), 7659 (spines and fragments), 7664 
Arbacia punctulata-Continued.

(few spines), $767 \mathrm{I}$ (spines), 7672 (I small), 7673 (spines), 7674 (few spines), 7678 ( $\mathrm{x}$ living), 7726 ( 2 shells, and spines), 7727 (I living), 773I (spines), 7732 (I fragment and one spine), 7733 (2 living), 7734 (few fragments and spines), 7735 (few spines), 7736 (few spines), $773^{8}$ (spines), 7739 (spines), 7740 (spines), 7744 (spines and fragments), 7746 (spines), 7748 (few spines), $775^{2}$ (spines), 7753 (few spines), 7755 (few spines), 7756 (few spines), 7764 (spines and fragments), 7766 (spines and fragments), 7767 (spines), 7769 (few spines), $777^{\circ}$ (spines), 777 I (spines), 7772 , (spines), 7776 (I small living and spines), 7777 (fragments), 7778 (I small living, spines, and fragments), 7779 (fragments and spines), 7780 (spines), 7782 (spines), 7783 (I shell). Supplementary stations (I909): 7624 (several small living), 7629 (2 small), 7645 (few spines), 7659 (many small living), 7672 .

Phalarope and Blue Wing stations: 5 (I spine), 7 (I spine), 8 (I spine), Ir (I spine), I3 (spines), I7 (I spine), 40 (I spine), 4I (spines), 42 (spines), 43 (spines), 44 (2), 45 (2), 52 (few), 65 (I spine), 73 (few spines), 78 (spines), 80 (few), 8 I (2 young), 82 (I), 83 (spines), 84 (I), 85 (I spine), 9r (spines), 92 (spines), 93 (spines), 95 (spines), 96 (spines), 97 (spines), 98 (spines), I08, II0, II 7 (spines), II8 (several young), I20, I2I (spines), I23 (spines), I 28 (living), I35 (feW spincs), I4I (spines), I.49 (2 small), I54 (few spines), 162 (I spine), I65 (I spine), I67 (I small living). Supplementary stations (I909): 79 (few spines), 83 (many spines), I46 (few spines).

Yields ripe eggs during the latter part of June, throughout July, and a portion of August.Bumpus. Dr. McClendon reports that Arbacia was "at the height of the breeding season" about August I (Ig08), and that "the ovaries began to degenerate about September r."

\section{Family SCUTELLIDE.}

Echinarachnius parma (Lamarck). Sand dollar. [Chart 53.]

Verrill and Smith, 1873 , pp. 717,362 , etc.; Bumpus, I898, I898a, I898b; Mead, I898, p. 703; Clark, 1904, p. 564; 1905, p. 8.

Generally distributed throughout Vineyard Sound; particularly abundant in the wester $\Omega$ third; in Buzzards Bay, with one exception, only found near the mouth; living specimens dredged in 2 to Ig fathoms, generally upon bottoms of nearly pure sand.-Survey. Likewise found on sandy shores at extreme low tide.-Verrill.
Echinarachnius parma-Continued.

Fish Hawk stations: $75^{2}$ I (few dead), 7.525 bis (several large and small), $75^{2} 7$ (few dead), $75^{28}$ (few dead), 753 I (few dead), 7532 (2 small), 7532 bis (I small), 7533 (many, all sizes), 7533 bis (many, I living), 7535 ( I small), 7536 (I small), 7536 bis (several small, dead), 7537 (I shell), 7537 bis (few dead), $753^{8}$ (several shells), 7538 bis (few fragments), 754 I (few dead), $754 \mathrm{I}$ bis (several dead), $754^{2}$ (many living and dead), 7542 bis (numerous), 7543 (many living and dead), 7543 bis (several), 7544 (several dead), 7545 (I shell), 7546 bis (many small, dead), 7547 bis (several small), $755^{\circ}$ bis (few dead), $755^{\mathrm{I}}$ (few), $755^{\mathrm{I}}$ bis (I living, few shells), $755^{2}$ bis (several living and shells), 7553 (few shells, I living), 7553 bis (few), 7554 (many living and dead), 7554 bis (several living and shells), $755^{6}$ (few dead), $755^{6}$ bis (many dead), 7557 (I shell), $755^{8}$ (few shells), 7559 (several living), 7560 (several living and dead), $75^{6} 3$ (few dead), $75^{63}$ bis (few), 7564 (I shell), $75^{6} 4$ bis (few dead), $75^{6} 5$ (few living), 7565 bis (few dead), 7566 (many of all sizes, living and dead), 7567 (few living and dead), 7568 (several living); 7569 (many living), 7570 (few), 7574 (few living), 7575 (many living), 7576 (many living), 7577 (few living), $757^{8}$ (many living), 7579 (many living), $75^{80}$ (I living), $75^{82}$ ( $\mathrm{I}$ ), $75^{83}$ (several), $75^{84}$ (many), $75^{85}$ (many living), $75^{86}$ (few living) 7588 ( I small), $75^{89}$ (many living), 7590 (few), 759 (few living), 7592 (few dead), 7593 (many living), 7595 (few living), 7596 (several living and dead), 7597 (few living and dead), 7599 (I dead), 7600 (many living), 7602 (few), 7666 (I small), 7674 (I fragment), 7676 (2 living), 7677 (very many), 7678 (many living and dead), 7680 (several small living), $768 \mathrm{I}$ (several living and dead), 7682 (few small dead), 7686 (few living), 7687 (many small), 7694 (many small and large), 7695 (few living), 7696 (few living and dead), 7698 (few living and shells), 7699 (few living and shells), 7700 (very many living), $770 \mathrm{r}$ (abundant, living and dead), 7702 (few small living and dead), 7703 (few living and dead), 7704 (many living), 7705 (few living), 7706 (many living), 7708 (very many living), 7709 (very many living), 77 Io (many living), 77 I 7 (many living and dead), 7718 (several), 7721 (few), 7722 (I living), 7723 ( I living), 7724 (several very small, living), 7725 ( 2 living), 7726 ( 1 living, many small shells), 7727 (many living), 7728 (I living, small dead), 7729 (several living), 7730 (I living, 2 shells), 773 I (I shell), 7732 (I small 
Echinarachnius parma-Continued.

dead), 7733 (I small shell), 7734 (few shells), 7735 (2 shells), 7736 (several shells), 7740 (few dead), 774I (I small dead), 7744 (few small shells), $775^{\circ}$ (I shell), 775 (I shell), 7752 (I shell), 7753 (few living and shells), 776 I (few 'medium sized, living), 777 I (I dead), 7774 (few shells), 7779 ( 2 small living, 3 dead), 7780 (I shell), 7782 (I shell), 7783 (I shell). Supplementary stations (I909): 7660 (I fragment), 7668 (few small living), $767^{2}$ (several small dead).

Phalarope and Blue Wing stations: 2 ( 2 dead), 3 (few, very small), 4 (I), 6 (I small, dead), 7 (few fragments), 8 (I dead), 9 (I shell), ro (I shell), II ( $\mathrm{I}$ ), I5 (I living), I6 (dead), I8 (I dead), 23 (several small living), 25 (I dead), 26 (I dead), 29 (I), 33 (several living), 40 (few shells), 4I (few dead), 42 (few dead), 52 (many), 53 (I dead), 60 (I small living), 6I (I fragment), 62 (few dead), 64 (few small dead), 65 (I very small dead), 66 (few dead) 67 (few shells), 73 (I), 74 (few small living), 83 (I shell), 99 (I dead), ror (I shell), i I (I small), I 8 (I shell), I22 (I), I63 (I fragment). Supplementary station (I909): 83 (several small dead).

Echinarachnius parma-Continued.

Eggs artificially fertilized as early as March 22; "breeding abundantly" early in April.-Mead. Continues to breed throughout June and the early part of July, and a limited number of eggs may be secured even during the later portions of the summer--Bumpus.

Large numbers of this species are consumed by flounders.-Verrill. Also by the cod.-Clark. Verrill states that the fishermen of Maine and New Brunswick prepare an indelible marking ink from the spines and skin.

Mellita quinquesperforata (Leske). Keyhole urchin.

Verrill and Smith, I873, p. 717, 427 (Mellita pentapora and testudinaria); Clark, I904, p. 565 (Mellita pentapora); I905, p. 8 (Mellita pentapora).

Vineyard Sound, 5 to 8 fathoms, on sandy bottom; rare, and only dead specimens taken.Verrill. Nantucket.-Agassiz, cited by Verrill. One taken in Vineyard Sound during summer of I9or.-G. M. Gray, cited by Clark. Not encountered during the Survey dredging.

\section{Class HOLOTHURIOIDEA.}

\section{Family CucumaritDAs.}

Cucumaria frondosa (Gunnerus). Sea cucumber.

Clark, I904, p. 566; I905, p. 9.

Off Sankaty Head, in I2 to 25 fathoms, several specimens taken.-Clark. Considerable numbers taken on halibut lines by V. N. Edwards, in same general region during summer of 1906.

Ripe gonads observed in August.-Clark.

This holothurian is said by Stimpson to be very palatable when boiled.

Cucumaria pulcherrima (Ayers).

Verrill and Smith, 1873, p. 715,420 , etc. (Pentamera pulcherrima); Clark, I904, p. 567; I905, p. 9 .

Nobska point and beach, washed ashore, abundant.-Verrill, Clark. Buzzards Bay bathing beach, near breakwater, a number cast ashore in winter of I903.-Gray, cited by Clark. Nearly all of the specimens recorded for this region were cast up on beaches after storms. Verrill concludes that they "doubtless live in the sand in shallow water a short distance off the beach," though he also records their having been dredged at 4 or 5 fathoms. Mr. Gray likewise reports the occurrence of this species on Ram Island, where he has found it living
Cucumaria pulcherrima-Continued. among the roots of eelgrass. A single specimen was dredged by the Survey near the west shore of Buzzards Bay, at a 1909 repetition of Phalarope station ${ }^{6} 6_{5}$.

The reproductive condition of those taken seems to indicate that breeding occurs in the late winter or early spring.-Clark.

Thyone briareus (Lesueur).

Verrill and Smith, 1873, p. 715,362 , etc.; Mead, I898; Clark, 1904, p. 567; 1905, p. Io.

Buzzards Bay, Vineyard Sound, off Waquoit; muddy and sandy shores and bottoms; more common, however, in shallow water, off shore, on shelly bottom; r to ro fathoms.-Verrill. Hadley Harbor, Waquoit, Cuttyhunk.-Clark. Vineyard Sound, in eastern third, a few stations; two stations in Buzzards Bay; 2 to II fathoms, on bottoms of sand and mud.-Survey.

Fish Hawk stations: 7538 bis*, 7674 (I).

Phalarope stations: 2 (? 1 ), $3^{*}, 9^{*}, 156^{*}$ (I small).

Collected by G. M. Gray in December and March as well as in summer. Full of nearly ripe eggs and sperm, April 24.-Mead. Probably breeds during June and July.-Bumpus. Apparently breeds in summer.-Clark. 
Thyone scabra Verrill a

Clark, 1904, p. 568; 1905, p. I0.

Rare; 5 specimens dredged by the Fish Hawk in Vineyard Sound in I9or; others taken by Prof. Bumpus in Narragansett Bay.-Clark.

Thyone unisemita (Stimpson).

Verrill and Smith, 1873, p. 7 I5, 503 (Stereoderma unisemita); Clark, 1904, p. 569; I905, p. Io.

Verrill records the taking of one specimen by Packard, off Marthas Vineyard in 2 I fathoms, on bottom of clear sand. A half dozen collected by Clark at Crab Ledge, in August, 1902, on sandy and gravelly bottom; also reported by this writer from Nantucket Shoals, off Gay Head, and in Narragansett Bay. Three specimens dredged by the Fish Hawk at Crab Ledge, 'July 23, 1907 (station $788^{*}$ ); two others dredged in August, I907, near station $7692^{*}$, at entrance of Vineyard Sound. (These specimens, according to Dr. Clark, "are remarkable for their elongated, slender form; stiff body wall; and comparatively few large pedicels."') A large individual, dredged August 15, I908, at the western end of Vineyard Sound, near Fish Hawk station 7719; several others on August 25, I908, near Phalarope station 33 .

\section{Family Molpadud死.}

Caudina arenata (Gould).

Verrill and Smith, I873, p. 715, 362, etc.; Clark, I904, P. 569; 1905, p. I2.

Woods Hole Harbor.-H. E. Webster, cited by Verrill. Clark notes the existence of a specimen in the United States National Museum, labelled "off Cuttyhunk, I $81 / 2$ fathoms." Lower half of Buzzards Bay: 8 records; dredged in 6 to 13 fathoms, on muddy bottom; I record at mouth of Vineyard Sound, in $17 \frac{1}{2}$ fathoms, sand.-Survey.

Fish Hawk stations: $7647(\mathrm{I})^{*}, 765^{8}(2)^{*}, 766 \mathrm{I}$ $(4)^{*}, 7669^{*} ; 7686$ (x fragment, identified by J.H. Gerould). Supplementary stations (1907): $7647(\mathrm{I})^{*}, 766 \mathrm{x}$ (I fragment)*, 7665 (4)*; (I909): Phalarope I6 $_{5}$ (I small).

?Molpadia oolitica (Pourtales).

Verrill and Smith, 1873, pp. 715, 510; Clark, 1904, p. 570 (Trochostoma ooliticum); I905, p. I2 (Trochostoma ooliticum).

One doubtful specimen recorded, taken by Packard $I_{5}$ miles east of No Mans Land (?) in 29 fathoms, sandy mud.
Family SyNAPTIDAs.

Leptosynapta inhcerens (Müller).

Verrill and Smith, 1873, p. 7I6, 36I, etc. (Leptosynapta girardii); Mead, 1898, p. 704 (Leptosynapta girardii); Bumpus, I898 c; Clark, r899, p. $2 \mathrm{I}-33$ (Synapta inhørens); r9.04, p. 57 I (Synapta inharens); I905, p. I3 (Synapta inharens).

Vineyard Sound, Naushon Island, etc.; burrows deeply in the sand or gravel, near low-water mark.-Verrill. Woods Hole Harbor, near entrance of the E.el Pond; abundant along shores of Buzzards Bay, about Naushon, Uncatena, and Nonamesset; less common on the sound side; occupying clean sand or soft mud, near, or at times above, low-water mark.-Clark. Vineyard Haven, near bridge; Tarpaulin Cove; head of Katama Bay, on western side.-R. C. Osburn.

Eggs and sperms nearly ripe, April 24, I898.Mead. Probably breed during June and July.-Bumpus. "Both species of Synapta breed during the spring and early summer. The sexual glands are well developed by the last of April, and individuals with ripe ova may be found well into August. About the last of June or early July seems to be the height of the breeding season."-Clark.

Leptosynapta roseola Verrill.

Verrill and Smith, I873, p. 7 I6, 362; Mead, I898, p. 704; Clark, I899, p. 2I-3 I (Synapta roseola); I904, p. 57 I (Synapta roseola); I905, p. I3 (Synapta roseola).

Naushon Island.-Verrill. Buzzards Bay, in the neighborhood of Woods Hole--Clark. According to Verrill the occurrence and habits are similar to those of $L$. inherens. Clark, however, notes characteristic differences of habitat, stating that $L$. roseola "occurs on rocky or gravelly shores under stones or among the pebbles, and never in pure sand or mud." He adds that he has never found this species in the Woods Hole region "except where there was sufficient iron present in the soil to give it a decidedly rusty color."

For breeding season see remarks under preceding species. 


\title{
Phylum ANNULATA. ${ }^{a}$ \\ Class CHÆTOPODA.
}

\author{
Subclass POLYCHE⿱TAA.
}

Family SvLLID杘.

Syllis pallida Verrill.

Verrill and Smith, I873, p. 590, 453 (Syllis, species undetermined).

Vineyard Sound, at surface, a single specimen, not at first determined specifically.-Verrill. Eastem part of Vineyard Sound, in Io fathoms, sandy and stony bottom (Fish Hawk station $\left.752^{*}\right)$, a single specimen.

Syllis sp. undetermined.

Mead, 1898 , records that a member of this genus was taken on several occasions in April, at Woods Hole, among hydroids and algæ.

Tetraglene agilis Verrill.

Verrill, I882d, p. 368 (sp. nov.); I884, p. 663.

No Mans Land, in the evening at surface, September, I880; Woods Hole, August 4, I88I; August 5 to September I2, 1882 .

Eusyllis fragilis (Webster).

Verrill, I882b, p. 368 (Eusyllis tenera); I884, p. $66_{3}$ (E. tenera).

Woods Hole, frequent at surface in evening, from August 2 to September I 5, I88I and I882; also dredged in Vineyard Sound in 8 to I2 fathoms, among Bryozoa and Amaroucium pellucidum.-Verrill. Vineyard Sound, near shore of Nonamesset, $4 \frac{1}{2}$ fathoms, gravel (Phalarope station $\mathrm{I}^{*}$ ), I specimen, on Styela partita.

Trypanosyllis sp. undetermined.

Eastern end of Vineyard Sound, Io fathoms, stony bottom (Fish Hawk station 7768), among Amaroucium pellucidum.* This specimen was unfortunately lost before being determined specifically.

Odontosyllis lucifera Verrill.

Verrill, I884, p. $66_{3}$.

Vineyard Sound, "very common in the surface nets all through August and to September I5." - Verrill. Vineyard Sound, near Nonamesset Island, $61 / 2$ fathoms, sand and gravel (Phalarope station $2^{*}$ ), 3 specimens, in Cliona celata.-Survey. Common on piles among mussels, etc.-Moore.
Syllides setosa Verrill.

Verrill, r882d, p. 369 (sp. nov.); r884, p. 664.

Vineyard Sound, taken at the surface in the evening, July 22, 29, and August I 5, 188I; August 3 to September I2, 1882 .

Syllides verrilli Moore.

Verrill, 1884 , p. 664, footnote (species undetermined); Moore, I9o7a, p. 448 (sp. nov.).

Woods Hole; taken along with Syllides setosa.Verrill. Woods Hole, at surface, rare.Moore.

Pterosyllis cincinnata Verrill.

Verrill and Smith, I873, p. 590, 453 (Gattiola sp.); Verrill, r874, p. 394.

Vineyard Sound, young specimens taken several times at the surface.

Grubiosyllis websteri Verrill.

Verrill, I882d, p. 370 (Grubea websteri); 1884, p. 664 (Grubea websteri).

Newport, r880, at surface; Woods Hole, July 28 to September I2, I88I and I882,-Verrill. Common on mussel beds in shallow water.Moore.

Spharosyllis sp. undetermined.

Verrill, r882d, p. 370 ; I884, p. 664.

Vineyard Sound.

Padophylax dispar Webster.

Verrill, 1879, p. I70 (Pcedophylax longiceps, sp. nov.); r882d, p. 370 ( $P$. longiceps); I884, p. $66_{5}$ ( $P$. longiceps).

Vineyard Sound, July Io, I875; identity of species not certain.-Verrill. Central and eastern portions of Vineyard Sound, several records; 5 to $x 2$ fathoms, on various bottoms. Survey.

Fish Hawk stations*: 7523 bis (I), 7768 (few).

Phalarope stations*: 8 (I), I5 (I).

Padophylax sp. undetermined.

Buzzards Bay, at Fish Hawk station 7634 (I)*.

A utolytus varians Verrill.

Verrill, I882d, p. 367 (A. varians, also A. mirabilis); I884, p. 662; Mensch, I900, p. 269 . 
Autolytus varians-Continued.

Vineyard Sound, abundant.-Verrill. Budding individuals may be found at any time of year, among hydroids on piles (particularly on Tubularia crocea), or dredged in and about Vineyard Sound.-Mensch. "It is not uncommon to find it carrying five or six sexual individuals in various stages, one behind another."-Verrill. The sexual worms are taken at the surface in the evening.

Autolytus ornatus Verrill.

Verrill, I879, p. I70 (sp. nov.); I882d, p. 367; I 884, p. 662 .

Vineyard Sound, at surface, July I 3 and August 28, r875.-Verrill. Eastern end of Vineyard Sound, at Fish Hawk station 7768; Io fathoms, stony bottom; one specimen*. Females filled with eggs taken in tow during the winter* (V. N. Edwards, col.).

Autolytus cornutus Agassiz.

Verrill and Smith, 1873, p. 590, 397, etc.; Bumpus, 1898; $1898 \mathrm{a}$; Mead, 1898 .

Vineyard Sound, low water to $\mathrm{I}_{5}$ fathoms; "constructs cylindrical tubes which are attached to seaweeds and the branches of hydroids." Verrill. Woods Hole.-Bumpus.

Frequently taken with eggs, March, I 898 . Bumpus. Mead and Bumpus likewise record the taking of "Autolytus" with eggs, during the months of April and May (species not specified). Dr. Moore states that the stock forms are especially abundant among hydroids on piles, the sexual zooids, at the surface in the evening.

Autolytus emertoni Verrill.

Verrill and Smith, 1873 , p. 590 (Autolytus, species undetermined); Verrill, I882b (figure only).

Vineyard Sound, females filled with eggs taken in tow during winter and spring.-(V.N. Edwards, col.)

\section{Family HeSIONID E:.}

\section{Podarke obscura Verrill.}

Verrill and Smith , I873, p. 589, 319, etc.; I882d, p. 370 ; I884, p. $66_{5}$; Treadwell, I90I, p. 399.

Woods Hole.-Verrill. Eel Pond, very abundant. Western shore of Little Harbor.Treadwell. This species, though common enough along shore, among eel grass and under stones, is not recorded from the survey dredgings. The sexually mature form may swim at the surface at night, "in vast numbers," according to Verrill.
Podarke obscura-Continued.

Breeding season from July I to about August 20; eggs laid in the evening betwcen 7 and io o'clock; artificial fertilization possible, if the eggs have been naturally extruded, not otherwise.-Treadwell.

\section{Family PhyLLODOCIDAE.}

Phyllodoce catenula Verrill.

Verrill and Smith, 1873, p. 587,494 (sp. nov.).

Woods Hole, at surface, evening, July 3.-Verrill. Tarpaulin Cove, and several records in Vineyard Sound, 6 to $I_{3}$ fathoms.-Survey.

Fish Hawk stations:* 7547 (I), 7724 (I).

Phalarope station $26(3)^{*}$.

Phyllodoce sp. undetermined.

Phalarope station $8 \mathrm{x}(\mathrm{I})^{*}$.

\section{? A naitis formosa Verrill.a}

Verrill, I885, p. 433 (sp. nov.).

Vineyard Sound, in shallow water; also taken at surface, August I, I88I.

2Anaitis picta Verrill.

Verrill, I885, p. 433 (sp. nov.).

Vineyard Sound, 1882 , in shallow water.

Eteone setosa Verrill.

Verrill and Smith, I873, p. 588 (sp. nov.).

Vineyard Sound, 6 to I2 fathoms, among ascidians.

Eteone robusta Verrill.

Verrill and Smith, I873, p. 746,588 (sp. nov.).

Woods Hole, in abundance in September (V. N. Edwards, col.).

Eteone, sp. undetermined.

Verrill and Smith, 1873 , p. 589, record that "a small and slender species was dredged off Gay Head, in Io fathoms, in soft mud."

Eulalia annulata Verrill. [Chart 54.]

Verrill and Smith, 1873 , p. 585 (sp. nov.).

Vineyard Sound.-Verrill. Vineyard Sound, at both ends, occasional; Buzzards Bay, at one station near Cuttyhunk; dredged in 6 to 14 fathoms, on bottoms of sand, gravel, and stones.-Survey. Also recorded from Vineyard Haven, on piles of a wharf* (R. C. Osburn, col.).

Fish Hawk stations*: 7689 (several), 7700 (2 young), 7702 (I), 7706 (I), 7718 (3), 7721 (2), 7738 (I), 7739 (5), 7742 (I), 7744 (I), 7747 (r), 7749 (3), 7750 (common), $775^{2}$ (several), 7757 (I), 7759 (several), 7768 (few).

Phalarope station* I I 2 (I).

a Dr. Moore regards this and the following species as "doubtfully distinct from $A$. speciosa Webster, which occurs from New Jersey to Eastport, Me," 


\section{Eulalia gracilis Verrill.}

Verrill and Smith, I873, p. 586 (sp. nov.).

Vineyard Sound, 6 to I4 fathoms, among ascidians and hydroids.-Verrill. Vineyard Sound, at both ends, 3 to I2 fathoms, sand and gravel.-Survey.

Fish Hawk stations*: 7699 (I), 7732 (I), 7737 (I). Blue Wing station $46(x)^{*}$.

\section{Eulalia pistacia Verrill.}

Verrill and Smith, 1873 , p. 584 (sp. nov.).

Vineyard Sound, 6 to 12 fathoms, among compound ascidians.-Verrill. Vineyard Sound, chiefly at eastern end; Buzzards Bay, at one station; dredged in 4 to ro fathoms, sand and gravel.-Survey.

Fish Hawk stations*: 7699 (2), $775^{*}$ (several), $7768(2)$

Phalarope stations*: I (2), 2 (several in Amaroucium), 3,9 (I), I32 (4).

Eulalia sp. undetermined.

Fish Hawk stations*: $75^{21}$ bis (several), $75^{2} 3$ bis (I), 7525 bis (I), 7535 bis (I), 7543 bis (I), 7544 bis (I), 7632 (2), 7634 (6).

Phalarope and Blue Wing stations ${ }^{*}: 5$ ( I), 6 (several), 22 (I), 28 (I), 33 (2), 37 (3), 45 (I), 48 (I), 66 (I), 67, 77 (I), 126 (I).

\section{Eumidia americana Verrill.a}

Verrill and Smith, 1873, p. 584, 494 (sp. nov.). Vineyard Sound, 8 to I2 fathoms, among compound ascidians.-Verrill. Vineyard Haven, $21 / 2$ to 3 fathoms ${ }^{*}, 3$ specimens; Vineyard Sound, at Fish Hawk station $7564^{*}$, in $I_{3}$ fathoms, sandy.-Survey. Specimens identified with doubt by Dr. Moore were also taken in Vineyard Sound at Fish Hawk station 7522, and at Crab Ledge (station 7606).

\section{Family POLYNOIDA.}

Harmothoë imbricata Malmgren. [Chart 55.]

Verrill and Smith, I873, p. 582, 321; Mead I 898.

Vincyard Sound.-Verrill. Universally distributed in Vineyard Sound; in the Bay, mainly restricted to the inshore stations; likewise recorded from Crab Ledge.-Survey, Dredged at all depths, and perhaps equally abundant on every kind of bottom; listed, also from piles and shores at a great number of points throughout the region.

Fish Hawk stations: $75^{21}$ bis (many small), $75^{22}$ bis (several), $75^{23}$ bis (several), $75^{24}(\mathrm{I})^{*}$,
Harmothoe imbricata-Continued. $75^{24}$ bis (I), $75^{2} 5$ bis(several ), $75^{26} 6(2)^{*}, 75^{28}(2)^{*}$, 7530 bis $(2)^{*}, 753$ I (several) ${ }^{*}, 7532(\mathrm{I})^{*}, 753^{2}$ bis (several), 7533 bis, 7536 bis ( $(x), 7538(4)^{*}$, 7538 bis $(\mathrm{r})^{*}, 7539(3)^{*}, 7547(\mathrm{I})^{*}, 7548(4)^{*}$, 7549 bis (several)* $755^{*}$ bis $(3)^{*}, 7553(2)^{*}$,

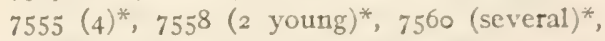
$756 \mathrm{I}^{*}, 7562$ bis $(\mathrm{I})^{*}, 7564$ (several)*, 7564 bis

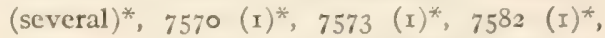
$75^{8} 3^{*}, 7599(\mathrm{I})^{*}, 7604$ (young)*, 7605 (I small $)^{*}, 7606(2 \text {, one young })^{*}, 7612(3), 7613$ (several), 7616 (I), 762 I (I), 7625 (3), 7628 (I), $76_{3 x}(\mathrm{I}), 76_{32}(2), 76_{34}(2), 76_{53}(2), 7656$ (r tube), 7667 ( 2 small), 767 I (2), 7672 (several), 7674 (I), 7675 (I), 7676 (I small), 7677 (I small), 7678 (several small), 7679 (I), 7680 (2), 7682 (several), 7689 (several), 7692 (several), 7697 (I), 7699 (several), 7700 (I), 7701 (several), 7702 (3), 7703 (1), 7706 (2), 7707 (I small), 7709 (common), 7718 (3 small), 7720 (I), $772 \mathrm{I}$ (2 small), 7722 (several), 7724 (common), 7725 (I), 7726 (I), 7727 (I), 7730 (I), 7732 (common), 7734 (I), 7736 (I), 7738 (common), 7739 (few). 7740 (I), 7742 (I) 7743 (I), 7744 (2), 7746 (I), 7747 (I), 7749 (few small), $775^{\circ}$ (common), $775^{\mathrm{I}}$ (several), 7753 (common), 7754 (common), 7758 (few) 7759 (several), 7761 (I), 7762 (several), 7763 (r), 7764 (common), 7768 (few), 7769 (common), 7772 (I), 7777 (many)*, 7778 (several)*, 7780 (several)* $^{*}, 7782$ (several)* $77^{8} 3$ (several $)^{*}$.

Phalarope and Blue Wing stations: I (few), 2 (few), 3 (few), 4 (few), 6 (3), 8 (many), 9 (I), II (several), I2 (I), I4, I5 (several), I6 (several), I8 (I), 20 (I), 2 I (I), 22 (several), 26 (several), 27 (few), 28 (several), 29 (I), 30 (several), 32 (several), 33 (I), 34 (several), 44 (2), 45 (I), 46 (I), 47 (I), 48 (several), 52 (common), 53 (several), 55 (I), 56 (3), 57 (3) , 58, 59 (many), 62 (several), 68 (several), $7 \mathrm{r}(\text { many })^{*}, 72(3)^{*}, 78$ (I very small), 79 (several small), 80 (small), $8 \mathrm{I}$ (common), $82,8_{3}$ (2 very small), 84 (3), 85 (3), 86 (several small), 87 (common), 88 (I), 90 (I small), Ioo (several), Io2 (I), I03 (2), Io7 (I small), Io8 (several small), Iog (I), III (several), I 4 (several), II5 (I), II7 (common, small), I 8 (several), I22 (I), I23 (3), I 25 (I), I26 (2), I28 (I), I29 (I small), I3I (I), I32 (several), $I_{34}(2), I_{37}$ (I), I3 8 (3), I4I (3), I 44 (I), I 45 (I), $I_{47}$ (I small), I48 (I), I53.

a Eumidia papillosa Verrill and $E$, vivida Verrill (Verrill and Smith, 1873, p. 584), which are recorded as occurring in Videyard Sound among compound ascidians, are regarded by Dr. Moore as doubtfully distinct from Eumidia americana. 
Harmothoë imbricata-Continued.

Dr. Mead notes the capture of many females with eggs in early April. Some eggs which were removed from the body on April I2 were found capable of being artificially fertilized.

Eunoë oerstedi Malmgren.

Crab Ledge, I7 fathoms, stones and gravel (Fish Hawk station $7603^{*}$ ).

Lepidonotus squamatus Leach. [Chart 56.]

Verrill and Smith, I873, p. 581,320 , etc.; Mead, I898; Bumpus, I898a.

Almost universally distributed in Vineyard Sound; much less frequent in Buzzards Bay; recorded from Crab Ledge--Survey. Dredged in great numbers at depths of 2 to I9 fathoms, on every sort of bottom, though less common in mud. Collected from shores and piles almost everywhere.

Fish Hawk stations: $75^{21}$ bis ( 2 large), $75^{22}$ bis (several), $75^{23}(7), 75^{23}$ bis (few), 7524 (3), $75^{24}$ bis (I), $75^{25}$ (8), $75^{25}$ bis (several), $75^{26}$ (5), 7527 (I2), $75^{28}$ (8), 7530 bis (several), 7532 (2), 7532 bis (several), 7533 bis, 7534 (2), $7535(2), 7535$ bis (few), $7536(3), 7536$ bis (I), $7537(5), 753^{8}(5), 7539$ (4), $7544(2), 7544$ bis (I), 7547 (4), 7547 bis (I), $755^{\circ}$ (few), 7550 bis (2), $755^{2}(4), 7553(2), 7555(2), 755^{6}$ (5 large), $755^{8}, 7560$ (few), 756 I few), $75^{6} 3$ (fev), $75^{64}$ (many large), 7565 bis (I), 757 I (I), 7572 (few), 7573 (many), 7578 (I), 7580 (I), 7588 (few), 7606 (young), $76 \mathrm{r}_{2}$ (I), 7613 (I), 7625 (1), $76_{30}(2), 76_{32}(2), 76_{34}(3), 76_{36}(\mathrm{I}), 7644$ (4), 7645 (2), 7653 (I), 7659 (several), 7670 (I), 7672 (2), 7680 (2), 7681 (r), 7682 (I), 7689 (numerous, small), 7692 (several), 7700 (2), 7701 (I young), 7703 (several), 7706 (1), 7717 (I), 7722 (4), 7724 (2), 7725 (I), 7730, 7732 (common), 7737 (common), 7740 (I), 7742 (several), 7744 (several small), 7747 (several), 7749 (few small), 7750 (common), 775 I (2), 7754 (several large), 7755 (common), 7756 (several), 7757 (common), $775^{8}$ (abundant), 7759 (abundant), 7760 (common), 776r (several), 7762 (abundant), 7764 (common), 7767 (common), 7768 (common), 7769 (common), 7770 (few), 7772 (several), 7778 (several), 7780 (several), 7783 (several).

Phalarope and Blue Wing stations: I (several), 2 (many), 3 (abundant), 4 (plentiful), 5 (few), 6 (3), 7 (several), 8 (several), ro (several), I I (several), I2 (I), I4, I5 (2 or 3), I7 (I), I8 (I), 20 (I), 22 (I), 24 (numerous small ones), 25
Lepidonotus squamatus-Continued.

(numerous), 26 (several large), 27 (few), 28 (several), 30 (several), 32 (several), 35, 36 (common), 53 (I), 56 (I), 57 (r), 58, 62 (2), 64 (2), 65 (2), 66 (3), 67,69 (few), 73, 82 (1), 83 (I), 84 (I), 85 (2), 86 (I), 87 (3), 96 (I), I00 (I) III, II 2 (several), II3 (2), II4 (several), II 5 (I), II7 (several small), II8 (several), I23 (2), I 24 (I), I32 (I), I36 (2), I37 (I), I38 (4), I44 (common), I45 (I), I48 (I), I52, I58 (I), I6 3 ( I), 167 .

Egg laying observed during last two weeks of April (Mead); first half of May (Bumpus); last week in May and throughout June (Treadwell). Eggs which have been laid may be artificially fertilized.-Treadwell.

Lepidonotus sublevis Verrill.

Verrill and Smith, 1873, p. 58r, 320, etc. (sp. nov.).

Vineyard Sound.-Verrill. Recorded from a few points both in the Sound and the Bay; dredged in 3 to $I_{5}$ fathoms, on various bottoms.-Survey. According to Dr. Moore this species is much more common in Buzzards Bay than in Vineyard Sound, though the dredging records do not indicate this.

Fish Hawk stations *: $75^{27}$ (I?), 7530 (I), 7616 (2), $7634(\mathrm{I}), 7664$ (I), 7701 (x), 7736 (I), 7740 (I).

Phalarope station 165 *

Lepidametria commensalis Webster.

Woods Hole and vicinity, Hadley Harbor, etc.; generally distributed and fairly common, living as a commensal in the tube of Amphitrite ornata.-Moore.

\section{Family Sigalionides.}

Sthenelais picta Verrill.

Verrill and Smith, 1873 , p. 582, 348, etc. (sp. nov.); Verrill, I879, p. 167 ; Bumpus, $1898 b$.

Vineyard Sound; low water to 2 I fathoms.-Verrill. Vicinity of Woods Hole, several stations; 2 in the lower portion of Buzzards Bay; dredged in 4 to ro fathoms, sand and gravel.Survey.

Fish Hawk stations *: $75^{27}$ (I), 7659 (I).

Phalarope stations *: 2 (I), 7 (I), IO (I), I I3 (I), II7 (I), I2O (I).

Bumpus records that "Sthenelais" (species not stated) has been taken with ripe eggs during the middle and latter part of August, and that these are capable of being artificially fertilized. 
Sthenclais gracilis Verrill.

Verrill, 1879 , p. I66 (sp. nov.; also described as S. emertoni; not recorded locally).

Western end of Vincyard Sound and Bay side of Cuttyhunk; 5 to 17 fathoms, sand.-Survey.

Fish Hawk stations: 7685 (several)*, $7687(3)^{*}$.

Phalarope station $102(\mathrm{I})^{*}$.

Sigalion arenicola Verrill.

Verrill, I879, p. I67 (sp. nov.).

Vineyard Sound and off Nantucket; io to 20 fathoms, clean silicious sand.-Verrill. A specimen doubtfully so identified by Dr. Moore was taken at the eastern end of Vineyard Sound, in ro fathoms, on shelly bottom (Fish Hawk station 7546 bis).

\section{Family ApHROdITIDE:}

\section{A phrodita aculeata Linnæus.a}

Verrill and Smith, 1873, p. 580, 507.

Off Gay Head, in $I_{5}$ to $I_{9}$ fathoms, on muddy bottom, common.-Verrill.

\section{Aphrodita hastata Moore. $b$}

Moore, I905, p. 294 (sp. nov.).

Nantucket, on beach after storm (type specimen and several others collected by Dr. Benjamin Sharp); No Mans Land, in lobster pots (V. N. Edwards, col.); dredged by the Fish Hawk in the deeper waters of the same region.-Moore. Gay Head * (G. M. Gray, col.). A specimen, presumably of this species, was taken on a trawl line, off Sow and Pigs Ledge, in March, rgog.

\section{Family AmpHinomde.}

\section{Amphinome pallasii Quatrefages.}

Woods Hole, August, I903*; carried in from Gulf Stream, on floating logs, overgrown with Lepas anatifera, upon which the worm feeds.

Hipponoë gaudichaudi Audouin \& Milne Edwards. Moore, I903, p. 793.

Woods Hole and Vineyard Sound, drifting in from Gulf Stream on logs bearing Lepas anatifera; recorded for summers of 1903 , I904, 1906, being sexually mature when taken.

\section{Family NEPHTHYDID AE.}

\section{Nephthys incisa Malmgren. [Chart 57.]}

Verrill and Smith, 1873 , p. 583, 431, etc. (Nephthys ingens. The "Nephthys ingens" of Verrill is not that of Stimpson).
Nephthys incisa-Continued.

Common throughout the entire length of Buzzards Bay; recorded but three times from Vineyard Sound; dredged in 4 to I9 fathoms, mud and muddy sand.-Survey. Verrill's only local record, so far as we can find, referred to specimens from the stomach of a skate taken in Vineyard Sound.

Fish Hawk stations *: 7540 (I), $76 \mathrm{rI}$ (many), $761_{2}$ ( 1 ), 761 7 (several), 7618 (1), 7619 (several), 7623 (many small), 7624 (several), 7629 (I fragment), 7637 (abundant), $76_{3} 8$ (abundant), 7640 (many), 764I (common), 7642 (many), 7643 (many), 7645 (x), 7646 (several), 7647 (several), 7648 (I), 7649 (several), 7650 (several), $765 \mathrm{I}$ (abundant), 7652 (common), 7653 (common), 7654 (common), 7655 (abundant), 7656 (several), 7657 (common), 7660 (many), 766 I (plentiful), 7662 (many), 7663 (several), 7669 (several), 7670 (r), 7673 (common), 7698 ( $\mathrm{I}$ ).

Phalarope stations *: 52 (I fragment), 78 (4 small), 79 (common), 8o (I small), 84 (I), I43 (2), I59 (4), r60 (I), I6r (several), I62 (several), I64 (3), I65 (4), I66 (several).

Nephthys ciliata Rathke.

Ehlers, I868; Verrill and Smith, I873, p. $5^{83}$.

Edgartown.-Ehlers.

Nephthys bucera Ehlers. [Chart 58.]

Ehlers, r868, p. 6I7, 632; Verrill and Smith, I873, p. $583,416,348$, etc. (Nephthys bucera and $N$. picta).

Vineyard Sound.-Verrill. Scattered stations throughout the Bay and Sound; dredged in 3 to I $_{7}$ fathoms, chiefly on sand and gravel.Survey. Naushon side of Robinsons Hole, on mud flat* (L. J. Cole, col.).

Fish Hawk stations *: 7533 bis (I), 7556 bis (I), 7648 (I), 7667 (I), 7674 (I), 7686 (I), 77 I9 (I), $7720(\mathrm{r}), 7767(\mathrm{r})$.

Phalcrope stations *: 99 (I), I4I (I).

\section{Family NEREIDAE.}

\section{Nereis pelagica Linnæus. (Chart 59.]}

Verrill and Smith, I873, p. 59r, 319, etc.; Sumner, I910, fig. 6.

Vineyard Sound.-Verrill. Of general occurrence throughout bottom of Vineyard Sound; in Buzzards Bay, almost wholly restricted to the shores of the Elizabeth Islands, near the passages connecting the Bay with the Sound.-

$a \mathrm{It}$ is more than possible that Verrill here refers to the next species, though it is also possible that both are present.

$b$ Perhaps this is the species listed by Verrill as $A$, aculeata, or perhaps both are present. 
Nereis pelagica-Continued.

Survey. Dredged in 2 to I9 fathoms, on bottoms of sand, gravel, stones, and shells, rarely in mud; sometimes present in great numbers in the interstices of Amaroucium pellucidum. Recorded from piles and shores at a great number of points throughout the region.

Fish Hawk stations: $75^{21}$ (I small)*, $75^{21}$ bis (very abundant), $75^{22}$ bis (few small), $75^{23}$ (6), $75^{23}$ bis ( 3 large and several small), $75^{24}$ (3), $75^{25}$ (numerous), $75^{25}$ bis (many), $75^{26}$ (numerous), $75^{27}$ (abundant), $75^{2} 8$ (abundant), 7530 bis (several)*, 753 I (several)*, 7532 (numerous), 7532 bis (several), 7533 (I), 7533 bis, $7534(2), 7535$ (3), 7536 (several), 7536 bis (several), $7537(5), 753^{8}(\mathbf{I} 5), 753^{8}$ bis (many) ${ }^{*}, 7539$ (6), 7540 ( $\mathrm{r}), 7542$ (4), 7543 bis (I), 7544 (I8), 7545 (3), 7545 bis (r), 7547 (I6), 7547 bis (several), 7549 bis (several)*, 7550 (few), 7550 bis $(3)^{*}, 755^{*}$ bis (many)*, $755^{2}$ (2), 7553 (5), 7555 (great number), $755^{6}$ (5), $755^{8}$ (many), $75^{60}$ (iew), 756 I (many), $75^{6} 3$ (few), $75^{64}$ (many), $75^{64}$ bis $(3)^{*}, 75^{6}$ (few), $75^{6}$ bis (I young)* 7566 (many), 7570 (few), 757 I (many), 7572 (few), 7573 (many), 7576 (I), 758 I (I), $75^{82}$ (few), 7594 (few), 7595 (many), 7596 (I), 7598, 7599 (many), 7603 (several)*, 7605 (3), 7606 (3 small), 7607 (several), 7608 (8), 7672 (several), 7679 (several), 7680 (several), 7681 (2), 7682 (several), 7689 (numerous small), 7692 (several small), 7699 (small, common), 7701 (2 young), 7702 (2), 7703 (several), 7706 (several), 7707 (2), 7709 (1), 7718 (several), 7720 (2), 7721 (many small), 7722 (several), 7724 (I), 7732 (abundant), 7733 (I large), 7734 (I small), 7735 (I small), 7736 (I), 7738 (several), 7739 (few), 7740 (few), 7742 (several small), 7743 (I), 7744 (several), 7747 (I), 7748 (I), 7749 (few small), $775^{\circ}$ (common), $775^{1}$ (common), $775^{2}$ (common), 7754 (several), 7755 (common), 7756 (several small), 7757 (several small), 7759 (common), 7760 (common), 7762 (several), $7763, \quad 7764$ (common), 7767 (few), 7768 (few), 7769 (common), 7770 (I), $777^{2}$ (few), 7773 (few), 77 So $\left(\right.$ several small)*, $778 \mathrm{I}$ (2 young)* $77^{*} 2$ (several small)*.

Phalarope and Blue Wing stations: I (many small), 2 (common), 3 (abundant), 4 (plentiful), 5 (few living), 6 (few), 7 (3), 8 (many), 9 (I large, others small), Io (many), II (many), I2 (several), I4, I5 (many), I6 (2), 20 (several), 22 (several small), 24 (numerous small), 25 (numerous), 26 (many), 27 (few), 28 (several), 29 (several), 32 (abundant), 33 (several small),
Nereis pelagica-Continued,

34 (abundant, small), 36 (common), 37 (many small), 44 (common), 45 (r), 46 (several), 47 (3), 48 (several, mostly young), 49 (several), $5^{2}$ (several), 56 (abundant), 57 (abundant), 58,59 (many), 60 (several), 62 (common), 63 (several), $64(2)^{*}, 65(2)^{*}, 66(3)^{*}, 67$ (few $)^{*}$, 68 (several), 69 (1), 73 (common)*, 74 (several), 77 (several small)* $\%$ I, 82, 83 (I young), 86 (small, common), 87 (common, generally small), 96 (3), 100 (common, mostly small), ror (I), I02 (2 small), , 08 (several small), II2 (several), II3 (several), II4 (2), II5 (several), II6 (abundant), II 7 (common), II8 (small, common), II9 (2 young), I2I (I), I27 (several).

Nereis arenaceodentata Moore.

Moore, rgo3, p. 720 (sp. nov.).

Woods Hole and vicinity, during summers of I902, 1903, and 1904; immature specimens were occasionally found among mussels and ascidians, mature ones common at surface on August evenings.-Moore. Eastern end of Vineyard Sound, at two stations; Bay side of Pasque Island;-5 to 7 fathoms, sandy bottom.Survey.

Fish Hawk station $775^{\circ}(4)^{*}$; Phalarope stations: $3(\mathrm{I})^{*}, 83(\mathrm{I})^{*}$.

Nereis virens Sars.

Verrill and Smith, 1873 , p. 590, 317, etc.; E. B. Wilson, I892; Bumpus, I898; G. M. Gray, in "Biological Notes."

Vineyard Sound.-Verrill. Recorded from shores at many points in the Sound and Bay; likewise dredged in 5 to ro fathoms at Fish Hawk station 7556 (9 large specimens), and Phalarope stations 26 and 79. Mainly a littoral species, dwelling in muddy sand, though taken occasionally at greater depths; during the reproductive season it leaves the burrow and swims freely at the surface.

G. M. Gray records that this species may be taken throughout the winter locally; that it appears in great numbers at the surface during its reproductive period in March, emerging from the mud or sand as the tide rises, and then disappearing again. Bumpus ( 1898 ) notes that on March 28, 1897, these worms appeared in such numbers at one point in Narragansett Bay that the water was "actually colored by extruded eggs and spermatozoa."

This worm is doubtless an important item of food with many fishes, and it is used extensively as bait by line fishermen. 
Nercis limbata Ehlers.

Verrill and Smith, 1873 , p. 590,318 , etc.; Andrews, "1892, p. 176 ; E. B. Wilson, 1892 , p. 371 ; Bumpus, 1898, 1898b; Mead, in "Biological Notes."

Charleston to Massachusetts Bay.-Verrill. Woods Hole, at surface--Bumpus. Survey records*: New Bedford, on piles; Fort Phoenix, beach; Wareham River, muddy bank, between tides; rocky shore at end of Scraggy Neck; West Falmouth Harbor; Head of Lagoon Pond; Katama Bay at two points. (Collected by R. C. Osburn and L. J. Cole.)

Wilson states of this species and Platynereis megalops that oviposition at Woods Hole continues "at least from June to September," the most favorable time apparently being August and early September. He adds that "the animals appear in abundance only on warm, still nights, and even then are rarely found unless the water has been quiet for some days." Mead records the spawning of this worm at Wickford, R. I., May 31, I899.

Verrill expresses the opinion that this species "must contribute largely to the food of many fishes."

?Nereis dumerilii Audouin \& Milne Edwards. ${ }^{a}$

Tarpaulin Cove; eastern end of Vineyard Sound (twice); Buzzards Bay (once); 3 to Io fathoms, sand and grave1.-Survey.

Fish Hawk station: 7525 bis (I) ${ }^{*}, 76$ I $_{5}$ (I)*; Phalarope station 2 (I) *.

Nereis sp. undetermined.

Fish Hawk station 7560 (several small).

Platynereis megalops (Verrill). [Chart 6o.]

Verrill and Smith, I873, p. 592, 400 (Nectonereis inegalops, sp. nov.); Verrill, I879, p. I 7 I (Nereis alacris), p. 172 (Nereis megalops); $1882 \mathrm{~d}$, p. 370 (Nereis megalops); 1884, p. 665 (Nereis megalops); Andrews, I892, p. I70 (Nereis alacris); E. B. Wilson, I892, p. $37 \mathrm{I}$ (Nereis megalops); Bumpus, I898b (Nereis megalops).

Vineyard Sound.-Verrill. Inshore stations of Buzzards Bay, common; a few scattered stations in the Sound; dredged by the Survey in 3 to $I_{5}$ fathoms of water, on various bottoms; also dug from shores at Lagoon Pond, near bridge *, and from Katama Bay*.

Fish Hawk station *: 7524 (2), $75^{2} 5$ (2), 7548 (I), $7724(\mathrm{I}), 7725$ (3), 7740 (3), 7763 (I large).

Phalarope station *: 8 (I), 33 (I), 78 (I small), 8 r (r male), 86 (I), 87 (common), I08 (several with ripe eggs), III (common), II 5 (I), I I6 (I), II7 (common), I22 (2), 130 (several small), I 32 (I), I40 (2), I4I (2), I 49 (I), I65 (I young).
Platyncreis megalops-Continued.

The sexual form is also common at the surface during the summer. (See statements by Wilson, under Nereis limbata). As in the case of other species of this family, the immature and the sexual forms were at first referred to different species. The former, in the present instance, was the Nereis alacris of Verrill.

\section{Family EUNICIDA.}

Marphysa leidyi Quatrefages. [Chart 6r.]

Verrill and Smith, 1873, p. 593, 3I9, etc.

Vineyard Sound.-Verrill. Dredged at several stations in the eastern end of Vineyard Sound, and at several inshore stations of Buzzards Bay; 3 to 5 fathoms, on various bottoms. Survey.

Fish Hawk station * : 752 I bis (fragments of two), $75^{22}$ bis ( $\mathrm{I}$ fragment), $75^{25}$ bis (fragment), 7535 bis (I fragment), 7615 (I), 7616 (I), 7672 (I fragment), 7777 (? I small fragment).

Phalarope station *: I (I), 3 (I), Io (I), I 8 (I), I47 (I small).

Lycidice americana Verrill.

Verrill and Smith, I873, p. 593, 508 (sp. nov.). Off Gay Head in ig fathoms, soft mud.

Family ONUPHIDE.

Diopatra cuprea Claparède. [Chart 62.]

Verrill and Smith, 1873, p. 593, 346, etc.

Vineyard Sound.-Verrill. Tubes dredged in great numbers, on all kinds of bottoms and at all depths, throughout the entire Sound and Bay; living specimens not once taken with the dredge.-Survey. Recorded from shores at Nobska Point, Bay side of local breakwater, West Falmouth, North Falmouth, Lagoon Pond, Katama Bay, Robinson's Hole, Round Hill Point, Fort Phoenix.

Fish Hawk stations: 7523 (I tube), 7524 bis (I tube), 7525 bis (few tubes), 7526 (several tubes), $75^{2} 7$ ( 2 tubes), 7528 ( 2 tubes), 7530 bis (r tube), 7532 (several), 7532 bis (few tubes), 7533 bis (several tubes), 7534 (few), 7535 (few), 7535 bis (I tube), 7537 (tubes), 7537 bis (few tubes), 7538 bis (few), 754 I bis (few), 7543 bis (2 tubes), 7545 bis (I tube), 7547 bis (several), 7549 (numerous tubes), 7549 bis (few), $755^{\circ}$ bis (few), 7554 ( 1 tube), 7554 bis (several tubes), $755^{8}$ (several tubes), 7559 (I tube), 7560 (I tube), 7572 (I tube), 7576 (I tube), 7578 (many tubes), 7579 (I tube), 7580 (I tube), 758 I (I tube), 7584 (I tube), 7587 (I tube), 7588 (few tubes), 7593 (I tube), 7597 (I tube), 


\section{Diopatra cuprea-Continued.}

7598 (I tube), 7599, 7605, 7612 (2 tubes), 762 I (x tube), 7626 (several ends of tubes), 7630 ( $\mathrm{I}$ tube), $76_{32}$ ( $\mathrm{I}$ ), $76_{33}$ (few tubes), 7634 (few tubes), 7636 (few tubes), 7637 (few tubes), 7638 ( $\mathrm{x}$ tube), 7639 (several tubes), 7643 (x tube), 7644 (few tubes), 7645 (fragment of I tube), $765_{2}$ (few tubes), 7653 (few tubes), 7654 (few tubes), 7655 (few tubes), 7656 (few tubes), 7659 (I tube), 7660 (few), 7661 (few tubes), 7662 (several tubes), 7663 ( 2 tubes), 7664 (many), 7665 (several), 7666 (many tubes), 7667 (many tubes), 7668 (few), $767 \mathrm{I}$ (few tubes), 7672 (few tubes), 7673 (I tube), 7674 (few), 7675 (few), 7678 (several tubes), 7679 (several tubes), 7680 (many tubes), 7682 (r tube), 7698 (several ends of tubes), 7699 (few tubes), 7700 (I tube), 7701 (I tube), 7702 (few tubes), 7703 (I tube), 7706 (few tubes), 7707 (few tubes), 7719 (I tube), 7720 (several tubes), 7722 ( 2 tubes), 7724 (I tube), 7725 (several tubes), 7730 (I tube), 7735 (I tube), 7736 (I tube), 775I (several tubes), 7755 (several tubes), 7757 ( 2 tubes), 7760 (few), 7761 (common), 7766 (several tubes), 7769 (1 tube), 7772 (I tube), 7774 ( 1 tube), 7777 (several), 7778 (several tubes), 7780 (several tubes), $778 \mathrm{r}$ (several tubes), 7782 (several tubes).

Phalarope and Blue Wing stations: I (many tubes), 2 (many tops of tubes), 3 (tubes), 4 (few tubes), 5 (I tube), 7 (many tubes), 8 (several tubes), 9 (common), II (several tubes), I2 (several), $r_{3}$ (tubes), $r_{5}$ (many tubes), I7 (tube), I9 (tubes), 21 (I tube), 24 (I tube), 25 (I tube), 26, 33 ( $\mathrm{r}$ tube), 35 (I tube), 49 (I tube), 52 (many tubes), 55 (I tube), 59 (I), 60 (several tubes), 62 (many), 65 (I tube), 69 (I), 7r (I tube), 72 (I tube), 73 ( $\mathrm{x}$ tube), 74 (few tubes), 75 (few tubes), 76 (many tubes), 77 (many tubes), 78 (tube), 8I (several), 82 (several tubes), 83 (few tubes), 85, 86, 9I, 93 ( $\mathrm{I}$ tube), 94 (tube), 95 (fragments of tube), 96 (I tube), 99 (I tube), I00 (I), ror (fragments of tubes), I02 (I tube), 105 (I tube), 107, 108, 109, III (I tube), II3 (tubes), II4 (3), II5 (I tube), II6, II (several tubes), II8 (many tubes), I20 (I tube), I22 (I tube), I25 (tubes), I26, I28 (tubes), I29, I30 (I tube), I32 (tubes), 134 (I tube), $\mathrm{r}_{39}, \mathrm{I}_{40}$ (I tube), I44 (I tube), I45 (tubes), I46 (2 tubes), I47 (I tube), I48 (I tube), I49 (few tubes), I50 (tubes), I52, I54 (nany tubes), I55 (few), I56 (few), I59 (fragment of tube), I62 (several tubes), I65 (I tube), I66 (I tube), I67. (few tubes).
Diopatra cuprea-Continued.

Egg laying observed by A. I. Treadwell in an aquarium at the Marine Biological Laboratory on evening of July 2, 1904 ; this is said to be rarely observed. For an account of tube forming and other habits, see Verrill and Smith, 1873, p. 346-347.

Nothria conchylegia (Sars).

Crab Ledge, 20 to 25 fathoms, on bottoms of gravel, sand, and shells (Fish Hawk stations $7608,7609)^{*}$, several specimens.

This worm forms a flat, scabbard-shaped tube, constructed of bits of stone or shells, which it drags about with it.

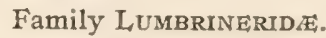

A rabella opalina (Verrill). [Chart 63.]

Verrill and Smith, 1873, p. 594, 320, etc. ( Lumbriconereis opalina, sp. nov.).

Vineyard Sound.-Verrill. In Survey dredgings recorded particularly from the eastern half of Vineyard Sound, and the lower half of Buzzards Bay, in 2 to $I 7$ fathoms, on bottoms of sand, mud, and gravel. Taken during shore collecting at West Falmouth, Scraggy Neck, and Vineyard Haven.

Fish Hawk stations*: $75^{2} \mathrm{I}$ bis (many small), 7532 bis (3), 7533 bis (2), 7538 bis (several), $76_{3}$ (fragment), $76_{34}$ (I), $76_{43}$ (3, I large), 7644 (I large), 7645 (I fragment), 7647 (several), 7649 (2), $76_{51}$ (2), 7652 (fragments of one), 7655 (3), 7656 (I), 7657 (I fragment), 7658 (2), 766 I (I), 7669 (I), 7674 (2), 7678 (I small), 7686 (I), 7697 (I fragment), 7732 (several), 7737 (I), 7738 (3), 7739 (few), 7744 (I), 7749 (few small), 7750 (very common), $775^{1}$ (common), $775^{2}$ (common), 7755 (very common), 7759 (common), 7761 (several), 7764 (common), 7767 (very common), 7768 (abundant), 7780,7782 .

Phalarope stations*: II (I), 62 (I), 73 (I), I24 (I small).

Reproductive season probably late in August; no ripe eggs have been noted earlier than August 1o.-A. L. Treadwell.

Arabella spinifera Moore.

Moore, I906, p. 501 (sp. nov.).

"Found among a lot of Ninoë nigripes Verrill dredged on the muddy bottom of the middle of Buzzards Bay, Mass., the exact spot being unknown."

\section{Drilonereis longa Webster.}

Webster, I878, p. 40 (not recorded locally).

North Falmouth, Kettle Cove, and similar places, rather common, on shores at low-water mark.-Moore. Two records in Buzzards Bay, at Fish Hawk stations $7642^{*}$ and $7674^{*}$. 
Lumbrineris tenuis Verrill.

Verrill and Smith, 1873 , p. 594, 320, etc. (Lumbriconereis tenuis sp. nov.).

Vineyard Sound; shores and flats of sandy mud.-Verrill. Recorded once by the Survey at Fish Hawk station $7642 *$, near middle of Buzzards Bay, 5 fathoms, mud.

? Lumbrineris fragilis Oersted.

Verrill and Smith, I873, p. 594, 507 (Lumbriconereis fragilis).

Mouth of Vineyard Sound and deeper waters outside, on muddy bottom.--Verrill. Dr. Moore expresses doubt concerning the occurrence of this species locally.

Lumbrineris hebes Verrill. [Chart 64.]

Vineyard Sound and Buzzards Bay; 5 to I3 fathoms, sand, gravel, and mud; taken at a few scattered stations.

Fish Hawk stations*: $75^{25}$ (? abundant on Amaroucium pellucidum), $75^{26}$ (?I), 7527 (?6), $75^{28}$ (?3), 7532 (several), 7535 ( I), 7538 (?7), 7540 (4), 7544 (2), 7545 (r), 7553 (I), 7556 (2), 7637 (several), $76_{3} 8$ (several), $76_{5} \mathrm{I}$ (I fragment), 7656 (I), 7674 (I), 7724 (I).

Phalarope stations*: 2 (common in Amaroucium), 3 .

Ninoë nigripes Verrill. [Chart 65.]

Verrill and Smith, 1873 , p. 595, 508 (sp. nov.).

Vineyard Sound and Buzzards Bay and waters outside. - Verrill. Generally distributed throughout Buzzards Bay; but one record for Vineyard Sound; dredged in 3 to I 7 fathoms, chiefly at depths under Io fathoms, on bottoms of mud and muddy sand.-Survey.

Fish Hawk stations*: 7558, 76r2 (plentiful), $76 \mathrm{r}_{3}$ (several), 76I4 (several), 76r8 (several), 76r9 (several), 7623 (I), 7632 (I), 7637 (common), 7638 (plentiful), 7640 (several), $764 \mathrm{I}$ (several), 7642 (several), 7643 (several), 7647 (many), 7648 (I), 7649 (I), 7650 (several), 765I (common), $765^{2}$ (common), 7653 (common), 7654 (severa1), 7655 (2), 7656 (several), 7657 (I fragment), 7658 (common), 766r (r), 7662 (several), 7667 (I), 7669 (I), 7674 (3), 7675 (I).

Phalarope stations*: 78 (3 small), Io7 (I), Iro (I), II7 (I), I62 (several), I63 (I), I65 (I).

Family Glycerrdis.

Rhynchobolus anericanus (Leidy). [Chart 66.]

Verrill and Smith, I873, p. 596, 342, etc.

Vineyard Sound, low water to 10 fathoms.-Verrill. Distribution pretty general throughout Buzzards Bay; only recorded from two points in the Sound; dredged at 4 to $I_{3}$ fathoms, mud and muddy sand.-Survey.
Rhynchobolus americanus-Continued.

Fish Hawk stations*: 7612 (several small), 7617 (3 small), 7625 (I), 763I (3), 7637 (I), 7638 (several), 7640 (several), 7643 (several), 7646 (several), 7647 (several), $7649(3), 76_{50}(\mathrm{I}), 76_{5} \mathrm{I}$ (3), $76_{52}$ (several), 7655 (I), 7656 (I), 7658 (I), 7660 (2), 766I (2), 7667 (I), 7669 (3), 7675 (2). Supplementary station 7723 (1906).

Phalarope stations*: I9, I60 (r).

Verrill records the taking of the young in tow in early September.

Glycera capitata Oersted.

Crab Ledge, $x 7$ fathoms, gravel (Fish Hawk station 7605$) *, 2$ specimens.

Euglycera dibranchiata (Ehlers).

Verrill and Smith, I873, p. 596, 34r, etc. (Rhynchobolus dibranchiaius).

Vineyard Sound.-Verrill. Western end of Vineyard Sound in $I_{3}$ fathoms, sand (Fish Hawk station $\left.7710^{*}\right)$; near Lucas Shoal, in 9 fathoms, sand (Fish Hawk station 7556*); one specimen at each point.-Survey. Also recorded from Tarpaulin Cove, sandy shore*; head of Lagoon Pond*, in 2 feet of water; Vineyard Haven ${ }^{*}$; Katama Bay, on gravel beach*; Robinsons Hole, on mud flats*; Ft. Phoenix*.

\section{Family GonIAdide.}

Glycinde gracilis (Verrill).

Verrill and Smith, I873, p. 596, 508 (Eone gracilis, sp. nov.).

Ofi Gay Head, Ig fathoms, in soft mud.

Ophioglycera gigantea Verrill.

Verrill, I885, p. 436 (sp. nov.).

Newport Harbor in the evening, August, I880.

Family ARICIID E.

Aricia ornata Verrill.

Verrill and Smith, I873, p. 596, 344 (sp. nov.; no local records).

Naushon, Marthas Vineyard, etc., on sandy beaches at low water.-Moore. Treadwell notes its occurrence in moderate abundance, on the Bay side of the local breakwater. ${ }^{a}$

Reproduction observed only during last week in in July and first two weeks in August; eggs can be artificially fertilized, if cut from body of female.-Treadwell, ${ }^{a}$

Scoloplos acutus (Verrill).

Verrill and Smith, I873, p. 599, 4I6, etc. (Anthostoma acutum, sp. nov.).

Off Gay Head, in Ig fathoms, soft mud; also from deeper parts of Vineyard Sound.

a Dr: Moore thinks it likely that $S$ coloplos fragilis (Verrill) is the species here referred to.

I $6269^{\circ}$-Bull. $3^{\text {I, pt. } 2-\text { I } 3-6}$ 


\section{Scoloplos fragilis (Verrill).}

Verrill and Smith, I873, p. 598,344 , etc. (Anthostoma fragile, sp. nov.).

Woods Hole.-Verrill. Quisset Harbor, 2 to 3 fathoms, muddy bottom (Phalaropestation I27), 2 specimens*; south arm of West Falmouth Harbor, beach of sandy mud, between tides*; Round Hill Point, between tides*; rocky shore at end of Scraggy Neck*; Lagoon Pond, at both ends*; Katama Bay, at two points*.-Survey. Great Pond* (E. D. Congdon, col.).

Scoloplos robustus (Verrill).

Verrill and Smith, 1873, p. 597, 343, etc. (Anthostoma robustum, sp. nov.).

Woods Hole.-Verrill. Lower half of Buzzards Bay, at four stations; dredged in 6 to 7 fathoms, sandy mud and muddy sand.-Survey. Also recorded from shores at Fort Phoenix* and Scraggy Neck*, Naushon side of Robinsons $\mathrm{Hole}^{*}$, on mud flats and Katama Bay, at two points*

Fish Hawk stations*: 7640 (I small), 7643 (I small), $765^{2}$ (I), 7675 (I fragment).

\section{Scoloplos sp., sp.}

A specimen, attributed to this genus by $\mathrm{Dr}$. Moore, was taken in Vineyard Sound at Fish Hawk station 7686 . Verrill and Smith ( 1873 , p. 600 and 508) record an undetermined "Anthostoma" from the deeper waters off Gay Head and Buzzards Bay.

\section{Family TOMOPTERIDIA.}

\section{Tomopterus helgolandica Greef.}

Verrill and Smith, 1873, p. 626, 453 (Tomopterus sp. undet.); Moore, r903a, p. 798.

Vineyard Sound, immature specimens taken in evening.-Verrill. Taken twice at Crab Ledge (Aug. I9 and 22, I902), by means of tow net lowered nearly to the bottom, in Ig fathoms of water.-Moore. Collected by V. N. Edwards in surface tow in Woods Hole Harbor, April, May, and December; sometimes in considerable numbers.

\section{Family SPIONIDAs.}

\section{Spio setosa Verrill.}

Verrill and Smith, I873, p. 602, 344, etc.(sp. nov.). Woods Hole and Naushon Island.-Verrill. Common under stones on shores of sand and mud; the young have been taken at surface in the evening.
Spio robusta Verrill.

Verrill and Smith, 1873, p. 603,345 , etc. (sp. nov.).

Woods Hole and Naushon, in sand at low-water mark.-Verrill. Great Pond * (E. D. Congdon, col.).

Spio sp. undetermined.

Near Weepecket Island, in 7 fathoms, clear sand (Phalarope station Iog*), I specimen, in fragments.

Scolecolepis cirrata Malmgren.

Verrill and Smith, 1873, p. 602, 416, etc.

In deeper parts of Vineyard Sound, near its mouth on bottoms of sand and gravel.- Verrill.

Scolecolepis viridis Verrill.

Verrill and Smith, 1873, p. 600, 345, etc. (sp. nov.); Mead, I897, p. 270; Bumpus, I898a.

Woods Hole.-Verrill. Tarpaulin Cove, both on shore and in 3 to 4 fathoms (Phalarope stations $I 7^{*}$ and $\left.19^{*}\right)$; Naushon shore of Robinsons Hole *, in shoal water; Katama Bay *.-Survey. Great Pond* (E. D. Congdon, col.).

"The breeding season of this worm is nearly over by the Ist of May. The eggs are deposited inside of the sand tubes in which the females live."-Mead.

? Prionospio tenuis Verrill.

Verrill, I882d, p. 370 ; I884, p. 665.

Woods Hole (?) in harbor mud, also at surface; a larva, probably of the same species, was taken once in September.-Verrill. Fewkes (1883, p. ${ }^{6} 67$ ) erroneously applies this name to a larva taken at Newport (see Magelona rosea).

Prionospio heterobranchia Moore.

Moore, I907, p. I95 (sp. nov.).

Only known specimen "was dredged from the soft ooze at the bottom of the deepest part of the Eel Pond at Woods Hole on August 4, I902."

Polydora tubifex Verrill.

Verrill, I885, p. 438 (sp. nov.).

Woods Hole, I to 5 fathoms, sandy mud; larvæ at surface in August and September.-Verrill. Rather common at North Falmouth, and occasional on muddy flats elsewhere.-Moore.

Polydora concharum Verrill.

Verrill, I879, p. I74 (sp. nov.; not recorded locally).

Vineyard Sound, in I2 fathoms, at Fish Hawk stations $75^{23}$ bis $\left(\mathrm{I}\right.$ ) and $773^{2}$ (several).*Survey. Crab Ledge and off Sankaty Head, in shells.-Moore. 
Polydora anoculata Moore.

Moore, 1907, p. I97 (sp. nov.).

"Uncommon. Usually taken in association with colonies of Amaroecium pellucidum in 7 to $x 7$ fathoms in Vineyard Sound. Less often on piles among $C_{y} n t h i a$ in Little Harbor and with Polydora colonia at Vineyard Haven. A specimen taken on July I4 contained nearly mature eggs."

Polydora colonia Moore.

Moore, I907, p. I99 (sp. nov.).

Vineyard Haven, on piles, among sponges and tunicates, forming large colonies of "soft mucoid tubes." Specimens containing large eggs were noted in July.

Polydora littorca Verrill.

Verrill, I873, p. 603, 345 (Polydora ciliatum?).

Naushon Island, in muddy sand, at about half tide.-A. Agassiz. Young frequently taken in tow nets.-Verrill. Very common on muddy shores.-Moore. Great Pond* (E. D. Congdon, col.).

Polydora sp. undetermined.

Fish Hawk station 7769 (I)*; Phalarope station $77(2)^{*}$; shore at Tarpaulin Cove, sandy beach. *

\section{Family MAGELONIDAE}

Magelona rosea Moore.

Moore, I907, p. 20 r (sp. nov.).

"This species has been found only on a sandy beach, chiefly below low water, in a little shallow bay on the Buzzards Bay side of Woods Hole. Prof. E. A. Andrews found it at the same place about ten years before it came to my notice, and has described a specimen under the name of $M$. papillicornis Müller. The remarkable larvæ have been described by Fewkes (as Prionospio tenuis) from Newport, and by Andrews from Beaufort, N. C., and Woods Hole.'

\section{Family CHATOPTERIDE:}

Chatopterus pergamentaceus Cuvier. [Chart 67.] Verrill, I882 b, p. 370 ; I884, p. 665; Mead, 1897 , p. 27 r. (Strangely omitted from Verrill and Smith's Invertebrates of Vineyard Sound.)

Naushon Island.-Verrill. In Buzzards Bay, tubes (never containing worms) were frequently brought up by the dredge, particularly in the upper half and at inshore stations, occurring at depths of 2 to 8 (once at I2) fathoms, on various bottoms, though relatively more common in mud; not recorded from the Sound.-Survey. Hadley Harbor-Moore, Treadwell. Ram Island; shore of Woods Hole
Chatopterus pergamentaceus-Continued.

Harbor in front of Marine Biological Laboratory supply department building.-G. M. Gray. Mr. Gray notes that this worm is particularly common among the roots of eelgrass, where it may readily be dug up after mowing down the latter with a scythe. On the shoal between Ram Island and Devils Foot, I3 specimens were thus obtained in the course of a few hours by J. F. McClendon and C. B. Bennett.

Fish Hawk stations: 76 I $_{3}$ (fragment of tube), 7616 (few ends of tubes), $76 \mathrm{I} 7$ (pieces of tubes), $76 \mathrm{I} 8$ (pieces of tubes), 76I9 (several tubes), 7620 (portions of tubes), 7621 (I tube), 7622 (many ends of tubes), 7624 (several tubes), 7626 (ends of tubes), 7630 (I fragment of a tube), 7632 (portions of tubes), 7633 (several tubes), 7634 (I tube), 7636 (I tube), 7637 (few tubes), 7638 (several), 7644 (I), 7645 (portions of several tubes), 7646 (I), 7664 (I tube).

Phalarope stations: 108 ( $I$ end of tube), rog (end of tube), II4 (I tube), I24 (I tube), I25 (I tube), I26 (I tube), I28, I29 (I tube), I30 (I tube), I33 (few tubes), I36 (I tube), I40 (I tube), I4I (tubes), I42, I45 (tubes), I46 (several tubes), $I_{50}$ (tubes), I54 (few tubes), I6o (I fragment of tube), 162 (I tube), I65 (several tubes), I66 (I fragment of tube).

Eggs taken from the body of the female during July and August may be artificially fertilizedMead, Treadwell. Commensal crabs of the genus $P$ innixa are of frequent occurrence in the tubes of this worm.

Spiochatopterus oculatus Webster. [Chart 68.]

Buzzards Bay, chiefly in lower half; two records from Vineyard Sound; dredged in 3 to I7 fathoms, chiefly in mud or mixtures of mud and sand.-Survey. This worm lives in a slender, quill-like tube, marked by numerous annular thickenings, and buried upright in the mud.-Moore.

Fish Hawk stations*: 7629 (I tube), 7634 (several tubes), $76_{37}$ (many tubes), 7638 (tubes common), 7640 (several tubes), 764 I (several), 7642 (several), 7643 (several tubes), 7647 (several), 7648 (I), 7649 (I tube), 7650 (I), 7652, 7653 (2 tubes), 7654 (tubes), 7655 (several tubes), 7656 , 7657 (tube and I fragment), $765^{8}$ (few tubes), 7659 (few tubes), 7660 (few tubes), 766r, 7662 (few tubes), $766_{3}, 766_{5}$ (few tubes), 7669 (few tubes), 7672 (I tube), 7673 (several tubes), 7733 (several tubes).

Phalarope stations*: 62 (I tube), 97 (I tube), I09 (I tube), II4 (2 tubes), II5 (I tube), I6I (I tube), I65 (tubes), I66 (tubes). 


\section{Family Ammocharides.}

Ammochares artifex Verrill.

Verrill and Smith, 1873, p. 610, 508 (Ammochares, species undetermined); Verrill, I885, p. 439 (Ammochares artifex, sp. nov.).

Fifteen miles east of Block Island, in 29 fathoms, sandy mud; 23 fathoms off Marthas Vineyard.-Verrill. $a$ Tubes of what are regarded as worms of this species have been taken in Buzzards Bay, near center (Fish Hawk stations $7612^{*}$ and $\left.7642 *\right)$, and in Vineyard Sound, near Nonamesset Island (Phalarope stations $4^{*}$ and $\left.8^{*}\right)$.- Survey. This worm constructs flexible tubes covered with imbricated sand grains.

\section{Family CiRRATULID五.}

Cirratulus grandis Verrill.

Verrill and Smith, 1873, p. 606, 319, etc. (sp. nov.); Mead, I8g8; Bumpus, I8g8b.

Vineyard Sound.-Verrill. Eastern half of Vineyard Sound, at 5 stations, 2 to II fathoms, sand and gravel; likewise dug up along shore at Katama Bay* ( 2 points), Naushon side of Robinsons Hole*, and the bathing beach at Fort Phoenix*.-Survey.

Fish Hawk stations*: $753^{8}$ bis (I), $775^{\circ}$ (I), 7767 (several), 7769 (I).

Phalarope station $73(\mathrm{I})^{*}$.

Eggs appeared to be nearly ripe, April I7; species known to breed during July; females will deposit eggs in the evening, in confinement.-Mead.

Cirratulus tenuis Verrill.

Verrill and Smith, I873, p. 607, 4I6 (sp. nov.). Vineyard Sound, 6 to I2 fathoms, among compound ascidians; 23 fathoms, off Marthas Vineyard.-Verrill. Two specimens recorded by the Survey from Vineyard Sound, near Nobska Point, 7 fathoms, stones and sand (Fish Hawk station 752I bis)*.

Cirratulus cirratus Müller.

Vineyard Sound, near Cedar Tree Neck, 7 fathoms, sand and shells (Fish Hawk station 755.3)*: I specimen.

Cirratulus parvus Moore.

Moore, I906, p. 505 (sp. nov.).

"Deeper waters of Vineyard and Nantucket Sounds, in from ro to Ig fathoms, where it lives in colonies among the crevices of Amarcecium pellucidum and in passages of shells. Quite common in the latter at Crab Ledge, off Chatham." An immature specimen recorded from near West Falmouth, at Phalarope station $\mathrm{I}_{3} 6^{*}$.
Cirrhinereis fragilis Quatrefages.

Verrill and Smith, I873, p. 607, 332; Verrill, I882d, p. 370; I884, p. 665 .

Specimens believed to belong to this species were dredged by Verrill in Vineyard Sound, on rocky bottom; others taken at surface. Dr. Moore thinks it possible that Cirratulus parvus was the form referred to.

Cirrhinereis phosphorea Verrill.

Verrill, r882b, p. 370 ; 1884 , p. 665 .

A form thus referred to by Verrill, but not described, was taken at the surface in Vineyard Sound or Woods Hole Harbor.

Dodecaceria coralii (Leidy).

Leidy, 1855, p. I2 (Naraganseta coralii); Verrill and Smith, 1873, p. 607 (Naraganseta coralii).

Vineyard Sound, near shores of Nonamesset and Naushon; Buzzards Bay, near Scraggy Neck; dredged in 4 to Io fathoms, on bottoms of sand and gravel, sometimes in dead coral (Astrangia dance); also taken on piles in Nantucket Harbor*. Hitherto not listed for Massachusetts.

Phalarope stations*: 2, 3 (2), 6 (I), II (I), I45 (I).

Acrocirrus leidyi Verrill.

Verrill, I882d, p. 370 ; I884, p. 665.

Woods Hole, surface, evening, August 2 to September 9 , I88I and 1882 .

\section{Family TEREBELLIDEA.}

Amphitrite cirrata (Müller).

Crab Ledge, on stony bottom, in tubes, among Amaroucium, etc., rare.-Moore. Three specimens taken by the Survey at Crab Ledge (station 7606$)^{*}$, in 16 fathoms, stones and gravel.

Amphitrite attenuata Moore.

Moore, I906, p. 506 (sp. nov.).

"This species has been taken only on the piles of the New York Yacht Club wharf in Vineyard Haven, where it occurs sparingly below low water among Cynthia and Amaracium; lives in small mud tubes and breeds in early July."

Amphitrite brunnea (Stimpson).

Crab Ledge and off Nantucket in 16 to 23 fathoms.-Moore.

Amphitrite ornata (Leidy).

Verrill and Smith, I873, p. 613, 320, etc.; Mead, I897, p. 229.

Vineyard Sound, common in sand and gravel at low-water mark.-Verrill. Lackeys Bay, Hadley Harbor, Ram Island.-Mead. Not taken during Survey dredging, but recorded from

a This statement applies to the "Ammochares, species undetermined" of the Vineyard Sound report. The A. artifex, when described, was only listed from 67 fathoms. 
Amphitrile ornata-Continued.

piles at New Bedford, * and from a gravel beach on west side of Katama Bay.*

"The limits of the breeding season are unknown. Although about 800 worms were collected.

between the first of June and the last of August, only seldom were ripe eggs and ripe spermatozoa obtained."'-Mead. Verrill records the taking of young in the tow in the evening, but the month is not stated.

Leprca nubra Verrill. [Chart 69.]

Verrill and Smith, 1873, p. 615,382 , etc. (sp. nov.).

Vineyard Sound; Woods Hole.-Verrill. Gay Head, at several stations; eastern half of Vineyard Sound, fairly common; recorded once from head of Buzzards Bay; dredged in 3 to 13 fathoms, sand and gravel; also recorded from Vineyard Haven ${ }^{*}$ and Edgartown, ${ }^{*}$ on piles.-Survey.

Fish Hawk station*: $75^{26}(2), 7543$ bis ( 1$), 7634$ (3 young), 7732 (I young), 7748 (2), 7750 (several), 7755 (I), 7757 (I), 7759 (several fragments), 7767 (several), 7769 (several), 7770 (several), 7772 (several).

Phalarope and Blue Wing stations*: 2 (frequent in hydroid colonies), 3 (frequent in hydroid colonies), 8 (2 young), 9 (I young, 44 (many young, among algæ), 45 (I), 49 (I), 57 (several young), $5^{8}$ (very common), 62 (several young).

Verrill records the taking of young at the surface in the evening.

Nicolea simplex Verrill.

Verrill and Smith, 1873, p. 613, 321, etc. (sp. nov.).

Vineyard Sound.-Verrill. Taken several times in the western end of Vineyard Sound; dredged but twice elsewhere; 8 to $\mathrm{I}_{3}$ fathoms, sand and stones, in one case on Laminaria; recorded also from Nobska Point on rocks below low tide* and from Vineyard Haven on piles of wharf.*

Fish Hawk stations*: $753^{2}$ (several young), 7656 (2 tubes on Laminaria), 7689 (several, chiefly young), 7690 (I), 7692 (I), 7693 (x), 7722 (I), $7730(3)$.

Verrill records the presence of the young in tow, July and August evenings.

Pista interniedia WVebster. [Chart 70.]

Buzzards Bay, tubes occasionally taken, chiefly at inshore stations; a few records from the western part of the Sound; 3 to 12 fathoms, on various bottoms, more commonly sandy mud.

Fish Hawk stations*: 762I (many fragments), 7626 (ends of tubes), 7629 (I tube), 7630 (sev-
Pista intermedia-Continued.

eral ends of tubes), 7639 (several tubes), 7645 (ends of several tubes), 7659 (fragments), 7664 (2 tubes), 7666 (I tube), 767 I (3 tubes), 7674 (I tube). Supplementary stations: 7567 (I go6), 7723 (Igo6).

Phalarope and Blue Wing stations*: 50 (I fragment of tube), 52 (fragment of tube), 83 (fragments of several tubes), 85 (fragments of tube), I23 (fragments of tubes), I60 (several tubes), I63 (I tube). I64 (tubes), I6 5 (tubes).

Pista palmata (Verrill). [Chart 7I.]

Verrill and Smith, I873, p. 6I4, 32I, etc. (Scionopsis palmata, sp. nov.); Bumpus, $1898 \mathrm{~b}$ (Scionopsis palmata).

Vineyard Sound, low-water mark to I fathom.Verrill. Tubes common at inshore stations of Buzzards Bay; less frequent at those of Vineyard Sound; dredged at 3 to 7 fathoms (rarely at greater depths), in sand, gravel, and mud; recorded also from Nobska Point, ${ }^{*}$ and from piles at Vineyard Haven.*

Fish Hawk stations *: 7688 (I tube), 775I (2), 778 I (several tubes).

Phalarope stations: 2 (I), 8 (I), 64 (several fragments of tubes), 65 (tubes), 87 (I tube), 96 (several tubes), 97 (several tubes), 98 (I tube), Io3 (I), ros (several tubes), Iro (many tubes), II4 (I tube), II5 (I tube), II7 (several tubes), 128, I29 (I tube), I32 (I tube), I33 (few tubes), I 37 (several tubes), I 40 (several tubes), I 4 I (3), I 44 (I tube), I46 (several tubes), I47 (several tubes), I49 (few tubes), I50 (tubes), I52, I53, r6o (several tubes).

Bumpus records that the eggs were apparently ripe in August, though artificial fertilization was not attempted.

\section{Thelepus cincinnatus (Fabricius).}

Crab Ledge, at 6 stations; 16 to 25 fathoms, chiefly on gravelly bottoms, forming sandincrusted tubes attached to stones.-Survey. Off Sankaty Head.-Moore.

Fish Hawk stations *: 7603 (2), 7605 (tubes), 7606 (I tube), 7607 (several with tubes), 7608 (1 tube), 7609.

\section{Loimia viridis Moore.}

Moore, I903, p. 723 (sp. nov.).

The type specimen was taken by G. M. Gray on Ram Island, Woods Hole harbor, in sandy mud, August 4, I902; a second specimen has been taken at North Falmouth. 
Polycirrus eximcus (Leidy). [Chart 72.]

Verrill and Smith, I873, p. 616, 320, etc.

Vineyard Sound.-Verrill. Eastern half of Vineyard Sound, at a number of stations; dredged in 5 to $I 7$ fathoms on various bottoms; also recorded for Vineyard Haven ${ }^{*}$ on piles and in bottom of harbor, and for Katama Bay.*

Fish Hawk stations *: $755^{8}, 773^{2}$ (several), 7757 (I), 7759 (I), 776r (I), 7770 (I).

Phalarope stations *: 2 (frequent in hydroid colonies), 3,5 (2), 6 (2).

Verrill records taking the young of this species in tow, August and September, evenings.

Polycirrus phosphoreus Verrill.

Verrill, I879, p. I8I (sp. nov.).

Stonington, Conn., to Bay of Fundy.-Verrill. Occasional in Buzzards Bay; Crab Ledge, I7 tathoms, in crevices of shells.-Moore.

Polycirrus, sp. undetermined.

Fish Hawk stations *: 7579 (r), 7637 (several), 7638 (several), 7639 (several).

Anoplobranchus sanguineus (Verrill).

Verrill and Smith, I873, p. 6I6, 320 (Chatobranchus sanguineous, sp. nov.).

Vineyard Sound, at low-water mark, in soft mud filled with decaying vegetable matter; included in list for brackish waters.-Verrill. Buzzards Bay at " breakwater," found at low water.-Moore.

\section{Family AMrPHARETIDAs.}

Ampharete setosa Verrill. [Chart 73.]

Verrill and Smith, I873, p. 6r2, 508 (Ampharete gracilis).

Off Gay Head.-Verrill. Scattered stations throughout entire length of Buzzards Bay; less frequent records for Vineyard Sound; dredged in 2 to 77 fathoms, sand and mud.Survey.

Fish Hawk stations *: 7533 bis (I), $755^{8}$ (I), 76I2 (I), 7613 (I), 7625 (I), 7630 (I), 763 I (I), 7637 (I), 7650 (I), 7653 (I), 7659 (I), 7667 (3), 7686, $775^{\circ}(\mathrm{I})$.

Phalarope stations *: 8 (I), 78 (I small), 84 (3), $\operatorname{Iog}(\mathrm{I}), \mathrm{I}_{52}, \mathrm{I} 62$ (I).

\section{Sabellides pusilla Verrill.}

Verrill and Smith, r873, p. 6r3 (Amage pusilla, sp. nov.; not listed for this region).

Blue Wing station $49^{*}$ (Gay Head, on sandy bottom): I specimen.
I Melinna cristata Sars.

Verrill and Smith, 1873 , p. 6ri3, 432, etc.

Mouth of Vineyard Sound, on muddy bottoms, in the deepest water.-Verrill. Dr. Moore states that he has never taken this species in local waters, but that all which he has examined belong to the following species.

\section{Melinna maculata Webster. [Chart 74.]}

Tubes dredged at scattered stations throughout Buzzards Bay, 3 to $I 7$ fathoms, muddy bottom; not recorded from Vineyard Sound.Survey. Tashmoo Pond*, in brackish water (E. D. Congdon, col.).

Fish Hawk stations*: 7623 (tubes), 7624 (I tube), 7629 (I tube), 7637 (common), 7638 (plentiful), 7639 (I tube), $76_{4}$ I (several tubes), 7663 (r), 7673 (several).

Phalarope stations*: 80 (several tubes), I59 (I tube), I6I (I), I62 (several tubes), I64 (tubes), I65 (tubes), I66 (tubes).

\section{Family AMPHICTENID E.}

Cistenides gouldii Verrill. [Chart 75.]

Verrill and Smith, I873, p. 612, 323, etc. (sp. nov.).

New Jersey to Cape Cod.-Verrill. Buzzards Bay throughout its entire length; Quicks Hole, Robinsons Hole, Woods Hole; not noted at any of Vineyard Sound stations; dredged in 2 to $I 7$ fathoms, chiefly at depths less than ro fathoms, occurring commonly in mixtures of mud and sand; recorded also from muddy banks or sand flats at Fort Phoenix, Wareham River, Katama Bay, and Lagoon Pond at both ends.-Survey. Woods Hole Harbor, on beach in front of Marine Eıological Laboratory supply department.-G. M. Gray.

Fish Hawk stations: $761_{3}$ (3 tubes), $76 I_{4}$ (I), 7615 (I), 76г6 (г tube), 7620 (several), 7622 (2), 7623 (3), 7625 (several small), 7626 (I tube), 7629 (3 tubes), 7637 (several), 7638 (I), 7640 (I), 764I (I), 7653 (I tube), 7656 (I tube), 7657 (I tube), $766 I$ (I tube), 7673 (2),

Phalarope stations: 28 (I empty tube), 85 (2), 89 (fragment of tube), 90 (I fragment of tube), 94 (fragments of tube), 95 (fragments of tube), 96 (fragments of tube), I 9 (I), 120 (several), I39 (I tube), I45 (I), I 56, I59 (several tubes), * I60 (I living), * I6I ( I living), * I62 (few tubes), ${ }^{*}$ I65 (many tubes), ${ }^{*}$ I66 (several tubes).

Mr. Gray notes that during life the apex of the tube is generally uppermost. 


\section{Family CaprTELLIDE.}

Capitella gracilis (Verrill).

South side of Nonamesset Island, on mud flats at low water, abundant.-Moore.

Capitella sp. undetermined.

Western end of Vineyard Sound; ir fathoms, Sandy bottom (Fish Hawk station 772I) 3 immature specimens (?).

\section{Heteromastus filiformis (Verrill).}

Verrill and Smith, I873, p. 6II, $34^{2}$ (Notomastus filiformis, sp. nov.).

Vineyard Sound, sandy shores.

Notomastus luridus Verrill.

Verrill and Smith, I873, p. 610, 342 (sp. nov.). Recorced by Verrill only for Savin Rock, near New Haven. Moore (MS.) includes this species in local list as "common at low water in mixed sand and mud."

\section{Family POLYGORDIID死.}

Polygordius sp. undetermined.

Fewkes, 1883 , p. 195; Bumpus, r898b; Cowles, 1903, p. 125.

Fewkes reports that "Loven's larvæ are among the most common Annelid larvæ taken in the tow-net at Newport." At Woods Hole, exceedingly abundant during early summer of I892; a few noted during summer of I898. Bumpus. "Often found in great abundance at Woods Hole." -Cowles.

\section{Family OPHELIDAE.}

Ammotrypane fimbriata Verrill.

Verrill and Smith, 1873, p. 604 (sp. nov.).

Off Buzzards Bay, in 25 fathoms, mud.-Verrill. Vineyard Sound, in neighborhood of Cuttyhunk (Fish Hawk station 7686*, Phalarope station $\left.33^{*}\right), 5$ to $I 7$ fathoms; sand, gravel, and mud.-Survey.

Ophelia denticulata Verrill.

Vineyard Sound, 5 fathoms, sand and shells (Fish Hawk station 7540)*, I specimen.

Travisia carnea Verrill.

Verrill and Smith, I873, p. 604, 508 (sp. nov.). Off Gay Head in I9 fathoms, soft mud.

\section{Family MALDANIDE.}

Rhodine attenuata Verrill.

Verrill and Smith, r873, p. 609, 508 (sp. nov.). Off Gay Head, 6 to 8 fathoms.
Nicomache dispar Verrill.

Verrill and Smith, I873, p. 608, 5 I2 (sp. nov.). Off Buzzards Bay, in 25 fathoms, forming rough tubes of sand, which are not very firm.

Clymenella torquata (Leidy). [Chart 76.]

Verrill and Smith, I873, p. 608, 343, etc.; Bumpus, r898a; Sumner, I9ro, fig. 7.

Vineyard Sound.-Verrill. Buzzards Bay throughout its length; Quicks Hole, Robinsons Hole, Woods Hole, Vineyard Haven; in the Sound, recorded only from Tarpaulin Cove, Menemsha Bight, and extreme western end; dredged in 2 to $I 7$ fathoms, chiefly at depths of less than ro fathoms, most commonly in mixtures of mud and sand.-Survey. The foregoing records refer chiefly to tubes. Also recorded from shore collections at Nobska Point; Lagoon. Pond, at two points; shores of Robinsons Hole, on both Pasque and Naushon sides; Katama Bay, at two points; and Fort Phœenix.

Fish Hawk stations: $76 \mathrm{r}_{2}$ (tubes), 76r3 (tubes), $76 \mathrm{r} 8$ (tubes), 76r9 (several), 7620 (I), 7625 (several tubes), 7632 (several tubes), 7638 (I), 7640 (many tubes), $764 \mathrm{I}$ (I), 7642 (several tubes), 7647 (2), $765^{\mathrm{I}}$ (several tubes), $765^{2}$ (several), 7653 (2), $76_{54}$ (I), $76_{55}$ (several tubes), 7656 (several tubes), 7657 (several tubes), $765^{8}$ (several tubes), 7664 (2), 7667 (several tubes), 7669 (several tubes), 7673 (common), 7675 (several tubes), 7685 (many tubes), 7686 (many tubes), 7687 (many tubes), 7688 (2 tubes), 77 Io (several tubes), 7724 (numerous tubes).

Phalarope stations: I7 (tubes), I9, 29 (2), 60 (several tubes), 72 (several tubes), 85 (several tubes), 89 (several fragments of tubes), 99 (many tubes), Ioo (several tubes), Ior (fragments of tubes), I02 (several tubes), Io7 (several tubes), II9 (2 tubes), I20 (2 tubes), I23 (fragments of tubes), 124 (2 tubes), 127 (tubes), I29, I33 (few tubes), I39 (several small tubes), I 45 (several tubes), I 47 ( 2 tubes), I 48 (I tube), I 50 (tubes), I52, I53, I54, I59 (I tube), I60 (I).

Found by Mead to be breeding during the early part of May.

Praxilella zonalis Verrill.

Verrill, I874, p. 384 .

Buzzards Bay, at a few scattered stations; one record for the western end of Vineyard Sound; Crab Ledge, at one station; 4 to 20 fathoms, chiefly in mud and sand.-Survey. 
Praxilella zonalis-Continued.

Fish Hawk stations*: 7608 (fragments of 2), 7612 (I fragment), 76I4 (2), $76 \mathrm{I}_{7}$ (I fragment), 7629 (several tubes), 7638, 7659 (I), 7686 (I). Supplementary station 7669 (I907).

Phalarope station: 162 (several fragments).

Praxilella tricirrata Moore.

Moore, Igo6, p. 503 (sp. nov.).

"Taken on two occasions at Crab Ledge ... in $I 7$ to 20 fathoms, on a stony and gravelly bottom, and not found elsewhere." "Filled with eggs on September 2."

Praxilella producta (Lewis).

Lewis, I899, p. III (Clymene producta, sp. nov.). Taken at Cotuit, on sand flat, at low water.Lewis, Moore. A search by Miss Lewis among the sand flats in other parts of Vineyard Sound failed to reveal this species.

Maldane elongata Verrill. [Chart 77.]

Verrill and Smith, I873, p. 609, 343, etc (sp. nov.).

Scattered stations throughout Buzzards Bay, 2 to $I_{3}$ fathoms, muddy bottom.-Survey. Abundant on mud flats just below low water.Moore. Listed by Verrill only from vicinity of New Haven.

Fish Hawk stations*: 7637 (plentiful, small), 7638 (common), 764I (I), 7642 (2), 7643 (I small), 7645 (I fragment), 7646 (I fragment), 7669 (common, tubes), 767 I (several), 7674 (several tubes).

Phalarope stations*: 94 (fragments of tubes), 97 (I tube), I27 (tubes), I28, I60 (I), I6I (several tubes).

\section{Family ARENICOLIDAE.}

Arenicola marina (Linnæus). $a$

Ram Island, in Woods Hole Harbor; stony shores, below low-water mark; not uncommon.-Moore. Nonamesset Island, on Woods Hole side *-Gray.

Arenicola cristala Stimpson.

North Falmouth, abundant.-Moore, Gray. Kettle Cove*; Buzzards Bay at local breakwater*.-Gray. Katama Bay, east shore*.-Survey. Dug on sand and gravel flats, below low-water mark.

Eggs may be found from the latter part of June to the latter part of July; at times they "may be collected by the bucketful."-Bumpus. Figgs laid in large jelly masses attached by one end to the mouth of the burrow; may be found late in the spring and throughout most of the summer.-Moore.
Family SCALIBREGMID层.

Scalibregma brevicauda Verrill.

Verrill and Smith, I873, p. 605 (sp. nov.).

Off New Haven.-Verrill. Buzzards Bay, near

Naushon shore (Fish Hawk station $765^{2}$ ) $; 7$

fathoms, sandy mud; 2 specimens. Supplementary station 76 I 2 (1907)*

\section{Family CHLORHEMIIDA.}

Brada setosa Verrill

Verrill and Smith, 1873 , p. 606, 508 (sp. nov.). Off Gay Head, 8 to to fathoms, among mussels, etc.-Verrill. Lower half of Buzzards Bay; 3 to 9 fathoms, mud.-Survey.

Fish Hawk stations: 7656 (I)*, $7657^{*}$ (several). Phalarope station $\mathrm{I}_{5}(\mathrm{I})^{*}$.

Trophonia affinis Verrill. [Chart 78.]

Verrill and Smith, 1873, p. 605, 432 .

Off Buzzards Bay in 25 fathoms, mud.-Verrill. Pretty general in the lower half of Buzzards Bay; sereral stations in the Sound; 4 to 17 fathoms, chiefly on muddy bottoms.-Survey.

Fish Hawk stations*: 7532 bis (2), 7537 (2), 7640 (2), 764I (I), 7647 (I small), 765I (I), 7652 (2), $76_{54}(\mathrm{I}), 7655(6), 76_{56}$ (several), $765^{8}$ (I), 7662 (I), 767 I (I), 7673 (3), 7674 (common), 7675 (3).

Phalarope stations*: 8 (I), 59 (I), 95 (I), I03 (I), I I9 (I).

\section{Family STERNASPIDEE.}

?Sternaspis fossor Stimpson. $b$

Verrill and Smith, I873, p. 606, 507.

Off Gay Head, ig fathoms, soft mud, quite common.

\section{Family SABELLIDEE.}

Myxicola steenstrupii (Kröyer).

Crab Ledge, stony bottom, I7 fathoms.-Moore. Twenty fathoms on bottom of sand and gravel (Fish Hawk station 7608)*, I specimen.

Euchone elegans Verrill.

Verrill and Smith, I873, p. 6I8, 432 (sp. nov.). Deeper parts of Vineyard Sound; much more abundant in the deeper waters outside.-Verrill. Western end of Vineyard Sound, at Fish Hawk station $7686^{*}$, I 7 fathoms, mud.-Survey.

Parasabella microphthalmia (Verrill). [Chart 79.]

Verrill and Smith, I873, p. 618, 323 (Sabella microphthalmia, sp. nov.); Hargitt, Igo6, p. 3 Io (Sabella microphthalmia).

Vineyard Sound.-Verrill. Scattered inshore stations in Buzzards Bay and eastern end of Vineyard Sound; dredged in 3 to 6 fathoms, on various bottoms; recorded also from Woods 
Parasabella microphthalmia-Continued. Hole Harbor*, Vineyard Haven* and Edgartown ${ }^{*}$, on piles, and from Nobska Point and beach*.

Fish Hawk stations*: 7616 (2 small), 7625 (I), 7634 (3), 7750 (I), 778 I (I young).

Phalatope stations*: I (several), 2 (rather common), 3 (rather common), 8 (2), 87 (2), I2O (I young), I 48 ( $\mathrm{I}$ ).

Pseudopotamilla oculifera (Leidy). [Chart 8o.]

Verrill and Smith, I873, p. 6I7, 322, etc. (Potamilla oculifera); Hargitt, I906, P. 3 Iо (Potamilla oculifera).

Vineyard Sound; off Buzzards Bay, in 25 fathoms.-Verrill. Abundant and generally distributed in Vineyard Sound; less frequent in Buzzards Bay and mainly confined to inshore stations; Crab Ledge at four stations; dredged in 2 to 25 fathoms, on every sort of bottom; also recorded from piles at Vineyard Haven

Fish Hawk stations: 752 I bis (several tubes), $75^{22}$ bis (2 tubes), $75^{26}$ (I), $75^{28}(3), 753$ I (2), 7534 (tubes), 7535 bis (I tube), 7544 bis (2 tubes), 7560 (I), $756 \mathrm{I}$ (I), 7570 (tubes), 7572 (tubes), 7594 (burrows in shells), 7595 (I tube), 7597 (several tubes and worms), 7606 (3), 7607 (several tubes), 7608 (3 tubes), 7609, 7612 (several), $76 \mathrm{r}_{3}$ (I), 7616 (plentiful, attached to shells), 7618 (I), $762 \mathrm{I}$ (several), 7625 (several), 7629 (I), 7679 (common), 7680 (common), 768I (2), 7700 (several), 7702 (I), 7706 (several, some with eggs), 7707 (many attached to sponge), 7708 (I tube), 7709 (I), 7730 (many tubes), 7732 (several), 7737 (tubes), 7742 (I tube), 7744 (I tube), 7747 (common), 7748 (I), 7756 (few), 7757 (I), 7767 (few), 7768 (common), 7769 (common), 7770 (several), 7772 (few), 777.3 (few), 7777 (I), 7782 (several tubes).

Phalarope and Blue Wing stations: I (several), 2 (several), 3 (several), 7 (4 tubes), 8 (several), II (I tube), I2 (I), I4, I5 (several tubes), I6 (several tubes), 22 (r), 25 (several), 36 (I), 52 (I); 53 (colony on Venus), 63 (I), 66 (I tube), $67,80,81,84$ (2 tubes), Io7 (I tube), II3 (I tube), II4 (2 tubes), II6 (I), II8 (I), I38 (I tube), I5 I, $6_{5}$ (tubes).

This worm constructs familiar tough flexible tubes, attached to stones and shells, often penetrating the latter.

Fabricia stellaris Blainville.

Vetrill and Smith, 1873, p. 6r9, 323 (Fabricia leidyi, sp. nov.).

Vineyard Sound, at and below low-water mark.Verrill. Abundant on piles.-Moore.
Family SERPULIDAE.

Protula sp.

Near West Chop (Fish Hawk stations $75^{2} 5^{*}$ and 7525 bis*), 7 to Io fathoms, sand; I tube at each dredging.

Filograna implexa Berkeley.

Crab Lcdge at five stations.-Survey. Off Sankaty Head.-Moore. Taken in 16 to 25 fathoms, on bottoms of gravel and stones, forming fine calcareous tubes in compact masses.

Fish Hawk stations*: 7603 (clump of tubes), 7605 (several clumps of tubes on shells), 7606 (tubes), 7608 (tubes), 7609 .

Chatinopoma greenlandica (Mörch).

Crab Ledge at Fish Hawk stations $7605^{*}, 7609^{*}$, I 7 to 25 fathoms, stones, gravel, and shells; calcareous tubes attached to the last (only tubes found). Living specimens taken at same point, August 12, I909.

Hydroides dianthus (Verrill). [Chart 8I.]

Verrill and Smith, 1873, p. 620, 322 (Serpula dianthus, sp. nov.); Hargitt, I906, p. 295 et seq.

Eastern half of Vineyard Sound, abundant and universally distributed; in western half curiously restricted to inshore stations; in Buzzards Bay abundant at inshore stations, less frequent in the deeper waters; dredged in from 2 to $I_{5}$ fathoms (only one record for a greater depth); perhaps in equal abundance on every kind of bottom, adhering to stones and shells.-Survey. Collected from piles and shores throughout the region.

Fish Hawk stations: $75^{2} \mathrm{I}$ (few), $75^{2} \mathrm{I}$ bis (many), $75^{22}$ (many), $75^{22}$ bis (many), $75^{23}$ bis (many), 7524 (many), $75^{24}$ bis (many), $75^{2} 5$ bis (few), 7526 (very abundant), 7527 (several clusters of tubes), $75_{22}$ (few tubes), 7530 bis (few tubes), 753 I (several tubes), $753 \mathrm{I}$ bis (few tubes), 7532 (few tubes), 7532 bis (several), 7533 bis (several), 7534 (abundant), 7534 bis (abundant), 7535 (several tubes), 7535 bis (few tubes), 7536 (several tubes), 7537 (many), 7537 bis (many), $753^{8}$ (numerous), 7538 bis (few), 7539 (numerous), 7539 bis (few tubes), $754 \mathrm{I}$ (many), $754 \mathrm{r}$ bis (few), 7543 (numerous), 7544 (numerous), 7545 (many), 7545 bis (several), 7547 bis (several tubes), 7548 (few), 7549 (many) 7549 bis (many), 7550 (few), $755^{I}$ (I), $755^{\mathrm{I}}$ bis (few), $755^{2}$ (many), 7553 bis (few), 7554 bis (few), 7557 (few), 7558, 756I (many), $75^{62}$ (many, some on algæ), $75^{63}$ (many), $75^{6} 5$ (few), 7573 (I tube), 7595 (few tubes), 7596 (I tube), $76 I_{3}$ (large cluster of tubes), 76I4 (I), 


\section{Hydroides dianthus-Continued.}

7616 (many clusters of tubes), 7620 (large cluster of tubes), 7621 (plentiful), 7623 (few tubes), 7625 (several), 7626 (several), 7627 (many), $76_{29}$ (many tubes), $76_{3}$ o (I tube), $76_{3}$ I (I), $76_{32}$ (few tubes), $76_{33}$ (many tubes), $76_{34}$ (many tubes), 7635 (many tubes), 7639 (few tubes), 7640 (few tubes), 764 I (few tubes), 7644 (several tubes), $76_{5}$ I (several tubes), $76_{53}$ (few), $76_{54}$ (few tubes), 7655 (I cluster), 7659 (few tubes), 7664 (few), 7671 (few tubes), 7672 (few), 7674 (I tube), 7675 (several), 770 I (I tube), 7732, 7733 (I tube), 7737 (tubes), 7738 (I), 7739 (little), 7743 (several), 7744 (many), 7746, 7747 (many), 7748 (many), 7749 (many), 7750 (little), $775^{2}$ (much), 7753 (common), 7754 (I tube), 7755 (few tubes), 7756 (many), 7758 (much), 7759 (much), 776 r (common), 7764 (common), 7765 (little), 7766 (much), 7767 (much), 7768 (tubes and living common), 7769 (much), 7770 (common), 777 I (several tubes), 7772 (abundant), 7773 (common), 7774 (many tubes), 7775 (common), 7776 (abundant), 7777 (common), 7778 (abundant), 7779 (common), 7780 (common), 778 I (common), 7782 (few), 7783 (common).

Phalarope and Blue Wing stations: I (many living), 2 (many), 3 (plentiful), 4 (few living), 5 (living), 6 (many), 7 (abundant), 8 (many), 9 (common), ro (pieces), II (quantities), I2 (several tubes), I $_{3}$ (common), I4 (few), I 5 common), I6 (few), I8 (several tubes), 20 ( 2 tubes), 21 (2), 22 (several tubes), 23 (few), 24 (I tube), 25 (common), 26, 27 (few), 28 (few dead), 29 (few), 30 (several), 32 (I tube), 34 (I tube), 36 (few tubes), 37 (few tubes), $3^{8}$ (I tube), 52 (few), 53 (few tubes), 62 (few), 63 (many), 64 (I tube), 65 (few), 66 (few tubes), 68 (few), 69 (I living), 7 I (many tubes), 72 (many tubes), 74 (few tubes), 76 (few tubes), 77 (few tubes), 78 ( 1 fragment), 79 (few), 80 (many tubes), 8I, 82 (common), 83 (several), $84,86,88$ (I fragment), 90 (I fragment of tube), 91, 92, 93, 95, $96,97,98$, I00 (living), Ior (fragments of tubes), Iо7, I08, I09, Iто, II3, II4 (few), II6, I 7 (few living), I 8 ( I clump of tubes), I2 I (common), I22 (few), I23 (fragments of tubes), I24 (many tubes on Venus), I2 5 (several tubes), I26, I28 (common), I29, I30 (I cluster of tubes), I3 I ( I fragment), I32 (common), I33 (shells), I34 (several), I36(I), I37 (fragments of tubes), I38 (abundant), I39, I40, I42 (I tube), I44 (living common), I45 (few), I47 (common), I48 (several), I 49 (common), I50 (tubes), I5I (few tubes), I 52, I 53 (few), I 54 (few), I 55 (few), I 56 (few),
Hydroides dianthus-Continued.

I 57 (few), I $5^{8}$ (few), I62 ( 2 tubes), I6 3 (several. large clusters), I64 (abundant), I65 (many tubes), I66 (few).

Eggs ripen through July and August; if fully ripe, they may be removed from the body and fertilized.-Treadwell. Verrill records the occurrence of a color variety, which he terms "citrina," having branchiæ of a bright lemon yellow color. These specimens are said to be found with the preceding, often in the same cluster of tubes.

Spirorbis spirorbis (Linnæus).

Verrill and Smith, I873, p. 621, 323 (Spirorbis borealis?; also referred to in lists as $S$. spirillatm).

As an intertidal species this is one of great abundance and general distribution, its small white tubes often occurring in conspicuous profusion on Fucus, less frequently on other algæ or various solid objects. We have shore records for Woods Hole Harbor, Elel Pond, Nobska Point, Tarpaulin Cove, Cedar Tree Neck, and Robinsons Hole. It could probably be found locally at almost any place where Fucus grows, but it is believed to be rare or wanting at the regular dredging stations of the Survey. Its reported occurrence at these points during the earlier seasons of the survey dredging, was doubtless due in most cases, at least, to confusion with S. tubaformis.

Breeds during May.-Bumpus. Eggs can be found during entire summer, being laid in a thin membranous tube, inside the calcareous tube, in which place they develop.-Treadwell.

Spirorbis tubaformis Bush.

Vineyard Sound, throughout its length; Buzzards Bay, near its mouth and at inshore stations almost to its upper end; dredged in from 2 to I7 fathoms, chiefly on non-muddy bottoms, the tubes being affixed to Phyllophora, Chondrus crispus and occasionally to other plants or shells, etc. Abundant on Chondrus, growing on stone wall in front of Bureau of Fisheries residence. Distribution doubtless more general than the following station list would indicate. (See remarks under Spirorbis sp.).

Fish Hawk stations*: 7525 bis (I tube), 7536 (many on seaweed), 7606 (on bryozoa), 7640 (several tubes), 7666 (several tubes), 767 I (several tubes), 7673 (several tubes); 7674 (several on shell), 7690 (many tubes), 7692 (several tubes), 7693 (several), $77 \times 8$ (several tubes), 7739 (few tubes). 
Spirorbis tubaformis-Continued.

Phalarope stations*: 8 (several tubes), I7 (tubes), I8 (many), 56 ? (abundant), 57 ? (abundant), $5^{8}$ ?, 63 (several), 66 (several tubes), 79 (common), 87 (on red algæ), ioo?, II2 (common).

Supplementary records ${ }^{a}$ during the summer and fall of 1908 , in the vicinity of the following former stations: $75^{25}$ (abundant on Phyllophora), 7545 (I on Phyllophora), 7593 (I on Polysiphonia elongata), 76,32 (few on Phyllophora), 7670 (on Phyllophora), 7602 (abundant on stones), 7722 (few on Phyllophora), 7726 (abundant on Phyllophora), $775^{8}$ (I), 2 (abundant on Phyllophora), r6 (abundant on Phyllophora, a few on Chondrus crispus and on shell of Ensis directus), Io7 (few on Phyllophora), II7 (abundant on Phyllophora, a few on Sargassum filipendula), I6 I (fairly numerous on Phyllophora).

To this species probably also belong the majority of specimens referred to under the head "Spirorbis sp. sp."

Spirorbis, sp. sp. (probably for the most part S. tubaformis, though perhaps comprising a certain proportion of $S$. spirillum and possibly also of S. spirorbis).

During the first summer's dredging, and probably to some extent later, the various species of Spirorbis were confused by the collectors in the field. For this reason, all records made during that period, unless known to be based upon Dr. Moore's identifications, have been thrown together under this head. The unequivocal records, which, of course, form very incomplete lists, have been included under their respective species. Owing to the unsatisfactory condition of the data for this genus, numerous supplementary dredgings were made during the summer and fall of I908, the results of which have been incorporated in the accounts given above.

Fish Hawk stations: 7537 bis (many on algæ), 7548 (I on Bugula), 7553 (few), 7557 (few), 7560 (many), 7562 (abundant on Chondrus), 7572 (many on algæ), $758 \mathrm{r}$ (many), $75^{82}$ (many), $75^{8} 3$ (abundant), $75^{8} 4$ (few), $75^{87}$ (numerous), 7588 (few), 759 I (many), 7594 (few), 7595 (abundant), 7596 (few on algæ), 7598,7656 (many tubes on Laminaria), 7663, $7693,7703,7705,7730$ (few), 7744 (few on algæ), 7745 (few), 7746 (few), 7749 (many), 7760 (many).
Spirorbis-Continued.

Phalarope stations: I (few), 2 (several tubes), 3 (several tubes), I6 (many), 30 (several), 32 (plentiful), 33 (tubes on algx), 65 (many), 67 (very abundant), 83 (2 tubes on red algæ), 86.

Spirorbis spirillum (Linnæus).

Verrill and Smith, 1873 , p. 622, 498, etc. (Spirorbis lucidus and S. porrecta?).

Vineyard Sound, near mouth; off Gay Head, in Io fathoms; off Buzzards Bay, in 25 fathoms. --Verrill. We have several unequivocal records for this species at Survey dredging stations of the regular series in the western part of Vineyard Sound; one in Buzzards Bay, west of Woods Hole. A special search during the summer and fall of 1908 revealed its occurrence at six points in Vineyard Sound beyond Robinsons Hole; none in more eastern parts of the Sound, and none in Buzzards Bay. The tubes were attached to Phyllophora and Chondrus crispus, once to a bit of eelgrass, and were in some cases associated with Spirorbis tubaformis. A species which was probably S. spirillum was likewise found in abundance on some eelgrass (drifting ?) found near the landing of the Bureau of Fisheries residence in Woods Hole Harbor.-Sumner. Some specimens in the museum bear the label " $\mathrm{Crab}$ Ledge."

Fish Hawk station 76 I I (many)*.

Phalarope and Blue Wing stations*: 20 (many tubes), 24 (many on algæ), 25 (many), 36 (common), 44 (several tubes), 45 (I), 49 (several tubes).

Supplementary records, $a$ during the summer of I908, in the vicinity of the following former stations: $7599,7695,7722,7726,7729,5^{8}$.

Spirorbis quadrangularis Stimpson.

Crab Ledge, at Fish Hawk station $7605^{*}$; I7 fathoms, grave1; tubes attached to shells. Abundant specimens of a Spirorbis, in part, perhaps, of this species, are recorded for Fish Hawk stations $7604,7607,7608$, and 7609 (all at Crab Ledge). Samples of these were unfortunately not preserved, since their identity with the others was taken for granted at the time by the collectors.

Spirorbis fewkesii Bush and S. stimpsoni Verrill. Included by Dr. Moore (MS.) as "Woods Hole species," but no more definite data are available at present. 


\section{Family HERMEILIDEA.}

Sabellaria vulgaris Verrill. [Chart 82.]

Verrill and Smith, I873, p. 6II, 32I, etc. (sp. nov.).

Vineyard Sound.-Verrill. Common and generally distributed throughout Vineyard Sound; in Buzzards Bay less common and chiefly confined to inshore stations; dredged in 2 to I9 fathoms, on various bottoms.--Survey.

Fish Hawk stations: $752 \mathrm{I}$ bis (large cluster of tubes on stones), 7526 (I), 7538 bis (I), 7543 bis (few tubes), 7544 bis (several tubes), 7546 bis (tubes), 7549 bis (I tube), 755 I (I tube), 7553 (I tube), $755^{8}$ (I tube on Venus sheli), 756I (few), 758I (I), 76I6 (few tubes), 7625 (I), 7629 (I cluster of tubes), 7633 (I cluster of tubes), 7664 (2), 7668 (I tube), 7682 ( 1 ), 7686 (I tube), 7687 (several tubes), 7688 (several tubes), 7697 (2), 7702 (I), 7706 (I tube), 7707 (I tube), 7724
Sabellaria vulgaris-Continued.

(I), 7732 (common), 7734 (x tube), 7737 (tubes), 7742 (2), 7744 (several), 7747 (common), 7749 (I), $775^{2}$ (several tubes), 7753 (several clusters of tubes), 7754 ( $\mathrm{I}$ colony of tubes), 7755 (several colonies), 7757 (several), 7760 (several), 7763 (I), 7767 (few), 7768 (I colony), 7769 (few), 7773, 7774 (few), 7775 (few), 7776 (few), 7777 (little), 7779 (few), 7780 (few), 7781 (few), 7782 (few), 7783 (common).

Phalarope and Blue Wing stations: 4 (few on stones), 6 (I), 7 (several on shells), 8 (I tube), I4, 30 (I), 36 (several tubes), 49 (several tubes), $5^{2}$ (I tube), 62 (I), 63 (I tube), 85 (fragments of tube), I07 (I), I48 (I tube), I 49 (few tubes), I 50 (tubes), r59 (tubes on shell), I66 ( $x$ tube on shell).

This worm constructs familiar hard tubes from aggiutinated sand grains, these tubes being adherent to stones, shells, and other objects.

Polychata undetermined.

Fish Hawk stations: $7523,7557,7572,7593,7594,7606,7607,76$ I4, 7779 .

Phalarope station 157 .

\section{Subclass OLIGOCHETA.}

\section{Family NAIIDAE.}

\section{Paranais littoralis (Oersted).}

Moore, 1905a, p. 376 . (Listed by Verrill and Smith, I873, as Enchytrcus triventralopectinatus, and recorded for New Haven, on authority of Minor).

Vineyard Sound and vicinity. "More than any other species it withstands a wide range of density in the water, being almost equally at home in the rain-soaked eelgrass above high tide, on the shores of brackish ponds, and under stones near low-water mark on the exposed shores of Vineyard Sound."-Moore.

\section{Family ENCHYTRAID屈.}

\section{Enchytrcus albidus Henle.}

Verrill and Smith, 1873, p. 623,324 (Halodrillus littoralis, sp. nov.); F. Smith, I895, Moore, I905a, p. 394 .

Woods Hole; very common under dead seaweeds and stones, near high-water mark.-Verrill. "The best known and most generally distributed of our littoral Oligochæta. . . Found in moist spots on farm lands on Marthas Vineyard, where it could readily be introduced in . . . celgrass spread for fertilizer. About Woods Hole it also lives in damp, sandy woods and on the shores of fresh-water ponds, especially of one that formerly was connected with the Sound."'-Moore.
Lumbricillus agilis Moore.

Moore, I905a, p. 395 (sp. nov.).

Vineyard Sound, etc., abundant among eelgrass thrown on shore near high-water mark, in sheltered coves.

\section{Family TubIFICIDAs.}

Clitellio arenarius (Müller).

Verrill and Smith, $18 \% 3$, p. 623, 324, etc. (Clitellio irrorata, in part); Moore, Igo5a, p. 377 .

"Common at many suitable points on the shores of Vineyard Sound, Buzzards Bay," etc., but "apparently less plentiful south of Cape Cod." -Moore.

Tubifex irroratus (Verrill).

Verrill and Smith, 1873, p. 622 (Clitellio irrorata, in part); Moore, I905a, p. $3^{84}$.

Vicinity of Woods Hole, not uncommon among roots of beach grass in brackish water.Moore.

Tubifex hamatus Moore.

Moore, rgo5a, p. 389 (sp. nov.).

So far found only on shores of the Acushnet River, under stones in brackish water.

Tubifex benedeni Udekem.

Moore, I905a, p. 388.

Found on muddy shores between tides, "only sparingly in the neighborhood of Woods Hole, and in water both fully salt and brackish." 
Monopylephorus glaber Moore.

Moore, I905a, p. 378 (sp. nov.).

"In suitable localities . . . very abundant about the shores of Vineyard Sound and Buzzards Bay." Commonly found among decaying vegetation, especially in brackish waters.

\section{Monopylephorus parvus Ditlevsen.}

Moore, I905a, p. 383 .

"In a few cases large numbers were found living gregariously beneath stones at half tide on the south shore of Naushon."
Limnodrilus subsalsus Moore.

Moore, rgo5a, p. 392 (sp. nov.).

"This species occurs in considerable numbers along with Tubifex hamalus under stones at half tide on the Acushnet River, above New Bedford, Massachusetts."

\section{Family LuMBRICULID.}

Lumbriculus limosus Leidy.

Several specimens* taken in brackish water at either 'Tashmoo Pond or Great Pond by E. D. Congdon, July 2, 1907 .

\section{Class HIRUDINEA.}

\section{Family ICHTHYOBDELLIDE,}

Ichthyobdella funduli Verrill.

Verrill and Smith, r873, p. 624 (not listed from this region).

Recorded once during dredging; being taken in Vineyard Sound, near Lucas Shoal (Fish Hawk station $7562 *$ ). Specimens occasionally found upon Fundulus heteroclitus.

Ichthyobdella rapax (Verrill).

Verrill and Smith, r873, p. 625, $45^{8}$ (Pontobdella rapax, sp. nov.); Moore, I898, p. 557 (Piscicola rapax).

Vineyard Sound, quite common on the upper side of Paralichthys dentatus.-Verrill. Menemsha Bight, on Paralichthy's dentatus.Moore.

\section{SIPUNCULIDA $a$}

\section{Family Sipunculide.}

Phascolion strombi Montagu. [Chart 83.]

Verrill and Smith, 1873, p. 627 , etc. losoma camentarium.)

Vineyard Sound--Verrill. Dredged by the Survey at a considerable number of (chiefly inshore) stations in Buzzards Bay; a few times in deeper waters of Vineyard Sound; taken in 3 to $\mathrm{I}_{3}$ fathoms, for the most part on bottoms of sand or sandy mud. This species is most commonly found in the shells of gastropods, which the worm plugs up with a sort of cement.

Fish Hawk stations: $7688(\mathrm{I})^{*}, 7699(\mathrm{I})^{*}, 7702$ (several in Tritia)*. One specimen each recorded from 1907 stations which coincided approximately with the original stations $76_{52}$, $767 \mathrm{I}^{*}$, and $7739^{*}$.

Phalarope stations: $7^{8}$ (several) $\uparrow, 85^{b}, 86$ (I) $b$, $93(3) \dagger, 94^{b}, 98 b, 109^{b}, \mathrm{II}^{b}, 120^{b}, 123^{b}, \mathrm{I} 25^{b}$, $\mathrm{I} 26^{b}, \mathrm{I} 34^{b}, \mathrm{I} 44^{b}, \mathrm{I} 47$ (I) $b, \mathrm{I} 66$ (I)*
Trachelobdella vividus (Verrill).

Moore, 1898, p. 551 .

Woods Hole, I specimen, collected by $\mathrm{V}$. N. Edwards. This species occurs both in fresh and salt water.

Branchellion ravenelii (Diesing).

Verrill and Smith, 1873 , p. 624, 458, etc. (Branchiobdella ravenelii).

Vineyard Sound, on a sting ray, Myliobatis freminvillei; August and September; several usually occurred together.-Verrill.

$a$ Specimens from points designated by an asterisk $(*)$ were identified by Prof. J. P. Moore. Specimens from points designated by a dagger ( $\dagger$ ) were identified by Prof. J. H. Gerould.

$b$ Referred by the collectors to same species as a lot coming from station 78 . This was found to include Phascolosoma vernilii as well, but it is likely that most or all of the specimens here indicated were Phascolion sirombi. 
Phascolosoma verrillii Gerould.

Verrill and Smith, I873, p. 627, 353 (Phascolosoma, sp. undet.); Gerould, I908, p. 488 (sp. nov.).

Vineyard Sound.-Verrill. Concerning this (?) species, Verrill writes that it "occurs in sand at low water, and has similar habits [to $P$. gouldii], but it appears to be rather uncommon and has not been satisfactorily identified." Dr. Gerould states that Prof. Verrill makes undoubted reference to the present species (p.627), but questions whether he had in mind the latter in writing the foregoing sentence. Dr. Gerould regards it as doubtful whether $P$. verrillii has been obtained by digging. Dredged by the survey in Buzzards Bay, at
Phascolosoma verrilli-Continued. several points near the eastern shore; at one of these (off West Falmouth) it was found in two different summers; also near Sound shore of Naushon; taken in 4 to 7 fathoms, on various bottoms. Dr. Gerould likewise furnishes the following earlier records: Off Nobska, I883, at Fish Hawk station II88; Vineyard Sound, I87I, exact locality unknown (this and the preceding specimen from collection in National Museum); off Nobska in 5 fathoms, July, I902 (collected by W. R. Coe).

Phalarope stationst: I5 (I), 78, 93, I35 (2). (One likewise taken by the Fish Hawk in 1907 , in neighborhood of last station.)

\section{Phylum ARTHROPODA. \\ Class CRUSTACEA.}

\section{Order PHYLLOPODA.}

\section{Family BRANCHIPODIDAE.}

Artemia gracilis Verrill.

Verrill and Smith, I873, p. 573; M. J. Rathbun, I $905, \mathrm{p}$. II 7 .

Falmouth, "in salt vats" (perhaps not properly to be included in the marise fauna).

Family POLYPHEMIDAE.

Podon leuckarti (Sars).

Sharpe, I910, p. 409, 434.

"Surface tows off Bureau of Fisheries wharf, Woods Hole, Mass., July to November."
Evadne nordmanni Lovén.

Sharpe, I910, p. 409, 435 .

"Surface tows off Bureau of Fisheries wharf, Woods Hole, Mass., August to November."

\section{Order OSTRACODA.}

\section{Family CYPRIDINIDAE.}

Sarsiella americana Cushman.

Cushman, 1906, p. 363 (sp. nov.).

A single female found at Fish Hawk Station 7723.

Sarsiella zostericola Cushman.

Cushman, I906, p. 364 (sp. nov.).

Both male and female specimens found in "Gut of Canso," Woods Hole Harbor, August 3, I905, among celgrass and hydroids.

Cylindroleberis mario (Baird).

Cushman, I906, p. 367 .

"Gut of Canso," Woods Hole Harbor, Av'gust 3, 1905. None found dredging either in the Sound or Bay.

\section{Family CYPRIDAs.}

Pontocypris edwardsi Cushman.

Cushman, I906, p. 368 (sp. nov.).

Eel Pond, August 22, 1905, from material taken with seine.

\section{Famile CYTHERIDE}

Cytherois zostericola Cushman.

Cushman, I906, p. 369 (sp. nov.).

Eel Pond, July 15, I905; not met with in any other locality.

Xestolebris depressa Sars.

Cushman, I906, p. 370 .

Vineyard Sound (Fish Hawk station 7723), a few dead shells. 


\section{Loxoconcha guttata (Norman).}

Cushman, I906, p. 370 .

Vineyard Sound (Fish Hawk station 7723) and Buzzards Bay (Phalarope station 82), living specimens.

Loxoconcha impressa (Baird).

Cushman, I906, p. 37 I.

Eel Pond; piles of Bureau of Fisheries wharf, among hydroids, etc.; "Gut of Canso," among eelgrass and hydroids, in great numbers; Cedar Tree Neck, among algx (collected by R. C. Osbum); also living specimens occasionally dredged in Vineyard Sound (Fish Hawk stations 7716 and 7723 ).

Cythere dawsoni Brady.

Cushman, I906, p. 372 .

Vineyard Sound, at Fish Hawk station 7723, "several shells were found, which seem to belong to this species;' Buzzards Bay, at I907 repetition of Fish Hawk station 7656, one shell.

\section{Cytheridea rubra Müller.}

Cushman, 1906, p. 373.

Westem end of Vineyard Sound, living; Buzzards Bay, near Cuttyhunk, shells only.

Fish Hawk stations: $7685,7686,7723,7725$.

Phalarope station ro2.

\section{Cytheridea papillosa Bosquet.}

Cushman, I906, p. 373.

Vineyard Sound at Fish Hawk station 7723 , empty shells.

\section{Cytheridea punctillata Brady.}

Cushman, I906, p. 374 .

Vineyard Sound at Fish Hawk station 7723, shells only.

\section{Cytheridea seminuda Cushman.}

Cushman, I906, p. 374 (sp. nov.).

Vineyard Sound at Fish Hawk stations 7723 and 7725 .

Cytheridea americana Cushman.

Cuthman, I9o6, p. 375 (sp. nov.)

Vineyard Sound at Fish Hawk station 7723 , living.

\section{Cythereis emarginata Sars.}

Cushman, Igo6, p. 376.

Western end of Vineyard Sound and Buzzards Bay, near Robinsons Hole, living specimens.

Fish Hawk stations: $7710,7723,7727,7729$.

Phalarope station 87 .
Cythercis tuberculata Sars.

Cushman, I906, p. 376 .

Vineyard Sound at Fish Hawk stations 7686 (I living), 7723 (shells).

Cythereis canadensis (Brady).

Cushman, 1906, p. 377 .

Vineyard Sound at Fish Hawk station 7723, shells only.

Cythereis dunelmensis Norman.

Cushman, 1906, p. 377.

Vineyard Sound at Fish Hawk stations 7725 and 7727 , shells only.

Cythereis concinna (Jones).

Cushman, 1906, p. 377.

Vineyard Sound at Fish Hawk station 7723 , "a single shell, apparently belonging to this species.'

Cythercis albomaculata (Baird).

Cushman, I906, p. 378 .

Living specimens taken once from hydroids, etc., growing on piles of Bureau of Fisheries wharf, Woods Hole.

Cythereis villosa Sars.

Cushman, I906, p. 378 .

Shells fairly common in deeper parts of Vineyard Sound, especially at Fish Hawk stations $77^{2} 3$ and 7727 .

Cythereis phalaropi Cushman.

Cushman, I906, p. 378 (sp. nov.).

Buzzards Bay at Phalarope station I29, many living specimens. Not recorded elsewhere.

Cythereis arenicola Cushman.

Cushman, r9o6, p. 379 (sp. nov.)

"Fairly common on sandy bottoms in Vineyard Sound."

Fish Hawk stations: 7710, 7723, 7761 (1907 repetition).

Cythereis vineyardensis Cushman.

Cushman, I906, p. 380 (sp. nov.).

Vineyard Sound at Fish Hawk station 7723.

Cytherideis fasciata (Brady \& Robertson).

Cushman, I906, p. $38 \mathrm{I}$.

Vineyard Sound at Fish Hawk station 7723.

Pseudocytheretta edwardsi Cushman.

Cushman, Igo6, p. $3^{82}$ (sp. nov.).

First taken in Vineyard Sound, near Menemsha Bight, in I7 fathoms; later "found to be the most common ostracod in the region." This species "seems to be confined to fairly deep water and as a rule to sandy bottoms." The following stations lie at the western end of Vineyard Sound and in Buzzards Bay, near Cuttyhunk.

Fish Hawk stations: $7686,7710,7724,7727,7729$. Phalarope station ro2. 
Order COPEPODA (free-living).

\section{Family CALANIDIE.}

Calanus finmarchicus (Gunnerus).

Wheeler, I900, p. I64; M. J. Rathbun, I905, p. I03; Sharpe, I910, p. 406, 409.

Numerous female specimens taken in tow by Fish Hawk in Vineyard Sound near Gay Head July ro.-Wheeler. Woods Hole, at Bureau of Fisheries wharf.-Sharpe. Said to be of great abundance, widespread, and economically important as a food of fishes.

\section{Family CENTROPAGIDEA.}

Centropages typicus Kröyer.

Wheeler, I900, p. I73; M. J. Rathbun, I905, p. 104; Sharpe, I9I0; p. 406.

Woods Hole, at Bureau of Fisheries wharf, and in adjacent parts of Vineyard Sound, "nearly always present in small numbers in the tow." Wheeler.

Centropages hamatus (Lilljeborg).

Wheeler, I900, p. I74; M. J. Rathbun, I905, p. I04; Sharpe, I910, p. 406.

Woods Hole, at Bureau of Fisheries wharf, and in adjacent parts of Vineyard Sound, "nearly always present in considerable numbers in tow."-Wheeler.

Temora longicornis (Müller).

Wheeler, I900, p. I75; M. J. Rathbun, I905, p. I04; Sharpe, I910, p. 406.

Woods Hole, at Bureau of Fisheries wharf, very common. Much more abundant in winter than summer; rarely seen in July and August.

Eurytemora herdmani Thompson \& Scott.

Sharpe, I9Io, p. 406, 4I0.

"Found very sparingly ... in a surface tow made from the Bureau of Fisheries wharf, Woods Hole, Mass., in August."

Eurytemora hirundoides (Nordquist).

Sharpe, I9I0, p. 406, 4 II.

"Rather sparsely found in brackish pools, Woods Hole, July; also in washings from sea urchins, Cuttyhunk, July."

Metridia lucens Boeck.

Wheeler, rgoo, p. I76 (M. hibernica); M. J. Rathbun, I905, p. 105; Sharpe, 1910, pp. 407, 412.

Woods Hole, December I5, I898, a single female specimen taken in tow.-Wheeler.

\section{Pseudodiaptomus coronatus Williams.}

Sharpe, I9IO, p. 407, 4I2.

"Very common in Birge and surface net tows among algæ, at Hadley Harbor, Great Harbor near Ram Island, and Eel Pond, Woods Hole, Mass."

\section{Family PONTELLIDE.}

\section{Labidocera astiva Wheeler.}

Wheeler, I900, p. I78 (sp. nov.); Parker, I902, p. I05; M. J. Rathbun, I905, p. ro5; Sharpe, Igro, p. 407 .

Woods Hole, at Bureau of Fisheries wharf, very common in tow during July and early August, r899.-Wheeler.

Pontella meadii Wheeler.

Wheeler, I900, p. I80 (sp. nov.); M. J. Rathbun, I905, p. 105; Sharpe, 1910, p. 407.

Woods Hole, at Bureau of Fisheries wharf, a few of both sexes taken on two occasions in July, I899, after heavy SE. wind.-Wheeler.

Anomalocera pattersonii 'Templeton.

Wheeler, 1900, p. I8I; M. J. Rathbun, I905, p. 105; Sharpe, I910, p. 407.

Woods Hole, but only after stormy weather with SW. winds.-Wheeler.

Acartia tonsa Dana.

Wheeler, I900, p. I83; M. J. Rathbun, I905, p. Io6; Sharpe, I910, p. 407, 4I4.

Woods Hole, at Bureau of Fisheries wharf, "one of the commonest copepods taken" (July and August, I899).-Wheeler. "Occurring abundantly in nearly all the tows examined... from the Woods Hole region, even in ... the brackish water ponds of the vicinity."Sharpe.

Tortanus discaudata (Thompson \& Scott).

Wheeler, I900, p. r84 (Corynura bumpusii); M. J. Rathbun, I905, p. 106 (Tortanus bumpusii); Sharpe, I9Io, p. 407, 4I4.

Wheeler records the occurrence of males in considerable numbers, July Io and Ix, I899; also a single female, taken in tow by Mr. Edwards, December I5, r898. Mr. Sharpe has found this copepod at various local points in July, I908, and has identified it in towing material collected by Mr. Edwards in May. 


\section{Family CyCLOPIDE.}

\section{Oithona similis Claus.}

Wheeler, I900, p. I86; M. J. Rathbun, I905, p. Io6; Sharpe, I9ro, p. 407.

Woods Hole, at Bureau of Fisheries wharf, July, 1899, "occasionally in small numbers." Tow off Bureau of Fisheries wharf, July I3, I908; common.-Sharpe.

\section{Family HARPACTICID开.}

Harpacticus chelifer (Müller).

Sharpe, I9ro, p. 407, 4I5.

Little Harbor, July 9, I908.

\section{Family EctinosomDz:}

Ectinosoma curticorne Boeck.

Sharpe, rgio, p. 408, 4I 5 .

"Collected by a Birge net among algæ, muddy bottom, in the brackish ponds about Woods Hole, Mass., July."

\section{Family Peltidid a}

Alteutha depressa Baird.

Sharpe, r9ro, pp. 408, 416.

"Surface net just off Fisheries wharf, Woods Hole, Mass."

\section{Family IDyid $z$.}

Idya furcata (Baird).

Sharpe, r9Io, p. 408, 4I7.

"Collected with a Birge net amongst floating algæ and eelgrass at I,ittle Harbor, Woods Hole, July. . . Also from Ee' Pond, Woods Hole, August."

\section{Family THALESTRID.E.}

Thalestris gibha (Kröyer).

Sharpe, 1910, p. 408, 417.

Woods Hole, in surface tow, December I, I905 (collected by V. N. Edwards, identified by R. W. Sharpe).

Dactylopusia thisboides (Claus).

Sharpe, I9I0, p. 408, 419.

"Collected among algæ with a Birge net, at Little Harbor, Woods Hole, July, sandy bottom, at about I2 feet depth."

$$
\text { I } 6269^{\circ}-\text { Bull. } 3 \text { I, pt } 2-{ }^{2}-7
$$

Dactylopusia vulgaris Sars.

Sharpe, I9ro, p. 408, 4 I9.

"Collected with a Birge net at Little Harbor, Woods Hole, Mass., among surface algæ, July. Also brackish ponds near Woods Hole, July, and among Fucus along the United States Fisheries wharf, July. Common."

Family Drosaccid

Diosaccus tenuicornis (Claus).

Sharpe, I9Io, p. 408, 420.

"Collected with Birge net among algx, Eel Pond, Woods Hole, August."

\section{Family LAOPHONTIDE.}

Laophonte longicaudata Boeck.

Sharpe, I9Io, p. 408, 42 I.

"Off the Bureau of Fisheries wharf, Woods Hole, Mass., July."

\section{Family LichomoLgrdat.}

Lichomolgus fucicolus Brady.

Sharpe, I910, p. 408, 42 I.

Collected in surface net at Buzzards Bay, Woods Hole, July.

\section{Family CORYCAIDAE.}

Sapphirina gemma Dana.

Verrill and Smith, I873, p. 573, 439; Wheeler, I900, p. I90; M. J. Rathbun, 1905, p. I08; Sharpe, I9ro, p. 409.

This species is listed by Wheeler only from the Gulf Stream at a point 70 miles south of Marthas Vineyard, and therefore far beyond the limits of our region. Smith, however, lists a species of Sapphirina, taken in "great numbers among Salpæ [as also were Wheeler's], off Gay Head, on several occasions, early in September."

Family ILYOPSYLLIDE.

\section{Ilyopsyllus sarsi Sharpe.}

Sharpe, Igro, p. 423 (sp. nov.).

"Collected plentifully with a Birge net among floating algæ in Eel Pond and Little Harbor, Woods Hole, Mass., July, August; also brackish ponds, Woods Hole." 
Order COPEPODA (parasitic).

\section{Family ARgULIDEA.}

Argulus alose Gould.

R. Rathbun, 1884a, p. 485 (no local records); C. B. Wilson, 1902, p. 707; 1905, p. I21; M. J. Rathbun, I905, p. 87.

Taken locally from outer surface of Pomolobus pseudoharengus and Osmerns mordax, very rare.

Argulus funduli Kröyer.

C. B. Wilson, 1902, p. $710 ; 1905$, p. 125; M. J. Rathbun, 1905 , p. 87

Hosts: Fundulus heteroclitus and $F$. majalis, outside of body, rare. Often taken in the tow net, when swimming freely.

Argulus laticarda Smith.

Verrill and Smith, I873, p. 574, $45^{2}$ (sp. nov.); R. Rathbun, $1884 a$, p. 484 ; C. B. Wilson, 1902 , p. $705 ; 1905$, p. I27; M. J. Rathbun, 1905, p. 86.

Vineyard Sound, among algæ.-Smith. Buzzards Bay, Woods Hole, Eel Pond, Waquoit, Katama Bay, the most abundant of the salt water species of this genus.-Wilson.

Hosts: Anguilla chrisypa, "blenny," Microgadus tomcod, Paralichthys dentatus, Pseudopleuronectes americanus, Myoxocephalus sp., Raja sp.; found on outer surface of the body, often becoming numerous enough to injure the host.-Wilson (MS.).

Argulus latus Smith.

Verrill and Smith, 1873, p. $574,45^{2}$ (sp. nov.); R. Rathbun, $1884 a$, p. 484 ; C. B. Wilson, I902, p. 704; I905, p. I28; M. J. Rathbun, I905, p. 86.

Only two specimens recorded from local waters, both taken at surface in Vineyard Sound; host unknown.

Argulus megalops Smith.

Verrill and Smith, 1873, p. 575,452 (sp. nov.); R. Rathbun, r884a, p. 485 ; C. B. Wilson, I902, p. 706; I905, p. I29; M. J. Rathbun, I905, p. 86.

Hosts: Fundulus sp., Lophius piscatorius, Lophopsetta maculata, Microgardus tomcod, Myoxocephalus octodecimspinosus, Paralichthys dentatus, Prionotus carolinus, Pseudopleuronectes americanus, Raja erinacea; "is often numerous enough on flounders to hasten their death."Wilson (MS.). Also reported from surface tow, in Vineyard Sound.-Smith.

Known to breed from August to November; eggs require 60 days' incubation at summer temperature.-Wilson (MS.).

\section{Family ERGASILID无.}

Ergasilus labracis Kröyer.

C. B. Wilson, Igri, p. 329 .

Woods Hole, on gills of the striped bass (Roccus lineatus). Two specimens of gills from this region which were examined by Dr. Wilson were found to be badly infested

Ergasilus manicatus Wilson.

C. B. Wilson, Igri, p. 337 (sp. nov.).

Woods Hole and vicinity. "This tiny parasite is very common on the gills of the silversides minnow, Menidia notata, along the Atlantic coast."

Tucca impressus Kröyer.

C. B. Wilson, IgII, p. 354 .

Woods Hole from the fins of a burrfish (Chilomicterus scheopfi.)

Tucca corpulentus Wilson.

C. B. Wilson, I9II, p. $35^{8}$ (sp. nov.).

Woods Hole, "a single lot of this species, which was taken from the northern swell toad, Spheroides maculatus."

Artacolax satiger Wilson.

C. B. Wilson, I9II, p. 36r (sp. nov.).

Woods Hole, "a single lot,... consisting of three females taken from the flying fish, Exocœtus volitans."

Bomolochus teres Wilson.

C. B. Wilson, Igrr, p. 379 (sp. nov.).

Woods Hole, from gills of menhaden, "quite rare, the examination of many fish yielding but a few specimens."

\section{Family CHONDRACANTHIDE.}

Chondracanthus cornutus Müller.

M. J. Rathbun, 1905, p. I00 (no local records). Common in mouth and gill cavities of fishes of the family Pleuronectidæ. (Here included on authority of C. B. Wilson, MS.).

Chondracanthus galeritus Rathbun.

R. Rathbun, I886, p. 3 I 7 (sp. nov.); M. J. Rathbun, I905, p. IOI.

Woods Hole and vicinity, Menemsha Bight. From interior of mouth of Paralichthys dentatus; common.

Breeds in July, August, September; male parasitic on female.

Chondracanthus merluccii Holten.

M. J. Rathbun, I905, p. I0I.

"Woods Hole region." (Wilson, MS.). Parasitic on Merluccius bilinearis. 
Chondracanthus phycidis Rathbun.

R. Rathbun, I886, p. 320 (sp. nov.); M. J. Rathbun, I905, p. Ior.

From gills of Urophycis tenuis, taken "off Marthas Vineyard," I5 specimens, taken on one occasion only (perhaps far beyond the limits of the region).

\section{Family CALIGIDAs.}

\section{Caligus belones Kröyer.}

C. B. Wilson, I905a, p. 586; M. J. Rathbun, I905, p. 9 I.

From external surface of a fish in the Woods Hole collection, labeled "Coryphana equisetis" [probably C. hippurus]; place of capture uncertain.-Wilson.

Caligus bonito Wilson.

C. B. Wilson, I905a, p. $5^{89}$ (sp. nov.); M. J. Rathbun, 1905, p. 89.

First obtained at Woods Hole, in summer of I883, by $R$. Rathbun, who never published a description. Found in the mouth and gill cavity of Sarda sarda, as many as Ioo having been taken from a single fish.

Larvæ may be raised in August through three or four successive molts; a typical metanauplius and chalimus.-Wilson (MS.).

Caligus chelifer Wilson.

C. B. Wilson, I905a, p. $5^{82}$ (sp. nov.); M. J. Rathbun, I905, p. 9 I.

Hosts: Brevoortia tyrannus, Trichiurus lepturus, $X$ iphias gladius; external surface, rare.

Female specimens only known; breeds in July and August.

Caligus curtus Müller.

Verrill and Smith, I873, p. 575, 459 (no local records); R. Rathbun, i884a, p. 486 (no local records); C. B. Wilson, 1905a, p. 578; M. J. Rathbun, I905, p. 90.

Hosts: Gadus callarias, Hippoglossus hippoglossus, Melanogrammus aglefinus, Pollachius virens, Raja lavis, Urophycis tenuis; very common on external surface and probably a serious menace to the life of the fish; rarely found in gill cavity.-Wilso' $($ MS.).

Breeds from May to September; a typical nauplius occurs, colored with dark brown pigment; chalimus may be found on cod in late July or early August.-Wilson (MS.).
Caligus mutabilis Wilson.

C. B. Wilson, I905a, 573 (sp. nov.); M. J. Rathbun, 1905, p. 90.

Hosts: Centropristes striatus; also one specimen each from Pollachius virens and Sarda sarda; found inside the mouth, fairly common.

Breeds in July.-Wilson (MS.).

Caligus pelamydis Kröyer.

C. B. Wilson, I905a, p. 594 .

Host: Sarda sarda; found in the gill cavity in company with Caligus bonito; rare and only the females known.-Wilson.

Caligus rapax Milne Edwards.

Verrill and Smith, I873, p. 575, 457; R. Rathbun, I884a, p. 487 ; C. B. Wilson, I905a, p. 568; M. J. Rathbun, I905, p. 89.

Hosts: Acipenser sturio, Alosa sapidissima, Ammodytes americanus, Carangus crysos, Carcharias littoralis, Cy'clopterus lumpus; Dasyatis centrura, Gaduscallarias, Kyphosus sectatrix, Melanogrammus aglefinus, Menticirrhus saxatilis, Monacanthus hispidus, Paralichthys oblongus, Pollachius virens, Pomolobus pseudoharengus, Pseudopleuronectes americanus, Raja erinacea, Raja lavis, Raja ocellata, Remora remora, Roccus lineatus, Scomber scombrus, Squalus acanthias, Stenotomus chrysops, Trichiurus lepturus, Urophycis chuss, Urophycis tenuis, Xiphias gladius. Always an external parasite, often being sufficiently numerous to seriously injure the host. Frequently taken in tow.

Breeds from April to October.-Wilson (MS.).

Caligus rufimaculatus Wilson.

C. B. Wilson, I905a, p. 56I (sp. nov.); M. J. Rathbun, I905, p. 89.

Hosts: Fundulus heteroclitus, F. majalis, Mugil cephalus, on external surface; also taken in tow net.

Breeds from June to September; chalimus stage found upon the host late in June or early in July.

Caligus schistonyx Wilson.

C. B. Wilson, I905a, p. 564 (sp. nov.); M. J. Rathbun, I905, p. 89.

Hosts: Brevoortia tyrannus (common), Pomatomus saltatrix (rare); external, also often taken in tow.

Breeds in late August or early September.Wilson (MS.). 
Caligodes megacephalus Wilson.

C. B. Wilson, I905a, p. 609 (sp. nov.); M. J. Rathbun, rgo5, p. 9r.

But a single specimen known, "which was taken from the underside of the mouth of the silver gar [probably Tylosurus marinus] at Woods Hole."

Lepeophtheirus edwardsi Wilson.

Verrill and Smith, I873, pp. 575, 459 (Lepeophtheirus sp.); C. B. Wilson, rgo5a, p. 627 (sp. nov.); M. J. Rathbun, I905, p. 92.

Hosts: Carangus hippos, Paralichthys dentatus, Paralichthy's oblongus, Pomolobus pseudoharengus, Pseudopleuronectes americanus, Raja erinacea, Tylosurus marinus. Found upon the external surface; abundant, sometimes numerous enough to cause death of host.

Breeds from May to September; nauplii may be reared through several moults in the laboratory; chalimus stage may be found upon flounders in June and early July.-Wilson (MS.).

Lepeophthcirus nordmannii Milne Edwards.

R. Rathbun, I884a, p. 487 ; C. B. Wilson, I905a, p. 623; M. J. Rathbun, 1905, p. 91 .

Parasitic on outer surface of Mola mola.

Lepeophtheirus thompsoni Baird.

Verrill and Smith, I873, pp. 575, 459 (Lepeophthsirus sp.); C. B. Wilson, I9o5a, p. 619; M. J. Rathbun, I905, p. 92.

Hosts: Dasyatis centrura, Lophius piscatorius; external.

Trebius tenuifurcalus Rathbun.

R. Rathbun, 1887 , p. 559 (sp. nov.); M. J. Rathbun, 1905, p. 93; C. B. Wilson, 1907, p. 679.

Two female specimens from a "sting ray" in Vineyard Sound, I871.-R. Rathbun.

Gloiopotes ornatus Wilson.

C. B. Wilson, r905b, p. 127 (sp. nov.); 1907, p. 699; M. J. Rathbun, I905, p. 93.

Two female specimens taken from a swordfish captured off Gay Head; an external parasite.Wilson.

Alebion glaber Wilson.

C. B. Wilson, r905b, p. I29 (Alebion glabrum, sp. nov.); I907, p. 708; M. J. Rathbun, I905, p. 93.

Hosts: Mustelus canis ("almost every fish yielding one or more specimens"); also Carcharias littoralis and Squalus acanthias; attached to outer surface of body, common.

Immature stages may be found attached to the skin of the shark, just in front of the posterior dorsal fin, and elsewhere, early in July.-Wilson (MS.).

"Very transparent and beautifully colored; an excellent species for morphological work."
Alebion gracilis Wilson.

C. B. Wilson, I905b, p. I28 (Alebion gracile, sp. nov.); I907, p. 704; M. J. Rathbun, I905, p. 93.

Hosts: Mustelus canis, Carcharias littoralis, Carcharhinus obscurus, "Trygon sp." (=Dasyatis centrura?), Pollachius virens; outer surface, common.

Perissopus communis Rathbun.

R. Rathbun, 1887 , p. 560 (sp. nov.); M. J. Rathbun, I905, p. 94; C. B. Wilson, I907b, p. 354.

Hosts: Carcharhinus milberti, Carcharhinus obscurus, Mustelus canis; external; common and widely distributed.

Breeds in July.-Wilson (MS.).

Echthrogaleus coleoptratus (Guérin).

Verrill and Smith, 1873 , p. 576,$459 ;$ R. Rathbun, I884a, p. 488; M. J. Rathbun, x905, P. 94; C. B. Wilson, I907b, p. 367 .

From dorsal fin of "mackerel shark" (probably Isurus dekayi).

Echthrogaleus denticulatus Smith.

Verrill and Smith, I873, pp. 576, 459 (sp. nov.); R. Rathbun, I884a, p. 488 ; M. J. Rathbun, I905, p. 94 ; C. B. Wilson, I907b, p. 369.

Vineyard Sound, a single female specimen known, taken from Carcharodon carcharias.

Echthrogaleus torpedinis Wilson.

C. B. Wilson, rgozb, p. 37 I (sp. nov.).

Two females from pectoral fins of a torpedo (Tetronarce occidentalis), taken in vicinity of Woods Hole in 1875 .

Dinematura latifolia Steenstrup \& Lütken.

C. B. Wilson, 1907, p. 383 .

"External parasite of Lamna cornubica; has been taken from this shark 120 miles offshore, and is probably present on those specimens that occasionally come into the Sound."'-Wilson (MS.).

Pandarus cranchii Leacn.

Verrill and Smith, r873, p. 576 (Pandarus Cranchii and Nogagus Latreillii); R. Rathbun, I884a, p. 488; I886, p. 3 I 7; C. B. Wilson, r907b, p. 403. (No definite local records given.)

Hosts: Carcharhinus obscurns, Carcharodon carcharias.

"The names Nogaus latreillii and Nogagus latreillii have been used for the male of this species; these males are occasionally found on the smaller sharks, Mustelus canis and Carcharias littoralis."-Wilson (MS.).

Pandarus sinuatus Say.

Verrill and Smith, I873, pp. 577, 459; R. Rathbun, I886, p. 310; M. J. Rathbun, I905, p. 95; C. B. Wilson, 1907b, p. 4 I 7 . 
Pandarus simuatus-Continued.

Hosts: Carcharhinus obscurus, Carcharias littoralis (very common), Carcharodon carcharias, Mustelus canis.

Breeds in July, August, September; eggs very numerous; nauplius larva very small and dark colored.

Pandarus smithii Rathbun.

R. Rathbun, I886, p. 3I 5 (sp. nov.); M. J. Rathbun, 1905 , p. 95; C. B. Wilson, I907b, p. 410.

Hosts: Carcharhinus obscurus, Carcharias littoralis, Carcharodon carcharias.

Nesippus alatus Wilson.

C. B. Wilson, I905b, p. I30 (sp. nov.); $1907 \mathrm{~b}$, p. 426 ; M. J. Rathbun, I905, p. 94.

Hosts: Carcharhinus obscurus, Carcharias littoralis (females on gill arches, males on outside of body), Fundulus majalis (caudal peduncle), Mustelus canis.

Breeds in July; nauplius of typical form.-Wilson (MS.).

Cecrops latreillii Leach.

Verrill and Smith, 1873, p. 577 (citing Gould); R. Rathbun, I884a, p. 489; M. J. Rathbun, I905, p. 96; C. B. Wilson, I907b, p. 468.

Parasitic on gills or outer body surface of Mola mola, very numerous.

Breeds from May to October.-Wilson (MS.).

Orthagoriscicola muricata (Kröyer).

M. J. Rathbun, I905, p. 96 (Lemargus muricatus), C. B. Wilson, I907b, p. 473 .

Hosts: Mola mola, Selcne vomer.

Philorthragoriscus serratus Kröyer.

C. B. Wilson, I907b, p. 479 .

Vineyard Sound, on Mola mola.

\section{Family DICHELESTHDAE.}

Anthosoma crassum (Abildgaard).

Verrill and Smith, 1873 , p. 577,460 (no local records); R. Rathbun, I884a, p. 490 ; M. J. Rathbur, I905, p. 97 .

Hosts: Carcharias littoralis, Squalus acanthias, "mackerel shark," Mola mola; attached to the inside of the opercula, roof of mouth, or a fin, rather rare.-Wilson (MS.).

\section{Lernanthropus brevoortic Rathbun.}

R. Rathbun, I887, p. $56_{3}$ (sp. nov.); MI. J. Rathbun, 1905, p. 97.

On gills of the menhaden (Brevoortia tyrannus), very abundant at times.

The male is not yet known.
Lernanthropus pomatomi Rathbun.

R. Rathbur, 1887 , p. 567 (sp. nov.); M. J. Rathbun, I905, p. 98.

On gills of Pomatomus sallatrix, mostly female specimens recorded.

\section{Dichelesthium sturionis Hermann.}

R. Rathbun, r884a, p. 490; M. J. Rathbun, 1905, p. 97.

From gill cavities and nasal cavities of "Acipenser oxyrhynchus" (=sturio).

Breeds in July.-Wilson (MS.).

Eudactylina nigra Wilson.

C. B. Wilson, r9o5b, p. I3I (sp. nov.); M. J. Rathbun, I905, p. 97

Type specimen from Buzzards Bay.

Parasitic on gills of Carcharias littoralis, "many hundreds may often be secured from a single shark."

\section{Family ANTHEACHERID死}

Philichthys xiphice Steenstrup.

Linton, I901, p. 448; M. J. Rathbun, I905, p. 98.

"Woods Hole region," on Xiphias gladius.C. B. Wilson (MS.). Six specimens found "in the frontal sinuses of a swordfish head." Linton.

Spharifer lintoni Wilson.

Linton, I900, p. 285 ; M. J. Rathbun, I905, p. 98. Woods Hole; found by E. E. Tyzzer " under the skin on the preopercular bone of a squeteague (Cynoscion regalis)."'--Linton.

\section{Family LERNAIDEE.}

Pennella costai Richiardi.

M. J. Rathbun, I905, p. 99.

On Xiphias gladius, the head buried in a cyst formed within internal organs of host; often 30 or 40 upon a single fish, appearing to impair its vitality.-Wilson (MS.).

Breeds in July.

Pennella fllosa (Linnæus).

M. J. Rathbun, I905, p. 99 (no local records).

Hosts: Mola mola, Xiphias gladius; the body of the parasite being external, the head buried within the tissues of the host; not so common as $P$. costai. (Not definitely recorded for local waters.)

Lernaenicus radiatus (I.esueur).

Verrill and Smith, I873, p. 578, 458 (Lemeonema radiata); $\mathrm{R}$. Rathbun, I884a, P. $49 \mathrm{I}$ (Lernconema radiata); M. J. Rathbun, I905, p. 99. 
Lernaenicus radiatus-Continued.

Vineyard Sound and Buzzards Bay.-Smith and later writers.

Hosts: Brevoortia tyrannus, Fundulus sp.; buried in the flesh of the body, or in the eye, sometimes causing blindness; not at all common.

Lernaa branchialis Linnæus.

Verrill and Smith, I873, p. 578,460 ; R. Rathbun, I884a, p. 492; M. J. Rathbun, I905, p. Iо0. (No local records given by these writers.)

Listed for Vineyard Sound by C. B. Wilson (MS.).

Hosts: Gadus callarias, Melanogrammus aglefinus, Pollachius virens, "hake" sp.; often so numerous as to affect the health of the fish.

Breeds in July; egg hatches into a typical nauplius; larva undergoes great degeneration.

Lernceolophus sultanus Milne Edwards.

R. Rathbun, I884a, p. 492; M. J. Rathbun, r905, p. 100 .

Four female specimens taken from Alutera schoepfii, from Vineyard Sound, in summer of I874.

\section{Family LERNAEOPODIDE.}

Clavella uncinata (Müller).

Verrill and Smith, I873, p. 578, 460 (Anchorella uncinata); R. Rathbun, r884a, p. 49 r (Anchorella uncinata). Neither author gives any local records.
Clavella uncinata-Continued.

Parasitic in mouth and on gills of the Gadidx, common and of very general distribution.

Breeds from June to September; male a dwarf, parasitic upon the female; larva a typical nauplius.-Wilson (MS.).

Brachiella ramosa Richiardi.

Goode, r883, p. 346(nolocal records); M. J. Rathbun, I905, p. I02.

Woods Hole region.-Wilson. Parasitic on gills of Xiphias gladius.

\section{Brachiella rostrata Kröyer.}

R. Rathbun, I884, p. 49I (no local records); M. J. Rathbun, 1905, p. I02.

Host: Hippoglossus hippoglossus. (Listed for "Woods Hole region" by Miss Rathbun, on authority of C. B. Wilson.)

Brachiella thynni Cuvier.

Verrill and Smith, I873, p. 34r (citing Gould; no local records); M. J. Rathbun, I905, p. Io2 (no local records).

Host: Thunnus thynnus, on gills. (Here included on the authority of C. B. Wilson, MS.)

\section{Order CIRRIPEDIA. $a$}

\section{Family TRYPETESIDE.}

Trypetesa lampas (Hancock).

M. J. Rathbun, I905, p. 79.

Woods Hole. Bores in dead shells of Polynices heros and $P$. duplicata, which are inhabited by hermit crabs.-Genthe, cited by Rathbun.

\section{Family Coronulides.}

\section{Coronula diadema (Linnæus).}

Verrill and Smith, I873, p. 579, 460; M. J. Rathbun, 1905, p. 80 . (No local records given in either work.)

Found upon whales. Mr. Edwards has observed barnacles, presumably of this species, locally upon the humpback whale, on which it seems to be commonly present in large numbers.

\section{Family BALANIDE.}

Balanus tintinnabulum (Linnæus).

M. J. Rathbun, I905, p. 80 (not recorded locally).

Great numbers collected by Mr. John J. Veeder in New Bedford Harbor, July or August, I908, from bottom of a whaling vessel. (Identified, with fair certainty, by F. B. Sumner.)

\section{Balanus amphitrite (Darwin).}

Verrill and Smith, 1873 , p. 578 (no local records); M. J. Rathbun, I905, p. 8 I.

Vineyard Sound, "on whales and bottoms of ships, but probably does not live long after arriving on New England coast."-Rathbun.

$a$ Specimens from points designated by an asterisk (*) were identified by Dr. F. B. Sumner. Specimens from points designated by a dagger ( $\dagger$ ) were identified by Dr. H. A. Pilsbry. 
Balanus eburneus Gould. $a$ [Chart 84.]

Verrill and Smith, 1873 , p. 579,381 , etc.; M. J. Rathbun, 1905, p. 8 I.

Abundant and generally distributed, from lowtide mark to the deepest waters of Buzzards Bay and Vineyard Sound, occurring on stones, shells, living mollusks, and Crustacea, the bottoms of boats, piles, and all sorts of submerged woodwork, or solid objects of any description. This species is quite at home in brackish water, and is said to occur at times in perfectly fresh water. It is occasionally met with between tides, but, generally speaking, its bathymetric range commences where that of Balanus balanoides ends, i. e., at low-tide mark.

Fisk Hawk stations: $75^{2} 3 \dagger$ (many on Polynices), 753 I $†$ (small cluster), $7535 \dagger$ (2), $7537 \dagger$ (group on shell of Polynices), 7543 bis* (great numbers, living, mainly small, on shell fragments), 7545 bis* (a number dead and detached), $7547 \dagger$ (I),

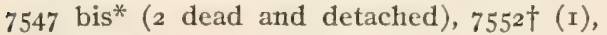
$7553 \dagger$ (4), $7557 \dagger$ (I dead), 7558†, 7559†, $7563 \dagger$ (many), 7569† (I on Mytilus shell), $7576 \dagger$ (many on fragment of Polynices), $7592 \dagger$ (few), $7607 \dagger$ (few on shell of Scala), $761 \mathrm{I}^{*}$ (many dead, on shells), $76 \mathrm{r} 5^{*}$ (? a number dead, on shells), $762 \mathrm{I}^{*}$ (several dead, on shells), $7648^{*}$ (? I dead, detached), $7663^{*}$ (? many, on Polynices), $7664^{*}$ (several dead, on shells), $767 \mathrm{I}^{*}$ (many dead, on shells), $7678^{*}$ (dense cluster, living, on Polynices), $7679^{*}$ (small cluster, living, on Polynices), $7682^{*}$ (I small living, on Mytilus), $7698^{*}$ (many living, on Polynices), 7699* (few living and dead, on shells), 7700* (many living, on shells), $7702^{*}$ (dense clusters, living, on shells), 7706* (many living, on Polynices shell), 7709* (many living, on Polynices), $77 \mathrm{r}^{*}$ (? I living, on Polynices), $77^{2} 5^{*}$ (small cluster, living, on Polynices), $7726^{*}$ (many living, on shell), $7728^{*}$ (? I detached), $773 \mathrm{I}^{*}$ (? x dead), $773^{*}$ (many dead, on mussel shell), $7734^{*}$ (several living and dead, on shells) $7740^{*}$ (several dead, on shells), $7749^{*}$ ( d dead, on shell), $7762^{*}$ (many small living, on cocoanut shell), $7763^{*}$ ( 2 living, on Crepidula fornicata), $7768^{*}$ (few small dead, on shell), $7769 *$ (? many, badly damaged). Supplementary stations (approximate repetitions in 1907 of the following stations) ${ }^{*}: 7526$ (few small dead), 7543 (few small dead, on shell), 7549 (many dead, on stones), 755 I (I dead, detached), $76_{5}$ I (cluster of dead, on shell fragment), 7656 (on living Crepidula fornicata), 7662 (many dead and few living, on
Balanus eburneus-Continued. shells), 7663 (many living and dead, on several kinds of mollusks), $776 \mathrm{r}$ (dense clusters, living, on small stones), 7766 (many dead, on small stones), 7783 (several dead, detached).

Phalarope stations: $16 \mathrm{I}^{*}$ ( $\mathrm{I}$ dead), $163^{*}$ ( 2 dead), I 67 ( I dead).

The rate of growth of this species is indicated by the fact that specimens ranging from 20 to 26 $\mathrm{mm}$. in diameter at the base were taken in abundance from the bottom of a whaleboat which had been moored within the inclosure of the local pier from May till November or December, 1908 .

Balanus sp. (largely, perhaps wholly, B. eburneus).

Under this head are included such specimens from the Survey dredgings as were poorly preserved or very young; also such as were listed by the collectors in the field, and not reserved for subsequent examination. Unless species occur in these waters which have not thus far been reported, it is very probable that the great majority of these records refer to $B$. eburneus. Balanus balanoides seem to be wholly confined to the intertidal zone, and, so far as we are aware, not a single specimen has been taken by us in the dredge. Moreover it can be distinguished at a glance from the former. The only other species recorded during the survey dredging are $B$. crenatus and $B$. porcatus. These are both comparatively rare, and the larger specimens, at least, are readily distinguished from B. eburneus. (See discussion on p. I29, I30). It has accordingly been thought best to combine the following stations with those of (known) B. eburneus upon a single distribution chart.

Fish Hawk stations: $75^{2} 3$ bis (several living), 7530 ( 2 dead), 7530 bis (few on shells), 7539 bis (few), 754I, 7542, 7543 (numerous on shells and stones), 7544 (few), 7549 bis (many living on Polynices heros), 7550,7550 bis, 7553 bis (many), 7556 bis (many dead), 7560 (few), 7563 bis (few dead), 7564 (several collections), 7564 bis (many), 7574 (few on Polynices), 7578 (many), 7579 (few), 759 I (I), 7598 (I on Crepidula shell), 7616 (few), 7617 (few), 7620 (several), 7624 (few), 7626 (many), 7627 (several), 7629, 7631 (several), $76_{32}$ (few), 7636, 7643 (few), 7644 (few), 7646,7650 (several), $765 \mathrm{r}$ (many on Crepidula fornicata), 7652 (many dead), 7653 (many), 7655 (several), 7656 (few), $765^{8}$ (few), 7659 (few), 7660 (few), 7662 (several), 7665,7668 , 7670 (few), $7672,7674,7675,7680$, (2 living on 
Balanus-Continued.

shells), 768ז (many on Polynices), 7701, 7739, $7744,7756,7757,7760,7761,7766,7767,7770$ 7772,7773 , (few small), 7774, 7775, 7776, 7777 , $7778,7779,7780,7783$.

Supplementary stations (approximate repetitions in 1907 of the following stations): 7542 (a number on shells), 7592 (few on Polynices shell, dead and overgrown by Hydractinia), 7728 (several on shell), 7739 (I small dead, detached).

Phalarope and Blue Wing stations: 6 (many alive), 7 (few shells), I6 (I dead), I7 (several on shells), I8 (on Polynices), 22 (few living), 28 (few dead), 35 (few dead), 36 (I), 42 (fragments), 68 (on Polynices), 7 I (on Vermicularia), 72 (several), 73 (few), 76 (many on shells), 80 (few dead), 83 (few), 84 (many masses), 85,88 , 90, 93 (dead), 98, I03, Iо7, IIO, II2, II 3 , II4, (common), II5, II7 (few), II8, I2I, I23 (few), I26 (few dead), I29, I35, r39, I44.

Balanus porcatus Costa.

M. J. Rathbun, I905, p. 8I.

Off Nobska.-Rathbun. Crab Ledge, at Fish Hawk station 7608,2 specimens $\dagger$, one or both living, the largest measuring about 55 by 65 mm. Off West Chop, July $I_{7}$, I908*, one living specimen, attached to a mussel shell. Specimens with opercular plates incomplete or lacking, and therefore impossible to identify with certainty, were taken in the eastern part of Vineyard Sound, at Fish Hawk stations $75^{2} 3$ bis ( 2 on stones), 7524 (station number somewhat doubtful, a single specimen), $776_{3}$ ( 1907 repetition); also near Phalarope station II (Aug. I8, 1908).

Balanus crenatus Bruguière.

Verrill and Smith, I873, pp. 579, 381 , etc.; M. J. Rathbun, r905, p. 82 .

Piles of wharf at Vineyard Haven ${ }^{*}$, clusters of large specimens taken by our collectors in 1906 and I909. The largest of these was $24 \mathrm{~mm}$. in diameter at the base. Three large dead specimens, doubtfully identified* (opercular plates almost wholly lacking), were found attached to a shell, taken near the mouth of Buzzards Bay, at a 1907 repetition of Fish Hawk station 7662. The largest was $18 \mathrm{~mm}$. across at the base. These may be $B$. porcatus, however. On the other hand, those specimens which were doubtfully assigned to $B$. porcatus may in reality belong here. In view of the few dubious records from the Survey dredging, we may well doubt the statement of Verrill and Smith that this species is "dredged abundantly in Vineyard Sound."
Balanus hameri (Ascanius).

M. J. Rathbun, 1905, p. 83 .

"Off Chatham; off Marthas Vineyard;" from I6 fathoms down (perhaps not properly to be included within the region)

Balanus balanoides (Linnæus).

Verrill and Smith, I873, p. 579, 304, etc.; M. J. Rathbun, I905, p. 82 .

Generally distributed and enormously abundant on rocky shores, between tides; also found in great profusion upon piles and other submerged timbers. Darwin expressed the doubt whether this species ever lived below the lowest tides. In any case, not a single specimen has been found among all the bamacles dredged by the survey.

Nauplii liberated in great numbers at Woods Hole in last week of December (1899).-Bigelow.

Chthamalus stellatus (Poli).

Sumner, I909, p. 373 .

Abundant on rocks and piles everywhere along the shores of the region, being confined, apparently, to the intertidal zone. "It extends considerably higher upon the boulders than does Balanus balanoides, with which, however, it is associated at a lower level. ... In local waters, so far as I have seen, Chthamalus never grows in such dense clusters as does Balanus balanoides, and indeed it appears unable to compete very successfully with the latter in its proper zone." Despite its world-wide distribution, and its abundance locally, this species has not apparently been previously recorded for New England. (See discussion, on p. Igo.)

Eggs were taken by Dr. M. A. Bigelow during two different summers throughout the month of July.

\section{Family LEPADIDAE.}

Lepas fascicularis Ellis \& Solander.

Verrill and Smith, 1873, p. 579,382 , etc.; Bigelow, I902, p. 65; M. J. Rathbun, I905, p. 85; Pilsbry, r907, p. 8r ("Lepas fasciculatus": apparently a misprint).

Vineyard Sound, and probably all local waters connecting with the open sea, growing in clusters upon drifting Fucus, A scophyllum, and Sargassum or upon floating wood, sometimes in great abundance. Taken in June, July, and August.

As regards reproduction, M. A. Bigelow states that when first taken locally during the summer season the eggs are mostly in advanced stages, though early stages have been found in June.

Lepas pectinata Spengler.

Verrill and Smith, I873, p. 579, 382, etc.; Bigelow, 1902, p. 65; M. J. Rathbun, 1905, p. 84; Pilsbry, I907, p. 8I. (No local records, except by Bigelow.) 
Lepas pectinata-Continued.

Bigelow records this species locally (Vineyard Sound or Buzzards Bay). Vineyard Sound, on floating Ascophyllum, and in independent clusters, July I, I90I †* (collected by V. N. Edwards).

\section{Lepas anatifera Linnreus.}

Verrill and Smith, 1873 , p. 580,382 , etc.; Bigelow, I902, p. 65; M. J. Rathbun, 1905, p. 84; Pilsbry, I907, p. 79.

Taken in various parts of Vineyard Sound during the months of July and August; found upon the bottoms of ships, and attached to floating planks and sargassum, sometimes in large numbers. Specimens in Woods Hole museum, dated July 5, I904†, August 29†, August 30†, and September 5, rgo6t. (All attached to sargassum.)

Bigelow notes that maturation and cleavage stages, as well as advanced eggs, were on one occasion found in great numbers in the middle of August.

Lepas hilli (Leach).

M. J. Rathbun, I905, p. 84; Pilsbry, I907, p. 80 (no local records).

Woods Hole, from German bark.-Rathbun. Woods Hole, December II, I888*; Vineyard Sound, July I, rgor; enormous cluster*; Gay Head, July 23, Igorł; Vineyard Sound, on floating wood, July 5, r904†; Menemsha Bight, on gulfweed, August 28, I906†; New Bedford Harbor, on bottom of whaling vessel, August, rgo6t; Vineyard Sound, August 29, 1906†.
Lepas hilli-Continued.

(Foregoing specimens for the most part collected by V. N. Edwards.) Abundant during the summer of rgog, several large clusters being brought in. Found by Mr. Edwards and others, growing upon buoys anchored in local waters, though this is not probably a common occurrence.

\section{Lepas anserifera Linnæus.}

Verrill and Smith, 1873 , p. 580,382 ; M. J. Rathbun, 1905 , p. 84; Pilsbry, I907, p. 80.

Nobska Beach.-Rathbur. Off Marthas Vineyard.-Pilsbry.

Conchoderma auritum (Linnæus).

Verrill and Smith, I873, p. 580, 390; M. J. Rathbun, 1905, p. 85; Pilsbry, 1907, p. 99.

Woods Hole, on ship's bottom.-Rathbun, Pilsbry.

Conchoderma virgatum (Spengler).

Verrill and Smith, 1873, p. 580,$392 ;$ M. J. Rathbun, 1905, p. 85 ; Pilsbry, I907, p. 99.

Woods Hole, on ship's bottom.-Rathbun, Pilsbry. Woods Hole, on bottom of Italian bark, August, I887 (perhaps the same specimens as referred to in the foregoing record). Off Gay Head, on Mola.-Pilsbry. New Bedford, several specimens taken from a whaling vessel, August, rgo6t; also taken in abundance in the same harbor by Mr. Gray's collectors. Several specimens of this species are attached to the top of the head of a large gar ( $T$ ylosurus acus) in the Woods Hole collection.

\section{Order AMPHIPODA. $a$}

\section{Family VIBILIIDĖ.}

Vibilia viatrix Bovallius.

M. J. Rathbun, I905, p. 50.

Off Marthas Vineyard, at the surface (doubtfully determined by Holmes); off Newport.Rathbun.

\section{Family HYPERIIDA゙.}

Hyperia galba (Montagu).

Holmes, I905, p. 464; M. J. Rathbun, 1905, p. 50. Woods Hole; commonly found in Aurelia.Holmes. Identified by Dr. Kunkel in nine different lots of amphipods, collected by Mr. Edwards at Woods Hole in April, May, June, and October. Some of these were freely swimming; others in the medusæ Tima formosa and Cyanea arctica (?).
Hyperia medusarum (Müller).

Verrill, r875a, p. 38; Holmes, r905, p. 464 (not listed for this region); M. J. Rathbun, I905, p. 50. (Verrill and Smith, I873, p. 567 and 439, likewise mention an unidentified Hyperia, found upon $C$ yanea).

Vineyard Sound and northward on Cyanea arctica and other jellyfishes.-Verrill.

Hyperoche abyssorum (Boeck).

Holmes, r905, p. 464 (not listed for local waters).

Specimens thus identified by Dr. Kunkel were taken at Woods Hole, in surface tow, April 27 and May 24, I906.

Euthcmisto compressa (Goes).

Holmes, I905, p. 464; M. J. Rathbun, I905, p. 5 I. "Off Marthas Vineyard."-Holmes. The stations listed by this writer are, however, beyond

a Specimens from points designated by an asterisk $(*)$ were identified by Dr. L. J. Cole; those from points designated by a dagger $(\dagger)$ by Dr. S. J. Holmes; those from points designated by a double dagger $(\ddagger)$ by - Dr. B. W. Kunkel. 
Euthemisto compressa-Continued.

the limits of the region. Woods Hole, in surface tow, December 22, I904, $\ddagger$ and November 10, I905. 7 .

\section{Euthemisto bispinosa (Boeck).}

Holmes, I905, p. 465; M. J. Rathbun, r905, p. 5 I. Vineyard Sound.-Holmes. Woods Hole, in surface tow, November Io, I905, $\ddagger$ and June ro, I906.

\section{Family Phronimide}

\section{Phronima sedentaria (Forskäl).}

Verrill and Smith, 1873, p. 567, 439 (Phronima sp.); Holmes, I905, p. "465 (no local records); M. J. Rathbun, I905, p. 5I (no local records). Smith states that a species of this genus "was taken at the surface in company with Salpa, off Gay Head, early in September." This was "closely allied to $P$. atlantica of Griérin."

\section{Family OXYCEPHALIDE.}

? Oxycephalus clausi Bovallius.

M. J. Rathbun, I905, p. 5 I.

"Off Marthas Vineyard, surface." (Doubtful whether the locality lay within limits of region.)

\section{Family SCELID E.}

Thyropus sp.

Verrill and Smith, 1873 , p. 567 ; M. J. Rathbun, I905, p. $5^{2}$.

"A single specimen of a species of this genus was taken with the Phronima and Salpa, off Gay Head, early in September." -Smith.

Family ORCHestrid FA.

Talorchestia longicornis (Say).

Verrill and Smith, 1873 , p. 556, 336, etc.; Holmes I905, p. 468; M. J. Rathbun, I905, p. 52.

Of very general distribution on sandy beaches, in burrows, at or above high-water mark. Nocturnal in habits: may be caught by the use of a lantern at nights.-Holmes.

Females with eggs noted among specimens collected in July and August, I906.-Kunkel.

Talorchestia megalophthalma (White).

Verrill and Smith, I873, pp. 556, 336, etc.; Holmes, I905, p. 469; M. J. Rathbun, I905, p. 52 .

Woods Hole, much less common than $T$. longicornis, but lives in similar situations.-Holmes. Recorded from Nobska Beach $\ddagger$ and Robinsons Hole $f$ at or above high tide. Found among specimens taken at station 7537 (I906) at a depth of ro fathoms $\ddagger$ (perhaps caught by dredge near surface).
Orchestia agilis Smith. Beach flea

Verrill and Smith, 1873, pp. 555, 314, etc. (sp. nov.); Bumpus, I898b; Holmes, I905, p. 470; M. J. Rathbun, I905, p. 53.

Distribution very general locally, occurring under masses of dead seaweed thrown up on the beaches; often enormously abundant.a Seldom found so far up on the beach as Talorchestia, and is much more active in the daytime.-(Holmes).

Found to be carrying eggs and embryos on June 20.-Bumpus. One female with eggs among specimens collected August 13.-Kunkel.

Orchestia palustris Smith.

Verrill and Smith, I873, pp. 555, 468 (sp. nov.); Holmes, I905, p. 47I; M. J. Rathbun, I905, p. 53 .

In salt marshes, occurring under driftwood, vegetable débris, etc., extending its range nearly or quite up to fresh water; may occupy nearly dry places above high-water mark.-Smith. Identified by Dr. Kunkel among collections made at New Bedford Harbor, above high tide; Nobska Beach, among driftweed; Cedar Tree Neck, on shore.

Allorchestes littoralis Stimpson.

Verrill and Smith, 1873 , pp. 556, 3I5, etc. (Hyale littoralis); Holmes, I905, p. 472; M. J. Rathbun, I905, p. 53 .

No definite local records given by any of the writers cited, though it is stated that this species is prevalent on the whole New England coast. Specimens have been identified by Dr. Kunkel from the following points: Tide pool on Naushon side of Robinsons Hole, August I8, 1906 (2 females with eggs); Tarpaulin Cove, August 9, I 906 (I); from algæ on rocks at Scraggy Neck, August I6, I906 (many); Woods Hole, in surface tow, February 22, 1905 (I); from hydroids, growing on Lepas, Vineyard Sound, August 9, Igo4 (I).

Holmes states that this species occurs high up on the beach, thus showing an approach to a terrestrial habitat.

Hyale prevostii (Milne Edwards).

A specimen thus identified by Dr. Kunkel was taken in shallow water at Round Hill Point, August 14, 1906.

\section{Family LysianasSIDA:}

A nonyx nugax (Phipps).

Holmes, I905, p. 473; M. J. Rathbun, I905, p. 54 .

a A curious belief seems prevalent at seashore resorts to the effect that the beaches are tenanted by real fleas. The presence of these vermin in the houses is thus explained and excused. 
Anonyx nugax-Continued.

Often found in great abundance near Woods Hole.-Holmes. Woods Hole and Vineyard Sound, surface and bottom,-Rathbun. A number of specimens identified by Dr. Kunkel were taken in surface tow, Woods Hole, January 23 , I902.

?Anonyx nobilis Stimpson.

A number of specimens taken at Fish Hawk station 7604 (Crab Ledge in I9 fathoms, gravel and sand) were referred to this species by Dr. Holmes, with the comment that this was "not really an Anonyx."

Tryphosa pinguis (Boeck).

Holmes, 1905, p. 473; M. J. Rathbun, 1905, p. 54 .

Often taken in abundance near Woods Hole; sometimes in company with Anonyx nugax.Holmes. Off Gay Head.-Rathbun. Three records from tow collections made at Woods Hole in December and January $\ddagger$.

Females with eggs taken in January.-Kunkel.

Hippomedon serratus Holmes.

Holmes, I905, p. 473 (sp. nov.); Rathbun, I905, p. 54 .

Newport.-Holmes.

Hoplonyx cicada Fabricius.

Holmes, 1905, p. 474; M. J. Rathbun, 1905, p. 54. Often taken in considerable numbers near Woods Hole; from 20 fathoms down.-Holmes. Off Marthas Vineyard on trawl line.-Rathbun. Woods Hole, in surface tow, January I3, r905 (many). $\ddagger$

Lysianopsis alba Holmes. [Chart 85.]

Holmes, I905, p. 475 (sp. nov.); M. J. Rathbun, I905, p. 55 .

Eel Pond, Nobska.-Holmes. Eastern half of Vineyard Sound, at II stations; dredged only twice elsewhere; dredged in 4 to $I_{3}$ fathoms on bottoms of sand and gravel.-Survey. Common also in mud.-Holmes.

Fish Hawk stations*: $752 \mathrm{r}$ bis (2), 7532 bis (7), 7537 bis (I), 7549 bis (I), 7748 (I with eggs), 775 I (I), 7764 (I), 7776 (I), 7780 (I), 7782 (I with eggs).

Phalarope stations: $6_{3}(4)^{*}$, I20 (I) †, I32 (2) †.

Lysianassa sp.

Verrill and Smith, 1873, p. 556, 43I, etc.

Several times dredged in Vineyard Sound and Buzzards Bay.
Family PONTOPOREIDAE.

Haustorius arenarius (Slabber) [Chart 86.]

Verrill and Smith, 1873, p. 556, 339, etc. (Lepidactylus dytiscus); S. I. Smith, I882 b, p. 280 (Lepidactylus arenarius); Holmes, I905, p. 476; M. J. Rathbun, I905, p. 55 .

Vineyard Sound.-Smith. Newport.-R a thbun. Smith states that this form frequents sandy shores, agreeing in its habits with Hippa; that it is likewise taken in 5 to Io fathoms, on sandy bottoms. Dredged by the Survey at scattered stations throughout Vineyard Sound; only one record for Buzzards Bay, near Cuttyhunk; taken in I to $I_{5}$ fathoms, chiefly on sandy bottoms. Recorded from shore collections at Katama Bay $\ddagger$ and Tarpaulin Cove $\neq$.

Fish Hawk stations: $7568(\mathrm{I}) \dagger, 7704(4)^{*}, 7705$ (I)*, 7726 (I)*, 7727 (I small)*, 7779 (I)*.

Phalarope and Blue Wing stations: 33 (x small) $\dagger$, $37(\mathrm{I})^{*}, 42$ (I)*, 5I (I)*, 55 (I) †, 99 (I small)*.

\section{Family Phoxocephalide.}

Phoxocephalus holbolli (Kröyer).

Verrill and Smith, I873, p. 556, 50r (Phoxus Kroyeri); Holmes, r905, p. 477; M. J. Rathbun, 1905 , p. 56 .

Vineyard Sound; rare, and usually in deep water.-Smith. Newport.-Rathbun. Phalarope stations $127 \dagger$ (Quisset Harbor), and $160^{*}$ (west shore of Buzzards Bay).--Survey.

Paraphaxus spinosus Holmes.

Holmes, I905, p. 477 (sp. nov.); M. J. Rathbun, I905, p. 56 .

Newport, taken by S. D. Judd.-Holmes. Western end of Vineyard Sound, at Fish Hawk stations $7686^{*}$ and $7723+$; surface tow at Bureau of Fisheries wharf, June, I906 $\neq$ J July, I905†; October, I905 $\ddagger$.

Harpinia plumosa (Kröyer).

Holmes, I905, p. 478; M. J. Rathbun, I905, p. 56. South of Marthas Vineyard, from 20 fathoms down.-Rathbun. It is possible that this does not occur within the region.

Urothoësp.

Verrill and Smith, 1873 , p. 556 .

"A species ... apparently belonging to this genus, was taken in great numbers at the surface at Woods Hole, on the evening of July 3, and on one or two other occasions. "-Smith. 


\section{Family Aureliscide.}

Ampelisca macrocephala Lilljeborg. [Chart 87.]

Verrill and Smith, I873, p. 56I (Ampelisca sp.); Verrill, I875a, p. 38; Holmes, I905, p. 479; M. J. Rathbun, I905, p. 56 .

Common and of general distribution in Buzzards Bay; in Vineyard Sound taken only at Tarpaulin Cove and Menemsha Bight; dredged at depths of from 2 to 12 fathoms, on bottoms of mud and muddy sand.- Survey. Also recorded from Wareham River $\ddagger$ and from Bay end of Robinsons Holet. The local distribution of this species is extremely interesting in comparison with that of $A$. spinipes. Listed for Newport by Rathbun.

Fish Hawk stations: $760 \mathrm{r}(\mathrm{I}) \dagger, 76 \mathrm{I} 2$ (few) ${ }^{*}, 76 \mathrm{I} 3$ (about I2)*, 76r4 (I)*, 76r6 (I)*, 76r8 (few)*, $7620(\mathrm{I})^{*}, 7622(2) \dagger, 7625(3)^{*}, 7640(2)^{*}, 7648$ $(2)^{*}, 7650(\mathrm{few})^{*}, 76_{51}(\mathrm{I})^{*}, 76_{52}$ (several)*, $7653(\mathrm{I})^{*}, 7655(\mathrm{I})^{*}, 7668(3)^{*}, 7675(4)^{*}, 7724$ $(2)^{*}, 7730$ (I)*. Supplementary stations (1909) $\ddagger: 76 \mathrm{r}_{5}$ (I), $76_{3} 6$ (4), 7645 (2), also several unchartered Bay stations.

Phalarope stations: I9 (many)* 78 (few)* 79 $(\mathrm{I})^{*}, 95(2)^{*}, 107$ (several)* $)^{*}, 2_{3}(\mathrm{I})^{*}, I_{3} 8(\mathrm{I})^{*}$, I 5 I $(2) \dagger$, I 52 (3 small)*, I62 (6)*, I66 (I $)^{*}$. Supplementary station I65 (I909) $\ddagger$.

Ampelisca spinipes Boeck. [Chart 88.]

Holmes, I905, p. 480; M. J. Rathbun, I905, p. 57.

Woods Hole, Newport.-Holmes. Common and of general distribution throughout both Vineyard Sound and Buzzards Bay; dredged in 2 to I9 fathoms, chiefly on bottoms of sand or sandy mud.-Survey.

Fish Hawk stations: $75^{21} \mathrm{I}(\mathrm{I})^{*}, 75^{25}(2) \dagger, 75^{25}$ bis $(3)^{*}, 7532$ bis $(I)^{*}, 7533$ bis $(2)^{*}, 7535$ (many) $\dagger$, $7536(\mathrm{I}) \dagger, 7537$ bis $(2)^{*}, 754 \mathrm{I}$ bis $(\mathrm{I})^{*}, 7546$ bis (I) †, 7549 bis $(\mathrm{I})^{*}, 755^{2}(\mathrm{I}) \dagger, 7554$ bis (I)*, $75^{6} 5$

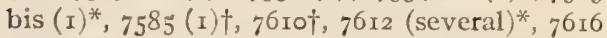
$(\mathrm{I})^{*}, 7625$ (several young) $\dagger, 7629$ (I small $)^{*}, 7630$ $(2)^{*}, 7640$ (? I small)*, 7642 (I small)*, 7648 (I)* ${ }^{*} 6_{52}$ (several)*, 7653 (2 small females), $7659(2) \dagger, 767$ I (I)*, 7680 (several)†, 7682 (2)*, $7683(\mathrm{I})^{*}, 7686\left(\right.$ several) ${ }^{*}, 7698(\mathrm{I})^{*}, 7710(\mathrm{I})^{*}$, 7724 (several) ${ }^{*}, 7725 \dagger, 7730(3)^{*}, 7732$ (I)* $775^{\circ}(2) \dagger, 775^{1}(2)^{*}, 775^{2}(2 \text {, I with eggs })^{*}$, 7759 (2) †. Supplementary stationst: (I906) 7748; (1909) 7627, 7636, 7659, 7668.

Phalarope stations: I (few) $\dagger, 64(I)^{*}, 74(I)^{*}, 75$ $(3)^{*}, 84(\mathrm{I})^{*}, 95(\mathrm{I})^{*}, \mathrm{II}_{4}(\mathrm{I})^{*}, \mathrm{I} 23(\mathrm{I})^{*}, \mathrm{I}_{3} \mathrm{I}(\mathrm{2}) \dagger$, I $54(2)^{*}$, I $59(I)^{*}, I 60(I)^{*}, I 63(2)^{*}, I 65(I)^{*}$. Supplementary stations (Ig09) $\neq: 83,165$.
Ampelisca compressa Holmes.

Holmes, 1905, p. 480 (sp. nov.); M. J. Rathbun, I905, p. 57.

Vineyard Sound, Newport.

Ampelisca agassizi (Judd).

Judd, I896, p. 599 (Byblis agassizi); Holmes, I905, p. 48I; Rathbun, I905, p. 57 .

Newport, June 20, about a dozen specimens taken.-Judd.

\section{Ampelisca sp.}

Fish Hawk station 7728; Phalarope station I02.

Byblis serrata Smith. [Chart 89.]

Verrill and Smith, 1873 , p. 561, 50r (sp. nov.); Judd, I896, p. 596; Holmes, I905, p. 482; M. J. Rathbun, 1905, p. 58.

Deep water off Vineyard Sound and Buzzards Bay, fine compact mud and sand, 20 to 29 fathoms.-Smith. Newport.-Judd. Common at western end of Vineyard Sound; scattered stations elsewhere, including a few in Buzzards Bay; dredged in 3 to ig fathoms, chiefly on sandy bottoms.-Survey.

Fish Hawk stations: 7584 (I)†, $75^{85}$ (2)*, 7586 (I) $\dagger^{*}, 76 \mathrm{I6}(\mathrm{I})^{*}, 762 \mathrm{I}(\mathrm{I})^{*}, 7668(\mathrm{I})^{*}, 7679(\mathrm{I})^{*}$, 7680 (several)†, $7682(\mathrm{I})^{*}, 7683^{*}, 7685(2)^{*}$, 7686 (I female) $^{*}, 7687$ (few) ${ }^{*}, 7698$ (I)*, 7709 $(\mathrm{I})^{*}, 77$ 10 $(\text { many })^{*}, 7730(4)^{*}$.

Phalarope stations; 55 (several) $\dagger, 63(\mathrm{I})^{*}$, I30 $(\mathrm{r})^{*}$.

\section{Family STEgOCEPHALIDIE.}

Stegocephalus inflatus Kröyer.

Holmes, I905, p. 482; M. J. Rathbun, I905, p. 59.

Near Woods Hole.-Holmes. Woods Hole in surface tow, September ro* (collected by V. N. Edwards).

\section{Family STENOTHOIDA.}

Stenothoë cypris Holmes.

Holmes, I905, p. 485 (sp nov.); M. J. Rathbun, I905, p. 60.

Woods Hole on piles, September, I900; among masses of Pennaria from Grassy Island.Holmes.

\section{Stenothoë minuta Holmes.}

Holmes, I905, p. 485 (sp. nov.); M. J. Rathbun, I905, p. 60.

Woods Hole on piles and among seaweed.Holmes.

Fish Hawk stations: $755^{2}$ bis (I), 7760 (about I2).

Females with eggs taken in August and September--Kunkel. 


\section{Family GeDICERIDAE.}

Monoculodes edwardsi Holmes.

Holmes, I905, p. 488 (sp. nov.); M. J. Rathbun, r905, p. 6r.

Woods Hole, a single specimen taken by V. N. Edwards; taken by Judd, at Newport.Holmes. Woods Hole, in surface tow, January I I, Ig06‡.

\section{Monoculodes sp.}

Verrill and Smith, I873, p. 556 .

A single specimen which was referred to this genus was taken in Vineyard Sound, December $2 \mathrm{I}$, by V. N. Edwards.

\section{Family PARAMPHITHOIDIA.}

Sympleustes latipes (Sars).

Holmes, I905, p. 490 (not listed for local waters).

One small specimen, thus identified by Dr. Kunkel, was dredged at Fish Hawk station 7718.

Sympleustes glaber (Boeck).

Holmes, I 905 , p. 490 (not listed for local waters); M. J. Rathbun, I905, p. 62 (listed only from Eastport, Me.).

One specimen, thus identified by Dr. Kunkel, was taken at Woods Hole, in surface tow, June 2I, Igor.

\section{Family LAFYSTIDA:}

\section{Lafystius sturionis Kröyer.}

Verrill and Smith, I873, p. 557, 457; Holmes, I905, p. 492; M. J. Rathbun, I905, p. 63.

From the mouth of a goosefish (Lophius piscatorius) taken in Vineyard Sound.-Smith. Seven specimens $\ddagger$ taken by Mr. Edwardsfrom the gills of Lophius, November 24, I904; 5 others $\div$ from the same host, October 20, rgo5; 7 others $\div$ in surface tow at Woods Hole, October 20, I904. Each lot contained females with eggs.

\section{Family CaLLIOPIIDAE.}

Calliopius laviusculus (Kröyer). [Chart 9o.]

Verrill and Smith, 1873 , p. 557,3 I5, etc.; ? Judd, I896, p. 593 (Calliopius rathkei); Bumpus, I898b; Holmes, I905, p. 494; M. J. Rathbun, I905, p. 64 .

Western end of Vineyard Sound, Robinsons Hole, one station near West Chop; dredged in 2 to $I_{7}$ fathoms on bottoms of sand and stones.--Survey. Recorded locally in surface tow during at least eight months of the year $\ddagger$; also collected along shore at various points in the vicinity $+;$ abundant on a piece of floating gulfweed, taken in July. $\dagger$
Calliopius laviusculus-Continued.

Fish Hawk stations: 7525 bis (I)* 7685 (few)*, 770 r (many small)*, 7707 (few) $\dagger, 77^{*} 3^{*}, 7725$ (r), * 7728 (2), * 773 I (few small). $\dagger$

Phalarope and Blue Wing stations: $20(\mathrm{I}), \dagger 2 \mathrm{I}$ $(\mathrm{I})^{*}, 44(\mathrm{I})^{*}, 45$ (several) $^{*}, 46(3)^{*}, 47(\mathrm{I})^{*}, 48$ $(\mathrm{I})^{*}$.

Females with eggs taken in tow throughout the year--Kunkel.

This species has been taken from the stomach of a tomcod (Smith), and from an anchovy (Cole).

Apherusa gracilis Holmes.

Holmes, I905, p. 495 (sp. nov.); M. J. Rathbun, 1905, p. 65 .

Off Gay Head, 2 specimens.

Pontogenia inermis (Kröyer). [Chart 9r.]

Verrill and Smith, I873, p. 557, 519; Holmes, I905, p. 496; M. J. Rathbun, I905, p. 65.

Surface of Vineyard Sound in March.-Smith. Western end of Vineyard Sound, common; few records elsewhere; dredged at from 2 to 17 fathoms, chiefly at depths of 8 fathoms or more; for the most part on sandy bottoms.- Survey. Also reported for tide pools, and in local tow, April and May.

Fish Hawk stations: $7594 \uparrow, 7676(\mathrm{x}) \dagger, 7678$ (several) $\ddagger, 7685$ (several) $^{*}, 7686$ (young) $†, 7689$ $(2)^{*}, 7690$ ( I small $)^{*}, 7698(4)^{*}, 7699(\mathrm{I}) \dagger, 7700$ (?r), 7701 (many small)*, $7702(2) \dagger, 7706(3) \dagger$, 7707 (few)†, $7709(6)^{*}, 7718$ (I) $\neq, 7719$ (I)*, 7720 (4 young) †, 7723 (I) $\ddagger, 7725$ (several)*, 7728 (many)*, 7729 (several)†, 7730 (rosmall)*, 773 I (many small)*, 7777 (I young)

Phalarope stations: $5^{8}$ (I)*, 87 (I male) $)^{*}$, I03 $(\mathrm{I})^{*}, \operatorname{III}(\mathrm{I})^{*}$.

\section{Family ATYLIDE.}

Dexamine thea Boeck.

Holmes, I905, p. 498; M. J. Rathbun, I905, p. 66. Woods Hole, a female carrying eggs, June 25.Holmes. Phalarope station 37 (Sow and Pigs Reef), 2 specimenst. Robinsons Hole, on weed from wharf pile, January 5, I905 $\neq$ (collected by V. N. Edwards).

\section{Family BATEIDF.}

Batea secunda Holmes. [Chart 92.]

Holmes, I905, p. 499 (sp. nov.); M. J. Rathbun, Ig05, p. 66.

Near Woods Hole; off Nobska, in about 6 fathoms.-Holmes. Vineyard Sound, common, chiefly in eastern half; one station near middle of Buzzards Bay; dredged in 4 to $I_{3}$ fathoms, chiefly on bottoms of sand and gravel.-Survey. Also recorded from surface tow, Woods Hole Harbor, May and Octoberł 
Batca secunda-Continued.

Fish Hawk stations: $75^{2} 7$ bis (I) ${ }^{*}, 7539$ bis $\dagger, 7549$ bis (few)*, $755^{2}$ bis (few) †, 7553 bis (5) $\neq, 7554$ bis $(I) \dagger, 7563$ bis $(3)^{*}, 7564$ bis $(3)$ †, 7612 †, $7732^{*}$, $7739(3)^{*}, 7753(2)^{*}, 7754$ (I)†, $7755(\mathrm{I})^{*}, 7760$ $(\mathrm{I})^{*}, 7764(3) \dagger, 7766(3) \dagger, 7768 \dagger, 7769$ (several) $\dagger$, $7770(6)^{*}, 7772(3) \dagger, 7775 \ddagger, 7776(3)^{*}, 7778$ (1 with eggs)* 7783 (few)*.

Females with eggs taken in August.-Kunkel.

\section{Family Gammaride.}

Gammarus locusta (Linnæus).

Verrill and Smith, I873, p. 557, 3I4, etc. (Gammarus ornatus); Holmes, 1905, p. 500; M. J. Rathbun, I905, p. 67 .

Distribution general along shores, between tides. Recorded for a considerable number of points on shores of Buzzards Bay and Vineyard Sound; taken in surface tow in December and June. Dredged by the Survey at a few stations, in 2 to 5 fathoms.

Blue Wing stations* (all at Gay Head): 45 (2 small), 47 (few), 48 (I).

Femaies with eggs taken in August.-Kunkel.

Gammarus annulatus Smith. [Chart 93.]

Verrill and Smith, 1873, p. 557,314 , etc. ( $G$. annulatus, sp. nov.), 558, 439 , etc. (G. natator); Holmes, I905, p. 501; M. J. Rathbun I905, p. 67.

Vineyard Sound, under stones, among rockweed, etc., on shore; also in vast numbers at the surface, usually among floating weed.-Smith. Nine scattered stations in Vineyard Sound; one in Quicks Hole; none in Buzzards Bay; dredged in $I \frac{I}{2}$ to $I 3$ fathoms.- Survey. Also recorded from Round Hill Point, between tidest; and in surface tow at Woods Hole + , for the months of January, March, April, May, June, July, and December.

Fish Hawk stations: $75^{25}$ bis $(5)^{*}, 7547$ bis (I) $\dagger$, 755 I (I) †, 7554 (3) †, 7557 (many) †.

Phalarope and Blue Wing stations: $3(20)^{*}, 29$ $(\mathrm{I})^{*}, 33$ (I small)†, $49^{*}, 5^{\text {I }}$ (I) †.

Females with eggs recorded for April, May, and June.-Kunkel.

Smith records the occurrence of this species in the stomach of the haddock, tomcod, herring, and mackerel.

Gammarus marinus Leach.

Verrill and Smith, I873, p. 559, 3I4, etc.; Holmes I905, p. 502; M. J. Rathbun, I905, p. 67.

Woods Hole, Weepecket, Cuttyhunk, and other places in Vineyard Sound and Buzzards Bay; Newport. Under stones, below high-water mark; sometimes abundant.
Carinogammarus mucronatus (Say).

Verrill and Smith, I873, p. 559, 37o, etc. (Gammarus mucronatus); Holmes, I905, p. 503; M. J. Rathbun, I905, p. 68.

Of general distribution. Eel Pond*, New Bedford Harbor $\neq$, West Falmouth Harbor $\ddagger$, Katama Bay $\ddagger$, head of Lagoon Pond $\ddagger$. Newport.-Rathbun. Found upon algæ and among eelgrass, even in brackish waters.

Females with eggs recorded August, I906.

Smith records the occurrence of this species in the stomach of the tomcod and spotted flounder (Lophopsetta maculata).

\section{Melita dentata (Kröyer).}

Holmes, I905, p. 504; M. J. Rathbun, 1905, p. 68 (no local records).

Buzzards Bay.-Holmes.

Melita nitida Smith.

Verrill and Smith, 1873, p. 560, 314, etc. (sp. nov.); Holmes, I905, p. 505; M. J. Rathbun, r 905 , p. 69 .

Woods Hole, near "breakwater."-Holmes. Beneath stones and among rockweed at low tide; among eelgrass in brackish waters.Smith. Specimens identified by Dr. Kunkel from shore collections at Wareham River and West Falmouth Harbor, August, I9o6.

\section{Melita parvimana Holmes.}

Holmes, I905, p. 506 (sp. nov.); M. J. Rathbun, I905, p: 69 .

A single specimen taken by S. D. Judd at Newport.

\section{Elasmopus lavis (Smith). [Chart 94.]}

Verrill and Smith, I873, p. 559, 3I5, etc. (Mora lavis, sp. nov.); Holmes, I905, p. 507; M. J. Rathbun, I905, p. 69.

Vineyard Sound, beneath stones and among rockweed at low tide.-Smith. Pretty generally distributed throughout Vineyard Sound, especially at inshore stations; taken a few times along the eastern shore of Buzzards Bay; dredged for the most part at depths of ro fathoms or less (2 to $1_{3}$ ) on bottoms of sand, gravel, and stones.-Survey. Recorded from shore collections $\ddagger$ at Nobska Point, Katama Bay, Wareham River, and New Bedford Harbor.

Fish Hawk stations: $75^{2} 5$ bis $(2)^{*}, 754 \mathrm{I}$ bis ( $\mathrm{I}$ with eggs)* 7547 bis $(\mathrm{I})^{*}, 755^{2}$ bis $(\mathrm{x})^{*}, 7553$ bis (2),$+ 75^{64}$ bis (r small)†, $7706^{*}, 7721(2) \dagger$, 7725 (I)十, 773I (I)*, 775 I (I small)*, 7764 (few, mostly small)* 7767 (I) ${ }^{*}, 7768$ (several) $^{*}$, 7775 (I small)*. 
Elasmopus.lavis-Continued.

Phalarope and Blue Wing stations: $8(2)^{*}, 20$ (3) †, 2I (2)*, 22 (I small) $)^{*}, 32(4)^{*}, 34$ (few)*, 37 (few $)^{*}, 44(\text { I })^{*}, 45(2)^{*}, 48$ (I male) ${ }^{*}, 49(2)^{*}$, $63(3)^{*}, 67(2)^{*}, 73\left(2\right.$ very small)*, $77(I)^{*}$, II 2 $(3)^{*}, \operatorname{II} 7(2) \dagger$, I 3 I $(\mathrm{I})^{*}$.

Females with eggs noted in August.-Kunkel.

Gammarellus angulosus (Rathke).

Holmes, I905, p. 508; M. J. Rathbun, 1905, p. 70. (By neither of these writers is this species recorded for the region.)

Taken by the Survey at Blue Wing stations 47 $\left(\right.$ few) ${ }^{*}$, and $5^{\mathrm{I}} \dagger$ (very many); both at Gay Head in less than 2 fathoms of water.

\section{Family Protrdas:}

Microdeutopus gryllotalpa Costa.

Verrill and Smith, I8I3, p. 562, 479, etc. (Microdeutopus minax); Holmes, I905, p. 5x4; M. J. Rathbun, I905, p. 70.

Vineyard Sound, sometimes abundant on eelgrass in brackish ponds.-Smith. Eel Pond, common.-Holmes, Cole. Identified by Dr. Kunkel in shore collections made at Katama Bay on sand flat, Robinsons Hole, New Bedford Harbor on algæ from rocks, West Falmouth Harbor.

Many females with eggs taken in August.-Kunkel.

Microdeutopus danmonensis (Bate).

Holmes, I905, p. 5I5; M. J. Rathbun, I905, p. 70.

Eel Pond, common.-Holmes. Near Naushon; eastern side of Buzzards Bay, at 2 stations; dredged in 4 to 5 fathoms of water-Survey. Collected, also, upon piles at Woods Holef and Vineyard Havent, and from shore in West Falmouth Harbor $\neq$.

Fish Hawk station 7537 bis $(I)^{*}$.

Phalarope stations: $\operatorname{II}_{7}$ (I male)*, I32 (5) $\dagger$.

Females with eggs taken in August.-Kunkel.

Microdeutopus sp.

Phalarope stations: $127 \dagger$ (Quisset Harbor), I $_{5} 8^{*}$ (Wareham River).

Autonö̈ smithi Holmes. [Chart 95.]

Verrill and Smith, I873, p. 562, 4I5 (Autonoë sp.); Holmes, I905, p. 5 I6 (sp. nov.); M. J. Rathbun, I905, p. 7I.

Vineyard Sound, common; found "in tubes in masses of a compound ascidian (Amouroucium pellucidum Verrill) in 3 to 8 fathoms."'-Smith. Eastern half of Vineyard Sound, at II stations; eastern shore of Buzzards Bay (upper half); only taken once elsewhere; dredged in 3 to $I_{3}$ fath:
Antonoë smithi-Continued.

oms, chiefly on bottoms of sand and gravel. Survey. Collected, also, at Wareham wiver, August 15, $1906 \ddagger$.

Fish Hawk stations: $752 \mathrm{I}$ bis (I)* ${ }^{*}, 7544$ (I)†, $76 \mathrm{I6}(\mathrm{I})^{*}, 7700$ †, 7732 (several)* $773^{*}(\mathrm{I})^{*}$, $7739(4)^{*}, 7757(2)^{*}, 7759(\mathrm{I}) \dagger, 7764(2)^{*}, 7776$ $(\mathrm{I})^{*}, 7777(4) \dagger, 7782$ (I)†.

Phalarope stations: II7 (I) †, II8 (I)* I 44 †, I47 $(I)^{*}$.

Ptilocheirus pinguis Stimpson. [Chart 96.]

Verrill and Smith, I873, p. 561, 431, etc.; Holmes, I905, p. 522; M. J. Rathbun, I905, p. $7 \mathrm{I}$.

Common and generally distrbuted in Buzzards Bay; common, though less general, in Vineyard Sound; dredged in 3 to $I 7$ fathoms, on bottoms of mud or sand.-Survey. Recorded, also, from a number of uncharted stations in Buzzards Bay; head of Lagoon Pond, between tides; surface tow, Woods Hole, December.

Fish Hawk stations: 7533 bis $(2)^{*}, 7537$ bis (several medium and small)*, $75^{86}$ (many) $\uparrow, 7605$ (I) $\dagger, 76$ I $2(\mathrm{few})^{*}, 75 \mathrm{I}_{3}(8)^{*}, 76 \mathrm{I}_{4}(\mathrm{I})^{*}, 76 \mathrm{I} 8$ (few)*, $76 \mathrm{rg}(\mathrm{I})^{*}, 762 \mathrm{I}(3)^{*}, 7622$ (few)†, 7625 (I small)*, $7629(\mathrm{I})^{*}, 7638(2)^{*}, 7640(\text { many })^{*}, 7643(5)^{*}$, $7644(5)^{*}, 7648(\mathrm{I})^{*}, 7650(3)^{*}, 765$ I (II)* $765_{2}$ (about 30$)^{*}, 7655$ (many)*, 7656 (many)*, 7657 (many)†, $7662(\mathrm{I})^{*}, 7668(7)^{*}, 7669(2)^{*}, 767 \mathrm{I}$ $(2)^{*}, 7673(\text { about } 12)^{*}, 7674(\mathrm{I})^{*}, 7685$ (many) $^{*}$, 7686 (many) ${ }^{*}, 7687$ (many) ${ }^{*}, 7688$ (many) $\dagger$, $7689(2)^{*}, 7724$ (many)* $7726(\mathrm{I})^{*}, 77^{*} 8$ (I moult) $\dagger$. Supplementary stations (Ig09) $\ddagger: 7636$ (12), 7643 (6), 7645 (8), 7659 (I).

Phalarope stations: I (few) $\dagger, 8(2)^{*}$, I9 (many) ${ }^{*}$, 78 (very many) $\dagger, 79(\mathrm{few})^{*}, 84(\mathrm{I})^{*}, 9 \mathrm{I}$ (several $)^{*}, 95(2)^{*}$, I00 (several $)^{*}$, IO2 (many)* 103 $(\mathrm{I})^{*}$, I IO $(5)^{*}$, II $4(2)^{*}$, I $20(\mathrm{I})^{*}, \mathrm{I} 27(\mathrm{I})^{*}, \mathrm{I} 28$ $(3)^{*}$, I $60(6)^{*}, I 62(3)^{*}, I 65(7)^{*}$. Supplementary stations (Ig09) †: 83 (I), I65 (many).

Podoceropsis nitida (Stimpson).

Holmes, I905, p. 524 (no local records); MI. J. Rathbun, I905, p. 7 I (no local records).

One female specimen, bearing eggs, taken at Fish Hawk station $7722^{*}$, in Vineyard Sound, near Gay Head, I3 fathoms, sand.

\section{Family PODOCERIDA,}

Amphithö̈ rubricata (Montagu). [Chart 97.] Verrill and Smith, 1873, p. $563,3^{15}$, etc. (Amphithoe valida and $A$. maculata); Holmes, I905, p. 5ro; M. J. Rathbun, 1905, p. 72. 
A mphithoë rubricata-Continued.

Inshore stations of Vineyard Sound, common; Quicks Hole and Robinsons Hole; a few stations on the eastern shore of Buzzards Bay; dredged chiefly at depths of less than 6 fathoms ( 1 to $I_{3}$ ), on bottoms of sand, gravel, and stones; almost exclusively confined to the adlittoral stations.-Survey. Recorded also from Nobska Point and Cedar Tree neck $\ddagger$, August, I906; Woods Hole, in surface tow, October 2, I904t. Some of the foregoing specimens were females with eggs. Smith notes that this species dwells in tubes of gravel, seaweed, etc., attached to under side of stones at low-water mark; also on Ulva, and among eelgrass on muddy shores.

Fish Hawk stations: $75^{2} 5$ bis (2 small) ${ }^{*}, 7536$ (5)†, 7537 bis (several) ${ }^{*}, 7656(\mathrm{I})^{*}, 7720(\mathrm{I})^{*}$, $7730(\mathrm{I})^{*}, 773^{\text {I }}$ (several)*,775I (2)*. Supplementary stations (I906): 7525t; (Ig09): 7670 (I) $\ddagger$.

Phalarope and Blue Wing stations: I (few) $\dagger, 20$ $(5) \dagger, 2$ I $(2)^{*}, 22$ (few)*, 25 (many)*, $29(6) *, 30$ (few)*, 32 (several)*, 33 (Io)*, 34 (few)*, 37 (few)*, $44(3)^{*}, 45$ (few)*, 46 (4 small)*, 47 (I)*, 48 (many)*, 49 (I with eggs)*, 5I (several)*, 55 (2)†, $5^{8}$ (many)*, $63(4)^{*}, 67(2)^{*}, 69(5)^{*}, 73$ $(3)^{*}, 74(2)^{*}, 77$ (I)*, 86 (2 with eggs)*, 87 (very many) $\dagger$, I00 $(2)^{*}, \operatorname{III}(\mathrm{I})^{*}$, II2 (2 small)*, I 6 (many medium and small) $\dagger$, I34 (3 small)*. Supplementary station (I909): $83 \ddagger$.

Amphithoë longimana Smith.

Verrill and Smith, I873, p. 563, 370, etc. (sp. nov.); Holmes, I90r, p. I65; I905, p. 509; M. J. Rathbun, I905, p. 72.

Vineyard Sound, common among eelgrass in sheltered situations; young taken at surface.Smith. Woods Hole.-Holmes. Newport.Rathbun. One specimen dredged by the survey at Phalarope station 137 , in Buzzards Bay, near West Falmouth. Recorded from eelgrass in the Eel Pond (many)*; surface tow at end of Bureau of Fisheries pier*; from algx, etc., on shores of Nobska Point $\ddagger$, New Bedford Harbor pier, Woods Hole $\ddagger$.

Sunamphitoë pelagica (Milne Edwards).

Specimens thus identified by Dr. Kunkel were dredged at a 1906 repetition of Fish Hawk station 7723; also taken upon gulfweed, in Vineyard Sound, August and September, 1906; and in surface tow, at Woods Hole, October ro, I905. All of these lots contained females with eggs.
Ischyrocerus anguipes Kröyer.

Verrill and Smith, I873, p. 565, 493, etc. (Podocerus fucicola); Holmes, I905, p. 5I3; M. J. Rathbun, 1905, p. 72. (No local records given by any of these writers.)

Gay Head, at Blue Wing stations $44(2)^{*}$, and 52 (I small)*; 3 to 7 fathoms.-Survey. Also recorded from nets at Menemsha Bight $\neq$.

? Podocerus falcatus (Montagu).

Bumpus, I898b; M. J. Rathbun, I905, p. 73.

Vineyard Sound, surface; determined with doubt by S. I. Smith.-Rathbun.

Taken with eggs during last two weeks of July and first two weeks of August.-Bumpus.

Dr. Holmes believes that Jassa marmorata is the species here intended.

Jassa marmorata Holmes. [Chart 98].

Holmes, I905, p. 5II (sp. nov.); M. J. Rathbun, I905, p. 73 (Podocerus marmoratas).

Narragansett Bay.--Holmes. Gay Head at 7 stations, Robinsons Hole, Cuttyhunk, Sow and Pigs Reef, a few other points in Vineyard Sound, but no records for the Bay; dredged in I to $I_{3}$ fathoms, on bottoms of sand, gravel, and stones.-Survey. Recorded also from piles at Woods Holef, Vineyard Haven+, Robinsons Holef, and Menemsha Bightł; from shore collections at Robinsons Holef and Cedar Tree Neck; and from surface tow, Woods Holeł, December II, I905. One specimen taken from stomach of anchovy caught at Menemsha Bight

Fish Hawk stations: 7537 bis (I)*, $7723(2) *, 7745$ (I)*.

Phalarope and Blue Wing stations: 20 (few) $\dagger, 2$ I $(2)^{*}, 22(\mathrm{I}) *, 30(\mathrm{I}) *, 34$ (few)*, 37 (3 very small)*, 44 (many)*, 45 (very many)*, 46 (many)*, 47 (many)*, 48 (I male, several females)*, $5^{\text {I }}$ (very many) $\dagger, 5^{8}$ (many)*.

Grubia compta (Smith).

Verrill and Smith, 1873 , p. 564, 370, etc. (Amphithoë compta, sp. nov.); Bumpus, I $898 \mathrm{~b}$ (Amphithoë compta); Holmes, I905, p. 510; M. J. Rathbun, 1905, p. 73 .

Vineyard Sound, found among eelgrass and on piles, likewise taken at surface.-Smith. Eel Pond.-Holmes. Upper half of Buzzards Bay at six inshore stations, Lackeys Bay, eastern end of Vineyard Sound (once); dredged in 2 to 5 (in one case 10 ) fathoms, on bottoms of sand, gravel, and mud.-Survey.

Recorded, also, from shore collections made at Katama Baył, Wareham River $\neq$, and Dumpling Rock Lightł. 
Grubia compta-Continued.

Fish Hawk station $7767^{*}$.

Phalarope stations: $8(2) \dagger$, I 8 (several) $\dagger$, I 30 $(4)^{*}, \mathrm{I}_{32}(\mathrm{I}) \dagger, \mathrm{I} 35(2)^{*}, \mathrm{I} 47(2)^{*}, \mathrm{I} 55$ (I female)*. Breeding throughout July and first week or two in August.-F. M. Watson, cited by Bumpus.

Ericthonius rubricornis (Stimpson).

Verrill and Smith, 1873, p. 565 (Cerapus rubri cornis); S. I. Smith, I882b, p. 278 (Ericthonius difformis); Holmes, I905, p. 518; M. J. Rathbun, 1905, p. 73.

Vineyard Sound, not common.-Smith. Common near Woods Hole; "lives in flexible tubes composed of sand or mud stuck together with a small amount of adhesive, weblike material." -Holmes. Vineyard Sound, at 8 scattered stations; not taken in the Bay; dredged mainly at depths of 10 to I 9 fathoms, on various bottoms.-Survey.

Fish Hawk stations: $75^{22}$ bis (? I female)* 7549 bis $(2) \dagger, 75^{6} 4$ bis ( 1 with eggs) $\dagger, 7606$ (several) $\dagger$, 7608 (I female)†, 7729 (several)†, 7730 (I female)*, 7735 (? I with eggs)*, 7746 (? I with eggs).*

Phalarope station 25 (? 2 females).*

Ericthonius minax (Smith). [Chart 99.]

Verrill and Smith, I873, p. 565 (Cerapus minax, sp. nov.); Holmes, I905, p. 5I9; M. J. Rathbun, I905, p. 74 .

Vineyard Sound.-Smith. Eel Pond; off Gay Head.-Holmes. Of general distribution throughout Vineyard Sound; only one record for Buzzards Bay, near its head; dredged in 4 to 16 fathoms, for the most part at depths of 8 fathoms or more, chiefly on bottoms of sand and gravel.-Sirvey.

Fish Hawk stations; 7524 bis (? 2)* 7525 bis (I male, several females)* 7539 bis (I male)*, 7546 bis $(\mathrm{I})^{*}, 755^{2}$ bis (several)*, $7554(\mathrm{I}) \dagger$, 7557 (2 females) †, $7560(2) \dagger, 75^{6} 3$ bis $(2)^{*}, 7569$ bis (I male) $)^{*}, 75^{82}(4) \dagger$ ?, $7606(2 \text { males })^{*}, 7632$ (I male)*, 7699 (? I female) $\dagger, 7704$ (I male)*, $7720(2)^{*}, 7723$ (many)*, 7724 (several)*, 7725 $(\text { several })^{*}, 7728(2)^{*}, 7730(4$ males, I female)* 773 I (few females)*, 7732 (few)*, 7739 (? I female)* 7740 (I male, I female)*, 7744 (I male, I female)*, 7745 (? several)*, $775 \mathrm{I}$ (few) ${ }^{*}, 775^{2}$ $(\text { ? })^{*}, 775^{8}(3)^{*}, 7759$ (several)*, 7760 (? I female)*, 7764 (many) ${ }^{*}, 7767$ (several) ${ }^{*}, 7768$ $(5)^{*}, 7769$ (several) $\dagger, 7775$ (several)*, 7777 (3) †. Supplementary stations $\ddagger$ (I906): 7567 (I), 7723 (I).

Phalarope stations: 63 (? I female) ${ }^{*}, 73(4)^{*}, 77$ (? 2 females).*

$$
\text { I6269 }- \text { Bull. } 31 \text {, pt } 2-13-8
$$

Ericthonius sp.

Fish Hawk stations: 7538 bis, 7553 bis, $76 \mathrm{r} 6$, 7734,7756 .

\section{Family COROPHIDA.}

Cerapus tubularis Say.

Verrill and Smith, 1873 , p. 565 (identification made doubtfully); S. I. Smith, I 882 b, p. 277 ; Holmes, I905, p. 517 (spelled C. tabularis); M. J. Rathbun, I905, p. 74 .

Vineyard Sound, 8 to ro fathoms, in Amouroucium pellucidum, several females carrying eggs.-Smith.

Siphonoceles smithianus Rathbun.

Verrill and Smith, 1873, p. 566, 50I, etc. (S. cuspidatus); Holmes, I905, p. $5^{22}$ (S. cuspidatus); M. J. Rathbun, I905, p. 74 (nom. nov.).

Taken in deep water off Vineyard Sound and Buzzards Bay, 20 to 29 fathoms, inhabiting tubes constructed of grains of sand.-Smith. Dr. Holmes has not encountered this species.

Corophium cylindricum (Say). [Chart Ioo.]

Verrill and Smith, 1873 , p. 566, 382, etc.; Holmes I905, p. 52 I; M. J. Rathbun, I905, p. 75.

Common and of general distribution in Vineyard Sound; taken at a few inshore stations on the lower haif of the eastern side of Buzzards Bay; dredged in from I to $x_{3}$ fathoms, on bottoms of sand, gravel, and stones, rarely in mud.-Survey. Recorded also from various points during the shore collecting. This species dwells in tubes, though frequently leaving these; it is found among weeds and hydroids, on piles and elsewhere, as well as in deeper waters.

Fish Hawk stations: $75^{24}$ bis $(2)^{*}, 75^{25}$ bis (few)*, 7535 bis $(I)^{*}, 7536(4) \dagger, 7537$ bis (many), 7539 bis $(\mathrm{I})^{*}, 755^{\mathrm{I}}$ bis (2), $755^{2}$ bis (several) $\uparrow, 7557$ (I with eggs)* $7560(\mathrm{I}) \dagger, 7640(\mathrm{I})^{*}, 7678_{+}^{+}, 7690$ $(\mathrm{I})^{*}, 7698(\mathrm{I})^{*}, 7699$ (very many) ${ }^{*}, 7700,770 \mathrm{I}$ $(\mathrm{I})^{*}, 7703(2) \dagger, 772 \mathrm{I}$ (several)†, $7722(\mathrm{I})^{*}, 7723$ $(\text { few })^{*}, 7724(\mathrm{few})^{*}, 77^{28}$ (many)*, $7730(2) \dagger$, 7732 (several)*, $7739(2)^{*}, 7744 \ddagger, 7745$ (many)*, $775^{\text {I }}$ (many) ${ }^{*}, 775^{2}$ (I male) ${ }^{*}, 7764$ (few) ${ }^{*}, 7765$ (many)†, 7767 (many)*, 7768 (many)t, 7769 (few) †, 777 I (few)*, 7772 (many)*, $7774(\mathrm{I})^{*}$, 7775 (few)*, 778I (I).*

Phalarope and Blue Wing stations: 8 (many)* 20 (several)*, 2 I (several)*, $22(3)^{*}, 25$ (many)*. $29(8)^{*}, 30(\mathrm{few})^{*}, 32$ (many) ${ }^{*}, 33(8)^{*}, 34$ (few) $)^{*}$, 37 (several $) *^{*}, 44$ (many) $^{*}, 45(\mathrm{I})^{*}, 46$ (several)*, $4^{8 \dagger}, 5$ I (I), $5^{2}(\mathrm{I})^{*}, 5^{8}(\mathrm{I})^{*}, 63(2)^{*}, 6 \%(3)^{*}$, $77(\text { few })^{*}, 87$ (many) $)^{*}$, IOO (many)*, I02 $(3)^{*}$, III $(\text { few })^{*}, \operatorname{II} 2(2)$ ** 
Corophium cylindricum - Continued.

Recorded from the stomach of an anchovy:L. J. Cole.

Females with eggs recorded for January, July, and August.-Kurikel.

Unciola irrorata Say. [Chart Ior.]

Verrill and Smith, 1873 , p. 567,340 , etc.; S. I. Smith, I882b, p. 280 ; Holmes, I905, p. 520; M. J. Rathbun, I905, p. 75 .

A tube-dwelling species, of very general distribution both in the Sound and the Bay; found on every sort of shore and bottom, from low water to the greatest depths in the region. Recorded from many points along shore, as well as from surface tow in April and May.

Fish Hawk stations: $75^{22}(2), 75^{22}$ bis (several)* $75^{24}$ bis $(4)^{*}, 75^{2} 5$ bis (I small)*, $75^{26}$ (I), 7534 (few), 7535 (3)†, 7535 bis (Io)*, 7537 (several), 7539 bis $(\mathrm{I})^{*}, 7543,7544$ (few), 7545 bis *, 7546 bis*, 7549 bis $(2)^{*}, 755^{I}(3) \dagger, 7554(2) \dagger, 7554$ bis $(\mathrm{I})^{*}, 755^{8}(\mathrm{2}), 7560$ (I), 7580 (I large), 760I (I), $76 \mathrm{I} 2(2)^{*}, 76 \mathrm{I} 3(2)^{*}, 76 \mathrm{I} 7(\mathrm{I})^{*}, 76 \mathrm{r} 8(\mathrm{I}), 7622$ (few) †, $7623(\mathrm{I}) \dagger, 7624(\mathrm{I})^{*}, 76_{32}(2)^{*}, 76_{34}(4)^{*}$, $7635(\mathrm{I})^{*}, 76_{3} 6(2 \text { large })^{*}, 7640(2)^{*}, 76_{51}(2)^{*}$, $7652(4)^{*}, 7653$ (several)*, 766I (I)* $7662(\mathrm{I})^{*}$, $7667(\mathrm{I})^{*}, 7668(\mathrm{I})^{*}, 7672^{*}, 7673(2)^{*}, 7675(\mathrm{I})^{*}$, 7678 (several) $^{*}, 7679(\mathrm{I})^{*}, 7680(\mathrm{I}) \dagger, 7682(2)^{*}$, $7683(\mathrm{I})^{*}, 7685$ (several) $^{*}, 7686$ (several) $^{*}, 7687$ (several) ${ }^{*}, 7700$ (young) $\dagger, 7701$ (several)*, 7702 $(3)^{*}, 7703$ (several) †, 77 I0 (I small)*, $7722(\mathrm{I})^{*}$, 7724 (few)*, $7725(2)^{*}, 7728$ ( 1 fragment) $\uparrow 7729$ (I)†, 7730 (2 small)*,773I (I small)*,7732 (many small)*, 7737 (I small) $\dagger, 773^{8}$ (several small) $\dagger$, 7740 (I small)*, 7744 (few small)* 7748 (I)*, 7749 (few small) $\dagger, 7753$ (few) ${ }^{*}, 7756$ (several small)*, $775^{8}$ (I small)*, 7759 (5)†, 7760 (many)*, 776I (4)*, 7765 (I small)*, 7766 (2 very small)*, $7767(\mathrm{I})^{*}, 7769(2)^{*}, 7770$ (few small)*, $7772(2)^{*}, 7773$ (several)*, $7774(2$ small)*, 7775 (several small)*, 7778 (2 small)*, 778 I (3 small)*, 7782 (2 young)*, 7783 (2 small)*. Supplementary stations (I909) $\ddagger: 76$ I 5 (I), 7627 (I), 7629, 7636 (few), 7643 (I), 7657 (I), $7668(\mathrm{I})$.

Phalarope and Blue Wing stations: I5 (4) $\dagger$, I9 $(\mathrm{few})^{*}, 2$ I (?), $5^{2}$ (I)*, 55 (I small)* 78 (few)*, 79 (several small)*, $80,84(4)^{*}, 86$ (I small)*, 95 (I)*, 99 (several small)*, Io7 (I), I I4 (2)*, II8 (I) †, I22 (I)*, I27 (several)*, I3I (I)*, I38 (I small)*, I47 (I $)^{*}$, I 58 (I)*, I6r (I small)*, I64 (I)*, I65 (2)*, I66 (I)*. Supplementary stations (I909) $\ddagger$ : 79 (few), I46 (I), I65 (I),

Smith reports the occurrence of this species in the food of the scup.

Females with eggs taken in May and August.Kunkel.
Family Cheluridas.

Chelura terebrans Philippi.

S. I. Smith, I879a, p. 232; Holmes, I905, p. 508; M. J. Rathbun, I905, p. 75 .

Woods Hole, two specimens recorded by Smith; apparently scarce locally. This amphipod burrows into piles, in association with Limnoria lignorum.

Family CAPRELLIDAE.

?Luconacia incerta Mayer.

P. Mayer, r9o3, p. 49 (sp. nov.); M. J. Rathbun, I905, p. 76.

Woods Hole, January, I882, one young female determined with doubt by Paul Mayer.

Eginella longicornis (Kröyer).

Holmes, I905, p. 525; M. J. Rathbun, 1905, p. 76 (Egina longicornis).

Common and generally distributed in Vineyard Sound, particularly at the western end; listed from only two stations in Buzzards Bay; dredged in 3 to $I 7$ fathoms, generally at depths of Io fathoms or more, for the most part on sandy bottoms.-Survey. Recorded, also, from surface tow at Woods Holet, and from fish pound at Menemsha Bightł. (See also records for "Caprellida sp. sp.".)

Fish Hawk stations: 7533 bis (few, taken from Asterias forbesi)* 7536 bis (?), 7537 bis (very many small, on Asterias vulgaris) ${ }^{*}, 7545$ bis*, 7547 bis (?), $755^{2}$ bis $(3)^{*}, 7554 \dagger, 7563$ bis $(3$ small)*, $7656(\mathrm{r}), 7676$ (several on Asterias)*, 7677 (few medium sized on algæ) ${ }^{*}, 7678$ $(\text { many })^{*}, 7679(2)^{*}, 7680$ (few large and small)* $768 \mathrm{I}$ (several)* 7685 (many large and medium)*, $7686(\text { few })^{*}, 7693(2)^{*}, 7698(4 \text { small })^{*}$, 7699 (many)*, 7700 (many)*, 770 or (many)*, 7702 (several), 7703 (many large and small)*, 7704 (several)* 7706 (very many, including one with eggs)*, 7707 (several large)*, 7709 (many)*, 77 I0 (?) ${ }^{*}, 7717$ (few medium sized)*, 7718 (several)*, 7720 (very many, mostly large)*, $772 \mathrm{I}(2)^{*}, 7722$ (several large), 7723 (many, mostly large)*, 7724 (few large and medium sized)*, 7725 (few, mostly large)*, 7726 (3 small)*, 7727 (several)*, 7728 (few large and medium)*, $7729(\mathrm{few})^{*}, 7730$ (very many, including one with eggs) ${ }^{*}, 773$ I (many)*, 7735 (4), 7739 (2)* 7745 (I small)*, 7764 (I small)*, 7778. ( I small $)^{*}$.

Phalarope and Blue Wing stations: I5 (many on Asterias forbesi)*, 22 (? few on Asterias forbcsi), $33(\mathrm{I})^{*}, 46$ (few) ${ }^{*}, 55$ (few large and medium on algx), $5^{8}(2)^{*}, r_{44}$ (several small)*.

A variety spinosissima Stimpson recorded by Holmes (p. 525), and Rathbun (p. 77). Taken at Crab Ledge (Fish Hawk station 7606$) \dagger$. 
Paracaprella tenuis Miaycr.

P. Mayer, I903, p. 68 (sp. nov.); MI. J. Rathbun, 1905, p. 77 .

Woods Hole. Described by Mayer from a number of specimens furnished by Prof. Whitman, dated July 30 , I89o.

Caprella geometrica Say. a

Verrill and Smith, I873, p. 567, 3r6, etc. ( $\mathrm{Ca}$ prella sp.-Verrill's records perhaps refer to more than one species); Mayer, I903, p. 87 (C. acutifrons); Holmes, I905, p. 526; M. J. Rathbun, r905, p. 77 (Caprella acutifrons).

"One of the most common species of amphipod on the southern coast of New England." Holmes. In the Survey dredging recorded from scattered stations throughout Vineyard Sound; from Gay Head (especially common), Robinsons Hole, Quicks Hole; recorded only once for the Bay, near lower end. (See also records for "Caprellida sp. sp.".) Dredged in I to $x_{3}$ fathoms, chiefly at depths of less than Io fathoms, and mainly on bottoms of sand, gravel, and stones, where it is usually found clinging to algæ, hydroids, etc. Common likewise among weeds, etc., growing on piles, and on eelgrass; on one occasion taken in great numbers among Obclia geniculata, from a floating plank in Vineyard Sound; Woods Hole, in surface tow

Fish Hawk stations: $755^{2}$ bis $(3)^{*}, 7554$ (I) $\uparrow$, $755^{6}(\mathrm{I})^{*}, 75^{6} 3$ bis (I)*, 7564 bis (I small) $\dagger$, $7724(\mathrm{I})^{*}, 7745(2)^{*}, 7764(3)^{*}, 7765(2 \text { small })^{*}$, 7768 (3 small)*, $778 \mathrm{I}$ (several)*

Phalarope and Blue Wing stations: 20 (several)*, 2 I $(2)^{*}, 22(2)^{*}, 29(2)^{*}, 44(\mathrm{few})^{*} 45$ (many, mostly large)*, 46 (many)*, 47 (several)*, 48
Caprella geometrica-Continued.

(I male) $^{*}, 5^{1}(2)^{*}, 5^{8}$ (I very small) ${ }^{*}, 87$ (I small)*.

Eggs observed in the brood pouch, July I5; maturing embryos found toward the end of the month.-J. P. McMurrich in Marine Biological Laboratory card catalogue.

Caprella linearis Linnæus.

Holmes, I905, p. 526 (not listed for local waters); M. J. Rathbun, I905, p. 78 (not listed for local waters).

Dr. Kunkel thus identifies specimens taken by Mr. Edwards in surface tow at Woods Hole, on several occasions in October and November, I905; likewise upon gulfweed and driftwood in Vineyard Sound.

Caprellide sp. sp.

Species of this family (doubtless in the main Caprella geometrica and Eginella longicomis) were taken at many points in Vineyard Sound, and occasionally in Buzzards Bay. It is necessary to list them as undetermined since these two species were at first confused in the records. For this reason the relative distribution of the two forms unfortunately can not be accurately portrayed.

Fish Hawk stations: 7545 (few), $755^{1}$ (many), $755^{2}$ bis ?, 7553 bis (I), 7557, 7560 (many), 7568,758 I (few), 7585 (I), 759 I (I), 7598 (many). Phalarope and Blue Wing stations: I6 ( 2 on Bugula), 20 (abundant among red algæ), 2 I (few on algæ), 22 (few on algæ), 33 ( 1 ), 36 (few) 44 (abundant), 45 (abundant on red algæ), 46 (abundant), 47 (common), 48, 5I (common on red algæ), 55 (several on Bugula), 57 (few), 58 (several), 67 (many), 74 (I), 82 (I), 134 (few).

Amphipods unidentified. Fish Hawk stations: $7580,7678,7718,7728$. Phalarope and Blue Wing Stations: 21, I 56 .

\section{Order ISOPODA.b}

\section{Family TANAIDEE.}

Tanais cazolinii Milne Edwards.

Harger, I879, p. I62 (Tanais vittatus); I88o, p. $4 \mathrm{I} 8$ (Tanais vittatus); Bumpus, I898b (Tanais vittatus); Richardson, I90I, p. 50r; I905, p. 8 (no local records); M. J. Rathbun, x905, p. 34 (no local records).

Woods Hole, on Bureau of Fisheries pier; Eel Pond; Vineyard Haven on piles.-Osburn. Found on piles, among algæ; also in eelgrass.
Tanais cavolinii-Continued.

According to Bumpus this species was found locally with eggs in various stages of development early in August. Osburn records the occurrence of unhatched eggs, as well as freeswimming young, during the latter half of July.

Leptochelia savignyi (Kröyer). [Chart I03.]

Verrill and Smith (Harger), 1873, pp. 573, 38I, etc. (Tanais filum); Harger, I879, p. I62 (Leptochelia algicola); r880, p. 42 I (Leptochelia

a Specimens from points designated by an asterisk (*) were identified by Dr. R. C. Osburn.

$b$ We have followed Prof. Holmes in retaining this name. Mayer assigns specimens from Woods Hole, examined by him to Caprella acutifrons Latreille. 
Leptochelia savignyi-Continued.

algicola); Richardson, Igor, p. 504 (Leptochelia dubia); 1905, p. 26; M. J. Rathbun, I905, p. 35.

Woods Hole, Vineyard Sound.-Harger, Richardson. Eel Pond, Hadley Harbor, Vineyard Haven.-Osburn. A few inshore stations along eastern shore of Buzzards Bay; likewise near shore of Sound in vicinity of Woods Hole; chiefly taken at depths of 6 fathoms or less, on various bottoms.--Survey. Common on piles, among ascidians and hydroids.-Harger. Likewise found on algæ and eelgrass, and living freely at surface.

Phalarope stations*: 4 (I), 5 (few), 6 (few), 83,87 (several), I00 (I), I08, II7 (many among algæ), I 8 (common), I32 (many), I4I (few).

\section{Family ANTHURIDAs}

Cyathura carinata (Kröyer).

Verrill and Smith (Harger), I873, p. 572, 426 (Anthura brunnea); Harger, 1879, p. I62 (Anthura polita); I880, p. 398 (Anthura polita); Richardson, I90I, p. 508; I905, p. 63; M. J. Rathbun, I905, p. 36.

Vineyard Sound.-Harger. Tarpaulin Cove, Head of Lagoวn Pond, West Falmouth Harbor--Osburn. Sand or sandy mud, between tides or just below low-water mark.

Ptilanthura tenuis Harger.

Harger, I879, p. I62; I880, p. 406 (sp. nov.); Richardson, I901, p. 508 (Anthura tenuis); I905, p. 66; M. J. Rathbun, I905, p. 35 ( $A n$ thura tenuis).

Waquoit, in sand at low water, September 8, 1875--Harger.

Calathura branchiata (Stimpson).

Verrill and Smith (Harger), I873, p. 573, 5 II (Anthura branchiata); Harger, I879, p. 162 (Paranthura branchiata); I880, p. 402 (Paranthura branchiata); Richardson, x9oI, p. 59; I905, p. 72 ; M. J. Rathbun, I905, p. 36 (spelled brachiata).

Vineyard Sound.-Harger, Richardson. Rare south of Cape Cod.-Harger.

\section{Family Cirolanides.}

\section{Cirolana concharum (Stimpson).}

Verrill and Smith (Harger), 1873, p. $572,746,426$, etc. (Conilera concharum); Harger, I879, p. 16I; 1880, p. 378; Richardson, I90I, p. 513; 1905, p. 95; M. J. Rathbun, I905, p. 36.

Woods Hole Harbor, sometimes very common. Vineyard Sound, Eel Pond.-Harger. Muskkeget Channel.-Rathbun. Fish Hawk station $7533(\mathrm{I})$, and Phalarope station 80 (I).
Cirolana concharum-Continued.

Reported for May and August as well as midwinter.

This isopod is a scavenger, and may sometimes be taken in great numbers in winter from dead fish.-V. N. Edwards. It has been drawn into the water supply of the Woods Hole hatchery in sufficient numbers to block up the cocks.

\section{Family Cymothorde:}

Nerocila munda Harger.

Verrill and Smith (Harger), I873, p. 57 I (sp. nov.); Harger, I879, p. I6r; I880, p. 392. Richardson, I90I, p. 528; I905, p. 223; M. J. Rathbun, I905, p. 38 .

Woods Hole and Vineyard Sound, a few specimens recorded by Harger. Buzzards Bay traps, near Woods Hole; Menemsha Bight.Osburn, Linton, Wilson, Edwards. A rather uncommon external parasite on various fishes. First recorded by Harger from the dorsal fin of the large file-fish "Ceratacanthus aurantiacus" (=Alutera schoepfii). Dorsal fin of Mustelus canis, August 26, I893.-(F. R. Lillie, in Marine Biological Laboratory card catalogue. Listed as Nerocila sp.). Found by C. B. Wilson on the pectoral fin of a remora; another found by V.N. Edwards on the same species; 2 reported by Osburn from Alutera schoepfii, at base of dorsal fin; another taken from cheek of butterfish.

Livoneca ovalis (Say).

Verrill and Smith (Harger), I873, p. 572, 477; Harger, I879, p. I62; I880, p. 395; Richardson, I90I, p. 53I; I905, p. 263; MI. J. Rathbun, I905, p. 38 .

Vineyard Sound; taken from a bluefish near the gills; likewise in one case from scup.--Harger. Woods Hole.-Richardson.

\section{Family LIMNORIDEA}

Limnoria lignorum (Rathke). Gribble.

Verrill and Smith (Harger), I873, p. 57x, 379, etc.; Harger, 1879 , p. I6r; I880, p. 373; Richardson, I90I, p. 532; I905, p. 269; M. J. Rathbun, 1905, p. 39 .

Of general distribution along the coast, and abundant locally. This species burrows into solid wood to the depth of about half an inch, often being "so numerous as to reduce the wood to mere series of thin partitions between the holes. . . . Where abundant it will destroy soft timber at the rate of half an inch or more every year." - Harger. According to Q. Andrews (cited by Harger), this species has likewise been observed to attack the guttapercha of submarine cables. 


\section{Family SPHAROMDAE.}

Spharoma quadridentata Say.

Verrill and Smith (Harger), 1873, p. 569, 315; Harger, 1879 , p. 161 (S. quadridentatum); 1880, p. 368 (S. quadridentatum); Richardson, I9or, p. 533 ; I905, p. 28 I; M. J. Rathbun, I905, p. 39.

Vineyard Sound, along the shores, under stones, and among algæ.-Harger. Beach near Fort Phoenix, under stones and on peat bank between tides. (Collected by Cole, identified by Osburn.)

\section{Family IDOTHEIDA}

Chiridotea caca (Say).

Verrill and Smith (Harger), r873, p. 569, 340, etc. (Idotea caeca); Harger, I879, p. I59; I880, p. 338; Richardson, I90r, p. 539; I905, p. 353; II. J. Rathbun, 1905, p. 40.

Vineyard Sound, occurring on moist sand flats and burrowing like moles beneath the surface of the sand, raising it up into little ridges as they go along--Harger. Woods Hole, Tarpaulin Cove.-Richardson. Katama Bay, Lagoon Pond, Muskeget, abundant at low water-Osburn. West Falmouth Harbor.Cole. Phalarope station 34 (Sound shore of Cuttyhunk): I adult.* Also recorded from a muddy beach and taken by Mr. Edwards in surface tow

About 40 specimens of this isopod were taken by Mr. Edwards from the stomach of a flounder, and one from the stomach of a puffer.

? Chiridotea tuftsii (Stimpson).

Verrill and Smith (Harger), I873, p. 569 (Idotea Tuftsii); Harger, I879, p. I59; I880, p. 340 ; Richardson, I901, p. 539; I905, p. 354; M. J. Rathbun, I905, p. 40.

No local records, although this region lies within the known range of the species.

Idothea metallica Bosc.

Verrill and Smith (Harger), I873, p. 56 s, 439 (Idotea robusta); Harger, 1879 , p. I60; (Idotea robusta); I88o, p. 349 (Idotea robusta); Bumpus, I898b (Idotea robusta); Richardson, Igor, $\mathrm{p}$. 54I; I905, p. 362; M. J. Rathbun, I905, p. 4I.

Taken very frequently in Vineyard Sound, either swimming freely or clinging to eelgrass or gulfweed.

Fish Hawk stations (probably coming from surface) ${ }^{*}: 7699$ (I), 7703 (I), 7735 .

Phalarope stations (likewise probably from surface) $)^{*}: 2,104$.
Idothea metallica-Continued.

Bumpus records the occurrence of specimens with eggs July $I 7$ and August 12. Osburn reports that on July 6 (I904) a few females carrying eggs or young in the brood pouch were taken; great numbers of young about 5 millimeters long and some older ones were likewise found upon the gulfweed.

Idothea baltica (Pallas). [Chart I04.]

Verrill and Smith (Harger), I873, p. 569, 316 , etc. (Idotea irrorata); Harger, I879, p. 160 (Idotea irrorata); I880, p. 343 (Idotea irrorata); Richardson, I901, p. 540 (Idotea marina); 1905, p. 364 ; M. J. Rathbun, I905, p. 40 (Idolhca marina).

Of practically universal distribution locally, along shores, and on the surface, among eelgrass, rockweed, and sargassum; sometimes taken in great numbers. Occasionally brought up in the dredge while operating at depths as great as $13 \frac{1}{2}$ fathoms; in these cases perhaps they were actually taken near the surface.

Fish Hawk stations: $75^{24}$ bis (2), $75^{25}$ (x), 7557 (I), 7717 (I), 7734 .

Phalarope and Blue Wing stations: 33 (I adult), 44 (few), 45 (few), 47 (several), 49 (I), 5I (many in algæ), I04.

Osburn records that on July 9, the larger females all seemed to have released their young; only the smaller females were still found bearing eggs or young. On July 5, specimens 5 to 8 $\mathrm{mm}$. long were taken.

A specimen ro $\mathrm{mm}$. long was taken by C. B. Wilson from the gills of a sand shark. Its presence here was, however, probably accidental.

Idothea phosphorea Harger. [Chart 105.]

Verrill and Smith (Harger), I873, p. 569, 316, etc. (Idotea phosphorea, sp. nov.); Harger, I880, p. 347; Richardson, 1901, p. 54I; 1905, p. 367; M. J. Rathbun, I905, p. 4 I.

Abundant and generally distributed throughout Vineyard Sound, though much more prevalent in the western half; in Buzzards Bay only recorded from a few stations near the mouth.Survey. Dredged in I to $I 7$ fathoms, on bottoms of sand, gravel and stones (rarely mud). Taken, also, along shore among weeds; likewise at surface, and on bottom at various depths; recorded by Dr. Osburn from gulfweed.

Fish Hawk stations: 7536 bis, $755^{\mathrm{I}}$ bis, $755^{2}$ bis (I), 7553 bis (I), 7557 (I), 7560 (I), 7563 bis (I), $75^{64}$ bis, $75^{82}$ (I), $75^{83}$ (I), 7672 (I), 7685 (7), 7698 (2), 7699 ( $\mathrm{I}$ adult and many young), 7700 (r young), 7701 (several), 7702 (2), 7703 (2), 
Idothea phosphorea-Continued.

7704 (2), 7706 (adults and young), 7707 (adults and young), 7717 (I), 7718 (3 small), 77 I9 (2), 7720 (I adult and I young), 772 I (several adult and young), 7722 ( $I$ adult and I young), 7724 (I), 7725 (I), 7727 (I small), 7728 (several), 7729 (I), 7730 (several), 773 I (several), 7732, $7745,7765,7767$

Phalarope and Blue Wing stations: 6 (I), I5 (I), 20 (young), 22 (few), 26, 27 (few), 28 (I with eggs), 30 (I), 32 (several), 33 (several young and I adult with eggs), 34 (common), 36 (few), 37 (I with eggs), 38 (few), 44 (abundant), 45 (several), 46, 47 (several), 48, 5I (I in algæ), 55 (several), $5^{6}$ (few), 57 (few), $5^{8}$ (common), 59 (I), 64 (I), 65 (I), 67 (several), 73 (few), 77 (I), $\delta_{2}(2), I 00$ (I), III (2), II 2, II 3 .

A few with eggs taken July 6.-Osburn.

Recorded in food of haddock.-Richardson.

Edotea acuta Richardson.

Richardson, I90I, p. 544; I905, p. 395 (not listed for this region).

Bay shore of Pasque Island, at Phalarope station 83 , I specimen thus identified by R. C. Osburn.

Edotea triloba (Say).

Verrill and Smith (Harger), I873, p. 571, 370, etc. (Epelys trilobus); Harger, I879, p. I80 (Epelys trilobus); I880, p. $35^{8}$ (Epelys trilobus); Richardson, I90I, p. 545; I905, p. 396; M. J. Rathbun, I905, p. 42 .

Vineyard Sound.-Harger, Richardson. Muddy shores, creeping about over the mud or among decaying vegetable matter, usually covered up with adhering dirt.-Harger.

Edotea montosa (Stimpson).

Verrill and Smith (Harger), I873, p. 57 I, 316 , etc. (Epelys montosus); Harger, I879, p. I6 I (Epelys montosus); r880, p. 359 (Epelys montosus); Richardson, I901, p. 545; I905, p. 397; M. J. Rathbun, 1905, p. 42.

Vineyard Sound.-Harger, Richardson. Frequents muddy bottoms and is concealed by the coating of mud which always adheres to the rough back.-Harger. Head of Lagoon Pond.-Osburn. Recorded by the latter observer as "common in coarse sand and ooze, just below low tide." Taken by Mr. Edwards in surface tow at Woods Hole, October I5 and October 28, 1905. Five stations at western end of Vineyard Sound and mouth of Buzzards Bay; 6 to $I_{3}$ fathoms, on bottoms of sand and mud.--Survey.

Fish Hawk stations*: 77 I0 (I), 7725 (I), 7728 (I), 7730 (r).

Phalarope station $78(2)^{*}$.
Erichsonella attenuata (Harger).

Verrill and Smith (Harger), I873, p. 570, 370 , etc. (Erichsonia attenuata, sp. nov.); Harger, I879, p. 160 (Erichsonia attenuata); 1880, p. 356 (Erichsonia attenuata); Richardson, Igor, p. 543; 1905, p. 400; M. J. Rathbun, 1905, p. 4I. This species has previously been listed only from New Jersey and Connecticut. "Found clinging to eelgrass in muddy situations. "- - Harger Taken by Cole at Wareham River, August I6, I906.*

Ericksonella filiformis (Say). [Chart I06.]

Verrill and Smith (Harger), I873, p. 570, 3I6, etc. (Erichsonia filiformis); Harger, 1879 , p. I60 (Erichsonia filiformis); I880, p. 355 (Erichsonia filiformis); Richardson, I901, p. 543; I905, p. $40 \mathrm{I} ;$ M. J. Rathbun, I905, p. 42 .

Vineyard Sound.-Harger, Richardson. Found on shore, among eel-grass and algæ, and down to 7 fathoms.-Harger. Nantucket Sound.Richardson. Lagoon Pond, on algæ.-Osburn. Distribution pretty general in Vineyard Sound and Buzzards Bay, particularly at inshore stations; dredged in I to I9 fathoms, on various bottoms. - Survey.

Fish Hawk stations: $a 532$ bis, 7537 bis (few), $755^{2}$ bis (2), 7554 bis, $76 \mathrm{I}_{3}$ (I), $76 \mathrm{I}_{4}$ (I), 7656 , 7657 (I), 7673 (I), 7677, 768I (2 young), 7682 (I), 7695, 7700 (I), 7701 (2), 7722 (I), 7725 (I), 7728 (several), 7729 (several), 7730 (2), 7744 ( 1 adult), 7751, 7768, 7769.

Phalarope and Blue Wing stations: $a_{\text {I }}$ (several adult females with eggs), 5 (2 females with eggs), 8 (few), 9 (I), II (I), I6 (several), 20 (3 females), 22 (few females), 23 (few females), 24 (few), 25 (few), 30 (I), 32 (I), 33 (I female with eggs), 34 (I), 45 (I), 46 (I), 48, 5 I (few in algx), $5^{2}, 53$ (I), 55 (few), 57 (I), 63 (I), 67 (several), 82 (I), 86, 87 (common), I08, III, II2, II6 (I), I28 (I), I29, I34 (I), I35.

Females with eggs and young in the brood pouch reported July 6.-Osburn.

\section{Family JANIRIDAE.}

\section{Jara marina (Fabricius).}

Verrill and Smith (Harger), I873, p. 57I, 3I5, etc. (Jara copiosa); Harger, I879, p. I58 (Jara albifrons); I880, p. 315 (Jara albifrons); Bumpus, I898 b (Jara albifrons); Richardson, I90I, p. 554; I905, p. 450; M. J. Rathbun, I905, p. 43 (Jara albifrons).

Woods Hole, on Bureau of Fisheries pier; Vineyard Sound; Vineyard Haven, on piles. Rocky shores, under stones, nearly up to highwater mark; on piles, in crevices, under bark, 
Jara marina-Continued.

or in the burrows of Limnoria; a very common species, though completely lacking in the dredging records.

McMurrich (cited by Bumpus) found this species breeding from middle of June till the first week in September (i. c., as long as observed). Osburn records eggs and young in the brood pouch July $\mathrm{I}_{4}$ and July $3 \mathrm{I}$.

Family BOPYRIDAE.

? Phryxus abdominalis (Kröyer).

Harger, I879, p. 158; r880, p. 312; Richardson, Igor, p. 577 ; 1904, p. 58 ; 1905, p. 50I; M. J. Rathbun, I905, p. 48.

"Off Marthas Vineyard, on Pandalus leptocerus and S. [Spirontocaris] liljeborgii"; parasitic on the abdomen of these shrimps.-Richardson. It is quite likely that these specimens were taken far beyond the limits of the region.

Ione thompsoni Richardson.

Richardson, I904, p. 75 (sp. nov.); 1905, p. 508; M. J. Rathbun, 1905, p. 49.

North Falmouth, on Callianassa stimpsoni, two specimens collected by Mr. G. M. Gray.

Stegophryxus hyptius Thompson.

Thompson, 1902, p. 53 (sp. nov.); Richardson, I904, p. 59; I905, p. 532; M. J. Rathbun, I905, p. 48 .

Edgartown; also dredged in Cataumet Harbor, at Phalarope station I42 (I specimen)*; likewise recorded from below-named localities.

Parasitic on the hermit crab, Pagurus longicarpus. "About I.5 per cent of the crabs at Great Harbor were thus infested ( 1892 ) and from 3 to 4 per cent of those at Hadley Harbor.
Stegophryxus hyptius - Continued.

... The female parasite occurs on the abdomen of the hermit, to which it is attached back downward, by its mandibles and legs. The male is found on the posterior part of the marsupium of the female."-Thompson.

Probopyrus pandalicola (Packard).

Richardson, I904, p. 66 (Probopyrus palamoneticola); 1905, p. 554; M. J. Rathbun, 1905, p. 49 .

Acushnet River, on Palcemonetes vulgaris.

\section{Family ONISCID五.}

Philoscia vittata Say.

Verrill and Smith (Harger), I873, p. 569; Harger, 1879, p. 157; 1880, p. 306; Richardson, I901, p. 565; 1905, p. 605; M. J. Rathbun, 1905, p. 45 .

Vineyard Sound, under rubbish below highwater mark.-Harger.

\section{Family SCYPHacid瓜.}

Scyphacella arenicola Smith.

Verrill and Smith 1873 , p. 568, 337, etc. (sp. nov.); Harger, I879, p. I57; I880, p. 307; Richardson, I901, p. 576; 1905, p. 67I; Rathbun, 1905, p. 47.

Nobska Beach and Nantucket.-Harger. Ram Island, in the sand.--Richardson.

Family LIGYDIDE.

? Ligyda oceanica (Linnæus).

Richardson, I905, p. 685; M. J. Rathbun, 1905, p. 47 .

"Off Newport," perhaps beyond limits of the region.

\section{Order CUMACEA.}

Family BODOTRIDEA.

\section{Cyclaspis varians Calman.}

Calman, I9I2, p. 6 ro (sp. nov.).

Vineyard Sound, surface, 1875 and I88I; Woods Hole, surface, 1882 and 1885 ; many specimens taken.

Leptocuma minor Calman.

Calman, I9I2, p. 616 (sp. nov.). "Vicinity of Woods Hole; U. S. F. C., . . . I female."Calman.

This record probably relates to a specimen taken in Vineyard Sound, at Phalarope station 33.

\section{Family LEUCONIDEE.}

? Eudorella hispida Sars.

S. I. Smith, I879, p. II5; M. J. Rathbun, I905, p. 30 ; Calman, I912, p. 621 .

No strictly local records for this species given by any of these writers.

Eudorella truncatula (Bate)

S. I. Smith, I879, p. II6 (Eudorella pusilla); M. J. Rathbun, I905, p. 3 I (Eudorella pusilla); Calman, 1912, p. 620.

Off Vineyard Sound Lightship, I6 fathoms, many females and young.-Calman. 
Eudorellopsis deformis (Kröyer).

S. I. Smith, I879, p. Ix6; M. J. Rathbun, I905, p. 31; Calman, I9I2, p. 623.

Off Vineyard Sound Lightship, I6 fathoms, I female.-Calman.

\section{Family DIASTYLIDE.}

Diastylis sculpta Sars.

S. I. Smith, I879, p. III (D. sculptus); M. J. Rathbun, I905, p. 3I; Calman, I912, p. 657.

Vineyard Sound, at the surface, in July, August, and September, mostly females or young; males rare; adult males taken by V. N. Edwards in April and May.-Smith. Low water to 60 fathoms.-Rathbun. Woods Hole, surface, I female.-Calman.

2 Diastylis quadrispinosa Sars.

Verrill and Smith, 1873, p. 554, 507; S. I. Smith, I879, p. II2 (D. quadrispinosus); M. J. Rathbun, 1905, p. 32; Calman, I912, p. 658.

Off Marthas Vineyard in 18 to 23 fathoms, on muddy bottom; Vineyard Sound, off Tarpaulin Cove, Io to 12 fathoms.- Smith. Vineyard Sound, I 8 fathoms, and neighboring parts of the ocean.-Calman.

Undetermined species belonging to this order are frequently taken in the local tow by Mr. Edwards, sometimes in considerable numbers.

\section{Order STOMATOPODA.}

Family CHLORIDELLIDE.

Lysiosquilla armata Smith.

M. J. Rathbun, I905, p. 29.

"From stomach of flounder, southwest of Gay Head, I7 to 27 fathoms (determination doubtful);" Vineyard Sound, in I882, one specimen.-Rathbun.

Lysiosquilla scabricauda (Lamarck).

M. J. Rathbun, 1905, p. 29.

"Vineyard Sound, surface," September I3, 1875. Chloridella empusa (Say).

Verrill and Smith, I873, p. 55I, 369, etc. (Squilla empusa); Bumpus, r898b (Squilla); M. J. Rathbun, I905, p. 29.

Adults comparatively rare locally. This species inhabits muddy shores and bottoms; "probably it usually burrows in the mud below low-
Diastylis abbreviata Sars.

S. I. Smith, I879, p. II3 (D. abbreviatus); M. J. Rathbun, I905, p. 32 .

No definite local records, though this region lies within the range of the species as stated by Smith.

Diastylis polita Smith.

S. I. Smith, I879, p. 108 (Diastylis politus, sp. nov.); M. J. Rathbun, I905, p. 33; Calman, I912, p. 655 .

Vineyard Sound, at surface, in January, March, April, May, July, and December; females with eggs in May.-Smith. Seven to ten fathoms.-Rathbun. Woods Hole, several lots recorded for February, April, and May.-Calman.

Oxyurostylis smithi Calman.

Calman, Igr2, p. 667 (sp. nov.).

The type of this species was taken at Woods Hole in surface tow, by V. N. Edwards, May 6, I906. Specimens identified by Dr. Calman were taken at Woods Hole and vicinity in $188 \mathrm{r}$ and I882; also December, I903, October, November, and December, I904, and April and May, I906.
Chloridella empusa-Continued. water mark." - Smith. Occurs down to I2 fathoms.-Rathbun. Smith records one from the stomach of Palinurichthys perciformis, taken at Woods Hole. Recorded by Miss Rathbun from Woods Hole, Vineyard Sound, Buzzards Bay and Acushnet River. One adult specimen taken by Mr. Edwards in a fyke net in Great Harbor, December, I908; another sent from Edgartown in same month. Mr. Gray, of the Marine Biological Laboratory supply department, is obliged to send to distant points for this species, being unable to obtain it locally in sufficient numbers for laboratory purposes. Bumpus records that the young are occasionally taken in the tow net during August. 


\section{Order SCHIZOPODA.}

Family EupHausinda.

Thysanoëssa inermis (Kröyer).

S. I. Smith, I879, p. 9I. (Thysanopoda inermis); M. J. Rathbun, I905, p. 26 (Rhoda inermis).

Vineyard Sound, on surface; in two successive years recorded as abundant in January.Smith.

Meganyctiphanes norvegica (Sars).

S. I. Smith, I879, p. 89 (Thysanopoda norvegica); M. J. Rathbun, I905, p. 26 (Nyctiphanes norvegica). (No local records given by either of these writers.)

Crab Ledge, at Fish Hawk station 7609,25 fathoms, gravel and shells (dredged by the Survey, identified by M. J. Rathbun). Essentially pelagic.-Smith. Surface and deep water.Rathbun.

Family MYside.

Michtheimysis stenolepis (Smith).

Verrill and Smith, 1873, p. 551, 370, etc. (Mysis stenolepis, sp. nov.); S. I. Smith, I879, p. I03 (Mysis stenolepis); M. J. Rathbun, I905, p. 27 (Mysis stenolepis).

Vineyard Sound, Buzzards Bay, Woods Hole, "shallow bays and coves about Vineyard Sound;" abundant locally among eelgrass; also dredged in a few fathoms among algæ; recorded for January, April, May, July, September, and December.-Smith.

"Ovigerous sacs" filled with eggs and young in December, January, and April.-Smith.

Schizopoda undetermined.

Fish Hawk stations: 7572 (I), $75^{83}$ (I), 77 I8.

Phalarope stations: 3,83 .

Great numbers of schizopods, doubtless representing several species, have for many years past been taken by Mr. Edwards in the tow at the local pier. It has thus far been impossible to find anyone willing to identify these.

\section{Order DECAPODA. $a$}

\section{Family PALAMONIDAE.}

Palcmonetes vulgaris (Say).

Verrill and Smith, r873, pp. 550, 339, etc.; S. I. Smith, I879, p. 88; Bumpus, I898a, I898b; Thompson, I899; M. J. Rathbun, I905, p. 25. of general distribution in suitable places. A shore-dwelling species, very abundant in the eelgrass, in salt or brackish waters. Recorded from Woods Hole Harbor, at surface, Katama Bay, Menemsha Bight, Tisbury Pond, Tarpaulin Cove, Wareham River, Fort Phœnix. The Eel Pond, at Woods Hole, is the chief local source of supply.
Neomysis americana (Smith).

Verrill and Smith, I873, p. 552, 370, etc. (Mysis americana sp. nov.); S. I. Smith, 1879, p. Io6 (Mysis americana); M. J. Rathbun, 1905, p. 27 (Mysis americana).

Among eclgrass and algæ along shore and swimming freely at the surface; taken in a dredge lowered to 25 fathoms, though probably caught on the way up.-Smith. This writer gives records for its local occurrence during winter, spring, and summer.

Recorded from stomachs of summer flounder. window-pane flounder, shad, mackerel, and lierring.

Heteromysis formosa Smith.

Verrill and Smith, I873, p. 553,396 , etc. (sp. nov.); S. I. Smith, r879, p. Ior; M. J. Rathbun, 1905, p. 28 .

Vineyard Sound, Buzzards Bay, Nantucket Sound; surface to I8 fathoms; sometimes abundant, hidden within a dead shell of Spisula or other bivalve.-Smith. Vineyard Haven and eastern end of Vineyard Sound* (identified by M. J. Rathbun.)

All the specimens examined by Smith were taken in August and September and a large proportion of these were females carrying eggs and young.

\footnotetext{
a Specimens from points designated by an asterisk (*) were identified by Miss M. J. Rathbun.
} 


\section{Family PANDALIDE}

Pandalus montagui Leach.

Verrill and Smith, I873, p. 550, 493 (Pandalus annulicornis); S. I. Smith, I879, p. 87; M. J. Rathbun, 1905, p. 24.

Vineyard Sound, in deep water off Gay Head also off Buzzards Bay in 25 fathoms.-Smith. Taken at Menemsha, in trawl, by V. N. Edwards, July I2, I875.-Rathbun. Western end of Vineyard Sound, at Fish Hawk station $7678^{*}$; I young specimen.

Pandalus leptocerus Smith.

S. I. Smith, I88I, p. 437 (sp. nov.); M. J. Rathbun, I905, P. 25. (No local records given by either of these writers).

Taken at 8 stations in western part of Vineyard Sound; likewise at Crab Ledge, 7 to 25 fathoms.-Survey.

Fish Hawk stations: 7570 (I ${ }^{*}, 75^{80}$ (I), $75^{8} \mathrm{I}$ (I), 7584 (I), 7593 (I), 7595 (I), 7598 (I), $7609(2)^{*}$, $768 \mathrm{I}(\mathrm{I})^{*}$.

\section{Family HIPPOLYTIDAE.}

\section{Latreutes ensiferus (Milne Edwards).}

S. I. Smith, I 879 , p. I2I; I882a; M. J. Rathbun, I905, p. 21 .

A Gulf Stream species, drifted into local waters with the sargassum. First recorded locally by Smith, who reported it from Vineyard Sound, August and September, I875, probably generally present upon the gulfweed. Taken in October, I905, and especially abundant in I906, when it is likely that hundreds of specimens were brought into the laboratory.

Hippolyte zostericola (Smith).

Verrill and Smith, I873, p. 550, 369 , etc. (Virbius zostericola, sp. nov.); Bumpus, I $898 \mathrm{~b}$ (Virbius zostericola); Thompson, 1899 (Virbius zostericola); M. J. Rathbun, I905, p. 2 I.

Vineyard Sound, Woods Hole. Falmouth, Hadley Harbor, Quisset Harbor.-Rathbun. Katama Bay; also taken in tow at the local pier in the fall and winter. Common among eelgrass, even in waters somewhat brackish. Recorded from Fish Hawk station 7762 .

Found by F. P. Gorham carrying eggs in all stages of development from the Ist of June to the Ist of September, the period of incubation being about two weeks.-Bumpus. Thompson records finding females with advanced eggs on September II.
Spirontocaris grenlandica (Fabricius).

M. J. Rathbun, I905, p. 22 (no local records).

Crab Ledge, at Fish Hawk station 7608, I specimen*.

2Spirontocaris liljeborgii (Danielssen).

M. J. Rathbun, I905, p. 22.

Off Marthas Vineyard and Nantucket, from 25 fathoms down (perhaps not strictly to be included in the present list).

Spirontocaris pusiola (Kröyer).

Verrill and Smith, I873, p. 550, 395, etc. (Hippolyte pusiola); S. I. Smith, 1879 , p. 77 (Hippolyte pusiola); Bumpus, 1898 (Hippolyte pusiola); M. J. Rathbun, r905, p. 24.

Vineyard Sound and off Nantucket; rocky, gravelly, and shelly bottoms, 2 to I 2 fathoms. Smith. Crab Ledge, at Fish Hawk station 7604 , I specimen*

Taken with eggs in March.-Bumpus.

\section{Family Cragonides.}

Crago septemspinosus (Say). [Chart Io7.]

Verrill and Smith, 1873 , p. 550, 339, etc. (Crangon vulgaris); S. I. Smith, I879, p. 56 (Crangon vulgaris); R. Rathbun, I884, p. 8I 7 (Crangon vulgaris); Bumpus, 1898 (Crangon vulgaris); Thompson, r899 (Crangon vulgaris); M. J. Rathbun, I905, p. 19 .

A species of very general distribution, under a great variety of conditions; found throughout both the Sound and the Bay, on all kinds of shores and bottoms from low-water mark to the greatest depths within the region; also frequently taken in tow from the Bureau of Fisheries pier.

Fish Hawk stations: $75^{22}(2)^{*}, 75^{22}$ bis (I small)*, $75^{23}$ bis (few), $75^{24}$ (few), $75^{2} 5$ (few), $75^{25}$ bis (few), $75_{28}$ (few, largest $\mathrm{I}$ inch), 7535 bis $(2)^{*}, 7536$ (2 small), 7536 bis, 7537 (several)*, 7537 bis $\left(\right.$ few) ${ }^{*}, 7538^{*}, 7538$ bis*, 754 I (few), 754 I bis*, 7543 bis*, 7547 bis (several)*, 7549 bis*, $755^{\circ}$ (I), 7553 (2, I with eggs), 7554 (few small), 7554 bis*, 7559 (2 small), 7560 (few), $75^{6}+$ (I), 7567 (I), 7570 ( 2 small), 7575 (I), 7576 (I small), 7577 (I), 7578 (I), 758 (2 small), 7582,7583 (2), 7584 (few), 7585 (many, some with eggs), 7593 (few), 76II (many with eggs) ${ }^{*}, 7612$ (many) ${ }^{*}, 7613$ (many)*, 76I4 (with eggs)*, 76I6 (I)* ${ }^{*}, 76 I 7$ (with eggs)* $7618^{*}, 7619^{*}, 7622$ (many with eggs)*, 7623 (many)* ${ }^{*}, 7624$ (some with eggs)*, $7627(2)^{*}$, $76_{34}(\mathrm{I})^{*}, 76_{37}$ (several) $^{*}, 76_{3} 8^{*}, 76_{4} \mathrm{I}$ (sev 
Crago sepiemspinosus - Continued. eral)*, $7643^{*}, 7644(\mathrm{I})^{*}, 7645(\mathrm{r})^{*}, 7653$ (few) ${ }^{*}$, $7654^{*}, 7655(\mathrm{I})^{*}, 7657$ (few, 2 with eggs) ${ }^{*}, 7660$ (with eggs)* ${ }^{*} 7661^{*}, 7662^{*}, 7663$ (with eggs)*, $7672(\mathrm{x})^{*}, 7673$ (with many eggs)*, $7675^{*}, 7676$, 7677 ( 2 with eggs), 7678 (I9), 7679 (I), 7680 (I), $768 \mathrm{r}$ (several), 7682 (several), 7685 (few), 7687,7689 (several), 7697 (I), 7698 (few), 7699 (several), 7700 (few), 770 т (many), 7702 (few), 7703 (4), 7704 (few), 7705 (few), 7706 (many), 7707 (few), 7708 (few), 7709 (few), 77 10 (2), 77 I, 7718 (few), 77 I9 (few), 7722 (I), 7725 (I), 7726 (several), 7727 (many), 7730 (I), 773 I (7), 7734 (r), 7760 .

Phalarope and Blue Wing stations: 4 (I), 5 (I), 8 (I fragment), 9 (2), I3 (several with eggs), I5 (several with eggs) ${ }^{*}, 9^{*}, 23^{*}, 24$ (I) $25^{*}$, 29 (few) ${ }^{*}, 33$ (several with eggs) ${ }^{*}, 37^{*}, 48$ (with eggs)* $49^{*}, 50^{*}, 5^{1}$ (several, some with eggs)*, $52^{*}, 53,55$ (many with eggs), 65 (2), 67 (I)*, 69 (several), 7 I (I), 72 (few), 73 (few)*, 75 (2)*, 78 (2), 79 (few), 80 (several), 8I (many), 82 (very common), 83 (many), $84,85,89,90,93$ (I), I00 (r small), ror (few), I03, 104, 108 (several), rog (many with eggs), IIo, III (few), II3, II4, II5 (common), II6, II7 (several), II8 (few), I22 (few), I23 (I), I27 (I), I29 (common), I30 (3), I3I (few), I33 (I), I34 (several), I35, $I_{37}$ (I), I38 (I), I39 (few), I40 (I), I45 (I), I 49 (I), I50 (I).

Reported by Bumpus as breeding in March. Egg-bearing females are common throughout the summer, one being reported by Thompson as late as September I9.

Collected as food in the neighborhood of New Bedford, according to R. Rathbun, I884. An important item in the food of fishes. Recorded by Verrill and Smith in the stomach contents of the following species: striped bass, white perch, kingfish, bonito, sea robin, toadfish, haddock, tomcod, summer flounder, windowpane flounder, herring, hickory shad, Raja lavis (?).

\section{Family PENEIDE.}

Peneus brasiliensis Latreille.

Verrill and Smith, 1873, p. 55 (Penous brasiliensis; no local records); M. J. Rathbun, I905, p. I9 (Penceus brasiliensis).

Katama Bay, I specimen.-Rathbun. Tisbury Pond, October I8, I906; I specimen, taken by V. N. Edwards.
Family Homarida.

Homarus americanus Milne Edwards. The American lobster. [Chart I08.]

Verrill and Smith, I873, p. 549, 313, etc.; S. I. Smith, I879, p. 55; Herrick, I895, p. I-252; I902, p. I6I; I9II, p. I49-408; Rathbun, I905, p. 18 .

Lobster fishing by means of "lobster pots" is conducted extensively in Woods Holc Harbor and in various parts of Buzzards Bay and Vineyard Sound, at Menemsha Bight, and many other points in the region. Recorded by the survey from scattered stations throughout Vineyard Sound and Buzzards Bay; dredged in 3 to $I_{5}$ fathoms on bottoms of sand, mud, and gravel. Lobsters come in toward shore in the spring, retreating to deeper waters in the fall.

Fish Hawk stations: $76 \mathrm{I} 8$ ( 1,5 inches long), 7645 ( I claw), 7654 (I fragment), 766r ( $I, 6$ inches), 7662 ( $x$, Io inches), 7687 (3 small), 7689 (2), 7703 ( I), 7707 (1 young), 7724 (2), 7728 (many medium sized), 7730 (several), 7731 (2), 7757 (I), 7762 (I young).

Phalarope and Blue Wing stations: 6 (I fragment), 7 (fragment), II (I young), 50 (I dead), 83 (I fragment).

According to Herrick, the mature female lobster as a rule lays eggs once in two years; the egglaying season at Woods Hole reaches its height during the latter part of July, though a considerable percentage spawn during the fall and winter. Those eggs which are extruded in July are carried on the abdominal appendages of the female until the following May or June, when they hatch.

Food: fish (which is sometimes taken alive), crustacea (chiefly crabs and isopods), small gastropods, algæ, echinoderms (starfish and sea urchins), and hydroids. "While the lobsters are great scavengers, it is probable that they always prefer fresh food to stale." - Herrick. On the other hand, the lobster is preyed upon by various fishes, among which the smooth dogfish (Mustelus canis) must be given an important place. "In fact every predaceous fish which feeds. upon the bottom may be looked upon in general as an enemy of the lobster."-Herrick. 
Family Axude.

? Axius serratus Stimpson.

S. I. Smith, I88I, p. 435; M. J. Rathbun, I905, P. I 7

No strictly local records, though this region lies within the known range of the species.

Naushonia crangonoides Kingsley.

Kingsley, 1895 , p. 95 (sp. nov.); Thompson, 1903 , p. I; G. M. Gray, in "Biological Notes" (Bulletin U. S. Fish Commission for I899); M. J. Rathbun, I905, p. I8.

Only two adult specimens of this decapod are recorded. The type was collected by $\mathrm{H}$. C. Bumpus on Naushon Island; the second was found by G. M. Gray about Io inches deep in the sand, on the shore of Ram Island, in July, I899. The second specimen was a female with eggs (July 22); zoeæ reported as common in the summers of I90I and I 902 by Thompson, who succeeded in rearing these to an advanced stage.

\section{Family CALLIANASSIDAs.}

\section{Callianassa stimpsoni Smith.}

Verrill and Smith, 1873, p. 549, 369, etc. (sp. nov.; no local records); Bumpus, r8g8b; M. J. Rathbun, I905, p. I7.

Ram Island, Devils Foot, Hadley Harbor, North Falmouth, West Falmouth.-G. M. Gray. Inhabits muddy shores and bottoms, in shallow water; a burrowing species. Miss Rathbun furnishes the following early Fish Commission records: Weepeckets, 1875 ; Buzzards Bay, I881; Vineyard Sound, I882, I883; Woods Hole, I879, I884; Naushon, I886, I887. Dredged by the Survey near the mouth of Buzzards Bay, at Fish Hawk station 7674 , ${ }^{*}$ and in the eastern part of Vineyard Sound, at Phalarope station 12 (latter a fragment).

According to Bumpus, this species was found with eggs on July $I$ and again on July ${ }_{3} 3$ (the latter segmenting); others with advanced embryos July 18 .

Upogebia affnis (Say).

Verrill and Smith, I873, p. 549, 368, etc. (Gebia affinis), Bumpus, I898b (Gebia affinis); M. J. Rathbun, I905, p. I7.

Woods Hole, head of Buzzards Bay.-Rathbun. Ram Island, Monument Beach (abundant).G. M. Gray. Occurring on muddy shores or muddy sand and digging deep burrows near low-water mark.

Found with advanced eggs on July 25.-Bumpus.
Family HIPPID五.

Emerita talpoida (Say).

Verrill and Smith, I873, p. 548,338 , etc. (Hippa talpoida); Mead, 1898, (Hippa talpoida); Bumpus, I898a, I898b (Hippa talpoida); Thompson, I899 (Hippa talpoida); M. J. Rathbun, I905, p. 16 .

Abundant at Nobska Beach, Cataumet Harbor and Scraggy Neck. Sandy shores at lowwater mark, and sandy bottoms in shallow water; an active, burrowing species.

Reported by Mead and Bumpus as without eggs in April and May; found to carry them during the latter part of June and throughout July. Many females still bore eggs on July $3^{1}$. - Sumner. J.S. Kingsley (Marine Biological Laboratory card catalogue) reports zocæ in the tow on August 5, and F. P. Gorham (cited by Bumpus) on August 9.

\section{Family PAGURIDA:}

Pagurus pollicaris Say. [Chart 109.]

Verrill and Smith, I873, p. 548, 3I3, etc. (Eupagurus pollicaris); M. J. Rathbun, I905, p. I4; Sumner, I9I0, fig. 25.

Distribution pretty general throughout Vineyard Sound and Buzzards Bay. Dredged by the Survey in 2 to $I 7$ fathoms, on quite various bottoms. Taken also in shallow water along shore-e. g., at Nobska Point and Tarpaulin Cove. This species, locally, is mainly found in the shells of Polynices heros and P. duplicata; sometimes in Busycon canaliculatum, B. carica, and Littorina litorea.

Fish Hawk stations: $75^{2} \mathrm{I}$ bis ( $\mathrm{I}$ in Polynices heros), $75^{23}$ (I), $75^{24}$ (about Io), $75^{26}$ (2), 7530 (few), 7530 bis (2), 7534 (several in Polynices shells), 7537 (several), 7537 bis ( $\mathrm{I}$ in P. heros), 7538 (several), 7542 (many in Polynices), 7543 (few), 7543 bis (several in P. heros), 7546 (several large), 7546 bis (in P. heros), 7547 bis (in $P$. heros), 7549 bis (several in $P$. heros), $755^{\circ}$ (few), $755^{\mathrm{I}}$ (few), $755^{2}$ (few), 7554 (several), $755^{6}$ (few), 7557 (few), $755^{8}$ (many), 7559 (few), 7560 (I), 756 r (few), 7562 (several), 7563 (many, all sizes), 7564 bis ( $\mathrm{x}$ large in $P$. heros), $75^{6} 5$ (few), 7569 (r), 7574 (few), 7576 (few), 7579 (few), 7590 (2), 7595 ( $\mathrm{I}$ ), 7598 ( $\mathrm{I}$ large), 7599 ( $\mathrm{I}$ ), 76 I 5 ( $\mathrm{I}$ in P.duplicata), 7617 (in Buscyon canaliculatum), 762 I (few), 7622 (fragments of large ones), 7627 ( $\mathrm{I}$ in $B$. carica), $76_{32}(\mathrm{I}), 76_{37}$ ( $\mathrm{x}$ in $P$. heros), $763^{8}(2), 7648(\mathrm{I}), 765^{2}$ (I), 7654 (I), 7660 ( $\mathrm{x}$ in Busyconcarica), $766 \mathrm{r}$ ( 2 in P.duplicata), 7676 ( 1 in Polynices), 7678 (3), 7702 ( 1 large), 7703 
Pagurus pollicaris-Continued.

(I), $7710(\mathrm{I}), 7728$ (I), 7732 (I), 7734 (2), 7735, 7736 (several), 7739 (several), 7740 (several), 7753 (I), 7757 (I), 7759 (2), 7760 (several), 7762 (many), 7766 (few), 7767 (few), 7768 (1), 7769 (few), $7770(1), 7772(2), 7773(2), 7774(2), 7777$ (several), 7778 (several), 7779 (I small), 7780 (I), 7781 (several), 7783 (several).

Phalarope and Blue Wing stations: 2 (in P. heros), 5 (2 in Polynices and Littorina), 7 (2), $\Upsilon_{3}$ ( 1 ), I7 ( $\mathrm{r}$ in P. heros), I8 ( $\mathrm{I}$ in Littorina), 22 (common in Littorina), 53 ( 1 small), 6r (several in P. heros). 64 (I), 68 (2 large), 7 I (many in Littorina), 73 ( $\mathrm{I}$ in $P$. duplicata), 74 (2), 75 (I dead), 89 (I claw), 98 (2), I07, 109, II2, I30 (I), I35, I36 (I), I45 (common), I48 (common), I49 (abundant), $5_{58}^{8}$ ( $\mathrm{x}$ in B. canaliculatum).

Reported by Smith from the stomach contents of the tautog and "fog-fish."

Pagurus acadianus Benedict. [Chart IIo.]

Verrill and Smith, I873, p. 548, 50r (Eupagurus Bernhardus); S. I. Smith, 1879, p. 46 (Eupagurus bernhardus); Benedict, I90r, p. 454 (Pagurus acadianus, nom. nov.); M. J. Rathbun, I905, p. I5; Sumner, I910, fig. 27.

Vineyard Sound, in deep water.-Smith. Almost exclusively confined locally to the western third of Vineyard Sound, where it is common; common also at Crab Ledge; dredged in 6 to zo fathoms; sand, gravel, and shells.-Survey.

Fish Hawk stations: 7563 (few small), 7567 ( in Polynices shell), 7569 (I), 7578 (I), $75^{82}$ (I), $75^{83}$ (I), 7584 (2), 7585 ( $\mathrm{I}$ in Polynices shell), $759^{2}$ (many in Polynices shells), 7594 (several in Polynices shells), 7603 (many), 7604 (I), 7605 (2), 7606 (several), 7607 (3), 7608 (those from Crab Ledge in shells of Buccinum undatum, Sipho sp., Chysodomus decemcostatus, Polynices, and Scalaria), 7664 (I), 7676 (few), 7677,7678 (several), 7680 (many, mostly large), 768I (many), 7682 (few), 7686 (I), 7698 (several, I with eggs), 7699 (several), 77 이 (several), 7702 (many), 7703, 7706 (many), 7707 (many), 7708 (many), 7709 (few), 77 I7 (2), 7718 (several), 77 I9 (many, I with eggs), 7720 (few), 7722 (I), 7724 (I young), 7725 (I), 7726 (several), 7727 (2), 7730 (several), 773 I (few), 7734 (several), 7736 (several), 7740 (I).

Phalarope stations: $5^{2}$ (2 small), 57 (I), 59 (common), 66 (x).

Pagurus longicarpus Say. [Chart III].

Verrill and Smith, I873, p. 549, $3^{1} 3$, etc. (Eupagurus longicarpus); S. I. Smith, I879, p. 47 (Eupagurus longicarpus); Bumpus, I898a (Eu-
Pagurus longicarpus-Continued.

pagurus longicarpus); Thompson, I899, I903, (Eupagurus longicarpus); M. J. Rathbun, 1905, p. 15; Sumner, 1910, fig. 24.

A littoral species of extreme abundance, occurring on every sort of shore and bottom, and down to considerable depths; sometimes found in waters which are somewhat brackish. Dredged by the Survey at all depths and on all kinds of bottom, both in Vineyard Sound and Buzzards Bay. Locally the shells of Littorina litorea, Ilyanassa obsoleta, and Tritia trivittata are the ones chiefly occupied by this species, though almost any receptacle of the right size may be employed, even the shell of Crepidula fornicata or the tube of Cistenides gouldii.

Fish Hawk stations: 7525 (few), 7526 (few), 7530 bis (several in Tritia trivittata), 753 $\mathrm{x}$ bis (few), 7532 (relatively few), 7532 bis ( 1 ), 7533 bis (in Littorina), 7534,7534 bis (in Urosalpinx), 7535 (few), 7535 bis (in Anachis), 7536 bis (several in Polynices triseriata), 7537 (several), 7537 bis (few), 7538 (several), 754I (comparatively few), $754 \mathrm{I}$ bis (many), $754^{2}$ (few), 7542 bis (few), 7543 (many), 7543 bis (2), 7544 (few), 7545 bis (several in Urosalpinx), 7546 (x), 7546 bis (in Tritia), 7547 bis (many), 7549 (few), 7549 bis (many), $755^{\circ}$ (few), $755^{\circ}$ bis (few), $755^{\mathrm{I}}$ bis (few), $755^{2}$ (few), 7553 (many), 7553 bis (many) 7554 (numerous), 7554 bis (many), 7556 (few), 7557 (few), 7558 (few), 7559 (few), 7560 (few), 756 I (few), $756_{3}$ (many), 7564 bis (many small), $75^{6} 5$ (few), 7565 bis (I in Urosalpinx), 7567 (few), 7568 (few), 7569 (few), 757 I (several), $757^{2}$ (few), 7576 (few), 7578 (many), $75^{80}$ (many), 758x (few), $75^{82}$ (few), 7583 (few), 7584 (few), $75^{85}$ (few), $75^{86}$ (few), $75^{87}$ (few), 7589 (I), 759 r (I), 7592 (few), 7596 (I), 7598 (few), 7599 ( I in small Polynices shell), 760 (I), 7602 (many), 7605, 76ri (few in Tritia), 76r2 (sev. eral with $P$. duplicata), $76 \mathrm{r}_{3}$ (in Littorina litorea), $76 \mathrm{I}_{5}$ (in P.duplicata, L. litorea, and Tritia), 7616 (many in $P$. triseriata, L. litorea, and Tritia), 761 7 (many), 7618 (many in Tritia), 76r9 (many), 7620 (many), 762I (many), 7622 (several in Busycon carica), 7623 (in Tritia), 7624 (many), 7625 (many in Tritia), 7626 (many in Tritia), 7627 (many in P.duplicata and Tritia), 7628 (few), 7629 (many in Tritia), 7630 (several), 7632 (several in $P$. duplicata), 7633 (few), 7634 (many), 7635 (few), 7636 (several in Littorina), $76_{37}$ (many), $76_{3} 8$ (many in Urosalpinx), 7639 ( $\mathrm{I}$ in $P$. duplicata), 7640 (several), 764I (many), 
Pagurus longicarpus-Continued.

7642 (I), 7643 (many), 7644 (few), 7645 (many), 7648 (several), 765 I (in Tritia), 7652 (I), 7653 (many), 7654 (few), 7655, 7656 (several in Tritia), 7657 (many), 7658, 7660 (many), 7662 (several), 7663 (several), 7664 (several), 7667 (few), 767 I (many), 7672 (few in Tritia), 7673 (many), 7674 (few in Tritia), 7675 (many; I in P. heros), 7676 ( 2 in Tritia), 7677 ( 1 in Polynices; $x$ in Tritia), 7679 (several), 7680 (several in Polynices), 768I (several), 7683 (I), 7685 (2), 7686 (2), 7696 (2), 7700 (I in Tritia), 7701 ( $\mathrm{x}$ in Tritia), 7702 (I), 7703 (several), 7704 (I), 7706 (several), 7707 (several), 7708 (several), 7709 (I), 7717 (I), 7718 (2), 7722 (I), 7723 (I), 7724 (many), 7725 (I), 7726 (several), 7728 (severai), 7730 (few), 773 I (several), 7732 (several), 7736,7737 (I), 7739 (few), 7740 (few), 774I (several), $774^{8}$ (I), 7749 (I), $775^{\text {I }}$ (2), $775^{2}$ (I), 7753 (several), 7754 (several), 7755 (several), 7756 (1), 7757 (several), $775^{8}$ (several), 7759 (several), 7760 (few), $776 \mathrm{r}$ (many), 7762 (I), 7764 (several), 7766 (few), 7767 (few), 7769 (several), 7770 (several), 7772 (several), 7774 (many), 7775 (I), 7776 (few), 7777 (several), 7778 (I), 7780 (several), 778 I (several), 7782 (few).

Phalarope and Blue Wing stations: I (few in Tritia), 3 (many), 5 (few in Tritia, 6 (few), 7 (many in Tritia), 8 (common), 9 (common), Io (few), II (common in Tritia), I3 (common), I4 (few), I7 (several in Tritia), I9 (common; with eggs), 20 (I), 22 (common), 23 (common), 26, 28 (in Tritia), 29 (few), 30 (few), 33 (several), 35 (I in Tritia), 48, 49 (I), 50 (I), 52 (many), 53 (many), 55 (few), 57 (few), 58 (I), 59 (few), 60 (few), 6 x (several), 63 (few), 64 (in Anachis, $P$. triseriata, P. immaculata?; Sipho, Eupleura, and many in Tritia; females with eggs), 65 (many in Tritia), 66 (several), 67 (severa1), 68 (many in Tritia and Littorina), 7o (few), 7 I (many), 72 (several), 73 (several), 74 (few), 76 (few), 77 (few), 78 (many with eggs), 79 (few), 80 (many), 8r, 82 (common), 83 (common), 84,86, 88, 89, 90, 92, 93 (common), 94 (young, common in tubes of Cistenides gouldii), 95, 98, 99 (few), I00 (living), IOI (few), I03, I04, I07 (many), I08, I09, II0, III (few), I I2, I I 4, I I 5 (common), II7 (few), II8 (common), I2I (common), I22 (many), I23 (common), I24 (common), I25 (common), I 26 (few), I28 (common), I29 (abundant), I30 (common), I3I (few), I32, I33 (in Eupleura), I34 (common), I35, I37 (common), I38 (common), I39 (few), I42 (com-
Pagurus longicarpus-Continued.

mon), I44 (several), I45 (common), I47 (common), I48 (common), I50 (several), I52 (few), I 53 (few), I 54 (few), I 55 (several), I 58 (many).

"Bearing well-developed eggs, May 9."-Bumpus. With eggs till September I3.-Thompson.

Devoured by various fishes, which swallow the crab bodily with its shell.

Pagurus pubescens Kröyer.

Verrill and Smith, I873,p. 549 (Eupagurus pubescens); S. I. Smith, x879, p. 47 (Eupagurus pubescens); M. J. Rathbun, Ig05, P. I5. (None of these writers record this species definitely for the region.)

Vineyard Sound, I88r, 2 specimens, bearing eggs July 20.-Rathbun. Dredged by the Fish Hawk off No Mans Land in 28 fathoms (thus not strictly within the region).

Pagurus kroyeri Stimpson.

S. I. Smith, I879, p. 48 (Eupagurus kroyeri; not listed south of Cape Cod); M. J. Rathbun, I905, p. I6 (no specific local records, though its range, as stated, would include this region).

Common at Crab Ledge in I7 to 25 fathoms, dwelling in the shells of Scala and Polynices.Survey.

Fish Hawk Stations: $7603^{*}$ (few), 7604 (I), 7607 (I?), $7609^{*}(2)$.

2Pagurus politus Smith.

M. J. Rathbun, I905, p. I6 (110t listed for region).

A specimen of this species was found by Miss Rathbun among Survey material from Tarpaulin Cove, in I fathom of water. It seems possible that either the specimen or the label had been shifted, for this has been known only as a deep-water species.

Pagurus annulipes (Stimpson). [Chart II2.]

(Not listed by Verrill and Smith!). Thompson, I899, (Eupagurus annulipes); M. J. Rathbun, I905, p. I6; Sumner, I9ro, fig. 26.

Abundant and of general distribution throughout Vineyard Sound and Buzzards Bay, with the exception of the deeper waters of the western end of the Sound, where this species appears to be wanting in just the area occupied by $P$. acadianus.-Survey. Dredged in 2 to I 7 fathoms, on every sort of bottom, most commonly inhabiting the shells of Anachis avara. Nantucket Sound.-Rathbun.

Fish Hawk stations: 7522 (many), 7523 (many), $75^{24}$ (few), $75^{25}$ (few), 7527 (many), 7530 (few), 7530 bis (many in Anachis), 753 I bis (few), 7532 (many), 7532 bis (few), 7533 bis 
Pagurus annulipes-Continued.

(several), 7534,7535 (few), 7535 bis (in Anachis), 7537 (many), 7537 bis (many in Anachis), 7538 (many), 7539 bis ( $\mathrm{I}$ in Anachis), $754 \mathrm{I}$ (comparatively few), $754 \mathrm{I}$ bis (many), 7544 (few), 7545 (few), 7545 bis (in Anachis), 7547 (comparatively few), 7547 bis (in Anachis), 7549 (many), 7549 bis (many), 7550 bis (few), $755^{\mathrm{I}}$ bis (few in Anachis), $755^{2}$ (few); 7553 bis (many), 7554 bis ( $\mathrm{I}$ ), 7557 ( 3 minute), $7560,75^{6} 3$ (few), $75^{6} 5$ bis ( $\mathrm{I}$ in Anachis), $75^{89}$ ( $\mathrm{I}$ ), 7602 ( $\mathrm{I}$ in Turbonilla sp.), 7612 (several in Anachis), 76 $\mathrm{I}_{3}$ (several), 76I5 (I), 7618 (in Tritia), 7621 (I), 7623 (in Eupleura), $76_{30}$ (several), $76_{32}$ (few), $7633^{\circ}$ (few), 7634 (few), 7635 (few), 7640 (few), 7644 (many), 7648 (several), 7649 (I), 765 I (3), 7653 (many), 7654 (many), 7655 (few), 7660 (many in Anachis), $766 \mathrm{I}$ (few), 7663 (few in Anachis), 767 I (many), 7672 (few), 7673 (few in Tritia), 7674 (few), 7675 (few), 7689 (I), 7730 (several), 773 I (few), 7733 (several), 7734 (I smal1), 7738 (many), 774I (few), 7744 (ccmmon), 7745 (I), 7746 (common), 7748 (many), 7749 (many), $775^{\circ}$ (many), $775^{1}$ (I small), $775^{2}$ (few), 7753 (few), 7754 (many small), 7755 (few small), $775^{6}$ (few), 7757 (many), $775^{8}$ (many), 7759 (very many), 7760 (common), 7764 (few small), 7765 (I), 7766 (many), 7767 (many), 7768 (few small), 7769 (several), 7770 (several), 7772 (several), 7774 (I), 7776, 7777 (few), 7778 (many), 7779 (few small), 7780 (I), 7781 (many in Astyris), 7782 (several), 7783 (few).

Phalarope and Blue Wing stations: I (many in Anachis), 2 (many in Anachis), 3 (many), 4 (few in Anachis), 5 (many in Anachis), 7 (many in Anachis), 8 (many), 9 (several), Io (common in Tritia), I I (common in Tritia), I3 (common), I4 (common), I5 (common), I 7 (many in Anachis), I8 (in Anachis), Ig (few in Tritia), 20 (common), 22 (common), 23 (common), 25 (few), 28 (few), 29 (few), 30 (few), 32 (few), 33 (I), 34 (I), 52 (few), 53 (few), 55 (few), 59 (few), 6r (I), 62 (several), 63 (several), 65 ( 1 in Anachis), 66 (few), 67 ( $x$ in $A n$ achis), 68 (few in Anachis), 69 (in Vermicularia), 70 (I), 7 I (several), 72 (I), 74 (many), 75 (I very small), 76 (many in Anachis and Vermicularia), 77 (many; I in Tritia), 78 (in Anachis), 79 (few), 8o (2), 81 (common), 82 (common), 83 (several), $84,85,86,89,90,9$ r, 92,93 (several), 95, 98, Ior (few), I02, I03, I06, I07 (few), I08, I09, IIO, II2, II4, II5 (common), II7 (few), II8 (few), I22 (many), I23 (common), I25, 128 (few), I29 (common), I32 (in Urosal-
Pagurus annulipes-Continued. pinx), I34 (several), I35, I36, I37 (few), I38 (few), I44 (common), I45 (few), I46 (few), I47 (few), I48 (common), I49 (few), I50 (in Seila terebralis), I 53 (I).

Found by 'Thompson to be bearing eggs early in September.

\section{Family PORCELLANIDEE:}

Polyonyx macrochcles (Gibbes).

Faxon, 1879, p. 256 (Porcellana (Polyonyx) macrocheles); S. I. Smith, I882a,; M. J. Rathbun, I 905 , p. I4.

Adult taken once by A. Agassiz at Newport under stones on shore; the zoex swarmed at the mouth of Narragansett Bay in August, r878.Faxon. One specimen*, in possession of Mr. Gray, was collected by. Dr. D. H. Tennent on Devils Foot Island, June Io, I903, where it was found in a Chatopterus tube.

\section{Family CALAPPIDE.}

Calappa flammea (Herbst).

S. I. Smith, I882a (Calappa marmorata); M. J. Rathbun, I905, p. I3.

Smith records the capture of two young specimens at Ram Island, under stones at low water, in 1875 and 1878 . Miss Rathbun mentions the taking of the megalops at Woods Hole at the surface, July I6, I886. An adult taken in Eel Pond, September 24, I897 (identified by $R . P$. Bigelow).

\section{Family PARTHENOPIDE.}

Heterocrypta granulata (Gibbes).

Verrill and Smith, I873, p. 548, 4I5; MI. J. Rathbun, I905, p. I2.

Vineyard Sound, off Falmouth, near Suconesset Lightship.-Smith. Three stations in the eastern half of Vineyard Sound ( 7533 bis, 7545 bis, 7769 ), 7 to $I_{5}$ fathoms, sand and gravel; one specimen taken by tangle near Sound shore of Naushon; another dredged near West Island, Buzzards Bay.--Survey. Mr. Gray reports its occurrence "off Nobska," and Mr. Edwards states that in former years it was not uncommon in Buzzards Bay off West Falmouth.

Family INACHID.s.

Hyas coarctatus Leach.

Verrill and Smith, 1873 , p. 548; S. I. Smith, 1879 , p. 43; M. J. Rathbun, I893, p. 69; 1905, p. II. (None of these writers report this species from points within the limits of the region.) 
Hyas coarctatus-Continued.

Crab Ledge (5 stations), western end of Vineyard Sound ( 6 stations); dredged in ro to 20 fathoms, only twice at lesser depths, on bottoms of sand and gravel.-Survey.

Fish Hawk stations: 7603 (many)*, 7604 (few), 7606 (few), 7607 (several small), 7608 (few), $7689(\mathrm{I})^{*}, 7700(\mathrm{I})^{*}, 7706(\mathrm{I})^{*}, 77 \mathrm{I} 7(\mathrm{I})^{*}, 77 \mathrm{I} 8$ $(\mathrm{I})^{*}$.

Phalarope station: $32^{*}$.

Pelia mutica (Gibbes). [Chart II3.]

Verrill and Smith, 1873 , pp. 548, 395, etc.; M. J. Rathbun, I 893 , p. 89 ; I905, p. 89 ; Bumpus, I $898 \mathrm{~b}$.

Rather common in Vineyard Sound, chiefly in eastern half; a few scattered stations in the Bay; dredged in 3 to $I 7$ fathoms, on sand, gravel, and stones.-Survey. Woods Hole Harbor, on local pier.

Fish Hawk stations: $75^{22}$ (I male, 2 females: I with eggs), 7530 bis (I), $753 \mathrm{r}$ bis (I), 7532 (I), 7533 bis (?I), 7536 (several), 7538 (r), 7538 bis (I with eggs), 754 I bis (I), 7543 (I), 7544 (I), 7546 (I), 7547 bis (I with eggs), 7550 bis (I), $575^{\mathrm{I}}$ bis (few), $755^{2}$ (I), $75^{6} 5$ bis (I very small?), $761_{3}$ (I with eggs), 7639 (I), 7689 (I with eggs)* $775^{*}, 7759^{*}, 7767^{*}, 7768^{*}, 777^{\circ}(\mathrm{I})^{*}, 7782^{*}$.

Phalarope and Blue Wing stations: 9 ( $\mathrm{I}$ with eggs), I4 (I), I6 (I with eggs), 22 (I with eggs), 24 (several with eggs), 25 (few with eggs), 26 (I), 32 (2 with eggs), 34 (I), 36 (I), 62 (I), 63 (few), 67 (I with eggs), 69 (few small), 74 (I), 86, I I3 (I ovigerous female), II7 (I), I34 (I), $\Upsilon_{4} \mathrm{I}(2)$.

Bumpus reports the occurrence of eggs in early embryonic stages during the first week in July.

Libinia emarginata Leach. [Chart II4.]

Verrill and Smith, 1873, p. 548,368 , etc. (Libinia canaliculata); S. I. Smith, I879, p. 45; M. J. Rathbun, I892, p. 235; I905, p. I2.

Abundant and almost universally distributed throughout Vineyard Sound and Buzzards Bay. Dredged by the Survey in 2 to is fathoms, on every sort of bottom. Found everywhere on muddy shores and flats. Large specimens are taken in great abundance in the local fish traps and lobster pots, I35 specimens being found on one occasion in a single lobster pot.

Fish Hawk stations: $75^{2}$ I bis (I small), $75^{22}$ bis (I small), 7523 ( $I$ very small), $75^{23}$ bis ( 2 smail), $75^{24}$ bis ( $\mathrm{I}$ small), $75^{27}$ ( $\mathrm{I}$ young), 7530 bis ( $\mathrm{I}$ ), 7532 bis (several small), 7533 bis (féw), 7534 (several small), 7535 (few small), 7535 bis (few small), 7536 (several), 7537 (several small), 7537 bis (few), 7538 bis ( I), 754 I (several small), 7543 (several large), 7543 bis (many large), 7544

\section{Libinia emarginata - Continued.}

(few small), 7545 (few small), 7545 bis (several small), 7546 (I small), 7547 (very few small), 7547 bis (several), 7549 (few), 7549 bis (few), $755^{\circ}$ (I), $755^{\circ}$ bis (few), $755^{\mathrm{I}}$ (several small), 7553 (I small), 7553 bis (2), 7554 (2), 7554 bis (2), $755^{8}$ (few), 756r (few small), 7563 (many small), 7564 (several small), 7564 bis (numerous, small), 7565 bis (I), 7570 (I small), 7573 (I), 7578 (I small), 758I (2 small), $759^{2}$ (I small), 76 ro (several large and small), $76 \mathrm{Ir}$ (several large), $76 \mathrm{I}_{2}$, (several), $76 \mathrm{I}_{3}$ (I), 76 $\mathrm{I}_{4}$ (2 large), $766^{\circ}(\mathrm{I}), 76 \mathrm{I} 7$ (I large), 7618 (I small), 76 19 (2 large with eggs, I small), 7620 (several large and small), $762 \mathrm{x}$ (few), 7622 (I large), 7623 (I large and I small), 7624 (few, I large), 7625 (several, I large), 7626 (several), 7627 ( 2 large), 7629 (I), 7630 (I small), 7632 (several large and small), $76_{33}$ (several), $76_{34}$ (few females, I with eggs), 7637 (several), 7638 (several large), 7646 (I), 7648 (I), $76_{52}$ (I large), 7653 (several alive), $76_{54}$ (several large), $76_{56}$ (several large and small), 7657 (many large), 7660 (few), 766I (several), 7662 (few), 7663 (few), 767 r (r small), $7^{6} 7^{2}, 7674$ (few), 7675 (few), 7677 (few small), 7679 (I small), 7680 (I young), 768 I ( 2 young), 7682 (2 young), 7689 (2), 7697 ( I young), 7698 (several), 7699 (small, young), 7700 (several small), 77 or (5 young), 7702 (several), 7703 (several small), 7706 (few small), 7707 (I small) 7708 (several small), 7709 (several small), 77 iо (5 small), 7718 (several small), 7724 (many young), 7725 (3 young), 7726 (many young), 7728 (4), 7729 (3), 7730 (many small), $773 \mathrm{I}$ 7735 (young), 7736 ( 2 medium), 7739, 7740 (3), 774I, 7749, 775I (I), 7752, 7755, (I), 7757 (I large and I medium), $7759(7), 7760,7761,7762$ (very many, large and small), 7763 (many large), 7765 (I large), 7766 (I), $7767,7768,7769,7770,7776$ (I large), $7777,7778,7780,778 x$ (several large and small), 7782,7783 (2 large).

Phalarope stations: I (many small), 2 (few small), 3 (few small), 5 (few small), 7 (I small), 8 (few), Io (few), II (several), I3 (2), I8 (I), 24 ( 2 young), 30 (few small), 34 ( $\mathrm{I}$ living, large), 52 (several small), 53 (several small, I with eggs), 59 (few), 62? (I), 63? (few), 64 (I very small), 65 (I very small), 67 (I small), 68 (I small), 70 ( 1 ), $7 x$ (several), 72 (several large), 73 (few), 74 (several), 76 (few), 77 (2), 78 (few small young), 79 (few young), 80 (few young), 8I (few young), $82,83,84,90$, IO4 (I young), I07 (I), IO8 (I), IIo (I), II4 (I half grown), II5 (young), II6 (2), II8 (several), I22 (I young), I25 (I young), I29 (I), r3 I (I dead), r 32 (sev eral), I34 (several small), I40 (I young), I42 (I young), I57 (I large). 
Libinia dubia Milne Edwards.

Verrill and Smith, I873, p. 548, 368; M. J. Rathbun, 1892, p. 237; 1905, p. 12 .

Woods Hole (abundant in 1882); Buzzards Bay, in 7 fathoms; Mattapoisett Harbor.-Rathbun. Locally, at least, this crab is nearly or quite restricted to very shallow waters, and is seldom, if ever, taken by larger vessels with the dredge. Libinias of all sizes were collected from $x y$ different stations in Buzzards Bay and Vineyard Sound during the summer of 1907 , and from 16 stations in 1909 , but not one specimen proved to be $L$. dubia (unless certain very small ones were referable to that species) though this was especially sought for. During the regular Survey dredging, the species was recorded from Fish Hawk stations 7678,7725 , and 7738 , but these specimens, it is believed, were all immature, and the determinations are very questionable. Libinia dubia is, however, common in shallow water at North Falmouth, having been taken there by Mr. Gray and by our own collectors. One specimen was taken by Dr. Cole near Dumpling Rock Light, another by Mr. R. I. Hall in the Eel Pond at Woods Hole.

\section{Family CANCRIDAE.}

Cancer irroratus Say. Rock Crab. [Chart II5.] Verrill and Smith, I873, p. 546, 3I2, etc.; S. I. Smith, I879, p. 38; R. Rathbun, I884, p. 766; M. J. Rathbun, I905, p. 9.

Abundant and generally distributed throughout Vineyard Sound, and to a lesser extent in Buzzards Bay; several stations at Crab Ledge; dredged in 2 to I9 fathoms, on every sort of bottom.-Survey. Common along shore, under rocks, or buried in the sand.

Fish Hawk stations: $75^{22}$ (I very small), $75^{23}$ bis (3), $75^{24}$ bis (few), $75^{25}$ bis (several small), $75^{29}, 753 \mathrm{I}$ bis (2), 7532 bis (few small), 7533 bis (many small), 7534 bis (several small), 7535 (several small), 7535 bis (few small), 7536 (I), 7537 (I small male), 7539 bis (I), 754I (many small), $754 \mathrm{I}$ bis (I), 7542 (I small), 7543 (I small), 7543 bis (few), 7544 (few small), 7545 (few small), 7546 (few small), 7546 bis (2), 7547 bis (several small), 7549 (few small), 7550 (2), $755^{\circ}$ bis (I), $755^{I}$ (several very small), $755^{\mathrm{I}}$ bis (few), $755^{2}$ (few small), 7553 (few), 7553 bis ( $\mathrm{I}$ ), 7554 bis (several), 755 इ (many large), 7556 (many large), 7556 bis (several), 7557 (several, very small), $755^{8}$ (many), 7560 (I very small), $75^{62}$ (r large), $75^{6} 3$ (few small), $75^{64}$ (many large), $75^{64}$ bis (numerous small), 7566 (I I6269 - Bull. $3 \mathrm{I}, \mathrm{pt} 2-\mathrm{I} 3 \longrightarrow$
Cancer irroratus-Continued.

small), 7570 (2 large, several small), 757 I (many large and small), 7573 (few large), 7574 (I), 7576 (few small), 7577 (few small), 7578 (several large and small), 7579 (I), 7580 (I), $75^{81}$ (several large and small), $75^{82}$ (several medium), $75^{8} 3$ ( 1 small), $75^{84}$ (few large and small), $75^{85}$ (I small), 7586 (I small), 7589 (2 small), 759 (few small), 7592 (many large and small), 7593 (few), 7594 (few large), 7595 (few small), 7598 (I very small), 7599 (many large and small), 7600 (I small), 7602 (few small), 7603 (I small), 7604 (I small), 7607 (I large), 7611,7616 ( I small), 7618, 7622 (several small), 7626 (few), 7627 ( 2 small), 7637 (several small), 7639 (few), $764 \mathrm{I}$ (few), 7647 (2), 7648 (several), $76_{51}$ (3), $76_{52}$ (2 small), 7653 (several), $76_{56}$ (several), 7659 (several, I with eggs), 7660 (few), 766 I (several), 7663 (several), 7664 (3), 7667 (2), 767 I (few large, many small), 7672 (few, mostly small), 7673 (several, especially small), 7674 (several, with eggs), 7675 (several), 7674 (4), 7677 (about 6), 7678 (many), 7679 (many), 7680 (many large and small), 768I (many large) 7682 (many large and very small), 7685 ( 2 young), 7686 (several large and small, 7687 (several medium), 7688 (4:I small), 7695 (I very small), 7696,7697 (several), 7698 (several) 7699 (many, adult and young), 7700 (several, large and small), 770 (many large and small), 7702 (many large and small), 7703 (many large and small), 7704 (few), 7706 (many large and small), 7707 (many large and small), 7708 (many large and small), 7709 (many large and small), 7710 (few small), 77 I 7 (few large and small), 7718 (few large and small; many medium), 77 I9 (many), 7720 (very many large and small), $772 x$ ( $\mathrm{r}$ ), 7722 ( $\mathrm{I}$ young), 7723 (I young), 7724 (few living), 7725 (3 young), 7728 (several), 7729 (2), 7730 (several), 773 I (few large and many small), 7732 (2 very small) 7733 (I small), 7734 (3 large), 7735 (I small), 7736 (I large), 7737 (I large), 7738 (several small), 7739 ( 2 medium, I small), 7743 (I claw), 7744 (few small), 7746 (I leg), 7749 (I), $775^{\text {I }}$ (2), $775^{2}$ (2 large, several small), 7753 (2 medium), 7755 (several small), 7757 (I medium), $775^{8}$ ( $\mathrm{I}$ ), 7760 (few), $776 \mathrm{I}$ (common, large and small), 7762 (many large and small), 7765 (I medium), 7767 (I), 7770 (I medium), $777^{2}$ (young), 7773 (I medium), 7775 (I small).

Phalarope and Blue Wing stations: 4 (I large), I 7, 22 (I small), 25 (2 small), 27 (2 small), 28 (I dead), 33 ( $\mathrm{r}$ dead, several young), 34 ( $\mathrm{r}$ old, several young), 35 (I small), 37 (I young), $3^{8}$ 
Cancer irroratus-Continued.

(I small), 44 (I small), 45 (I small), 46 (several), 48 (2), 49 (2 small), 52 (many small), 53 (many small), 59 (6, many young), 6o (few small), 6 I (I small), 63 (I small), 64 (few small), 65 (2 small), 66 (r), 68 (2 small), 70 (few small), 7x (several small), 73 (2), 74 (2 small), 75 (2), 76 (few), 77 (few), 79 (I), 8I (I small), 82, 84, 85 , IO2 (4 young), IO4'(2 young), IO7 (7), II2 (young), II3, II4 (young), I22 (I young), I27 (I small).

Smith reports the zoex and megalops stages as being abundant in June and July.

This crab is important as a food of fishes. Smith reports it from the stomachs of the striped bass, sea bass, tautog, kingfish, sea robin, goosefish, summer flounder, toadfish, dogfish, dusky shark, sand shark, common skate, Raja lavis (?), Dasyatis centrura, and Myliobatis freminvillei. This and the following species are on the market as food, though little or no fishery exists locally.

Cancer borealis Stimpson. Jonah crab. [Chart II6.] Verrill and Smith, I873, p. 546,395; S. I. Smith, I879, p. 39; R. Rathbun, I884, p. $769 ;$ M. J. Rathbun, I905, p. 9 .

Along the sandy beach of Marthas Vineyard, from Menemsha Bight to Gay Head; Cuttyhunk; No Mans Land.-Smith. According to this writer there is a very pronounced difference in habit between $C$. borealis and $C$. irroratus, the latter concealing itself beneath rocks, the former remaining exposed. Fairly common at the western end of Vineyard Sound; a few scattered stations elsewhere.Survey. Dredged in 2 to 20 fathoms, more commonly at depths of ro or more fathoms, on various bottoms.

Fish Hawk stations: $75^{24}$ bis (I), 7537 bis (few small)* 7574 (I), 7578 (I), 7599 (I small), 7608 (? I small), $7676(2)^{*}, 7678(2)^{*}, 7680$ (I young)*, 7701 (I young)*, 7704 (I large)*, 7717 (I large and I small)*, 77 I9 (I large)*, 7720 (I large)*, 7726 (I medium)* 7728 (2)*, 7738 (I small)*, $7741^{*}, 7759$ (claw)*.

Phalarope stations: 24 (I young), 28 (I dead), 30 (I fragment), 33 (I small), 59 (3), I I I (I)*, I I 7 (I young)*.

\section{Family PORTUNIDA:}

Carcinides manas (Linnæus). Green crab.

Verrill and Smith, I873, p. 547,312, etc. (Carcinus granulatus); S. I. Smith, I879, p. 34 (Carcinus manas); Bumpus, I898, I898b (Carcinus granulatus); M. J. Rathbun, I905, p. 8.
Carcinides manas-Continued,

Vineyard Sound, Buzzards Bay, and the various connecting ponds and estuaries; very common in shallower waters, and under stones on shore up to high-water mark.

Bumpus records the finding of females bearing eggs from March till June 25.

Portunus sayi (Gibbes).

S. I. Smith, 1879, p. I2I (Neptunus sayi; not listed for this region); M. J. Rathbun, I905, p. 8 .

Found in company with Planes minutus upon the gulfweed which is drifted into Vineyard Sound during the late summer and fall, sometimes in great numbers. Especially abundant during the summer of 1906.

Females bearing eggs observed in August, September, and October.

Portunus ordwayi (Stimpson).

Two young specimens* taken from gulfweed collected by V. N. Edwards in Vineyard Sound, October I0, I905. This is the only record for New England.

Callinectes sapidus Rathbun.

Verrill and Smith, I873, p. 548, 367, etc. (Callinectes hastatus); S. I. Smith, I879, p. 33 (Callinectes hastatus); Thompson, 1899 (Callinectes hastatus); M. J. Rathbun, I905, p. 9.

Great Pond, common. Muddy shores and bottoms and among celgrass, particularly in brackish water. Not encountered in dredging, with the exception of one doubtful claw, dredged at Phalarope station I49, near head of Buzzards Bay.

A rencus cribrarius (Lamarck).

Vineyard Sound, October 10, I905; II young specimens*; Menemsha Bight, on gulfweed, August 29, I906; 2 specimens*. Not previously recorded for New England.

Ovalipes ocellatus (Herbst). Lady crab. [Chart II 7.]

Verrill and Smith, I873, p..547, 338, etc. (Platy. onichus ocellatus); S. I. Smith, I879, p. 33 (Platyonichus ocellatus); M. J. Rathbun, I905, p. 9 .

Western half of Vineyard Sound, common; dredged at a few points elserwere, including a few stations in the Bay; 3 to 19 fathoms, almost exclusively on sandy bottoms.-Survey. Common on the Bay shore, at the local bathing beach; recorded from Menemsha and Vineyard Haven. In general this species frequents sandy shores and bottoms, burrowing 
Ovalipes ocellatus-Continued.

in the sand and lying with only the eyes and antennac exposed. Occasionally taken swimming at the surface.

Fish Hawk stations: 7543 (1), 7543 bis (2), 7546 (2 large, I small), 7547 bis (2), 7554 (several small), 7557 (I), 7562 ( I large), 7566 (few small), 7567 (2), 7569 (4 large), 7570 (I), 7574 (I), 7575 (2), 7576 (I), 7584 (2), 7589 (3 large), 7590 (I), 7591 (several large), 7598 (I large), 7676 (3), 7679 (many), 768o (several), 768I (many), 7682 (r), 7698 (few), 7699 (several), 7700 (several), 7701 (few), 7702 (several), 7703 (few), 7704 (2), 7705 (I), 7706 (several), 7708 (several), 7709 (several large), 7710 ( I large), 7717 (3), 7718 (few), 77 I9 (several), 772 I (I), 7725 (several), 7726 (several), 7727 (I), 7728 (several), 7729 (many), 7730 (few), 7734 (I), 7735 (I), 776 r (many, large and small), 7782 (I medium).

Phalarope stations: I40 (I), I42, I 50 .

Reported by Smith from the stomachs of the tautog, squeteague, and mackerel.

\section{Family XanTHIDAs.}

Panopeus herbstii Milne Edwards.

Verrill and Smith, 1873 , p. 547,472 (no local records); Benedict and Rathbun, I89r, p. 358; M. J. Rathbun, I905, p. 6 (Eupanopeus herbstii).

Vineyard Sound, in 1875 ; Woods Hole, January 8, I876; Newport.-Rathbun. Bay shore of Pasque Island, at Phalarope station $84^{*} ; x$ young.-Survey. Found in oyster beds, according to Smith, "apparently ... introduced from farther south with the oysters."

Eurypanopeus depressus (Smith).

Verrill and Smith, I873, p. 547, 3I2, etc. (Panopeus depressus); S. I. Smith, I879, p. 37 (Panopeus depressus); Benedict and Rathbun, I89I, p. 366 (Panopeus depressus); M. J. Rathbun, I905, p. 6 .

Vineyard Sound, I875, I882; New Bedford, I882 (W. Nye, jr., collector).-Rathbun. Thisspecies was listed by Verrill and Smith (I873) from nearly every sort of shore and bottom, as well as from piles and upon oyster beds, where it was said to be very abundant. These authors apparently regarded $P$. depressus as even commoner locally than $P$. sayi. There is here apparently a confusion of species. Miss Rathbun has not found a single undoubted specimen
Eurypanopeus depressus-Continued.

of depressus among the very numerous crabs from the survey dredging collections which have been referred to her; and but a single specimen in a lot of panopeid crabs obtained at about a dozen different points along shore. This last was taken at Wareham River, on a muddy bank.

Neopanope texana sayi (Smith). [Chart II8.]

Verrill and Smith, I873, p. 547, 3I2, etc. (Panopeus sayi); S. I. Smith, I879, p. 37 (Panopeus sayi); Benedict and Rathbun, I89I, p. 363 (Panopeus sayi); M. J. Rathbun, I905, p. 7.

Very abundant in the eastern half of Vineyard Sound and the upper half of Buzzards Bay, though not confined to these regions; apparently absent from the westem end of Vineyard Sound.-Survey. Dredged in 2 to I7 fathoms, on all sorts of bottoms. Very common, likewise, along shore, especially in muddy places, and on piles among algæ, etc. Recorded from Woods Hole Harbor, Nobska Point* and Beach*, Vineyard Haven*, Edgartown*, Katama Bay*, West Falmouth*, Scraggy Neck*, Fort Phœnix*, Round Hill Point*.

Fish Hawk stations: $a 75^{2 I}$ bis (I), $75^{22}$ ( 4 females, 4 males), $75^{22}$ bis (I), 7523 (2 very small), $75^{23}$ bis (few small), $75^{24}$ (I fernale, I male), $75^{2} 5$ ( I female), $75^{2} 5$ bis (few), 7526 ( 2 females), $75^{27}$ (5 males and females, latter with eggs), 7530 bis (I), 7532 (6), 7534 bis (I), 7535 (I), 7536 (I), 7537 (I male), 7538 bis (3), 754 I (I male), 7543 bis (few small), 7545 (I male), 7547 (few), $755^{\circ}$ bis (I), $775^{\mathrm{I}}$ bis (few), 7554 bis (I small), 7555 (few), $755^{6}$ (many), 7564 (many), $757^{\circ}$ (I), 7572 (2), 7573 (many), 7610 (I), 76II (2), $76 I_{2}$ (I small), 76I3 (several)*, 76I4 (I female with eggs and 1 small), $76 I_{5}(3), 7616(\mathrm{I}), 76 \mathrm{I}_{8}$ (2, I with eggs), 76r9 (several), 7620 (several small), 762 I (several), 7623 (few), 7624 (several), 7625 (several), 7626 (I small), 7628 (many), 7629 (several), 763I (many), 7632 (few), 7633 (few), 7634 (several), 7635 (several), 7644 (I), 7645 (2), 7646 (I), 7647 (few), 7648 (few), 765 I (I), 7656 (I), 7659 (I), 7663 (I), $7697^{a}(2), 773^{*}, 7737$ (female with eggs)*, $773^{8}(\mathrm{I})^{*}, 7749(\mathrm{I})^{*}, 775^{\circ}(\mathrm{I}), 7753^{*}, 775^{*}$, $7757^{*}, 775^{*}, 7759$ (female with eggs)*, 7762 (female with eggs)* ${ }^{*} 7763^{*}, 7764^{*}, 7767^{*}, 77^{*}$, $7769^{*}, 777^{*}, 7776^{*}, 7777^{*}, 7781^{*}, 7783^{*}$ 。

$a$ In addition to those cases where the asterisk has been used, many specimens from stations 7697 to 7750 and 82 to $r_{53}$ were referred to Miss Rathbun for identification. It is possible that in some cases this species was confused in the field with anoustifrons or depressus. 
Neopanope lexana sayi-Continued.

Phalarope and Blue Wing stations: I (few), 2 (few), 3 (few), 5 (I), 6 ( ) , 8 (few), IO (I), II (I), $I_{5}$ (few), I7*, 24 (few), 25 (2), 26 (I small), 27 (I), 29 (few), 30 (few), 62 (r), 63 (few), 69 (few small), 70 (several small), 7 I (several), 72 (several), 74 (I), 82 (I), 84, 85, 86, 87 (I), I07 (I female with eggs), I08 (II) III (I), II2, II4 (I), II6 (2), II 7 (4 ovigerous females), II8 (7 ovigerous females), I2I (2), I23 (I), I24 (I), I25 (2), I27 (I), I3O (I), I32 (common, ovigerous female), 137,138 (3 ovigerous), I39 (fragment), I 4 I (2), I 42 (2 ovigerous), I44 (many), I45 (several), I46 (several), I47 (several), I49 (many), I 50 (3), I $5^{I}$ (I), I $5^{2}$ (4), I 53 (I), I 54 (2 small)*, 157 (few living) ${ }^{*}, 5^{8}$ (I small) (?).

Reported by Smith from the stomach contents of the sea bass (Centropristes), tautog and sea robin.

Hexapanopeus angustifrons (Benedict \& Rathbun).

Benedict and Rathbun, I891, p. 373 (Panoperes angustifrons, sp. nov.); M. J. Rathbun, I905, p. 7 .

Vineyard Sound, off East Chop, in 1887 (Fish Hawk stations I205-I208); Nantucket Sound; Buzzards Bay.-Rathbun. Buzzards Bay at Fish Hawk stations $7612^{*}, 7628^{*}$, and $7639^{*}$ (Igo7 repetitions), where this species was taken in company with Neopanope texana sayi. Also at Phalarope stations $84^{*}, \mathrm{I} 44^{*}, \mathrm{r} 45^{*}, \mathrm{I} 47^{*}$ (all likewise at Buzzards Bay).

? Rhithropanopeus harrisii (Gould).

Verrill and Smith, $x 873$, p. 547,3 I3, etc. (Panopeus harrisii); S. I. Smith, I879, p. 37 (Panopeus harrisii); Benedict and Rathbun, r $89 \mathrm{r}$, p. 378 (Panopeus harrisii); M. J. Rathbun, I905, p. 8 .

Rocky shores, "occasionally met with under stones, but lives rather higher up [than dcpressus or sayi] toward high-water mark;" found in brackish, even nearly fresh, water.-Smith. No definite local records, though this region lies within the known range of the species.

\section{Family Pinnotheridzi.}

Pinnotheres ostreum Say. Oyster crab.

Verrill and Smith, 1873 , p. 546,438 , etc.; M. J. Rathbun, 1905, p. 5 .

Naushon, 1886.- Rathbun. The female of this species is the familiar "oyster crab," and is doubtless frequently taken locally, though but one definite record exists. The male is frec swimming, and has been taken at the surface in Vineyard Sound.-Smith.
Pinnotheres maculatus Say. Mussel crab. [Chart I I9.]

Verrill and Smith, 1873 , p. 546, 309, etc.; R. Rathbun, I884, p. 766; Bumpus, I898b; M. J. Rathbun, I905, p. 5 .

Buzzards Bay, in I887 (Fish Hawkstation I 2 5).Rathbun. In Survey dredging, only recorded from Vineyard Sound; absence from Bay records may, however, be due to our failure to examine the mussels. Males taken in tow at the local pier in July, October, and December*.-Edwards. Like the preceding species, this crab lives commensally in bivalve mollusks. It is common in Mytilus edulis, Modiolus modiolus, and Pecten magellanicus. R. Rathbun states that from a bushel of the last species, taken off Newport, nearly a pint of the crabs were taken; while single specimens of Modiolus, examined by members of the Survey, have been found to contain as many as seven or eight crabs. The male, as with the preceding species, is free swimming, though sometimes met with in tle hosts.

Fish Hawk stations: 7530 (2, with eggs, in Modiolus), 7555 ( $\mathrm{I}$ in Mytilus), 7556 (many in $M y$ tilus), $75^{6} \mathrm{r}$ (many of both sexes in Modiolus), 7563 (in Mytilus), 7564 (in Mytilus), 7565 (in Mytilus), $75^{8} 3$ (I large female, from Modiolus), 7593 (3 from Modiolus), 7679 (female with eggs), 768 I (3), 7732 ( I), 7733 (4), 7737 (2 females and I male), $775^{8}$ (I).

Egg-bearing females observed by F. P. Gorham from July 9 to August 29.-Bumpus.

Pinnixa chcetopterana Stimpson.

S. I. Smith, I882, p. 250; M. J. Rathbun, I905, p. 5 .

Adults dredged in Buzzards Bay, young taken at the surface in Vineyard Sound.-Smith. According to Smith this is by far the commoner of the two local species of Pinnixa. Woods Hole, Naushon.-Rathbun. Buzzards Bay, at Fish Hawk station 76I4 (I9o7 repetition), 2 specimens.-Survey. This crab inhabits the tubes of Chatopterus pergamentaceus and of Amphitrite ornata. One of the Pinnixas, believed to be this species, is fairly common on a shoal between Ram Island and Devils Foot. Four specimens were taken here with $\mathrm{I}_{3}$ Chatopterus by J. F. McClendon and C. B. Bennett.

Pinnixa sayana Stimpson.

Verrill and Smith, I873, p. 546,367 , etc. (Pinnixa cylindrica); S. I. Smith, I882, p. 250; M. J. Rathbun, I905, p. 6.

Vineyard Sound and Buzzards Bay (dredged), living in the tubes of certain large annelids. - 
Pinnixa sayana-Continued.

Smith. Buzzards Bay, in 1887 , at Fish Hawk stations I21I-I221,-Rathbun. Wareham River, at Phalarope station 154,2 specimens*.-Survey.

Reported by Smith from the stomach of the summer flounder.

Dissodactylus mellita (Rathbun).

Sumner, I909, p. 985.

A single specimen was dredged July 29, I908, in the vicinity of Fish Hawk station 7703, * along with large numbers of the "sand dollar" (Echinarachnius parma); another is recorded from Fish Hawk station 7579.

Family GRAPSIDA.

Planes minutus (Linnæus).

S. I. Smith, 1879, p. I20 (Nautilograpsus minutus; not listed for this region); I882a (Nautilograpsus minutus); M. J. Rathbun, I905, p. 4 .

Western part of Vineyard Sound, commonly on gulfweed; of variable abundance, depending upon the occurrence of the weed; recorded as very common during the summers of 1904 and I906; not seen in 1907. Wareham River (doubtless a straggler).-Rathbun.

Recorded from August 9 to October I5. During August and September many of the females carry eggs.

Sesarma reticulatum (Say).

Verrill and Smith, 1873, p. 546,467 , etc. (Sesarma reticulata); M. J. Rathbun, I905, p. 4.

Wareham, Acushnet River--Rathbun. Wareham River*.-Cole. Burrows in salt marshes and the banks of estuaries. Usually associated with $U$ ca pugnax.-Smith.

\section{Family OCYPODIDĖ.}

Ocypode albicans Bosc.

Verrill and Smith, I873, p. 545, 745, etc. (Ocypoda arenaria); S. I. Smith, I882a (Ocypode quadrata); M. J. Rathbun, I905, p. I.
Ocypode albicans-Continued.

Only the megalops is known locally. This has been taken by V. N. Edwards in Vineyard Sound in September (Smith) and by J. S. Kingsley on August I (Marine Biological Laboratory card catalogue). The adult burrows in sandy beaches, above high tide.

Uca pugnax (Smith).

Verrill and Smith, 1873, p. 545,367 , etc. (Gelasimus pugnax); S. I. Smith, 1879, p. 33 (Gelosimus pugnax); Bumpus, I898b (Gelasimus pugnax); M. J. Rathbun, I905, P. I.

Acushnet River, in I882 (W. Nye, jr., collector.)Rathbun. Hadley Harbor, Wareham River*. Abounds in salt marshes and on the borders of estuaries, where it riddles the ground with its holes.

Reported by Bumpus as breeding early in June.

Uca pugilator (Bosc).

Verrill and Smith, I873, p. 545, 336, etc. (Gelasimus pugilator); S. I. Smith, I879, p. 33 (Gelasimus pugilator); Bumpus, I898b (Gelasimus pugilator); M. J. Rathbun, I905, p. 2.

Head of Woods Hole Harbor, Ram Island, Hadley Harbor. Wareham River*, Katama Bay*, Sippowisset.-Rathbun. Inhabits sand or mud flats and beaches near high-water mark, including the shores of brackish waters.

Breeds early in June.-Bumpus.

Uca minax (Leconte).

Verrill and Smith, I873, p. 545, 337, etc. (Gelasimus minax); Bumpus, I8g8b (Gelasimus minax); M. J. Rathbun, I905, p. 2. (Nodefinite local records published by any of these writers).

Woods Hole, I875; Wareham (U. S. Nat. Mus.); New Bedford, in I882 and I886 (W. Nye, jr., collector).-Rathbun (MS. notes). This crab, according to Smith, "lives upon salt marshes, usually farther from the sea than the others, and frequently where the water is most of the time nearly fresh."

Breeds early in June.-Bumpus.

\section{Class INSECTA.}

Anurida maritima (Guerin).

Verrill and Smith, 1873, p. 544, 33 I.

Woods Hole; Nantucket.-Verrill. Abundant at Nobska Point and doubtless many similar places, beneath stones, between tides, etc.

Chironomus halophilus Packard.

Verrill and Smith, I873, p. 539, 4I5 (description by A. S. Packard).
Chironomus halophilus-Continued.

"Full-grown larvæ were dredged in to fathoms in Vineyard Sound, several miles from land, among compound ascidians (A. E. V.), and severail young larvæ were dredged in 8 to ro fathoms in Woods Hole Passage, September ro (A. S. P.)."’ 
Verrill and Smith $(1873$, p. 540, 543) also list for local waters a larva which they refer to the genus Eristalis, "found in Vincyard Sound, among algæ in April"; and another listed as "Molanna, species undetermined," which was "found in a . . tube . . attached to the piles of a wharf, below highwater mark, at Menemsha Bight."

The following is a list of the species of insects taken by Mr. E. D. Congdon in brackish water at Great Pond and Tashmoo Pond, July and August, I907. While these insects are not strictly marine in their habitat, it seems worth while to include this list in the present work. The species were identified by Messrs. Banks, Clemons, Currie, Heidemann, and Schwartz, of the United States National Museum.

\section{NEUROPTERA. \\ Limnophilidæsp., larva. Tashmoo, Great Pond.}

\section{OdONATA.}

Eschna sp., larva. Great Pond.

Anax junius (Drury), larva. Tashmoo.

Sympetrum sp., larva. Great Pond.

\section{HEMIPTERA.}

Corixa burmeisterii Fieber. Tashmoo.

Corixa harrissii Uhler. Great Pond.

Gerris marginatus Say. Tashmoo.

Mesoveliasp.(probably M. bisignata Uhler), nymph.

Tashmoo.

Notonecta undulata Say. Tashmoo, Great Pond.

\section{COLEOPTERA.}

Acilius fraternus Harris. Great Pond. Berosus peregrinus Herbst. Tashmoo.

\section{Class ARACHNIDA.}

Chernes oblongus Say.

Verrill and Smith, 1873, p. 544, 331.

"Under stones near low-water mark at Woods

Hole... several specimens were found to-
Bidessus discretus Sharp. Tashmoo.

Cnemidotus muticus Leconte. Great Pond.

Gyrinus sp., larvæ. Tashmoo, Great Pond.

Haliplus ruficollis De Geer. Tashmoo, Great Pond.

Hydroporus sp., larvæ. Tashmoo.

Laccophilus maculosus Germar. Great Pond.

Philhydrus perplexus Leconte. Tashmoo.

Tropisternus glaber Herbst. Great Pond.

Tropisternus nimbatus Say. Great Pond.

Tropisternus sp., larvæ and egg cases. Tashmoo, Great Pond.

\section{DIPTERA.}

Ceratopogon sp., pupa. Tashmoo.

Chironomus sp., larvæ. Tashmoo, Great Pond.

Culicide sp., larva. Tashmoo.

Odontomya sp., larva. Tashmoo.

Tabanus sp., larva. Great Pond.

Telanocera sp., larva. Tashmoo.

\section{XIPHOSURA.}

Limulus polyphemus (Linnæus).

.Verrill and Smith, 1873 , p. 580, 340; Bumpus, I898; г898a; $1898 \mathrm{~b}$.

Common locally wherever physical conditions are favorable, e. g., in Woods Hole Harbor, Katama Bay, Vineyard Haven, Menemsha Bight, West Falmouth Harbor. This animal frequents muddy and sandy shores and mud flats, below low-water mark, often burrowing a short distance below the surface. Occasionally dredged by the Survey, even at a depth of several fathoms; in one case recorded from $12 \mathrm{I} / 2$ fathoms, though it it is not certain that this was a living specimen.

Fish Hawk stations: 7633 (x living), 7779,7780 (2 large).

Phalarope stations: ${ }_{3} 8$ (I dead), I4o (I dead), I5I.
Chernes oblongus-Continued. gether."-Verrill and Smith. Juniper (Butlers) Point.-W. M. Wheeler, in Marine Biological Laboratory card catalogue.

Limulus polyphemus-Continued.

Limulus disappears through the winter, reappearing in the spring. Bumpus reports the taking of one at Waquoit as early as March 25 (r898); and Mr. Edwards reports that they first appeared in Narragansett Bay, at about the same day of the month in I909. They begin to spawn in May, at which time they come to shore in great numbers, and are easily taken. A limited area at the head of Great Harbor has for years been a much frequented breeding ground. The spawning season seems to continue actively throughout part of June; and I. A. Field has observed paired individuals at Menemsha Bight as late as July I7. The eggs are deposited in the sand, a short distance below the surface. Young from one-half inch to 2 or 3 inches long are found during the middle of August, and small tests are sometimes exceedingly abundant on the beaches. 
PYCNOGONIDA. $a$

\section{Family NyMPHONIDA:.}

Nymphon grossipes (Fabricius).

F. B. Wilson, r88o, p. 49r (no local records). One specimen dredged by the Phalarope at Crab Ledge, in 15 fathoms, August 22 (?), I902.Cole.

\section{Family AMMOTHEIDAE.}

Tanystylum orbiculare Wilson. [Chart 120.]

Verrill and Smith, I873, p. 544, etc. (Pallene sp.); E. B. Wilson, 1878, p. 5 (sp. nov.); I88o, p. 47r; Morgan, 189r; Bumpus, I898b; Cole, IgOI.

Woods Hole, Vineyard Sound, Vineyard Haven, occurring on piles; likewise taken in the dredge among ascidians and hydroids.-Verrill. Numerous stations throughout length of Vineyard Sound; also in Quicks Hole and Robinsons Hole; none taken in Buzzards Bay; dredged in I to $I_{5}$ fathoms, on sand, gravel, and stones.-Survey.

Fish Hawk stations*: $75^{2} \mathrm{I}$ bis ( $\left.\mathrm{I}\right), 75^{22}$ (many), 7522 bis (about I2), 753 I bis (I), 7535 (I), 7554 bis (2), $7560(\mathrm{x}), 7564$ bis (I), 7594 (I), 7742 (I), 7743 (I), 7745 (4), $775^{8}$ (several), 7759 (I), 7760 (I), 7764 (2), 7765 (I).

Phalarope and Blue Wing stations*: I3 (I), I5 (few on hydroids), I6 (I), 22, 27 (few), 51 (few on Crisia), 57 (few).

With eggs in July, August, and September; abundant larvæ found July $I$ and later.T. H. Morgan.

\section{Family PALIENIDE.}

Pallene brevirostris Johnston.

E. B. Wilson, 1878, p. 9 (Pallene empusa); r88o, p. 476 (Pallene empusa); Morgan, i89I (Palleneempusa); Bumpus, I898b (Pallene empusa); Cole, Igor, p. rg6.

Vineyard Sound, on Pennaria tiarella.-Wilson. Bureau of Fisheries pier, Eiel Pond.-Morgan. Abundant in Eel Pond.--Cole. Confined to shoaler water than Tanystylum and Anoplodactylus, and for this reason not so often taken in the Survey dredgings. One specimen dredged near Gay Head, at Blue Wing station $45^{*}$.

Carries eggs in July, August, and September.Morgan.

\section{Family Proxichilididd: \\ Anoplodactylus lentus Wilson.b [Chart r2r.] \\ Verrill and Smith, 1873, p. 544, 415 (Phoxichil- idium maxillare); E. B. Wilson, $x 878$, p. 200 (Anoplodactylus lentus sp. nov.); I878a, p. 14; I880, p. 482; Morgan, I8gI (Phoxichilidium maxillare); Bumpus, $1898 \mathrm{~b}$ (Phoxichilidium maxillare); Cole, I901; I906.}

Piers at Woods Hole and Vineyard Haven; found on piles between tides and down to considerable depths, usually among hydroids, algæ, ascidians, etc.; a very common species, especially abundant in colonies of Eudendrium, upon the hydranths of which it feeds.-Cole. Dredged almost exclusively in the eastern half of Vineyard Sound, where it is common; taken once off Penikese; 7 to $I 7$ fathoms, chiefly on sandy and stony bottoms.-Survey.

Fish Hawk stations: $75^{22}$ (I), $75^{27}$ (4, I with eggs), $75^{28}$ (I), 7532 (x), 7537 (I) 7538 (2), 7538 bis (about $x 2$ ), 754I bis ( $\mathrm{I}$ male with eggs), 7549 bis (many males carrying eggs), 7550 bis (I male with eggs), $755^{1}$ bis (I), $755^{2}$ bis (2), 7553 bis (about I5), 7554 bis (I), $75^{6} 5$ bis (several, some with eggs), 7672 (I), 7755 (I adult female), $775^{8}$ (2 females, 3 males), 7759 (I male with eggs), 7760 ( 2 males with eggs, I female).

Phalarope station: 63 (I).

Carries eggs from July to September 30.-Morgan. Larvæ probably parasitic in some hycroid.

Family ENDEID正.

Endeis spinosus (Montagu).

Cole, I9ro, p. I93.

A species of Endeis [Phoxichilus] which was found abundantly, in association with Obelia dichotoma, upon floating gulfweed in the western. part of Vineyard Sound, can not be separated from this European species, though it differs so markedly in habitat. Collected July 5, I3, September 4, I9, I904, October I5, I905, August 22, I906, October 8, I906. (Collected by V. N. Edwards and J. A. Cushman, identified by L. J. Cole). Adult males (many bearing eggs), females and young taken.

\section{Family Pycnogonidides.}

\section{? Pycnogonum littorale (Ström).}

E. B. Wilson, I880, p. 469 .

No local records, though this region is included within the known range of the species. It probably occurs, however, only in the deeper water outside the limits of the Survey.

a Specimens from points designated by an asterisk $(*)$ were identified by Dr. L. J. Cole.

${ }^{b}$ Norman (Journal Linnæan Society, vol. 30, 1908, p. 204) has substituted the earlier name Anaphia (Say, r $\$ 21$ ) for Anoplodactylus (Wilson, 1878). Since, however, Say's descriptions and figures were far from perfect, and it is by no means certain that the forms are congeneric, Dr. Cole has thought it advisable to retain the later name. 


\section{Phylum MOLLUSCA. ${ }^{a}$}

\section{Class PELECYPODA.}

\section{Family OSTREIDAE.}

Ostrea virginica Gmelin. Oyster. [Chart 122.] Gould, I87o, p. 202 (Ostrea virginiana), p. 203 (O. borealis); Verrill and Smith, 1873, p. 697 , 3Io, etc. (Ostrea virginiana); Dall, 1889, p. 32; Sumner, I9ro, fig. I2.

Oysters are raised in Wareham River, and in Waquoit Bay and Cotuit Bay on Cape Cod. Adult specimens have been found in Hadley Harbor (Edwards) and the young are occasionally met with in the vicinity of Woods Hole. Shells were dredged by the Survey in from 2 to 19 fathoms, being particularly common in the western end of Vineyard Sound, where they had probably been thrown overboard from passing vessels. Living specimens recorded from only two stations: once near the shore of Pasque Island (Bay side); again in Wareham River.

Fish Hawk stations: 7523 bis (I shell), $755^{\mathrm{I}}$ (I shell), 7557 (I shell), 7563 (few shells), 7566 (several shells), 7567 (few shells), 7568 (few shells), $75^{8} 3$ (few shells), $75^{84}$ (few shells), 759 I (few shells), 7592 (I shell), 7607 (I shell), 7623 (I shell), 7624 ( $\mathrm{I}$ shell fragment), 768I (I shell, eroded), 7683 (I shell), 7699 (I shell), 7701 (several shells), 7702 (2 shells), 7706 (few shells), 7707 (I shell), 7708 (several shells), 7717 (few fragments), 7718 (several worn shells), 77 I9 (few worn fragments).

Plialarope stations: 83 (I living), I $_{52}$ (I), I $_{53}$ (I shell), I 54 (several shells), I 56 (several shells), I57 (many large shells and I living), I63 (I shell), 164 (few shells).

\section{Family ANOMIDA:}

Anomia simplex d'Orbigny. Jingle shell, gold shell, silver shell. [Chart I23.]

Gould, 1870, p. 204 (Anomia ephippium), p. 205 (A. electrica); Verrill and Smith, 1873 , p. 696, 3 II, etc. (Anomia glabra); Dall, I889, p. 32 .

Distribution general throughout the region; almost equally abundant in the Bay and Sound. Shells dredged by the Survey in I to 25 fathoms, on bottoms of all kinds; living specimens taken in 2 to 9 fathoms, though comparatively seldom at these depths. Especially abundant near low-water mark, adhering to stones or to other shells.
Anomia simplex-Continued,

Fish Hawk stations: $75^{21}$ (few shells), $75^{21}$ bis (many shells), $75^{24}$ bis (I), 7526 (I shell attached to tube of Diopatra), $75^{28}$ (several shells), 753 I (I small shell), 7532 bis (I shell), 7533 (fragment), 7535 (fragments), 7536 bis ( 2 shells), $753^{8}$ (fragment), 7542 bis (few shells), 7543 (few shells), 7544 (few shells), 7546 bis, 7547 bis ( $I$ shell), 7549 bis? (I fragment), $755^{2}$ bis (few shells), 7553 (I shell), 7553 bis (few shells), 7554 bis (few shells), 7556 bis (many shells), 7557 (2 shells), 7562 bis (I shell), 7563 (few shells), 7563 bis (few shells), 7564 (I), 7564 bis (few shells), 7565 (I shell), 7566 (several shells), 7567 (many shells, few small living), 7568 (few shells), 7569 (few shells), 7569 bis (few shells), 7570 (I shell), 7575 (fragment), 7576 (I shell), 7577 (I shell), 7578 (I shell), 7579 (few shells), $75^{80}$ (few shells), $75^{8} 3$ (few shells), $75^{8} 5$ (several shells), 759r (several shells), 7592 (few shells), 7594 (few shells), 7596 (I shell), 7598 (few shells), 7603 (living, on Boreoscala granlandica), 7609 ( 1 worn shell), 7610 (several shells), $761_{2}$ (fragment), 7613 (several shells), 76r4 (few shells), 76r5 (many shells), 76 6 (several shells), 76r8 (several shells), 7620 (abundant, shells), 762 I (many shells), 7623 (few shells), 7624 (many shells), 7625 (few shells), 7626 (shells abundant), 7627 (many shells), 7628 (few), 7629 (many shells), 7630 (many shells), 763I (very abundant), 7632 (many shells), 7633 (many shells), 7634 (many shells), 7635 (many shells), $76_{3} 6$ (several shells), 7637 (several shells), 7639 (many shells), 7640 (few shells), 7643 (few shells), 7644 (shells), 7645 (many shells), 7646 (fragment), 7647 (many shells), 7648 (many shells), 7649 (few shells), $765^{1}$ (few shells), $765^{2}$ (few shells), 7655 (ferw shells), $765_{56}, 76_{5} 8$ (few living and shells), 7659 (few shells), 7660 (i fragment), 7662 (few shells), 7663 (few shells), 7664 (few shells), $766_{5}$ (few shells used in Diopatra tubes), 7666 (I shell), 7667 (few shells in Diopatra tube), 7668 (few shells), 7669 (I shell), 767 I (few shells), 7672 (few shells), 7674 (few shells), 7675 (few shells), 7678 (few shells), 7679 (few shells), 7680 (few shells), 768 I (few shells), 7682 (several shells), 7686 (I fragment), 7694 (I shell), 7695 (few shells), 7698

a Specimens from points desiguated by an asterisk (*) were identified by Messrs. W. H. Dall and Paul Bartsch; those from points designated by a dagger $(\dagger)$ by Dr. F. M. MacFarland; those from points designated by a double dagger ( $\downarrow$ ) by Dr. Bartsch. 
Anomia simplex - Continued.

(few shells), 7700 (I shell), 770r (few shells), 7702 (several shells), 7703 (several shells), 7704 (I shell), 7706 (few shells), 7707 (several shells), 7708 (few shells), 7709 (I shell), 7717 (few shells), 7718 (many shells), 77 I9 (many shells), 7722 (I shell), 7726 (several shells), 7727 (2 small shells), 7730 (many shells), 7734 (several shells), 7739 (few shells), 7740 (many shells), 7744 (several shells), $775^{2}$ (several shells), 7755 (I shell), 7757 (few shells), $775^{8}$ (I shell), 7761 (few shells), 7764 (I small shell), 7766 (I shell), 7767 (I shell), 777x (I shell), 7772 (I shell), 7776 (several shells), 7777 (few shells), 7778 (few shells), 7779 (many shells), 7780 (few shells), 7783 (few shells).

Phalarope and Blue Wing stations: 2 (I), 3 (few shells), 5 (I fragment), 6 (few shells), 7 (many shells), 8 (few), 9 ( I shell), Io (few), II (few shells), I2 (several), I5 (few shells), 22 (I shell), 23 (I shell), 24 (I shell), 25 (few shells), 27 (several), 30 (few), 32 (I) 34 (few shells), 35 (few living), 37 (few shells), 38 (shells), 39 (few shells), 40 (few shells), 4I (few shells), 42 (few shells), 43 (shells), 44 (I piece), 5I (I small living on Thais shell), $5^{2}$ (few shells), 57 (I small living), 58,60 (I shell), 62 (I shell), 66 (I shel1), 68 (I living), 7 I (several shells), 72 (few shells), 74 (I living), 76 (few shells), 77 (r living), 79 (I shell), 80 (several), 8I (several) 82 (several shells), 84 (many), $85,86,87,88$ (I shell), 91, 93 (I shell), 94, 95, 96, 97, 98, ro3, I05 (shells), I07 (shells common), I08, IIо, II2, II 3 , II 4 (few shells), II 5 (few shells), I I7 (few shells), II8 (few shells), I2 I (few shells), I23 (many shells), I24 (several shells), r26 (shells common), I27 (I shell), I28 (shells common), I29 (shells common), I30 (shells common), I32 (common), I33 (common), I34 (shells abundant), I35, I36 (shells abundant), I37 (many shells), I38 (shells common), I39 (abundant), I 40 (common), I4I (shells common), I 42 (common), I43 (few shells), I44 (abundant, living and shells), I45 (many), I 46 (shells common), I 47 (shells common), I 49 (many shells), I5 I (few shells), I $5^{2}$ (shells), I 53 (few shells), I $_{54}$ (shells abundant), I55 (many large living), ${ }_{15} 6$ (many living and shells), I57 (few living and shells), $15^{8}$ (few living and many shells), I59 (many shells), I60 (few shells), I6I (several shells), 162 (few shells), $16_{3}$ (several shells), I64 (many shells), I65 (many shells), I67 (few shells).
Anomia aculeata Gmelin. [Chart I24.]

Gould, 1870, p. 204 (not listed for this region); Verrill and Smith, 1873, pp. 697, 495, etc.; Dall, 1889 , p. 32 .

Off Gay Head.-Verrill. Living specimens taken at Crab Ledge (abundant); Vineyard Sound, at both ends, and the mouth of Buzzards Bay; shells more widely distributed than living specimens, though far less general than those of $A$. simplex.-Survey. Dredged in 3 to 25 fathoms, on various bottoms, rarely in mud.

Fish Hawk stations: $75^{24}$ bis (I living), $75^{2} 5$ bis, 7537 bis (several shells), $754 \mathrm{I}$ bis (I shell), 7549 bis (I shell), $755^{\mathrm{I}}$ bis (I shell), 7553 bis (I shell), 7556 bis (I shell), 7563 bis (few shells), 7595 (2 shells), 7603 (many living)* ${ }^{*}, 706$ (few), 7607 (many), (in the last three cases recorded as attached to stones and to Modiolus), 7609 (few on Modiolus), 7665 (few shells in Diopatra tube), 7679 (living on Modiolaria), 7682 (I shell), 7688 (several shells), 7696 (I shell), 7697 (I shell), 7699 (I shell), 7700 (several living and shells), 770r (I shell), 7704 (I shell), 7706 (several living and shells), 7707 (I shell), 7708 (I shell), 7709 (I living), 7718 (I shell), 7719 (I shell), 772I (fragment, I small shell), 7744 (I shell), 775 (I shell), 7753 (I shell), 7756 (I shell), 7757 (I shell), 7764 (I shell).

Phalarope and Blue Wing stations: 7 (I shell), Io (I), I5 (I shell), I6 (I shell), 22 (2 shells), 24 (I shell), 25 (I shell), 27 (many), 28 (I), 30 (I), $3^{2}$ (2 shells), 34 (several), 35 (few shells), 37,38 (shells), 42 (few shells), 43 (shells), 45 (I sheil), $5^{2}$ (I shell), 57 (I shell), 58 (several), 59 (common), 60 (several), 62 (I living), 65 (many shells and living), 66 (several), 67 (I shell), 68 (several shells), 79 (I shell), 82 (I living), 84 , $86,87,92$ (shells), 99, I02, III (I living), II2, II3, II4 (few living), II6.

\section{Family PeCTINID我.}

Pecten magellanicus (Gmelin). Smooth scallop (or scollop). [Chart 125.]

Gould, I870, p. I96 (Pecten tenuicostatus; not listed for this region); Verrill and Smith, 1873 , p. 696, 397, etc. (Pecten tenuicostatus); Dall, I889, p. 34; Sumner, I9ro, fig. 17

Off Gay Head in 29 fathoms; "rare and local south of Cape Cod."-Verrill. Shells common in the western end of Vineyard Sound, occasional farther to the eastward; likewise taken at Crab Ledge; living specimens scarce 
Pecten magellanicus-Contiuued. locally.-Survey. Dredged in 4 to 20 fathoms, for the most part at depths of Io fathoms or more.

Fish Hawk stations: 7537 bis (I very small shell), $755^{8}$ (I shell), $757 x$ (I shell), 7572 (I shel1), 7577 (I shell), 7578 (I small shell), 758I (I shell, used in Diopatra tube), 7585 (I living), 7592 (I shell), 7593 (I shell), 7598 (few shells), 7603 (several shells), 7604 (fragment), 7607 (I fragment), 7608 (I small living), 7672 (I shell), 7678 (few shells), 7679 (several shells), 7680 (several large and small shells), 768r (several shells), 7682 (several shells), 7683 (2 shells), 7702 (several shells), 7706 (2 shells), 7707 (several large shells), 7709 (I fragment), 77 I9 (I small shell), 7724 (2 small living), 7725 (2 shells), 7728 (I shell), 7730 (I fragment), $773 \mathrm{I}$ (living and shells).

Phalarope stations: 6 (I fragment), 7 (few fragments), 9 (I shell), 52 (I shell), 59 (several shells).

Pecten gibbus borealis (Say). Common scallop (or scollop.) [Chart I26.]

Gould, 1870, p. 199 (Pecten irradians); Verrill and Smith, 1873, p. 695, 361, etc. (Pecten irradians); Dall, I889, p. 34 (Pecten irradians); Sumner, I9Io, fig. I6.

Very common in Vineyard Sound and Buzzards Bay, especially in sheltered weedy places, such as occur in Woods Hole Harbor, Vineyard Haven, Wareham River, or Nantucket Harbor, etc. Shells dredged by the Survey throughout both the Bay and the Sound, in 2 to $I_{5}$ fathoms, on bottoms of all sorts; living scallops occasionally taken in 2 to 8 fathoms, mainly on somewhat muddy bottoms.

Fish Hawk stations: $75^{2}$ I (few shells), $75^{25}$ bis ( $x$ shell), 753 (I small shell), 7533 (I shell), 7535 (fragments), 7536 bis (I fragment), 7546 bis (shells and fragments), $755^{\mathrm{I}}$ (few shells), $755^{6}$ bis ( 2 fragments), 7562 bis (few fragments), 7563 (few shells), 7564 bis (I fragment), 7566 (I shell and fragment), 7567 (fragment), 7574 (few shells), 7579 (fragment), 7580 (I shell), 7594 (2 shells), 7595 (I shell), 7596 (fragment), $761_{4}$ (I fragment), 76I5 (few shells), 76r6 (I fragment), 76I9 (I shell), 7620 (many shells), 7624 (few large shells), 7625 (few shells), 7626 (few shells), 7628 (many fragments), 7629 (several shells), 7630 (few shells), $76_{31}$ (several), $76_{32}$ (several shells), 7633 (many shells), 7635 (many shells and fragments), $76_{3} 6$ (I shell), 7639 (sev-
Pecten gibbus borealis-Continued.

eral fragments), 7644 (small shells and fragments), 7645 (few shells), 7646 (I shell and fragments), 7647 (few shells), 7648 (several shells), 7649 (few shells), 765 I (few shells), 7653 (I living), 7659 (few shells), 7660 (several shells), 7667 (few fragments), 7668 (fragments), 767 I (few shelis), 7674 ( $\mathrm{I}$ living and few shells), 7675 (few shells), 770 (I shell and I fragment), 7703 (I fragment), 7717 (few fragments), 7730 (I fragment and I shell), 773 I (I fragment), 7739 (I shell), 7740 (I shell), 7752 (I fragment), 7755 (I shell), 7762 (many shells and few living), 7766 (many shells), 7769 ( I living and several shells), $777 \circ$ (several shells), 777 I (I shell), 7772 (I fragment), 7774 (several fragments), 7776 (I small shell), 7777 (many shells), 7778 (many shells), 7779 (few shells), 7780 (few shells), 778 I (several shells), 7783 (fragments).

Phalarope stations: I (I), 5 (few fragments), 7 (I shell), 8 (few shells), 9 (I piece of shell), II (I fragment), I6 (I shell), I9 (I shell), 25 (few shells), 28 (I), 29 (I shell), 37 (I shell), 38 (I small), 43 (shells), 53 (I shell), 60 (few shells), 62 (x), 63 (I), 65 ( $\mathrm{I}$ small shell and living), 68 ( 2 shells), 7o (few shells), 7 I (several living and many shells), 72 (many living and shells), 74 (few), 75 (2), 76 (2 shells), 78 (I small), 80 (few shells), 82 (few shells), 83 (2 shells), 85 (I shell), 86, 9I, 92 (shells), 95, 96, 97, 102 (I shell), I07 (few shells), ro8, Io9, IIo, II 3 , I I4 (shells), II5 (few shells), II7 (I shell), II8 (I shell), I20 (I shell), I22 (fragments), I23 (I shell), I26 (few shells), I27 (shells common), I29 (2 shells), I32 (shells), I33 (shells), I34 (few shells), I35 (I shell), I36 (many), I37 (many shells), I38 (shells common), I40 (few fragments), I4I (few shells), I42 (several shells), I43, I44 (several shells), I45 (several shells), I46 (few shells), I47 (few shells), I48 (several shells), I49 (many shells), I50 (many shells), I 5 I (fragments), I52 (living), I53 (few shells), I 54 (many shells), I 55 (several shells), I 56 (few shells), I57 (many shells), I $5^{8}$ (many living and shells), I59 (shell fragments), I60 (few fragments), I6r (few shells), I62 (I shell), I63 (2 shells), I64 (few shells), I65 (few shells), I67 (I shell).

\section{Pecten islandicus Müller.}

Gould, I870, p. I98; Verrill and Smith, I873, p. 696. (In neither case listed for this region.)

Fish Hawk station 7608 , at Crab Ledge (I shel1).* 


\section{Family MY̌TILID}

Mytilus edulis Linnæus. Common sea mussel. [Chart I27.]

Gould, I870, p. 183; Verrill and Smith, I873, pp. 692,307 , etc.; Dall, I889, p. 38; Field, I9Ir, p. 87 .

Shells abundant and universally distributed in Vineyard Sound, at I to Ig fathoms; in Buzzards Bay, less frequent and restricted to the southern portions. During the Survey dredging living mussels were chiefly taken in the western half of the Sound, where they were occasionally brought up by the bushel. Extensive mussel beds occur locally in shallow waters near shore, and the species is also frequently abundant on piles. In early life they become attached to almost any solid object, and two living specimens were taken from the gill chamber of a lobster. Owing to causes which are not always obvious, great mussel beds may be completely exterminated within a limited period, leaving deposits of shells. Thus several localities where mussels were extremely abundant during the summer of I903 were redredged in I908, but only shells and fragments were taken.

Fish Hawk stations: $75^{2} \mathrm{I}$ (few shells), $75^{2} \mathrm{I}$ bis (fragments), 7525 bis (fragments and a few whole shells), 7533 (several), 7533 bis (several shells), 7535 (many), 7536 (numerous), 7536 bis (many fragments), 7539 bis (I shell), 7540 (fragment), 754I (several shells), 754I bis (many shells), 7542.(I shell), 7542 bis (few shells), 7543 (fragments), 7545 (many large fragments), 7545 bis (many fragments), 7546 bis (many fragments), 7547 bis (abundant), $754^{8}$ (large fragment), $755^{\circ}$ (many), $755^{\circ}$ bis (few shells and fragments), 755I (living), $755^{x}$ bis (I bushel, living), $755^{2}$ (many fragments), $755^{2}$ bis (few shells), 7553 (shells, forming large part of contents of dredge), 7553 bis (many shells), 7555 (several bushels, living), $755^{6}$ (tons, living), $755^{6}$ bis (many shells), 7557 (few shells), $755^{8}$ (fragments and shells abundant, constituting greater part of catch), 7559 (few), 7560 (few shells), 756r (many), 7562 (many fragments), 7562 bis (few fragments), 7563 (many shells), $75^{6} 3$ bis (few fragments), $75^{64}$ (many, constituting greater part of catch), $75^{64}$ bis (very many shells), 7565 (many), 7565 bis (fragments), 7566 (many living), 7567 (few shells), 7568 (fragments), 7569 (few fragments), 7569 bis (few fragments), 7570 (many living), $757 \mathrm{I}$ (several bushels, many living), $757^{2}$ (many
Mytilus edulis-Continued.

shells), 7573 (bushels, living), 7574 (many shells and living), 7575 (fragments), 7576 (fragments), 7577 (few shells), 7578 (many living), 7579 (few shells), $75^{81}$ (several shells), $75^{82}$ (several shells), $75^{8} 3$ (few shells), $75^{8} 4$ (few shells), 7585 (few shells,) $75^{87}$ (I shell), 7588 (few shells), 759r (many shells), 7592 (many living and shells), 7593 (many shells), 7594 (many shells), 7595 (many living), 7596 (many), 7597 (few shells), 7598 (few shells), 7599 (many), 7600 (few shells), 7602 (few shells), 7603 (I shell), 7604 (I shell), 76ro (fragments), 7636 (few shells), 7638 (several shells), 7639 (several shells), 7653 (few small), 7656 (several large and small shells), 7660 (I shell), 766 I (I shell), 7664 (few shells), 7665 (several shells), 7667. (shells and living), 7668 (few shells), 7670 (many living and shells), 7672 (I shell), 7673 (I shell), 7674 (very few shells), 7675 (few shells), 7677,7678 (many shells), 7679 (large and small living), 7680 (very abundant, small living), 768r (many small living and large shells), 7682 (many large and small shells), $768_{3}$ (I fragment), 7685 (many small living), 7693 (several young and living), 7695 (fragments), 7696 (shells and fragments), 7697 (many shells), 7698 (few small living and fragments), 7699 (fragments and living), 7700 (many fragments), 770I (many fragments), 7702 (many fragments), 7703 (many fragments and living), 7704 (fragments), 7705 (few fragments), 7706 (few shell fragments), 7707 (many living and shells), 7708 (few shells), 7709 (fragments), 7717 (few fragments), 77 I8 (many shells), 77I9 (many shells), 7720 (fragments and very many small living), $77^{2} \mathrm{I}$ (very many living and shells), 7722 (fragments and very many small living), 7723 ( I small shell), 7724 (several living), 7725 (few small living), 7726 (few shells and fragments), 7727 (2), 7729 (I small shell), 7730 (I living), 773 I (many fragments and small living), 7732 (many living), 7733 (many living and shells), 7734 (very many shells and fragments), 7735 (many shells), 7736 (many shells), 7737 (few fragments), 7738 (several small living), 7739 (few shells and fragments), 7740 (many shells), 774 I (many shells), 7744 (many fragments), 7745 (few fragments), $775^{2}$ (few fragments), 7769 ( $\mathrm{x}$ large shell), 777 I (I shell fragment), 7772 (I shell fragment), 7773 (I shell fragment), 7776 (very many shells and fragments), 7779 (few fragments), 7780 (few shells), 7783 (very many shelis).

Phalarope and Blue Wing stations: I (I shell), 4 (few shells), I6 (several shells), 22 (shells 
Mytilus cdulis-Continued.

abundant), 25 (few shells), 26 (very abundant), 27 (very abundant), 28 (very abundant), 29 (few), 30 (few), 32 (I small living), 34 (few shells), 35 (many small), 37 (fragments of shells), 38 (few small), 39 (few shells), 40 (few shells), 4I (few fragments), 42 (few shells), 43 (shells), 46 (few small), 47 (many very small), 48, 49 (few small), 50 (I small), 5 I (many small living), 52 (few), 55 (I shell), 56 (shells), 57 (few shells), 58, 59 (young very abundant), 60 (few shells), 63 (I shell), 65 (x shell), 66 (many shells), 68 (few shells), 69 (several), 7 I (I living), 73 (few shells and fragments), 74 (few shells), 75 (few shells), 8r (few shells), 82 (I shell), 83 (fragments and young), 85, 92, 99 (few shells), 100 (few shells), I02, I03, I05 (shells), III (great beds, living and shells), I12, II7 (few fragments), II8 (shells), I2 I (shells), I22 (shells and fragments), I29 (I shell), I4I (shells and fragments), I65 (several fragments), I67 (many fragments).

Prof. Verrill writes: "This species breeds early in the spring. I have found immense numbers of the young, about as large as the head of a pin, . . . on the I2th of April." On the other hand, Prof. I. A. Field, who has made a careful study of the reproduction of the mussel at Woods Hole, states that "no mature sexual products were observed before July 3 [I909]," when active spermatozoa were noted, though material was examined at monthly intervals commencing with February 7 . The extrusion of eggs and spermatozoa was studied in the laboratory troughs on August 2 I and 26. Field believes that locally "the mussel does not breed earlier than June, and continues to breed on into September."

The mussel is used extensively as food in Europe, but only to a small extent on our own coast. It is sometimes used as a fertilizer and as bait. It is doubtless important as a food for tautog and other fishes. For an interesting account of the natural history of this species see Field, I9II.

2Modiolus hamatus (Say).

Verrill and Smith, 1873, p. 693, 374; Verrill, I882a, p. 577 .

Living animals not rccorded from this region, though Verrill states that shells have been found in the post-Pliocene of Nantucket.
Modiolus modiolus (Lamarck). Horse mussel, bearded mussel. [Chart I28.]

Gould, 1870, p. I86 (Modiola modiolus); Verrill and Smith, I873, p. 693, 309, etc. (Modiola modiolus); Dall, I889, p. $3^{8}$ (Modiola modiolus).

Common and generally distributed throughout Vineyard Sound; in Buzzards Bay it is far less frequently taken and scems to be restricted to the inshore zone. Large specimens abundant at Crab Ledge. This species occurs from lowtide mark to the greatest depths of the region, attaining great size in deeper waters offshore; sometimes taken on piles. Dredged by the Survey in 3 to 25 fathoms, living specimens being most common on stony and gravelly bottoms. Several small specimens were taken from the gill chamber of a living lobster, some being even attached to the gills themselves.

Fish Hawk stations: $75^{22}$ (several), $75^{23}$ (2), $75^{23}$ bis (few living), $75^{24}$ (many living), $75^{24}$ bis (many living), $75^{2} 5$ bis (few shells), $75^{26}$ (few), 7527 (I shell), $75^{28}$ (few living), 7529 (few shells), 7530 (many), 7530 bis (many shells), 753 I (many shells), 753I bis (few shells), $753^{2}$ (2 small shells), 7533 (many fragments), 7533 bis (I shell), 7534 (few shells). 7535 bis (several shells), 7536 (numerous shells), 7538 (several shells), 7538 bis (few shells), 7540 (few fragments), $754 \mathrm{r}$ bis (I shell), 7543 (few fragments), 7544 (I shell), 7546 (fragments), 7547 (few shells), 7549 (I living), 7550 (few shells), 755 (few shells), $755^{2}$ ( I living), 7555 (few), $755^{8}$ (few), 756r (few large), 7563 (few living), 7576 ( $\mathrm{x}$ shell), $75^{8} 3$ ( $\mathrm{x}$ living), 7586 (I shell), 7592 (x large), 7594 (x large shell), 7598 (few large living), 7600 (I large shell), 7604 (several shells), 7605 ( 2 very large), 7606 (many very large), 7607 (several very large living; one $5 \frac{1}{2}$ inches long), 7608 (many very large living), 7609 (many large, living and dead), $762 \mathrm{I}$ (small living), 7630 ( $\mathrm{I}$ fragment), 7670 (few), 7672 (few shells), 7676 (I small living on algx), 7677 (many small living on algæ), 7678 (few shells), 7679 (I shell), 7680 (living and shells), 768 I (several large living), 7699 (I shell), 7702 (I large shell), 7706 (I large shell), 7708 (several large shells), 77 I7 (I large), 77 I8 (I large shell), 77 I9 (few shells), 7720 (I small shell), 7726 (I shell), 7732 (I shell), 7734 (I shell), 7740 ( $\mathrm{I}$ ), 7742 (I small living), 7749 (few living and many shells), 775 I (fragment), $775^{2}$ (fragments 
Modiolus modiolus-Continued.

and several shells), 7753 (I fragment), 7754 (I living), 7757 (many living and shells), $775^{8}$ (many living and shells), 7759 (many shells and few living), 7760 (many shells), 7763 (living and shells, common), 7764 (few shells), 7765 (x living), 7766 (several shells), 7767 (few shells), 7768 (few shells), 7769 (I shell), 7770 (many shells), 777 I (several shells), 7772 (few shells), 7773 (I shell fragment), 7777 (I living and several shells), 7779 (few shells), 7783 (several shells).

Phalarope stations: I (I small living), 3 (few living), 4 ( 2 small living), 5 ( I shell), 6 (I fragment), 8 (I young), II (I shell), I5 (I shell), 32 (I living), 34 (I shell), 52 (few shells), 59 (few), 63 (few), 65 (I shell, I living), 69 (living and shells), 7 I (few living and shells), 77 (few shells), I00, I04, I10, II6, I22 (fragments), 130 (few shells), I49 (I living), I67 (2 shells).

Modiolus demissus (Dillwyn). Ribbed mussel, marsh mussel.

Gould, 1870, p. 188 (Modiola plicatula); Verrill and Smith, I873, p. 693, 307, etc. (Modiola plicatula); Dall, 1889, p. $3^{8}$.

Buzzards Bay, Vineyard Sound, and connecting ponds and estuaries; e. g., Wareham River and head of Woods Hole Harbor. Abundant in marshes and on muddy shores, in salt or brackish water; occurring near high-tide level. Shells dredged by the Survey in 3 to 7 fathoms; these had probably drifted into deeper water from the littoral zone, however.

Fish Hawk stations: 7639 (few shells), 7643 (few shells), 7644 (I shell), 7645 (few shells).

Phalarope stations: I56 (I shell), I6 I (I shell).

Modiolaria nigra Loven. [Chart I29.]

Gould, I870, p. I90 (not listed for this region); Verrill and Smith, I873, p. 694, 418, etc.; Dall, I889, p. 40.

Deeper parts of Vineyard Sound and off Gay Head.-Verrill. Lower ends of Vineyard Sound and Buzzards Bay, 3 to is fathoms; living specimens dredged in 7 to $I 7$ fathoms, nearly always on sandy bottoms.-Survey. This species was never taken in large numbers.

Fish Hawk stations: 7580 (I living)*, 759I (3 shells), 7597 (I shell), 7598 (few living), 7599 (I shell), 7655 (I living), 7657 (I shell), 7660 (2 shells), 7666 (I living), 7672 (2 shells), 7674 (I shell), 7679 (I shell), 7680 (I shell), 768 I (I shell), 7682 (I shell), 7686 (I small living), 7699 (I shell and I living), 7700 (I shell), 7701 (I
Modiolaria nigra-Continued,

shell), 7702 (several shells), 7703 (I shell), 7706 (several shells), 7709 (I shell), 77 I 7 (I fragment and I very small living), 7722 (I fragment), 7728 ( 1 shell), 7730 (few very small living), 776 r (I fragment).

Phalarope stations: ${ }_{5}$ (I shell), 52 (few shells), 53 (I shell), 68 (I fragment), 8 I (I), II6.

Modiolaria corrugata Mörch.

Gould, I870, p. I93 (not listed for this region), Verrill and Smith, I873, p. 694; Dall, I889, p. 40.

"Off Marthas Vineyard and Buzzards Bay, 20 to 25 fathoms, rare." -Verrill.

\section{Modiolaria lavigata (Gray).}

Gould, r870, p. I93 (Modiolaria discors; not listed for this region); Verrill and Smith, 1873, p. 694 (Modiolaria discors; no definite local records).

Crab L.edge, one record at lower end of Vineyard Sound, I4 to 25 fathoms.-Survey.

Fish Hawk stations: 7578 ( 2 small living)*, 7605 (r living), 7606 (2), 7607 ( 1 living), 7608 ( $\mathrm{r}$ living), 7609 ( 2 living).

Crenella glandula Totten. [Chart $\left.\mathrm{I}_{3} \mathrm{O}.\right]$

Gould, I870, p. I94 (not listed for this region); Verrill and Smith, I873, p. 695, 4r8, etc.; Dall, I 889 , p. 40 .

Buzzards Bay, Vineyard Sound, off Gay Head.Verrill. Western half of Vineyard Sound; two records in Buzzards Bay, near Quicks Hole; one at Crab Ledge; dredged chiefly in waters of ro fathoms or more; living specimens rarely taken.-Survey.

Fish Hawk stations: 7568 (I living)* ${ }^{*} 75^{83}$ (I shell), $75^{85}$ (I shell), 7605 ( 1 living), 7679 (2 shells), 7682 (I shell), 7683 (I small shell), 7696 (x shell), 7697 (I shell), 7698 (I shell), 7700 (I shell), 7702 (3 shells), 7708 (3 shells), 7709 (2 shells), 77 I7 (I shell), 77 I9 (I shell), 774 I (I shell).

Phalarope stations: $52,5^{8}$ (I shell), 59 (I living), 65 (I shell), 8 r (living), 83 (2 shells).

\section{Family ARCIDE.}

Arca ponderosa (Say). [Chart I3r.]

Verrill and Smith, 1873, p. 692; Verrill, ISS2a, p. 573; Dall, r889, p. 40 .

Shells recorded from beach at Edgartown, Marthas Vineyard-Verrill. Shells dredged not infrequently in Vineyard Sound, at depths of 4 to I6 fathoms; 3 doubtful records for Buzzards Bay; no living specimens taken.Survey. 
Arca ponderosa-Continued.

Fish Hawk stations: 7536 bis (I shell), 7543 bis ( 1 ), 7546 (2 shells)*, 755 I (several shells), 7556 (few shells), 7556 bis ( 2 shells), 7557 (I shell), 7562 (I shell), 7563 (few shells), 7563 bis, 7567 (several shells), 7568 (few shells), 7574 (few shells), 7576 (several shells), 7577 (several shells), 7579 (2 shells), $75^{83}$ (I small shell), 7592 (I small shell), 76I9 (? few shells), 7620 (? few shells), 7661 (? few shells)*, 7680 (I small shell), 770I (several shells), 7703 (2 shells), 7734 (2 shells), 7740 (I shell), 777 I (I shell).

Verrill has expressed doubt as to whether $A$ rca ponderosa lives in this region, since no living specimens have been noted north of Cape Hatteras. He thought it possible that the shells found at Edgartown might have been washed out from submerged post-Pliocene deposits. Mr. G. M. Gray likewise reports that he has never taken this species alive. Dr. Dall informs us, however, that the National Museum contains a fresh valve, retaining the epidermis, taken in Vineyard Sound in 1870; and Mr. C. W. Johnson reports that he has found more than one shell of this species still bearing evident traces of the hinge ligament and epidermis, on a beach near Chatham Light.

Arca transversa (Say). Bloody clam. [Chart 132.]

Gould, I870, p. I48; Verrill and Smith, I873, p. $69 \mathrm{r}, 309$, etc. (Scapharca transversa).

Shells very abundant and generally distributed, both in the Bay and the Sound, being dredged in 2 to 19 fathoms; living specimens comparatively scarce, taken in 3 to $I_{3}$ fathoms on various bottoms. - Survey.

This mollusk is abundant in shallower waters than those reached by the dredge.

Fish Hawk stations: $75^{2} \mathrm{I}$ (many shells), $752 \mathrm{I}$ bis (2 shells), $75^{25}$ bis (few shells), 7526 (few shells), 7528 (few shells), 753 I (many shells), 7532 (I shell), 7533 (few shells), 7533 bis (2 shells), 7534 (I shell), 7535 (several shells), 7536 (few shells), 7536 bis (few shells), 75.37 bis (few shells), 754I (I shell), 7543 (many shells), 7543 bis (I large living), 7546 ( I shell), 7546 bis (several shells), 7547 (few shells), 7547 bis (several shells), 755 I bis (I shell), $755^{2}$ bis (few shells), 7553 (I shell), 7554 (I shell), 7554 bis (few shells), 7556 (few shells), 7556 bis (numerous shells), 7557 (I shell), $755^{8}$ (few shells), 7563 (few shells), 7563 bis (numerous shells), 7565 (2 shells), 7565 bis (few shells), 7566 (few shells)*, 7567 (many shells), 7568 (few shells), 7569 ( I shell), 7569 bis (few shells), 7570 (few shells), 757 I (few shells), 7575 (I shell), 7576 (several shells), 7577 (many shells), 7578 (few), 7579
Arca transversa-Continued.

(several shells), 7580 (two shells), 758 I (I small shell), $758_{2}$ (few shells), $758_{3}$ (few shells), $75^{84}$ (few shells), $75^{8} 5$ (several shells), $75^{88}$ (I shell), 759 I (few shells), 7593 (I shell), 7596 (several shells), 7597 (few shells), 7598 (few shells), 760I (I shell), 7610 (several shelis),

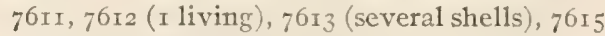
(several shelis), 76 I6 (several shells and living), 76 I8 (several shells), 7620 (many shells), 7621 (many shells), 7622 (many shells), 7624 (many shells), 7625 (several shells), 7626 (many shells), 7628 (many shells), 7629 (many shells), $76_{30}$ (few shells), 763i (abundant), $76_{32}$ (several), 7633 (many shells), 7634 (many shelis), 7635 (many shells), $76_{3} 6$ (several shells), $76_{3} 8$ (few shells), 7639 (many shells), 7642 (I shell), 7643 (few shells), 7644 (several shells), 7645 (several shells), 7646 (few shells), 7647 (few shells), 7648 (many shells), 7649 (few shells), 765 I (many shells), 7652 (I living and many shells), 7653 (few shells), 7654 (few shells), 7655 (very few shells), 7656 (few shells), 7657 (numerous shells), 7658 (few shells), 7659 (numerous shells), 7660 (numerous shells), 766 I (many shells)*, 7663 (many shells), 7664, 7667 (I shell on Diopatra tube), 7671 (numerous shells), 7672 (few shells), 7674 (several shells), 7675 (numerous shells), 7678 (2 shells), 7679 (several shells), 7680 (several shells), 7682 (I shell), $768_{3}$ (I shell), 7688 (I shell), 7694 (few shells), 7695 (few shells), 7696 (I shell), 7697 (few shells), 7698 (I shell), 7699 (I shell), 7700 (several shells), 770 I (many shells), 7702 (many shells), 7703 (many shells), 7704 (I shell), 7705 (I shell), 7706 (2 shells), 7709 (few small shells), 7717 (few shells), 77 I9 (shells), 7720 (I shell), $77^{23}$ (I shell), $77^{24}$ (I small living), $77^{26}$ (I shell), 7728 (I living), 773 I (2 shells), 7734 (several shells), 7736 (I shell), 7739 (I shell), 7740 (several shells), 7741 (I shell), 7744 (few shells), $775^{1}$ ( $x$ shell), $775^{2}$ (several shells), 7753 (I shell), 7755 ( 2 shells), 7757 (I living and I shell), $775^{8}$ (I shell), 7760 ( $x$ living and few shells), 7762 (several shells), 7763 (I shell), 7764,7766 (several shells), 7767 (I shell), 7769 (several shells), 7770 (few shells), 777 I (several shells), 7772 (I shell), 7776 (I small shell), 7777 (I shell), 7778 (I shell), 7779 (few shells), 7780 (few shells), 7782 (I small shell), 7783 (I shell).

Phalarope stations: I (few shells), 2 (few small shells), 5 (I shell), 7 (I shell), 8 (few), ro (I), I I (I), I5 (few shells), 25 (few shells), 27 (I), 28 (I), 29 (few shells), 30 ( I living), 34 (few shells), 39 (few shells), 40 (fow shells), 4 I (few shells), 42 (few shells), 43 (shells), 52 (few living and shells), 53 (few shells), 56 (few shells), 58, 59 
Arca transversa-Continued.

(few shells), 60 (few small living), 62 few, 65 (several shells), 66 (few), 67 (I shell), 68 (few shells), 70 ( $\mathrm{I}$ shell), 7 I (many shells and living), 72 (many living and shells), 74 (few shells), 76 (few shells), 77 (few shells), 79, 80 (several), 8 I (common), 82 (common, shells), 83 (several), 84 (very common), $85,86,9 x, 92$ (shells), 93 (shells), 95, 96, 97, I0I, 102, I07 (many living and shells), I08, II0, II3, II4 (few shells), II 5 (several shells), II7 (few shells), I20 (shells), I2 I (few shells), I22 (few shells), I23. (shells common), I24*, I25 (living and shells), I26 (shells common), I28 (shells common), I29, I30 (shells common), I32 (several), I33 (shells common), I34 (shells common), I37 (several shells), I3S (shells common), I39 (abundant), I 40 (few shells), I4I (ferv shells), I42 (several shells), I 43 (I shell), I 44 (shells common), I 45 (several shells), I47 (shells common), I48 (shells common), I49 (shells common), I 50 (common), I52 (few shells), I54 (several shells), I 55 (few shells), I 57 (few shells), I 58 (few shells), I59 (I living and several shells), I60 ( 1 living and several shells), I62 (2 living, several shells), I63 (several shells), I64 (few shells), I65 (several shells), I66 ( I small living, several shells), I67 (many shells).

Arca campechiensis pexata (Say). Bloody clam. [Chart I33.]

Gould, I870, p. I47 (Arca pexata); Verrill and Smith, 1873, p.692, 309, etc. (Argina pexata).

Buzzards Bay, chiefly in the shallower parts; shells taken at a few stations in the Sound.Survey. Dredged at 2 to 25 fathoms, though rarely at depths greater than 6 fathoms; living specimens appear to be restricted to shallow waters, especially where the bottom is more or less muddy.

Fish Hawk stations: 7546 bis (I), 7576 (I shell), 7609 (2 shells), 76I 7 (many shells), 7620 (several shells), 7622 ( I living and shells), 7624 (few large shells), 7627 (several shells), 7629 (several shells), 7632 (several), 7633 (several living and shells), 7634 (few living and shells), 7635 (several shells), 7646 (few shells), 7647 (few shells), 7648 ((few living and shells), 7649 (few shells), 7657 (few shells), 770 I (several shells), 7703 (several shells), 7766 (I shell).

Phalarope stations: 9I, I24 (I shell), I37 (? I shell), I38 (shells), I49 (several shells), I5o (I shell), I54 (several shells), I 55 (many shells), I56 (several shells), I57 (few shells), I58 (abundant shells and living), I59 (several shells), 160 (several shells), I65 (I small living, I large shell).

\section{Family Nuculide.}

Nucula proxima (Say). [Chart 134.]

Gould, I870, p. I50; Verrill and Smith, I873, p. 69I, 4r8, etc.; Dall, I889, p. 42.

Buzzards Bay and Vineyard Sound in about equal abundance. Living specimens dredged by the Survey in I to $I 7$ fathoms, for the most part on bottoms of sand or mud, or mixtures of the two.

Fish Hawk stations: $75^{2 I}$ (few shells), $75^{22}$ bis (few), $75^{23}$ bis (I), $75^{24}$ bis (2), $75^{25}$ bis (few shells), 7532 bis (few shells), 7533 (many shells), 7533 bis (few shells), 7535 (few shells), 7536 (several shells), 7537 (shells), 7537 bis (few shells), 7538 bis (several living and shells), 754 I (few shells), 7542 ( $\mathrm{x}$ shell), 7543 (few shells), 7543 bis (I shell), 7545 (few shells), 7547 (few shells), 7547 bis (few shells and living), 7549 (few shells), 7549 bis (few), 7554 (few shells), $755^{6}$ bis (few shells), $75^{6} 3$ bis (few shells), $75^{6} 5$ (2 shells), $75^{6} 5$ bis (r shell), 7566 (few shells), 7568 (few shells), 7569 bis, 7572 (few shells), 7574 (I shell), 7575 (I shell), 7579 (I shell), 7597 (i shell), 76 ro (shells abundant), $76 \mathrm{I}$ ( $\mathrm{I}$ shell), 76 $\mathrm{I}_{2}$ (several small living), 76I4 (several shells), $76 \mathrm{I} 7$ (few small living), $762 \mathrm{I}$ several living), 7623 (ferv living), 7624 (few shells), 7626 (many living), 7628 (few living), 7630 (several shells), 763r (several shells and living), 7633 (few shells), 7635 (few shells and living), 7638 (few shells), 764 I (few small living), 7642 (few shells), 7643 (few living), 7645 (few shells), 7646 (few shells), 7647 (I), 7649 (few shells), 765 I (few shells), 7654 (living), $7656,7657,7658$ (shells), $76_{59}$ (many shells), 7660 (many shells), 766r (very many living), 7662 (few living), 7663, 7668 (few), 7669 (living), $7671,7673,7675$ (many shells), 7686 (I living), 7687 ( I living), 7695 (few shells), 7700 (2 shells), 770 (several shells), 7702 (I shell), 7703 (several shells), 7704, 7705 (few shells), 7708 (few shells), 77 I7 (several shells), 77 I 8 7724 ( $\mathrm{I}$ small living), 7726 (few shells), 7727 ( 1 living.and I shell), 7730 (I shell), 7732 (few shells), 7734 ( 2 shells), 7738 (2 shells), 774I (I shell), 7744 (I shell), 7748 (many shells), $775^{2}$ (several shells), 7753 (living and shells), 7755 (2 shells), $775^{6}$ (I shell), 7757 (few shells), $775^{8}$ (few shells), 7759 (few shells), 7760 (several living and shells), $776 \mathrm{r}$ (few shells), 7763 (I living), 7764 (several shells), 7766 (few shells), 7767 (many shells, few living), 7769 (many shells), 7770 (few shells), 777 I (several shells), 7772 (few shells), 7775 (I shell), 7776 (I living and few shells), 7777 (several shells), 7778 (I living), 7779 (many shells), 7780 (few shells), 
Nucula proxima-Continued.

778 I (few shells), 7783 ( 1 living and many shells).

Phalarope and Blue Wing stations: I (many shells and I living), 2 (few shells), 3 (few shells), 5 (I shell), 6 (few shells), 7 (few shells), 9 (I), II (several), I3 (I shell), I5 (I living), I7 (many living), I8 (many living), I9 (many), 20 (I living and shells), 26 (I living), 28 (few), 33 (I shell), 40 (few shells), 43 (shells), 52 (few), 62 (2), 70 (abundant), 7 I (many living), 72 (many living and shells), 73 ( 1 living), 78 (many living, all sizes), 79 (several living), 80 (few living), 82 ( I), $84,86,88$ (I small), 89 , 91, 92, 95, 96, 97, 98, 100 ( 1 living), 104, 107 (few living), I08, I 10, I 6 , I 7 (few living and shells), iI8 (shells common), II9 (several shells), I20 (shells and living), I2 I (shells), I22 (few shells and living), 123 (shells), I2 5 (living and shells), I26 (few living), I27 (many living), I28 (common), I29, I30 (shells), I3I (living and shells), I32 (living and shells common), I33 (several living), I35 (few shells), I39 (few), I40 (I shell), I4I (living and shells), I44 (few), I45 (living and shells common), I46 (several shells), I47 (living common), I48 (living and shells common), I49 (common), r5o (living), I 5 I (living), I $5^{2}$ (few living), I 53 (living), I 54 ( 1 living), I 55 (many living), I 56 (several living), I57 (few living), I 58 (few living) I6o (2 shells), I6r ( 1 shell), I63 ( 1 shell and fragments) I64 (many living and shells), I65 (few shells and living), r67 (I living, several shells),

Observed breeding from Jume 20 into August.G. A. Drew.

Nucula proxima ovata Verrill \& Bush.

Verrill and Bush, r898.

One living specimen taken in Vineyard Sound, off Cuttyhunk, in I8 fathoms (I880).

\section{Nucula delphinodonta Mighels.}

Gould, I870, p. I53 (not listed for this region); Verrill and Smith, I873, p. 69I, 509; Dall, I889, p. 42 .

"Off Gay Head, I9 fathoms, soft mud."-Verrill. One living specimen taken by the survey at Phalarope station Io 7 * (off Weepecket Rocks, 51/2 fathoms, mud and shells).

\section{Family LEDIDAs.}

Yoldia limatula (Say). [Chart 135].

Gould, I870, p. I54 (Yoldia limatula), p. I60 ( $Y$. myalis); Verrill and Smith, 1873, p. 689, 432, etc.; Dall, r889, p. 44; Sumner, I9Io, fig. 8 .
Yoldia limatula-Continued.

Living specimens taken throughout Buzzards Bay, to which the local distribution seems to be chiefly restricted; one record each at Menemsha Bight, Vineyard Haven and mouth of Vineyard Sound; shells taken at several points in the Sound and at Crab Ledge.-Survey. Living specimens dredged in 2 to $\mathrm{I} 7$ fathoms, nearly always at depths of less than Io fathoms, and almost exclusively on bottoms of clear or sandy mud.

Fish Hawk stations: 7566 (several shells), 7593 (I shell), 7601 (several shells), 7602 (few shells), 7609 ( 1 shell), 76II (living abundant), 76 12 (several living), 76r3 (several living), 76r4 (few living and shells), 76I5 ( 1 living), 7616 ( 1 living), $76 \mathrm{I} 7$ (many shells and living), 76 I8 (several living), $76 \mathrm{Ig}$ (several living), 7620 (few living), 7622 (few living), 7623 (many living and shells), 7624 (many living), 7629 (several living), 7632 (fragment), 7633 (I living), 7637 (living and many shells), 7638 (many living), 7640 (many living and shells), 764I (many living and shells), $764^{2}$ (many living and shells), 7643 (many living and shells), 7644 (many living and shells), 7645 (few living), 7646 (many living and shells), 7647 (few living and shells), 7649 (few living and shells), $765^{\circ}$ (living and shells), 765 (few living), $76_{52}$ (few living), $76_{53}$ (few living), 7654 (shells and living), 7655 (few living and shells), 7656 (I), 7657 (many living), $765^{8}$ (living), 7660 (few living), 766 r (many living and shells), 7662 (many living and shells), 7663 (many sheils and living), 7668 ( $\mathrm{r}$ living), 7669 (many shells), 7673 (many living and shells), 7675 (many living and shells), 7686 (few living and shells), 7688 (I shell), $77^{28}$ ( 1 shell and I living).

Phalarope and Blue Wing stations: Ig (several shells), 20 (I shell), 52 (I shell), 53 (I shell), 72 (few living), 78 (many living), 79 (living common), 83 (few, I living), 84 (common), 85 ( living), 86, 93 (several living), 94, 107 (several living), II 3 , II5 (I shell), II9 (living and shells), I22 (few shells), I27 (many living), I28 (few), I33 (I shell), I40 (I living), I 43 (I shell), I53 (I living), I59 (several living and shells), I60 (several living), I6r (many living and shelis, very large and small), I62 (several living), I64 (few living and shells), I6 (few living), r66 (many living).

Yoldia sapotilla (Gould).

Gould, I87o, p. I59 (not listed for this region); Verrill and Smith, 1873, p. 689, 509; Dall, I889, p. 44 .

"Off Gay Head, ro fathoms, soft mud; off Buzzards Bay, 25 fathoms, sand."-Verrill. 
? Yoldia thraciaformis Storer.

Gould, I870, p. I57; Verrill and Smith, I873, p. 690,509 (Long Island to Greenland).

No definite local records, though this region is included within the recorded range of the species.

? Leda tenuisulcata Stimpson.

Gould, I87o, p. I6I (not listed for this region); Verrill and Smith, r873, p. 69o, 500 .

Off Newport.-Sanderson Smith.

Family SOLENOMYIDE.

Solemya velum Say. [Chart $\left.{ }^{36} 6.\right]$

Gould, 1870, p. 48; Verrill and Smith, 1873, p. 688,360 , etc. (Solenomya velum); Dall, r889, p. 46 (Solenomya velum).

Dartmouth Harbor.-Adams, cited by Gould. Vineyard Sound, Buzzards Bay.-Verrill. Katama Bay.-Osburn. Upper half of Buzzards Bay, at frequent inshore stations; 2 to 5 fathoms, chiefly on bottoms of mud or muddy sand.-Survey.

Fish Hawk stations: 7629 ( $x$ shell), $763 x$ ( 1 living), 7669 (I shell).

Phalarope stations: II8 (I shell), 127 (living young), I29 (I shell), I30 (I shell), I33 (I living), I39 (I shell), I 47 (I shell), I 5 ( 1 living), I 56 ( I small living), I 57 (I small living), I6o (2 living), 164 (several living).

? Solemya borealis Totten.

Gould, 1870 , p. 50; Verrill and Smith, I873, p. 689 (Solenomya borealis).

Vicinity of Newport.-Totten, cited by Gould. Vineyard Sound, at Cuttyhunk, rare; "may prove to be only the mature state of the preceding," i. e., S. velum.-Verrill.

\section{Family Carditidas.}

Venericardia borealis (Conrad). [Chart $\mathrm{I}_{37 .]}$

Gould, 187o, p. 146 (Cardita borealis); Verrill and Smith, I873, p. 683,418 , etc. (Cyclocardia borealis); Dall, r889, p. 46; Sumner, I9ro, fig. $\mathbf{r}_{3}$.

"Common in the deeper parts of Vineyard Sound near its mouth, and off Gay Head and Buzzards Bay, ro to 25 fathoms." - Verrill. Western end of Vineyard Sound and Buzzards Bay, near its mouth, common; shells likewise taken at Crab Ledge; living specimens dredged in 6 to I9 fathoms, chiefly on sandy bottoms. Survey.

Fish Hawk stations: $756 \mathrm{r}$ (I shell)* $75^{62}$ bis ( 1 shell), $75^{6} 3$ ( $\mathrm{I}$ shell), $75^{67}$ ( 2 shells), 7568 (few shells)*, 7569 (3 shells), 7570 (several

$$
\text { I6269 }{ }^{\circ} \text {-Bull. } 3 \mathrm{I}, \mathrm{pt} 2-\mathrm{I} 3-\text { - }
$$

Venericardia borealis-Continued.

shells), 757 I (I shell), 7572 (several shells), 7576 (few shells), 7577 (several shells), 7578 (several shells, 2 living), 758 I (few shells), $75^{82}$ (few shells), $75^{83}$ (few shells), $75^{84}$ (many shells), $75^{85}$ (several living and shells), $75^{86}$ (? I shell), $75^{8} 7$ (I shell), 759 I (several shells), 7592 (few shells), 7594 (few shells), 7597 (I living, several shells), $759^{8}$ (many living), 7604 (few shells), 7607 (few shells), 7609 (several shells), $7664,766_{5}, 7666$ (few living and shells), $767 \mathrm{I}, 7672$ (many living and shells), 7673 (numerous living and shells), 7674 (few shells), 7678 ( 2 shells), 7679 (many living and shells), 7680,768 I (many shells), 7682 (few shells), 7683 (several shells, I living), $7686^{*}, 7688$ (few fragments), 7694 (few shells), 7698 (few shells), 7699 (few shells), 7700 (many shells), 7701 (few shells), 7702 (many shells), 7703 (few shells), 7704 (few shells), 7706 (few living and shells), 7707 (few shells), 7708 (few shells), 7709 (few shells), 77 Io (several small shells), 77 I 7 (few living and shells), 77 r 8 (many shells), 7719 (shells), 7720 (few shells), 7723 (few small shells), 7724 (several small shells), 7725 (few small living), 7726 (few shells), 7727 (several small shells), 7728 (I small living), 7730 (few shells), 773 I (several shells), 7735 (I living and I shell), 7750 (I shell).

Phalarope stations: 52, 53, 59, 65 (several shells and living), 66 ( $\mathrm{x}$ ), 76 ( $\mathrm{I}$ shell), $8 \mathrm{r}$ (living and shells), 82 (few shells), 94, I Ir (I shell), I 3 , II4, (shells common), i 5 (shells common).

Venericardia borealis novanglia Morse.

Verrill and Smith, I873, p. 684,423 , etc. (Cyclocardia novanglice).

"Mouth of Vineyard Sound and off Gay Head, ro to 25 fathoms." -Verrill.

\section{Family AstaRTID瓜,}

Astarte undata Gould. Chestnut shell. [Chart 138.]

Gould, I870, p. II9 (Astarte sulcata); Verrill and Smith, 1873, p. 684, 508; Dall, x889, p. 46.

"Off Gay Head and Buzzards Bay, and in the deeper parts of Vineyard Sound."-Verrill. Vineyard Sound, abundant at the westem end, though occasionally met with throughout its length; Buzzards Bay, near its mouth; Crab Ledge at several stations.-Survey. Living specimens dredged almost exclusively at depths of ro fathoms or more, on quite various bottoms.

Fish Hawk stations: $755^{6}$ bis, $755^{8}(x$ living and 2 shells) ${ }^{*}, 7560$ (I small shell) ${ }^{*}, 75^{6} 7$ (I shell), 
Astarte undata-Continued.

7574 (I living), 7577 (few shells), 7579 (I living) $75^{81}$ ( $\mathrm{I}$ living), $75^{82}$ (I), $75^{8} 3$ (few shells), $75^{84}$ ( I living), $75^{85}$ (few living), $75^{86}$ (I living), $75^{87}$ (several living), 759 I (I), 7594 (several shells), 7595 (few living), 7596 (2 shells), 7597 (few shells), 7598 (many living), 7599 (I living), 7604 (shells and living)*, 7605,7609 ( $x$ very small living, 2 shells) ${ }^{*}, 76_{5} 6$ (several shells), 766r (few shells), 7664 (many), 7665 (shells and living)*, 7666 (many living and shells)*, 7670 (several living)*, 7672 (many living and shells), 7673 (several shells), 7674 (many shells)*, 7679 (few small shells), 7681 (few shells), 7682 (several shells), 7687 (I shell), 7688 ( 1 living and few shells), $7698^{*}$, 7699 (several shells), 7700 (few shells, I small living), 7702 (many shells), $7703^{*}, 7706$ (2 shells), 7707 (I living and several shells), 7708 (few shells), 7709 (few small shells)* 77 I 7 (I small shell), 77 I $8^{*}, 77$ 19 (2 shells), 7720 (several living and small shells), 7722 (I shell), 7723 ( 2 small shells), 7724 (I small living), 7725 (several small), $77^{26}$ (few small shells), 7730 (several shells), 773I (I living), 7735 (several small shells), 774x (I shell), 7753*.

Phalarope stations: 8 (I shell), 28 (2), 40 (few shells), 43 (shells), 52 (few), 53 (I shell), $5^{8}$ (shells), 59 (few shells), 65 (many shells), 78 (several), 79 (few living), 80 (few shells), 8x (few shells,) 82 (common), $x_{12}, \mathrm{I}_{3}, \mathrm{II}_{4}$ (shells common), II5 (living and shells common).

Verrill speaks of a variety lutea, occurring off Gay Head and Vineyard Sound, along with the ordinary form.

Astarte castanea Say. Chestnut shell. [Chart I39.]

Gould, I870, p. II7; Verrill and Smith, 1873, p. 685,423 , etc.; Dall, r889, p. 46.

Abundant throughout Vineyard Sound and the lower portion of Buzzards Bay. More generally distributed than $A$. undata, with which it is often associated. Dredged by the Survey in 3 to ig fathoms, though rarely taken at depths less than 6 fathoms; commonly found upon bottoms free from mud.

Fish Hawk stations: 7525 bis (several shells), $75^{28}$ (several shells), 7533 (several), 7533 bis (many shells), 7534 bis (I shell), 535 (few), 7536 (several), 7536 bis ( 2 shells), 7537 bis (few shells), $754 \mathrm{I}$ bis (numerous shells), 7543 (several shells), 7547 (I), 7547 bis (2), 7550 bis ( $\mathrm{I}$ shell), $755^{2}$ (I), $755^{2}$ bis (several small shells), 7555 ( 2 shells, very small), 7556 bis (? I shell), 7560 (I shell), 7562 ( $x$ shell), 7562 bis (I shell),
Astartc castanca-Continued.

7563 (few shells), $756_{3}$ bis, 7564 bis (few shells and I small living)*, 7566 (several shells), 7567 (4 shells), 7568 (few shells), 7569 (few shells), 7569 bis (few shells), 7570 (few), 757 I (I shell), 7572 (many shells), 7575 (few shells), 7576 (many shells), 7578 (many shells), 7579 (few shells), 7580 (several shells), 7583 (I living, few shells), $75^{8} 4$ (few shells), 75 co (few shells), 7653 ( I living, I shell), 7654 (I), 7656 (several shells), 7657 (I shell), 7662 (few shells), 7665 (shells and living)*, 7666 (many living and shells)*, 7672 (few living and shells), 7674 (very many living and shells)*, 7675 (many living), 7680 ( 3 shells), 7683 ( I living and few shells)*, 7695 (few shells)*, 7696 (I living and few shells), 7697 (few shells)*, 7698 (i shell)*, 7699 (several shells), 7700 (few shells), 770 I (few shells)*, 7702 (few shells), 7703 (several shells), 7704 (many small shells)*, 7705 (few small shells)*, 7706 (many small shells), 7708 (I shell), 7700 (few small shells)*, 77 I 7 (many shells), 7718*, 7719 ( 1 living and few shells), $7725^{*}, 7726$ (few small shells), $773 \mathrm{I}^{*}, 7734$ (2 small shells), 7736 (several shells), 7740 (several shells), 7744 (I small living and I shell), 7745 ( $\mathrm{x}$ small shell), 7751 (I small shell), $775^{2}$ (few shells), 7753 (few shells)*, 7755 (I shell), 7761 (I worn shell), 7775 (I shell), 7779 (I small shell).

Phalarope stations: 25 (few shells), 26, 41 (few shells), 42 (few shells), 52 (several), 53 (few), 56 (many), 57 (many living), 58, 60 (several shells), 65 (many shells), 66 (few shells), 68 ( shell), 77 ( 2 shells), 8x (few shells), 82 (few), 83 (few living), Ir3, ri4 (few shells), I59 (1 shell), I67 (r shell).

Astarte quadrans Gould.

Gould, I870, p. I23 (not listed for this region); Verrill and Smith, I873, pp. 685, 509.

"Mouth of Vineyard Sound, and off Marthas Vineyard, I9 to 25 fathoms, rare."-Verrill. Crab Ledge, at 20 fathoms; western half of Vineyard Sound, at 5 to $I_{3}$ fathoms, sandy bottom.-Survey.

Fish Hawk stations: 7556 bis*, 7608 (I living)*, 7700 (several shells)*, 770 (several shells).

Astarte sp. undertermined.

Fish Hawk stations: 7600 (I shell), 760 I (I shell).

Crassinella mactracea (Gould). [Chart I40.]

Gould, I870, p. I28 (Gouldia mactracea); Verrill and Smith, 1873, p. 685,418 , etc. (Gouldia mactracea). 
Crassinella mactracea-Continued.

"Vineyard Sound and Buzzards Bay, especially at Woods Hole."-Verrill. Abundant and generally distributed throughout the Sound; in the Bay, chiefly restricted to the inshore stations.-Survey, Living specimens dredged in 3 to 17 fathoms, for the most part on bottoms free from mud.

Fish Hawk stations: $75^{22}$ bis (I shell), 7525 bis ( $\mathrm{I}$ living), $75^{27}$ (I shell), 7532 bis (several shells), 7534 (I shell), 7534 bis (I shell), 7536 (several shells), 7536 bis (several shells), 7537 bis, 7538 (I shell), 7538 bis (I shell), 7542 bis (I shell), 7543 ( $x$ valve), 7545 bis (several), 7546 bis (shells), 7547 bis (living and many shells), 7549 bis (few), 7550 bis (few shells), $755^{2}$ (I shell), $755^{2}$ bis (few shells), 7554 (I shell), 7554 bis (few shells), 7556 bis (few shells), 7557 (I shell), 7563 bis (few shells), 7564 bis (I shell), 7566 ( 3 shells), 7568 (several shells), 7569 (I living), 7569 bis, 7572 (I shell), 7579 (I living), 7595 (I), 7597 (I), 7620 (I shell), 762 I (many shells), 7626 (many shells), 7628 (many shells and living), 7630 (few shells), $763 \mathrm{r}$ (several), 7634 (few shells), 7635 (few shells), 7637 (few shells), 7639 (few shells), 7656 (few living), 7659 (many shells, few living), 7664 (I living), 7665 (few shells), 7666 (several on Diopatra tubes), 7667 (I living), 7670,767 I (many shells), 7672 (many shells), 7673 (I shell), 7674 (many shells), 7679 (few shells), 7682 (I shell), 7683 ( 2 shells), 7688 (I shell), 7695 (many shells), 7696 (few shells), 7697 (I living and few shells), 7699 ( 1 shell), 7699 (few shells and living), 7700 (I living and few shells), $770 \mathrm{I}$ (few shells), 7702 (few shells), 7703 (several shells), 7704 (few shells), 7705 (few shells), 7706 (I living), 7708 (few shells), 7709 (few living and shells), 77 18 (I shell), 77 I9 (I living and shells), 7726 (few shells), 7727 (I shell), 7732 (many shells), 7733 (few shells), 7734 (several shells), 7735 (several shells), 7736 (several shells), 7738 (I shell), 7739 (several shells), 774I (several shells), 7744 (few living and shells), 7746 (I shell), 7748 (few shells), $775^{2}$ (I shell), 7753 (few living and shells), 7754 (I shell), 7755 (I shell), 7756 (I shell), 7757 ( $\mathrm{I}$ shell), 7760 (few shells), 776r (few shells), 7764 (few shells), 7766 (few shells), 7767 (several shells), 7769 (several shells), 7770 (few shells), $777 \mathrm{r}$ (few shells), $777^{2}$ (few shells), 7775 (several shells), 7776 (I shell), 7777 (few shells), $777^{8}$ (few living and many shells), 7,79 (many shells), 7780 (few shells), 778r (many shells and $\mathrm{I}$ living), $778_{3}$ (many living and shells).
Crassinclla mactracea-Continued.

Phalarope stations: I ( 2 shells), 3 (I shell), 5 (I shell), 6 (I shell), 7 (I living, several shells), 8 (I living), IO (2), II (2), I3 (few), I (few shells), 25 (few shells), 26 (I shell), 28 (I), 29 (I shell), 32 (I shell), 33 (I shell), 35 (2 living), 40 (few shells), 4 x (few shells), 42 (few shells), 43 (shells), 52 (many living), 53 (few living), 59 (few shells), 60 (few), 62 (I), 64 (I living), 65 (many shells and living), 66 (common), 69 (I), 74 (I shell), 77 (few shells), 8I (few shells), 82 (few living and shells), 83 (several living and shells), 86 (living), 9I (many living), 92, 96, 97, 100 (I shell), 101, 102, 106, 107 (few living), I08, I09, IIo, II $3, I_{4}$ (few), II (living and shells common), II7 (few living and shells), II8 (few shells), I20 (I shell), I2 I (several living), I22 (few shells), I23 (I shell), 126 (few shells), I28 (few shells), I29 (I living), I32 (living abundant), I33 (living), I34 (few), I35, I37 (I shell), I40 (I shell), I4I (few living and shells), I44 (living common), I48 (living common), $5_{52}$ (I shell), 167 (few shells).

\section{Family LEPTONIDE.}

Rochfortia planulata (Stimpson).

Gould, 1870, p. 83 (Kellia planulata); Verrill and Smith, 1873, p. 688, 3 Io, etc. (Kellia planulata); Dall, I889, p. 48 (Kellia planulata).

New Bedford.-Gould. "Vineyard Sound and Buzzards Bay, I to 8 fathoms, not common; "also sometimes found under stones at low water."-Verrill.

\section{Montacuta percompressa Dall.}

Verrill, r882d, p. 37 I (Tellimya ferruginosa); Verrill, 1884, p. 666 (Tellimya ferruginosa); Verrill, r884a, p. 225 (Tellimya ferruginosa); Dall, 1889 , p. 50 (Tellimya ferruginosa); Verrill and Bush, I898, p. 784 (Tellimya ferruginosa).

Hadley Harbor, "Gut of Canso" and "gutters" of Naushon, in sand and mud below low-water mark.-Verrill.

Montacuta bidentata (Montagu).

Verrill, I882d, p. 371; 1884; 1884a; Verrill and Bush, I898, p. 784 .

Vineyard Sound, 1875 .

Aligena elevata (Stimpson).

Gould, 1870 , p. 86 (Montacuta elevata); Verrill and Smith, I873, p. 688, 418 , etc. (Montacula elcvata); Dall, r889, p. 50 (Tellimy elevata); Verrill and Bush, 1898, p. 784 (Kelliopsis elevata).

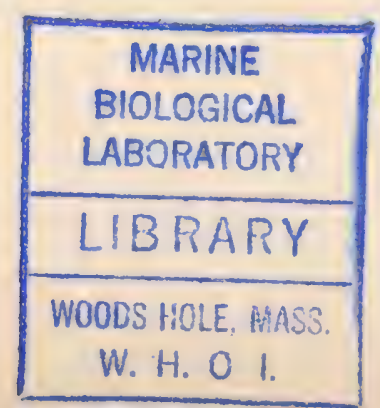


Aligena elevata - Continued.

New Bedford.-Gould. "Gut of Canso," Naushon "gutters" and "Sheep Pen Cove" at low water.-Verrill. Western end of Vineyard Sound, three records at Io to 14 fathoms.Survey.

Fish Hawk stations: $7700^{*}, 77^{18^{*}}, 77^{2} 6^{*}$.

Thyasira trisinuata (d'Orbigny).

Verrill, 1872 , p. 287 (Cryptodon obesus); Verrill and Smith, 1873, p. 687,509 (Cryptodon obesus); Verrill, I882 c, p. 569 (Cryptodon obesus); Dall, 1889, p. 5o (Cryptodon obesus).

Off Gay Head, Ig fathoms, mud.-Verrill.

Thyasira gouldii (Phillippi).

Gould, 1870, p. 100 (Cryptodon gouldii; not listed for this region); Verrill and Smith, 1873, p. 686, 509 (Cryptodon gouldii); Dall, I889, p. 50 (Cryptodon gouldii).

"Buzzards Bay, 6 fathoms, mud;" also listed for "muddy bottoms off the open coast." - Verrill.

\section{Family LucinIDA.}

2Divaricella dentata (Wood). ${ }^{\alpha}$

Gould, 1870, p. 99 (Lucina dentata); Verrill and Smith, I873, p. 686, 418, etc. (Cyclas dentata); Dall, I889, p. 50 .

Nantucket.-Gould. "Not uncommon, dead, but rarely obtained living, in Vineyard Sound, 6 to I4 fathoms." - Verrill.

Divaricella quadrisulcata (d'Orbigny). [Chart I4r.] Dall, 1889 , p. 50 (Hatteras to Trinidad).

Shells dredged by the Survey at scattered stations throughout the length of Vineyard Sound and Buzzards Bay, chiefly in waters of less than 8 fathoms ( 2 to 12 ), on quite various bottoms.

Fish Hawk stations: 7536 bis (I), 7546 bis (I shell), $755^{6}$ (I shell)*, 7556 bis ( 2 shells), $75^{66}$ ( 4 shells), 7577 (I shell), 7630 (few shells), $76_{32}$ (several shells), 7639 (I fragment), 7730.(I shell), 776 I ( $x$ fragment), 7769 (I shell).

Phalarope stations: 82 (I shell), 98, ro7 (I shell), $I_{22}$ (shells), I36, I37 (I shell), I42 (2 shells), I44 (I shell), I $5^{2}$ (I shell).

Phacoides filosus (Stimpson).

Gould, 1870, p. 98 (Lucina filosa; not listed for this region); Verrill and Smith, r873, p. 686, 509 (Lucina filosa); Dall, r889, p. 50 (Lucina filosa).

"Off Gay Head, Ig fathoms, soft mud."-Verrill. Off Gay Head ( 2 stations) and Bay end of Quicks Hole; 8 to 7 fathoms, sand and shells. - Survey.

Fish Hawk station 77 I9 (I shell); Phalarope stations: 59 ( $x$ shell), 82. (In each case identified by R. C. Osburn).
Phacoides sp.

Fish Hawk station: 7698 (I young living)*

\section{Family CardIDde:}

Cardium pinnulatum Conrad. [Chart 142.]

Gould, I870, p. I4I (not listed for this region); Verrill and Smith, I873, p. 683,423 , etc.; Dall, I 889 , p. $5^{2}$.

Shells almost universally distributed in Buzzards Bay and Vineyard Sound. Living specimens dredged by the Survey in 4 to $I 7$ fathoms, on quite various bottoms.

Fish Hawk stations: $75^{2} 5$ bis, $753^{2}$ (I shell), 7533 bis (several shells), 7535 (I shell), 7537 bis (I shell), $754 \mathrm{I}$ (few shells, I living), $754 \mathrm{I}$ bis ( shell), 7546 bis (several), 7547 bis (few shells), $755^{2}$ (? I), $755^{6}$ bis (few shells), $755^{8}$ (few shells), 7562 (I shell), $75^{6} 3$ bis (few shells), 7565 (2), 7568 (I shell), 7569, 757 I (I shell), 7577 (few shells), $757^{8}$ (many shells, few living), $7579,75^{80}$ (I small shell), 7581 (several shells), $75^{82}$ (few shells), $75^{8} 3$ (few shells and living), $75^{8} 5$ (I living), 759 I (I shell), 7595 (few shells), 7597 (few shells), 7599 (2 shells, I living), 7601 ( $\mathrm{I}$ shell), 7606 ( $\mathrm{I}$ shell), 76 го (abundant shells), 76r1, 76r2 (many shells), $76 \mathrm{I}_{3}$ (many shells), 76I4 (many shells), 7616 (several shells), 7618 (many shells), 7619 (several shells), 7620 (many shells), 762I (many shells), 7622 (many shells), 7623 (few shells), 7624 (few shells), 7625 (few shells), 7626 (many shells), 7627 (I), 7629 (many shells), 7630 (several shells), 7633 (few shells), 7634 (few shells), 7636 (several shells), 7637 (many shells), $766_{3} 8$ (few shells), 7639 (few), 7640 (many shells), 764 I (many living and shells), 7642 (few shells), 7643 (many shells), 7644, 76.45 (several shells), 7646 (few shells), 7647 (few shells), 7648 (several shells), 7649 (few shells), 7650 (several shells), $76_{51}$ (many shells), $76_{52}$ (many living and shells), $76_{53}$ (few), $76_{54}$ (few shells), 7655 (few shells), 7656 (few shells), $765^{8}$ (few shells), 7659 (numerous shells), 7660 (many shells), 7661 (many shells), 7662 (numerous shells), 7663 (shells), 7664 (few shells in Diopatra tubes), 7668 (few shells), 7660 (few shells), 7671,7672 (few shells), 7673 (shells and few living), 7674 (few shells), 7675 (few shells), 7680 (I living), 7682 (few shells), 7686 (I shell), 7687 (I shell), 7688 (living and shells), 7695 (few shells), 7697 ( 2 shells), 7698 (several shells), 7699 (I living), 7702 (I shell), 7704 (several shells), 7706 (I shell), 7707 (I shell), 7709 (2 shells), 7710 (2 shells), 7717 (several shells), 7718 (few shells), 7719 (few shells), 7720 ( 1 liv-

a Dr. Dall is now of the belief that this species is not found north of Cape Hatteras. In that case, the records here given doubtless refer to the next species. 
Cardium pinnulatun-Continued.

ing and I shell), 772I (I shell), 7723, 7724 (several living), 7725 (few living), 7726 (few shells), 7727 (several shells), 7728 (few living), 7729 (few living), 7730 (few living and shells), 773 I (few shells), 7734 (I shell), 7736 (I shell), 7740 (I shell), 774 I (I shell), 7744 (I shell), 7778 (I shell).

Phalarope and Blue Wing stations: I (several shells, I living), 2 (many shells), 3 (few shells), 5 (I shell), 6 (2 shells), 7 (several shells), 8 (shells common), 9 (several), II (I), I5 (few), I8, 19 (few shells), 22 (I shell), 25 ( $\mathrm{r}$ small living), 27 (I shell), 28 (I), 29 (I), 32 (few shells), 34 (I shell), 35 (I fragment), 38 (fragments), 40 (few shells), 42 (few shells), 43 (shells), 52 (living common), 53 (many shells), $5^{6}$ (few), 57 (few), 59 (few), 60 (few shells), 62 (many shells), 65 (many living and shells), 69 (few shells), 74 (I shell), 77 (few shells), 78 (living common), 79 (many shells and living), 80 (living), 8I (several shells), 83 (several shells), 85,88 (few), 89 (few), 90, 91, 92 (shells), 93 (shells), 94, 95, 96, 98, 100 (shells), 101, 102, 103, 105 (shells), Io7 (many shells), I08, Io9, IIo, II3, I 4 (few), II5 (living and shells common), ir6, II 7 (few shells), II8 (few shells), rig (I shell), I20 (I shell), I2I (shells), I22 (few), I23 (living and shells), I24 (few shells), I26 (few shells), I28 (common), I29, I30 (common), I32 (living and shells), 133 (shells common), I35, I36, 138 (few shells), I39 (several), I40 (few shells), I4I (living), I43 (few shells), I44 (several), I45 (shells common), I46 (several living), I47 (shells common), I50 (few shells), I60 (I broken shell), I62 (many shells), I6 3 (few shells,) I64 (I shell), I65 (few shells), I66 (several shells), I67 (several shells).

Cardium ciliatum Fabricius.

Crab Ledge at Fish Hawk station 7609 (25 fathoms, shells and gravel), 2 shells*.

\section{Lavicardium mortoni Conrad. [Chart I43.]}

Gould, 1870, p. I43 (Liocardium mortoni); Verrill and Smith, 1873, p. 683,358 , etc.; Dall, I889, p. 54 (Liocardium mortoni).

Abundant in Buzzards Bay, particularly at inshore stations; shells taken at scattered stations in Vineyard Sound; living specimens dredged in 2 to 5 fathoms on various bottoms, with or without mud.-Survey.

Fish Hawk stations: 7528 (I shell), 7566 (I shell), 7560 bis, 7584 ( I shell), 76 Iо (several shells), $76 \mathrm{I}_{2}$ (several), 7613 (2 shells), 76r4 (several shells), 76 5 (few large, many young living), 76 I6 (several shells), 7618 (several shells), 7620
Lavicardium mortoni-Continued.

(I living, shells abundant), 762 I (many shells), 7622 (several shells), 7625 (few shells), 7630 (many shells), 763I (several shells), 7632 (few shells), 7633 (living and shells), 7634 (many shells), 7635 (many shells), 7639 (several shells), 7643 (few shells), 7644 (few shells), 7645 (many shells), 7648 (many shells), 7650 (few shells), 7652 (few shells), 7653 (few shells), 7659 (numerous shells), 7694 (I), 7695 (I shell), 7702 (I small shell), 775I (I sliell), 7766 (I shell), 7769 (I shell), 7779 (2 shells).

Phalarope stations: 2 (I shell), 8 (few), 9 (I), 42 (few shells), 7 I (many living and shells), 72 (several shells), 87, 88 ( 1 shell), 89, 91 , 92, 93 (shells), 94, 95, 96, 97, 98, 100 (2 shells), 107 (few shells), I08, I09, I I0, II3, I I4 (few shells), I 7 (several shells), Ir 8 (few shells), I20, I22 (shells common), I23 (few shells), I24 (living and shells), I25 (living), I26 (I living), I27 (living), 128 (few), I29 (x), I30 (living common), I3I, I32 (living common), I33 (living common), 135, I36 (few shells), I37 (few shells), I38 (shells common), I39, I40 (few shells), I4 I (few shells)), I42 (shells common), I44 (living and shells), I45 (living and shells), I46 (several living), I47 (living common), $\mathrm{r}_{4} 8$ (shells common), I49 (many), I50 (few shells), I5I (few shells), I52 (few shells), I53 (I shell), I 54 (2 shells), I55 (many living and shells), I 56 (several shells), I 57 (few shells), I 58 (few shells), I60 (2 shells), I62 (few shells), I63 (2 shells), I64 (I living, several shells).

\section{Family VENILIIDEE.}

Cyclas islandica Lamarck. Black quahog. [Chart I i4.]

Gould, I870, p. I29 (Cyprina islandica; not listed for this region); Verrill and Smith, 1873 , pp. $68_{3}, 505$ (Cyprina islandica); Dall, I889, p. 54 (Cyprina islandica).

"Off Gay Head, Marthas Vineyard, Ig fathoms, soft mud." - Verrill. Western end of Vineyard Sound and mouth of Buzzards Bay, not uncommon.-Survey. Dredged chiefly in waters of 10 fathoms or more, though recorded for 5 fathoms; found on various bottoms, living specimens being apparently more common where some mud is present.

Fish Hawk stations: $75^{8}$ I (I small shell)* 7587 (several shells), 7596 (I valve)*, 7598 ( $\mathrm{I}$ living and few shells), $760 \mathrm{I}$ ( I small living and I shell), 7607 ( I living and $x$ small shell)*, 7609 (I small shell)*, 7662 (few shells), 7663,7664 (I living), 7666 (I living, I shell), 7669 (few living and 
Cyclas islandica-Continued.

shells), 7673 (I living), 7678 (numerous shells), 7680 (2 shells), 7682 (I shell), 7686 (I shell), 7702 (many shells), 7706 (several large shells), 7709 (I shell), 7722 (2 small shells), 7730 ( $x$ shell), 773x (several shells).

Phalarope stations: 62 (I), 78 (I living), I00 (I living).

\section{Family VENERIDE.}

Venus mercenaria Linnæus. Quahog, round clam, hard clam, Little Neck clam. [Chart I45.]

Gould, I870, p. I33 (Venus mercenaria), p. I35 (Venus notata); Verrill and Smith, 1873, p. 68r, 359, etc.; Dall, I889, p. 54.

Littoral distribution general throughout the region. Abundant in sand or mud, just below low-tide level, especially in harbors, estuaries, or other sheltered places, where it is also taken at depths of several fathoms. Shells, and occasionally living specimens, dredged by the Survey throughout the length of Buzzards Bay; much less frequent in Vineyard Sound. Shells recorded from depths of 2 to $I_{3}$ fathoms, most frequently in mixtures of mud and sand; living specimens taken in depths as great as 6 fathoms, though rarely found within the field of the dredging operations.

Fish Hawk stations: 7537 bis (few shells), 7564 bis ( $\mathrm{r}$ large shell), 76 10 ( $\mathrm{r}$ shell), $76 \mathrm{r} 2$ (few small shells), 76г3, 76г 5 (few small shells), 76r6 (several large shells), 76 7 (2), 76I8 (I shell), 76 9 (few shells), 7620 (several shells), 762 I (many shells), 7622 (few shells), 7627 (several shells), $76_{3} 6$ (I young shell), $76_{39}$ (several fragments), 7640 (few shells), 764I (few shells), 7642 (few shells), 7643 (few shells), 7644 (several living and shells), 7645 ( $I$ very small shell), 7646 (few fragments), 7647 (few shells and living), 7648 (several shells), 7649 (I small shell), 7650 (few shells), $765^{2}$ (few small), 7653 (few small shells), 7654 (r small shell), 7655 (few shells), 7656 (few small shells), 7668 (few small shells), 7672 (few shells), 7674 (several shells), 7675 (I large living and several small shells), 7679 (I small shell), 7695 (few small shells), 7730 (I large shell), 7736 (several fraginents), 7760 (I worn shell), 7762 (several shells), 7772 (very much worn shell), 7778 (several large shells), 7783 ( 2 large shells).

Phalarope stations: 5 (I large shell), 52 (few shells), 53 (2 shells), 65 (few shells), 68 (I shell), 7 I (shells abundant), 72 (many shells and I living), 78 (I small), 79 (I small), So (few
Venus mercenaria - Continued.

shells), 8I (many shells), 82 (few shells), 85, 86, 89 (I shell), 93 (2 shells), 94, 95, roo, ror (shells), I05 (shells), I07 (many living and shells), ro8, Io9, IIo, II3, II4 (I shell), Ir6, II9 (I small), I24 (shells), I25 (several shells), 127 (shells), I29 (common), I37 (I shell), I38 (I young shell), I39, I42 (I shell), I49 (I), I 54 (I small), I55 (many shells), I56 (few shells, I living), I57 (several shells), I62 (2 shells), I63 (I shell), I64 (few shells), I65 (I large shell), I66 (I shell), 167 (many shells).

Gemma gemma (Totten.) ${ }^{a}$

Gould, I870, p. I37; Verrill and Smith, 1873, p. 682 , 359, etc. (Tottenia gemma); Dall, r889, p. 56 .

Newport Harbor.-Totten, cited by Gould. Buzzards Bay, Vineyard Sound, Nantucket.Verrill. Katama Bay*, West Falmouth Harbor*. (Osburn and Cole, collectors). Shells found in enormous numbers by Mr. Edwards on beach at Waquoit Bay, February I7, I909, where they had been washed ashore. According to Verrill this species is "peculiar to sandy shores, both above and below low-water mark, and it often occurs in immense numbers on the sandy flats laid bare by the tides." Rarely met with in the Survey dredgings, though (shells only ?) were taken on a few occasions, in one case at a depth of 14 fathoms.

Fish Hawk stations: $77^{2} 6^{*}, 7755^{*}$, Phalarope station $19 *$.

Callocardia morrhuana (Linsley). [Chart r46.]

Gould, I87o, p. I3I (Cytherea convexa); Verrill and Smith, I873, p. 68I, 432, etc. (Callista convexa); Dall, 1889 , p. 56 (Cytherea convexa).

Shells taken in abundance throughout Buzzards Bay, and in certain portions of Vineyard Sound; records for the living animals chiefly confined to the Bay.-Survey. Living specimens dredged in 2 to $I_{5}$ fathoms, most frequently on bottoms containing mud.

Fish Hawk stations: 7537 bis (I shell), 7543 (I shell), 7543 bis ( $I$ shell and fragment), 7546 bis (few shells), 7548 (several shells), 7554 (I shell), 7555 (x), $755^{8}$ (many shells), 7559 (few shells), 7560 (I shell), $75^{67}$ (2 shells)*, 7568 (few shells), 7569 (I shell), 757 I (I shell), 7572 (few shells), 7574 (I sheli), 7576 (several shells), 7577 (several shells), 7578 (several shells), $75^{81}$ (few shells), $75^{83}$ (few shells), $75^{84}$ ( ( living), $75^{8} 5$ (several shells), 7592 (few small shells), 7594 (several large shells), 7598 (I shell), 7600 (I shell), 7602 (few shells), 76 Iо (I shell), 76I I

$a$ Verrill and Smith, 1873 , also list a "Tottenia manhatten sis," which they are not sure is distinct from $T$. gemma. 
Callocardia morrinana-Continued.

(few living and shells), 7612 (many living and stells), 76I3 (many shells), 76I5 ( 1 shell), 76I6 (several shells), 7617 (many shells), 7618 (several shells), 6 I9 (several shells), 7620 (several shells), 7622 (several shells), 7623 (few fragments), 7625 (few shells), 7627 (few), 7629 (I shell), 7630 (few shells), $763_{2}, 7636$ (few shells), 7637 (several shells), 7638 (several shells), 7639 (several shells), 7640 (few shells and living), 7641 (few shells), 7642 (few living and shells), 7643 (shells), 7644 (living and shells), 7645 (many shells), 7646 (few), 7647 (several shells and living), 7648 (several shells), 7649 (few shells), 7650 (many shells), $76_{51}$ (several shells), $765^{2}$ (few shells), 7653 (few shells), 7654 (many shells), 7655 (few shells), 7656 (few shells), 7657 (many shells), 7658, 7659 (many shells), 7660 (many shells), 766r. (many living and shells), 7662 (many shells), 7663 (few shells), 7664 (numerous shells, few living), 7665 (few shells), 7666 (few shells), 7668 (few shells), 7669 (living and shells), 7670, $767 \mathrm{I}$ (numerous living and shells), 7672 (few shells), 7673 (few shells), 7674 (few shells), 7675 (several shells), 7678 (many shells), 7679 (shells common), 7680 (few shells), 768I (several shells), 7682 (several shells), 7685 (i shell), 7686 , 7687 (few small shells), 7688 (I small shell), 7692 (I shell), 7695 (few small shells), 7698 (several shells), 7699 (several shells), 7700 (several shells), 770 I (few shells), 7702 (several shells), 7703 (few shells), 7706 (I shell), 7707 (I shell), 7708 (I shell), 7709 (I shell), $7710 *, 7717$, (I shell), 77 I8 (I shell), 77 I 9 (several shells), $77^{22}$ (I shell), 7723 (2 shells), 7724 (several shells and small living), 7726 (several shells*, 7728*, 7729 (several small shells), 7730, 773 I (several shells), 7735 ( 2 shells).

Phalarope and Blue Wing stations: r ( $\mathrm{r}$ shell), 6 (few shells), 7 (many shells), 9 (I shell), I5 (I shell), I9 (several shells), 20 ( 1 small living), 28 (2), 50 (I small shell), 52 (many shells), 53 (many shells), 55 (I shell), 6I (I fragment), 65 (I shell), 68 (few shells), 7 I (many), 72 (few living and shells), 74 ( 2 shells), 76 (few shells), 77 (2), 78 (few), 79 (many shells), 80 (several shells), 81 (many), 82 (few shells), 83 (few), 84 (few shells), 85, 86, 88 ( I living), 89, 90, 92 (shells), 93 (I living, several shells), 94, 95, 96, 98, 100, 102, 103, 104, I07 (many living and sheils), Iog, IIo, I 4 (few shells), I 5 (shells common), II7 (I shell), II8 (living), I I9 (few shells), I20 (I shell), I22 (several shells), I23 (living and shells), I24 (several shells), I25
Callocardia morrhuana-Continued

(several shells), I26 (few shells), I29 (living), I3I (few shells), I33 (I shell), I38 (few shells), I39, I40, I4I (few shells), I42 (I small shell), I43 (I shell), I44 (few small), I5 (I living), I57 (? I shell), I60 (I young)*, I6I (I living, several shells)*, r62 (I living, several shells)*, I64 (I living, many shells)*, r65 (many shells)*, i66 (many shells)*.

\section{Family Petricolidis.}

Peiricola pholadiformis Lamarck. [Chart I47.]

Gould, I870, p. 90; Verrill and Smith, 1873, p. $680,37^{2}$, etc.; Dall, $x 889$, p. $5^{8}$.

"Buzzards Bay; Vineyard Sound (Lackeys Bay, etc.)," dwelling particularly on shores of mud or clay.-Verrill. Living specimens dredged only once, near the Sound shore of Cuttylunk; shells frequently taken throughout the Sound and lower end of the Bay, in 3 to I 7 fathoms, on nearly every sort of bottom.-Survey. Ram Island, Eel Pond.-G. M. Gray. New Bedford Harbor, Fort Phœenix.-L. J. Cole.

Fish Hawk stations: $75^{21}$ bis (2 shells), 7533 bis (I shell), 754I (I shell), 754I bis (I shell), 7543 (I fragment), 7553 (I shell), $755^{6}$ bis (I shell), $755^{8}$ (I shell), $75^{6} 3$ (I shell), $75^{6} 5$ bis (I very small), 7566 (I fragment), 7567 (several shells), 7568 (I shell), 7572 (2 shells), 7579 (I shell), 7596 ( 2 shells), 7643 (few shells), 7655 (I small shell), $7^{6} 66,7660$ ( 2 shells), 7669 (I shell), 7675 (I shell), 7678 (few shells), 7699 (I young), 77 or (several shells), 7705, 77 I9 (I small sheli), $77^{24}$ (I shell fragment), 7725 ( 2 shells), 7729 (I very small living), 7736 ( $\mathrm{I}$ shell), 7744 ( $\mathrm{I}$ fragment), 7774 (I fragment), 7779 (few shells), 7780 (I fragment).

Phalarope stations: 2 (I shell), 6 (I fragment), I3, I5 (several shells), 28 (I shell), 33 (very many living), 52 ( 2 shells), 53 (I shell), 60 (I shell), 66 (I), 7I (I shell), 82 (several shells), I04, II4 (I shell), Ir7 ( $r$ shell).

\section{Family PSAMmoBIIDA.}

\section{Tagelus gibbus Gray. [Chart 148.]}

Gould, I870, p. 43 (Solecurtus gibbus); Verrill and Smith, 1873, p. 675,373 , etc.; Dall, I889, p. 58 .

"Vineyard Sound and Buzzards Bay, not uncommon."-Verrill. Upper half of Buzzards Bay, for the most part at stations near the shore; not recorded for the Sound; dredged in 2 to 7 fathoms, chiefly on sandy and muddy bottoms; with one exception, shells only.Survey. 
Tagelus gibbus--Continued.

Fish Hawk stations: 76 Io (I shell), 7614 (I shell), 7620 (I shell), 762 I (few shells), 7625 (2 shells), 7626 (I shell), 7630 (few shells), $763^{2}$ (I shell), 7633 (few shells), 7639 (several shells), 7643 (I shell), 7645 (I shell).

Phalarope stations: Iog (I living), Ir7 (I shell), I22 (2 shells), I27 (shells common), I29 (I small), I30 (2 small), I37 (2 shells), I40 (I shell), I4I (several shells), I45 (2 shells), I46 (several shells), I47 (several shells), I49 (few shells), I $50, I_{53}$ (several shells), I 54 (I young).

Tagelus divisus (Spengler).

Gould, I87o, p. 44 (Solecurtus divisus); Verrill and Smith, 1873, p. 676,435 ; Dall, 1889, p. $5^{8}$.

Buzzards Bay.-Gould. "Vineyard Sound and Buzzards Bay, not common."-Verrill.

\section{Family TELLINIDAE.}

\section{Tellina tenella Verrill.}

Verrill, 1872, p. 285 (Angulus modestus); Verrill and Smith, I873, p. 677 (Angulus tenellus); Verrill, i882 c, p. 568 (Angulus tenellus); Dall, I889, p. 60.

Vineyard Sound.-Verrill. Recorded but once by the Survey, at Fish Hawk station $7694^{*}$, near the mouth of Vineyard Sound, I2 $1 / 2$ fathoms, stony.

\section{Tellina tenera Say. [Chart I49.]}

Gould, 1870, p. 97 (not listed for this region); Verrill and Smith, I873, p. 677,358 , etc. ( $A n$ gulus tener); Dall, I889, p. 60.

Abundant and generally distributed both in Buzzards Bay and Vineyard Sound; living specimens dredged in 2 to 19 fathoms, on bottoms of sand or mud or mixtures of the two.-Survey. Also occurs on sandy and muddy shores at low-water mark.-Verrill.

Fish Hawk stations: $752 \mathrm{I}$ bis (few), 7525 bis (few shells), 7532 bis (few shells), 7533 (2 shells)*, 7533 bis ( 1 shell), 7542 bis (fairly abundant), 7546 bis (few shells), 7550 bis (I shell), $755^{2}$ bis (few shells), 7554 (few shells), 7554 bis (many shells), 7556 bis (many shells), 7559 (I shell), 7560 (I shell), $75^{62}$ bis (I shell), $75^{6} 3$ bis (few shells), 7564 bis ( $\mathrm{I}$ shell), 7566 (numerous shells), 7567. (several shells), 7568 (many shells), 7569 (few shells), 7569 bis (few shells), 7570 ( 2 shells), 7572 (few shells), 7574 (many shells), 7575 (many shells), 7579 (I shell), 7580 (several shells), 758I (I shell), 7584 (few shells), $75^{86}$ (I shell), 7593 (I shell), 7596 (I living and shells), 7597 (many shells), 76ro (several shells), 7612 (few shells), 76 $\mathrm{I}_{3}$ ( $\mathrm{I}$ living), 76 $\mathrm{I}_{4}$ (few shells), 76 5 (several shells), 76r6 (living and several shells), 7618 (few shells), 76r9 (sev-
Tellina tenera-Continued.

eral living), 7620 (many shells), 7622 (few living), 7623 (many), 7624 (many living and shells), 7626 (several shells), 7629 (few shells), $76_{32}$ (few shells), $76_{33}$ (many living and shells), 7634,7635 (few shells), 7636 (I shell), 7639 (few shells), 7640 (few shells), $764 \mathrm{I}$ ( 2 shells), 7643 (few shells), 7645 (many shells and living), 7648 (several shells), 7650 (few shells), $76_{5}$ I (I), $76_{52}$ (I living), 7653 (few living), 7654 (I living), $7656,7664,766_{5}$ (few in Diopatra tubes), 7666 ( I living and several shells), 7667 ( I living and several shells), 7668 (few shells), 7675 (few shells), 7680 (few shells), 768r (I living), 7682 (I living), 7683 ( 1 shell), 7685 ( 2 or 3 living), 7686,7687 (few living and shells), 7688 (few living and shells), 7695 (many shells), 7606 (I shell), 7698 (I living and few shells), 7699 (few living), 7700 (few shells), 770 I (many shells), 7702 (I shell), 7703 (several shells), 7704 (many living and shells), 7705 (few living and shells), 7706 (few shells), 7707 (few shells), 7709 (few shells), 7710 (several shells), 7717 (several shells), 7718, 77 I9 (shells), 7723 (I shell), 7725 (few living and shells), 7726 (few shells), 7727 (few shells), 7729 ( 1 living and shells), 7730 (few living and I shell), 773 (few shells), 7734 (several shells), $773^{8}$ (several shells), 7744 (I shell), 7750 (few shells), 775 I (2 shells), 7755 (I shell), 776r (I shell), 7762 (I shell), 7766 (I shell), 777 I (several shells), 7779 (few living and shells).

Phalarope and Blue Wing stations: I (few living and shells), 3 (few shells), 6 (few), 7 (shells), I $5, I 7,20$ (few shells), 23 (I shell), 29 (few), 30 (I), 33 (few shells), 34 (few), 40 (few shells), 4 I (few shells), 42 (few shells), 43 (shells), 50 (x shell), 52 (few shells), 53 (many shells), 55 (few shells), 60 (few shells), 6I (several shells), 62 (few), 64 (few shells), 66 (many shells), 67 (many shells), 7 I (several shells and living), 72 (few shells), 74 (few shells), 75 (few shells), 76 (few shells), 78 ( 1 living), 82 (few shells), 85 , $89,90,9$ I, 92 (shells), 94, 95, 97, 98, 99, 100 (shell and living), IOI (living and shells), I02, I03, 104, I07 (many living and shells), I08, Io9, II8 (few shells), Ir9 (I shell), I20 (living), I22 (few), I23 (living and shells), I24 (shells), I25 (living and shells), I26 (living and shells), I27 (living common), I29 (shells), I37 (I shell), I3 8 (few shells), I39, I40 (few shells), I42 (several), I45 (few), I 46 (several shells), $x_{5}$ I (living common), I52 (several living and shells), I53 (living), I 54 (few living and shells), I55 (few shells), I59 (I broken shell ?), I60 (2 living), r63 ( $\mathrm{r}$ shell), I64 (several living), I65 (few shells), 166 ( 1 living, many shells). 


\section{Macoma tenta Say. [Chart I50.]}

Gould, 187o, p. 96 (Tellina tenta); Verrill and Smith, 1873, p. 678,429 , etc. (Tellina tenta); Dall, 1889, p. 60.

Dartmouth Harbor, New Bedford Harbor.Adams. "Vineyard Sound and Buzzards Bay 2 to Io fathoms, mud, common;" Hadley Harbor.-Verrill. Survey records, with one exception, confined to Buzzards Bay, where living specimens were dredged at depths of 3 to 7 fathoms, on bottoms of mud or muddy sand.

Fish Hawk stations: $76 \mathrm{r}_{2}$ (few shells), 76 $\mathrm{I}_{3}$ (few shells), 76I 7 (few shells), 76 I9 (few shells), 7620 (many shells), 7622 (few shells), 7623 (few living and shells), 7624 (several shells and living), 7629 (few living and shells), 7638 (few shells), 7640 (few shells), 764I (few shells), 7643 (several shells), 7645 (few shells), 7646 (many shells and living), 7647 (shells), 7649 (shells common), 7658,7675 (I shell), 7727 (several shells).

Phalarope stations: 88 (I shell), 92 (shells), II (several living and shells), I20 (living and shells), I25 (I living), I27 (living), I43 (several shells), $x_{59}$ (several shells), I6o (several living and shells), I6r (several living), I62 (few living), I64 (I), I65 (I shell), I66 (several shells).

Macoma balthica (Linnæus).

Gould, r87o, p. 93 (Macoma fusca; not listed for this region); Verrill and Smith, I873, p. 676,359 , etc. (Macoma fragilis and $M$. fusca.)

Wareham River, shallow water at low tide.Cole. Nonamesset Island, I shell.-Osburn. Tisbury Great Pond, perhaps common (several living specimens collected by Mr. Edwards). Not recorded among the shells taken by the dredge. Common, according to Verrill, on muddy shores, between tides.

Verrill states that two varieties, fusca and fragilis, are taken together, which, in this region, grade insensibly into each other.

? Macoma calcarea (Gmelin).

Verrill and Smith, I873, p. 677 (Macoma sabulosa).

No definite local records, though this region is included within range of the species as stated.

\section{Family SOLENIDAE.}

Siliqua costata (Gould).

Verrill and Smith, IS 73, p. 675, 358, etc.; Dall, ז889, p. 70.

Vineyard Sound, sandy shores and bottoms.Verrill. One young specimen (shell or living ?) recorded by the Survey from Fish Hawk station $7685^{*}$, at mouth of Vineyard Sound, in I7 fathoms.
Ensis directus Conrad. Razor clam, razor shell, razor fish. [Chart $\mathrm{I}_{5} \mathrm{x}$.]

Gould, I870, p. 40 (Solen ensis); Verrill and Smith, 1873, p. 674, 356, etc. (Ensatella americana); Dall, 889 , p. 72 (Ensis americana); Mead, 1898 (Solen ensis).

Shells abundant throughout both Sound and Bay, in 2 to 19 fathoms, on bottoms of every kind; living specimens abundant in the Bay, in 2 to 8 fathoms, chiefly on bottoms of muddy sand and sandy mud, scarcely ever dredged in the Sound.-Survey. This species is also littoral and adlittoral in its habitat, forming deep burrows in the sand. Large living specimens reported by Osburn in a sand flat near entrance of Lagoon Pond; probably common in all similar localities.

Fish Hawk stations: 752I (2 shells), $75^{21}$ bis (few fragments), 7225 bis (few shells), 7527 (several shells), 7528 (few shells), 7529 (I shell), 753 I (I shell), 7532 (few shells), 7532 bis (few shells), 7533 (several shells), 7533 bis (several shells), 7534 (I shell), 7534 bis (few shells), 7535 (few shells), 7536 (several shells), 7536 bis (fragments), 7537 (many shells), 7538 (shells), 7538 bis (few shells), 754 (few shells), 7543 (many shells), 7544 (few shells), 7545 (few shells), 7546 bis (many fragments), 7547 (few shells), 7547 bis (many shells), 7549 (many shells), 7549 bis (few shells), 7550

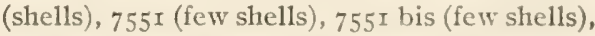
$755^{2}$ bis (I shell), 7553 bis (I shell), 7554 (few shells), 7554 bis (few shells), $755^{6}$ bis (few shells), $755^{8}$ ( ( shell), $75^{6} 3$ (few shells), $75^{63}$ bis (few fragments), 7565 bis (few fragments), 7566 (few shells), 7567 (I shell), 7568 (few shells), 7569 bis (few fragments), 7570 (I shell), 757 I ( s shell), 7572 (few shells), 7574 (few shells), 7576 (I shell), 7577 (several shells), 759 I (I shell), 7595 (I shell), 7598 (I shell), 76 I 2 (shell and fragments), $76 \mathrm{I}_{3}$ (several shells, I living), $76 \mathrm{I}_{4}$ (fragments), 76I5 (few, many young), $76 \mathrm{I} 6$ (several fragments), 7619 (few shells), 7620 (shells abundant), 7621 (few shells), 7622 (few shells), 7624 (few young and living), 7625 (many shells and living), 7626 (few shells), 7627 (few), 7629 (shells and small living), 7630 (few fragments), $7 \sigma_{3}$ I ( 1 fragment), 7632 (several shells), 7633 (many living and shells), 7634 (many living), $76_{35}$ (shells and fragments), 7636 (few fragments), 7637 (I small living), 7639 (several shells and fragments), 7640 (few living and shells), 7643 (few young living, fragments and shells), 7644 (small living and many fragments), 7645 (many shells and living), 7646 (many small living and shells), 7647 (few shells, small living), 
Ensis directus-Continued.

7648 (many shells), 7650 (many young living), $765_{2}$ (numerous small living), $76_{53}$ (few small living), 7655 (few small living), 7656 (few shells), 7659 (few shells), 7668 (few small living), 7670 (few shells), 7674 (few living and shells), 7675 (many shells and living), 7679 ( $\mathrm{I}$ shell), 768I (I small shell and fragment), 7699 ( $\mathrm{I}$ frag ment), 7700 (I shell), 7703, 7706 (several shells), 7708 (several shells), 77 I 7 (fragments), 7721 (fragments), 7724 (I shell), 7726 (several fragments), 7730 (I shell), 773 I (several shells), $773^{8}$ (I shell), 7740 (I fragment), 7744 (I fragment), 7748 (several fragments), $775^{2}$ (several fragments), 7755 (few fragments), $775^{6}$ (fragments), 7760 (fragments), 776I (few shells), 7762 (several shells), 7764 (fragments), 7766 (many shells and fragments), 7767 (few fragments), 7768 (I fragment), 7769 (many fragments and shells), $777^{\circ}$ (several shells), $777 \mathrm{I}$ (several shells), 7772 (several shells), 7773 (several shells), 7774 (few shells), 7775 (several shells), 7776 (several shells), 7777 (many shells and fragments), 7778 (many shells), 7780 (few shells), 778 I (few shells), 7782 (few shells), 7783 (many fragments).

Phalarope stations: I (I shell), 2 (few shells), 3 (many shells, I living), 4 (few shells), 5 (several shells), 6 (few shells), 7 (few shells), 8 (few shells), 9 (I shell), II (I), I3 (I fragment), I4 (I), I 5 (few shells), I7 ( I fragment), I9 (I young living), 24 (I shell), 28 (fragments), 29 (I shell), 43 (shells), $5^{2}$ (small living), 53 (I small), $5^{8}$, 62 (few), 65 (several shells), 66 (several shells), 68 (few shells), 7 I (few shells), 72 (several shells), 73 (I shell), 74 (few shells), 75 (few shells), 76 (few shells), 77 (few shells), 78 ( I shell), 79 (few shells), 80 (i fragment), 8I (few shells), 82 (few shells), 83 (shells), 85,88 (I shell), 89, 90, 91, 92 (shells), 94, 95, 98, 99 (shells), I00 (I shell), I01, 102, 103, 106, 107 (living and shells), I08, Io9, Iro, Ir 3, Ir 4 (few shells), I 5 ( I shell), in 7 (few shells), ir8 (several), I22 (few shells), I23 (shells), I24 (shells), I25 (several shells), I26 (shells), I27 (I shell), I28 (several shells), I29 (shells), I30 (several shells), I3I (common), I32 (few shells), I33 (shells), I34 (I shell), I35 (I shell), I36, I37 (few), ${ }_{3} 8$ (shell), I39 (many fragments), I40 (shells), I $_{42}$ (several shells), $x_{44}$ (shells common), I45 (few shells), I46 (several shells), I48 (several shells), I49 (many shells), I50 (shells common), I5I, I52 (few shells), I53 (I shell), I 54 (many shells and living), I55 (few shells), ${ }_{5} 6$ (I shell), I58 (few shells), I60 (2 shells),
Ensis directus-Continued. I62 (I shell), I63 (I small living), I64 (several shells and small living), I65 (several shells), I67 (many shells).

A. D. Mead ("Biological Notes," No. I) reports the taking of a large number of young, measuring from I to Io mm. long, in tow at Wickford, R. I., June 20, I899. For a good description of habits see Verrill and Smith, 1873 , p. 356-357.

\section{Family SEMELID E.}

Cumingia tellinoides Conrad. [Chart I52.]

Gould, I870, p. 79; Verrill and Smith; 1873, p. 679, 374, etc.; Dall, r889, p. 62.

Shells common in Vineyard Sound, particularly in the eastern half; in the Bay, common at the inshore stations; dredged in from 2 to $I_{5}$ fathoms, chiefly at depths of Io fathoms or less, on quite various bottoms; living specimens rarely taken at these depths.-Survey. Found by Osburn at the head of Lagoon Pond, living in 6 feet of water, and doubtless common in the shallower waters generally. It is possible that most of the shells scattered throughout Vineyard Sound have been carried thither by currents.

Fish Hawk stations: $75^{21}$ ( 3 , I living), $75^{25}$ bis, $75^{27}$ (few), $75^{28}$ (few), 7532 ( 2 shells), 7532 bis (few shells), 7533 (few), 7533 bis (several shells), 7536 bis (I shell), 7537 ( 3,2 in Diopatra tube), 7538 (several, 2 in Diopatru tube), 7538 bis (several), 7543 ( 4 shells), 7544 (few shells), 7547 bis (few living), 7554 (I shell), 7554 bis (I shell), 7563 bis (few shells), 7566 (I shell), 7568 (few shells), 7569 bis (I shell), 7584 (I shell), 76ro (several shells), 76II (I shell), 76I4 (several shells), 763I (I small), 7639 (I shell), 7643 (several shells), 7659 (many shells), few living), 7675 (few shells), 7694 (several shells), 7695 (I shell), 7703 (2 shells), $773^{2}$ (2 shells), 7744 (I shell), 7746 (I fragment), 775 I (I shell), $775^{2}$ (2 shells), 7753 (several shells), 7755 (several shells), $775^{8}$ (I shell), 7759 (I shell), 7760 (I shell), 7767 (I fragment), 7769 (several shells), 777 I (several shells), 7776 (I shell), 7777 (I shell), 7779 (I small shell), 7780 (I small shell), 778 I (I shell), 7782 ( $\mathrm{I}$ shell).

Phalarope stations: I (few shells), 2 (few shells), 3 (few shells), 4 (2), 5 (few shells), 6 (several shells), 7 (few shells), 8 (shells common), 9 (I shell), II (I), I5 (few shells), I6 (I shell), 26 (I living), 28 (I), 32 (I shell), 34 (I shell), 43 (shells), 52 (few shells), 62 (I), 65 ( 2 shells), 7 I (I shell), 72 (few shells), 77 (I shell), 78 (I shell), 83 (2 shells), 86, 88 (I shell), 89, 9I, 92, 
Cumingia tellinoides-Continued.

94 (I shell), 95, 96, 97, 98, гог, Iо8, Iro, II3 I 6 , II7 (many shells), I 8 (few shells), I i9 (I shell), I20 (I shell), I2 I (several shells), I22 (shells common), I23 (shells), I28 (few shells), I30 (few shells), I3x (shells), I33 (few shells), I34 (shells common), I35, I37 (I sliell), I4I (common), I42 (several shells), I44, I46 (I shell), I47 (few shells), I50, I67 (I shell).

Observed in act of depositing eggs in latter part of July and early August; probably breeds all summer.-G. A. Drew.

\section{Family Mactrids.}

Spisula solidissima (Dillwyn). Surf clam, sea clam. [Chart r 53.] $^{2}$

Gould, I87o, p. 73 (Mactra solidissima); Verrill and Smith, I873, p. 680, 358 , etc. (Mactra solidissima); Dall, 1889, p. 62 (Mactra solidis$\operatorname{sim} a)$.

Abundant throughout the Sound, and common at the inshore stations and lower end of the Bay; almost wholly absent from the deeper waters of the latter; recorded from Crab Ledge; living specimens dredged in I to I9 fathoms, predominantly on bottoms free from mud: shells more generally distributed.-Survey. The living specimens taken during the Survey dredging were all or nearly all small; shells of large size were frequently taken, however. Mr. Gray reports that half-grown living specimens are to be found on Devils Foot Island, and at Falmouth Heights, no full-grown specimens having been taken by him in this region. According to Verrill, "its proper home is on sandy bottoms in shailow water, just beyond low-water mark and down to the depth of 4 or 5 fathoms."

Fish Hawk stations: 7521 (many large and small shells), $75^{2}$ I bis (several living), $75^{2} 5$ bis (few shells), $75^{26}$ (2 shells), $75^{28}$ (few shells), 7529 (I shell), 753I (few shells), 753 I bis (I shell), 7532 (several shells), $753^{2}$ bis (many shells), 7533 (many shells), 7533 bis (several shells), 7535 (several shells), 7536 bis (several shells and living), 7537 (several shells), 7538 (several shells), 754I bis (many shells), 7542 (few shells), 75.42 bis (several shells), 7543 (numerous shells), 7543 bis (several shells), 7544 (many shells), 7546 (several shells), 7546 bis (few shells), 7547 bis (few shells), 7548 (few shells), 7549 (few shells), 7549 bis (few shells), $755^{\circ}$ (few shells), $755^{\circ}$ bis (few shells), $755^{\mathrm{I}}$ (few shells), $755^{\mathrm{I}}$ bis (? I fragment), $755^{2}$ bis (few shells), 7553 (I shell), 7554 (many shells),
Spisula solidissima-Continued.

7554 bis (many shells), $755^{6}$ (few shells), $755^{6}$ bis (many shells), 7557 (few shells), $755^{8}$ (many shells), 7560 (I shell), 756r (few shells), 7562 (I shell), 7563 (many shells), $756_{3}$ bis (few shells and small living), 7564 (few), 7564 bis (few shells), 7565 (few), $756_{5}$ bis (few shells), 7566 (many shells, I very small living), 7567 (few small), 7568 (I living and many shells), 7569 ( I shell), 7570 (few shells), 7572 (many shells), 7574 (few shells), 7575 (several shells), 7576 (few shells), 7578 (few shells), 7579 (few shells), $75^{80}$ (few small shells), 758I (shells), 7583 (I shell), 7584 (few shells), $75^{8} 5$ (I living), $75^{87}$ ( I living and I shell), $75^{88}$ (I shell), $75^{89}$ (I shell), 759 I (many small shells), 7592 (few shells), 7593 (few shells), 7595 (I), 7596 ( 2 small living), 7597 (few shells), 7598 (few small living and shells), $760 \mathrm{r}$ (few shells and I living), 7604 (I broken shell), 7606 (I fragment), 7607 (I living), 7609 (several shells), 76ro (I fragment), $761_{4}$ (I fragment), 7615 (r fragment), 7630 (few shells), 7636 (few shells), 7639 (few shells), 7643 (shells), 7659 (many small shells), 7664 (few shells on Diopatra tubes), 7666 (few shells), 7667 (few small shells), 767 I (few shells), 7672 (few shells), 7674 (living and shells), 7675 (several shells), 7678 (few small shells), 7679 (several shell fragments), 7680 (few shells), 768I (several shells), 7682 ( $\mathrm{I}$ living and small shells), 7683 (2 large shells), 7687 (i small shell), 7689 (I shell), 7695 (few shells), 7696 (few shells), 7697 (few shells), 7698 (few small shells), 7699 (several very large and small shells and I living), 7700 (several large and small shells and I living), 770 (few large and small shells), 7702 (several small shells), 7703 , 7704 (I large and few small), 7705 (few small living and shells), 7706 (few shells), 7 70S (few shells), 7700 (I large and few shells), 7717 (few shells and fragments), 7718 (few shells), 77 I (many shells and I small living), 7720 ( 1 shell), 7721 (I), 7722 (I fragment), 7723 ( $\mathrm{I}$, ) 7724 (I shell), $77^{25}$ (few small living and shells), $77^{2} 6$ (many small shells), 7727 (many small shells), 7728 ( I small shell), 7729 (2 small shells), 7730 (several shells), 773 I (few small shells), 7732 ( 1 small living), 7734 (few medium and small shells), 7735 (several shells), 7736 (I small living and I shell), 7739 ( $I$ large and several small), 7740 (few shells), 7750 (I small shell), 775 I (few shells), $775^{2}$ (few shells), 7753 (few shells), 7754 (I small shell), 7755 (few shells), 7764 (several shells), 7765 (very many large shells), 7769 (many large shells), 777 I (I living 
Spisula solidissima-Continued.

and few shells), $777^{2}$ (many shells), 7774 (few large and medium shells), 7775 (few shells), $777^{6}$ (many large and medium shells), 7777 (many shells), 7778 (many shells), 7779 (many shells), 7780 ( $\mathrm{x}$ living and many shells), $778 \mathrm{I}$ (many shells), 7782 (many large and small shells), 7783 (many large and small shells).

Phalarope and Blue Wing stations: I (several shells), 2 (many shells), 3 (many shells), 4 (several shelis), 6 (few shells), 7 ( I shell), 9 (I), Io (I shell), I3, I5 (few shells), 25 ( 2 shells), 28 (I), 32 (I shell), 33 (2 small), 34 (few), 37 (I shel1), 38 (I living), 39 (few dead), 4I (few shells), 42 (few shells), 5I (several living), 52 (many shells), 55 (few shells), 57 (r), 60 (few small shells), 6I (several shells), 62 (several shells), 65 (I shell), 66 (many small shells), 67 (few shells), 68 (several shells), 69 (x shell), 7 I few shells), 72 (few shells), 76 (few shells), $8 \mathrm{I}$, 82 (shells), 89, 90, 9r, 93 (I shell), 95, 99 (shells), I00 (shells), I0I, I02, 103, 105 (living), I06, I07 (few shells), I09, Iro, III (shells), II3, II5 (I shell), II8 (several shells), I20 (living and shells), I22 (I shell), I23 (shells), I35 (I shell), I37 (I shell), I42 (I), I67 (shells abundant).

\section{Mulinia lateralis (Say). [Chart ${ }^{54}$.]}

Gould, I870, p. 77 (Mactra lateralis); Verrill and Smith, 1873, p. 680, 373, etc.; Dall, I889, p. 62 (Mactra lateralis).

Living animals abundant throughout Buzzards Bay, in 4 to 9 fathoms, nearly always in mud or mixtures of mud and sand; shells occasionally taken at the western end of Vineyard Sound.-Survey. Mr. Edwards found this species living in great abundance at Tisbury Great Pond.

Fish Hawk stations: 7597 (shells), 76rI (many living and shells), 76r2 (many living and shells), 76r3 (many living and shells), 76r4 (several living and shells), $76 \mathrm{I}_{7}$ (several shells and living), 76r8 (several shells and living), $76 \mathrm{r}_{9}$ (several living and shells), 7620 (few living), 762 (few living), 7622 (few living and shells), 7623 (living), 7624 (few shells), 7629 (few shells), 7630 (many small shells), 763I (many shells), $76_{32}$ (few shells), $76_{3} 6$ (few shells), 7637 (many living and shells), 7638 (several shells), 7640 (several shells), $764 \mathrm{I}$ (very many living and shells), 7642 (many living and shells), 7644 (several living and shells), 7645 (few shells), 7646 (few shells), 7647 (few shells), 7649 (shells common), 7650 (numerous shells), $765^{\mathrm{I}}$ (few shells), $765^{2}$ (few shells), 7653 (few shells), 7654 (many shells), 7655
Mulinia lateralis-Continued.

(few shells), 7657 (many living and shells), 7658 (living and shells), 7659 (numerous shells), 7660 (many shells), 766r (many shells), 7662 (few shells), 7663, 7668 (several shells), 7669 (many shells), 7673 (few shells), 7674 (few shells), 7675 (few shells), 7680 (I shell), 768 I (I small shell), 7696 (few shells), 7697 (I shell)*, 7700 (shells), 7701 (2 shells), 7703 (I shell), 7704 (2 shells), 7706 (I shell), 7726.

Phalarope stations: 43 (shells), $5^{2}$ (few shells), 80 (few shells), 8 I (few), 89, 90, 91, 92, 93 (several living), 94, 95, 96, 98, 106, 107 (many living and shells), I08, 109, IIO, II5 (several shells), 124 (I living and shells), I36, I4I (I she11), I43 (shells common), I 54 (2 shells), I 59 (few living and many shells), 160 (many shells), I6I (many shells), I62 (few), I63 (several shells), I64 (few shells), I65 (many shel1s), I66 (several shells).

Verrill states that this species constitutes an important item of the food of the scup and some other fishes.

\section{Family Mesodensmatrde:}

\section{Mesodesma arctatum Conrad.}

Gould, 1870 , p. 80 (Ceronia arctata); Verrill and Smith, 1873 , p. 679, 426, etc. (Ceronia arctata). Nantucket, rare.-Gould.

\section{Family THRACIDAE.}

Thracia conradi Couthouy. [Chart I55.]

Gould, I870, p. 69; Verrill and Smith, I873, p. 673,426 , etc.; Dall, 1889, p. 64 .

Buzzards Bay.-Gould. Vineyard Sound.Verrill. Shells dredged at the western end of Vineyard Sound and one station near the mouth of Buzzards Bay; 6 to ig fathoms, on sandy bottoms; no living specimens recorded.-Survey. According to Verrill, this mollusk buries itself 6 inches or more beneath the surface of the sand.

Fish Hawk stations: 7594 ( 2 shells)*, 7678 (I broken shell), 7679 (I fragment), 768 I (2 shells), 7682 (2 shells), 7702 (I shell), 7706 (I shell), 7708 (I shell), $77^{24}$ (several large shells).

Phalarope station 80 (I shell).

Thracia septentrionalis Jeffreys.

Gould, I870, p. 72 (Thracia truncata); Verrill and Smith, 1873, p. 674,509 , etc. (Thracia truncata; not listed specifically for this region.)

Off Marthas Vineyard.-Agassiz, cited by Gould. Crab Ledge and the western end of Vineyard Sound; 6 to Ig fathoms.- Survey.

Fish Hawk stations: 7604 ( 2 broken shells)*, 7605 (I living)*, 7679 (I shell), 7706*.

Phalarope station 65 (I shell). 


\section{Family Periplomatidat.}

Periploma papyracea Verrill.

Gould, x870, p. 66 (Anatina papyracea); Verrill and Smith, 1873, p. 673,509 , etc.

Newport.-Gould, after Totten. "Muddy bottoms off the open coast."'-Verrill. Menemsha Bight, at Fish Hawk station 7728*, 8 fathoms, sticky mud.-Survey.

Periploma sp.

Vineyard Sound, near Menemsha Bight (Fish Hawk station 7724 )*

Cochlodesma leanum Couthouy. [Chart r56.] $^{6}$

Gould, 1870, p. 68; Verrill and Smith, 1873, p. 673,418 , etc.; Dall, I889, p. 64 .

About Nantucket.-Gould. Vineyard Sound.Verrill. Shells taken throughout Vineyard Sound and at numerous inshore stations of Buzzards Bay; at 2 to 19 fathoms, chiefly at depths less than 8 fathoms; recorded principally for bottoms of sand and gravel; taken once at Crab Ledge; living specimens recorded only twice in the dredgings.-Survey. Vineyard Haven, on sand flats near bridge, living.-Osburn.

Fish Hawk stations: $75^{21}$ bis ( 2 shells), 7542 bis (several shells), 7549 bis (? 2 fragments), $755^{6}$ bis ( $I$ shell), $75^{62}$ bis (I shell), $75^{6} 3$ bis ( $I$ shell), 7595 (3 shells)*, 7597 (2 shells), 7604 (I shell), 7694*, 7695 (2 shells), 7700 (several shells), 7701 (several shells), 7702 (several shells), 7706, 7739 (I shell), 7745 (I fragment), $775^{2}$ (I shell), 7760 (I shell), 776r (I shell), 7764 (I fragment), 7766 ( 1 shell), 7769 (several shells), 7770 (few shells), 777 I (several shells), 7774 (I shell), 7777 ( $x$ shell), 7778 ( $x$ shell), 7779 (few shells), 7780 ( $I$ shell), 7782 (several shells),

Phalarope and Blue Wing stations: 4 (several shells), 8 (several), 9 (2 shells), 22 (2), 30 (I living), 37 (few shells), $3^{8}$ (few shells), $5^{2}$ (abundant), 6r (I), 64 (few living and shells), 65 (several shells), 66 (many shells), 67 (several shells), 68 (several shells), 83 (I shell), 99, I00 (I shell), I0I, I02, I08, I09, II3 (I shell), II8 (few shells), I30 ( 2 shells), I35, I4I (few shells), I42 (few), I $5^{2}$ (I shell).

\section{Family LyonsIID}

Lyonsia hyalina Conrad. [Chart 157.$]$

Gould, I870, p. 64 (not listed for this region); Verrill and Smith, 1873 , p. $672,35^{8}$, etc.; Dall, I889, p. 64 .

Buzzards Bay and Vineyard Sound.-Verrill. More common in the Bay than in the Sound,
Lyonsia hyalina-Continued.

and in both chiefly restricted to inshore stations.-Survey. Dredged in from 2 to 17 fathoms, principally at depths of less than 8 fathoms, on various kinds of bottoms, including muddy ones; chiefly living specimens taken.

Fish Hawk stations: 7532 ( 1 living), $761 \mathrm{I}$ ( 1 living), 7614 (several living), 7616 (few shells), I living), 7618 ( $\mathrm{I}$ living), 7620 ( 1 living), 7625 ( I small living), 7626 ( 1 living), 7629 ( 1 living), 7630 ( I small living), 7668 (I shell), 7685 (2 shells), 7686 (I shell), 7687 (numerous shells and living), 7688 ( 1 shell), 7720, 7724 ( 1 shell), 7725 (few shells), 7726 (r), 7728 (fragment), 7729 (several living), 7730 ( 3 shells), 7750 (I shell).

Phalarope and Blue Wing stations: I (2 shells), 7 (I living and I shell), 9 (several living), I5 (few), r9 (few living), 20 ( $\mathrm{r}$ shell), 52 ( $\mathrm{r}$ living), 60 ( 1 living), 64 (several living), 78 (several living), 79 (shells), 8r, 86, 9r, 95, 96, 98, roo (r living), IOI, I02, I05 (living), I I (living), I I3, I 4 ( 1 living), II6, I 7 (2 living), I 8 (few living), 122 (few living), I28 (living common), I29 (living), I30 (common, living and shells), I35 (few living), ${ }_{3} 8$ (several living), I40 (several), $x_{4} \mathrm{I}$ (few living), I46 ( $\mathrm{I}$ living), I47 (few living and shells), I59 (I living), I60 (I living, I shell), I64 (several living).

\section{Family PANDORIDE.}

\section{Clidiophora gouldiana Dall. [Chart $15^{8}$.]}

Gould, r87o, p. 62 (Pandora trilineata); Verrill and Smith, 1873 , p. 673,418 , etc. (Clidiophora trilineata); Dall, I889, p. 68.

Living specimens and shells abundant and of general distribution, both in Buzzards Bay and Vineyard Sound, this being one of the commonest mollusks of the region; shells recorded from one station at Crab Ledge.-Survey. Living specimens dredged in 3 to $x_{9}$ fathoms, predominantly on bottoms of sand or mud or mixtures of the two; less commonly found among stones and gravel.

Fish Hawk stations: $75^{2} 5$ (I shell), $75^{27}$ (I shell), 7532 bis (2), 7533 bis (several shells), 7534 (I shell), 7535 (several shells), 7536 (I shell), 7537 ( 2 shells), 7537 bis (few shells), 7538 ( 2 shells), 7538 bis (I shell), 7539 ( 2 shells), 754 I ( 2 shells, I living), $754 \mathrm{I}$ bis (few shells), 7542 bis (few shells), 7543 (few shells, I living), 7544 ( I living), 7545 (I shell), 7547 (I shell), 7547 bis (I shell), 7549 (2 living), 7549 bis (I shell), 755 I (2 shells), 755 I bis (few shells), 7553 bis (I shell), 7554 (few shells), $755^{6}$ (I shell), $755^{8}$ 
Clidiophora gouldiana-Continued.

(few shells), 7563 (I shell), 7563 bis (few shells), 7565 bis (I living), 757 I (few shells), 7574 (2 shells), 7575 (several shells), 7576 (several livo ing and shells), 7578 ( 1 ), 7579 (few shells), $75^{82}$ (few shells), 7584 (few living and sheils), $75^{8} 5$ (several), 759I (I shell), 7595 (I shell), 7597 (2 shells), 7598 (several shells), 760 I (I), 7605 , 76 Io (I shell), 76II (few living), 7612 (several), 7613 (several living), 7614 (I shell), 7616 ( $\mathrm{r}$ small), 7617 (several living), 7618 (few shells), 7619,762 (few shells), 7622 (living), 7623 (few living), 7624 (I small), 7626 ( 1 living), 7630 (2 living), 7633 (few living), 7636 (few shells), 7637 (several shells), 7638 (several shells), 7639 (few shells), 7640 (few shells), 764I (many living), 7642 (many living), 7643 (several living and shells), 7644 (several living and shells), 7645,7646 (few), 7647 (I shell), 7648 (few shells), 7649 (few living and shells), 7650 (few), $765^{2}$ (I shell), 7653 (few shells), 7654 (living and shells), 7655 (few living and shells), 7656 (few), 7657 (many living), 7658 (few living and shells), 7659 (few shells), 7660 (few shells), 766 I (numerous living and shells), 7662 (numerous living and shells), 7663 (shells and living), 7664 (few shells), 7665 (few living and shells), 7668 (few living), 7669 (many shells and living), $767 \mathrm{I}$ (several shells), 7672 (few shells), 7673 (numerous living), 7674 (few living and shells), 7675 (few), 7678 (few shells), 7679 ( $\mathrm{r}$ shell), 7680 (few shells), 768I (ז living), 7682 (few shells), 7683 (few living and shells), 7685 (several living), 7686 (I small living), 7687 (I living), 7688 (several living), 7694 (I shell), 7697 (few living and shells), 7698 (I living and few shells), 7699 ( $\mathrm{x}$ living and I shell), 7700 (several shells), 770 (few shells), 7702 (several shells), 7703 (several shells and living), 7704 (I living), 7706 (I shell), 7708 (2 shells), 7709 (I living and few shells), 7710 (I shell), 7717 (several shells), 7719 (few living and shells), 7720 (few shells), 7724 (few living and shells), 7725 (few living), 7726 (few shells), 7727 (I small living), 7728 (few shells and living), 7729 (several living), 7730 (I living and $\mathrm{x}$ shell), 773 (few living and shells), 7734 ( I shell), 7739 (few large shells), 774I (few shells), 7742 (I small living), 775I (I living and I shell), 7753 (I shell), 7755 (I shell), 7760 (I shell), 776 (few shells), 7766 (several shells), $777^{2}$ (I shell), 7777 (I she!!), 7779 (several shells), 778I (few shells), 7783 (I living and few shells).

Phalarope and Blue Wing stations: I (several shells), 2, 3 (many shells), 5 (few living and shells), 6 (few shells), 7 (several shells), 8 (few),
Clidiophora gouldiana - Continued.

9 (I), I2 (I), I3 (I), I4 (few shells), I5 (few shells), 22 (I), 29 (I), 32 (I shell), 34 (I) 52 (many shells), 53 (many), 60 (few shells), 62 (I), 64 (2 living), 65 (few shells), 68 ( $x$ living), 69 (I shell), $7 \mathrm{I}$ (I shell), 72 (few living), 74 (few shells), 76 (few shells), 78 (living), 79 (few living), 80 (shel1), $8 \mathrm{I}$ (several living and shells), 82 (common), 83 (I living), $84,85,86,88$ (several living), 89 (living), 90, 91, 92 (living), 93 (I shell), 95, 96, 98, 100 (shells), 102, 103, 107 (many living), 108, I09, IIO, II $3, \mathrm{II}_{4}$ (living common), II5 (living common), II6, II8 (several living and shells), Irg (few living), I20 (living), I2I (several living), I22 (few), I23 (few shelis), I24 (shells and r living), I26 (few shells), I28 (few shells and living), I32 (few living and shells), I35, I40 (few living), I4I (few shells), I43, I44 (few living and shells), I45 (few living and shells), I46 (I), I49 (living and shells), I50 (living), I5I (few shells), ${ }_{52}$ (few living and shells), I53 (few shells), I54 (2 shells), I57 (I shell), I59 (2 shells), I60 (2 shells), I62 (several shells), I64 (few shells), I66 (I• shell), I67 (I shell).

\section{Family CORBULIDA.}

\section{Corbula contracta Say. [Chart 159.]}

Gould, 1870, p. 60; Verrill and Smith, 1873, p. 672,418 , etc.; Verrill, 1882 d, p. 37 I; 1884; Dall, I889, p. 70 .

Shells taken abundantly throughout Vineyard Sound; in Buzzards Bay, mainly restricted to stations not far from land; dredged in 2 to 19 fathoms, on all sorts of bottoms; living specimens comparatively infrequent, though recorded from both the Bay and the Sound at 4 to I3 fathoms.- Survey.

Fish Hawk stations: $75^{21}$ bis (several shells), $753^{2}$ (2 shells), 7533 (I shell), 7536 bis, 7539 (I shell), 7545 bis (I shell), 7547 bis (few shells), $755^{\circ}$ bis (few shells), $755^{\mathrm{I}}$ bis (few shells), $755^{2}$ bis, 7554 bis (numerous living and shells), 7555 (i shell), $755^{6}$ bis (I shell), 7563 bis (few shells), 7564 bis (numerous living and shells), 7566 ( shell), 7570 (I shell), 757 I (I shell), $757^{8}$ (I shell), 7598 (I living, I shell), 76ro (several shells), 7614 (few shells), 7630 (several), 7635 (few shells), 7637 (few shells on Diopatra tubes), 7644 ( 2 shells), 7659 (few shells and living), 7664 (shells on Diopatra tubes), 7666 (numerous on Diopatra tubes), $767 \mathrm{r}, 767_{2}$ (living and few shells), 7674 (several shells), 7675 (few shells), 7679 (I shell), 7682 (I shell), 7686 (I shell), 7688 (few living and shells), 7696 (many shells), 7697 (living and shells), 7698 (I shell), 7699 
Corbula contracta-Continued.

(1 shell), 7701 (few shells), 7702 (I living and several shells), 7703 (several shells), 7705 ( shell), 7706 (I shell), 7707 (I shell), 7718 (few shells), 77 I9 (2 shells), 7720 ( 1 shell), $77^{23}$ (several shells), 7724 (I shell), 7726 (few shells), 7732 (many shells), 7733 (few shells), 7734 (few shells), 7735 (several shells), 7740 (I shell), 774 I (I shell), 7744 (few shells), 7748 (I shell), $775^{6}$ (I shell), $775^{8}$ (I shell), 7764 (several shells), 7767 (few shells), 7769 (several shells), 7770 (few shells), 777 I (I shell), $777^{2}$ (few shells), 7776 (I shell), 7777 (several shells), $777^{8}$ (many shells), 7779 (many shells), 7780 (shells common), 778I (few living and shells), 7782 (few shells), 7783 (many shells).

Phalarope stations: 2 ( $\mathrm{r}$ living), 6 (I shell), Ir (I shell), I5, 28 (few shells), 29 (I), 33 (few shells), 34 (several shells), 35 (few shells), 43 (shells), 52 (I shell), 57 (I shell), 58 (I shell), 59 (I shell), 65 (several shells), 78 (I shell), 8 I, 83 (few shells), $84,86,9$ r, 96, 98, roo (shells), I02, I08, I10, III (I shell), II3, II5 (shells), II6, II7 (2 shells), Ir8 (I shell), I20 (I living and shells), I2 I (few shells), I22 (few shells), I23 (living and shells), I26 (shells), I28 (I shell), I3I ( 1 shell), I34 (I shell), $1_{3}^{8}$, I40 (few shells), I4I (few shells), I44 (I shell), I47 (few shells), I 50 ( I shell), I60 (I worn shell?), I6 3 (I shell), I64 (I shell), I67 (I shell, I living).

\section{Family MYACIDAs.}

Mya arenaria Linnæus. Long clam, soft-shelled clam. (Locally called simply "clam," the latter term seldom being applied to Venus). [Chart I6o.]

Gould, I870, p. 55; Verrill and Smith, I873, p. $672,309,463$, etc.; Dall, I889, p. 70; Bumpus, I $898 \mathrm{~b}, \mathrm{p} .857$.

Abundant and of very general distribution along the sandy and muddy shores of the region, particularly where the water is somewhat brackish. The clam does not occur much below low-tide mark; hence it is comparatively infrequent in the dredging records. Shells occasionally dredged by the Survey in 2 to 13 fathoms, chiefly at depth of 5 fathoms or less.

Fish Hawk stations: 7614 (I shell), 7639 (? I shell), 7645 (several shells), 7698 (? small), 7702 (? I small).

Phalarope stations: 53 (few shells), I27 (shells), I37 (I), I46 (I shell), I49 (I shell), I50 (I shell), I54 (I fragment), I55 (few shells), I 56 (few shelis), I57 (few shells), I64 (I shell), I65 (I shell).
Family Saxicavida.

Saxicava arctica Deshays.

Gould, I870, p. 89 (not listed for this region); Verrill and Smith, 1873, p. 671, 309, etc. (No specific local records).

Vineyard Sound, at 5 stations; Crab Ledge, at 4 stations; 4 to 25 fathoms, gravel and stones.Survey.

Fish Hawk stations: 7532 bis (I small shell), 7572 (r living)*, 7603 (several living), 7606 (many), 7608 (several), 7609 (2 living), 7718 (I shell).

Phalarope stations: I (I shell), 62 .

\section{Cyrtodaria siliqua (Spengler).}

Crab Ledge, at Fish Hawk stations $7603^{*}, 7604$, and $7608 ; 17$ to 20 fathoms, sand and gravel. Shells only were taken.

\section{Family PHOLAdide.}

Pholas costata Linnæus.

Gould, I870, p. 37; Verrill and Smith, 1873 , p. 670, 433; Dall, I889, p. 72 (Bamea costata).

New Bedford, dredged living.-Gould. Great Harbor, Woods Hole, dead shells.-Verrill. Mouth of New Bedford Harbor, at Fish Hawk stations $7646^{*}$ and $7647^{*}$, fragments only.Survey. Numerous large fragments found by Mr. Edwards on the beach at the south shore of Marthas Vineyard, just outside of Tisbury Great Pond*. Mr. G. M. Gray reports that this species is so scarce locally that he is obliged to send to Florida for specimens for the supply department. According to Gould, it lives buried in the mud to a depth of 2 or 3 feet. The specimens recorded by him were brought up by harbor dredging machines.

Pholas truncata Say.

Gould, r870, p. 38; Verrill and Smith, 1873, p. $670,372,433$, etc.; Dall, I889, p. 72 (Barnea truncata).

New Bedford.-Gould. Woods Hole in Great Harbor (dead shells).-Verrill. Buzzards Bay shore, near breakwater, on one occasion.-G. M. Gray. Like the preceding species, this mollusk buries itsclf so deeply in the mud that it is seldom taken with the dredge. Verrill states that is "quite common in mud and peat-banks, above low-water mark."

Zirphaca crispata (Linnæus).

Verrill and Smith, 1873, p. 67I, 433; Dall, I889, p. 72 .

Great Harbor, Woods Hole; fragments of shells dredged by Verrill. Two living specimens dredged by the Survey near the Sound shore of 
Zirphcea crispata-Continued.

Cuttyhunk at Phalarope station $33^{*}$ (5 fathoms, hard mud and grave1); $x$ shell taken at Fish Hawk station $7718^{*}$ ( 14 fathoms, sand and shells).

\section{Family TEREDINIDAR.}

Teredo navalis Linnæus. Ship-worm.

Gould, I870, p. 28; Verrill and Smith, 1873, p. 669, 384, etc.; Dall, I889, p. 74 .

Local waters generally, infesting piles, buoys, pound stakes, lobster pots, and every sort of floating or submerged woodwork. Of great abundance and rapid growth, constituting a serious pest to shipping and the fisheries. Pieces of wood inhabited by this mollusk dredged by the Survey in Vineyard Sound at $\mathrm{r}_{3}$ to $\mathrm{I}_{5}$ fathoms (Fish Hawk stations $75^{6} 4^{*}$ and 7565). In the former of these cases, at least, a living specimen was found.

According to Verrill, the eggs are exceedingly numerous, probably amounting to millions. These are retained in the gill cavity during
Teredo navalis-Continued.

the first stages of development; they are liberated in May and probably throughout the rest of the summer, larvæ being taken at the surface in May and June. (For a good account of the natural history of this animal, see Verrill and Smith, I873, p. 383-387.)

Teredo megotara Hanley.

Gould, 1870, p. 31; Verrill and Smith, 1873, p. 670,387 , etc.; Dall, 1889 , p. 74 .

Newport and New Bedford, occurring in cedar buoys and floating pine wood.-Gould.

Teredo thomsoni Tryon.

Gould, r870, p. 32; Verrill and Smith, 1873, p. 670,387 , etc.; Dall, 1889, p. 74 .

Found in great numbers on marine railway at New Bedford; also in cedar buoys.-Gould, after Tryon.

Teredo sp. undetermined.

Vineyard Sound, at Fish Hawk station 7550; I2 fathoms. (Probably one of the foregoing species.)

\section{Class AMPHINEURA.}

\section{Family IschNochronide.}

\section{Trachydermon ruber Carpenter.}

Gould, I870, p. 260 (Chiton ruber; not listed for this region); Verrill and Smith, I873, p. 662, 399 , etc. (sometimes referred to as Leptochiton ruber); Dall, I889, p. 172 .

"Rare and local in the colder outer waters south of Cape Cod"; living on rocks which are covered with red nullipores; not listed specifically for this region.-Verrill. Mr. Gray reports its occasional occurrence in the "gutters" near Hadley Harbor. A single specimen was dredged by the survey at Phalarope station $116^{*}$ (near Penikese Island, 4 fathoms, gravel and sand).

Chatopleura apiculata Carpenter. [Chart I6r.]

Gould, r87o, p. 258 (Chiton apiculatus); Verrill and Smith, r873, p. 66r, 399 (also referred to as Leptochiton apiculatus); Dall, I889, p. I72.

Nantucket.-Gould. Vineyard Sound and Buzzards Bay.-Verrill. Distribution general throughout the eastern half of Vineyard Sound; in Buzzards Bay and the western half of the Sound it is restricted to the inshore stations.Survey. Dredged in 2 to 15 fathoms, on various bottoms; more frequent among stones or shells, and less common where mud is present. This species, when alive, is invariably found clinging to other solid objects. Nearly all of the
Chøetopleura apiculata-Continued. specimens dredged were living. One was collected by Mr. J. W. Underwood on a shell occupied by Pagurus pollicaris, taken along shore at Nobska Point.

Fish Hawk stations: $75^{22}(2), 75^{22}$ bis (2), 7523 (few), $75^{23}$ bis (few), $75^{24}$ (few), $75^{24}$ bis (r), $75^{27}$ (few), $75^{28}$ (few), 7530 ( $), 7530$ bis (2), $753 \mathrm{I}$ bis (few), 7533 bis (I), 7536 (I), 7537 (numerous), 7537 bis (I), 7539 (I), 754 I (2), 7544 (few), 7545 (few), 7547 bis (2), $755^{\circ}$ (I), $755^{\mathrm{I}}$ bis (many), 7554 bis (I), 7560 (I), 7572 (I), 758r (few), $762 \mathrm{I}$ (few), 7626 (I), 7628 (2), 7630 (I), 7634 (several), 7635 (several), 7648 (several), 7659 (few), 7672, 7675 (I), 7743 (I), 7744 (2), 7745 (I), 7746 (I small), 7753 (I), 7757 (I), 7760 (I), 776r (I), 7762 (several), 7766 (2), 7768 (I), 7769 (2), 7773 (I), 7776 (2), 7777 (few), 7778 (few), 7780 (I), 7783 (several).

Phalarope stations: 2 (2), 5 (2), 7 (r), 9 (r young), I2 (2), I5 (I), 32 (I), 52 (several), 62 (I), 65 (2), 68 (I), 69 (I), 70 (abundant), 7I (abundant), 72 (many), 8I (few), 82 (several), 83 (2), 84 (several), I07 (I), Iro (I small), II4 (I), I18 (r), 123 (2), I28 (2), I32 (many), I34 (I), I4I (I), I42 (I), I44 (common), I 45 (few shells), I47 (I), I48 (several), I49 (several shells), I50 ( $x$ ), I $_{5} \mathrm{x}(\mathrm{I})$, I58 (few), I67 (several). 


\section{Class GASTROPODA.}

\section{Family CAVOLINIDE.}

\section{Styliola vitrea Verrill.}

Verrill, 1872, p. 284 (sp. nov.); Verrill and Smith, 1873 , p. 668,443 , etc.; Verrill, r882a, p. 556 .

"Taken among Salpa, off Gay Head, Marthas Vineyard, in the afternoon, September 9, I87 r." -Verrill.

Diacria trispinosa Gray.

Stimpson, I851, p. 27 (Hyalea trispinosa); Gould, r870, p. 504; Verrill and Smith, 1873, p. 669, 444; Verrill, I88oc, p. 392 ; Dall, I889, p. 82 (Cavolina trispinosa).

“Occasionally cast ashore at. Nantucket."Stimpson. At Newport, numerous specimens taken from the stomach of a bluefish.-Verrill.

\section{Cavolina tridentata Forskäl.}

Verrill, I872; Verrill and Smith, I873, p. 669,

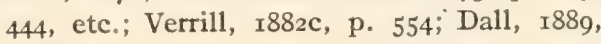
p. 82 .

"Shells dredged off Marthas Vineyard, at two localities, in rg and 22 fathoms;" "a southern species which comes north in the Gulf Stream." -Verrill. One shell taken north of Gay Head at Fish Hawk station $768 \mathrm{r}^{*}$.- Survey. More than 30 shells, probably of this species, taken from the stomach of a loggerhead (?) turtle, caught in vicinity of Woods Hole during the summer of Igrr.

\section{Family Limacinides.}

Heterofusus retroversus (Fleming).

Verrill and Smith, 1873 , p. 669, 443, etc. (Spirialis gouldii).

"Near Naushon Island (A. Agassiz). Twenty miles off No Mans Land, in stomach of herring (S. I. Smith)."

\section{Family Cymbulimes.}

Corolla calceola (Verrill).

Verrill, I882c, p. 553 (Cymbulia calceolus).

A mile off Gay Head, at the surface, several taken by V. N. Edwards, August 27, I890*. Verrill records the capture of a specimen 30 miles ESE, of Block Island, at the surface, October 2, I880.

\section{Family Clionidas.}

\section{Clione limacina (Phipps).}

Gould, I870, p. 507 (not listed for this region); Verrill and Smith, 1873, p. 668,444 , etc. (Clione papillionacea); Verrill, r88oc, p. 39 I (Clione papillionacea); Dall, I889, p. 82 .

$$
\text { r6269 - Bull 3I, pt 2-I3-Ir. }
$$

Clione limacina-Continued.

"Mr. Vinal N. Edwards obtained two specimens in Vineyard Sound, April zo." -Verrill. Vineyard Sound, September 10, I888; Woods Hole, in tow, March 20, 1896. (Collected by V. N. Edwards, identified by Dall and Bartsch.)

\section{Family ACtenonides.}

Acteon puncto-striatus (Adams).

Adams, 1840 , p. 323 (Tomatella puncto-striata); Gould, I870, p. 224 (Tornatella puncto-striatus); Verrill and Smith, 1873, p. 664; Dall, r889, p. 84 .

New Bedford.-Adams. "Vineyard Sound and Buzzards Bay, not uncommon." Verrill.

\section{Family TORNATINIDAE.}

Tornatina canaliculata (Say). [Chart 162.]

Gould, I870, p. 219 (Utriculus canaliculatus); Verrill and Smith, 1873, p. 663,426 , etc. (Utriculus canaliculatus); Dall, r889, p. 84.

"Common in Buzzards Bay and Vineyard Sound."-Verrill. Dredged almost exclusively in the Bay, where the distribution is pretty general; living specimens taken at 3 to 5 fathoms, chiefly on muddy bottoms; occurrence of shells more general, including two records for Vineyard Sound.-Survey.

Fish Hawk stations: $76 \mathrm{r}_{2}$ (?), $76 \mathrm{r}_{3}(?), 7623,7625$ (several shells), 7636 (I shell), 764I (I shell), 7649 ( 1 living and I shell), 7650,7651 (several shells), 7653 (I shell), 7655 (I shell), 7657, 7661,7727 ( 3 shells), 7728 (I shell).

Phalarope stations: 78 (few living), 79 (few shells), 84,94, I00, I07 (few living), I I9 ( 3 shells), 120 (I), I23 (I shell), I24 (2 living), I25, I59 (I shell), I6I (I living, 2 shells), I62 (2 shells), I65 ( 2 shells).

\section{Family SCAPHANDRIDE.}

Cylichnella oryza (Totten). [Chart I63.]

Stimpson, I85I (Bulla oryza); Gould, r870, p. 22 I (Cylichna oryza); Verrill and Smith, 1873, p. 663,426 , etc. (Cylichna oryza); Dall, 1889, p. 86.

New Bedford Harbor.-Stimpson. Vineyard Sound and Buzzards Bay, not uncommon.Verrill. Survey records confined to Buzzards Bay, chiefly to inshore stations; dredged in 3 to 7 fathoms, on bottoms of sandy mud and muddy sand.

Fish Hawk stations: 7623,7630 (I shell), $765^{2}$, 7655 .

Phalarope stations: 78 (few), 79, 89, 100 (I shell), Ix9 (many living), I20 (living), I27 (few shells), I38 (I), I59 (3 shells). 
Cylichna alba (Brown).

Gould I870, p. 220; Verrill and Smith, I $\delta_{73}$, p. 663,508 , etc. (In neither work listed for this region).

Dredged by the survey near the lower end of Buzzards Bay, at Fish Hawk stations 7657 ( I shell), and $766 \mathrm{I}$ ( 2 shells); 9 to $\mathrm{I}_{3}$ fathoms, mud. (Identified by R. C. Osburn.)

\section{Family BuzLIDE.}

\section{Haminea solitaria Say.}

Gould, 1870, p. 222 (Bulla solitaria); Verrill and Smith, I873, p. 662, 37I, etc. (Bulla solitaria); Dall, 1889, p. 88.

New Bedford. - Gould. "Common - in the muddy lagoons and salt-ponds along the shores of Vineyard Sound, Buzzards Bay. . . . Abundant in a small pond near Holmes Hole."-Verrill. Eel Pond, Hadley Harbor.G. M. Gray. Katama Bay at several points.Osburn. This species is doubtless of pretty general distribution in such localities as those mentioned but, being of strictly littoral habitat, it was only recorded three times during the survey dredging, viz, at Phalarope stations 127 (shells common), I6r (few shells), and I66 ( 1 living).

Eggs laid in large jelly-like balls, which are fastened by stalks to the sand; deposited August 20 or earlier.-E. G. Conklin, Marine Biological Laboratory card catalogue.

"Devoured in large numbers by the flounders and doubtless by other fishes."-Verrill.

\section{Family APLySIDAs.}

Tethys willcoxi (Heilprin) var.

Dall, I889, p. 90 (Aplysia willcoxi).

Katama Bay, October 31, I900, I large specimen* (sent by Mr. Fisher of Edgartown to Mr. Edwards). Buzzards Bay, near Woods Hole, October II, I906, I specimen (probably of this species) taken in a lobster-pot. During October, rgro, this mollusk was taken rather frequently throughout the waters of the region, one or more specimens being recorded from New Bedford, Westport, Buzzards Bay (near Woods Hole), Lamberts Cove, Tarpaulin Cove, Robinsons Hole, and Menemsha Bight. One of these specimens was referred to Dr. Dall for identification

\section{Family Plevrobranchide.}

\section{? Pleurobranchca tarda Verrill.}

Verrill, I882c, p. 546 .

Off Marthas Vineyard in 28 fathoms, $188 \mathrm{I}$ (thus not strictly within the limits of the region).Verrill. Four specimens, presumably from the vicinity of Woods Hole, though not labeled, were assigned to this species by Dr. MacFarland. It is quite possible, however, that these were likewise taken beyond the limits of the region.

\section{Family DENDRONOTIDE.}

Dendronotus arborescens (Müller).

Gould, I870, p. 234; Verrill and Smith, I873, p. 665,495 , etc.

"Rare and local south of Massachusetts Bay."Verrill. Not yet recorded for this region, though the latter lies within the stated range of the species.

Dendronotus robustus Verrill.

Verrill, I879, p. 197; I882c, p. 550.

Vineyard Sound.-Verrill. Six specimens from the vicinity of Woods Hole $\dagger$ (collected by G. M. Gray).

\section{Family SCYLLAIDA.}

Scyllaa pelagica Linnæus.

Verrill, I878, p. 21 I. (Scyllcea edwardsii); r882c, p. 550 (Scyllaca edwardsii).

Little Harbor, Woods Hole, on eel grass; also in the Sound on sargassum; first reported in the autumn of 1877 --Verrill. Specimens which are probably of this species have been taken among floating sargassum in Vineyard Sound, on the following dates, of ten in great numbers: August 20, 22, 28*, and September 5, 1906. Some were collected likewise during the preceding summer and probably at other times. Dr. MacFarland comments: "A careful anatomical study of the Woods Hole specimens must be made before their identity with $S$. pelagica L. can be positively determined."

\section{Family POLYCERID疘.}

Polycerella emertoni Verrill.

Verrill, r88oc, p. 387 (sp. nov.); r882c, p. 548 .

Woods Hole Harbor, August and September, 1875 and $\mathbf{I} 88 \mathrm{I}$, on cel grass and hydroids; Newport, on piles.

Eggs laid in confinement, July 24.-Verrill. 
? Palio lessonii (d'Orbigny).

Gould, I87o, p. 226 (Polycera Lessonii); Verrill and Smith, 1873, p. 665,333 , etc. (Polycera lessonii).

No definite local records, though this region lies within the stated range of the species.

Acanthodoris pilosa (Abildgaard).

Verrill and Smith, 1873, p. 664, 307, etc. (Doris bifida).

No definite local records given by Verrill. A specimen collected in this vicinity by $\mathrm{Mr}$. Gray has been thus identified by Dr. MacFarland. According to Verrill this species is to be found on the underside of rocks near shore. Its eggs are said to be "contained in convoluted gelatinous ribbons."

\section{? Lamellidoris muricata (Müller).}

Verrill, I882c, p. 550 .

No definite local records, though this region lies within the stated range of the species.

\section{Lamellidoris pallida (Agassiz).}

Gould, r87o, p. 229 (Doris pallida); Verrill and Smith, 1873, p. 665, 495 (Onchiaoris pallida).

"Dredged by Messrs. Prudden and Russell, off Cuttyhunk Island, in April, I872."-Verrill.

Idaliella modesta (Verrill).

Verrill, r875a, p. 4I (Idalia modesta); Verrill, I $882 \mathrm{c}$, p. 548 .

Vineyard Sound and off No Mans Land.

\section{Family CORAMBID}

\section{Corambe obscura (Verrill).}

Verrill and Smith, 1873, p. 664,307 , etc.(Doridella obscura).

Vineyard Sound.-Verrill. Said to occur on the under side of stones and among hydroids. Six specimens were taken by one of the survey collectors off Gay Head†, on floating weed, July 7, I904. Dr. MacFarland notes that this species "requires detailed study with sections to determine its position and relationships."

According to Verrill "the eggs are inclosed in a delicate gelatinous string, which is coiled up something like a watch-spring, and attached to the under side of stones."
Family EOLIDIADAE.

Eolidia papillosa (Linnæus).

Gould, 1870 , p. 239 (Eolis papillosa); Verrill and Smith, 1873, p. 666,486 , etc. (Eolis papillosa); Mead, 1898, p. 703 (Eolis papillosa).

No local records by Gould or Verrill. Mentioned by Mead as taken in spawning condition during April, presumably at Woods Hole. A specimen collected by Mr. Gray at Quicks Hole, March 25, 1898†; another taken somewhere in this vicinity, but not labeled.

Cratena pilata (Gould).

Gould, 1870, p. 243 (Eolis pilata); Verrill and Smith, 1873, p. 666, 383 (Montagua pilata and Eolis pilata); Bergh, I885, p. $3 \mathrm{I}$.

Two specimens studied by Bergh were taken by Verrill in Vineyard Sound, April, 1873. E. G. Conklin (Marine Biological Laboratory card catalogue) notes the presence of this species among Tubularia on the piles of the local pier. Specimens from the following points were sent to Dr. MacFarland for identification: Fish Hawk station 7560; vicinity of Woods Hole (G. M. Gray, collector); local pier in surface tow, taken on a number of occasions as follows (V. N. Edwards, collector): October I2, I904 (I specimen); January 29, 1907 (4); March 30, I907 (I); April I, I907 (r); April 4, I007 (4); April 23, 1907 (2); June 2I, 1907 (I).

Dr. Conklin records taking the eggs from June $I_{5}$ to July $x_{5}$, in close white masses of jelly; deposited amongst Tubularia.

Cratena gymnota (Couthouy).

Gould, I870, p. 249 (Eolis gymnota); Verrill and Smith, I873, p. 667,383 (Coryphella gymnota, also Cavolina gymnota); Verrill, I88ob, p. 390.

A specimen (or specimens) apparently of this species was "found by Prof. Todd, on an old wreck in the Woods Hole passage." - Verrill. Local pier, in surface tow specimen (V. N. Edwards, collector).

Tergipes despectus (Johnston).

Gould, I870, p. 248 (Eolis despecta); Verrill and Smith, 1873, p. 667, 495. (In neither work listed specifically for this region).

J. S. Kingsley (Marine Biological Laboratory card catalogue) notes that the eggs of this species were laid on campanularian hydroids (presumably at Woods Hole) July I4, I88g. 
Embletonia pallida Alder \& Hancock.

Bergh, I885, p. 36 .

Vineyard Sound, near Woods Hole, 3 specimens (described by Bergh) were collected by Verrill July I5, I88r.

Coryphella mananensis (Stimpson).

Verrill, I $882 \mathrm{c}$, p. $55^{2}$.

No specific local records given by Verrill. Specimens from the following points were assigned to this species by Dr. MacFarland: Woods Hole, March I8, I896; vicinity of Woods Hole (G. M. Gray, collector); Quicks Hole, March 25, I898 (G. M. Gray, collector); Vineyard Sound, near Quicks Hole, May, ı898; Vineyard Sound, at Fish Hawk stations 7686 and 7718 .

Coryphella salmonacea (Couthouy).

Gould, 1870, p. 240 (Eolis salmonacea; not listed for this region).

Four specimens, thus identified by Dall and Bartsch, were taken at Crab Ledge (Fish Hawk station 7603). Others which were regarded by the collectors as being of the same species as the foregoing were taken at Fish Hawk stations 7605 and 7607 (likewise at Crab Ledge).

Facelina bostoniensis (Couthouy).

Gould, 1870, p. 24I (Eolis bostoniensis); Verrill, r88oc, p. 389; Bumpus, I898, p. 488 (Eolis bostoniensis).

At Newport, etc., "common from above low water to 20 fathoms, on Obelia and other hydroids." - Verrill. Woods Hole, or vicinity, March, 1898; "breeding."-Bumpus. Surface tow, local pierf, November I9, I904; 3 specimens (V. N. Edwards, collector). Piles of local piert, February 2, I907: I specimen.

Fiona marina (Forskäl).

Verrill, I882a, p. 339 (Fiona nobilis); Verrill, $1882 \mathrm{c}, \mathrm{p} .55^{\mathrm{I}}$ (Fiona nobilis).

South of Marthas Vineyard, on floating timbers.-Verrill. Vicinity of Woods Holet, 2 specimens (G. M. Gray, collector).

\section{Family DoTONIDA.}

\section{Doto coronata (Gmelin).}

Gould, 1870, p. 236; Verrill and Smith, 1873, p. 665,400 , etc.; Bumpus, I898, p. 487.

Vineyard Sound.-Agassiz, cited by Gould. Off Gay Head.-Verrill. Woods Hole Harbor, among sertularians.-G. M. Gray. Bumpus records the taking of this species locally by dredge in March, I898. Gay Head, at Blue Wing station $44 \dagger$, I specimen.-Survey.
? Doto formosa Verrill.

Verrill, $1875 \mathrm{a}$, p. $4 \mathrm{r}$; $1882 \mathrm{a}$, p. $55^{\mathrm{r}}$.

No definite local records, though this region lies within the range of the species as stated by Verrill.

\section{Family HERMAEIDAE.}

Hermaa cruciata (A. Agassiz) Gould.

Gould, r870, p. 253; Verrill and Smith, r873, p. 667 .

Naushon Island.-A. Agassiz.

Alderia harvardiensis (A. Agassiz) Gould.

Gould, 1870 , p. 254 (not listed for this region); Bumpus, 1898 , p. 488 .

Woods Hole, or vicinity, March, I898; "breeding."-Bumpus.

Elysia chlorotica (A. Agassiz) Gould.

Gould, I870, p. 255; Verrill and Smith, I873, p. 667,480 . (In neither work listed for this region.)

Six specimens, thus identified by Dr. MacFarland, were collected by Mr. Gray in the vicinity of Woods Hole. Mr. Gray reports the occurrence of this species in the Eel Pond, Lackeys Bay and Hadley Harbor.

Elysiella catula (A. Agassiz, Gould).

Gould, I87o, p. 256 (Placobranchus catulus); Verrill, 1872 , p. 284; Verrill and Smith, 1873 , p. 668,480 .

"Woods Hole, among eelgrass, common." "It also has the power of floating with the bottom of the foot at the surface of the water." Verrill.

\section{Family AURICULIDAE.}

?Alexia myosotis (Draparnaud).

Verrill and Smith, 1873, p. 662,383 , etc.

In brackish waters, on piles, etc., near high-water mark. No definite local records, though this region lies within the stated range of the species.

Melampus lineatus Say.

Gould, ז870, p. 467 (Melampus bidentatus; not listed for this region); Verrill and Smith, 1873 , p. 662,463 , etc. (Melampus bidentatus); Dall, r889, p. 92 .

Salt marshes and weedy shores of Vineyard Sound and Buzzards Bay, very common. Wareham River, on muddy banks, between tides; beach east of Fort Phœnix, under rocks between tides; south arm of West Falmouth Harbor. (Collected by Cole; identified by Dall and Bartsch.)

"Contributes largely to the food of the minnow and other small fishes, as well as to that of many aquatic birds." -Verrill. 


\section{Family TURRITIDE.}

\section{Mangilia bicarinata (Couthouy).}

Gould, r87o, p. 349 (Pleurotoma bicarinata; not listed for this region); Verrill and Smith, 1873 , p. 638,418 , etc. (Pleurotoma bicarinatum). "Vineyard Sound, 6 to $I 2$ fathoms, rare."-Verrill.

Mangilia cerina (Kurtz \& Stimpson).

Stimpson, I85I (Pleurotoma cerinum); Verrill, I872; Verrill and Smith, I873, p. 637, 432, etc.; Verrill, I882c, p. 488; I884a, p. 250; Dall, I889, p. 102 .

Vineyard Sound, Buzzards Bay, Quissett.Verrill. Dredged by the survey at Phalarope stations I9* (Tarpaulin Cove), I24* (off Penzance), ${ }_{5} 4^{*}$ (mouth of Wareham River).

\section{Mangilia plicosa (Adams).}

Adams, I840, p. 318 (Pleurotoma plicata); Gould, I870, p. 350 (Pleurotoma plicata); Verrill and Smith, I873, p. 637,383 , etc. (Bela plicata).

New Bedford, in mud.-Adams.

\section{Drillia sp.}

A specimen referred to this genus by Messrs. Dall and Bartsch was taken at Phalarope station ${ }^{5} 6$

\section{Bela harpularia Adams.}

Gould, 1870, p. $35^{2}$ (not listed for this region); Verrill and Smith, 1873, p. 636, 508; Verrill, I882a, p. 473; Dall, I889, p. 98 .

Off Gay Head, Io to 29 fathoms, on muddy bottom, in $187 \mathrm{r}, \mathrm{I} 880$, and $188 \mathrm{r},-$ Verrill.

\section{Bela pleurotomaria Adams.}

Verrill and Smith, 1873 , p. 637 (not specifically listed for this region); Verrill, $1882 \mathrm{c}$, p. 478.

Off Chatham, I6 fathoms, I88I,-Verrill.

\section{Family FAScIOLARIDEE.}

Busycon canaliculatum (Say). Conch shell; locally called "winkle." [Chart r64.]

Gould, .1870, p. 380 (Fulgur canaliculata); Verrill and Smith, 1873, p. 640, 332, etc. (Sycotypus canaliculatus); Dall, I889, p. II2 (Fulgur canaliculata); Mead, I898 ("Sycotypus").

Abundant in shallower waters generally, the shells being familiar on the beaches almost everywhere. Fifty-one large specimens were taken from three lobster pots in a single day by Mr. Edwards. In the Survey dredging this species was found to be pretty generally distributed throughout Buzzards Bay and Vineyard Sound, though somewhat commoner in the former. Living specimens were dredged in 2 to 12 fathoms, on quite various bottoms,
Busycon canaliculatum-Continued.

though most frequently on muddy ones. The shells were frequently occupied by the larger hermit crabs.

Fish Hawk stations: 7524 (I shell), 7525 bis (I small shell), 7526 (2 shells), 7527 (I shell), 7535 (I fragment), 7543 bis (I), 7547 bis (I young shell), 7553 bis (I small shell), 7572 (I shell and fragments), 7602 ( 2 shells), 76 I I ( 1 living), 7612 (I shell), 76I4 (fragment), 76I7 (I shell and I small living?), 762 I ( $x$ shell), 7622 (I shell), 7624 (I shell fragment), 7632 (several), 7633 (several living), 7634 (few living and shells), 7636 (fragment), 7637 (I living), 7638 (living and shells), 764 I (2 large living), 7644 (small shells), 7645 (several shells), 7646 (several small living), 7648 (several shells), 7650 (I), $765_{2}$ (I living), 7653 (living and shells), 7657 ( $x$ living), 7659 ( $\mathrm{I}$ shell), 7660 (few shells and living), 766I (few shells and living), 7662 (few living), 7663 (few living), 7664 (I shell), 7668 ( I living and shells), 7672 (I shell), 7673 (I shell), 7675 (I shell), 7678 ( 2 living and few shells), 7696 (I fragment); 7706 (I large shell), 7724 (many living, large and small), 7728 ( $x$ living and $I$ shell), 7729 (I living), 7734 (I worn shell), 7735 (I living), 7739 (I shell), 7759 (small shell), 776 r (several living and few shells), 7762 (many large shells and egg cases), 7767 (I shell), 7768 (I shell), 7769 (I shell), 7772 (I shell), 7778 (few large shells).

Phalarope stations: 2 ( 2 shells), 4 (I very large shell), 6 (2 living), I7 ( $\mathrm{x}$ large living), I9 (I shell), 52 (I), 53 (I), 62 (I), 7 I (few shells), 72 (I), 73 (I), 80 (I piece), 8I (I fragment), 82 (I shell), 89 (I fragment), 93 (I shell), 94, 98, I0I (I shell), I09, II3 (I living), I I9 (I living), I26 (shells), I3 I (I living), I32 (I shell), I35, I37 (I shell), I47 (I shell), I49 (few shells), I 56 (2 shells), I58 (few shells and living), I63 (I shell), I64 (I small shell), I65 (I living, I shell), I66 (several small shells).

Spawns in August.-G. M. Gray. Egg strings deposited as late as second week in Septem. ber.-Thompson. Egg strings containing well-formed shells found in April--Mead. The egg cases of this species, like those of $B$. carica, are familiar objects upon the sea beach in summer. Like those of the related species, they consist of a string of disk-shaped capsules, composed of a parchment-like material. For an account of egg laying of Busycon canaliculatum and B. carica, see Verrill and Smith, 1873 , p. 355 .

This species preys upon other mollusks and is said to be very destructive to the oyster. 
Busycon carica (Linnæus). Conch or "winkle." [Chart r65.] $^{2}$

Gould, 1870, p. $3^{8} 3$; Verrill and Smith, 1873, p. 640,3 I3, etc. (Fulgur carica); Dall, I889, p. II2 (Fulgur carica.)

Fairly common in the shallower waters generally, judging from the number of shells found on shore. Much less abundant than B. canaliculatum, however. Shells dredged frequently in Buzzards Bay, occasionally in the Sound; taken in 2 to $I_{3}$ fathoms, on various kinds of bottom; few living specimens recorded during the Survey dredging.

Fish Hawk stations: 7530 bis (I shell), 755I (I large shell), 7616 (I fragment), 7618 (3), $762 \mathrm{I}$ (several shells), 7622 (several living and shells), 7627 ( 1 shell), 7632 ( 1 living), 7634 (I living), 7645 (I shell), 7648 (I shell), 7660 (I shell and egg case), 766r (I living), 7709 ( $x$ shell), 7762 (2 shells), 7777 (I large shell), $777^{8}$ (I very small), 778I (I very large and I small shell).

Phalarope stations: 107 (shells), I09, I29 (I shell), I36, I38 ( 2 shells), I42 (I shell), I45 (I), $I_{4} 8$ ( $\mathrm{I}$ ), $I_{53}$ ( $\mathrm{I}$ shell), $\mathrm{I}_{58} 8$ ( $\mathrm{I}$ living and many shells), $6_{3}$ (I young).

"At New Haven they spawn as early as March and April."-Verrill. Egg strings, containing well-formed shells found in April.-Mead.

\section{Family BucciNIDE.}

Buccinum undatum Linnæus. European whelk. [Chart i66.]

Gould, 1870 , p. 366 (not listed for this region); Verrill and Smith, I873, p. 638, 494; Dall, I889, p. I 4 ; Sumner, I9Io, fig. I5.

"Mouth of Vineyard Sound and off Gay Head, 6 to I9 fathoms;" "a decidedly northern and Arctic shell. .. Not common south of Cape Cod except on outer islands and in deep water."-Verrill. Western end of Vineyard Sound; Sow and Pigs Reef; Crab Ledge; dredged in 3 to 25 fathoms, on various bottoms.-Survey.

Fish Hawk stations: 7554 (few shells, one over I $1 / 2$ inches long)*, 7579 (? I), 7603 (2 large worn shells and I small shell)*, 7604 (I shell and I living), 7606 ( 2 living), 7607 ( 2 large living), 7608 (I small)*, 7609 (I small living), 7664 (I living), 7679 (I shell), 768I (2 shells), 7706 (I large shell), 7707 (2 large shells), 776r (I large worn shell).

Phalarope and Blue Wing stations: 29 (I young), 32 (I small living), 36 ( $\mathrm{I}$ young living), 45 (I small shell), 46 (several living), 56 (small shells), 59 (I large, I small living), 60 (I small shell).
Chrysodomus decemcostatus (Say).

Gould, 1870, p. 375 (Fusus decerncostatus; not listed for this region).

Dredged by the survey at Crab Ledge in 17 to 19 fathoms: Fish Hawk stations 7603 (I large shell)* and 7604 ( 1 fragment).

Tritonofusus islandicus (Gronovius).

Gould, 1870, p. 37 I (Fusus islandicus); Verrill, I882 c, p. 508 (Sipho islandicus); Dall, I889, p. II4 (Sipho islandicus).

Crab Ledge, at Fish Hawk station 7608 ( 3 shells)*; Vineyard Sound, at Phalarope stations $2^{*}$ and 64 * (I shell each). Not previously listed for this region.

Tritonofusus stimpsoni (Mörch).

Dall, 1889, p. II4 (Sipho stimpsoni).

Dredged by the survey at Crab Ledge in I 6 to 20 fathoms: Fish Hawk stations 7603 (r large and 3 small shells)*, 7606 ( 2 shells), 7608 ( 2 shells).

? Tritonofusus curtus Verrill.

Gould, I87o, p. 37x (Fusus islandicus); Verrill and Smith, 1873, p. 638 (Neptunea curta).

No definite local records, though this region lies within the stated range of the species.

Siphonorbis pygmaus (Gould).

Gould, I870, p. 372 (Fusus pygmcus; not listed for this region); Verrill and Smith, I873, p. 639, 508 (Neptunea pygmaa); Dall, r889, p. I 4 (Sipho pygmaus).

"Off Buzzards Bay, 25 fathoms; off Gay Head, Ig fathoms, mud, abundant and large." -Verrill.

\section{Family Aléctryonide:}

Tritia trivittata (Adams). [Chart 167.$]$

Gould, 187o, p. 364 (Nassa trivittata); Verrill and Smith, I873, p. 641, 354, etc.; Dall, I889, p. II6 (Nassa trivittata); Sumner, I9ro, fig. 5 .

Abundant and of very general distribution throughout the region, being recorded from more dredging stations than any other spcies of animal. Living specimens dredged in 2 to 17 fathoms, on every sort of bottom. Likewise abundant in the tidal zone.

Fish Hawk stations: $75^{21}$ (I), $75^{22}$ (few), $75^{22}$ bis (2), $75^{23}(\mathrm{I}), 75^{24}$ bis (I), $75^{25}$ (few), $75^{25}$ bis (few shells), 7526 (few), 7527 (few shells), 7530 (few shells), 7530 bis (few shells), 753 I (I shell), 7532 (few shells), 7532 bis (I living, also shells), 7533 (fragments), 7533 bis (I shell), 7534 (several shells), 7534 bis ( $\mathrm{x}$ shell), 7535 (several shells), 7535 bis (I), 7536 (I shell), 7536 bis (I shell), 7537 (few shells), 7537 bis (few shells), 7538 (I shell), 754 I (few shells), $754 \mathrm{I}$ bis (few shells), 7542 (few shells), 7542 bis 


\section{Tritia trivittata-Continued.}

(few shells), 7543 (many), 7543 bis (2 shells), 7544 (numerous), 7545 (few), 7545 bis (several), 7546 bis, 7547 bis (many), 7549 (few shells), 7549 bis (few shells), $755^{\circ}$ bis (few shells), $755^{2}$ (few), $755^{2}$ bis (few fragments), 7553 (few shells), 7553 bis (few, I living), 7554 (many shells), 7554 bis (numerous shells), $755^{6}$ bis (numerous shells), 7557 (few shells), $755^{8}$ (few shells), 7560 (few shells), 756r (few shells), 7563 (many shells), $75^{6} 3$ bis (few shells), $75^{6} 4$ bis (few shells), $756_{5}$ (several), $756_{5}$ bis (I shell), 7566 (few shells), 7567 (many shells), 7568 (few shells), 7569 (few shells), 7570 (few shells), 757 (few shells), 7572 (few shells), 7573 (several shells), 7575 ( I shell), 7577 ( 1 living), 7578 (many shells), 7579 (several shells), 7580 (some living, many shells), 758r (several shells), $75^{82}$ (few shells), $75^{8} 3$ (few shells), $75^{8} 4$ (few), $75^{8} 5$ (few shells and living), $75^{86}$ (few shells), $75^{88}$ (I shell), $75^{89}$ (I shell), 759 (few shells), 7592 (I shell), 7593 (few shells), 7594 (I shell), 7595 (many shells), 7597 (fragment), 7598 (few shells), 7599 (I shell), 7601 (several living and shells), 7602 (many shells and few living), 7609 ( $\mathrm{s}$ shell), 7610 (living and shells abundant), $76 \mathrm{II}$ (many living and shells), $76 \mathrm{I2}$ (many shells), 76r 3 (many living), 76r4 (many shells and living), 76I5 (many shells), 76I6 (many shells), 7617 (very many living and shells), 7618 (many shells and living), 76I9 (many shells), 7620 (very many living and shells), $762 \mathrm{r}$ (many living and shells), 7622 (many shells and living), 7623 (many shells), 7624 (very many shells), 7625 (many shells), 7627 (few), 7628 (few shells), 7629 (many shells), 7630 (few shells), 7631 (several shells), $76_{32}$ (several shells), 7633 (few shells), 7634 (many shells), $76_{35}$ (several shells), $76_{3} 6$ (living), $76_{37}$ (many living and shells), $763^{8}$ (many shells), 7639 (many shells), 7640 (many living and shells), 764r (very many living, few shells), 7642 (many living and shells), 7643, 7644 (numerous shells), 7645 (several shells), 7646 , 7647 (few living), 7648 (many shells), 7649 (few shells), 7650 (few shells), 765I (many shells), $765^{2}$ (numerous shells and living), 7653 (many shells), 7654 (many living and shells), 7655 (many living and shells), $76_{5} 6$ (several shells), 7657 (many shells), $765^{8}$ (few shells), 7659 (few shells), 7660 (many shells), 766I (very many living and shells), 7662 (many living and shells), 7663 (many shells and living), 7664 (few shells), 7665 (I shell), 7666 (few shells), 7667 (few shells), 7668 (living and shells), 7669
Tritia trivittata-Continued.

(few living and shells), 7670 ( $\mathrm{r}$ shell), $767 \mathrm{I}$ (many), 7672 (few shells), 7673 (many shells and living), 7674 (many shells), 7675 (numerous shells), 7676 ( 2 shells), 7677 (I), 7678 (several shells), 7679 (few shells), 7680 (few shells), 768 I (few shells), 7682 (r shell), 7683 (2 shells), 7685 (living and shells), 7686 (several shells and living), 7687 (several shells and living), 7688 (few living and shells), 7689 (I shell), 7694 ( I shell), 7695 (few shells), 7696 ( 2 shells), 7697 (few shells), 7698 (I small shell), 7699 (few shells), 7700 (few shells), 770 (few shells), 7702 ( $\mathrm{r}$ living and $\mathrm{x}$ shell), 7703 (several shells), 7704 (I shell), 7706 (I shell), 7707 (several shells), 7708 (several shells), 7700 (few shells), 77 ro (I living and I shell), $77 \mathrm{r} 7$ (few shells), 77 I8 (few shells), 77 I9 (many shells), 7720 (several shells), 7722 (few shells), 7723 (several shells) 7724 (many living and shells) 7725 (several living and shells), 7726 (few living and shells), 7727 (I fragment), 7728 (few shells and living), 7729 (several living), 7730 (few living and shells), 773I (many shells), 7732 (several shells and 2 living), 7733 (I shell), 7734 (several shells), 7736 (I shell), 7738 (I), 7739 (I shell), 7740 (few shells), 774x (few shells), 7744 (few shells), 7745 (I shell), 7746 (I shell), 7748 (I shell), 7749 (I shell), 775 I (several shells), $775^{2}$ (few shells), 7753 (I fragment), 7754 (I shell), 7755 (few shells), 7760 (few), 776r (many shells and living), 7762 (few shells), 7764 (I shell), 7766 (several shells), 7770 (2 shells), 7772 (I shell), 7774 (I shell), 7775 (I shell), 7776 (r shell), 7777 (r shell), 7778 (I shell), 7779 (several shells), 7780 (few shells), 778I (several living), 7782 (few living).

Phalarope and Blue Wing stations: I (many shells and few living), 2 (many shells), 3 (many shells), 4 (few shells), 5 (many living and shells), 6 (shells and living abundant), 7 (many), 8 (living), 9 (very many living), ro (common), I2 (several living), I3 (frequent), I4 (some living), I5 (common), I6 (few living), I7 (many living), I8 (shells common), 20 (living common), 2 I (living and shells), 22 (living common), 23 (few shells), 24 (not common), 25 (few shells), 26 (I shell), 28 (common), 29 (few), 30 (few), $3^{2}$ (r living), 33 (several shells), 34 (few living), 35 (several shells, few living), 42 (few shells), 44 ( 1 living), 48 (2 shells), 50 (shells), 52 (living and many shells), 53 (many), 55 (several living), 56 (few living), 57 (I living), 58, 59 (few shells), 60 (many shells and living), 61 (several shells), 62 (few living), 63 
Tritia trivittata-Continued.

(several), 64 (few shells and living), 65 (many), 66 (many), 68 (many shells and living), 69 (few shells), 70 ( 2 shells), 7 I (few living), 72 (several living), 73 (few shells), 74 (several), 75 (few living and shells), 76 (few shells), 77 (few shells), 78 (many living and shells), 79 (living and many shells), 80 (many living and shells), 8 r (many shells), 82 (living and shells), 83 (many living), 84 (living), 85 (living), 86 , 88 (several living), 89 (living), 90, 91, 92 (living), 93 (several), 94 (living), 95, 96, 97, 98, 99, 100 (living), Ior (living), 102 (living), 103, I04, I05 (living and shells), 106, ro7 (many living and shells), I08, I09, II0, II2, II3, II4 (shells common), II5 (shells common), II6, II7 (I shell), in8 (few), Irg (few living and shells), I20 (living), I2r (living and shells common), 122 (living and shells abundant), 123 (shells common), I24 (shells common), I2 5 (living and shells), I26 (shells common), I27 (many shells), 128 (living common), I29 (living and shells), I30 (common living), I32 (common), I33 living), I34 (living common), I35 (living), I36 (many living), I37 (living and shells), I38 (living and shells), I39 (living), I40 (living and shells common), I4I (living and shells), I42 (living common), r43 (several shells), I44 (shells common), I45 (several shells), I46 (few shells), I47 (living common), I48 (several shells), I49 (many), I50 (several shells), I5I (I shell), I $_{52}$ (living), I 53 (few shells), ${ }_{54}$ (few living and shells), $5_{5} 6$ ( $I$ small shell), $5^{8}$ (few shells), I59 (several living and shells), I60 (I living, several shells), I6 I (several shells), I62 (several living and shells), r63 (many living and shells), I64 (many shells), I65 (I living, many shells), I66 (many shells), I67 (many shells).

Ilyanassa obsoleta Stimpson. [Chart r68.]

Gould, I87o, p. 362 (Nassa obsoleta), Verrill and Smith, I873, p. 64I, 468, etc.; Dall, I889, p. II6 (Nassa obsoleta), Bumpus, I8gs, a.

Distribution probably very general throughout the muddy shores and shallow waters of the region. Extremely abundant at certain points such as the Ecl Pond, Great Pond, Wareham River, etc., and perfectly at home in waters which are decidedly brackish. Owing to its littoral habitat it was rarely taken during the survey dredging, except at stations close to shore. In deeper waters dead shells were occasionally met with, these having probably been transported by hermit crabs.

Fish Hawk stations: 7539 ( $\mathrm{I}$ shell), $76 \mathrm{r2}$ ( $\mathrm{I}$ shell), $76 \mathrm{r}_{4}$ (few shells), 7624 (I shell), 7625 (I shell),'
Ilyanassa obsoleta-Continued. 7629 (I shell), 7630 (I shell), 7633 (few shells), 7634 (few shells and living), 7635 (few shells), 7645 (I shell), 7766 (I shell), 7767 (2 shells).

Phalarope stations: 2 (?), 3 (I), ro (I), 33 (I shell), I2 I, I36, I4I (I shell), I42 (several), I45 (shells common), I47 (several shells), I48 (several shells), I49 (common), I50 (few shells), I $5^{2}$ (few shells), I53 (I shell), I54 (2 shells), ${ }_{55}$ (several shells), I $_{56}$ (I shell), I 57 (I shell), i 58 (many shells), I64 (few shells).

Eggs noted by A. D. Mead April 25 and 27.

Arcularia vibex (Say).

Adams, 1839 , p. 264 (Buccinum vibex); Gould, 1870 , p. 365 (Nassa vibex; not listed for this region), Verrill and Smith, 1873, p. 640, 371 , 377 (Nassa vibex); Dall, I889, p. Ir6 (Nassa vibex).

New Bedford.-Adams. "Northward to Vineyard Sound," where it is "found sparingly in shallow water among eelgrass." - Verrill. Wareham River and a few other points in Buzzards Bay, 2 to 4 fathoms, mud.-Survey.

Phalarope stations: I53 (I shell), I55 (several living), I57 (I small shell), I63 (I)*.

\section{Family COL,UMBELLIDAE.}

\section{Anachis avara (Say). [Chart r69.]}

Gould, 1870, p. 350 (Columbella avara); Verrill and Smith, 1873, p. 643,306 , etc.; Verrill, I882d, p. 37 I; I884, Dall, r889, p. Ir6.

Shells generally distributed and of great abundance in both Vineyard Sound and Buzzards Bay, dredged in from I to is fathoms, on every sort of bottom; living specimens abundant throughout the Sound and along the eastern shore of the Bay; rarely recorded from the deeper portions of the latter.-Survey. The shells of this species are widely transported by the smaller hermit crabs, probably being the ones most commonly chosen by $P$. annulipes.

Fish Hawk stations: 752I bis (many shells), $75^{22}$ (many shells), $75^{22}$ bis (many shells), $75^{2} 3$ (many shells), $75^{23}$ bis (many shells), $75^{24}$ (few shells), $75^{24}$ bis (many shells), 7525 (few shells), $75^{2} 5$ bis (few shells), 7527 (many shells)*, 7530 bis (many shells), 753 I bis (many), 7532 (many shells), 7532 bis (few shells), 7533 (few shells), 7533 bis (few shells), 7534 bis (I shell), 7535 (many shells), 7535 bis (few), 7536 bis (several shells), 7537 (many shells), 7537 bis (many), $753^{8}$ (many shells), 7538 bis (few living), 7539 bis ( 1 ), $754 \mathrm{r}$ (few), $754 \mathrm{I}$ bis (many shells), 7543 bis (few), 7544 (comparatively few shells), 7545 (comparatively few shells), 
Anachis avara-Continued.

7545 bis (many), 7546 bis, 7547 (many shells), 7547 bis (very many shells), 7549 (many shells), 7549 bis (many shells), $755^{\circ}$ (few shells), $755^{\circ}$ bis (many living and shells), 755 I bis (many living and shells), 7552 (few shells), $755^{2}$ bis ( 1 worn shell), 7553 bis (many shells), 7554 bis (many shells), 7556 (few), 7556 bis (few worn shells), $7557,755^{8}$ (many shells), 7560 (I shell), 7562 bis (few shells and fragments), 7563 (few shells), 7563 bis (numerous shells and fragments), 7564 (few), 7564 bis (living and shells), 7565 (few shells), 7565 bis (several living and shells), 7566 (I shell), 7567 (few shells), 7568 (few shells), 757 I (few), 7572 (few shells), 7573 (several living and shells), 7576 (I shell), $75^{82}$ (few shells)*, $75^{83}$ (I), $75^{84}$ (I shell), $75^{8} 5$ (several shells), $75^{87}$ (few shells), 7595 (shells), 7596 (I), 7610 (several shells), 7612 (several), $76 \pi_{4}$ (few shells), 7616 (several shells), 7617 (few shells), 7620 (r shell), 762 I ( $x$ shell), 7628 (I shell), 763I (few shells), 7633,7634 (many shells), 7635 (few shells), $76_{3} 6$ (few shells), 7637 (several shells), 7638 (few shells), 7640 (fẹw shells), 7642 (I living), 7643 (several shells), 7644 (many shells), 7645 (few shells), 7648 (few shells), $76_{51}$ (few shells), $76_{52}$ (few shells), 7563 (many shells), 7655 (few shells, 7656 (few shells), 7659 (few shells), 7660 (many shells), 7662 (few shells), 7663 (few living and shells), 7664, 7669 (few shells), 767I (many shells), 7672 (many shells), 7673 (few shells), 7674 (many shells), 7675 (many shells), 7677 (I small shell), 7678 (few living, few shells), 768I (I living and shells), 7682 (I shell), 7688 (I living), 7697 (living and shells), $770 \mathrm{O}$ ( $\mathrm{I}$ living, few shells), 7703 (several shells), 7707 (several), 7718 (I lving), 7720 (I shell), 7724 (several shells), 7725 (I living), 7726 (2 shells), 7727 (I living), 7730 (few), 773 I (many shells), 7732 (many living and shells), 7733 (many living and shells), 7734 (I shell), 7736 (few living and shells), 7737 (few living and shells), 7738 (many living and shells), 7739 (many shells), 774I (many shells), 7742 (I living), 7744 (shells common), 7745 (several living), 7746 (many shells), 7747 (several living and shells), 7748 (I living, many shells), 7749 (many), 7750 (many shells), 775I (I), $775^{2}$ (few shells), 7753 (many shells), 7754 (several shells), 7755 (few shells), 7756 (few shells), 7757 (many shells, few living), $775^{8}$ (many shells, few living), 7759 (very many shells), 7760 (common), 7762 (few shells), 7763 (few living), 7764 (few living and shells), 7765 ( 1 shell), 7766 (many shells), 7767 (few shells), 7768 (few shells and frag-
Anachis avara-Continued.

ments), 7769 (I shell), 7770 (several shells), 777 I (several shells), 7772 (few shells), 7774 (several shells), 7776 (several shells), 7777 (few shells), 7778 (few shells), 7779 (2 wom shells), 7780 (I worn shell), 7782 (few shells), 7783 (few shells).

Phalarope and Blue Wing stations: I (many shells), 2 (many shells), 3 (many shells), 5 (many shells), 7 (many shells), 8 (many)*, 9 (I), to (many shells), I2 (several), I3 (common), I4 (few), I5 (common), I6 (few shells), I7 (many shells), I8 (many shells and living), 20 (shells common), 2 I (shells common), 22 (shells common), 23 (shells common), 24 (few), 25 (I shell), 26 (few shells), 27 (few living), 28 (several), 29 (few living), 32 (few) 33 (several shells), 34 (several shells and living), 35 (several living), 36 (several living), 37 (few shells), $3^{8}$ (I living), 40 (few shells), 4I (few shells), 42 (few shells), 43 (shells), 45 (many living), 46 (many living), 48 (?), 49 (shells), 5 I (few living), $5^{2}$ (several shells), 53 (several shells), 56 (few), $5^{8}$ (common), 59 (several shells), 60 (several shells), 62 (few), 63 (few), 64 (several), $\sigma_{5}$ (few shells), 66 (living and shells), 67 (2 living), 68 (several), 69 (few living), 70 (living), 7 I (many living and shells), 72 (few shells and living), 73 (I living), 74 (many living and shells), 75 (few living and shells), 76 (many shells), 77 (many), 78 (few shells), 79 (common), 80,8 I (several shells), 82 (common), 83 (living and shells common), 84 (several living and shells), $85,86,87$ (few shells), 89, 90, 9r, 92, $93,95,97,98,99$, roo (living and shells), ror, I02, I03, I04, I08, 109, I10, III (shells), II2, II 3 , I 4 (shells common), I I5 (shells), I I 7 (few shells), I 8 (few shells), I I9 (few living and shells), r2o (shells), I2 I (shells), I22 (few shells) I23 (few shells), I24 (few shells), I25 (shells), I 26 (few shells), I28 ( 2 shells), I30 (few living),

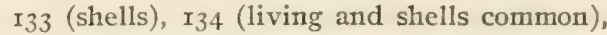
I35, I36 (few. shells), I37 (few shells), I4I (few shells), I42 (I shell), I44 (living and shells), I45 (several shells), I46 (few shells), I47 (several shells), I $_{4} 8$ (few shells), I49 (several shells), I58 (I shell), I60 (2 shells), r62 (I shell), I63 (several shells), I65 (few shells), I66 (several shells), I67 (many shells).

The eggs of this species are deposited in hemispherical white masses, from I to $2 \mathrm{~mm}$. in diameter, which are of frequent occurrence, attached to various objects. For the identity of these eggs, we rely on the records of Mr. T. E. B. Pope, who observed several of the mollusks depositing them upon the egg capsules of Urosalpinx cinereus, July 7, I9II. 
Anachis avara similis (Ravenel).

Verrill and Smith, 1873, p. 644 (Anachis similis); Dall, r889, p. II6 (Anachis avara, var. similis).

"Abundant in Vineyard Sound," according to Verrill. Dr. Dall regards this form as being merely a variety of $A$. avara. In the survey records the two have not been distinguished.

\section{Astyris lunata (Say). [Chart I70.]}

Gould, I870, p. 359 (Columbella lunata); Verrill and Smith, I873, p. 645,306 , etc.; Verrill, I882d, p. 37I; I884; Dall, I889, p. II8.

Abundant and generally distributed throughout Vineyard Sound; in Buzzards Bay chiefly restricted to the inshore stations; dredged in I to ig fathoms, on every sort of bottom. - Survey. This mollusk is equally abundant among algæ growing on piles or upon rocks near shore.

Fish Hawk stations: $752 \mathrm{I}$ bis (many), 7522 bis (I), $75^{24}$ bis (several), $75^{2} 5$ bis, $75^{26}$ ( 2 shells), 7530 bis (few shells), 7531 (5 water-worn shells), 753 I bis (few shells), 7536 bis (several shells), 7537 bis (many shells), 7538 bis (few), 7539 bis, 754I bis (common), 7543 bis (few), 7545 bis (many), 7547 bis (many shells), 7549 bis (few), $755^{\circ}$ bis (few), $755^{\mathrm{I}}$ (several), 755 I bis (few), 7552 bis (few), 7553 bis (numerous shells), 7554 (I shell), 7554 bis (few shells), 7555 ( 2 shells), $755^{6}$ bis (few shells), 7557 (many), $755^{8}, 7560$ (several), $75^{6} \mathrm{r}$ ( $\mathrm{I}$ ), 7563 bis (many shells), 7564, 7564 bis (many living and shells), 7565 bis (few shells), 7568 (I shell), 7572 (several), 7576 (I), $758 \mathrm{r}$ (several), 7582 (many), $75^{8} 3$ (I), 7589 (abundant, large and small), 7592 (few), 7593 (r), 7594, 7595 (few shells), 7599, 7602 (many shells), 76ri , 7612 (few shells), 76 I $_{5}$ (I shell), 7627 (I small), 7630 (few), 7634, 7640 (I shell), 7644 ( 2 shells), 7651 , 7653 (few shells), $7656,7657,7659$ (numerous shells), 7661 (few shells), 7671, 7672, 7674 (few shells), 7675 (few shells), 7676 (few), 7677,7678 , 7679 (few living), 7682 (few living), 7687, 7688 (I), 7697 (few living), 7698 (I shell), 7699 (I); 7701 (few living), 7703 (many living), 7706 (few living), 7707 (few living), 7709 (I shell), 77 I 7 (few living), 77 I8 (few living), 77 I9 (few shells), 7720 (few living), 772 I (I shell), 7722 (few shells), 7723 (few), 7724 (many living and shells), 7725 (several living), 7726 (several shells), 7727 (living), 7728 (few living and shells), 7729 (few living), 7730, 7731 (many living and shells), 7732 (few shells), 7733 (I living), 7734 (several shells), 7739 ( $\mathrm{I}$ shell), 7740 (few shells), 774I (I living), 7742 (2 shells), 7743 (several living), 7744 (few), 7746 (several living
Astyris lunata-Continued.

and I shell), 7748 (few living and shells), 7749 (very many living), $775^{\circ}$ (few living), $775^{\mathrm{I}}$ (few), 7753 (few shells), 7754 (many living), 7755 (few living and shells), 7756 (many living and shells), 7757 (many living), 7759 (many living and shells), 7760 (living and shells common), 776I (many living and shells), 7762 (many living), 7763 (scarce), 7764 (living common), 7765 (few), 7766 (few), 7767 (many), 7768 (many living and shells), 7769 (few living), 777 I (few shells), 7772 (few), 7775 (few), 7776 (few shells), 7777 (many), 7779 (few), 7780 (living and shells common), 778r (many shells), 7782 (few shells), 7783 (many shells).

Phalarope and Blue Wing stations: I (many), 2 (I living), 3 (few shells), 4 (few shells), 5 (few living), 6 (several shells), 7 (few), 9 (several shells), Io (several), II (I), I3, I5 (few), I6 (few living), I7 (living and shells), I8 (many living), 20 (abundant on red algæ), 2 I (living common), 22 (abundant), 23 (few), 24 (few), 25 (living abundant), 26, 27 (many), 29 (I), 30 (many), 32 (few), 34 (common), 35 (I shell), 36 (abundant), 37 (few living), 38 (living), 42 (few shells), 43 (shells), 44 (abundant), 45 (many living), 46 (very common), 47 (many living), 5 I (few living), 52 (many living), 53 (few), 55 (few living), 56 (few), 57 (few), 58 (many), 59 (few), 6o (few shells), 62 (few), 63 (few), 65 (many), 67 (few shells), 68 (few), 69 (several shells), 73 (many), 74 (many), 75 (several living), 76 (few living), 77 (few), 78 (few shells), 79,80 (few shells), 8 I (few), 82 (few shells), 83 , 84 (few), 86, 87 (few), 88 (I shell), 89, 91, 92 (shells), 94, 96, 97, 99, I00 (shell), I01, го2, I05 (shells), 106, I08, II0, II (few living), II2, II3, II5 (few shells), II6, II7 (many living), II8 (living and shells common), I 9 (shells), I20 (shells), I2 I (many shells), I22 ( 1 living), I23 ( $\mathrm{I}$ living), I29 (I), I30 (living common), I3I (few), I34 (common), I38 (I shell), I40 (few shells), I4I (several living and shells), I44 (I shell), I47 (I shell), I48 (2 shells), I55 (several shells,) I57 (I shell), I 58 (I shell), I59 (I shell), I6I (I shell), I63 (I living), I65 ( $\mathrm{I}$ living), I67 ( $\mathrm{r}$ shell, I living).

Astyris rosacea (Gould).

Gould, I87o, p. 357 (Columbella rosacea; not listed for this region); Verrill and Smith, 1873 , p. 645,508 , etc.

"Muddy bottoms off the open coast." No definite local records given by Verrill, though this region lies within the stated range of the species. 
Astyris zonalis Verrill.

Verrill and Smith, I873, p. 645, 399, etc.

Vineyard Sound, rare.-Verrill.

\section{Family MURICIDA.}

\section{Eupleura caudata (Say). [Chart I7x.]}

Gould, I870, p. 386 (Ranclla caudata); Verrill and Smith, I873, p. $642,37 x$, etc.; Dall, 1889 , p. 120 .

Vineyard Sound, etc., especially at Waquoit.Verrill. Distribution very general throughout Buzzards Bay, though seldom numerous in any one dredge haul; in the Sound, much less common, and chiefly restricted to the inshore stations.-Survey. Living specimens dredged in 3 to $I_{3}$ fathoms, on various bottoms, with or without mud. Verrill records it as "living in considerable numbers in the shallow ditches on the marshes."

Fish Hawk stations: $75^{21}$ bis ( 1 shell), 7602 (I shell), $76 \mathrm{II}_{\mathrm{I}}$ (I), $76 \mathrm{I}_{2}$ (several), $76 \mathrm{I}_{3}$ (2), $76 \mathrm{I}_{4}$ (shells and fragments), 76r5 (few shells), 7616 ( 2 shells), 7617 (several shells), 7618 (several), 7619 ( 1 shell), 7620 (several living), 762 I (several shells), 7622 (many shells and living), 7623 (many shells), 7624 (many shells), 7625 (few shells), 7626 (1), 7627 (4 living), 7628 (few shells), 7629 (few living), 7630 (2), 7632 (few shells), $76_{33}$ (few), 7634 (few living and shells), 7637 (r fragment), $76_{3} 8$ (few shells and living), 7639 (living and few shells), 7642 ( 1 shell), 7643 (2 shells), 7644 (I shell), 7645 (I shell), 7646 (I shell), 7648 (few shells), 765 I (few shells), 7655 (I shell), 7660 (several shells), 766r (several shells), 7662 (several shells), 7663 (several living), 7668 (few living), 7673 ( $I$ shell), 7688 ( $I$ shell), 7723 (I shell), 7724 (I small shell), 7736 (I living), 7778 ( 2 living), 778 ( 1 living).

Phalarope stations: 3 (several shells), 6 (I large living), I9 (I shell), 53 (2 living), 64 (I shell), 65,68 (I shell), 76 (I shell), 78 (I shell), 80 (few shells), 8 I (shells and $\mathrm{r}$ living), 82 (few shells), 83 (several shells), 84 (many shells), 91, 92, 93 (I shell), 94, 95, 106, 107 (few shells), 108, 109, I Io, I I2, I I3, I 5 (I shell), I 8 (I shell), I I9 (I shell), I22 (living and shells), I32 (few shells), I33 (I shell), I36, I39 (I shell), I40 (I shell), I44 (few shells), I45 (few living and shells), $I_{4} 8$ (several shells), I50 (several shells), I55 (I), I $5^{8}$ ( l living), I62 (several living), $x 6_{3}$ ( living), I65 (few shells), I67 ( 1 living).

Urosalpinx cinereus (Say). Oysterdrill. [Chart I 72.] Gould, 1870 , p. 370 (Buccinum cinereum); Verrill and Smith, r873, p. 641, 306, etc. (Urosalpinx cinerea); Dall, I889, p. $\mathbf{1} 20$.
Urosalpinx cincreus-Continued.

Distribution of shells general throughout the Sound and Bay; relatively seldom dredged alive in the Bay; living specimens dredged in I to $I_{5}$ fathoms, preponderantly on stony and shelly bottoms, rare where mud is present.-Survey. Abundant as a littoral species, being frequently found in large numbers on rocks exposed at low tide.

Fish Hawk stations: 7521 (I), 7525 bis (I fragment), $7527(\mathrm{I}), 7530(\mathrm{r}), 7530$ bis (living and shells), 7532 (I), 7532 bis ( $\mathrm{I}$ fragment), 7533 bis ( $\mathrm{I}$ shell), 7534 (I), 7534 bis (2 broken shells), 7535 (I), 7537 (few shells), 7538 (several shells and I living), 7543 ( I), 7544 (I), 7545 (I), 7545 bis (several shells), 7546 bis (fragments), 7547 bis (few shells), 7549 bis (2 living), 755 I bis (I shell), $755^{6}$ bis (few shells), 7563 bis (fragments), 7564 bis (few shells), 7565 bis (I shell), 7570 (I shell), 7576 (I shell), 7577 (I living), $75^{82}$ (few shells), $75^{87}$ (I fragment), 7595 (few shells), 7596 (I shell), 7602 (I shell), 76ro (2 fragments), $761_{4}$ ( 2 shells), 7626 (I), 7627 (I), $76_{29}$ ( 1 living), $76_{34}$ (few shells), $76_{36}$ (i shell), $76_{3} 8$ (I shell), 7639 (shell), 7642 (I shell), 7645 (several shells), 765I (x shell), 7660 (I shell), 766r (few shells), 7664 (few shells), 7666 (I shell), 7667 ( 2 shells), 7675 ( 3 shells), 7694 (I shell), 7699 (I living), 7700 (I living), 770 \% (I shell), 7702 (I shell), 7703, 773I (2 shells), 7732 (r fragment), 7733 (I living), 7734 ( 1 worn shell), 7736 (I shell), 7738 (I fragment), 7739 (I living), 774r (I living, I shell), 7745 (I living), $775^{2}$ (I small), 7753 (I shell), 7755 (few shells), 7756 (I small shell), 7757 (many living), $775^{8}$ (living and shells common), 7759 (few living and shells), 7764 (I shell), 7767 (I shell), $777 \mathrm{I}$ (I fragment), 7774 (few shells), 7776 ( $x$ living), 7779 ( 1 fragment), 7782 (I fragment), 7783 (I shell).

Phalarope and Blue Wing stations: I (2 shells), 4 (I shell), 5 (I shell), 6 (I), 7 (2 shells), 8 (few shells), I3 (I shell), I9 (2 shells), 2 I (2), 22 (shells common), 24 (few), 26 (I shell), 28 (x), 30 ( 1 ), 34 (2), 35 (I fragment), 36 (few shells), 37 (few shells), 38 (living), 40 (few shells), 44 (2 shells), 45 (several living), 46 (many living), 47 (several living), 48, 5 I (few living), 52 (few), 56 (few), 57 (many), 60 (several), 63 (I), 64 ( I fragment), 68 (I shell), 69 (I shell), 70 (I living), 76 (? I fragment), 79, 8I (shells), 82 ( I shell), 83 (few shells), 84 (living), $85,86,87,88$ (I shell), 91, 92 (shells), 98, гог (I shell), то7 (few shells), I08, I10, III (living common), II3, II4 (few shells), II6, II7 (I shell), Ir8 
Urosalpinx cinerews-Continued.

(several shells), I2 I (living), I22 (few shells), 124 (shells), I26 (few shells), I28 (few shells), I29 (I shell), I30 (few shells), I32, I36, I45 (few shells), I50 (few shells), I 5 I (2 shells), I 55 (I shell), I58 (few shells), I63 (r shell), I64 (several living), 167 (few shells).

The horny egg cases may be found attached to the under surface of stones, commonly in clusters. According to Dr. Bumpus's statement, Urosalpinx was found breeding on May 2I; oviposition being observed during several weeks in June. Mr. T. E. B. Pope found specimens laying eggs at Woods Hole on July 13; young were found hatching on July 27. This species perforates the shells of various living mollusks, hence the popular name of "drill." It is of tenvery destructive to oysters.

Thais lapillus (Linnæus).

Gould, r870, p. 360 (Purpura lapillus; not listed for this region); Verrill and Smith, $1873, p$. 642,306 , etc. (Purpura lapillus); Dall, I889, p. I22 (Purpura lapillus).

Not very common nor generally distributed in this region. Recorded from rocky shores at Cuttyhunk, Nobska Point, and at Buzzards Bay, near Woods Hole. Gay Head, at Blue Winstation 5 I (many living specimens were here either dredged in shoal water or collected from rocks by hand). Eggs were taken at two stations (Fish Hawk $7707^{*}$ and $7720^{*}$ ) in neighboring parts of the Sound.

The egg cases of this species are similar to those of Urosalpinx. Mr. T. E. B. Pope observed individuals laying eggs at Woods Hole on July I3; young were found hatching on July 27.

\section{Family SCALID}

Boreoscala granlandica (Perry).

Gould, I870, p. 3 I4 (Scalaria granlandica; not listed for this region); Verrill and Smith, 1873 , p. 660 (Scalaria gronlandica); Dall, I889, p. 124 (Scala gronlandica).

South Shoals off Nantucket.-Agassiz, Stimpson. Crab Ledge; Buzzards Bay, near West Falmouth Harbor (latter possibly an erroneous record).--Survey.

Fish Hawk stations: 7603 ( 2 shells)*, 7604 ( 1 living), 7605 ( $\mathrm{I}), 7607$ (I), 7609 (I shell).

Phalarope station I35 (I shell, thus identified by R. C. Osburn).
Epitonium multistriatum (Say).

Stimpson, $185^{1}$ (Scalaria multistriata); Gould, 1870, p. 3 3 3 (Scalaria multistriata); Verrill and Smith, I873, p. 660, 4I8, etc. (Scalaria multistriata); Dall, I889, p. I22 (Scala multistriata).

Buzzards Bay.-Stimpson. Vineyard Sound and Buzzards Bay.-Gould, Verrill, Survey. Recorded from Fish Hawk station 7532 bis (I small shell), and Phalarope stations 91 and 96; 3 to 9 fathoms. (All identified by R. C. Osburn).

Epitonium dallianum (Verrill \& Smith).

Dall, I889, p. I24.

Sound shore of Pasque Island, at Phalarope station $25^{*}$.

Epitonium lineatum (Say).

Stimpson, I85I; Gould, I87o, p. 312 (Scalaria lineata); Verrill and Smith, I873, p. 660, 418, etc. (Scalaria lineata); Dall, 1889, p. I24 (Scala lineata).

Buzzards Bay.-Stimpson. New Bedford and vicinity.-Gould. Vineyard Sound and Buzzards Bay.-Verrill, Survey.

Phalarope stations: 7 (I shell) ${ }^{*}, 8 \mathrm{I}^{*}$, I4I (2 shells)* I44 (I shell.)

Epitonium sp. (undetermined).

Fish Hawk station 7532 bis (I); Phalarope stations: 123 (I shell), I59 (I).

\section{Family JANTHINIDE.}

Janthina fragilis Lamarck.

Stimpson, I85I, p. 32 (Ianthina fragilis); Gould, I870, p. 277; Verrill and Smith, 1873, p. 660.

"Occasionally cast ashore at Nantucket."Stimpson.

\section{Family Eulimidas.}

Eulima oleacea Kurtz \& Stimpson.

Stimpson, I851; Gould, I870, p. 332; Verrill and Smith, 1873, p. 655,418 , etc.

Buzzards Bay.-Stimpson. "Vineyard Sound ... not uncommon on Thyone briareus, in 4 to Io fathoms." - Verrill. Appears "to live as a quasi parasite or 'commensal.' "'

Specimens of Eulima from various local points were referred by us to Messrs. Dall and Bartsch, and were unhesitatingly identified by them as E. conoidea (see below). It is possible, therefore, that the foregoing records really relate to the following species. On the other hand, Stimpson himself lists E. oleacea from Buzzards Bay. 
Eulima conoidea Kurtz \& Stimpson. [Chart I73.]

Dall, r889, p. I26 (Hatteras to West Indies).

Taken by the Survey at a few scattered stations in the eastern half of Vineyard Sound; likewise at widely distant points in Buzzards Bay; dredged in 3 to $\mathrm{I}_{3}$ fathoms, on various bottoms (mainly shells).

Fish Hawk stations: $75^{22}$ (2 shells)*, 7528 (I shell), 7537 bis, 7549 bis ( 1 ), 7755 ( $I$ shell and I fragment), 7757 (I shell), 7772 (I shell).

Phalarope stations: 79 (few shells), II6, I44 (I shell), 147 (I living).

Stilifer stimpsoni Verrill.

Verrill and Smith, I873, p. 655, 460 (Stylifer Stimpsoni; no local records); Dall, r889, p. I26; Sumner, I908, p. 319.

A number of specimens found upon the surface of a "green urchin" (Strongylocentrotus droebachiensis), taken in Vineyard Sound at a repetition of Fish Hawk station $7592^{*}$, August 23 , 1907; 4 large specimens found upon the same species of echinoid, July 29, I908, in the neighborhood of Fish Hawk station 7593.

\section{Family Pyramideldide}

\section{Pyramidella producta (Adams).}

Adams, I840, p. 322 (Jaminia producta); Gould, I87o, p. 325 (Odostomia producta); Verrill and Smith, I873, p. 656, 333, etc. (Odostomia producta); Bartsch, I909, p. 72 .

Fairhaven.-Adams. Vineyard Sound.-Verrill. Woods Hole [region],-Bartsch.

Pyramidella fusca (Adams).

Adams, I839, p. 282 (Pyramis fusca); Gould, I870, p. 325 (Odostomia fusca); Verrill and Smith, I873, p. 656, 307 , etc. (Odostomia fusca); Bartsch, r909, p. 73 .

New Bedford, Dartmouth.-Adams. Fairhaven, New Bedford, Woods Hole, Naushon Island.-Bartsch.

Pyramidella bartschi Winkley.

Winkley, I909, p. 40 (sp. nov.).

A single specimen from Woods Hole.

Turbonilla stricta Verrill.

Verrill and Smith, 1873 , p. 659 (sp. nov.; only recorded from Long Island Sound); Bartsch, I909, p. 76 .

Woods Hole [region], Naushon Island, a number of specimens listed by Dr. Bartsch.
Turbonilla nivea (Stimpson).

Gould, I870, p. 33I (not listed for this region); Bartsch, I909, p. 77 .

Dredged by the Survey near Round Hill Point, at Fish Hawk station 7650 $;$; Gay Head at Phalarope station 6of; Bay shore of Naushon, at Phalarope station 9rf. Various specimens from this region, in National Museum and elsewhere, likewise recorded by Bartsch.

Turbonilla aqualis (Say).

Verrill and Smith, 1873, p. 659 (T. equalis); Verrill, I882a, p. 537; Bartsch, r909, p. 78 .

"Vineyard Sound, 6 to 8 fathoms."-Verrill.

? Turbonilla verrilli Bartsch.

Bartsch, I909, p. 82 (sp. nov.).

"The type, cat. no. 94826 a U. S. National Huseum, comes from Marthas Vineyard, Mass." (This may really mean off Marthas Vineyard, at a considerable depth.)

Turbonilla vinee Bartsch.

Bartsch, I9o9, p. 83 (sp. nov.).

Woods Hole [region], many specimens in United States National Museum and elsewhere catalogued by Bartsch. Dredged by the Survey in Buzzards Bay, at Fish Hawk stations $7649 \ddagger$ and $7656 \ddagger$ and Phalarope station $78 \neq$.

Turbonilla elegantula Verrill.

Verrill, 1872, p. 282 (T. elegans); Verrill and Smith, 1873, p. 657,418 , etc. ( $T$. elegans); Verrill, I882c, p. 538; Bartsch, r909, p. 84.

"Vineyard Sound, 6 to Io fathoms." -Verrill. Eel Pond, Woods Hole, Vineyard Sound.Bartsch. Buzzards Bay, at Fish Hawk stations $7634 \ddagger$ and $765 \mathrm{r} \neq$.- Survey.

Turbonilla areolata Verrill.

Verrill and Smith, I873, p. 658 (sp. nov., not listed for this region); Verrill, I882c, p. 537 , Bartsch, I909, p. 86.

Vineyard Sound, 2 to 8 fathoms.-Verrill. Woods Hole [region].-Bartsch. Near Hadley Harbor, at Phalarope station reof, one specimen.-Survey.

Turbonilla interrupta (Totten).

Adams, I839, p. 275 (Turritella interrupta); Gould, I870, p. 33I; Verrill and Smith, I873, p. 657,418 , etc.; Dall, 1889, p. I28; Bartsch, I909, p. 87 .

Dartmouth.-Adams. Newport Harbor.-Totten. "Quite common in Vineyard Sound and Buzzards Bay, in 3 to Io fathorns."-Verrill. Woods Hole [region].-Bartsch. Recorded 
Turbonilla interrupta-Continued.

from a few scattered stations both in Vineyard Sound and Buzzards Bay, at 2 to 17 fathoms.Survey.

Fish Hawk stations: 7564 bis, 7623 (the foregoing thus identified by R. C. Osbum), 7686 , 77 Iof, $7725 \ddagger$.

Phalarope stations: 9I, I57 (both identified by Dr. Osburn).

Turbonilla mighelsi Bartscl.

Verrill and Smith, I873, p. 658 (Turbonilla costulata; not listed for this region); Verrill, I882a, p. 537 (T. costulata); Bartsch, Igog, p. 88 (nom. nov.)

Vineyard Sound, I to 5 fathoms.-Verrill. Woods Hole.-Bartsch.

Turbonilla buteonis Bartsch.

Bartsch, Igog, p. 89 (sp. no-v.).

Woods Hole [region], several records.

Turbonilla winkleyi Bartsch.

Bartsch, I909, p. 90 (sp. nov.).

Woods Hole [region], many records given by Bartsch. Dredged by the Survey at scattered stations throughout Buzzards Bay; recorded twice for Vineyard Sound; 2 to $I 7$ fathoms, on more or less muddy bottoms.

Fish Hawk stations: 7537 bis (? several shells), 7612 (?), 7617 (?), 7647 (few shells) $\ddagger, 7650 \ddagger$, $7656 \neq, 7657 \ddagger, 7660 \neq, 7661+, 7663 \ddagger, 7686 \neq$.

Phalarope stations: $78 \pm$, II9 (several) $\ddagger$, I20 I55t.

Turbonilla winkleyi senilis Bartsch.

Bartsch, I909, p. 92 (var, nov.).

Woods Hole [region], several specimens catalogued by Dr. Bartsch.

Turbonilla sumneri Bartsch.

Bartsch, I909, p. 93 (sp. nov.).

Type specimen from Woods Hole [region]. Later more than a dozen specimens (identified by Dr. Bartsch) were taken in the Eel Pond by Rev. H. W. Winkley.

Turbonilla rathbuni Verrill \& Smith.

Dall, I889, p. 128; Bartsch, I909, p. 94.

Dredged once at the head of Buzzards Bay (Phalarope station $154 \ddagger$ ). Listed by Bartsch from Woods Hole [region] and from Newport.

Turbonilla sp. sp. (undetermined).

Many specimens referable to species of this genus were taken at the following stations. A large proportion of them are listed as undetermined, owing to ambiguities in the records; others were referred to Messrs. Dall and Bartsch, but were not sufficiently well preserved for identification.
Turbonilla-Continued.

Fish Hawk stations: 7528 (I shell), 753 I (2 shells) 7563 bis, 7583 (I), 7602 (3 shells), 7622,7626 , $7639,7649,765^{2}, 7653,7656,7657,7662,7664$, 7707 (I shell), 7709, 7710 ( 1 living and I shell), 7723 (several shells), 7724 (I fragment), 7726 , 7727 ( 1 living, 2 shells), 7728, 7729, 7731, 7734 (I much worm shell), 774I, 7744 (fragment), 7746 (I shell), 7748 (I shell), 7753 (several shells), 7756 (2 shells), 7764 ( 2 shells), 777 I (I worn shell).

Phalarope stations: $17,18,19,62,65$ (I), 70 (several shells), 72 ( 2 living), $78,79,80,81,82,84$, $89,90,91,92$ (shells), 96, roo (living and shells), ro7 (few living), I08, I I0, II 3 , I I 5 (I), II6, II7, II8, II9 (many living), I20 (living and shells), I2I, I23, I24, I25, I26 (several living), I27, I32, I38 (several shells), I4I, I42, I44, I47 (I shell), I5I (living, shells), I 52 (I shell), I59 (3 shells), I62 (2), I65 (several), I66 (several shells), I67 (I).

Odostomia seminuda (Adams).

Adams, r839, p. 280 (Jaminia seminuda); Gould, 1870, p. 329; Verrill and Smith, $x 873$, p. 657 , 4I8, etc.; Dall, I889, p. I30; Bartsch, I909, p. 97 .

Dartmouth.-Adams. "Common in Vineyard Sound and Buzzards Bay, in 2 to rofathoms. "Verrill. Recorded by Bartsch from various local points. Dredged by the Survey at a few scattered stations in both the Bay and the Sound, at 2 to 7 fathoms; likewise collected at Vineyard Haven.*

Fish Hawk stations: $7634^{*}, 7^{6} 5^{*}$; Blue Wing station 20 (I shell); Phalarope station 30 (I shell).

Odostomia bushiana Bartsch.

Bartsch, Igog, p. 99 (sp. nov.).

Vineyard Sound.

Odostomia hendersoni Bartsch.

Bartsch, rgog, p. ror (sp. nov.).

Woods Hole [region], type and three other specimens listed by Bartsch.

Odostomia impressa (Say).

Bartsch, Igog, p. I03.

New Bedford.-Stimpson, cited by Bartsch.

Odostomia trifida (Totten).

Gould, I870, p. 328; Verrill and Smith, 1873, p. 656,307 , etc.; Dall, I889, p. 130 ; Bartsch, r909, p. I04.

New Bedford Harbor.-Adams. Vineyard Sound and Buzzards Bay, common; found beneath rocks, among hydroids, bryozoa, etc.; also listed for piles, etc., and for gravelly and 
Odostomia trifida-Continued. shelly bottoms.-Verrill. “Woods Hole," New Bedford, Weepecket Island.-Bartsch. One small shell, thus identified with doubt by Dr. Bartsch, was taken at Fish Hawk station 7679 .

Odostomia bisuturalis (Say).

Gould, 1870, p. 327 (not listed for this region); Verrill and Smith, 1873, p. 656, 307 , etc.; Dall, 1889, p. I30; Bartsch, 1909, p. Io6.

Vineyard Sound and Buzzards Bay, not uncommon.-Verrill. Specimens from many local points catalogued by Bartsch.

Odostomia modesta (Stimpson).

Bartsch, I909, p. 108.

Woods Hole [region], two records by Bartsch.

? Odostomia dealbata Stimpson.

Gould, 1870 , p. 327 ; Verrill and Smith, 1873 , p. 656.

No definite local records, though this region lies within the stated range of the species.

Couthouyella striatula (Couthouy).

Bartsch, I909, p. Iro.

Buzzards Bay.

\section{Family TRIFORIDAE.}

Triforis nigrocinctus Stimpson.

Gould, 1870, p. 323; Verrill and Smith, 1873, p. 648, 305, etc.; Verrill, I882 d, p. 37 r; I884.

Dartmouth Harbor.-Adams, cited by Gould. "Vineyard Sound and Buzzards Bay, 2 to I2 fathoms, not uncommon;" also mentioned as occurring on weeds between tides, as well as in other habitats.-Verrill. Apparently scarce except as a littoral and shallow water form. Recorded but once by the survey (Fish Hawk station $\left.7701^{*}\right)$.

\section{Family Cerithiopsidas.}

Seila terebralis (Adams). [Chart 175 .]

Adams, 1840 , p. 320 (Cerithium terebrale); Gould, I870, p. 389 (Cerithiopsis terebralis); Verrill and Smith, 1873 , p. 648,417 , etc. (Cerithiopsis terebralis), Dall, I889, p. I38.

New Bedford.-Adams. Vineyard Sound and Buzzards Bay.-Verrill. Eastern half of Vineyard Sound; inshore stations and upper end of Buzzards Bay, scarce; dredged in 2 to I $_{3}$ fathoms, on very various bottoms.--Survey.

Fish Hawk stations: 7549 bis (I small fragment), $755^{2}$ bis $^{*}, 7628$ (I), 763 I (I shell), 7633 ( 1 shell), $7634(\mathrm{r}), 7635$ (I shell), $767 \mathrm{r}, 7757$ (I shell), 7778 (I shell), 7780 (I shell).
Seila terebralis-Continued.

Phalarope stations: 8 (I), I xo (I shell), I2 I (2 living), I26 (I shell), I32 (I shell), I33 (I shell), I 44 (I), I 45 (several living and shells), I 47 (I), I48 (living and shells common), I5O (i), I 55 (2 shells), I57 (r), I64 (I shell)* ${ }_{167}$ (several shells)*

\section{Cerithiopsis greenii (Adams).}

Adams, 1839, p. 286 (Cerithium greenii); Gould I87o, p. 322 (Bittium greenii); Verrill and Smith, I873, p. 647,383 , etc.; Dall, r889, p. $\mathrm{r}_{3} 8$.

Dartmouth Harbor.-Adams. " "Vineyard Sound and Buzzards Bay, 3 to Io fathoms."-Verrill.

Cerithiopsis emersonii Adams. [Chart 176.$]$

Gould, I870, p. 387 ; Verrill and Smith, 1873, p. 648,417 , etc.

Nantucket and New Bedford.-Adams, cited by Gould. Vineyard Sound and Buzzards Bay.Verrill. Vineyard Sound, chiefly in the eastern half; in Buzzards Bay, fairly common, but for the most part restricted to inshore stations; dredged in 2 to $I_{3}$ fathoms, on every sort of bottom, but never taken in large numbers.Survey.

Fish Hawk stations: $75^{22}(\mathrm{I})^{*}, 753^{8}$ bis (I shell), 7543 (I shell), 7554 bis (I shell), 7572 (I shell), 7629 (I shell), 7632 (I shell), 7634 (2), 7635 (2 shells), 7659 ( 1 shell), 7674 (I fragment), 7753 (I shell), 7767 (I shell fragment), 7770, 7777 (I shell), 7782 (I shell),

Phalarope stations: 2 (I), 6 (I shell), 52 (I shell), 7I (I shell), 80, 8I (I) 82 (I shell), 84 (2), 85 (I shell), 91, 96, 97, 108, I10, I20 (shells), I23 (I shell), I45 (living and shells), I47 (few), I48 (I shell), I49 (I living), I5o (I shell), I52 (I shell), 158 (4 shells), 159 ( 1 shell), I6j (2 fragments), I67 (I).

\section{Family CERITHIDAs.}

\section{Bittium alternatum (Say). [Chart I77.]}

Gould, I870, p. 32 I (Bittium nigrum); Verrill and Smith, I873, p. 648, 305, etc. (Bittium nigrum); Dall, I889, p. I40.

Nantucket.-Gould. Vineyard Sound and Buzzards Bay.-Verrill. More frequent in the Bay than in the Sound, and in both cases mainly restricted to inshore stations; seldom dredged at depths greater than 5 fathoms.Survey. Recorded as abundant at nearly all points where shore collecting was carried on.

Fish Hawk stations: $755^{2}$ bis ${ }^{*}, 7724^{*}, 7762$ (I shell), 7778 (2 shells), 778 I (I shell). 
Bittium alternatum-Continued.

Phalarope stations: $8,17,25^{*}, 73,82^{*}, 87,91,92^{*}$, 95, 96 (many), 97, ror (I shell), ro5 (shells), I07 (few shells), I08, I09, II0, II7 (living and shells), ir8 (r shell), rig (r shell), I20 (shells), I2 I (few shells), I22 (I shell), I26 (I shell), I29, I30 (many living), I3I (abundant), I33 (I shell), I34 (few), I36, I38 (I shell), I4I (few), I42 (I shell), I43 (I shell), I44 (several shells), $I_{47}$ (I), I48 (I shell), I 52 (I shell), I 58 (I), I 59 (I shell), I6I (I shell).

\section{Family CEACIDEA}

Cacum pulchellum Stimpson.

Stimpson, 1851; Gould, 1870, p. 315; Verrill and Smith, 1873 , p. 649,417 , etc.; Dall, I889, p. I42.

New Bedford Harbor.-Stimpson. "Vineyard Sound, I to 4 fathoms, and dead on shore at Nobska beach.'--Verrill. Buzzards Bay, at a number of stations along the eastern shore; dredged in 3 to 7 fathoms on bottoms of sand and grave1.-Survey.

Phalarope stations: $91^{*}, 92$ (I living), I09 (I shell), I Io, I I6 (many)*, II7 (I living), I I8 (I), I34 (I living), I35 (I living).

Cacum johnsoni Winkley.

Winkley, r9o8, p. 54 .

"Dredged at Woods Hole, Mass., on gravel bottom in 2 to 3 fathoms."

Cacum cooperi Smith. [Chart I78.]

Verrill, 1872 , p. 283 (Caecum costatum); Verrill and Smith, 1873, pp. 649,417 , etc. (Cacum cooperi and $C$. costatum); Verrill, I882a, p. 525; Dall, r889, p. I42.

"Vineyard Sound, 8 to ro fathoms."-Verrill. Taken at a number of inshore stations in Buzzards Bay, and two in Vineyard Sound; dredged in 3 to 7 fathoms, chiefly on bottoms of sand and gravel.-Survey.

Phalarope stations: 33 (several living)*, 52, 91*, 100, I02, I08 (living), II7 (2 shells), I23 (2 shells), I33 (2 shells), I33 (2 living), I35, I40 (r shell), I4I (common), I46 (I).

\section{Family VERMETIDE.}

\section{Vermicularia spirata Philippi. [Chart I79.]}

Stimpson, I85r, p. 39 (Vermetus radicula); Gould I870, p. 3 I6 (Vermetus radicula); Verrill and Smith, 1873 , pp. 649,417 (Vermetus radicula); Dall, I889, p. r44.

New Bedford Harbor.-Gould. "Vineyard Sound and Buzzards Bay, 3 to Io fathoms, not uncommon."-Verrill. Common in Great
Vermicularia spirata-Continued.

Harbor, Woods Hole.-V. N. Edwards. By the Survey taken chiefly in the eastern half of Vineyard Sound, and near the shores of Buzzards Bay; dredged in 3 to $x_{3}$ fathoms, chiefly on bottoms of gravel and sand; in nearly all cases empty shells.

Fish Hawk stations: 753 I (I shell), 7534 (I shell), 7535 bis (I shell), 7536 (Io shells), 7537 bis (many shells, mostly broken), $754 \mathrm{I}$ bis (several shells), 7546 bis, $755^{2}$ bis, 7556 bis (few shells), 7557 (I), 7563 (? I broken shell), $75^{6} 3$ bis (few shells), $761_{4}$ (few fragments), 7630 (few fragments), 7643 (I shel1), 7659, 7730 (I shell), 7748 (many shells), 7750 (I shell), $775^{2}$ (I'shell), 7753 (I small shell), 7757 (I shell), 7759 (I shell), 7760 (I shell), 7763 (I small shell), 7764 (many small shells), 7767 (few shells), 7768 (2 shells).

Phalarope stations: I (r shell), 6 (2 tips), 7 (I), 8 (shells and living), 9 (I), II (I), 42 (few shells), 62 (2), 63 (several shells), 69 (I), 70 (r shell), 74 (I), 76 (I), 77 (few shells), 83 (several shells), 84 (I shell), 9I, 92, 96, 97, 108, I09, Iro, II5 (shells common), I20 (shells), I23 (shells), I34 (I shell), I4I (few shells), I46 (2 shells), I6o (I fragment ?).

Eggs "deposited in July ... in an advanced stage of development." -Stimpson.

\section{Family ITTORINIDAE.}

\section{Littorina irrorata Say.}

Gould, I870, p. 3 II (not listed for this region); Verrill and Smith, 1873, p. 65I, 372; Dall; r889, p. r $_{4} 6$.

"Vineyard Sound, sparingly;" found on muddy shores; it "may have been introduced from farther south with oysters."'-Verrill.

\section{Littorina rudis Maton.}

Gould, 1870, p. 304 (Littorina rudis), p. 306 (L. tenebrosa); Verrill and Smith, $1873, \mathrm{pp} .65 \mathrm{r}$, 305; Dall, I889, p. I46.

Distribution general along stony shores throughout the region, commonly associated with $L$. litorea and $L$. palliata. Unlike the latter species, however, it is, in such localities, usually found upon the rocks themselves and seldom upon the rockweeds attached to them. Littorina rudis has a wide range of habitat, being found upon the surf-beaten bowlders at Gay Head, as well as upon eelgrass in Great Pond, where the water is somewhat brackish. It is strictly littoral, however, and hence even the shells are seldom dredged. 


\section{Littorina rudis-Continued.}

Phalarope and Blue Wing stations: 20 (I shell), 22 (I shell), 44 ( $x$ shell), 45 (I shell), 48, 5 I (several living, perhaps not taken by dredge), $5^{2}$ (I living and 2 shells), 60 (I shell), 94.

This species is viviparous. Dr. M. T. Thompson states that the eggs are carricd throughout the year.

\section{Littorina palliata Say.}

Gould, 1870 , p. 309 (not listed for this region); Verrill and Smith, 1870, pp. 652, 305, etc.; Dall, I889, p. I46.

Abundant and of general distribution along the shores throughout the region, though not recorded among the species dredged. 'This mollusk is seldom found locally except upon the common rockweeds (Fucus vesiculosus and Ascophyllum nodosum), where it is sometimes extremely abundant. It is very variable as to color and form, and might readily be regarded as belonging to a number of distinct species.

According to the observations of Dr. Sumner, the eggs are laid in small patches of clear, stiff jelly, which are deposited upon the weeds. These are abundant all through the summer, and are, perhaps, to be found throughout the entire year, having been taken as early as March r $_{4}$ (I908) and as late as November 30 (1907). A veliger stage is passed through while in the capsule, and the young which emerges from the latter is practically adult except as to size.

Littorina litorea (Linnæus). European periwinkle. [Chart I80.]

Gould, I870, p. 308 (listed only from Halifax); Verrill, I880a, p. 25I; Ganong, I886, p. 935; I889; M. T. Thompson, I899, p. 582 . (It is striking to note that this species is not even mentioned by Verrill and Smith, I873.)

Enormously abundant on shores, between tide marks; commoner among rocks, but of almost universal occurrence as a littoral species. The shells are frequently dredged, even in the deeper waters of Vineyard Sound and Buzzards Bay, whither they have doubtless in most cases been transported by hermit crabs. This species, which seems to have been originally European, "was first reported from Halifax in I 857 by Mr. John Willis, but Sir William Dawson states that he collected it in the southern part of the Gulf of St. Lawrence earlier than this, and Prof. E. S. Morse received it from Bathurst in 1855 . It was found near St. John by Mr. G. F. Matthew in I861 or 1862 . It was unknown on the coast of New England prior to

$$
\text { I6269 } 69^{\circ} \text { Bull. } 3 \text { r, pt } 2-13-12
$$

Littorina litorea-Continued.

1868, but has since spread southward very rapidly, reaching Casco Bay about 1873 , Cape Cod in r875, New Haven, Conn., in 1879." Ganong. "In 1872 it was very rare at Provincetown, Mass., but in 1875 it was common there. In 1875 it was collected by the writer at Barnstable, Mass., on the shores of Cape Cod Bay, in large quantities. In 1879 it had become exceedingly abundant at Provincetown. In 1875 our parties found two specimens only on the southern shores of Cape Cod, at Woods Hole, but in 1876 it was found to be common there, and is now very abundant." -Verrill.

Fish Hawk stations: $75^{2} \mathrm{I}$ bis (I), $75^{2} 5,75^{2} 5$ bis (I), $75^{26}$ (several shells), 7533 bis (I shell), 7534 (I shell), 7538 (I shell), 754I bis (I shell), 7542 (few shells), 7543 (few shells), 7544 (few shells), 7549 bis ( $\mathrm{x}$ shell), $755^{\circ}$ bis (I shell), 755 I bis (I shell), 7553 bis (I shell), 7554 (several shells), 7559 (I shell), 7560 (2 shells), 7579 (I shell), 7602 (2 shells), 76ro (I fragment), 76 I $_{3}$ (several shells), 76 44 (i shell), 76 I $_{5}$ (few), 7616 (I shell), 7617 (several shells), 76r9, 762 I (I shell), 7622 (I shell), 7625 (I), 7630 (few shells), 7632 (few shells), 7633 (I), 7634 (few living and shells), $76_{3} 6$ (several shells), $766_{3} 8$ ( 1 shell), 7640 ( 2 shells), 7644 (few fragments), 7645 (few shells), 7648 (few), 7650 (I fragment of shell), $76_{52}$ (I fragment), 7653 (I shell), 7656 (I shell), 7659 (few shells), 766r (I shell), 7662 (I shell), 7663 (I shell), 774I (I shell) 7761 (I shell), 7762 (I shell), 7769 (I shell), 7770 (I shell), 7774 (I shell), 7776 (I shell), 7779 (I shell), 778I ( 3 shells), 7782 (I shell).

Phalarope and Blue Wing stations: I (I fragment), 2 (I shell), 3 (several shells), 5 (I shell), 6 (several shells), 7 (few shells), I3 (2 shells), I8 (2 shells), 22 (shells common), 28 (several), 29 (I), 30 (I large), 33 (several shells), 50 (shells), 53 (I shell), 6r (I), 68 (I shell), 7 I (few shells), 72 (few shells), 78 (shells), 79 (few shells), 80 (few shells), 8I (several), 82 (several shells), 83 (I shell), 84 (few shells), 88 ( 1 shell), 89, 92 (shells), 93 (2), 94, 95, 97, 98, 103, I04, I09, Iro, II6, II7 (I shell), Ir8 (several shells), i I (few shells), I 20 (living and shells), I22 (many shells), I23 (few shells), I24 (shells), I2 5 (several shells), r26 (few shells), I27 (few shells), I28 (few shells), I29 (shells), I30 (few shells), I32, I33 (shells), I35 (I shell), I36, I37 (few shells), I38 ( $x$ shell), I39 (I fragment), I 40 (few shells), I4I (few shells), I42 (several), I45 (several shells), I49 (common), I 50 (few shells), I53 ( 1 shell), I $_{54}$ (I shell), ${ }_{58}^{8}$ (few shells), I6o 
Littorina litorea-Continued.

(I fragment), I6I (I fragment), I63 (I shell), I64 (2 shells), I65 (2 shells).

Gonads ripe, commencing middle of June; veligers noted latter part of August and early September; young I mm. in length taken off Nobska Point, September 20.-M. T. Thompson.

This valuable mollusk is entirely neglected on our shores; in some parts of Europe it forms an important item of food.

Lacuna puteola Turton. [Chart I8r.]

Vincyard Sound, abundant, chiefly at the inshore stations; in Buzzards Bay almost wholly confined to the neighborhood of the Elizabeth Islands; dredged in $I$ to $I 7$ fathoms, chiefly at depths less than 8 fathoms, and almost exclusively on non-muddy bottoms.-Survey. This species is often associated with Astyris lunata.

Fish Hawk stations: $75^{2} 5$ bis $(2)^{*}, 7549$ bis (I), 7557 (many), 7560 (several), 7572 (several), $75^{82}$ (few), $75^{8} 3,75^{89}$ ( 1 living), 7593 (3 shells), 7595 (several), 7596, 7602 (many shells), 77 I9*, 7720*, 7730 (2 shells), 773I (I shell), 776I (I shell), 7764 (many shells), 7767 (shells common), 777 I (I shell), 7778 (2 shells), 7779 (x shell), 778I (few shells).

Phalarope and Blue Wing stations: I7 (few), 20 (abundant among algæ), 22 (many living), 23 (I shell), 25 (few living), 27 (I shell), 28 (I shell), 29 (few), 30 ( $\mathrm{r}$ ), 32 (few), 33 (few living), 34 (few), 36 (few), 37 (few living), 38 (few shells), 40 (I shell), 42 (few shells), 44 (abundant), 46 (many living), 47 (very common living), 48, 50 (few), $5 \mathrm{I}^{*}, 5^{2}$ (few shells), 53 (few), 55,57 (few), $5^{8}$ (few living), 60 (few shells), 62 (I), 64 (I shell), 65 (few), 66 (I), 67 (I shell), 69 , 72,73 (abundant), 74 (many), 75 (several), 82 (I shell), 87 (few), 90,9 I, 92 (shells), 99, I00, IOI, I02, IO4, IO5 (shells), II2, II3 (I shell), Ix4 (I), II6, II7 (I), II8 (I shell), I2I (few living), I29 (I), I30 (common), I3I (abundant).

Lacuna vincta (Montagu).

Gould, I870, p. 302 (not listed for this region); Verrill and Smith, I873, p. 652, 305, etc.; Dall, 1889 , p. I46.

Vineyard Sound and Buzzards Bay, Sheep Pen Cove, Tarpaulin Cove, Cedar Tree Neck, Gay Head, Sow and Pigs Reef. Found among algae and eelgrass near low-water mark. Verrill states that this species occurs at depths of 4 or 5 fathoms, but this is certainly not usual locally, for it was recorded from only four of the survey dredging stations.
Lacuna vincta-Continued.

Fish Hawk station 7557 bis; Blue Wing stations: 47 and $5 \mathrm{I}$; Phalarope station III.

Taken in the act of spawning during February and March; the eggs have likewise been found December 10 . These are inclosed in ringshaped masses of jelly, commonly having a somewhat greenish tint.-Edwards, Sumner.

Lacuna sp. (undetermined).

Fish Hawk stations: 7721 (young), 7725.

\section{Family LITIOPIDA.}

Litiopa melanostoma Rang.

Verrill, 1882a, p. $5^{23}$ (Litiopa bombix; not listed for this region); Dall, I889, p. I48 (Litiopa bombix).

Menemsha Bight, on gulfweed.*

\section{Family RISSOIDE.}

\section{Rissoa arenaria (Mighels).}

Fish Hawk station $7718^{*}$ (off Gay Head, I4 fathoms, sand and shells).

Rissoa exarata Stimpson.

Gould, I870, p. $30 \mathrm{I}$ (not listed for this region); Verrill and Smith, 1873, p. 654, 495; Dall, I889, p. I48.

"Rocky bottoms off the open coast," rare; a northern species.-Verrill. Not specifically recorded for this region, though the latter lies within the stated range of the species.

Rissoa stimpsoni Smith.

Verrill, I882a, p. 523 .

Woods Hole.

Cingula minuta (Totten).

Gould, I87o, p. 289 (Rissoa minuta; not listed for this region); Verrill and Smith, 1873, p. 653 , $38_{3}$, etc. (Littorinella minuta).

"Brackish and muddy shores of ... Buzzards Bay, Vineyard Sound ...'-Verrill. South arm of West Fialmouth Harbor, between tides. (Collected by Cole, identified by Dall and Bartsch.) Dredged in Vineyard Sound, at Fish Hawk station $755^{\circ}$ bis (probably an empty shell).

Verrill states that this species forms much of the food of certain small fishes and aquatic birds.

\section{Cingula aculeus Gould.}

Gould, IS7o, p. 299 (Rissoa aculeus; not listed for this region); Verrill and Smith, $1873, p$. 654,306 , etc. (Rissoa aculeus); Dall, I889, p. 148 (Rissoa aculeus).

Vineyard Sound, on algæ and under stones, along rocky shores; likewise on piles, etc., in brackish water.-Verrill. 
Skenea planorbis Fabricius.

Gould, 1870 , p. 296 (not listed for this region); Verrill and Smith, 1873, p. 655,383 ; Verrill, I878, p, 2 II ; I882C, p. 550; Dall, I889, p. I50.

Cuttyhunk Island.-Verrill. Listed for rocky shores; also for piles, etc.

Family AssIMINEIDA:

Assiminea modesta (Lea).

Verrill, r884a, p. 253 .

Newport.

Assiminea grayana Leach.

Verrill, r882c, p. 525 .

Among decaying seaweeds, at high-water mark, between tides, at Newport (I880).

Family TRUNCATELLIDE:

Truncatella truncatula (Draparnaud).

Verrill, r882c, p. 525 .

Considerable numbers taken on decaying seáweeds, at high-water mark, among docks at Newport, I880.

\section{Family CALYPTRAID死.}

Crucibulum striatum (Say). [Chart I82.]

Gould, 1870 , p. 275 (not listed for this region); Verrill and Smith, 1873, p. 651, 399, etc.; Dall, I889, p. I52.

"Vineyard Sound and Buzzards Bay, 3 to I2 fathoms, not uncommon."-Verrill. Western end of Vineyard Sound, beyond Quicks Hole, fairly frequent; Bay side of Sow and Pigs Reef, I station.--Survey.

Fish Hawk stations: $75^{82}$ (I shell), $75^{8} 5$ ( 2 shells, I living), 759 (6 shells), 7592 (I shell), 7598 (many living; some on Venericardia shells), 7664 (few living on Astarte), 7679 (I shell), 7680 (I living), 7682 ( $\mathrm{I}$ living and shell), 7688 (I living), 7698 (several living), 7699 ( 1 living), 7700 (2 shells), 7702 ( 1 living), 7706 (2 living and shells), 7708 (I small shell), 7709 (I shell), 7719 (I small shell).

Phalarope station 59 (I shell).

Crepidula fornicata Lamarck. Boat shell. [Chart I83.]

Gould, I870, p. 27I; Verrill and Smith, I873, p. 649, 417, etc.; Dall, I889, p. I52; Conklin, I897, p. I4; Mead, I898, p. 703; Bumpus, I8g8b, p. 857; Sumner, I910, fig. 22.

Abundant and of general distribution throughout the entire region; living specimens dredged rather more frequently in the Sound than in the Bay, being taken in 2 to Ig fathoms, on very varied bottoms. Extensive beds, composed very largely of shells of this species,
Crepidula fornicata-Continued.

occur in Vineyard Sound. This mollusk is perhaps most frequently encountered on the shells of hermit crabs. It is likewise usually present on the carapace of Limulus; sometimes on rocks or piles, or merely clinging to others of the same species. In the last case a considerable number may adhere in series, forming a sort of chain.

Fish Hawk stations: $75^{2 I}$ (few shells), 752 I bis (many shells), 7523 (few shells), 7524 (many large), 7524 bis (many large living), 7525 (I shell), $75^{2} 5$ bis (few shells), $75^{26}$ (several), $75^{2} 7$ (few small), 7528 (few), 7530 (many with eggs), 7530 bis (many shells), 753 I (many shells), 7532 (few small shells), 7533 (several shells), 7535 (few shells), 7536 (I shell), 7536 bis (few shells), 7537 (I shell), 7538 (few shells), 7540 (few shells), 754I (few shells), 7542 bis (few shells), 7543 (few shells), 7544 (x shell), 7545 bis (few fragments), 7546 (few shells), 7546 bis (many shells), 7547 bis (many shells), 7548 (few shells), 7549 bis (few living, on Polynices heros), 755 (living and shells), 755 I bis (few living and shells), $755^{2}$ (many living and shells), $755^{2}$ bis (few shells), 7553 bis (few shells), 7554 (many small living), 7554 bis (few shells), 7555 (few on mussels), 7556 (many on shells), 7556 bis (many shells), 7557 (few on shells of Polynices heros and $P$. duplicata), $755^{8}$ (I shell) 7559 (many living), 7560 (several shells), 756I (few shells), 7562 (few shells), 7562 bis. (few shells), 7563 (many), 7563 bis (few shells), 7564 (few), 7564 bis (living and shells), 7565 (few shells), $75^{6} 5$ bis (I shell), 7566 (many shells), 7567 (many shells), 7568 (many shells), 7569 (few shells), 7569 bis (few shells and fragments), $757 \mathrm{I}$ (few shells), 7572 (few shells), 7574 (few shells), 7575 (few shells), 7576 (many living and shells), 7577 (many shells, few living), $757^{8}$ (few living, many shells), 7579 (few), 7580 (several shells), $758 \mathrm{I}$ (few living), $75^{82}$ (several), $75^{8} 3$ (few shells), $75^{84}$ (few), $75^{8} 5$ (several shells), $75^{8} 7$ (many shells), 7588 (many shells), 759 I (few shells), 7592 (few living and shells), 7593 (few shells), 7595 (many shells), 7596 (several shells), 7597 (many shells, few living), 7598 (many shells), 7599 (few shells), 7602 (few shells), 7610 (several shells), $76 \mathrm{r}_{3}$ (several fragments), $76 \mathrm{r}_{4}$ (few shells), 76I5 (several shells), 76I6 (few șclls), $76 \mathrm{I} 7$ (many living and shells), $76 \mathrm{Ig}$ (few shells) 7620 (many shells), 7621 (very many shells), 7623 (few shells), 7624 (very many shells), 7625 (very many shells), 7626 (very many shells) 


\section{Crepidula fornicata - Continued.}

7627 (many shells), 7628 (very abundant), 7629

(very many shells), 7630 (many shells), 7631

(very abundant), $763_{2}$ (several shells), 7633 (many shells), 7634 (many shells), 7635 (very many shells), 7636 (I shell), 7638 (few living), 7639 (I shell), 7640 (few shells), 764I (I shell), 7642 (I small shell), 7643 (few shells), 7644 (few shells), 7645 ( 2 shells), 7646 (few shells), 7647 (few shells), 7648 (many shells), 7649 (few shells), 765I (shells abundant), 7652 (many shells), 7653 (many living and shells), 7654 (few shells), 7655 (few shells), 7656 (few shells and living), 7659 (few shells), 7660 (few shells), 766r (few living and shells), 7662 (few living), 7663 (very many shells and few living), 7664 (few shells), 7665 (few shells), 7666 (few shells), 7667 (few shells), 7668 (few shells), 7670 (many living and shells), 7672 (living and few shells), 7674 (many shells), 7675 (many shells), 7678 (many living and few shells), 7679 (many large living and shells), 7680 (living and shells abundant), 768r (many shells), 7682 (living and shells), 7683 (few fragments), 7688 (I shell), 7694 (few shells), 7695 (few shells), 7696 , 7697 (few shells), 7698 (many living), 7699 (few living), 7700 (few living), $770 \mathrm{O}$ (few living and several shells), 7702 (many living), 7703 (many shells), 7704 (I shell), 7706 (many living), 7707 (few living), 7708 (few shells), 7709 (few shells), 7717 (few living and shells), 7719 (many living and shells), 773I (few shells, small living), 7733 (I shell), 7734 (many living and shells), 7736 (few shells), 7738 (I shell), 7739 (few shells), 7740 (many shells), 774I (few living and shells), 7744 (few shells), 7748 (I shell), 7749 (many living), $775^{1}$ (few shells), 7753 (few living), 7755 (few shells), 7757 (very many living and shells), $775^{8}$ (very many living and shells), 7759 (many shells and few living), 7760 (many shells), 776r (few living and many shells), 7762 (shells and living abundant), 7763 (many living and shells), 7764 (few living and shells), 7766 (many shells and fragments), 7767 (few shells), 7769 (few shells), 7770 (several shells), 777 I (several shells), 7773 (I shell), 7774 (few shells), 7776 (few small living), 7777 (few shells), 7779 (few small living and shells), 7780 (many living and shells), $778 \mathrm{I}$ (few living and shells), 7782 (few living and shells), 7783 (few living and shells).

Phalarope and Blue Wing stations: I (few shells), 2 (few shells), 3 (few shells), 5 (few living), 6 (several large living), 7 (many shells and few living), 8 (few), 9 (few), II (few), I2 (I), I3 (I
Crepidula fornicata-Continued.

shell), I5 (few living), I6 (I shell), I7 (I small), I9 (I shell), 22 (many shells), 24 (I shell), 25 (few shells), 26 (I shell), 27 (I shell), 28 (few), 29 (few), 30 (few), 32 (I shell), 34 (several small shells), 35 (shells), 37 (few small shells), 38 (I), 39 (few shells), 40 (few shells), 4I (few shells), 42 (few shells), 43 (shells), 50 (I small), $5^{2}$ (many shells), 53 (few shells), 56 (several shells), 57 (few), 58 (2), 59, 60 (few shells and living), 62 (few), 63 (few), 64 (few shells and living), 65 (many large shells), 66 (several shells), 68 (many living and shells), 69 (few shells), 70 (masses), 7 I (masses), 72 (masses), 73 (few living and dead), 74 (few shells), 76 (few fragments), 77 (few shells), 79 (r small), 80 (masses), 8I (abundant), 82 (few shells), 83 (many shells), 84 (masses, living and shells), $85,86,87$ (I shell), 9I , 92, 93, 94, 95, 96, 97, 98, 99, I00 (shells), тог (shells), ro2, ro7 (few shells), I08, I09, Iro, III (few), II3, II4 (shells common), II5 (shells common), II7 (few shells), II (few shells), I20 (shells), I2 I (shells common), I22 (shells common), I23 (shells common), I24 (shells), I25, I26 (very many shells), I28 (shells common), I29 (shells), I30

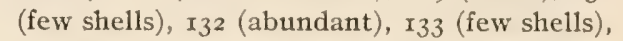
I34 (shells common), I35, I37 (few shells), I38 (few shells), I39 (abundant), I40 (common), I4I (shells), I42 (shells common), I43 (several shells), I44 (masses), I45 (abundant), I46 (several shells), $\mathrm{I}_{47}$ (living and shells common), I48 (shells abundant), I49 (abundant), I50 (many), I5I, I52 (few shells), I53 (few shells), I54 (many shells), I57 (I small), I58 (many shells and few living), I59 (few shells), I6r (I shell), I6 3 (I living, several shells), I64 (many shells), I65 (many shells), I66 (I living, many shells), I67 (abundant, shells forming considerable part of material brought up).

Eggs reported as early as April 6 (Mead) and as late as September I (Conklin).

\section{Crepidula convexa Say. [Chart I84.]}

Gould, r87o, p. 273 (Crepidula convexa), p. 274 (C. glauca); Verrill and Smith, 1873, p. 650, 355, etc.; Dall, I889, p. I52; Conklin, I897, p. I3; Sumner, 1910, fig. 23.

Inshore stations of Buzzards Bay and Vineyard Sound, common. Living specimens of this species were occasionally dredged by the survey at depths as great as ${ }_{5}$ fathoms, though it was commonly taken at depths of less than 8 fathoms, occurring upon very varied bottoms. In its habitat, Crepidula convexa differs very characteristically from the other two members 
Crepidula convexa-Continued,

of the genus which are present locally, the former being almost exclusively a littoral or adlittoral form. It is commonly found upon the shells of Littorina litorca and Ilyanassa obsoleta, when occupied by Pagurus longicarpus; occasionally upon the shells of the living mollusks, or even upon eelgrass.

Fish Hawk stations: 7524 bis (? I living), 7525 bis (? I living), 7532 (I), 7546 bis (? living), 7547 bis (? living), $755^{2}$ bis (I shell), 7560 (I), $75^{84}$ (2, I living), 762 I (? few shells), 7630 (I living), 7632 (I living), 7654 ( 1 shell), 7668 (I living), 7672 ( 3 living), 7725 ( 2 living), 7782 ( $\mathrm{s}$ shell and I living).

Phalarope and Blue Wing stations: 6 ( $\mathrm{x}$ living), 9 (I), I7 (I living), I9 (common on Tritia and Littorina), 20 (I living on Tritia), 34 (I fragment), 50 ( 1 on Littorina), $5^{2}$ (several living), 53 (x), 62 (several living), 68 (2 living on Tritia) 7 I (I living), 72 (I with eggs), 78 (I on Anachis shell), 79 (on Littorina), 80 (many shells), 8r (r), 82 (I living), 83 ( 1 living), 93 (I living), $94,95,98,104,107$ (I shell), 109, 122 (x living), I26 (I living), I30 (I shell), I34, I36, I38, I40 (few shells), I45 (few living), I47 (2 living), I 50 ( I shell), I $_{2}$ (I living), I 54 (several shells), $I_{57}, 5^{8}$ (2), I63 (I small living), I64 (several living), I65 (several living and shells), I66 (I shell), I67 ( 1 living).

Breeds from July I to September I; males smaller than females and motile.-Conklin. "A depressed variety (glauca) is found, chiefly on broad and nearly flat surfaces."-Verrill.

.Crepidula plana Say. [Chart 185.$]$

Gould, I870, p. 272; Verrill and Smith, I873, p. 650,355 , etc. (Crepidula plana and Crepidula unguiformis); Dall, I889, p. I52; Conklin, 1897, p. 12; Thompson, 1899, p. $5^{82}$.

Abundant and of general distribution throughout the shallower and deeper waters of the region. Distribution coextensive with that of the hosts. Most frequently found inside shells occupied by hermit crabs; small specimens (perhaps a "dwarf variety"-Conklin) being associated with Pagurus longicarpus, larger ones with $P$. pollicaris and $P$. acadianus; also occurring on the outside of oysters, on Limulus and in other places. Dredged by the Survey in 2 to 25 fathoms, on every variety of bottom.

Fish Hawk stations: $75^{2} \mathrm{I}$ (few shells), $75^{2} \mathrm{I}$ bis (few shells), $75^{23}$ (few shells), $75^{23}$ bis, $75^{24}$ (few shells), $75^{2} 5$ (few shells), $75^{2} 5$ bis, $75^{2} 6$ (several), 7527 (I), 7530 (few), 7530 bis (few living), 753 I (few), 7532 (few), 7534 (many in
Crepidula plana-Continued.

Polynices shells, I in Littorina shell), 753 ; (many), 7538 (many), 7540 ( 1 in Ilyanass shell), $754 \mathrm{r}$ (few shells), $754 \mathrm{I}$ bis (few shells), 7542 (many), 7543,7543 bis (many living), 7544 (few), 7545 bis (I small), 7546 bis (living), 7547 (few shells), 7547 bis (living), 7548 (few shells), 7549 (few shells), 7549 bis (many living in Polynices heros shells), 7550 (many), 755 I (many in Polynices shells), $755^{\mathrm{I}}$ bis (few living and shells), $755^{2}$ (few shells), $755^{2}$ bis (few shells), 7554 (many small in Polynices shells), 7556 (few in Polynices), $755^{6}$ bis (numerous shells), 7557 (many in and on shells of Polynices heros and $P$. duplicata), $755^{8}$ (few shells), 7559 (many in and on shells of $P$. heros and $P$. duplicata), 7561 (many in and on shells of $P$. heros and $P$. duplicata), $756_{3}$ (many: some on the outside of shells), 7563 bis (few shells), 7564 (several; some on the outside of shells), 7564 bis (living and shells), 7565 (I shell), 7565 bis (several shells), 7566 (few shells), 7567 (few shells), 7568 (few shells), 7569 (few shells), 7570, 757 I (r shell), 7572 (few shells), 7574 (few), 7576 (in Polynices shells), 7577 (few), 7578 (many living in Polynices shells), 7579 (many living in Polynices shells), 7581 (I), $75^{82}$ (several), $75^{8} 3$ (few shells), $75^{84}$ (few), $75^{85}$ (few shells), 7587. (I shell), 7592 (many in Polynices shells), 7595 (few), 7597 (few shells), 7598 (few shells), 7602 (I shell), 7609 (in Polynices shells), 7612 (I small), 76r3 (I shell), $76 r_{4}$ (few shells), $76 I_{5}$ (few shells), 76r 7 (many living), 7620 (few shells), $762 \mathrm{I}$ (many living and shells), 7624 (few shells), 7625 (few shells), 7626 (few shells), 7627 (few shells), 7628 (many shells), 7629 (few shells), 7630 (many small shells), $763 \mathrm{I}$ (common living), 7632 (many living and shells), 7633 (few), 7634 (several), 7635 (many shells), 7636 (I living), 7638 (several living), 7639 (few shells), 7640 (few living), $764 \mathrm{I}$ (few living), 7643 ( $\mathrm{I}$ shell), 7644 (few shells), 7645 (I shell), 7647 (I shell), 7648 (many living and shells), 765 I (few shells), 7652 (few), 7653, 7655 (r shell), 7656 (few shells), 7657 (few shells), $765^{8}, 7659$ (few shells), 7660 (many living), 766r (many living and shells), 7663 (many shells), 7664 (many living), $766_{5}$ (several living), 7668 (few shells), 7672 (several living and shells), 7674 (few shells), 7675 (few shells), 7676 (living in Polynices shells), 7677 (living in Polynices shells), 7678 (many living in Polynices, also shells), 7679 (living and many shells), 7680 (very abundant), 768I (living abundant), 7683 (few living), 7695 ( 1 shell), 
Crepidula plana - Continued.

7697 (many shells), 7698 (many living), 7699 (many living), 7700 (many living), 770 (many living), 7701 (many living), 7702 (tnany living), 7703 (living abundant), 7706 (many living), 7707 (many living), 7708 (few shells), 7709 (few living), $77 \mathrm{r} 7$ (few living and shells), $77 \mathrm{r} 8$ (few living and shells), 7719 (many living and shells), 7720 (many living), 7722 (few living and shells), 7724 (several living), 7725 (few living), 7726 (I living, $x$ shell), 7727 (I shell), 7728 (few living), 773 (few living and shells), 7732 (few living and shells), 7733 (few living), 7734 (many living and shells), 7735 (few living), 7736 (few living and shells), 7738 (2 shells), 7739 (few living and shells), 7740 (few living and shells), 774I (few living and shells), 7744 (few shells), 7749 (few shells), 7750 (I shell), 7753 (few living), 7757 (few shells), $775^{8}$ (few shells), 7759 (few living and shells), 7760 (few living), $776 \mathrm{x}$ (many living and shells), 7762 (many living and shells), 7764 (few living) 7765 (I living), 7766 (few living), 7767 (few living), 7768 (few living), 7769 (few living), $777^{2}$ (few living), 7773 (few living), 7774 (few living), 7775 (several shells), 7776 (few living), 7777 (few living), 7778 (few living), 7780 (few living), $778 \mathrm{I}$ (few living), 7783 (few living and shells).

Phalarope and Blue Wing stations: 2 (many), 3 (few), 5 (many living), 6 (few shells), 7 (many), 8 (few), 9 (few), Iо (few), II (few), I2 (I), I3, I5 (common), I6 (few living), I7 (many on Polynices heros), I8 (several on $P$. heros and Littorina), I9 (several living), 20 (few), 22 (few), 25 (few shells), 27 (I shell), 28 (few), 29 (r), 30 (few), 32 (I shel1), 34 (several shells), 36 (I fragment), 37 (few small shells), $3^{8}$ ( ( s shell), 40 (few shells), 4I (few shells), 42 (few shells), 43 (shells), 50 (I inside Littorina shell), $5^{2}$ (many living), 53 (many living), 59 (common), 60 (few shells and living), $6 x$ (several shells), 62 ( $\mathrm{x}$ living), 64 (many living on $P$. heros), 65 (many shells), 68 (many in $P$. heros shells), 69 (few), 70 (many), 7 I (shells abundant), 72 (several living), 73 (few living and shells), 74 (few shells), 76 (few living and shells), 77 (few living), 79 (I small), 80 (several), 8I (few shells), 82 (I shell), 83 (few), 84 (many shells), 86, 88 (I shell), 89, 93 (few living and shells), 94, 96, 97, $98,100,103,105$ (shells), 107 (few living and shells), I08, I09, IIO, III (I living), II3, II4 (few shells), II5 (few living and shells), II 7 ,
Crepidula plana-Continued.

II8 (few living and shells), I20 (shells), x2 I (several shells), I22 (several), I23 (few), I26 (shells common), I29 (living), I30 (common), I3I (few living), I32 (living and shells common), I35, I36 (many), I37 (few shells), I38, I39 (common), I4O, I4I (few living and shells), I42 (few shells), I 44 (common), I 45 (living and shells common), I47 (several living and shells), I5o, I5I, I52 (few shells), I55 (I shell), I 58 (shells), I6I (I shell), I63 (several shells), I64 (several shells), I65 (many living and shells), i66 (several living), I67 (few shells).

Eggs from July I to September-Conklin. Early cleavage stages found as late as September r9.-M. T. Thompson.

\section{Family NATICID王.}

\section{Natica pusilla Say. ${ }^{a}$}

Gould, 1870, p. 344; Verrill and Smith, 1873, p. 647,417 , etc.; Dall, I889, p. I54.

"Vineyard Sound and Buzzards Bay . . . common in 2 to Io fathoms."-Verrill. Chiefly recorded from inshore stations of Buzzards Bay.-Survey. Dredged in 2 to 7 fathoms (in one case $I 7$ fathoms), on quite various bottoms.

Fish Hawk stations: $755^{\circ}$ bis $^{*}, 7563$ bis*, $761 \mathrm{I}^{*}$, 7633 (?), 7634 (?), $7777^{*}$; likewise at a 1907 repetition of $7624^{*}$.

Phalarope stations: $71^{*}, 100^{*}, 101^{*}, 109^{*}, 122^{*}$, I29*, I3I (?), I33 (?), I36 (?), I38 (?), I40 (?), I 45 (?), I47 (? several), I 48 (? 2), I 52 (? 2), I 53 (? I living), I54* $156^{*}, 159^{*}$.

Natica clausa Broderip \& Sowerby.

Gould, I87o, p. 342 (not listed for this region); Verrill and Smith, 1873, p. 647 .

"One small dead specimen ... dredged ... in I9 fathoms, off Gay Head"; no record of living specimens south of Cape Cod.-Verrill.

Polynices duplicata (Say). [Chart I86.]

Gould, I87o, p. 345 (Neverita duplicata); Verrill and Smith, 1873, p. 646,354 , etc. (Neverita duplicata); Dall, r889, p. I54 (Neverita duplicata).

Fairly abundant and of general distribution both in Buzzards Bay and Vineyard Sound, from low-water mark down. Living specimens occasionally dredged at 2 to 8 fathoms; shells much more common and occurring at all depths, being frequently occupied by hermit crabs. Verrill's statement that this species is "generally much more abundant [than $P$.

$a$ Owing to a confusion which was at first made between this species and certain other small Naticidx, some of the records here given are not wholly trustworthy. Specimens from the starred stations, on the other hand, were referred to Alessrs. Dall and Bartsch. 
Polynices duplicata - Continued.

heros], except on the outer beaches," certainly does not apply at present to the greater part of Vineyard Sound. It is perliaps true, however, of the shallower waters skirting shore. Of eight living specimens of this genus collected at scattered points in the immediate vicinity of Woods Hole by Mr. Pope and assistants during June and July, IgII, all proved to be $P$. duplicata.

Fish Hawk stations: $75^{22}$ (I very small shell), 754 I bis (I shell), 7542 (2 shells), 7543 (I liv ing), 7554 (few shells), 7559 (few shells), 756I (I), 7563 (I shell), 7576 (I shell), 7577 (? I), $75^{85}$ (I shell), $75^{88}$ (I shell), 7602 (2 shells), $76 r_{3}$ ( 1 shell), 76 I $_{5}$ (several shells and living), 7617 (2), 7620 (I shell), 7622 (few shells), 7626 (I), 7627 (few), 7630 (few shells), 7632 (several), $76_{34}$ (I shell), 7637 (I shell), 7638 (few shells and I living), 7639 ( $I$ shell), 7644 (fragments), 7648 (I shell), 7653 (2), 7654 (I shell), 7657 (I shell), 7659 (I shell), 766r (several shells), 7675 (I fragment), 7719 (I shell), 7740 (several shells), 7753 (I shell), 7762 (several shells), 7766 (few shells), 7767 (several shells), 7769 (several shells), 7770 (I shell), 7773 (I shell), 7778 (several large shells), 778 I (I small shell), 7783 (I shell).

Phalarope stations: I9 (4), 28 (I), 52 (few, I living), 53 (I shell), 59 (I), 60 (I small shell), 63 (I), 66, 7 I (I shell), 73 (I shell), 76 (I shell), 79 ( $r$ shell), 8r, 82 (r shell), 84 ( I shell), 89, 90, 9I, 95, 96, 97, 100 (shell), Iог, I03, I09 (I shell), II3, II6, II8 (I young shell), I22 (few shells), I29 ( 1 living), I30 (few small shells), I3 I ( I living), I32, I35 ( 2 small), I38 (I), I40 (2 small), I43 (I shell), I44 (I living), I46 (I living), I 48 (I), I49 (I), I5I (I small), I54 (I living), I55 (fragments), I60 (I shell), I65 (I shell), I66 (I shell).

The egg cases of this species constitute "sand collars" similar to those of $P$. heros. Mr. T. E. B. Pope finds some evidence that more than one collar may be formed in a season. Eggs which were deposited in the laboratory were observed to hatch in a period of about two weeks.

Polynices heros (Say). [Chart 187.]

Gould, I870, p. 338 (Lunatia heros); Verrill and Smith, 1873 , p. 646, 353, etc. (Lunatia heros); Dall, I889, p. 154 (Lunatia heros).

Abundant and of general distribution throughout Vineyard Sound; far less frequent in Buz-
Polynices heros-Continued.

zards Bay, though not uncommon at the inshore stations; living specimens not infrequently dredged in 3 to 17 fathoms, predominantly on bottoms free from mud; shells of much more general occurrence, these being very frequently inhabited by hermit crabs (Pagurus pollicaris and $P$. acadianus).-Survey. This mollusk is common likewise in the shallow waters along shore, and its shells are familiar objects upon the beaches everywhere.

Fish Hawk stations: ${ }^{a} 75^{21}$ ( 2 shells), $752 \mathrm{I}$ bis (

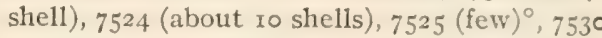
(2 shells), 7530 bis ( $\mathrm{r}$ ), 753 I (I shell) ${ }^{\circ}, 7533$ (fragment $)^{\circ}, 7534$ (several shells) $^{\circ}, 7535$ (few shells) $^{\circ}$, 7536 ( 2 small shells), 7536 bis (several living), 7537 (several shells), 7537 bis (I shell), 7538 (severalshells) $)^{\circ}, 7539$ (fragment) $^{\circ}, 754$ I (several shells) ${ }^{\circ}, 7542$ (many shells) ${ }^{\circ}, 7543$ (many shells), 7543 bis (several), 7544 (many shells), 7546 bis (several shells), 7547 bis (several shells), 7549 bis (several shells), $755^{\circ}$ ( $\mathrm{x}$ living, and shells) ${ }^{\circ}$, $755^{\text {I }}$ (few shells), $755^{2}$ (few shells) ${ }^{\circ}, 7553$ (I small shell) ${ }^{\circ}, 7554$ (several large and many small), 7554 bis, $755^{6}$ (few shells) ${ }^{\circ}, 7557$ (few large and small), $755^{8}$ (many shells) ${ }^{\circ}, 7559$ (sev-

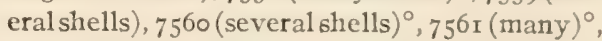
7562 (several shells) $^{\circ}, 7563$ (many shells) $^{\circ}, 7564$ (I), $75^{6} 4$ bis ( 2 shells), 7565 (few) $^{\circ}, 7566$ (I shell) 7567 (2), 7568 (several), $75^{6}$ (few small shells) ${ }^{\circ}$, 7570 ( 2 shells) ${ }^{\circ}, 7572$ (few shells) ${ }^{\circ}, 7574$ (few shells), $757^{8}$ (3 living, several shells) ${ }^{\circ}, 7579$ (few

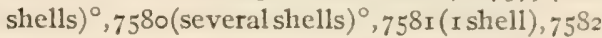
$(\mathrm{r})^{\circ}, 75^{8} 3$ (I small shell) $^{\circ}, 75^{8} 4$ (few shells), 7590 (2 shells) ${ }^{\circ}, 759$ I (I living, I shell) ${ }^{\circ}, 759^{2}$ (many shells) ${ }^{\circ}, 7593$ (I young) $)^{\circ}, 7594$ (several shells) $^{\circ}$, 7595 (living and shells) $^{\circ}, 7598$ (few small shells and I living) ${ }^{\circ}, 7599$ (many large living), $760 \mathrm{I}$ ( small shell) ${ }^{\circ}, 7602$ (many shells) $^{\circ}, 7607$ (2 living, 2 shells) ${ }^{\circ}, 7633$ (?), 7634 (?), $76_{37}$ (I shell), 7638 (I), 7645 (I shell ?), 7650 (? I living), 7664 (I), 7667 (I living), 7675 (I shell), 7676 (I), 7678 (many shells, mostly large, and I living), 7679 (living and large shells), 7680 (many large shells), 768I (many shells), 7682 (several shells), 7683 (I fragment), 7692 (I fragment), 7698 (I living and few shells), 7699 (several shells), 7700 (I living, several shells), 770 or (I living, several shells), 7702 (many large shells), 7703 (many shells), 7704 ( $r$ living), 7706 (several living and shells), 7707 (many shells), 7708 (many shells), 7709 (many shells), 7710 (I shell), 77 I7 (2), 7718 (several shells), 7719 (many shells),

a During the summer of 1903 (Fish Hawk stations 7521 to 7607 ) the distinction was not always made in the field records between small shells of Polynices heros and those of $P$. triseriata. It is likely, therefore, that certain of the foregoing records refer in part to the latter species. The symbol ${ }^{\circ}$ denotes those cases in which such ambiguity is believed to be possible. 
Polynices heros-Continued.

7720 (few shells), 7722 (I large shell), 7725 (I shell), 7726 (many shells), 7727 (2), $7730^{\circ}$ (several), 773 I (few shells), $773^{2}$ (2 shells), 7733 (2 shells), 7734 (many living and shells), 7735 (I shell), 7736 (several shells), 7739 (several shells), 7740 ( $\mathrm{r}$ living and few shells), 774I (few shells), 7745 (I small fragment), 7757 ( 1 large shell), 7759 (I shell), 7760 (few), 776r (few' shells), 7762 (few shells), 7766 (few shells), 7767 (2 shells), 7769 (I large shell), 7772 (several shells), 7773 (I shell), 7774 (2 large shells), 7777 (several shells), $777^{8}$ (few shells), 7780 (several shells), $77^{8} 3$ (several shells).

Phalarope stations: 3 (I shell), 5 (I large shell), 7 (few shells), 8 (I), 9 (I fragment), Io (I fragment), II (I fragment), I3 (I fragment), I5 (I shell), I7 (I shell), I8 (2 shells), 25 (I shell), 30 (I shell), 52 (few shells)*, 53 (few shells), $57^{*}$, 59 (shells common), 60 (I shell), 6x (several shells), 64 (I shell), 65 (few shells), 66 (few shells), 68 (few shells), 7 I (several living and shells), 74 ( 2 shells*, I living), 76 (several shells), 77 (I), 96*, IO2 (I shell), III*, II7 (I shell), I 8 (I shell), I22 (I shell), I3I, I40 (I shell), $15^{8}$ (I shell).

The "sand collars" of this and the preceding species are cast up on the beaches throughout the summer. They are likewise frequently dredged in Vineyard Sound.

This and the preceding species feed upon various mollusks, whose shells they perforate by means of the lingual ribbon.

\section{Polynices triseriala (Say). [Chart I88.]}

Gould, I870, p. 340 (Lunatia triseriata); Verrill, 1872 , p. 282 (Lunatia heros, var. triseriata); Verrill and Smith, 1873, p. 646,354 , etc. (Lunatia heros, var. triseriata); Dall, I889, p. I54 (Lunatia heros, var. triseriata.-Dr. Dall now regards this as a true species).

Abundant and of pretty general distribution, both in Vineyard Sound and Buzzards Bay; far commoner in the latter than $P$. heros, but somewhat less frequent in the former.-Survey. Living specimens dredged in I to I2 fathoms, on various bottoms, including muddy ones; shells widely distributed by hermit crabs. Verrill's statement that this "variety" "is the more common form in the deeper waters" (i. e. commoner than $P$. heros) does not hold for the region dredged.

\section{Polynices triseriata - Continued.}

Fish Hawk stations: $a$ 752I bis, $75^{23}$ bis (I), 7525 bis ( $\mathrm{I}$ shell), 7532 bis ( $\mathrm{I}$ living), 7536 bis ( $\mathrm{I}$ shell), 7537 bis (2 shells), 754I bis (I shell), 7545 bis (I living), 7546 bis (few shells), 7549 bis ( $\mathrm{x}$ shell), 7553 bis ( $\mathrm{I}$ shell), 7554 bis (living and I shell), 7557 (I), 7563 (3), 7564 bis (I small shel1), 7567 bis, 7574 (I), 7576 (I shell), $75^{84}$ (I), $75^{85}$ (I), 7586 (few), 7604 (I small), 7608 (?), 7614 (several living), 7616 (few shells), 7617 (few shells), 7620 ( 1 living), 7630 (few living and shells), 7633 (?), 7638 (few shells), 7640 (I shell), 7643 (few shells), 7644 (few living and shells), 7645 (few shells), 7648 (I shell), $76_{50}$ (I living), $76_{52}$ (I), 7654 (I shell), 7657 (few shells), 7660 (several shells), 766r (several shells), 7662 (several shells), 7663 (few shells), 7664 ( I living), 7665 ( 1 shell and I living), 7666 (I shell), 7668 (fragment), 7669 (I shell), 767 I (several shells), 7672 (several living and shells), 7673 (few shells), 7674 (I muchworn shell), 7675 (few shells), 7677,7678 (sevcral shells), 7679 (I shell), 7680 (I shell), 768I (few shells), 7685 (I small living), 7687 ( 2 living and shells), 7688 (fragments), 7702 (I shell), 7706 (I shell), 7707 (2 shells), 7718 (I shell), 77 r9 (few shells), 7720 (I small shell), 7722 (several shells), 7724 ( 3 living), 7728 (I small living), 7729 ( $\mathrm{I}$ small living), $773 \mathrm{I}$ (few shells), $773^{2}$ (several shells), 7740 (I shel1), 7744 (fragments and I shell), 775 I (I shell), 7759 (I shell), 7766 (2 shells), 7780 (I shell).

Phalarope and Blue Wing stations: 5 ( $I$ shell), 6 (several shells and living), 7 (several shells), II (2), I 5 (2), I9 (living abundant), 20 (few), 22 (few shells), 23 (few), 28 (several), 30 (I), 32 (I), 33 (I shell), 35 (I shell), 36 (I shell), $4^{8}$ (I), 49 (shells), 5I (few living), $5^{2}$ (several living and shells), 53 ( $\mathrm{r}$ living), 56 (few living), 57 (few shells), 58, 59 (shells common), 60 (living and few shells), 62 ( 1 living and shells), 64 (several shells), 65 (several shells), 66, 67 (few shells), 68 (r living, few shells), 73 (I), 74 (few living and shells), 76 (few living and shells), 77 (I shell), 78 (few), 79 ( 2 shells), 80 (I shell), $8 \mathrm{r}$ (few), 83 (living and shells common), 89,9 , 92 (shells), 100 (living), ror, 102, 104, 106, 108, I IO, I I I (many living and shells), II 2, II3, II4 (few living and shells), II5 (few shells), II 7 (I shell), II8 (I living and I shell), I22 (several shells), I23 (living and shells common), I 28 ( $x$ shell), I32 (r shell), I36, I40 (few shells), I62 (I shell), I6 3 (I shell).

a See note under Polynices heros. Certain records for the latter perhaps apply to the present species. The converse is not believed to be true. 
Polynices immaculata ('Totten).

Gould, I87o, p. 344 (Mamma? immaculata); Verrill and Smith, I873, p. 646, 508 (Lunatia immaculata); Dall, 8889 , p. I54 (Lunatia immaculata).

Newport.-Totten, cited by Gould. "Off Marthas Vineyard, 20 fathoms"; a northern shell.Verrill. Vineyard Sound, at Fish Hawk station 7549 (I small shell)*. South arm of West Falmouth Harbor* (collected by L. J. Cole).

PPolynices nana (Möller)

Verrill, I882c, p. 516 (Lunatia nana).

South of Marthas Vineyard and Block Island; 22 to 29 fathoms, I880 and I88I.

Polynices sp. (undetermined).

Fish Hawk stations: $7568,7586,7604,7608,7609$, $76 \mathrm{I} 4,770 \mathrm{I}, 7730,7732,7767,7776$.

Phalarope stations: $52,57,64,65,68$, III,- I65 (I fragment), I67 (I fragment).

Some of these specimens were identified in the field as $P$. immaculata, but the identification now seems doubtful.

Polynices sp. (egg cases).

Fish Hawk stations: 7534 (I), $755^{\circ}$ (few), 7563 (few), 7567 (I), 7578 (I), 7590 (fragments), $759 \mathrm{I}$ (fragments), 7596 (r), 7609 (fragment), 76I5 (fragment), 7700 (I), 7717 (I), 7740 (I).

Phalarope stations: I (I), 28 (I), 20.(I), 30 (I).

Family MarsenIID E.

Velutina lavigata Gould.

Gould, I870, p. 334 (Velutina haliotoidea; not listed for this region).

Crab Ledge, August, I902, I5 to I7 fathoms*; Fish Hawk station 7609 (also at Crab Ledge), I living*.

Velutina zonata Gould.

Gould, I870, p. 335 (not listed for this region). Fish Hawk stations $7608 *$ and $7609 *$ (both at Crab Ledge); in each case, I living.

\section{Class CEPHALOPODA.}

\section{Family SPIRULIDA.}

Spirula peronii Lamarck.

Stimpson, I851, p. 57; Gould, I870, p. $5_{16} 6$ (Spirula fragilis); Verrill and Smith, 1873, p. 636 ; Dall, r889, p. r74.

Shells washed ashore at Nantucket.-Stimpson, Gould, Verrill. One found by R. L. Baird at Muskeget in I904; another by F. B. Sumner at No Mans Land in I904.
Family ACMAtid A:

Acmøa testudinalis (Linnæus). Limpet.

Gould, I87o, p. 267 (Tcctura testudinalis), p. 269 (Tectura alveus); Verrill and Smith, I873, p. 661, 307, etc.; Dall, 1889, p. I56.

"Marthas Vineyard, Cuttyhunk, and adjacent islands;" "comparatively rare and local south of Cape Cod."'-Verrill. Common at the end of Nobska Point, on rocks, below low-tide level. Recorded from Devils Foot Island, Tarpaulin Cove, and Round Hill Point. Dredged by the Survey at a few inshore stations, both in Vineyard Sound and Buzzards Bay, in 3 to 5 fathoms. These were all or nearly all dead shells.

Fish Hawk station 7536 (I shell); Phalarope stations: 7 I (several), 79 (I shell), 9I, I32 (I shell).

Verrill states that "a peculiar narrow form of this shell, (var. alveus)... lives on the leaves of eelgrass." We are informed by Dr. Dall that recent anatomical studies indicate that $A$. alveus is a good species.

\section{Family TrocmD死.}

\section{Margarites obscurus Gould.}

Gould, I87o, p. 283 (Margarita obscura; not listed for this region); Verrill and Smith, 1873, p. 66r, 508 (Margarita obscura); Dall, I889, p. I64 (Solariella obscura).

"Off Marthas Vineyard, 20 to 25 fathoms." -Verrill. Crab Ledge, at Fish Hawk station $7607^{*}$.-Survey.

Margarites undulatus (Sowerby).

Crab Ledge, August 19, I902, in 17 fathoms, living*.

Margarites sp. (undetermined).

Fish Hawk station 7609 (Crab Ledge). 
Loligo pealii-Continued.

during the winter. $a$ Taken in great numbers in the local fish traps; likewise at Menemsha Bight, where barrels of them are sometimes caught. Dredged in all parts of Vineyard Sound and Buzzards Bay, though such specimens were not necessarily caught at or even near the bottom. Eggs, however, were taken during the Survey dredging as deep as I5 fathoms, and it is therefore certain that the animal frequents depths as great as this. Indeed, Verrill states that it descends to 50 fathoms.

Fish Hawk stations: $75^{22}$ bis (2), 7530 (6 small), 7542 (few small), 7543 bis ( 1 ), 7547 bis (2), 7554 (2 small), 7570 (2 large, I small), 757 I (few), 7576 (2 small), 7578 (I large), 7579 (many), 7580 (2), 758 I (few small), $75^{82}$ (r small), $75^{8} 3$ (several small), $75^{84}$ (few small), 7586 (2 small), $75^{89}$ (few small), 7590 (few small), 759 (several, I large), 7592 (few small), 7599 (I large), 7600 (2 large), 7612 (2), 7613 (2 large, many small), $76 r_{4}$ (I large and several small), 76 5 (several small), 7618 (several small), 7619 (2), 7622 ( I small), 7627 ( 2 small), 7637 (I very small), $764 \mathrm{I}$ (x), 7643 (several small), 7644 (few small), 7653 (i small), 7656 (young), 7657 (few small), 7660 (few), 7662 (I adult), 7675 (I small), 7678 (several small), 7680 (I small), 768 I (2), 7683 (I), 7685 (several, mostly small), 7686 (several medium sized), 7687 (several medium sized), 7688 (4), 7704 (I small), 7708 (I medium), 7710 (2 small), 7724 (several), 7725 (I small), 7726 (several small), 7727 (2 small), 7729 (few small) 7730,7734 (3), 7735 (2), 7737 (2 small), 7739 (I medium sized), 7740 (few large and medium sized), 7749 (many), 7753 (I), 7754 (several large and small), 7756 (I), 7772 (I large, I small), 7775 (I), 7776 (2 large), 7778 (I small), 7780 (several), $778_{3}$ (several).

Clusters of eggs were dredged at the following stations: Fish Hawk stations: $75^{22}$ bis (I), $75^{24}$ (I), $75^{24}$ bis (I), $75^{25}$ bis (several), 7537 bis (I), 7543 bis (I), 7544 (I), 7548 (r), 7553 (I),
Loligo pealii-Continued. 7554 (I), 7557 (I), 756r (I, 7593 (I), 7624 (2), 7638 (several), $7656,767 x(2), 7762$ (2).

Phalarope stations: $2,8,9$ (I), $5^{2}$ (I), 76 (I).

The eggs are taken throughout the summer. Dr. Bumpus reports that they have been deposited in the laboratory in May, while Verrill states that the spawning occurs as late as September. Eggs were dredged by the Survey from July 6 to August 30 , at depths of from 4 to $I_{5}$ fathoms, on every sort of bottom, chiefly in Vineyard Sound. They are also found in fish traps, often in considerable numbers. The young are frequently abundant at the surface during the summer.

The squid is important as a food for many fishes. It is used extensively as bait by line fishermen, but its value as a food for man is not yet realized in this country.

Ommastrephes illecebrosa Verrill. Short-finned squid; "soft squid;" the common squid north of Cape Cod.

Gould, I870, p. 5 ro (Ommastrephes sagittatus); Verrill and Smith, I873, p. 634,441 , etc.; Verrill, I880, p. 289 ; I88r, p. 268 ; I882, p. $293^{-}$ 309,412 .

Distribution general, though this species is far less common than Loligo. Recorded by Verrill for Newport, Gay Head, and Vineyard Sound. Taken by trap fishermen at Menemsha and in the laboratory trap in Buzzards Bay.

For an interesting account of the habits of this species, see Verrill, I882, p. 305 et. seq.

\section{Family PHILONEXIDE.}

\section{Parasira catenulata Steenstrup.}

Verrill, 1878, p. 2 1о (Octopus granulatus); 1880, p. $293 ;$ 1881, p. $362 ; 1882$, p. 389 .

One specimen taken in Vineyard Sound in 1876 (collected by V. N. Edwards, identified by Verrill).

Properly a Mediterranean and West Indian form.

\section{Phylum CHORDATA.}

\section{Class ADELOCHORDA.}

Balanoglossus aurantiacus (Girard).

Verrill and Smith, 1873 , p. 627,35 , etc.; Morgan, I89I.

Beach beyond Nobska Point; Newport.-A. Agassiz. Naushon.-Verrill. Hadley Harbor; Bay shore of Penzance.-Morgan. Katama Bay; Tarpaulin Cove. (Collected by Dr. Os-
Balanoglossus aurantiacus-Continued. burn; identified with some doubt by Prof. Ritter as "Balanoglossus Kowalevskii A. Agassiz"). Balanoglossus occurs in beaches or flats of clear or muddy sand or gravel, into which it burrows rather deeply.

Tomaria abundant in tow in August.-Morgan.

a According to Mr. Edwards's records, the date of the earliest reported capture of squid in local waters has ranged, during the past $z 0$ years (1900-1909), from April 16 to May 7. The mean of these dates is April 26. 


\section{Class UROCHORDA (TUNICATA).}

Family Molgulida:

Molgula arenata Stimpson, $b$ [Chart igo.]

Gould, IS70, p. 2I; Verrill and Smith, I873, p. $699,4 i 9$, etc.

Region of Nantucket and Martlias Vineyard.Gould. "Vineyard Sound and Buzzards Bay, 5 to I $_{5}$ fathoms, sand and gravel." - Verrill. Western half of Vineyard Sound, fairly frequent; Crab Ledge, at one station; not recorded for Buzzards Bay; dredged in 2 to 25 fathoms, on bottoms of sand, gravel, and stones.-Survey.

Fish Hawk stations: $7532^{*}, 7560$ (abundant) ${ }^{*}$, 756 I (few), 7579, $75^{84}$ (2), 7596 (I), $759^{8}$ (I), 7609 (3 small $)^{*}, 7683^{*}, 7702$.

Phalarope stations: $32,33^{*}, 37,64$ (several), 66 (many), 67 (I), III (I).

? Molgula citrina Alder \& Hancock.

Crab Ledge at Fish Hawk station 7606 (I6 fathoms, gravel and stones), I specimen.*

? Molgula koreni Traustedt.

Vineyard Sound, at Fish Hawk stations $7524^{*}$ and 7563,8 to io fathoms, gravel and stones.

Molgula manhattensis (DeKay). [Chart Igr.]

Gould, I870, p. 25 (Ascidia manhattensis; no local records); Verrill and Smith, I873, p. 699, 3xr, etc.; Bumpus, r898a; Bumpus, r898b; Metcalf, r9oo.

Abundant on piers at Woods Hole, Vineyard Haven, and New Bedford. Recorded also from Nobska Point, Menemsha Pond, Katama Bay (abundant on eclgrass), Warellam River, West Falmouth Harbor, Round Hill Point. A very common species, with great diversity of habitat, being found in shallow waters near shore, as well as at considerable depths. Dredged by the Survey at scattered stations throughout Buzzards Bay; in Vineyard Sound seldom found far from land. Taken in 2 to $I_{5}$ fathoms, on every sort of bottom. Large clusters composed of this species and Stycla partita are sometimes encountered.

Fish Hawk stations: 7522 bis, 7524 bis (few), 7554 bis*, 7564 bis*, 7612* 7614,7615 (several clusters), $7616,7619^{*}, 7627$ (several), 7653 . Supplementary stations (I909): 76.48 (?), 7659 (?).

Phalarope and Blue Wing stations: $x$ (several), $5^{*}, S, 9,12,13,20,21,24(1), 32$ (few) $6 I^{*}, 6$; (I), 76,83 (2), $85,86,87$ (many), I00 (?), I Io, II7 (few), I2I (few), I30 (I), I34 (I), I45 (I).

Eggs ripe during May and probably throughout. the summer.-Bumpus.
? Molgula pannosa Verrill.

Verrill, 187 r, p. 55 .

Off West Chop, at Fish Hawk station $7524^{*}$, I specimen doubtully identified.-Survey.

Molgula papillosa Verrill.

Verrill, 1872; Verrill and Smith, 1873, p. 699, 495.

"Off Marthas Vineyard, 10 fathoms, stony," occurring "sparingly."

\section{Molgula pellucida Verrill.}

Verrill and Smith, I873, p. 699, 426 .

No definite local records, though this region lies within the range of the species as given by Verrill.

\section{? Molgula producta Stimpson.}

Gould, r870, p. 2 I (no local records); Verrill and Smith, 1873 , p. 6039,502 , etc.

"Off Buzzerds Bay, 25 fathoms;" this species "was dredged in some numbers on a bottom of fine sand, with some mud." (The foregoing record scarcely warrants the inclusion of this species in the fauna of the region.)

Molgula sp. undetermined.

Unidentified specimens referable to this genus were taken at Fish Hawk stations 7554, 7622, and 7686 , and Phalarope station 160 ; also at r9o9 repetitions of 7648 and $767 \mathrm{I}$.

\section{Bosirichobranchus molguloides Metcalf.}

Metcalf, I 900, p. $58_{3}$ (sp. nov.).

"Collected by Vinal N. Edwards, from soft mud, at a depth of 9 fathoms, in Buzzards Bay, near Woods Hole, Mass." A number of specimens taken.

Eugyra pilularis Verrill.

Verrill, 1872 (Molgula pilularis and Eugyra pilularis); Verrill and Smith, I873, p. 700, 509.

"Off Gay Head . . . , I9 fathoms, solt mud," covering itself with a thick coating of fine sand or mud.-Verrill.

Eugyra glutinans (Möller).c [Chart 190.]

Dredged by the survey at a number of stations in vicinity of Cuttyhunk, both in the Sound and the Bay; 3 to $r 7$ fathoms, sandy bottom.

Fish Hawk stations: 7686 (?), $7687^{*}, 7688$ (?), 7689 (?).

Phalarope stations: $30^{*}, 99^{*}$, ror (?), 102 (?), IO3 (?).

$a$ Specimens from points designated by an asterisk (*) were identified by Prof. WW. E. Ritter; those from points designated by a dasser ( $\dagger$ ) by Dr. W. G. Van Name

$b$ See note under Eugyra glutinans.

$c$ It is not unlikely that some of the specimens listed in the field as M lolgula arcnate likewise belong liere. "Extemally these two specics are very much alike. Identification of preserved specimens is hardly possible without dissection."- If. IE. Ritter. 


\section{Family CyNTHIIDA.}

Cynthia carnca (Agassiz).

Gould, I870, p. 25 (Ascidia carnea; no local records); Verrill and Smith, I873, p. 701, 495.

"Off Gay Head, Io fathoms, stony.'"-Verrill.

Halocynthia echinata (Linnæus).

Gould, I870, p. I8 (Cynthia echinata; no local records); Verrill and Smith, I873, p. 702, 495 Cynthia echinata).

"Off Marthas Vineyard, Io fathoms, stony, rare."-Verrill. Off Sankaty Head, in 20 fathoms, 2 or more specimens*. Crab Ledge, at Fish Hawk stations $7605^{*}$ (? I specimen) and 7606 ( 2 specimens); likewise one specimen found off Kopeecon Point at Phalarope station 66.-Survey.

Boltenia sp. undetermined.

Considerable numbers of a beautiful Boltenia have been dredged by the Survey and by various other collectors at Crab Ledge, in I6 to 25 fathoms on bottoms of gravel and stones. Prof. Ritter has been unable to determine with certainty the identity of this species. In the notes which he has furnished us it is entered as "Boltenia ovifera ( $\left.\mathrm{L}_{\text {. }}\right)$ ? Boltenia burkhardti Agassiz?"

Fish Hawk stations: 7603 (5), 7604 (2), 7605, 7606 (I), 7607 (several large and small), 7608 (several large), 7609 (I small).

Glandula arenicola Verrill.

Verrill and Smith, 1873, p. 701, 502 .

" Dredged by Mr. Prudden, off Cuttyhunk Island,

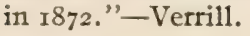

\section{Glandula sp.}

Verrill and Smith, 1873, p. 70r, 502.

Verrill records an undetermined species of this genus from "Vineyard Sound and off Marthas Vineyard, ro to 20 fathoms, sand." The specimens were less than one-fifth of an inch in diameter; "the integument was densely covercd by rather coarse and very firmly adherent grains of sand in several layers."

Styela partita (Stimpson). [Chart I92.]

Gould, I87o, p. I8 (Cynthia partita; no local records); Verrill and Smith, I873, p. 70I, 3 II (Cynthia partita); Bumpus, I898b, (Cynthia partita).

Generally distributed throughout the eastern half of Vineyard Sound; occasionally met with elsewhere in the Sound and in Buzzards Bay, where it appears to be confined to the inshore stations; dredged in 3 to ${ }_{5}$ fathoms on bottoms
Styela partita-Continued.

of sand, stones, and gravel.-Survey. Large clusters of this species, sometimes associated with Molgula manhattensis, Perophora viridis, Didemnum lutarium, and various hydroids, Bryozoa, and algæ, were not infrequently brought up in the dredge. It is common, also as a littoral species, being recorded from the stone wall of the local pier, Vineyard Haven and Fidgartown, on piles, Nobska Point, and Katama Bay.

Fish Hawk stations: $75^{21}$ bis (few), $75^{24}$ (several)*, $75^{24}$ bis (few), $75^{2} 5$ bis (few), $75^{26}$ (3 very small)*, 7528 (I), 7530 (I), 7532 (I on Eudendrium), 7534 (I), 7534 bis*, 7536 (many), 756 I (several), $774^{2}$ (much)*, 7744 (few small), 7745 (few)*, 7746 (I), 7749 (x), 7750 (few), 775 I (few), 7756 (I), 7763 (few), 7764 (few), 7765 (few), 7766 (few), 7767 (many)*, $7769^{*}, 7770$, 7774. Supplementary station (rgog): 7659 .

Phalarope and Blue Wing stations: I (many), 2 (few), 3 (few)*, 4 (I), 5 (I small), 6 (few), 7 (I) , 8, 9, 22, 24 (many), 25, 32 (few), 46*, 63 (abundant), 69 (I), $77^{*}$, II6, II8 (I small), I2I (few), I34 (I), I4I (I), I46 (few). Supplementary station (rgog): ${ }_{4} 46$.

Styela sp. undetermined.

A specimen believed by Dr. Ritter to belong to an undescribed species was taken in Vineyard Sound, at Fish Hawk station 7539.

\section{Family Ascidmda.}

Ascidia complanata Fabricius.

A specimen thus identified by Prof. Ritter was taken at Crab Ledge (Fish Hawk station 7608).

Ciona intestinalis (Linnæus).

Gould, I87o, p. 24 (Ascidia tenella; no local records); Verrill, I872, p. 99 (Ciona tenella); Verrill and Smith, r873, p. 698, 4r9 (Ciona tenella); Verrill, I88ob, p.25r (Ciona ocellata); Bumpus, I898a; Bumpus, I898b.

New Bedford.--L. Agassiz. Abundant at Newport.-Verrill. Sometimes very common in Woods Hole Harbor upon suitable objects. On January 4, I908, Mr. V. N. Edwards took great numbers from a "cod car" anchored at the Bureau of Fisheries pier*; and it was present in equal abundance upon the "cars" throughout the summer of r9o9. One or more specimens were collected by Dr. Osburn at Vineyard Haven, on piles July 3 I, 1906*. Mr. G. M, Gray reports the occurrence of this species in Little Harbor and in the Eel Pond. Ciona has not 
Ciona intestinalis-Continued.

been recorded during the survey dredging, though Verrill states that it occurs on dead shells, etc., at a depth of 20 fathoms.

"Ripe" throughout May (Bumpus); in July (F. W. Bancroft). Iiggs were fertilized throughout September, and as late as the $3 \mathrm{~d}$ of October, I909, by Prof. T. H. Morgan.

\section{Family BOTRYLLIDEA.}

Botryllus schlosseri (Pallas).

Gould, 1870 , p. 3 (no local records); Verrill and Smith, 1873, p. 702, 375 (Botryllus gouldii); Bumpus, $1898 \mathrm{~b}$ (Botrullus gouldii); Van Name, Igro, p. 350.

Woods Hole Harbor, on Revenue wharf, Eel Pond, Waquoit Bay, Tarpaulin Cove, also on floating eelgrass in the open Sound. Very abundant locally, encrusting eelgrass, rockweed, woodwork, and all sorts of objects in shallow water. Occasionally brought up in the dredge, when coming from depths of 3 to ro fathoms, though such specimens may have actually been taken near the surface, or may have been carried to the deeper waters by currents. Dredged near West Chop, at Penikese, and near Quisset.-Survey.

Fish Hawk stations: $75^{2} 5$ bis (small colony on Zostera), $775^{\text {I }}$ (2 large colonies).

Phalarope stations: 73 (on Zostera), Ir6, r3I (I colony).

"Found breeding from the 6 th to the end of July, and almost all the older colonies contained either large ova or embryos." - Bumpus, citing F. W. Bancroft.

The color of this species is extremely variable, so much so that Verrill distinguished nine different color varieties, though he did not make it clear whether or not these were intended as varieties in the taxonomic sense. Dr. Van Name informs us that Prof. Verrill himself attached very little importance to these "varieties."

\section{Family PEROPHORIDE.}

Perophora viridis Verrill. [Chart I93.]

Verrill, I87ra, p. 359 (sp. nov.); Verrill, I872; Verrill and Smith, I873, p. 702, 388; Bumpus, I898b; Lefevre, I 898 , p. 369; Van Name, IgII, p. 357 .

Little Harbor, Vineyard Haven, and Edgartown, on piles, abundant. Eastem half of Vineyard
Perophora viridis-Continued.

Sound, common; not recorded from the western half; two records for Buzzards Bay; dredged at 4 to 15 fathoms, chiefly on gravelly or stony bottoms, where it often occurred in company with Styela partita and other ascidians.-Survey.

Fish Hawk stations: $75^{24}$ (on Stycla), $75^{25}$ bis, 7536 (abundant, attached to seaweed), 7537 (few), 7537 bis (I), 7538 bis (abundant), 7539, 754 I bis (few), 7548 (few clusters), 7553 bis (very many), 7742, 7744 (little), 7745 ( 1 small bunch), 7746 (little), 7747 (much), 7748 (much), 7749 (much), $775^{\text {I }}$ (few), 7754 (much), 7755 (much), 7756 (much), 7757 (much), 7763 (few colonies), 7765 (little), 7773 (much), 7774 (few), 7775 (little). Supplementary station (1909): 7672 (several large colonies).

Phalarope stations: 62 (many), 63 (very abundant), 69 (several masses), 73 abundant), 77 (few), 135 (abundant).

\section{Family DIDEMNIDE:}

Didemnum lutarium Van Name. [Chart 194.]

Verrill, 1872 (Leptoclinum albidum and $L$. luteolum); Verrill and Smith, 1873, p. 705, 706, 403 , etc. (Verrill's local records for "Leptoclinum albidum" and "Leptoclinum luteolum" refer to Didemnum lutarium, which was confused by him with the more northern species); Van Name, igro, p. 37 I (sp. nov.).

Occurrence pretty general throughout Buzzards Bay and the eastern half of Vineyard Sound; in the western half of the Sound its occurrence seems to be limited to the inshore stations; Crab Ledge? $a$; dredged in $\mathrm{I}$ to $\mathrm{I}_{5}$ or more fathoms on all sorts of bottoms.-Survey. Recorded also from wharves at Woods Hole, Vineyard Haven, and Edgartown, and from drifted material on Nobska Beach. A very common species, incrusting shells, stones, algæ, sponges, and frequently other ascidians, such as Styela partita and Amaroucium.

"South of Cape Cod (including also the south shore of the cape) it is the common, and in most places the only, species of the genus. Probably all the published records of $L$. albidum and L. luteolum Verrill from that part of the coast refer to it. . . . North of Cape Cod thisform is local and for the most part replaced by Tctradidemnum albidum. "-Van Name.

a From what we know of the Crab Ledge fauna it seems possible that the specimens from this point (stations 7604 to 7609 ) might have belonged to the northern species, Telradidemnum albidum (Verrill). No material from these stations has been examined by Dr. Van Name. 
Didemnum lutarium - Continued.

Fish Hawk stations: $75^{22}$ (abundant), $75^{22}$ bis (small patches), $75^{24}$ bis (few small), $75^{2} 8$ (many), 7533 bis (several patches), 7537 (few small patches), $754 \mathrm{I}$ bis (little), $75^{6} 5$ bis (I small mass), $757^{2}$ (small mass), $75^{8} 7$ (I small mass), 7604 (I small piece), $7605,7606,7607$ (covering stones and Modiolus shells), 7608 (common), 7609 (2 patches), 7612 (I small patch), $76 \mathrm{r}_{3}$ (few masses) $\dagger, 7620$ (I mass), 7625 (several masses), 7626 (several masses), 7627 (several patches), 7629 (few masses), 7632 (I patch), 7633,7634 (few masses), 7639 (I mass), 7644 (small mass), 7659 (I large mass), 7742 (little) †, 7746 (little), 7749 (much), 775 I (little), $775^{2}$ (little), 7753 (much), 7754 (little), 7755 (several colonies) 7757 (much), 7759 (very much), $77^{60}$ (much), $77^{6} 3$ (much), 7765 (much), 7766 (little), 7768 (much), 7769 (little), 7772 (little), 7773 (little), 7774 (little), 7775 (much), 7777 (much), 7778 (much), 7780 (much), 7781 (little), 7782 (very little), 7783 (very little). Supplementary stations (I909): $7627,7629,7634,7636,7643,7648,7657,7659$, 7672 .

Phalarope and Blue Wing stations: I (few small masses), 2 (small piece), 5 (many patches), 6 (I patch), 7 (few patches), 8 (I small colony), 9 (I), Io (few crusts), II (I small colony), I2 (I small colony), I5 (I colony), 24 (I colony), 32 (small patch), 33 (few), 34 (few), 36 (I small mass), 45 (1 patch), 51 (few), $5^{6}$ (few), $5^{8}$ (I colony), 64 (several masses), 69 (I), 74 (I large colony), 77 (common), 8r (several masses), 83 (several masses), 85, 86, I09, I I2, II 3, II 5 (few), II6, II 7 (common), II8 (common), I2I (common), I24 (few masses), I28 (common), I30 (quantities), I3I (common), I33 (I colony), I34 (many colonies), I35 (abundant), I36 (common), 137 (abundant), I4I (abundant), I42 (abundant), I44 (several), I45 (few), I48 (common), I49 (common). Supplementary stations (Ig09): 83, I3 I, I46.

\section{Family SYNOICIDAs.}

Aplidium pallidum (Verrill).

Verrill and Smith, I873, p. 705, 496. (Amaracium pallidum); Van Name, I9ro, p. 400.

"Off Buzzards Bay, 25 fathoms, gravel;" "south of Gay Head, Io fathoms, stony." - Verrill. Vineyard Sound, near Cuttyhunk, at Fish Hawk station $7690+$ ( 9 fathoms,stony bottom). Survey.
Amaroucium pellucidum (Leidy). [Chart 195.]

Verrill, I87I, p. 290; Verrill, I872; Verrill and Smith, I873, p. 703, 40I, etc. (Amarceium pellucidum); Van Name, I91o, p. 404.

Abundant throughout the eastern half of Vineyard Sound; in the western half confined to inshore stations; recorded but twice from Buzzards Bay; dredged in I to $I 7$ fathoms, on bottoms of sand, gravel, and stones.-Survey.

Fish Hawk stations: $75^{21}$ (few colonies), $75^{2} \mathrm{I}$ bis (very abundant), $75^{22}$ (few colonies), $75^{24}$ (very abundant), $75^{25}$ (very abundant), $75^{25}$ bis (abundant), $75^{26}$ (few pieces), 7527 (abundant), $75^{2} 8$ (very abundant), 7529 (I mass), $753 \mathrm{I}$ bis (I colony), 7532 (great abundance), $753^{2}$ bis (many), 7533 bis (few), 7535 (abundant), 7536 bis (few), 7538 (very abundant), 7538 bis (very much), 7539 (numerous), 7540 (few), 754I (abundant), 754I bis (several colonies), 7542 bis (few), 7544 (abundant), 7544 bis (small fragments), 7546 (small piece), 7547 (many), $755^{\circ}$ bis (little), $755^{2}$ (few), 7553 (abundant), 7553 bis (much), 7554 bis (few colonies), $755^{8}$ (few masses), 7560 (few small pieces), $75^{6} 3$ (I piece), $75^{6} 5$ (I piece), $75^{6} 5$ bis (little), 7595 (I piece), 7645 (small mass), 7732 (few masses), 7737 (I large clump), 7738 (several small clumps), 7739 ( 3 clumps), 7745 (very little), 7749 (much), $775^{\circ}$ (very much), 775 I (much), $775^{2}$ (very much), 7754 (much), 7755 (few), 7757 (I colony), 7759 (much), 7760 (much), 7764 (common), 7767 (much), 7768 (much), 7769 (little), 7782 (little). Supplementary station (Igo9): 7672 (small colony).

Phalarope and Blue Wing stations: 2 (abundant), 3 (abundant), 4 (few), 9 (several colonies), to (quantities), II (I colony), I2 (several pieces), I3 (2 colonies), 22 (I small colony), 25 ( $\mathrm{x}$ small colony), 27 (I), 34, 37 (f cw), 38 (I mass), 44 (several pieces), 46, 47 (few small), $5^{\text {I }}$ (few), 56 (few), 62 (abundant), 63 (abundant), 66 (few colonies), 69 (I mass), 74 (many), 75 (few colonies).

"This species exists in two very dissimilar forms, which have been considered distinct species (the typical $A$. pellucidum, and $A$. constellatum Verrill), but which are in reality not even true subspecies, as is shown by some colonies which in one part have the typical pellucidum characters, while in the remainder of the colony the constellatum characters are equally well developed."-Van Name. 
Amaroucium pellucidum form constellatum (Verrill). [Chart 196.]

Verrill, r871a, p.359 (Amouroucium constellatum, sp. nov.); Verrill, 1872 (Amouroucium constellatum); Verrill and Smith, I873, p. 704, 388, etc. (Amarccium constellatum); Bumpus, $1898 \mathrm{~b}$ (Amarccium constellatum); Van Name, rgro, p. 406 .

Abundant and generally distributed in the eastern half of Vineyard Sound; elsewhere in the Sound, and in Buzzards Bay, it is almost wholly confined to the inshore stations; dredged in I to $x_{5}$ fathoms, on bottoms of sand, gravel, and stones.-Survey. Likewise common on piles in Woods Hole Harbor, Vineyard Haven $\dagger$ and Edgartown. $\dagger$

Fish Hawk stations: $75^{2} \mathrm{I}$ bis (many clumps), $75^{22} \dagger$ (several masses) ${ }^{a}, 75^{22}$ bis (several clumps), $75^{23}$ (several masses), 7523 bis (few masses), $75^{24}$ bis (I mass), $75^{26}$ (I small piece), $75^{27}$ (abundant), $75^{28}$ (many), 7530 (several masses), 753 I (3 small), 7532 (few), 7532 bis (I), 7536 bis (I small piece), 7537,7538 (several pieces), 7539 (several masses), $754^{\circ}$ (few masses), 7544 (I clump), 7547 (few), 7549 bis (I small colony), 7553 bis (few colonies), 7557 (few small pieces) $\dagger^{a}, 7588$ ( 2 pieces), 7595 (few pieces), 76rg (2 masses), 7645 (I small colony), 7737 (I large clump), 7738 (several colonies), 7739 (little), 7740 (little), 7746 (little), 7748 (little)†, 7749 (much), $775^{\circ}$ (much), $775^{\text {I }}$ (much), $775^{2}$ (common), 7754 (much), 7758 (little), 7759 (little), 7760 (little), 776r (little), $776_{3}$ (much),, 7764 (little), $776_{5}$ (little), 7766 (very little), 7767 (little)†, 7768 (much), 7769 (little), 7770 ( $\mathrm{r}$ small piece), 7772 (very little), 7773 (little), 7775 (little), 7777 (little), 778 I (little).

Phalarope and Blue Wing stations: I (few pieces) 2 (few), 3 (few), 9 ( I colony), Io ( 2 colonies), I I (common), I2 (several pieces), I4 (I colony), 22 (few), 24 (x colony), 25 (few), 30 (I mass), 32 (few pieces)?, 34 (few), 44 (scarce), 45 (many small), 46 (few small masses), 5I (few), 56 (few), 57 (few), $5^{8}$ (few), 62 (several), 63 (many), I II (young colony), II2, II3 (small colony), II8 (few colonies), I2 I (several), I30 (few), I3 I (few), I35, I36 (few). Supplementary station (I 909$): 83$ (? I mass).

Found frequently to contain large ova and em. bryos in July.-F. W. Bancroft, cited by Bumpus.
Amaroucium glabrum Verrill.

Van Name, I9io, p. 4 Io.

Vincyard Sound, near Cuttyhunk, at Fish Hawk station $7689 \dagger$ (9 fathoms, sand, and stones). Certain other specimens were referred by Prof. Ritter to this species, but are assigned to A. pellucidum constellatum by Dr. Van Name. We have adopted the identifications of the latter authority in the case of the composite ascidians.

Amaroucium stellatum Verrill. [Chart 197.]

Verrill, I871, p. 29r (Amouroucium stellatum, Sp.nov.); Verrill, I872; Verrill and Smith, 1873, p. 704, 402, etc. (Amaracium stellatum); Bumpus, I898b (Amarocium stellatum); Van Name, rgio, p. 4 I6.

Abundant and generally distributed throughout most of Vineyard Sound, though apparently wanting in the deeper parts at its western end; Crab Ledge, at several stations; not recorded from Buzzards Bay; dredged in $4 \frac{x}{2}$ to $I \gamma$ fathoms, on bottoms of sand, gravel, and stones.Survey. This species does not appear to occur in such shallow waters as the preceding, though the two are frequently taken together at moderate depths. They both form extensive colonies, which commonly are readily distinguishable from one another by their general appearance. A. stellatum has been collected by V. N. Edwards in shallow water at Sheep Pen Cove, though such specimens had perlaps drifted in from deeper waters. It is frequent in drifted material on Nobska Beach. Living specimens have been taken in January by both Mr. Edwards and Mr. Gray.

Fish Hawk stations: $75^{23}$ (several masses), 7525 bis (many masses), 7526 (few small pieces), $75^{27}$ (abundant), 7528 (many), 7530 (several masses), 753 I bis $\dagger, 753^{2}$ (few), 7532 bis (many), 7535 (few), 7537 (several pieces), 7538 (many masses), 7539 (few masses), 754 I (few masses), 754I bis (few), 7542 (many long and rope-like masses), 7542 bis (several living colonies), 7543 (2 pieces), 7543 bis (several masses), 7544 (several pieces), 7545 (few small pieces), 7547 (few pieces), 7548 (many pieces), 7550 bis (?), $755^{\mathrm{I}}$ (I piece) $\dagger, 755^{2}$ (few pieces), 7553 (few pieces), 7554 (several pieces), 7554 bis (numerous colonies), $755^{6}$ ( 1 ropy mass), $755^{8}$ (many masses), 7560 (several pieces), $756 \mathrm{I}$ (few masses), 7579 (3 large picces), 7580 (I mass), 7594 (I large piece), 7603 (few small)*, 7605, 7606 (few),

$a$ Specimens from stations 7522 and 7557 were identified as A. glabrum by Prol. Ritter, in the first case doubtfully. Dr. Van Name, after examining the same specimens, dissents from these determinations. In the present report we have consistcntly followed D. Van Name's identifications for all the composite ascidians submitted to him. 
Amaroucium stellatum-Continued. 7724 (several clumps)†, $77^{2} 5$ (little), 7729, 7730, 773 I (little), 7732 (little), 7733 (little), 7734 (I mass), 7740 (little), 7742, 7744 (little)†, 7745 (little)†, 7753 (I mass), 7755 (I mass), 7780 (2 colonies), 7782 (little), 7783 (little).

Phalarope stations: 2 (large masses), 3 (few), I5 (few colonies), 63 (3), 74 (several), 76 (very abundant), 77 (few).

Amaroucium sp.

A species which Dr. Ritter believes to be undescribed was dredged at Crab Ledge (Fish Hawk stations $7605,7606,7608$, and 7609 ) in 16 to 25 fathoms.

Doliolum sp.

Verrill and Smith, I873, p. 707, 446; Bumpus, I 898 b.

Vineyard Sound.-A. Agassiz, cited by Verrill. Often taken near Gay Head.-Bumpus.

Family SAIPIDAE.

Salpa democratica-mucronata Forskä1.

Gould, I870, p. 6 (Salpa caboti); Verrill and Smith, 1873 , p. 706,445 , etc. (Salpa caboti).

Quite common in Vineyard Sound and Buzzards Bay.-Gould. "Found in wonderful abundance on September 8, off Gay Head and throughout the outer parts of Vineyard Sound, and on several other occasions were nearly as
Salpa democratica-mucronata-Continued. abundant." - Verrill. The latter author speaks of these animals (locality not stated) as "at times completely filling the water for miles in every direction, from the surface to the depth of several fathoms, and . . . so crowded that a bucket of water dipped up at random will often contain several quarts of Salpe."

Verrill mentions a variety cyanea, taken in "Vineyard Sound, especially off Gay Head, in September."

Salpa zonaria-cordiformis (Pallas).

A specimen, thus identified by Prof. Ritter, was taken in the dredge (probably near surface) off Gay Head at Fish Hawk station 7718. Other specimens taken at the surface in the vicinity of Woods Hole (date unrecorded) have likewise been referred to this species by Prof. Ritter. Salpa of this or some other species are occasionally brought into the laboratory in considerable numbers.

\section{Family APPENDICULARIDAE.}

Appendicularia sp. sp.

Verrill and Smith ( 1873, p. 707,446 , etc.) list two undetermined species, " $a$ " and " $\mathrm{b}$ "; and Bumpus ( $1898 \mathrm{~b}$ ) reports the occurrence of a species of this genus which was "abundant near Gay Head, on July 28."

\section{Class MARSIPOBRANCHII.}

\section{Family MYXINIDAs.}

Myxine glutinosa Linnæus. Hag-fish, slime eel. Jordan and Evermann, 1896, p. 7; Kendall, ı9o8, p. I (in neither work recorded south of Cape Cod).

Crab Ledge, occasionally drawn up on codfish bait.-V. N. Edwards.

\section{Family PETROMyzonIdE.}

Petromyzon marinus Linnæus. Lamprey, lamprey eel.

Baird, 1873, (Petromyzon americanus); Bean, 1884; Jordan and Evermann, ı896, p. ıо;
Petromyzon marinus-Continued.

Bumpus, r $898 \mathrm{a}$, p. 58 ; H. M. Smith, I 898 , p. 88; Sharp and Fowler, I904, p. 505; Kendall, r908, p. I.

Buzzards Bay.-Smith, Edwards. Vineyard Sound.-Edwards. Taken in traps in May and June; not common, though reported to have been more so formerly. Nantucket, one specimen reported April, 1904.-Sharp and Fowler.

Known to spawn in Taunton River.-Edwards. Eggs ripe latter part of May; breeds as late as June $r 7$.-Bumpus.

Class PISCES. $a$

Family GALEIDA:

Mustelus canis (Mitchill). Dogfish (locally called "smooth dogfish," to distinguish it from Squalus acanthias).

Storer, I867, p. 252; Baird, r873; Verrill and Smith, I873, p. 521; Bean, I884; Jordan and
Mustelus canis-Continued.

Evernann, I896, p. 29; Bumpus, I898b, p. 85I (Galeus canis); H. M. Smith, I898, p. 88; Thompson, I899; Linton, I90I, p. 425; Sharp and Fowler, I904, p. 505; Field, 1907, p. Io et seq.; Kendall, Igo8, p. 3 .

a Spccimens from points designated by an asterisk (*) were identified by Dr. B. WV. Evvermann; those from points designated by a dagger $(t)$, by Dr. R. C. Osburn; those from points designated by a double dagger $(\ddagger)$, by Dr. F , B. Sumner. 
Mustelus canis-Continued.

Throughout the region, very abundant in shallower waters, on all kinds of bottom. Taken in traps (sometimes roo or more at once) and on lines; occasionally in the seine. Present from May to November, but most abundant in June.

Females containing eggs and embryos taken throughout the summer. Bumpus believes that there are probably two broods, in June and August, respectively. Thompson reports the capture of three females containing $27 \mathrm{em}$ bryos, ro to $\mathrm{rr} \mathrm{cm}$. long as late as about Sep. tember 25.

Food: Homarus americanus, Libinia emarginata, Cancer irroratus.-Verrill and Smith. Mostly crabs.-H. M. Smith. Usually crabs (Panopeus, Ovalipes, Cancer, Libinia, etc.), also squid, annelids, and fish.-Linton. In order of frequency: Cancer irroratus, Libinia emarginata, Homarus americanus, fishes (menhaden, puffer, scup, pipefish, sculpin, stickleback), Ovalipes ocellatus, Loligo pealii, Nereis (mostly $N$. virens), eelgrass (Zostera marina), Pagurus pollicaris, Ensis directus, Upogebia affinis, Panopeus depressus, Palamonetes vulgaris, amphipods, small gastropods.-I. A. Field.

Parasites: Nematodes (Linton)-Ascaris sp. Cestodes (Linton)-Calliobothrium eschrichtii, $C$. verticillatum, Dibothrium sp., Otobothrium crenacolle, Phyllobothrium loliginis, Rhynchobothrium bulbifer, $R$. heterospine, $R$. lomentaceum, R. tumidulum, Synbothrium filicolle, Tetrarhynchus sp. Copepods (C. B. Wilson)Alebion gracile, A. glabrum, Pandarus sinuatus.

Galeocerdo tigrinus Müller \& Henle. Tiger shark.

Baird, I873; Verrill and Smith, I873, p. $52 \mathrm{I}$; Goode, I884, p. 673; Jordan and Evermann, I896, p. 32; H. M. Smith, r898, p. 88; Linton, rgor, p. 425; Kendall, I908, p. 3 .

Woods Hole, I871.-Goode. Vineyard Sound and Buzzards Bay, in traps, occurring from August till October, rarely before August; present every year in variable abundance.Smith. Formerly more common.-Edwards.

Food: Buccinum undatum and Lunatia heros.Verrill and Smith, Goode. Fish (menhaden and bonito), Busycon canaliculatum and squid.-Linton.

Parasites (Linton): Nematodes-Acanthocheilus nidifex, Ascaris brevicapitata. Cestodes-Crossobothrium angustum, Monorygma sp., Ory'gmatobothrium paulum, Synbothrium filicolle, Tetrarhynchus bicolor, Thysanocephalum crispum.
Prionace glauca (Linnæus). Great blue sliark.

Jordan and Evermann, r896, p. 33; H. M. Smith, I898, p. 88; Sharp and Fowler, I904, p. 505; Kendall, r9o8, p. 4 .

Buzzards Bay, at breakwater, one taken in July, I877. One $70 \mathrm{~cm}$. long taken at Menemsha Bight, August 4, I905 (collected by Edwards, identified by Osburn, Cole and Sumner). Another, which was reported to be about I2 feet long, was taken in a trap at the same point August 21, 1906; and large specimens were reported during the summers of 1907 and Igo8, three being taken in the latter year.Edwards. Nantucket.-Sharp and Fowler.

Parasites (Linton):-Anthrobothrium laciniatum, Crossobothrium angustum.

Carcharhinus obscurus (I,e Sueur). Dusky shark.

Verrill and Smith, 1873 , p. 520 (Eulamia obscura); Bean, r884 (Carcharias obscurus); Jordan and Evermann, I806, p. 35; H. M. Smith, I898, p. 88; Linton, I9or, p. 426; Sharp and Fowler, I904, p. 505: Kendall, 1908, p. 4.

Vineyard Sound and Buzzards Bay, common. Present from June I through part of November: taken in traps and on lines.-Smith. Not so abundant as formerly.-E,dwards.

Food: Homarus americanus, Cancer irroratus.Verrill and Smith. Fish (menhaden and squeteague).-Linton.

Parasites: Acanthocephala (Linton)-Echinorhynchus clavaceps. Cestodes (Linton)-Anthobothrium laciniatum, Crossobothrium angustum, Discocephalum pileatum, Otobothrium crenacolle, Phoreiobothrium lasium, P. triloculatum, Platybothrium cervinum, Rhynchobothrium speciosum, R. tumidulum, Synbothrium filicolle, Tetrarhynchus bicolor, $T$. bisulcatus, $T$. robustus, T. sp. Trematodes (Linton)-Gasterostomumarcuatum. Copepods (C. B. Wilson)-Alebion gracile, Pandarus smithii, $P$. cranchii, Perissopus communis.

Carcharhinus milberti (Müller \& Henle). Blue shark.

Verrill and Smith, I873, p. 52 I (Eulamia milberti); Baird, 1873 (Eulamia milberti); Jordan and Evermann, 1896, p. 37 ; H. M. Smith, 1898 , p. 88 ; Linton, I90I, p. 426 ; Kendall, I908, p. 4 .

Four specimens about 4 feet long taken in a trap near the local breakivater, August 8, 1873.Smith. None seen since.

Food: One specimen contained a large quantity of Yoldia sapotilla.-Verrill and Smith. Bonito.-Linton.

Parasites (Linton): Immature nematodes; cestodes-Anthobothrium laciniatum, Crossobothrium angustum, Monorygma sp., Phoreiobothrium lasium, Platybothrium parvum, Rhynchobothrium tenaispine.

$$
\text { I6269 }{ }^{\circ} \text {-Bull. } 3 \text { I, pt } 2 \text { - } 13-\text { I3 }
$$


Carcharhinus limbatus (Müller \& Henle). Spotted-fin shark.

Goode, I884, p. 673 (Isogomphodon maculipinnis); Jordan and Evermann, I896, p. 40; H. M. Smith, I898, p. 88; Kendall, I908, p. 5.

Woods Hole in $1875 .-$ Goode. Quisset Harbor and at breakwater, at least 20 specimens during summer of 1878 ; all found dead in traps.-Smith.

\section{Family SPIYYRIDA.}

Sphyrna zygana (Linnæus). Hammerhead shark. Storer, 1867, p. 263 (Zygana malleus); Baird, 1873; Jordan and Evermann, I896, p. 45; H. M. Smith, I898, p. 88; Linton, I90I, p. 427; Sharp and Fowler, I904, p. 505; Kendall, I908, p. 5 .

Vineyard Sound, Buzzards Bay, Quisset Harbor; common. Nantucket.-Sharp and Fowler. Taken in traps from July to October, being most numerous in July and August.-Smith. Occasionally seen in local waters, swimming at the surface with caudal and dorsal fins projecting above surface, being sometimes harpooned in such cases. Local specimens, so far as known, all immature--Edwards. In recent years specimens have been recorded ranging in length from about 2 feet to 6 feet.

Food: Fish and squid.-Linton.

Parasites (Linton): Nematodes-Ichthyonema sp., Spiroptera pectinifer, immature nematodes. Cestodes-Anthobothrium laciniatum, Otobothrium crenacolle, Phoreiobothrium lasium, Platybothrium parvum, Tania sp., Tetrarhynchus sp.

\section{Family AlopIIDAs.}

Alopias vulpes (Gmelin). Thresher shark.

Baird, I873; Jordan and Evermann, I896, p. 45; H. M. Smith, 1898 , p. 89; Linton, I90I, p. 428 ; Sharp and Fowler, I904, p. 505; Kendall, r908, p. 5 .

Menemsha Bight (common), Gay Head, Buzzards Bay; taken from April till late in the fall; traps and hand lines.-Smith. Nantucket.-Sharp and Fowler. This shark, like the preceding, is a surface swimmer.

Food: Fish.-Linton.

\section{Family CARCharIIDAs.}

Carcharias littoralis (Mitchill). Sand shark.

Baird, 1873 (Eugomphodus littoralis); Verrill and Smith, 1873, p. 521 (Eugomphodus littoralis); Jordan and Evermann, r896, p. 46; H. M. Smith, I898, p. 89; Linton, I90I, p. 428 ; Sharp and Fowler, 1904, p. 506; Field, 1907, p. I6 et seq.; Kendall, I908, p. 6.
Carcharias littoralis-Continued.

Everywhere in shoal waters of Vineyard Sound and Buzzards Bay, sometimes entering the mouth of streams; the commonest local shark with the exception of Mustelus canis. Nantucket.-Sharp and Fowler. Present from June to November. Traps, lines, occasionally in seines.

Unripe eggs found July 8 and Io (I890, I892); immature through July.-F. R. Lillie in Marine Biological Laboratory card catalogue. Mr. Edwards states that he has never found the eggs of this shark.

Food: Homarus americanus, in abundance, Cancer irroratus, Loligo pealii.-Verrill and Smith. Fish, crabs, and various other animals.H. M. Smith. Menhaden, sea bass, scup, butterfish, and squid.-Linton. In order of frequency: Menhaden (probably eaten after capture in the trap), other fishes (flounder, scup, alewife, squeteague, sea robin, butterfish, bonito), squid.-I. A. Field.

Parasites: Acanthocephala (Linton)-Echinorhynchus acus, E. carcharia. Nematodes (Linton)-Acanthocheilus sp., Ascaris sp. Cestodes (Linton)-Crossobothrium angustum, C. laciniatum, Rhynchobothrium longicorne. Copepods (C. B. Wilson)-Alebion gracile, Anthosoma crassum, Caligus rapax, Nesippus alatus, Pandarus sinuatus, $P$. smithii.

\section{Family LAMNIDAE.}

Isurus dekayi (Gill). Mackerel shark.

Baird, 1873 (Isuropsis dekayi); Jordan and Evvermann, I896, p. 48; H. M. Smith, I898, p. 89; Linton, 1901, p. 429; Sharp and Fowler, 1904, p. 506; Kendall, I908, p. 6.

Buzzards Bay and Vineyard Sound, in traps, particularly at Menemsha; comparatively common, though not so common as formerly.Edwards. Most numerous in fall; taken until December.-Smith.

Food: Conger eel, fragments of fish.-Linton.

Parasites: Immature nematodes. Cestodes (Linton)-Anthobothrium laciniatum, Monorygma sp., Phyllobothrium sp., Platybothrium parvum, Tetrarhynchus robustus, Thysanocephalum ridiculum.-Copepods (C. B. Wilson)-Anthosoma crassum, Echthrogaleus coleoptratus.

?Lamna cornubica (Gmelin). Porbeagle, mackerel shark.

Jordan and Evermann, r896, p. 49; Kendall, I908, p. 7 . 
?Lamna cornubica-Continued.

A shark believed to be of this species was taken at Wauwinet, Nantucket, July 29 (year?).Howard Ayers, in Marine Biological Laboratory card catalogue. Not otherwise recorded for this region.

Carcharodon carcharias (Linnats). Man-eater shark.

Baird, 1873 (Carcharodon atwoodi); Verrill and Smith, 1873, p. 576; Jordan and Evermann, I 896 , p. 50; H. M. Smith, I898, p. 89 ; Kendall, I908, p. 7 .

Buzzards Bay in neighborhood of Woods Hole, rare. Recorded by Baird in I87I; two specimens taken in local trap in 1903 (June 17 and 25).

Parasites: Cestodes (Linton)-Dinabothrium septaria, Phyllobothrium sp. Copepods-Echthrogaleus denticulatus (Verrill and Smith); Pandarus sinuatus (C. B. Wilson).

\section{Family CETORHINIDE.}

?Cetorhinus maximus (Gunner). Basking shark, bone shark.

Jordan and Evermann, I8g6, p. $5^{\text {I. }}$

A specimen, apparently of this species, was taken in a trap at Menemsha Bight August r6, I906. It was reported as being I2 to $I_{4}$ feet long. This shark was identified by Prof. I. A. Field from a description given by $\mathrm{Mr}$. Edy Flanders. It was called a "bone shark" by the fishermen. Another large specimen taken at same point in 1908 .-Edwards.

\section{Family SQUALIDAE.}

Squalus acanthias Linnæus. Dogfish (called "horned" or "spiny" dog locally, to distinguish it from Mustelus).

Storer, 1867, p. 257 (Acanthias americanus); Baird, $x 873$ (Squalus americanus); Bean, 1884; Jordan and Evermann, 1896, p. 54; Bumpus, I898 a, p. 58; H. M. Smith, I898, p. 89; Linton, I90I, p. 430; Sharp and Fowler, I904, p. 506; Field, 1907, p. 18; Kendall, 1908, p. 8.

Buzzards Bay and Vineyard Sound; comparatively scarce in the neighborhood of Woods Hole at present, a fact in striking contrast to its pestiferous abundance at some other points of the coast. Formerly so numerous locally that it was the chief source of the "fish guano" produced at the Woods Hole factory. Abundant at Nantucket, according to Sharp and Fowler. Taken in May, and again in smaller numbers in October; not taken locally in the
Squalus acanthias - Continued.

intervening months.--Edwards. Caught in traps, seines, and gill nets.

Always full of well-developed embryos during the run.-Edwards. Embryos from Balfour's "B" to $30 \mathrm{~mm}$. in length; also young "pups" 6 inches long, July 2 to 17,1895 .-W. A. Locy, in Marine Biological Laboratory card cata$\log u$ e).

Food: In May largely ctenophores.-Smith. In order of frequency: Ctenophores (Pleurobrachia in great numbers, squid, Nereis, fishes (hake, herring).-I. A. Field.

Parasites: Nematodes (Linton)-Ascaris clavata. Cestodes (Linton)-Calliobothrium verticillatum, Monorygma sp., Phyllobothrium loliginis, Rhynchobothrium bulbifer, $R$. hetcrospine, $R$. imparispi:ze, Trilocularia gracilis. Copepods (C. B. Wilson)-Anthosoma crassum, Caligus rapax.

\section{Family SQUATINID王.}

Squatina squatina (Linnæus). Angel fish, monkfish.

Baird, ז873, (Squatina dumerili); Jordan and Everman, I806, p. 58; H. M. Smith, 1898 , p. 80; Kendall, I908, p. Io.

A single specimen, weighing 35 or 40 pounds, and 3 or 4 feet long, was taken in a trap at Menemsha Bight, September I, 1873.--Smith.

\section{Family RajIDAs.}

Raja erinacea Mitchill. Common skate, summer skate. [Chart 198.]

Baird, I873; Bean, I884; Jordan and Evermann, I896, p. 68; Bumpus, I898b, p. 85I; H. M. Smith, I898, p. 89; Linton, I9or, p. 430; Sharp and Fowler, 1904, p. 506; Field, 1907, p. 23; Kendall, I908, p. Io; Sumner, I9Io, fig. Io.

Common everywhere on sandy bottoms in the deep and shoal waters of Vineyard Sound; in Buzzards Bay having a much more restricted distribution. Present from April to October.-Edwards. Taken in traps, fyke nets and seines. Likewise dredged by the Survey in from 6 to 17 fathoms, particularly in the western end of Vineyard Sound; in the Bay dredgings only recorded from stations near the lower end.

Fish Hawk stations: $75^{24}$ (I), 7542 (I), 7543 bis (I small), 7547 bis (I medium), 7548 (I), 7553 (2), $756 \mathrm{r}$ (I), 7570 (r), 757 r (r), 7572 (I), 7579 (I), 7584 (I young, I adult), 7592 (I), 7593 (I large, I small), 7598 (I male), 7602 (I large, I small), 7662 (I very small), 7663 (I small), $767 x$ 
Raja erinacea-Continued.

(x), 7676 (2), 768I (I large, I small), 7686 (I), 7689 (I), 7698 (I young), 7699 (I), 7700 (I), 7702 (I small), 7703 (I young), 7708 (I), 7717 (I large, $\mathrm{I}$ small), $7719(\mathrm{I}), 7721$ (I), $7722(\mathrm{I}), 7724$ (2), 7725 (I small), 7726 (2 small), 7727 (I), 7728 (I small), 7729 (x small), 7730 (3), 776I (I small).

Prof. I. A. Field has frequently found encapsuled eggs (never more than one at a time) in the oviducts of this skate, at Menemsha Bight, during July and August. Judging from the condition of the ovaries he believes that the eggs are laid during the entire summer, perhaps from May until October. Bumpus states that "at times fully a bucketful of eggs have been deposited in the 'fish cars' in a single night" (month not stated).

Food: Usually Crustacea (hermit crabs, Cancer, Callinectes, Panopeus, etc., shrimps and amphipods), annelids, also bivalve mollusks, squid, and fish.-Linton. In order of frequency: crabs (rock crab and lady crab), shrimps, small fishes (mostly Ammodytes), squid, amphipods, razor clams, lobster, algæ.I. A. Field.

Parasites: Acanthocephala (Linton)-Echinorhynchus sagittifer. Nematodes (Linton)-Ascaris clavata, $A$. rotundata, immature nematodes. Cestodes (Linton)-Echeneibothrium variabile, Rhynchobothrium bulbifer, $R$. imparispine, $R$ : tenuispine, $R$. tumidulum, Tetrarhynchus sp. Copepods (C. B. Wilson) $-A r$ gulus laticauda, A. megalops, Caligus rapax, Lepeophtheirus edwardsi.

Raja ocellata Mitchill. Winter skate, big skate. Bean, I884; Jordan and Evvermann, I896, p. 68; Bumpus, I898a, p. 58; H. M. Smith, I898, p. 89; Linton, I90I, p. 43I; Kendall, I908, p. II. Common in Vineyard Sound in water of at least 5 or 6 fathoms; never taken in shoal water, and not found in Buzzards Bay,-Edwards. A specimen doubtfully assigned to this species was taken in Vineyard Sound, August 8, 1905 (at Fish Hawk station 7730). Present from February till June, and from October till the end of trap fishing; absent or very rare in summer.-Smith.

Food: Squid and annelids.-Lir ton. Mostly crabs.-Edwards.

Parasites: Nematodes (Linton)-Acanthocheilus sp., Ascaris rotundata, immature nematodes. Cestodes (Linton)-Echeneibothrium variabile, Phyllobothrium loliginis, Rhynchobothrium imparispine. Copepods (C. B. Wilson)-Caligus rapax.
Raja radiata Donovan. Starry ray.

Bean, I884; Jordan and Evermann, I896, p. 69; H. M. Smith, I898, p. 89 ; Kendall, I908, p. I2.

Menemsha Bight, fish traps; not common, none having been taken for years.-Edwards.

Raja eglanteria (Bosc). Briar ray.

Baird, I873 (Raia diaphana); Bean, I884 (Raia eglanteria); Jordan and Evermann, I896, p.7r; H. M. Smith, r898, p. 89; Kendall, r908, p. I2 .

Menemsha, not common, a few every year; formerly at the breakwater.--Smith. Woods Hole, one taken September I4, I9Ir.

Parasites (Linton): Acanthocephala-Echinorhynchus acus. Nematodes-Ascaris rotundata. Cestodes-Acanthobothrium paulum, Antho. bothrium laciniatum, Rhinebothrium minimum, Rhynchobothrium imparispine.

Raja lavis Mitchill. Barndoor skate.

Baird, 1873; Verrill and Smith, 1873, p. 52I; Bean, I884; Jordan and Evermann, I896, p. 7 I; H. M. Smith, I898, p. 89; Linton, I9or, p. 43I; Sharp and Fowler, I904, p. 506: Kendall, I908, p. I3.

Vineyard Sound and Buzzards Bay, in traps. Common in spring and fall, rare in summer.Smith. Nantucket.-Sharp and Fowler.

Food: Crago septemspinosus, Cirolana concharum, Nephthys incisa, Cerebratulus lacteus, Phascolosoma gouldii, Ensis directus, Tautogolabrus adspersus, Cancer irroratus, Homarus americanus.-Verrill and Smith ( $R$. lavis?). Lobsters.-Linton. Crabs.-Edwards.

Parasites: Nematodes (Linton)-Ascaris rotundata. Cestodes (Linton)-Acanthobothrium coronatum, Echeneibothrium variabile, Monorygma sp., Phyllobothrium foliatum, $P$. loliginis, Rhinebothrium minimum, Rhynchobothrium imparispine, Scolex polymorphus, Tetrarhynchus robustus. Trematodes (Linton)Distomum veliporum, trematodes undetermined. Copepods (C. B. Wilson)-Caligus curtus, C. rapax.

Raja sp.

Eggs of undetermined skates (probably chiefly $R$. erinacea) were dredged at the following points:

Fish Hawk stations: 7543 bis ( 1 ), 7545 (few), 7545 bis (I), 7546 bis (2), 7547 bis (I), $755^{2}(\mathrm{I})$, 7554 (2), 7554 bis (I), $755^{8}$ (several), 756I (few), $75^{6} 3$ (I), 7564 (I), 7565 (I), 759 I (I), 7592 (few), 7593 (several, I living), 7599 (I), 7620 (I), 7629 (I), $7648,76_{53}$ (I), 7657 (I), 766I (I), 7664 (I), $7671(2), 7672(2), 7676$ (I), 7679 (I), 7680 (I living), 7682 (I), 7706, 77 I 8 (few), $7720(4), 7744$ (I), $775^{2}$ ( $\mathrm{x}$ living).

Phalarope stations: $52(\mathrm{I}), 6_{5}(\mathrm{I})$. 
Family NarCOBATIDAE.

Tetronarce occidentalis (Storer). Torpedo, cramp fish.

Storer, 1867 , p. 272 (Torpedo occidentalis); Baird, I873 (Torpedo occidentalis); Jordan and Evermann, I896, p. 77; H. M. Smith, I898, p. 89; Linton, I90I, p. 432; Kendall, I908, p. I3.

Menemsha Bight, in traps, from May till November; most common late in the fall, at which time several may be taken together at one haul of the trap; reported, also, for Buzzards Bay. According to Smith the average weight of local specimens is 30 pounds. A specimen weighing I 44 pounds was sent to the station from Nantucket, October 23, 1908.

Eggs nearly ripe June 23, 1890 .- - Howard Ayers, in Marine Biological Laboratory card catalogue.

Food: Fish.-Linton.

Parasites (Linton): Calyptrobothrium minus, $C$. occidentale, Rhynchobothrium bulbifer, $R$. imparispine, Tetrarhynchus bisulcatus.

\section{Family Dasyatid 死.}

Dasyatis centrura (Mitchill). Sting ray.

Baird, 1873 (Trygon centrura); Verrill and Smith, I873, p. 52 I (Trygon centrura); Bean, I834 (Trygon. centrura); Jordan and Evermann, r896, p. 83 ; H. M. Smith, r898, p. 90; Linton, Igor, p. 432; Kendall, I908, p. I4.

Common in Buzzards Bay; rare at Menemsha, appearing in June or early July.-Edwards. Taken in traps.

Food: Cancer irroratus, Loligo pealii, Mya arenaria, Polynices heros.-Verrill and Smith. Crustacea and annelids, and in one case a small fish.-Linton.

Parasites: Nematodes (Linton)-Ascaris (?) sp., immature Cestodes (Linton)-Acanthobothrium paulum, Anthobothrium pulvinatum, Anthocephalum gracile, Lecanicephalum peltatum, Onchobothrium uncinatum, Orygmatobothrium crenulatum, Paratania medusia, Phyllobothrium foliatum, Rhinebothrium cancellat: tum, R. flexile, Rhynchobothrium hispidum, $R$. imparispine, $R$. longispine, $R$. tenuispine, $R$. wageneri, Spongiobothrium variabile, Synbothrium filicolle, Tetrarhynchus robustus, T. lintoni, $T$. sp. Trematodes (Linton)-Epibdella bumpusii Protozoa (Linton)-Intestinal parasites. Copepods (Wilson)-Alebion gracile, Caligus rapax, Lepeophtheirus thompsoni.
?Dasyatis hastata (DeKay). Sting ray.

Storer, 1867, p. 269 ("Pastinaca hastata"-uncertain whether $D$. hastata or $D$. centrura is intended); Jordan and Evermann, 1896, p. 83; Kendall, I908, p. I4.

Holmes Hole (Vineyard Haven)?-Storer.

Pteroplatea maclura (Le Sueur).-Butterfly ray.

Baird, I873; Jordan and Evermann, I896, p. 86; H. M. Smith, I898, p. 90 ; Kendall, I908, p.

I4. Buzzards Bay, rare.-Edwards. Observed mostly in August and September.-Smith. One taken July 28, I903.

Food: Crabs.-Edwards.

\section{Family MyLiobatida.}

Myliobatis freminvillei Le Sueur. Eagle ray, sting ray.

Baird, I873, Verrill and Smith, I873, p. 52r; Jordan and Evermann, I896, p. 89; H. M. Smith, I898, p. 90; Linton, I90r, p. 433; Kendall, I908, p. I5.

Buzzards Bay; taken in local trap from July to October; not very common.-Edwards.

Food: Homarus americanus in abundance; also Cancerirroratus, Mya arenaria, Polynices heros.Verrill and Smith. Large univalve mollusks, probably "Sycotypus."-Linton.

Parasites (Linton): Cestodes-Acanthobothrium paulum, Echeneibothrium sp., Rhinebothrium longicolle, Rliynchobothrium agile, $R$. imparispine, Tetrarhynchus robustus. TrematodesDistomum macrocotyle.

Rhinoptera bonasus (Mitchill). Cow-nosed ray.

Baird, 1873 (Rhinoptera quadriloba); Bean, 1884 (Rhinoptera quadriloba); Jordan and Evermann, I896, p. 90; H. M. Smith, I898, p. 90; Linton, I90r, p. 434; Sharp and Fowler, I904, p. 506; Kendall, I908, p. I5.

Buzzards Bay and Menemsha Bight, common in traps; 145 taken at Menemsha in one day, October I5, I902.-Edwards. Nantucket, Sharp and Fowler. Present from July to October.

No eggs noted.-Edwards. Ripe females, July 12, 1889.--Howard Ayers, in Marine Biological Laboratory card catalogue.

Food: Clams, gastropods, small lobsters, crabs, other Crustacea.-Linton.

Parasites (Linton): Echeneibothrium sp., Rhinebothrium cancellatum, $R$. longicolle, Rhynchobothrium agile, $R$. brevispine?, Tetrarhynchus robustus, Tylocephalum pingue. 


\section{Family ACIPENSERIDE.}

Acipenser sturio Linnæus. ${ }^{a}$ Common sturgeon.

Baird, 1873 (Acipenser oxyrhynchus and A. brevirostris); Jordan and Evermann, r896, p. I05; H. M. Smith, 1898, p. 90 (A. sturio and A. brevirostris); Bumpus, $1898 \mathrm{~b}$, p. $85 \mathrm{I}$ (Acipenser brevirostris); Linton, I90I, p. 435 (A. sturio and $A$. brevirostris); Sharp and Fowler, I904, p. 506; Kendall, 1908, p. 16 (A. sturio and $A$. brevirostrum?).

Vineyard Sound and Buzzards Bay, occasional; at times common, half a dozen having been seen at once. Nantucket.-Sharp and Fowler. Most numerous in June and July.-Smith. As late as last of September.-Edwards. Taken in traps.

Females carrying large eggs noted in June and July.--Eidwards.

Parasites: Acanthocephala (Linton)-Echinorhynchus attenuatus (listed for "Acipenser brevirostris"). Nematodes (Linton)-Dacnitis spherocephala. Cestodes: cysts. Trematodes (Linton)-Nitzschia elongata. Copepods (C. B. Wilson)-Caligus rapax.

\section{Family SILURID屈.}

Felichthys marinus (Mitchill). Sea catfish, gafftopsail.

Baird, 1873 (Elurichthys marinus); Jordan and Evermann, 1896, p. I18; H. M. Smith, I898, p. 90 ; Kendall, I908, p. I8.

One at Menemsha in 1871 . - Baird. Reported from New Bedford in 1879 (Goode); from Menemsha in 1886 (Smith). Another taken at same place September II, Igo6.

Galeichthys felis (Linnæus). Sea catfish.

Jordan and Evermann, I896, p. I28 (Hexanematichthys felis); H. M. Smith, I898, p. 9o; Kendall, I908, p. 18.

Vineyard Sound, very rare, none being recorded since I887; formerly reported common.Smith.

\section{Family ANGUILLIDIE.}

Anguilla rostrata (Le Sueur). Eel.

Storer, 1867, p. 215 (Anguilla bostoniensis); Baird, 1873 (Anguilla bostoniensis); Jordan and Evermann, r896, p. 348 (Anguilla chrysypa) Bumpus, 1898, p. 486 (Anguillachrysypa); H. M. Smith, I898, p. 90 (Anguilla chrysypa); Linton, I90I, p. 435 (Anguilla chrysypa); Sharp and Fowler, 1904, p. 506 (Anguilla chrysypa); Kendall, rgo8, p. 32 (Anguilla chrysypa); B. Bean, Igo9.
Anguilla rostrata-Continued.

Abundant and generally distributed along shores everywhere, particularly in weedy places; taken throughout the year. Three hundred and fifty barrels were caught in one trap in two weeks in October, 1896.-Smith. In winter they are speared through the ice.

Young 2 to $2 \frac{1}{2}$ inches long taken in March.Bumpus. Fishes of that length taken in tow in April and May.-Edwards.

Food: Shrimps, crabs, annelids, mollusks, small fish.-Linton.

Parasites: Acanthocephala (Linton)-Echinorhynchus clavceceps, E. globulosus. Nematodes (Linton)-Agamonema capsularia, Lecanocephalus annulatus, immature nematodes. Cestodes (Linton)-Dibothrium crassiceps, Rhynchobothrium bulbifer, $R$. heterospine, $R$. imparispine, $R$. sp. (cysts), Scolex polymorphus, Tonia dilatata, $T$.sp. Trematodes (Linton)Distomum grandiporum, $D$. ocreatum, $D$. vitellosum, D. sp. Copepods (C. B. Wilson)Argulus laticauda.

\section{Family LEPTOCEPHALID}

Leptocephalus conger (Linnæus). Conger eel.

Baird, 1873 (Conger oceanica); Bean, I884 (Conger niger); Jordan and Evermann, I896, p. 354 ; H. M. Smith, I898, p. 90; Linton, I90r, p. 436 ; Kendall, I908, p. 33.

Vineyard Sound, Buzzards Bay, Great Harbor; very common for several years, but rather rare formerly; quite abundant in I902, when 124 were taken in one fyke net at head of Great Harbor, in October.-Edwards. Appears in July and remains till fall. Taken in traps, lobster pots, and fyke nets and on lines.

Largest recorded local specimen, caught at Falmouth, weighed 12 pounds.-Smith.

Food: Fish (herring, butter-fish, eel), annelid (Nereis),-Linton.

Parasites (Linton): Acanthocephala-Echinorhynchus acus. Nematodes-Dacnitis hians, immature nematodes. Cestodes-Rhynchobothrium imparispine, larval cestodes (Scolex polymorphus). Trematodes-Distomum simplex, D. vitellosum.

\section{Family MURANIDĖ.}

Murcna retifera Goode \& Bean. Moray.

Jordan and Evermann, I896, p. 40r; H. M. Smith, I900; Kendall, 1908, p. 34.

One specimen ( 6 feet 2 inches long, weighing 39 pounds) taken in a lobster pot at Tuckernuck Island, July 25, I899.-Smith.

a The various records for "Acipenser brevirostris" (=brevirostrum) probably refer to "blunt-nosed individuals of the common sturgeon."-H. M. Smith. 
Family ELOPIDA.

Tarpon atlanticus (Cuvier \& Valenciennes). Tarpon.

Jordan and Evermann, I896, p. 409; H. M. Smith, 1898 , p. 90; Sherwood and Edwards, r9or; Kendall, I908, p. 34.

South Dartmouth (every year); occasionally at Quisset Harbor and Menemsha Bight.Smith. Woods Hole,-Sherwood and Edwards. Present chiefly during latter part of September; one recorded for August 3r. Taken in traps, but can not be sold locally for food. Weight of local specimens, 80 to Ioo pounds, of uniform size.-Smith.

Parasites (Linton): Ichthyonema globiceps.

Elops saurus Linnæus. Ten-pounder, big-eyed herring.

Baird, I873; Goode, r884, p. 6ri; Jordan and Evermann, I896, p. 4Io; H. M. Smith, I898, p. 90; Sharp and Fowler, I904, p. 507; Kendall, I908, p. 35 .

Marthas Vineyard, southward.-Goode. Vineyard Sound, Vineyard Haven.-Smith. Edgartown, Tisbury Pond.-Edwards. Nantucket.-Sharp and Fowler. Common; reported as more numerous of late years. Present only in the fall, none being recorded before October; then taken in traps and herring gill nets.-Smith.

Parasites (Linton): Rhynchobothrium bulbifer.

\section{Family AlBULIDAs.}

Albula vulpes (Linnæus). Ladyfish, bonefish.

Baird, 1873 (Conorhynchus macrocephalus); Jordan and Evermann, I896, p. 4II; Smith, I898, p. 9r; Kendall, I908, p. 35 .

Menemsha Bight fish traps.-Edwards. Reported by Baird in $187 \mathrm{I}$, but none seen for many years.-Smith.

\section{Family Clupeidas.}

Etrumeus teres (De Kay), Round herring.

Jordan and Evermann, I896, p. 420 (Etrumeus sadina); H. M. Smith, I898, p. 9 I (E. sadina); Kendall, 1908, p. 36.

Buzzards Bay trap, Eel Pond, Menemsha Bight; ordinarily rare, occasionally common; very abundant in 1905 , several barrels being taken in single lift of the trap; abundant again in 1908 , when they appeared in the local traps on July 3 , and were taken until October 21 . During part of this period many hundreds were taken at once.

Parasites (Linton): Scolex polymorphus.
Clupea harengus Linnæus. Herring.

Storer, 1867 , p. I 53 (Clupea elongata); Baird, 1873 C. elongata); Verrill, 1873, p. 520 (C.elongata); Jordan and Evermann, 1896, p. 42I; Bumpus, I898 a, p. 59; Mead, 1898, p. 702 ; H. M. Smith, I898, p. 9r; Linton, I9or, p. 437; Sharp and Fowler, 1904, p. 507; Kendall, I908, p. 36.

Seasonally abundant and generally distributed throughout the region. Adults with spawn appear about October $x_{5}$, remaining until cold weather. Taken in traps and gill nets.

Spawn in the fall; young taken in tow from October to June; few or none in midsummer.Towing records of $\mathrm{V}: \mathrm{N}$. Edwards.

Food: Crago septemspinosus, Mysis americana, Gammarus natator, also small fishes.-Verrill and Smith. (For young fish only): Squid, shrimps, annelids, copepods, other small Crustacea, including megalops of crabs, diatoms.

Parasites (Linton): Nematodes-Agamonema capsularia, Ascaris sp. (immature). CestodesRhynchobothrium imparispine, larval cestodes (Scolex polymorphus). Trematodes-Distomum appendiculatum, $D$. bothryophoron, $D$. ocreatum, D. vitellosum. Protozoa-sporozoz in muscles.

Clupanodon pseudohispanicus (Poey). Spanish sardine.

Kendall and Smith, 1895, p. 17-18 (Clupea pseudohispanica); Jordan and Evermann, I896, p. 423; H. M. Smith, I898, p. 91 ; I901 a; Linton, I901, p. 438; Kendall, I908, p. 37.

Menemsha Bight, Woods Hole, Eel Pond; generally rare; abundant in 1892 . - Smith. A number in 1900; 6 taken in Eel Pond, October and November, I908.-Edwards. Appear during September, October, and November; taken in traps and seines.

Food: Numerous copepods (August).-Linton.

Parasites (Linton): Distomum appendiculatum.

Pomolobus mediocris (Mitchill).-Hickory shad.

Baird, I873; Jordan and Evermann, I896, p. 425; H. M. Smith, 1898, p. 91; Linton, r9or, p. 438 ; Kendall, I908, p. 37 .

Vineyard Sound and Buzzards Bay, common, 3,500 having been taken in one trap.-SmithPresent from spring till end of trap-fishing sea. son; most numerous in the fall, when they are taken as food fish.

Food: Fish, squid, small crabs, other Crustacea.Linton.

Parasites (Linton): Acanthocephala-Echinorhynchus acus. Nematodes-Ascaris clavata, A. habena, A. sp. Cestodes-Larvæ (Scolex polymorplius), Tetrarhynchussp. TrematodesDistomum appendiculatum. 
Pomolobus pseudoharengus (Wilson). Alewife, branch herring (known locally as "herring").

Baird, I873; Jordan and Evermann, I896, p. 426; Bumpus, I898, p. 486; H. M. Smith, r898, p. 9r; Linton, rgor, p. 439; Sharp and Fowler, I904, p. 507, Kendall, I908, p. 38.

Common throughout local waters, ascending streams in the spring. It arrives in March and April, passing then into fresh water and returning in May.-Smith. Abundant also in October and November.-Edwards. Taken in traps and in dip-nets.

Spawns in streams and ponds in April and May. Food (only young examined): All contained copepods, shrimps, young squid.-Linton.

Parasites: Acanthocephala (Linton)-Echinorhynchusacus; immature nematodes. Cestodes (Linton)-Rhynchobothrium imparispine, larvæ (Scolex polymorphus). Trematodes (Linton)Distomum appendiculatum, D. bothryophoron, D. vitellosum, Monostomum sp. Protozoa: sporozoa in muscles. Copepods (C. B. Wilson)-Argulus alose, Caligus rapax, Lepeophtheirus edwardsi.

Pomolobus astivalis (Mitchill). Glut herring, black back.

Jordan and Evermann, 1896, p. 426; H. M. Smith, I898, p. 91; Kendall, r908, p. 38 .

Vineyard Sound, Buzzards Bay, etc., common. Comes later than branch herring.-Smith. Taken in September and October.-Edwards.

Spawns in brackish ponds.

Parasites (Linton): Acanthocephala-Echinorhynchus acus. Nematodes-Heterakis foveolata.

A losa sapidissima (Wilson). Shad.

Baird, x873; Jordan and Evermann, 1896, p. 427; H. M. Smith, r898, p. $9 \mathrm{r}$; Linton, rgor; Sharp and Fowler, I904, p. 507; Kendall, I908, p. 39.

Vineyard Sound, Buzzards Bay, etc. Not uncommon, though far less numerous than formerly.-Smith. Nantucket.-Sharp and Fowler. Comes about May $\mathrm{r}$, remaining only about a week; contains well advanced spawn on arrival.-Eidwards. Taken in traps.

Parasites: Acanthocephala (Linton)-Echinorhynchus acus. Nematodes (Linton)-Ascaris adunca, Ascaris sp. (immature). Copepods (C. B. Wilson)-Caligus rapax.

Opisthonema oglinum (Le Sueur). Thread herring. Jordan and Evermann, I896, p. 432; H. M. Smith, 1898, p. 9x; Kendall, I908, p. 40.

Vineyard Sound and Buzzards Bay, very rare, though reported as common one year (1885).Smith. Several taken in I9OI and r902.Edwards. Occur from July till fall.
Brevoortia tyrannus (Latrobe). Menhaden, pogy. Storer, I867, p. I59 (Alosa menhaden); Baird, I873 (Brevoortia menhaden); Goode, I879, p. I-5I4; Peck, I894; Jordan and Evermann, I896, p. 433; Bumpus, I898a, p. 59; 1898b, p. 85 I; H. M. Smith, I898, p. 9I; Linton, I9or, p. 440; Sharp and Fowler, I904, p. 507; Kendall, I908, p. 40.

Abundant everywhere throughout the region, swimming in schools at the surface and often running into brackish water; in winter probably going to deep water. They arrive in schools about May 20, though scattered ones are taken in March, and remain till December I or later. Most abundant in June. Taken in traps and purse nets. One taken in 1876 measured I 8 inches, probably the largest on record.-Smith.

Reproduction not well understood (see H. M. Smith, r898, p. 9r). Appears to breed in June, schools of young $3 / 4$ to $I$ inch in length being common during July.-Bumpus, Edwards.

Food: Minute Crustacea and unicellular animals and plants. (For full statement see Peck, I894.)

Parasites: Cestodes (Linton)-larvæ (Scolex polymorphus), Synbothrium filicolle. Trematodes (Linton)-Distomum appendiculatum, D. fenestratum, D. vitellosum, D. sp., Gasterostomum arcuatum. Copepods (C. B. Wilson)-Bomolochus teres, Caligus chelifer, $C$. schistonyx, Lernceniscus radiatus, Lernanthropus brevoortice.

A serious epidemic occured among local menhaden in 1904; enormous numbers of dead drifted to shore in Narragansett Bay, and considerable numbers in New Bedford Harbor.

\section{Family ENGRAULIDIDAE.}

Anchovia brownii (Gmelin). Anchovy.

Goode, r884, p. 6 II (Stolephorzis brownii); Jordan and Evermann, I896, p. 443 (Stolephorus brownii); H. M. Smith, I898, p. 92 (Stolephorus brownii); Linton, 1901, p. 440 (Stolephorus brownii); Kendall, I908, p. 4x.

Throughout Vineyard Sound and Buzzards Bay, Great Tisbury Pond; usually abundant. Present from first of May till late in fall.-Edwards. Taken in traps and seines.

With ripe spawn till August.-Edwards.

Food: Usually copepods, also univalve mollusks.-Linton.

Parasites (Linton): Immature nematodes. Cestodes-larva (Scolex polymorphus). Trematodes-Distomum appendiculatum, D. sp. 
Anchovia argyrophanus (Cuvier \& Valenciennes. Anchovy.

Jordan and Evermann, 1896, p. 444 (Stolephorus argyrophanus); H. M. Smith, 1898, p. 92 (Stolephorus argyrophanus); Kendall, r908, p. $4 \mathrm{I}$.

Woods Hole, Menemsha Bight, Buzzards Bay trap, and Great Tisbury Pond; not uncommon at times; very plentiful in 1902 , but not seen in 1903; abundant in 1905.-Edwards. Specimens in Woods Hole collection dated November 20, I899, and September 5, I902. Most numerous in fall. - Smith. Traps and seines.

Parasites (Linton): Scolex polymorphus.

Anchovia mitchilli (Cuvier \& Valenciennes). Anchovy.

Goode, I884, p. 6 II (Stolephorus mitchilli); Jordan and Evermann, I896, p. 446 (Stolephorus mitchilli); H. M. Smith, I 898 , p. 92 (Stolephorus mitchilli); Kendall, I908, P. 42 .

Abundant, having a distribution the same as that of $A$. brownii, and occurring from the first of May till fall.-Edwards.

\section{Family SalmoNidA:}

Salmo salar Linnæus. Atlantic salmon.

Baird, I873; Jordan and Evermann, I896, p. 486; H. M. Smith, 1898 , p. 92 ; Sharp and Fowler, r904, p. 507; Kendall, I908, p. 44.

Vineyard Sound and Buzzards Bay, a few (chiefly small specimens) taken every year, generally in May; a 25-pound specimen taken in trap at Menemsha, June 28, 1899.-Smith. No large specimens seen locally for a number of years.-Edwards. Off Tuckernuck, I in I904.-Sharp and Fowler.

Parasites: Immature nematodes (Ascaris). Copepods (C. B. Wilson)_Lepeophtheirus salmonis.

Salvelinus fontinalis (Mitchill). Brook trout, speckled trout.

Jordan and Evermann, r896, p. 506; H. M Smith, I898, p. 92; Kendall, I908, p. 46.

Great and Little Harbors, entering salt water from streams and remaining through winter, when they are occasionally taken in fyke nets.-Smith.

Parasites (C. B. Wilson): Lepeophtheirus salmonis.

\section{Family ARgENTINIDEA.}

Osmerus mordax (Mitchill). Smelt.

Baird, I873; Jordan and Evermann, I896, p. 523; H. M. Smith, 1898, p. 92, Kendall, I908, p. 48 .
Osmerus mordax-Continued.

Eel Pond and Hadley Harbor, Vineyard Sound and Buzzards Bay generally. Present throughout the year but reported as most abundant in March. Taken in seines and fyke nets.

Spawns in February and March.-Smith.

Parasites: Nematodes (Linton)-Ascaris sp. immature. Cestodes (Linton)-Dibothrium ligula, Rhynchobothrium imparispine. Copepods (C. B. Wilson)-Argulus alosœ.

\section{Family SyNODONTIDAE}

Trachinocephalus myops (Forster). Ground spearing, snake fish.

Jordan and Evermann, I896, p. 533; H. M. Smith, r898, p. 92 ; Kendall, I908, p. 49.

Nobska; Great Harbor, rare, taken during years $\mathbf{I} 876, \mathbf{1 8 7 8}, \mathbf{1 8 8 7}, \mathbf{I} 892$ and $\mathbf{1} 898$. - Smith. One taken in I903.- Edwards. Recorded for July, September, and October.

Synodus fotens (Linnæus). Lizard fish.

Jordan and Evermann, 1896, p. 538; H. M. Smith, I898, p. 92; Kendall, I908, p. 50.

Beach inside Nobska Point, Vineyard Sound, Great Tisbury Pond, Katama Bay, Buzzards Bay, Quisset Harbor.-Edwards. A few taken in the seine nearly every year during Septem. ber.

\section{Family MaUrolicides.}

Maurolicus pennanti (Walbaum).

Bean, I884 (Maurolicus borealis); Goode and Bean, 1895 , p. 96 (M. borealis); Jordan and Evermann, I896, p. 577 ; H. M. Smith, I898, p. 92 ; Kendall, I908, p. 50.

Woods Hole, one found in January, r884.-Smith. Buzzards Bay at local bathing beach, 2 I specimens collected by Mr. Edwards on November 27 , I906 f. These fishes were found dead on shore, but were in good preservation. They had evident scales, which, however, were very thin; and a long, low, adipose caudal fin (cf. Jordan and Evermann, 1896, p. 576).

\section{Family Pecilime}

Fundulus majalis (Walbaum). Killifish, May fish, striped minnow, mummichog.

Baird, 1873 (Hydrargyra majalis); Jordan and Evermann, I896, p. 639; H. M. Smith, I898, p. 92 ; Bumpus, I898b, p. 85 I Sharp and Fowler, I904, p. 507, Kendall, I908, p. 53. 
Fundulus majalis-Continued.

Common nearly everywhere throughout the year, on sandy shores and among weeds; extremely abundant in certain localities. Vineyard $\mathrm{Ha}$ ven (Lagoon Pond) is perhaps the most satisfactory local collecting ground. Commonly obtained with the seine.

Begins spawning in June; fertile spawn obtainable throughout July and early August. Prof. Whitman (Marine Biological Laboratory card catalogue) states that the eggs are laid in sand 3 or 4 inches deep.

Parasites: Nematodes (Linton)-Heterakis sp. Copepods (C. B. Wilson)-Argulus funduli, A. megalops, Caligus rufimaculatus.

Fundulus heteroclitus (Linnæus). Common killifish, mummichog, common minnow.

Baird, r873 (Fundulus pisculentus and F. multifasciatus); Verrill and Smith, 1873, p. 520 (Fundulus pisculentus); Jordan and Evermann, 1896, p. 640 ; H. M. Smith, I898, p. 92 ; Bumpus, r898a, p. 59 ; Bumpus, I 898 b, p. $85^{2}$; Linton, I901, p. 44I; Sharp and Fowler, I904, p. 507 ; Kendall, r908, p. 54 .

Occurs everywhere and at all seasons in shallow weedy waters and on sandy shores, even where the sea water is considerably diluted; frequently taken in great abundance.

Spawns throughout June and July; ripe spawn has been taken as early as the middle of May and as late as early August. Cross fertilization has been artificially effected between this species and $F$. majalis.

Food: A variety of vegetable matter, eelgrass, etc., enormous numbers of diatoms and Foraminifera; shrimps and other Crustacea.-Linton.-Large numbers of Melampus bidentatus.-Verrill and Smith. In order of frequency: Diatoms (mostly Pleurosigma), small Crustacea (amphipods), algæ, prawns, Molgula, Nereis, eelgrass, small fishes (sp. ?), Haminea, lady crabs, Mya arenaria, Solenya velum.-I. A. Field.

Parasites: Acanthocephala (Linton)-Echinorhynchus acus, E. clavaceps. Nematodes (Linton)-Ascaris sp. (immature), Heterakis sp. Cestodes (Linton) - Otobothrium crenacolle, larvæ (Scolex polymorphus). Trematodes (Linton)-Diplostomum sp. (cyst in liver), Distomum tornatum, D. sp. Copepods (C. B. Wilson)-Argulus funduli, A. megalops, Caligus rufimaculatus, Lernaeniscus radiatus.

Locally this fish has for many years served as one of the most important objects of biological study and experimentation.
Fundulus diaphanus (Le Sueur).-Killifish, freshwater minnow.

Jordan and Evermann, 1896, p. $645 ;$ H. M. Smith, I898, p. 92; Kendall, I908, p. 55.

Waquoit Bay, Great Pond, Hadley Harbor, Eel Pond (rare), Tashmoo Pond (very abundant), Tisbury Pond (abundant). A brackish and fresh-water species, seldom or never found in undiluted sea water. Mr. Edwards records the unexpected presence of this fish in the small streams flowing down the clay bank at Gay Head.

Parasites (Linton): Acanthocephala-Echinorhynchus acus. Nematodes-Heterakis sp. Cestodes-Tania sp.

Lucania parva (Baird \& Girard). Rain-water fish. Jordan and Evermann, I896, p. 665; H. M. Smith, I898, p. 92 ; Kendall, I908, p. $5^{6 .}$

Waquoit Bay, and brackish ponds between latter and Woods Hole, Eel Pond, Quisset Harbor, Tashmoo Pond (few in I904), Vineyard Haven, Katama, Tisbury Pond (many in 1906). A resident fish, fairly common in suitable localities (weedy shores in brackish waters), but seldom taken in any abundance.

Cyprinodon variegatus Lacépède. Short minnow, variegated minnow.

Storer, I867, p. 280; Baird, I873; Gurley, I893, I894; Jordan and Evermann, I896, p. 671; Bumpus, I8g8b, p. 852 ; H. M. Smith, I898, p. 92 ; Linton, 1901, Kendall, 1908, p. 56.

Salt and brackish water ponds near Falmouth, occasionally a few in Woods Hole Harbor; 10cally abundant on shallow, weedy shores; a resident fish.

Spawns in June.-Smith. Ripe eggs recorded July I3.-Osburn.

Parasites: Myxobolus lintoni.-Gurley.

\section{Family ESOCIDE:}

Tylosurus marinus (Walbaum). Silver gar, billfish.

Storer, 1867, p. I37 (Belone truncata); Baird, 1873 (Belone longirostris); Bean, r884; Jordan and Evermann, I896, p. 7 r4; H. M. Smith, I 898 , p. 93; Linton, I90I, p. 442; Kendall, I908, p. 56.

Shores of Vineyard Sound and Buzzards Bay, common. Especially common at Quisset Harbor.-Edwards. Present from May to Octo. ber.-Smith. Taken in traps and seines.

Food: Fish and shrimps.-Linton.

Parasites: Acanthocephala (Linton)-Echinorhynchus clavaeceps. Cestodes (Linton)-larvæ 
Tylosurus marinus-Continued.

(Scolex polymorphus). Trematodes (Linton)Gasterostomum sp., Microcotyle sp. Copepods (C. B. Wilson)-Caligodes cephalus, Lepeophtheirus edwardsi.

Tylosurus acus (Lacépède). Houndfish.

Goode, 1879 , p. 6 (Belone latimanus); r884a, p. 459 (Tylosurus caribbanes); Bean, 1884 ( $T$. caribbæus); Jordan and Evermann, 1896, p. 716; H. M. Smith, I898, p. 93; Sharp and Fowler, I904, p. 508; Kendall, I908, p. 57.

Woods Hole.-Goode, Bean. Woods Hole in Buzzards Bay trap, occasional specimens taken, one in I902.-Edwards. A specimen in local collection, about 4 feet long, dated July 27, 1886. Nantucket, rare.-Sharp and Fowler.

Parasites (Linton): Acanthocephala-Echinorhynchus pristis; Nematodes-Ascaris sp. immature. Cestodes-Dibothrium restiforme, Rhynchobothrium speciosum. TrematodesDistomum nitens.

On the r886 specimen a cluster of stalked barnacles (Conchoderma virgatum) was growing between the eyes.

Athlennes hians (Cuvier \& Valenciennes).

Jordan and Evermann, r896, p. 7 r 8 ; H. M. Smith, r898, p. 93; Kendall, r908, p. 57.

Buzzards Bay trap, one taken in summer of 1895.-Smith. A second on August I4, 1902.-Edwards.

\section{Family HEMIRAMPHDE.}

Hyporhamphus robertia (Cuvier \& Valenciennes). Halfbeak, skipper.

Cope, 187o, (Hemirhamphus unifasciatus); Goode, I884a, p. 46I (Hyporhamphus unifasciatus); Jordan and Evermann, I896, p. 721 ; H. M. Smith, r898, p. 93; Kendall, I908, p. 57.

Newport.-Cope. Woods Hole-Goode. Menemsha, West Falmouth, Gay Head, common to abundant.-Smith. Preşent in July, August, and September. Taken with the seine or in the fish traps.

Hernirhamphus brasiliensis (Linnæus).

Jordan and Evermann, 1896, p. 722; H. M. Smith, I898a, p. 544 .

Woods Hole, in Buzzards Bay, August 9, 1898, a specimen $53 / 4$ inches long.-Smith.

Euleptorhamphus velox Poey。

Jordan and Evermann, r896, p. 724; Kendall, I908, p. $5^{8}$.

Newport.-Goode. Off Nantucket.-Putnam.

\section{Family SCOMBRESOCIDE.}

Scombresox saurus (Walbaum). Saury, skipper.

Baird, 1873 (Scomberesox scutellatus); Jordan and Evermann, 1896, p. $725 ;$ H. M. Smith, I898, p. 93; Kendall, I908, p. 58.

Nobska Point.-Smith. Menemsha (r905), Hadley Harbor (I906).-Edwards. Commonly very rare locally, though many have been taken on two occasions ( 1905 and I906). Records for August, September, and December.

\section{Family ExOCCETIDA:}

Parexocœtus mesogaster (Bloch). Flying-fish.

Jordan and Evermann, 1896, p. 728; Kendall, I908, p. 59 .

Newport.-Jordan and Meek.

Exocotus rondeletii (Cuvier \& Valenciennes). Flying-fish.

Jordan and Evermann, I896, p. 733; H. M. Smith, I90r; Kendall, rgo8, p. 59.

Menemsha Bight, one specimen taken in trap October I3 $_{3}$ 1900.- Smith. A specimen in the local collection, dated August 7, 1886, and labelied "Exocatus volitans," seems to belong to the present species.-Sumner.

Exocætus volitans Linnæus. Flying-fish.

Baird, I873 (Exocotus melanurus); Jordan and Evermann, I896, p. 734 ; H. M. Smith, I898, p. 93; Kendall, I908, p. 59 .

Vineyard Sound, especially in traps at Menemsha Bight; also at Great Harbor; of variable frequency, but usually scarce. Appears during September and October--Edwards. The authors have not seen any specimens of this species from local waters. One so labeled in the museum of the station is probably E. rondeletii.

Cypselurus heterurus (Rafinesque). Flying-fish. Jordan and Evermann, 1896, p. 735 (Exocœtus heterurus); Smith, I899; 1900 (Exocotus heterurus); Kendall, rgo8, p. 59.

Woods Hole in r886; Menemsha Bight, one specimen seined on August I, I899; another in trap, August 21.-Smith. Several specimens of this species in the National Museum are from Woods Hole or vicinity. Two fishes of this species were taken at Menemsha Bight, July 10, I908 (identified by F. B. Sumner). This is probably the commonest local flying-fish.

Cypselurus furcatus (Mitchill). Flying-fish.

Jordan and Evermann, 1896, p. 737 (Exocatus furcatus); Kendall, I908, p. 60.

Newport.-Jordan and Meek. 
Cypselurus gibbifrons (Cuvier \& Valenciennes).

Jordan and Evermann, 1896, p. 74I (Exocœius gibbifrons); Kendall, I908, p. 60.

Newport.-Jordan and Evermann.

\section{Family GASTEROSTEIDAE.}

\section{Pungitius pungitius (Linnæus). Nine-spined} stickleback.

Baird, I873 (Pygosteus dekayi); Bean, I884 (Pygosteus pungitius); Jordan and Evermann, I896, p. 745 (Pygosteus pungitius); H. M. Smith, r898, p. 93 (Pygosteus pungitius); Kendall, rgo8, p. 6r.

Eel Pond, Quisset Harbor, Hadley Harbor, Lagood Pond; common at the head of harbors where water is not fully salt.-Edwards. A resident fish. Taken with seine.

Spawns in April and May.-Edwards.

Parasites: A small Distomum.-Linton.

Gasterosteus aculeatus Linnæus. Three-spined stickleback.

Baird, I873 (Gasterosteus biaculeatus); Bean, 1884; Jordan and Evermann, I896, p. $747 ; \mathrm{H}$. M. Smith, I898, p. 93 (Gasterosteus bispinosus); Bumpus, I898a, p. 59 (Gasterosteus bispinosus); Kendall, Igo8, p. 6r.

Shores everywhere; the most common local stickleback. A resident fish, taken in greatest abundance in March and April.-Edwards. Dredged at Blue Wing station 50.

Breeds in May and early June.-Edwards.

Gasterosteus bispinosus Walbaum.a Stickleback. Jordan and Evermann, 1896, p. 748; H. M. Smith, I898, p. 93 (Gasterosteus gladiunculus); Kendall, I908, p. 63 .

Smith (I898) records the capture of one specimen of "Gasterosteus gladiunculus Kendall," in October, 1897. Dr. Kendall informs us that this species, now known to be $G$. bispinosus Walbaum, is fairly common at Woods Hole in summer, but that few except small specimens have been taken, these being collected by the tow net.

Apeltes quadracus (Mitchill). Four-spined stickleback.

Baird, 1873; Bean, I884; Jordan and Evermann, I896, p. 752; Bumpus, I898a, p. 59; H. M. Smith, I898, p. 93; Linton, I901, p. 443; Kendall, I908, p. 63 .

Very common, along shores everywhere, both in salt and brackish water; taken at all seasons.

Spawns in May and June.

Food: Copepods.-Iinton.

\section{Family FistUlaRIDAE.}

Fistularia tabacaria Linnæus. Trumpet-fish.

Storer, I867, p. I4I (Fistularia serrata); Jordan and Evermann, 1896, p. $755 ;$ H. M. Smith, I898, p. 94; I900; Kendall, I908, p. 64.

Buzzards Bay near Quissett, a few every year; Great Harbor.-Smith. Tisbury Pond.-Edwards. A specimen in the museum was taken in the inclosure of the local pier, close to the laboratory. Present in September, October, and early November. Taken with the seine:

Usual size 7 or 8 inches.-Smith. Largest, seined November I, I899, 20 inches in length, exclusive of tail.-Edwards.

\section{Family Syngnathides.}

Syngnathus fuscus Storer. Pipefish. [Chart 199.] Baird, I873 (Syngnathus peckianus); Bean, I884 (Siphostoma fuscum); Jordan and Evermann, I896, p. 770 (Siphostoma fuscum;) H. M. Smith, 1898, p. 94 (Siphostoma fuscum); Bumpus, I898, p. 486; r898a, p. 59 (Siphostoma fuscum); Linton, I901, p. 443 (Siphostoma fuscum); Sharp and Fowler, 1904, p. 507 (Siphostoma fuscum); Kendall, I908, p. 65.

Very common among eelgrass along shores everywhere; also taken by means of the dip net in the open Sound among floating weed. A resident species Dredged by the Survey at scattered stations throughout Buzzards Bay and Vineyard Sound, in waters of 2 to $I 7$ fathoms.

Fish Hawk stations: 7530 bis (I), 755I (2), 7554 (2), 7564 bis (I), 7566 (I small), 7570 (I small), 7576 (several small), 7577 ( 2 young), 7580 (2, I a male with eggs in pouch), 7582 (I), $759 \mathrm{r}$ (I small), 7598 (I small), 7600 (I large), 7602 (I), 7622 ( 3 , I a male with well-developed eggs), 7633 (I), 7657 (I), 7673 (I), 776 I (I), 7762 (2, I a male with eggs), 7778 (I), 7783 (I male with eggs).

Phalarope and Blue Wing stations: 50 (4), 53 (several), 73 (I), rog ( $\mathrm{r}$ adult male with eggs), I50(male with eggs), I54 (I small), I 58 (I).

Spawns about June $I$; males carrying eggs in the brood pouch found throughout July. "Breeding" as early as May I3.-Bumpus. Young taken in tow from April to August. Records of V. N. Edwards.

Food: Small Crustacea.-Linton.

Parasites: Rhynchobothrium heterospine.-Linton.

Hippocampus hudsonius De Kay. Sea-horse.

Storer, I867, p. 223; Baird, I873; Goode, I884, p. I72 (Hippocampus heptagonus); Jordan and Evermann, I 896, p. 777 ; H. M. Smith, I 898 , p. 94; Sherwood and Edwards, I9or; Kendall, r908, p. 65.

a This is not the "Gesterostcus bispinosus" of former Woods Hole lists, which really referred to G. aculeaius. 
Hippocampus hudsonius-Continued.

Woods Hole.-Goode. Vineyard Sound, in gulfweed or rockweed; a few every year, during August and September.-Smith. Gay Head, one specimen.-Edwards. A dead specimen taken dredging in Tarpaulin Cove, July, I903.

\section{Family ATHERINIDE.}

Menidia beryllina cerea Kendall. Silverside.

Kendall and Smith, I895, p. 2 I (M. beryllina); Jordan and Evermann, 1896, p. 797 (Menidia gracilis); H. M. Smith, I898, p. 94 (M.gracilis); Bumpus, r898b ( $M$. gracilis); Kendall, I902, p. $26 \mathrm{I}$; Kendall, Igo8, p. 66.

Shores everywhere, abundant, appearing early in spring. Often seen in dense bodies about piers in July, August, and September and as late as December.-Smith.

Spawns in June and July; seems to spawn later than $M$. notata.-Bumpus.

Menidia menidia notata (Mitchill). Silverside.

Baird, I873 (Chirostoma notata); Bean, I884 (Menidia notata), Jordan and Evermann, I896, p. 800 (M. notata); I898, p. 2840 (Menidia menidia notata); Bumpus, I898b, p. 852 ( $M$. notata); H. M. Smith, I898, p. 94 (M. notata); Kendall, I902 ( $M$. notata); Linton, I9or, p. 443 (M. notata); Sharp and Fowler, I904, p. 508 (M. notata); Kendall, Igo8, p. 66.

Shores everywhere, very abundant, more so than the foregoing species. Taken from April to December, being most abundant late in the fall.

Spawns in June and July. Eggs in ropy threads attached to beach grass above low-tide level.Edwards. Fry $1 \frac{1}{2} \mathrm{~cm}$. in length at surface in July.-Bumpus.

Food: Small Crustacea, shrimps, vegetable material, annelids, univalve mollusks, diatoms.Linton. Kendall (1902) gives a number of tables of food of "silversides" without specifying species. The records probably refer to the present form. This fish is, in its turn, an important item of food for larger species.

Parasites: Nematodes (Linton)-Filaria sp. (immature). Cestodes (Linton)-larvæ (Rhynchobothrium bulbifer, $R$. imparispine). Trematodes (Linton)-Distomum tornatum, D. valdeinflatum, D. sp., Gasterostomum sp. Copepods (C. B. Wilson)-Ergasilus manicatus.

\section{Family Mugridis.}

Mugil cephalus Linnæus. Striped mullet.

Baird, 1873 (Mugil lineatus); Jordan and Evermann, I896, p. 8I I; H. M. Smith, x898, p. 94; Linton, I90I, p. 444; Kendall, I908, p. 67.

Woods Hole, Great Pond, Vineyard Haven; common along shores locally. Present from June to December; most common in the fall. Local specimens all appear to be immature, and the fish does not seem to spawn here.-Edwards. A specimen $I_{3}$ inches long taken in I900.

Food: Diatoms, green algæ, occasionally copepods.--Linton.

Parasites: Caligus rufimaculatus.-C. B. Wilson. Mugil curema Cuvier \& Valenciennes. White mullet.

Jordan and Evermann, I896, p. 8I3; H. M. Smith, I898, p. 94; Kendall, I908, p. 68.

Woods Hole, Quisset, Vineyard Haven. Common from July ist to October.-Smith. Local specimens all immature.-Edwards. Young $I \frac{1}{4}$ inches in length taken June 28.Bumpus.

It is not certain that all the foregoing records are reliable, since some confusion seems to have occurred in the identification of local mullets. Three specimens in the Woods Hole collection, which had been labeled "Mugil curema," are in reality $M$. cephalus.-Sumner.

Mugil sp. undetermined (immature).

Kendall and Smith, 1895, p. 20 (Querimana gyrans); Jordan and Eivermann, r896, p. 8r8 (Querimana gyrans); H. M. Smith, I898, p. 94 (Querimana gyrans); Kendall, Igo8, p. 68 (Mugil trichodon).

An immature form which has for a number of years been listed locally as "Querimana $g y$ rans," occurs at Woods Hole and vicinity during the summer and fall. (Concerning identity, see Bean, Catalogue of the Fishes of New York, r903; Smith, The Fishes of North Caro- lina, I907).

\section{Family SPHYRANIDE.}

Sphyrena barracuda (Walbaum). Barracuda.

Goode, I884, p. 448 (Sphyrana picuda); Jordan and Evermann, 1896, p. 823 (S. picuda); H. M. Smith, I898, p. 94; Kendall, I908, p. 68.

Woods Hole, Quisset Harbor, a rare straggler, only a few specimens having been taken, the last recorded being in September, 1897. Smith. 
Sphyrana guachancho Cuvier \& Valenciennes. Barracuda.

Jordan and Evermann, I8g6, p. $824 ; \mathrm{H} . \mathbf{M}$. Smith, r898, p. 94; Kendall, I908, p. 69.

Only two records: Woods Hole, July 7, 1876; Buzzards Bay, July I7, r883.-Smith.

Sphyrana borealis DeKay. Barracuda.

Storer, I867, p. 86; Goode, I884, p. 448; Jordan and Evermann, 1896, p. 825 ; H. M. Smith, I898, p. 94; Linton, I90I, p. 444; Kendall, r 908, p. 69 .

Vineyard Sound and Buzzards Bay, Woods Hole, Katama Bay, Gay Head. The young fishes are common, adults rare, seldom reaching i2 inches in length.-Smith. Present from July to December; most common after October r.-Smith. Taken in traps and seines.

Food: Young fish, young gastropods.-Linton.

Family POL,YNEMIDA.

Polydactylus octonemus (Girard). Eight-threaded threadfin.

Jordan and Evermann, I896, p. 830; H. M. Smith, I898, p. 94; Kendall, r908, p. 69.

One taken by seine in Little Harbor in September, I882.- Smith. Another, 61/2 inches long, in trap at Menemsha Bight, October 28, rgo8 (collected by Edwards, identified by Sumner).

\section{Family AmModytidis.}

Ammodytes americanus De Kay. Sand launce, sand eel, lant. [Chart 200.]

Baird, I873; Storer, I867, p. 217; Bean, I884; Jordan and Evermann, I896, p. 833; Bumpus, I898, p. 486; Mead, I898, p. 902 ; H. M. Smith, r898, p. 95 ( $A$. americanus and $A$. dubius); Kendall, I908, p. 70.

Abundant throughout region, frequenting sandy beaches and flats, and darting into the sand when disturbed. Taken throughout the year, though most abundant late in fall and early spring; rare in winter.-Smith. Dredged by the Survey throughout Vineyard Sound at depths of $21 / 2$ to $I_{3}$ fathoms, on sandy bottoms; not taken in Buzzards Bay dredgings. Young in tow from $1 / 2$ to $I$ inch in length in March, 1898.-Bumpus. Young taken from January till November, being most frequent from March to May, especially April.-Towing records of V. N. Edwards.

Fish Hawk stations: 7533 (2), 7540 (6), 7545 (I small), 7546 bis (r), $75^{62}(3), 7562$ bis $(3), 7566$ (I), 7569 bis (about I2), 7575 (I), 7596 (several), 7703 (few), 7704 (few), 7705 (many), 7739 (I), $7771(2)$.
Ammodytes americanus-Continued.

Phalarope stations: 43 (2), 60 (I).

Important food for mackerel (Smith), and probably other fishes.

Parasites: Cestodes (Linton)-Rhynchobothrium bulbifer, $R$. imparispine (listed for "Ammodytes dubius"). Copepods (C. B. Wilson)Caligus rapax.

\section{Family HolocenTridA:}

?Holocentrus tortuge Jordan \& Thompson. Squirrel-fish.

H. M. Smith, I899, I900, I901a; Kendall, I908, p. 70 (these specimens were referred to Holo. centrus ascensionis (Osbeck)).

Katama Bay; one young specimen seined September I, I899, another August 28, r900.

\section{Family MULLIDA:}

Mullus auraius (Jordan \& Gilbert). Goatfish, surmullet.

Jordan and Evermann, 1896, p. 856; H. M. Smith, 1898, p. 95; Kendall, I908, p. 7 I.

"Rare. Taken every year in September, mostly in Quisset Harbor. "-Smith. Specimens from the following points are contained in the local collection: Woods Hole (4 specimens, July 25 , I894); Menemsha Bight (22 in one seine haul, July 29, 1908, and again in some numbers, August 19, I908), Great Harbor (one specimen, September 20, I908). A young fish, probably of this species, was dredged by the Fish Hawk in Buzzards Bay during the summer of 1906. The foregoing specimens are all small (mostly 4 inches or less in length).

\section{Family SCOMBRID王.}

Scomber scombrus Linnæus. Common mackerel. Storer, 1867 , p. 55 (Scomber vernalis); Verrill and Smith, I873, p. 516 (Scomber vernalis); Baird, I873; Jordan and Evermann, I896, p. 865; H. M. Smith, 1898, p. 95; Bumpus, 1898a, p. 59; Sherwood and Edwards, I90I; Linton, r901, p. 444; Sharp and Fowler, I904, p. 508: Kendall, r 908 , p. 7 I.

Vineyard Sound and Buzzards Bay; believed to be less abundant here than formerly, though still taken on a commercial scale. According to Smith $(1898)$ the mackerel appear about June $I$, for two weeks, then disappear for a few weeks for spawning (?); after reappearance, they remain through November. Mr. Edwards states that they arrive the first week in May, and remain in the region till November; that they are scarce in the Bay trap after July 
Scomber scombrus-Continued.

$\mathbf{r}$, though taken in Menemslia traps and by line fishermen till November. First one in 1898 taken May 3 (Bumpus); first in Igoo taken April 29 (Sherwood and Edwards).

Spawns during middle and latter part of June, off shore.-Bumpus. In the middle of May fish are taken with ripe eggs and milt, this condition lasting about a month; young, $2 \frac{1}{2}$ inches long, recorded June 3, r903.-Edwards.

Food: Some taken in July, 20 miles south of No Mans Land, contained shrimps, various larval and immature Crustacea, copepods, and numerous pteropods.-Verrill and Smith. Small fish, small Crustacea, squid, copepods (recorded for young fish only).-Linton.

Parasites: Acanthocephala (Linton)-Echinorhynchus acus. Nematodes (Linton)-Agamonema capsularia (immature), A. papilligerus, Ascaris capsularia, A. clavata, A.sp. Cestodes (Linton)-Dibothrium punctatum, D. sp. (larvæ), Rhynchobothrium bulbifer, $R$. imparispine, R. speciosum, Scolex polymorphus (larvæ), Tetrarhynchus bisulcatus. Trematodes (Linton)Distomum appendiculatum, D. gulosum. D. vitellosum, Octocotyle major. Copepods (C. B. Wilson)-Caligus rapax.

An extensive local mackerel fishery exists, chiefly by means of lines operated from small schooners. Many are likewise taken in gill nets during May and June, and by traps throughout the season.

Scomber colias Gmelin. Chub mackerel, bull's-eye mackerel.

Jordan and Evermann, I896, p. 866; H. M. Smith, r898, p. 95; Kendall, r908, p. 72 (Scomber japonicus).

Vineyard Sound and lower part of Buzzards Bay, uncommon to abundant.-Smith. About 5,000 taken at Meriemsha, August 25, I906.-Edwards. Abundant in I908. Taken in traps and on lines, along with other mackerel, from July $x_{5}$ to the end of October.-Smith.

This fish is sold by local fishermen along with the common mackerel.

Auxis thazard (Lacépède.) Frigate mackerel.

Goode, I884a, p. 305; Jordan and Evermann, I896, p. 867 ; H. M. Smith, I898, p. 95; Kendall, $x 908$, p. 72 .

Sow and Pigs Lightship.-A. H. Clark, cited by Goode. Menemsha Bight (1885), Woods Hole (June 29, I892 [2 specimens]). - Smith. Apparently very rare in local waters.
Gymnosarda pelamis (Linneus). Oceanic bonito Jordan and Evermann, I896, p. 868; H. M. Smith, 1898, p. 96; Kendall, I908, p. 72.

Menemsha Bight, recorded for only one season (1878), in which year they were abundant, 2,000 to 3,000 being taken in the traps during several weeks. - Smith. 'Taken again October 10, 1905.-Edwards.

Parasites: Tristomum lave.-Linton.

Gymnosarda alleterata (Rafinesque). Little tunny, bonito.

Baird, I873 (Orcynus alliteratus); Verrill and Smith, 1873, p. 516 (Orcynus thunnina); Goode, I884a, p. 322 (Orcynus alliteratus); Jordan and Evermann, 1896, p. 869; H. M. Smith, I898, p. 96; Kendall, I908, p. 73.

Buzzards Bay and Vineyard Sound-Goode. Taken regularly at Menemsha, where sometimes as many as roo are taken at a single lift of the trap.-Smith. Present in July and August. They are said to be all of about the same size (about 8 pounds).

Food: One local specimen in August contained I Loligo pealii.-Verrill and Smith.

Parasites (Linton): Cestodes-Rhynchobothrium bulbifer. Trematodes-Distomum monticellii.

Thunnus thynnus (Linnæus). Horse mackerel, tunny.

Baird, I873 (Orcynus secundi-dorsalis); Bean, $\mathrm{r} 884_{4}$ (Orcynus thynnus); Jordan and Evermann, I896, p. 870; H. M. Smith, I898, p. 96; Linton, I90I, p. 445; Kendall, I908, p. 73.

Quisset Harbor, Buzzards Bay, Menemsha, No Mans Land (6 in 1904). Formerly plentiful but now rare. Several at Menemsha in 1908.Edwards. Nantucket.-Sharp and Fowler. Taken in traps.

Food: Squid (only one fish examined).-Linton. Parasites (Linton): Acanthocephala-Echinorhynchus sp. Trematodes-Distomum clavatum.

Germo alalunga (Gmelin). Long-finned albacore. Jordan and Evermann, 1896, p. 87r; H. M. Smith, I898, p. 96; Kendall, I908, p. 74 .

One taken in a fyke net in Great Harbor, May $2 \mathrm{x}$, 1895 , this being the only known occurrence on the Atlantic coast of the United States.Smith.

Sarda sarda (Bloch). Bonito.

Storer, I867, p. 64 (Pelamys sarda); Baird, I873 (Sarda pelamys); Verrill, I873, p. 516 (Sarda pelamys); Goode, I884a, p. 319; Jordan and Evermann, 1896, p. 872 ; H. M. Smith, 1898 , 
Sarda sarda-Continued.

p. 96; Linton, Igor, p. 445; Sherwood and Edwards, I901; Kendall, I908, p. 74.

Vineyard Sound, from Gay Head to Woods Hole, also Buzzards Bay; scarce to abundant, usually common. Taken in local traps from June to first of October. A fine food fish.

Spawns throughout June.-Edwards.

Food: An abundant of Crago septemspinosus.Verrill and Smith. Fish and squid.-Linton.

Parasites: Nematodes (Linton)-Ascaris sp. (immature), Ichthyonemasp. Cestodes (Linton) Otobothrium crenacolle (cysts), Rhynchobothrium bulbifer (cysts), $R$. imparispine (cysts), Scolex polymorphus (larvæ), Tetrarhynchus bicolor, T. sp. Trematodes (Linton)-Distomum pyriforme, $D$. vitellosum, Gasterostomum arcuatum; Hexacotyle thynni, Nematobothrium sp. Copepods (C. B. Wilson): Caligus bonito, C. exilis, C. mutabilis.

Scomberomorus maculatus (Mitchili). Spanish mackerel.

Baird, I873 (Cybium maculatum); Jordan and Evermann, I896, p. 874; H. M. Smith, I898, p. 96; Sherwood and Edwards, r9or; Linton, I901, p. 446; Sharp and Fowler, x904, p. 508; Kendall, I908, p. 74.

Buzzards Bay at local fish trap, also Vineyard Sound; formerly abundant, now rare and growing scarcer.-Smith. One reported in I898; three in 1900 ; only one in I902.-Edwards. Nantucket.-Sharp and Fowler. Has been taken from August to October.

Parasites (Linton): Nematodes-Ascaris clavata, A. habena, A. incurva, Ichthyonema globiceps, immature nematodes. Cestodes-Rhynchobothrium bulbifer (cysts), R. longispine (cysts), $R$. speciosum (cysts), Synbothrium filicolle (cysts). Trematodes-Distomum sp., Gasterostomum $\mathrm{sp}$.

Scomberomorus regalis (Bloch). Kingfish, cero.

Baird, I873 (Cybium regale); Jordan and Evermann, I896, p. 875; H. M. Smith, I893, p. 96; Linton, I901, p. 447; Kendall, I908, p. 75.

Buzzards Bay; about as common as S. cavalla.Smith. Few taken lately.-Edwards.

Food: Small fish.-Linton.

Parasites: Synbothrium filicolle (cysts), Tetrar. hynchus sp. (cysts).-Linton.

Scomberomorus cavalla (Cuvier). Kingfish, cero. Jordan and Evermann, I896, p. 875; H. M. Smith, I898, p. 96; Linton, I9or, p. 447 ; Kendall, 1898, p. 75 .
Scomberomorus cavalla-Continued.

Menemsha Bight, Quisset Harbor; formerly much more common than the Spanish mackerel.-Smith. Three recorded in rgor, one in I902, none in I903.-Edwards. Present from July I to end of trap fishing.

Food: Fish and squid.-Linton.

Parasites: Synbothrium filicolle (cysts).-Linton.

\section{Family TrichIURIDE.}

Trichiurus lepturus Linnæus. Cutlass-fish, scabbard-fish.

Storer, 1867 , p. 70 ; Goode, I884a, p. 335; Jordan and Evermann, 1896, p. 889; H. M. Smith, I898, p. 96; Sherwood and Edwards, Igor; Sharp and Fowler, I904, p. 508; Kendall, I908, p. 76 .

Woods Hole, for "past ro years."-Goode, $x 884$. Woods Hole, Buzzards Bay, Menemsha Bight, Cuttyhunk, Vineyard Haven, Cedar Tree Neck.-Edwards. Nantucket.-Sharp and Fowler. Rather rare; one or two each year; four taken in 1903 (near breakwater). Present from June till October.-Edwards. Taken in traps.

Parasites: Acanthocephala (Linton)-Echinorynchus acus. Cestodes (Linton)-Gtobothrium crenacolle (cysts), Rhynchobothrium speciosum (cysts), Scolex polymorphus. Trematodes (Linton)-Distomum sp. Copepods (C. B. Wilso 1)-Caligus chelifer, C. rapax.

These fishes are occasionally sent to the Woods Hole station as curiosities.

\section{Family ISTIOPHORIDA心.}

Istiophorus nigricans (Lacépède). Sailfish.

Baird, I873 (Histiophorus gladius); Goode, I883, p. 304 (Histiophorus americanus); Jordan and Evermann, I896, p. 891 ; H. M. Smith, I898, p. 97; I.inton, I90I, p. 448; Kendall, I908, p. 76 .

Quisset Harbor; rare, a half dozen having been taken in 25 years.-Smith. Taken in early fall.

Parasites: Dibothrium manubriforme.-Linton.

Tetrapterus imperator (Bloch \& Schneider). Spearfish.

Baird, r873 (Tetrapterus albidus); Goode, r883, p. 303 (Tetrapterus albidus); Jordan and Evermann, 1896 , p. 892 ; H. M. Smith, I898, p. 97 ; Kendall, I908, p. 76. 
Tetrapterus imperator-Continued.

Vineyard Sound, Buzzards Bay, Quisset Harbor; generally rare; numbers taken in local traps, during July and August, from $188_{5}$ to 1890 .Smith.

Parasites (Linton): Nematodes-Ascaris incurva. Cestodes-Dibothrium manubriforme, Tetrarhynchus sp. (cysts).

\section{Family XIPHUD死.}

Xiphias gladius Linnæus. Swordfish.

Storer, 1867, p. 72; Baird, 1873; Goode, 1883, p. 29I; Goode, I884a, p. 336; Jordan and Evermann, I896, p. 894; H. M. Smith, 1898, p. 97; Sharp and Fowler, I904, p. 508; Kendall, I908, p. 77 .

Off Gay Head and No Mans Land, western end of Vineyard Sound; abundant enough to occupy a.swordfishing fleet during the latter part of the summer. Present from July I to October; most common in July and August.-Edwards. Taken by spearing from a "pulpit" on the bowsprit of a sloop or small schooner.

Probably do not breed locally.-Goode.

Food: Fish and squid.-Linton. In one specimen II hake ( $\mathrm{I}$ to 2 feet long) and I menhaden were found; in another, 9 menhaden; the food is, however, more commonly squid.- Eidwards.

Parasites: Nematodes (Linton)-Ascaris incurva. Cestodes (Linton)-Dibothrium plicatum, Otobothrium crenacolle (cysts), Phyllobothrium loliginis (immature), Rhynchobothrium attenuatum, $R$. imparispine (cysts), Scolex polymorphus, Tetrarhynchus bicolor (cysts), T. bisulcatus (cysts). Trematodes-Distomum clavatum, Tristomum coccineum, T. papillosum. Copepods(Linton) - Philichthys xiphia. Copepods (C. B. Wilson)-Branchiella ramosa, Caligus chelifer, C. rapax, Chondracanthus merluccii, Penella costai, P. filosa.

\section{Family CARANGIDEE.}

Oligoplites saurus (Bloch \& Schneider). Leather jacket.

Jordan and Evermann, I896, p. 898; H. M. Smith, I898, p. 97; Kendall, r908, p. 77.

Only four records for this region: Menemsha Bight traps in 1874 and August $I_{3}, 1875$; breakwater, September, I886; Newport, September, I886. - Smith.

$$
\text { I6269 }{ }^{\circ}-\mathrm{Bull} .3 \mathrm{I}, \mathrm{pt} 2-\mathrm{I} 3-\mathrm{I} 4
$$

Naucrates ductor (Linnæus). Pilot-fish.

Jordan and Evermann, I896, p. 900; H. M. Smith, 1808, p. 97; Kendall, 1908, p. 78.

"Reported by Baird in I871."-Smith. Two others reported by Dr. Smith from Great Harbor, Woods Hole, September 9 and ro, 1898 . The first was seined, the other caught off the wharf.

Seriola zonata (Mitchill). Rudder-fish; pilot-fish. Baird, 1873 (Halatractus zonatus); Jordan and Evermann, 1896 , p. 902 ; H. M. Smith, 1898 , p. 97; Sharp and Fowler, I904, p. 508; Kendall, I908, p. 78 .

Vineyard Sound, Eel Pond, Great Harbor, Quisset Harbor, Hadley Harbor, Woods Hole, and elsewhere.-Smith. Nantucket.-Sharp and Fowler. Rather common about piers, poundnet stakes, vessels, and under floating seaweed and eelgrass. Present from July to October. Taken by dip net, pound, and seine.

Food: Menidia gracilis.-Smith. Fish (probably butterfish).-Linton.

Parasites (Linton): Nematodes-Ascaris incurva. Cestodes-Tetrarhynchus bisulcatus (cysts).

Seriola lalandi Cuvier \& Valenciennes. Amberfish.

Jordan and Evermann, I896, p. 903; H. M. Smith, r898, p. 97 ; Kendall, r908, p. 79.

Woods Hole, Menemsha Bight; most frequent at latter point, but never common.-Edwards. A specimen which had been so labeled in the local collection is very doubtfully of this species.-Sumner.

Parasites (Linton): Nematodes-Ascaris incurva. Cestodes-Dibothrium sp. (larvæ), Rhynchobothrium sp. (cysts). Trematodes-Distomum sp., Gasterostomum sp.

Seriola dumerili (Risso). Amber-fish, amber-jack. Jordan and Evermann, 1896, p. 903; Smith and Kendall, I898; H. M. Smith, I898, p. 97.

Buzzards Bay, under the same circumstances as S. zonata, but of rare occurrence. Only two specimens recorded prior to 1898 .- Smith and Kendall. One taken in r905.-Edwards. Owing to the difficulty with which members of this genus are distinguished from one another, all records of occurrence must be accepted with caution.

Parasites: Synbothrium filicolle (cysts),-Linton. 
Decaplerus punctatus (Agassiz). Round robin, scad, cigar-fish.

Baird, 1873; Goode, r884a, p. 325; Jordan and Evermann, 1896 , p. 907 ; H. M. Smith, I898, p. 97; Linton, I90r, p. 449; Kendall, I908, p. 79 .

Woods Hole.-Goode. Quisset Harbor.-Smith. Little Harbor, August II, I906; six in trap at Menemsha Bight, August I9, I908.-Edwards. Woods Hole, October I0, I908, four specimens. Apparently rare.

Food: Copepods and annelids (young specimens only examined).--Linton.

Parasites: Dibothrium punctatum, Scolex polymorphus.-Linton.

Decapterus macarellus (Cuvier \& Valenciennes). Mackerel scad.

Baird, 1873; Jordan and Evermann, I896, p. 909; H. M. Smith, I898, p. 97; Kendall, I908, p. 79 .

Newport-Groode. Great Harbor, Vineyard Sound.-Smith. Tisbury Pond, Hadley Harbor--Edwards. Common in the fall, when large numbers (several hundred in a seine haul; Io barrels in a trap) are sometimes taken, but not observed at other times.-Smith. Mr. Edwards reports that these fish were still present in large numbers in Woods Hole Harbor as late as November 22, I908, but that they seemed nearly overcome with the cold at that time.

Parasites (Linton): Cestodes-Scolex polymorphus, Tetrarhynchus bisulcatus (cysts). Trematodes-Distomum appendiculatum, D. vitellosum.

Trachurus trachurus (Linnæus). Saurel.

Jordan and Evermann, I896, p. 9ro; Kenda1l, 1908, p. 80.

Newport.-Jordan and Evermann.

Trachurops crumenophthalmus (Bloch). Goggler, big-eyed scad.

Baird, 1873; Jordan and Evermann, I8g6, p. 9II; H. M. Smith, 1898, p. 97; Linton, I901, p. 449 ; Kendall, I908, p. 80.

Vineyard Sound, Great Harbor, Eel Pond, Tisbury Pond.-Edwards. Common every fall. Recorded from August 7 to November I5. Taken in fyke nets and with the seine.

Food: Annelids.-Linton.

Parasites (Linton): Nematodes-Ascaris (immature). Cestodes-Dibothrium punctatum. Trematodes-Distomum appendiculatum.
Carangus bartholomai (Cuvier \& Valenciennes). Yellow jack.

Jordan and Evermann, 1896, p. 9r9 (Caranx bartholomai); H. M. Smith, I898, p. 98 (Caranx bartholomai); Kendall, I908, p. 80.

Great Harbor in 1885 and $1897 .-$ Smith. Naushon (I904), Great Harbor (I906), Quisset Harbor (I906), Little Harbor (I906), Lamberts Cove (October, I908).-Edwards. Great Harbor, October 7, I9ro, Little Harbor, September 25 and October 3, I9I. (Identified by Sumner, after comparison with specimens in the National Museum). Reported to have been less frequent formerly. Present from August to November. Taken by seine, fyke net, and trap.

Carangus hippos (Linnæus). Crevallé, horse crevalle.

Baird, 1873 ; Jordan and Evermann, I896, p. 920 (Caranx hippos); H. M. Smith, I898, p. 98 (Caranx hippos); Kendall, r908, p. 8I.

Shores of Vineyard Sound, Woods Hole Harbor, Eel Pond, Katama Bay, Tisbury Pond; common.-Edwards. Present from July I till the end of trap fishing; most numerous in October.-Smith. Taken in traps and seines.

Parasites: Acanthocephala (Linton)-Echinorhynchus proteus. Copepods (C. B. Wilson)Lepeophtheirus edwardsi.

Carangus crysos (Mitchill). Yellow crevallé, hardtail.

Baird, I873 (Paratractus pisquetos); Bean, 1884 Caranx chrysus); Jordan and Evermann, I896, p. 92 I (Caranx crysos); H. M. Smith, I898, p. 98 (Caranx crysos); Linton, rgor, p. 450 ( $C a$ ranx crysos); Sharp and Fowler, I904, p. 508 (Caranx crysos); Kendall, I908, p. 8r.

Shores of Buzzards Bay, Katama Bay, few in Sound.-Eidwards. Nantucket.-Sharp and Fowler. Present from July I till end of the trap season. Taken in traps and seines.

Food: Shrimps very abundant in food in August (only young fish examined).-Linton.

Parasites: Acanthocephala (Linton)-Echinorhynchus pristis. Nematodes (Linton)-Heterakis foveolata. Cestodes (Linton)-Dibothrium sp. (larvæ). Trematodes (Linton)-Distomum sp. Copepods (C. B. Wilson)-Caligus rapax.

Alectis ciliaris (Bloch). Cobbler-fish, threadfish.

Baird, 1873 (Blepharichthys crinitus); Jordan and Evermann, 1896, p. 931; H. M. Smith, I898, p. 98; Kendall, r9o8, p. 8x.

Newport.-Bean. Buzzards Bay; not common, 2 or three being taken every year.-Eidwards. Two reported in I9or. Recorded from June 15 to November. Taken in traps. 
Vomer setipinnis (Mitchill). Moonfish, horsefish, dollar-fish. (Goode records the picturesque vernacular name "humpbacked butterfish".)

Cope, I870 (Vomer curtus); Baird, I873; Goode $1884 \mathrm{a}$, p. 322, (Selene setipinnis); Jordan and Evermann, I896, p. 934 ; H. M. Smith, 1898 , p. 98 ; Kendall, 1908, p. 82 .

Woods Hole.-Goode. Newport-Cope. Buzzards Bay, Vineyard Sound; rare to common, appearing during August and remaining during September.-Smith. Taken in traps.

Selene vomer (Linnæus). Moonfish, lookdown, dollar-fish.

Storer, 1867 , p. 78 (Argyreiosus capillaris); Goode, I884a, p. 323 (Selene argentea); Jordan and Evermann, 1896, p. 936; H. M. Smith, I898, p. 98; Sharp and Fowler, 1904, p. 508; Kendall, Igo8, p. 82 .

Woods Hole.-Goode. Buzzards Bay, Tisbury Pond.-Edwards. Nantucket.-Sharp and Fowler. Not common. Taken during September and October. 'Traps and scines.

Trachinotusfalcatus (Linnæus). Round pompano.

Storer, 1867, p. 280 (Trachinotus ovatus); Baird, I873, (Trachinotusovatus); Goode, I884a, p.329 (Trachinotus ovatus); Jordan and Evermann, I896, p. 94I; H. M. Smith, I898, p. 98; Kendall, I908, p. 83 .

Vineyard Haven.-Goode. Katama Bay, Lackeys Bay, Great 'Tisbury Pond, Great Harbor, Quisset Harbor, Nobska Beach.-Edwards. The young are very common some years (e. g., I908); no adults taken. Recorded from July to October I8.-Edwards. Taken by seine.

Trachinotus goodei Jordan \& Evermann. Permit, black-finned pompano.

Jordan and Evermann, I896, p. 943; H. M. Smith, I898, p. 98; Kendall, I908, p. 83 .

Nobska Beach and other places.-Edwards. Rare; not observed every year; recorded in September, 1894 and 1897 ; only young taken.Smith. Caught by seine.

Trachinotus argenteus Cuvier \& Valenciennes. Silvery pompano.

Jordan and Evermann, I896, p. 944; H. M. Smith, r898, p. 98; Kendall, I908, p. 84.

One taken by seine at Nobska Beach September 7, I885.-Baird, cited by Smith.

Trachinotus carolinus (Linnæus). Common pompano.

Baird, I873; Goode, I884a, p. 327; Jordan and Evermann, I896, p. 944; H. M. Smith, r898, p. 98; Sharp and Fowler, 1904, p. 509; Kendall, I908, p. 84 .
Trachinotus carolinus-Continued.

Woods Hole as early as I863.-Baird, cited by Goode. Nobska Beach, West Falmouth.Edwards. Nantucket.-Sharp and Fowler. Young common; adults not observed for io years.-Smith. Present from latter part of July till end of September.-Smith. Taken with seine.

\section{Family Pomatomide.}

Pomatomus saltatrix (Linnxus). Bluefish.

Storer, $x 867$, p. 82 (Temnodon saltator); Baird, in first report United States Fish Commissioner, p. XxıIr; Baird, I873; Verrill and Smith, 1873 , p. 516; Bean, I884; Goode, I884a, p. 433; Jordan and Evermann, I896, p. $946 ;$ H. M. Smith, I898, p. 98; Linton, I901; Sherwood, and Edwards, I901; Sharp and Fowler, I904, p. 509; Kendall, I908, p. 84 .

Common throughout the region. They first appear in Vineyard Sound from the middle of May to the first week in June.-Groode. Most numerous in July and October.-Edwards. Mr. G. H. Sherwood reports that on July I2, Igor, over 200 were taken from the United States Fish Commission "Bay trap" (near Woods Hole station), and that a school 4 or 5 miles long and over a mile wide was noted in Narragansett Bay, remaining for about ro days. In 1908, reported as more common in Vineyard Sound than for many years.

A few have well-developed spawn on arrival.Smith. Young $I \frac{1}{2}$ inches long; ordinarily first seen in July, though noted as early as May 29, in 1903 .-Edwards.

Food: Some taken in August contained Loligo pealii and various fishes.-Verrill and Smith. Fish (hake, herring, scup, cunner), and squid; in younger individuals smaller fish, as a rule, but shrimps and amphipods were also found.Linton.

Parasites: Acanthocephala (Linton)-Echinorhynchus lateralis, E. proteus, E. sagittifer. Nematodes (Linton)-Ichthyonema globiceps, immature nematodes. Cestodes (Linton)Dibothrium crassiceps, Otobothrium dipsacum, Rhynchobothrium bulbifer (cysts), R. speciosum (cysts), Scolex polymorphus (larvæ), Synbothrium filicolle (cysts), Tetrarhynchus bisulcatus (cysts), T. erinaceus (cysts). Trematodes (Linton)-Distomum monticellii, D. ocreatum, D. vitellosum, D. sp., Microcotyle pomatomi, M. sp. Copepods (C. B. Wilson)-Caligus schistonyx, Lemanthropus pomatomi.

For growth of young and other notes of interest, see Sherwood and Edwards, Igor. 


\section{Family RACHYCENTRIDA.}

Rachycentron canadus (Linnæus). Crab-eater, cobia.

Baird, 1873 (Elecate canadus); Jordan and Evermann, I896, p. 948; H. M. Smith, r898, p. 98, 1899: Linton, I899; Kendall, I908, p. 85 .

Buzzards Bay, Menemsha Bight; rare; less common than formerly.-Edwards. A specimen $43 / 4$ feet long, and weighing over 60 pounds, was taken in the United States Fish Commission trap in Buzzards Bay, July I8, I899.-Smith. Records for July and September. Taken in traps.

Food: Fish (squeateague, etc.).-Linton.

Parasites: Ascaris inquies.-Linton.

\section{Family CORYPHENIDE.}

Coryphana hippurus Linnæus. Dolphin.

Jordan and Evermann, I896, p. 952; H. M. Smith, 1898, p. 99; Kendall, 1908, p. 85.

Vineyard Sound, Menemsha Bight; adults very rare, a few young taken nearly every year in floating gulfweed.-Smith. Recorded for July and August.

Parasites (Linton): Nematodes-Ascaris increscens. Cestodes-Tetrarhynchus bicolor (cysts). Trematodes-Distomum tornatum.

\section{Family BramD死.}

Brama raii (Bloch). Pomfret.

Jordan and Evermann, I896, p. 959.

No Mans Land, one specimen taken in trap at Bureau of Fisheries camp, August 9, I904, this being the only record for the region. (Identified by H. M. Smith).

\section{Family CENTROLOPHDA.}

Centrolophus niger (Gmelin).

Goode and Bean, I895, p. 2 I4 (Centrolophus pompilus); Jordan and Evermann, I896, p. 963 : H. M. Smith, I898, p. 99; Kendall, r908, p. 86.

Off Dennis, Mass., one specimen 9 inches long taken November 23, I888.-Goode and Bean. A southern European fish.

Palinurichthys perciformis (Mitchill). Rudder-fish, polefish.

Storer, I867, p. 75 (Palinurus perciformis); Baird, I873; Verrill and Smith, I873, p. 5r5; Bean, 1884 (Lirus perciformis); Jordan and Evermann, I896, p. 964; H. M. Smith, I898, p. 99; Linton, I899; Sharp and Fowler, I904; p. 509; Kendall, I908, p. 86.
Palinurichthy's perciformis-Continued.

Common and generally distributed in local waters, being found in gulfweed and other floating objects or under anything adrift. Nantucket.-Sharp and Fowler. Present from the last of June till October.-Smith.

Food: One specimen taken in August contained young Squilla empusa and young Loligo pealii.-Verrill and Smith. Squid, small crustaceans, univalve mollusks, also Salpa and green algæ, in two fishes taken at Menemsha, September r.-Linton.

Parasites (Linton): Acanthocephala-Echinorhynchus pristis. Nematodes-Ascaris habena, Lecanocephalus annulatus. Cestodes-Dibothrium punctatum, Scolex polymorphus. Trema. todes-Distomum pyriforme, D. sp.

\section{Family Stromateide.}

Nomeus gronovii (Gmélin). Portuguese-man-ofwar-fish.

Jordan and Evermann, 1896, p. 949; H. M. Smith, 1898, p. 99; Kendall, 1908, p. 87 (Gobiomorus gronovii).

Vineyard Sound; taken with the Portuguese man of-war (Physalia). Recorded for July and August, I889, and July, I894 (common on latter occasion); not observed otherwise.Smith.

Peprilus paru (Linnæus). Harvest-fish, longfinned butter-fish.

Jordan and Evermann, I896, p. 965 (Rhombus paru); H. M. Smith, I898, p. 99 (Rhombus paru); Kendall, I908, p. 87 .

Buzzards Bay, Menemsha Bight, usually rare, occasionally common, 300 or 400 being re. corded for one season.-Smith. A half dozen taken in rgor; fairly common in 1908. Present during June and July. Taken in traps.

Poronotus triacanthus (Peck). Butter-fish.

Baird, I873; Bean, I884 (Stromateus triacanthus); Goode, I884a, p. 333 (Stromateus triacanthus); Jordan and Evermann, I896, p. 967 (Rhombus triacanthus); H. M. Smith, I898, p. 99 (Rhombus triacanthus); Bumpus, $1898 \mathrm{a}$, p. 59 (Rhombus triacanthus); Linton, I90I, p. 453 (Rhombus triacanthus); Sharp and Fowler, I904, p. 509 (Rhombus triacanthus); Kendall, I908, p. 87 .

Abundant along shores generally, occurring from early summer till late fall. There is an especial run in June lasting one or two weeks. Smith. The advance guard (in 1898 ) arrived May Ir at Cuttyhunk.-Bumpus. Caught for 


\section{Poronotus triacanthus-Continued.}

the market in fish traps; also taken in the seine. The young arc often observed swimming under jellyfish. A young specimen taken with the dredge at Fish Hawk station 7740 .

Spawns in June.-Bumpus.

Food: Fish. Smaller specimens were found by Dr. Linton to contain copepods, annelids, and small fish, and in September principally amphipods.

Parasites: (Linton)-Acanthocephala-Echinorhynchus acus, E. sagittifer. NematodesHeterakis sp., Ichthyonema sp., Lecanocephalus annulatus, immature nematodes. CestodesDibothrium angustatum, Otobothrium crenacolle (cysts), Rhynchobothrium bulbifer (cysts), $R$. longispine (cysts), Scolex polymorphus (larvæ), Tetrarhynchus bisulcatus (cysts), $T$. erinaceus (cysts), T. sp. (cysts). Trematodes-Distomum gulosum, D. sp., Microcotyle sp., Monostomum sp. Protozoa-sporocyst in liver. A parasitic isopod (Nerocila munda) has also been found upon this fish by Messrs. Linton and Osburn.

The attractiveness of this delicately flavored fish for the table is frequently diminished by the presence of abundant cestode cysts throughout its muscles.

\section{Family TETRAgONURIDEE.}

Tctragonurus cuvieri Risso. Squaretail, sea raven.

Goode and Bean, 1895 , p. 230; Jordan and Evermann, I896, p. 976; H. M. Smith, I898, p. 99; I899; Kendall, r908, p. 88.

Woods Hole, November I0, I890.-Goode and Bean. Vineyard Sound, August I, 1899.Smith. In the latter case the specimen was taken with the dip net among floating rockweed. These are the only two records locally.

Until i 890 known only from the coast of southern France and Madeira Islands.

\section{Family CHEILODIPTERIDF,}

Apogon imberbus (Linnæus). King of the mullets. Cope, 1870 (A. americanus); Jordan and Evermann, I896, p. I107; Kendall, I908, p. 95.

Newport.-Cope.

Apogon maculatus (Poey). King of the mullets Jordan and Evermann, I896, p. II09; H. M. Smith, I899; I900; Kendall, I908, p. 95.

Newport.-Cope. Katama Bay, II specimens taken in the seine from September I to I6, I899.-Smith.

\section{Family SERRANIDE.}

Roccus lineatus (Bloch).--Striped bass, rockfish. Storer, 1867 , p. 6 (Labrax lineatus); Baird, x873; Verrill and Smith, I873, p. 514; Goode, I884a, p. 425; Jordan and Evermann, 1806, p. II 32 H. M. Smith, I898, p. 99; Bumpus, I898a, p. 59; Sherwood and Edwards, I90I; Linton, r90r, p. 455; Sharp and Fowler, 1904, p. 509 ; Kendall, I908, p. 95.

Vineyard Sound.-Goode. Cuttyhunk, Woods Hole breakwater (many small formerly), Tarpaulin Cove trap (30 or 40 in 1908). Edwards. Nantucket, rare. - Sharp and Fowler. Not common recently. Present from May I to November I, most frequent in June.-Smith.

This fish does not appear to spawn locally.

Food: Ulva latissima, remains of a fish, Cancer irroratus, Homarus americanus.-Verrill and Smith. A few fish scales noted in stomach contents.-Linton.

Parasites: Acanthocephala (Linton)-Echinorhynchus acus, E. proteus. Nematodes (Linton)-Ascaris sp. (immature), Filaria rubra, Ichthyonema sp., Lecanocephalus annulatus. Cestodes(Linton) - Rhynchobothrium speciosum (cysts). Trematodes (Linton)-Distomum tenue, D. tornatum. Copepods (C. B. Wilson).Ergasilus labracis, Caligus rapax.

Morone americana (Gmelin).-White perch.

Baird, I873; Jordan and Evermann, 1896, p. II34; Bumpus, I898a, p. 59; H. M. Smith, 1898, p. 99; Linton, I90r; Kendall, I908, p. 96.

Vineyard Sound, Buzzards Bay, and brackish ponds connected therewith; abundant, especially in Tashmoo Pond. Occurs along shores in undiluted sea water from fall till early spring, when large specimens are taken.Edwards. Resident (landlocked) in some fresh-water ponds. Taken in traps and with the seine.

Spawns in ponds in May and June.-Smith.

Food: Fish, shrimps, and other Crustacea.Linton.

Parasites (Linton): Ancanthocephala-Echinorhynchus clavceces, E. thecatus, E. sp. Nematodes-Heterakis sp., Lecanocephalus annulatus. Trematodes-Distomum areolatum, $D$. tenue tenuissime, D. vitellosum, D. sp., cysts with trematode ova.

Epinephelus adscensionis (Osbeck). Rock hind. Jordan and Evermann, I896, p. II $52 ;$ H. M. Smith, I899, I900; Kendall, I908, p. 97.

One young specimen seined at Katama Bay September I9, I899. 
Epinephelus niveatus (Cuvier \& Valenciennes). Spotted grouper, snowy grouper.

Cope, 1870 (Hyporthodus flavicauda); Jordan and Evermann, I896, p. II56; Smith and Kendall, I898; H. M. Smith, I898, p. 99; I899; I901a; Kendall, rgo8, p. 97.

Woods Hole, Great Harbor, Menemsha Bight, Cuttyhunk, Edgartown, Katama Bay, Tisbury Pond. Newport.-Cope. Not rare locally. First reported in I895; upward of 75 in 1899. Smith. One in r9o6.-Edwards. None of this or any other species of grouper reported in I908. Recorded from August I 5 till November. Taken by seine, fyke net, lobster pot, and dredge.

Epinephelus morio (Cuvier \& Valenciennes). Red grouper.

Jordan and Evermann, I896, p. Ir6o; H. M. Smith, I899, I900, r9ora; Kendall, I908, p. 98.

Katama Bay, seven young specimens seined in 1899; one in 1900; September I to $26 .-$ Smith.

Garrupa nigrita (Holbrook). Black jewfish. Jordan and Evermann, I896, p. II6r; H. M. Smith, I899, I900; Kendall, I908, p. 98.

Katama Bay, a number of specimens seined in September, I899; these were young and the identification consequently uncertain.Smith.

Mycteroperca bonaci (Poey). Black grouper.

Jordan and Evermann, I896, p. II74; H. M. Smith, I899, I900, I9ora; Kendall, I908, p. 98.

Katama Bay and Eel Pond. One specimen in 1899, one in 1900.-Smith. Two taken in IgoI.-Edwards. Recorded for August, September, and October. Taken with seine.

? Mycteroperca interstitialis (Poey).

Jordan and Evermann, I896, p. II78; H. M. Smith, I899; I900 (M. interstitialis); rgor a, ( $M$. venenosa); Kendall, r9o8, p. 99.

Katama Bay, ro specimens seined in September and October, I899; others in I900.-Smith. Tisbury Great Pond in r906.-Edwards. Recorded as early as August, and as late as October 20 .

Centropristes striatus (Linnæus). Sea bass.

Storer, 1867 , p. Io (Centropristes varius); Baird, I873, (Centropristes atrarius); Verrill and Smith, I873 (Centropristis fuscus); Bean, 1884 (Centropristis nigricans); Goode, I884a, p. 407 (Serranus atrarius); Wilson, I89r, p. 209 (Serranus atrarius); Jordan and Evermann, r896, p. Ir99; Bumpus, I898a, p. 59; Smith, I898,
Centropristes striatus - Continued.

p. 100; Linton, I90I; Sherwood and Edwards, rgor; Sharp and Fowler, I904, p. 5ro; Kendall, I908, p. 99.

In deeper waters locally, common though decreasing in numbers. Nantucket, ro barrels in one day in rg03.-Sharp and Fowler. The sea bass arrives about the middle of May.Wilson. Present from May to October, most abundant from July to September.-Smith. First seen (in 1898) on May ro; abundant on the I2th.-Bumpus. Taken in traps and on lines. Small specimens dredged by the Survey in the eastern end of Vineyard Sound and lower end of Buzzards Bay; 2 to 8 fathoms.

Fish Hawk stations: 7663 ( 1 small), 7675 (2), 7760 (I small), 7766 (several small), 7769 (2 small), 7778 (2 small), 778 I (I).

Phalarope station: ${ }_{5} 8$ (I small).

Spawns from middle of May to first of July. For occurrence of young, see Sherwood and Edwards, rgor.

Food: Cancer irroratus, Panopeus sayi, three species of fishes, Loligo pealii.-Verrill and Smith. Fish, squid, crabs (Pagurus, Panopeus, Ovalipes, etc.).-Linton.

Parasites: Acanthocephala (Linton)-Echinorhynchus proteus, E. sagittifer, E. aurantiacus, E. sp., Nematodes (Linton)-Filaria rubra. Cestodes (Linton)-Rhynchobothrium imparispine (cysts), Scolex polymorphus (larvæ). Trematodes (Linton)-Distomum globiporum. Copepods (C. B. Wilson)-Caligus mutabilis.

Rypticus bistrispinus (Mitchill).

Cope, 1870 (Promicropterus decoratus); Jordan and Evermann, 1896, p. I233; Kendall, I908, p. 100 .

Newport.-Cope.

\section{Family LовотіD落.}

Lobotes surinamensis (Bloch). Flasher, triple-tail.

Baird, r873; Goode, 1884a, pp. 444; Jordan and Evermann, I896, p. I235; H. M. Smith, 1898, p. I00; Sherwood and Edwards, Igor; Linton, I90I, p. 457 ; Kendall, I908, p. I00; Sumner, r9o9, p. 984 .

Woods Hole.-Baird. Menemsha, very rare, having been observed on only a few occasions, viz, August, I873; December, I875; September, 1886; August, 1890.-Smith. One taken at Nantucket, August I5, r908. Taken in traps.

Parasites (Linton): Acanthocephala-Echinorhynchus pristis. Nematodes - Ichthyonema globiceps. Cestodes - Synbothrium filicolle (cysts). Trematodes-Gasterostomum ovatum. 
Family PRIACANTHDAE.

Priacanthus arenatus Cuvier \& Valenciennes. ${ }^{a} \mathrm{Ca}$ talufa, big eye.

Jordan and Evermann, 1896, p. 1237; H. M. Smith, 1898 , p. 100; Kendall, r908, p. roo.

Newport.-Jordan and Evermann. Quisset Harbor, Katama Bay.-Edwards. Specimen in museum, from Woods Hole, dated November 2,1885 . Present in the fall, taken by seine.

Pseudopriacanthus altus (Gill).b Short big eye.

Cope, $187 \circ$ (Priacanthus altus); Jordan and Evermann, 1896, p. 1239; H. M. Smith, 1898, p. roo; r899; rgora; Kendall, r908, p. ror.

Newport.-Cope. Katama Bay, many taken in September, 1899. Since then they have occasionally been taken in the vicinity of Woods Hole.

\section{Family Lutianide.}

Lutianus griseus (Linnæus). Gray snapper, mangrove snapper.

H. M. Smith, 1898, p. roo (Neomcenis griseus); Igora, (Neomanis griseus); Jordan and Evermann, I898, p. 1255 (Neomanis yriseus); Kendall, I908, p. Iоr.

Eel Pond, Great Harbor, Katama Bay; a rare straggler, two being taken in 1897 , five in 1900.- Smith. Tisbury Great Pond, in r906.Edwards. Recorded for August, September, and October. Taken with seine.

Lutianus jocu (Bloch \& Schneider).-Dog snapper.

H. M. Smith, 1898, p. 100 (Neomanis jocu); Jordan and Evermann, I898, p. I257 (Neomcenis jocu); Kendall, Igo8, p. Ior.

One young specimen seined in the Eel Pond September 21, I897.

Lutianus apodus (Walbaum). Schoolmaster.

H. M. Smith, 1898, p. 100 (Neomcenis apodus); rgora (Neomenis apodus); Jordan and Evermann, I898, p. 1258 (Neomanis apodus); Kendall, r908, p. ror.

Woods Hole, September 20, I888; Katama Bay, August 29 and September II, I900.-Smith. Again, August, rgor.-Edwards. Taken with seine; all young specimens.
Lutianus blackfordii (Goode \& Bean). Red snapper.

H. M. Smith, 1898, p. 100 (Neomanis aya); rgora (Neomanis blackfordi); Jordan and Evermann, 1898, p. 1264 (Neomanis aya); Kendall, r9o8, p. 102 .

Menemsha, in trap, October 10, r89o; seined at Katama Bay, September and October, Igo.Smith. Only young specimens taken.

Lutianus analis (Cuvier \& Valenciennes). Mutton-fish.

H. M. Smith, I898, p. Ioo; I899; Igora (Neomanis analis); Jordan and Evermann, $1898, \mathrm{p}$. I265 (Neomanis analis); Kendall, I908, p. I02.

Woods Hole, seven specimens in 1876 ; Quisset Harbor, two in 1897; Katama Bay, twenty in 1899, twenty in 1900.-Smith. Tisbury Great Pond, one in I906.-Edwards. Recorded for August, September, and October. Taken with seine. The largest of the Igoo specimens were 2 inches long.-Smith.

Ocyurus chrysurus (Bloch),-Yellow-tail.

Jordan and Evermann, I898, p. 1275; H. M. Smith, I9or; Kendall, r908, p. I02.

Katama Bay, one young specimen taken with seine, October 4, 1900.- Smith.

\section{Family HAMULIDE.}

Orthopristis chrysopterus (Linnæus). Pigfish, sailor's choice.

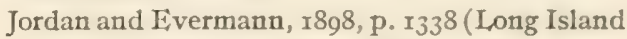
to Rio Grande); Sumner, I909, p. 984 .

One specimen, $81 / 4$ inches long, taken in trap at Lamberts Cove, October 2I, rgo8.

\section{Family SPARIDI.}

Stenotomus chrysops (Linnæus). Scup, porgy. [Chart 20I.]

Storer, $\mathrm{x} 867$, p. 50 (Pagrus argyrops); Baird, I873 (Stenotomus argyrops); Verrill and Smith, I873, p. 515 (Stenotomus argyrops); Bean, I884; Goode, I884a, p. 386 (Stenotomus versicolor and S. gardeni); Jordan and Evermann, I898, p. I346; H. M. Smith, r898, p. roo; Bumpus, 1898a, p. 59; Linton, 1899 ; Sherwood and Edwards, rgor; Sharp and Fowler, 1904, p. 510; Kendall, I908, p. ro3.

a Owing to a typographical error, this species instead of the next was desiguated as "short big eye" in Dr. Smith's list af Woods Hole fishes. This error has resulted in uncertainty regarding some of the records furnished by Mr. Edwards for this and the following species, and such records have accordingly been omitted.

$b$ See preceding footnote. 
Stenotomus chrysops-Continued.

Abundant everywhere, being taken from May I. to the latter part of October; most abundantly in June and July. An important item in the local trap fishery. Small specimens were taken during the Survey dredging throughout Vineyard Sound and the lower half of Buzzards Bay, in waters of 3 to $I 7$ fathoms depth.

Fish Hawk stations: 7548 (many), 7554 (many), 7567 (few), 7569 (2), 7570 (few), 7574 (I), 7575 (I), 7576 (many), 7578 (many), 7579 (many), $75^{80}$ (many), $75^{82}$ (several), $75^{83}$ (I), $75^{84}$ (I), 7593 (many), 7594 (few), 7597 (I), 7508 (I), 7599 (I), 7602 (few), 76 I $_{5}$ (I), 7643 (I), 7654 (I), 7656 (many), 7657, 7660 (several), 7673 (several), 7675 (I), 7734 (x), 7739 (2), 774I (I), 7757 (I), 7759 (x), 776r (several), 7765 (2), 7767 (few), 7772 (I), 7774 (2), 7777 (several), 7778 (few), 7780 (many), 7781 (few), 7782 (several), 7783 (many).

Spawns early in June. For growth of young, see Sherwood and Edwards, rgor.

Food: All kinds of small Crustacea, annelids, bivalve and univalve mollusks, etc.-Verrill and Smith. Small fish and squid, also annelids, crabs, shrimps, amphipods, mollusks, hydroids, young sea urchin, holothurians, vegetable débris, copepods, small Crepidula.Linton.

Parasites: Acanthocephala (Linton)-Echinorhynchus acus, E. sagittifer. Nematodes (Linton)-Ascaris sp. (immature). Cestodes (Linton)-Rhynchobothrium imparispine, $R$. longispine (cysts), R. speciosum (cysts), Scolex polymorphus '(larvæ), Tetrarhynchus bisulcatus (cysts). Trematodes (Linton)-Distomum appendiculatum, D. vitellosum, D. sp., Microcotyle stenotomi. Rhynchobdellida(Linton)Pontobdella rapax. Copepods (C. B. Wilson)Caligus rapax.

Lagodon rhomboides (Linnæus). Sailor's choice, pinfish.

Goode, r884a, p. 393 ; H. M. Smith, I898, p. Ior; Jordan and Evermann, I898, p. 1358; Kendall, I908, p. I03.

Woods Hole-Goode. Quisset Harbor, Great Harbor, Tisbury Great Pond, Eel Pond.Edwards. A specimen $10 \mathrm{x} / 2$ inches long taken in Buzzards Bay in 1899 . Smith. Ordinarily scarce; common throughout the region in 1906. Recorded from June till October 25. Taken with the seine.
Archosargus probatocephalus (Walbaum). Sheepshead.

Storer, 1867 , p. 49 (Sargus ovis); Goode, I884a, p. 38 I (Diplodus probatocephalus); H. M. Smith, I898, p. Ior; Jordan and Evermann, I898, p. I36I; Linton, I90r, p. 459; Kendall, 1908, p. I04.

Wareham-Goode. Buzzards Bay.-Edwards. Very uncommon of late, though said to have formerly been quite common. Recorded for July and August. Taken by line.

Parasites: Echinorhynchus proteus.-Linton.

\section{Family GERRIDE.}

Eucinostomus gula (Cuvier \& Valenciennes). Silver jenny, Irish pompano.

Goode, I884a, p. 279 (Gerres argenteus); H. M. Smith, I898, p. Ior; Jordan and Evermann, I898, p. I370; Kendall, I908, p. I04.

Woods Hole.-Goode. Quisset Harbor, Eel Pond; usually very uncommon, but small specimens were taken on a number of dates during August, September, and October, 1897.-Smith.

\section{Family KyPHOSIDA:}

Kyphosus sectatrix (Linnæus). Rudder-fish, Bermuda chub.

Baird, I873 (Pimelepturus boscii); Goode, I884a, p. 394 (Cyphosus boscii); H. M. Smith, I898, p. Ior; Jordan and Evermann, r898, p. I387; Kendall, I908, p. I04.

Woods Hole.-Goode. Quisset Harbor, Tisbury Great Pond.-Edwards. Not rare in summer and fall, occasionally met with in April.Smith. Taken seining; sometimes found among gulfweed at surface.

Parasites: Caligus rapax.-C. B. Wilson.

Kyphosus incisor (Cuvier \& Valenciennes).

Jordan and Evermann, I898, p. I386 (not recorded locally).

One specimen taken in trap at Nantucket, October 3 I, I906 (sent to G. M. Gray and identified by H. M. Smith).

\section{Family SCIANIDAE.}

Cynoscion regalis (Bloch \& Schneider). Squeteague, weakfish, sea trout.

Storer, 1867 , p. 45 (Otolithus regalis); Baird, 1873 ; Verrill and Smith, 1873, p. $5 \times 5$; Bumpus, I898a, p. 59; H. M. Smith, I898, p. Iоr; Jordan and Evermann, 1898, p. I407; I.inton, r899; Sherwood and Edwards, Igor; Sharp and Fowler, I904, p. 510; Kendal1, I908, p. I05. 
Cynoscion regalis-Continued.

Abundant throughout region, being the principal food fish taken in local traps. Commonly present from May till the middle of October. First in 1898 taken in April.-Bumpus. In Igor they were reported as very late in appearing, the first being noted June I4. The squeteague was unusually scarce in 1908 . - Edwards.

Spawn about June $I$. Young $I \frac{1}{2}$ inches long taken in July.-Smith. For migration and occurrence of young, see Sherwood and Edwards, I9oI.

Food: Local specimens taken in July often contained Ovalipes ocellatus and Loligo pealii.Verrill and Smith. Fish (menhaden, butterfish) and squid; shrimps and amphipods occasionally.-Linton.

Parasites (Linton): Acanthocephala-Echinorhynchus acus, E. pristis, E. proteus, E. sagittifer. Immature nematodes. Cestodes-Otobothrium crenacolle (cysts), Rhynchobothrium bulbifer (cysts), R. speciosum (cysts), R. sp. (cysts) Scolex polymorphus (larvæ), Synbothrium filicolle (cysts), Tetrarhynchus bisulcatus (cysts), T. erinaccus (cysts). TrematodesDistomum appendiculatum, D. monticellii, $D$. polyorchis, D. pyriforme, D. vitellosum, Microcotyle longicauda, M. sp.

Larimus fasciatus Holbrook. Banded drum.

H. M. Smith, I898, p. Ior; Jordan and Evermann, I8g8, p. I424; Kendall, I908, p. I05.

Buzzards Bay, at breakwater, a specimen 8 inches long taken August I3, I889.-Smith.

Scianops ocellatus (Linnæus). Red drum; channel bass; redfish.

H. M. Smith, I898, p. Ior; Jordan and Evermann, I898, p. 1453; Linton, I90r, p. 46r; Kendall, I908, p. 106.

Buzzards Bay, in trap at breakwater; one (the only recorded) taken in 1894 - Smith.

Parasites: Ascaris sp. (immature).-Linton.

Leiostomus xanthurus (Lacépède). Spot, goody. Baird, 1873 (Liostomus obliquus); H. M. Smith, r8g8, p. Iоr; Jordan and Evermann, I898, p. I458; Kendall, I908, p. I06.

Woods Hole Harbor, Tisbury Great Pond.Edwards. Small specimens common in the fall, being observed throughout October.Smith. Taken in traps, seines, and fyke nets.

Micropogon undulatus (Linnæus). Croaker.

H. M. Smith, $x 898$, p. Ior; Jordan and Evermann, I898, p. I46r; Kendall, I908, p. Io6.

Only one taken; September 9, 1893, in Buzzards Bay trap at breakwater.-Smith.
Menticirrhus saxatilis (Bloch \& Schneider). King fish, sea mink.

Baird, $x 873$ (Menticirrhus nebulosus); Verrill and Smith, I873, p. 515 (Menticirrhus vebulosus); Goode, 1884a, p. 375, 376 (Menticirrluzs nebulosus); H. M. Smith, I898, p. ror; Jordan and Evermann, I898, p. I475; Linton, I9or, p. 46r; Sharp and Fowler, I904, P. 5 I0; Kendall, I908, p. 107 .

Buzzards Bay, Vineyard Sound, Vincyard Haven. Adults common in June, uncommon after July $1_{5}$; young found till early October.Smith. Large fish taken in traps, young with the seine.

Adults full of spawn in June.-Smith.

Food: Crago septemspinosus, Cancer irroratus, Loligo pealii.-Verrill and Smith. Amphipods, isopods, shrimps, annelids, young fish, bryozoa.-Linton.

Parasites: Nematodes (Linton)-Ascaris sp. (immature). Cestodes (Linton)-Rhynchobothrium bulbifer (cysts), R. longispine (cysts), Scolex polymorphus (larvæ). Trematodes (Linton)-Distomum areolatum, D. globiporum, D. pyriforme, $D$. vitellosum, D. sp.-Linton. Copepods (C. B. Wilson)-Caligus rapax.

Pogonias cromis (Linnæus). Drum.

Goode, I884; H. M. Smith, I898, p. Ior; Jordan and Evermann, I898, p. I482; Kendall, I908, p. 107 .

Quisset Harbor, in September and October, very rare; one (locality unstated) recorded for May.-Smith. Taken in traps.

\section{Family POMACENTRIDE.}

Eupomacentrus leucostictus (Müller \& Troschel). Cocky pilot.

Jordan and Evermann, I898, p. I555; H. M. Smith, I899; I900; Kendall, I908, p. I08.

Katama Bay, nine specimens seined between August 30 and October 4, I899.-Smith.

Abudefduf saxatilis (Linnæus).-Cocky pilot.

Cope, I870 (Glyphidodon saxatilis); Jordan and Evermann, 1898, p. 156r; Kendall, I908, p. 108.

Newport.-Cope.

\section{Family LABRIDEE.}

Tautogolabrus adspersus (Walbaum). Cunner, chogset. [Chart 202.]

Baird, I873; Bean, I884 (Ctenolabrus adspersus); H. M. Smith, I8gS, p. I02; Jordan and Evermann, I898, p. 1577; Sherwood and Fidwards, I90I; Linton, r901, p. 462 ; Sharp and Fowler, I904, p. 510; Kendall, Ig08, p. I0S. 
Tautogolabrus adspersus - Continued.

Taken everywhere and in large numbers, especially under wharves and around piers. A resident fish, said to take refuge among eelgrass in winter. Caught with seine, fyke, small trap, or hand line. Dredged by the Survey (chiefly young specimens) throughout Vineyard Sound and Buzzards Bay, in waters of $2 \frac{T}{2}$ to 20 fathoms depth.

Fish Hawk stations: $75^{2 I}$ bis (I), 7525 I (small), 7543 bis (I small), 7548 (I), $755^{6}$ (I small), $75^{64}$ (I small), 7572 (I large, I small), 7580 (I), 7608 (I small), 7610 ( 1 small), 76I5 ( 2 very small), 7619 (several), 7622 (several young), 7624 (several young), 7626 (several small), 7633,7637 (I very small), 7638 ( $\mathrm{I}$ very small), 7643 (few small), 7644 (2 large, several small), $766_{3}$ (r), 767 I (several), 7675 (3), 7688 (I small), 7689 (5), 7720 (I), $772 x$ (several), 7742 (I small), 7745 (I medium), 7750 ( 1 ), 7759 (2), 7762 (many), 7763 (several), 7764 (very many), 7767 (many small), 7768 (I), 7778 (I medium).

Phalarope and Blue Wing stations: 3 (I small), 48 (I small), 60 (I), 73 (I), 75 (I), I30 (I small), I36.

Spawns in June and early July. Young taken in tow from June to October, being most abundant in June and July.-Towing records of V.N. Edwards.

Food: Seaweed, hydroid stems, bryozoa, tunicates, annelids, small crustacea (Caprella, shrimps, etc.), univalve mollusks.-Linton. In order of frequency: Amphipods, eelgrass, snails, prawns, small fishes (silversides, sticklebacks, pipefish, etc.), Botryllzs, rock crab, algæ, teleost eggs, lady crabs, hydroids, Nereis, hermit crab, isopods, Soleyma velum, bryozoa.-I. A. Field.

Parasites (Linton): Immature nematodes. Cestodes-Rhynchobothrium imparispine (cysts). Trematodes-immature distomes in skin, Distomum areolatum, D. vitellosum, D. sp.

This species is sometimes destroyed in great numbers during severe winters. Mr. Edwards states that barrels of dead cunners were found floating in the water after "anchor ice," February, Igor.

Tautoga onitis (Linnæus). Tautog, blackfish.

Baird, 1873; Verrill and Smith, 1873, p. 515, Bean, I884; H. M. Smith, I898, p. I02; Jordan and Evermann, I898, p. $x_{578}$; Sherwood and Edwards, I90r; Linton, I90r, p. 463; Sharp and Fowler, I904, p. 510; Kendall, I908, p. 108 .
Tautoga onitis-Continued.

Abundant everywhere and at all seasons throughout the region. Taken in traps and on hand lines; the young frequently caught in the seine.

Spawns in June and July. Young taken in tow in June, July, and August.- - Towing records of V. N. Edwards.

Food: Cancer irroratus, Pagurus longicarpus, $\mathrm{Pa}$ gurus pollicaris, Panopeus depressus, P. sayi, Ovalipes ocellatus, Pelia mutica, Homarus americanus, Balanus crenatus, Loligo pealii, Crepidula fornicata, C. plana, Triforis nigrocinctus, Arca pexata, Pecten gibbus borealis, Mytilus edulis, Modiolus modiolus, Nucula proxima, Mya arenaria, Petricola pholadiformis, Bittium alternatum, Tritia trivittata, Echina. rachnius parma, Crisia eburnéa, Styela partita, Didemnum lutarium.-Verrill and Smith. A great variety of crabs and mollusks; in young specimens, seaweed, small crustacea, mollusks, and annelids.-Linton. Astonishing as it may seem, the tautog unquestionably devours sessile barnacles of considerable size.

Parasites (Linton): Acanthocephala-Echinorhynchus acus. Cestodes-Rhynchobothrium hispidum (cysts), Scolex polymorphus (larvæ). Trematodes-Distomum vitellosum, D. sp., Microcotyle hiatule, immature distomes in skin.

Mr. Edwards reports that great numbers of this fish, like the preceding species, were killed (by "anchor ice") in February, Igor (see note above).

\section{Family SCARIDA:}

Sparisoma flavescens (Bloch \& Schneider). Parrotfish.

Jordan and Evermann, I898, p. I639; H. M. Smith, r90r; Kendall, r908, p. Iro.

One specimen picked up on shore of Buzzards Bay, November I3, 1900.-Smith.

Scarus croicensis (Bloch.) Parrot-fish.

Jordan and Evermann, I898, p. I650; H. M. Smith, Igor, Kendall rgo8, p. Iro.

Katama Bay, two specimens seined October 20, Ig00.-Smith.

\section{Family EPHIPPIDE.}

Chatodipterus faber (Broussonet). Angel-fish, spadefish.

Goode, I884a, p. 445-446; H. M. Smith, I898, p. I02; Jordan and Evermann, I898, p. I668; Linton, Igor, p. 463; Kendall, I908, p. III. 
Chetodipterus faber-Continued.

Woods Hole, several.-Goode. Menemsha, in traps, August and September; very rare. Tisbury Great Pond, one seined in October, 1906.-Edwards.

Parasites (Linton): Nematodes-Ichthyonema sp. Cestodes-Rhynchobothrium speciosum (cysts), Tretrarhynchus sp. (cysts).

\section{Family CHETODONTIDEE.}

Chatodon capistratus Linnæus. $a$ Butterfly-fish.

H. M. Smith, I898, p. I02 (Chatodon bricei), p. I03 (C. striatus); 1899; rgora (C. bricei); Jordan and Evermann, 1898 , p. 1677 (C. capitstratus), p. I678 (C. bricei); Kendall, I908, p. III.

Quisset Harbor, Great Harbor, Eel Pond, Katama Bay. Common in Katama Bay in 1899 ; few prior to that date; 35 taken in I900.Smith. Only a few taken since then.-Edwards. Recorded for August, September, and October. Taken with seine.

This and other members of the genus taken locally are undoubtedly stragglers from southern waters.

Chatodon ocellatus Bloch. Parché, butterfly-fish. Cope, I87o (Sarothrodus maculocinctus); H. M. Smith, I898, p. 102; I899; Igor a; Jordan and Evermann, 1898, p. 1674; Kendall, I908, p. III.

Katama Bay, Woods Hole, Tisbury Great Pond, a few specimens taken each year. Common at Katama Bay in I899; I23 in I900.-Smith. Newport.-Cope. Present from August till November. Seined among eelgrass.

\section{Family TEUTHIDIDA.}

Teuthis caruleus (Bloch \& Schneider). Surgeon fish.

Jordan and Evermann, I898, p. I69г; H. M. Smith, I899; r900; I90ra; Kendall, I908, p. I12.

Katama Bay, a number seined in I899; again in I900.-Smith. Recorded from August to October. Only young specimens noted.

Teuthis hepatus Linnæus. Surgeon-fish.

Jordan and Evermann, I898, p. I69I; H. M. Smith, I899; I900; I901a; Kendall, I908, p. II 2 .

Katama Bay, a number seined in 1899 ; again in I900, during same months as the preceding.Young specimens only.
Teuthis bahianus (Castelnau). Surgeon-fish.

Jordan and Evermann, I898, p. I693; H. M. Smith, I899, I900; I90ra; Kendall, r908, p. II 2 .

Katama Bay, a number seined in 1899 ; again in I900, during same months as the preceding.Smith. Only young specimens.

Family BALISTIDE:

Balistes carolinensis Gmelin. Trigger-fish, leatherjacket.

H. M. Smith, I898, p. I04; Jordan and Evvermann 1898, p. r7or; Kendall, I908, p. I12,

Menemsha Bight, in traps, during fall; very rare.

Balistes forcipatus Gmelin. Trigger-fish.

Cope, 1870 (Balistes poiselli); Jordan and Evermann, I898, p. I702; Kendall, I908, p. II3.

Newport.-Cope.

Balistes vetula Linnæus. Trigger-fish, leatherjacket.

Baird, I873; H. M. Smith, I898, p. I03; Jordan and Evermann, I898, p. I703; Linton, I90I; Sharp and Fowler, I904, p. 510; Kendall, r908, p. II3.

Menemsha, in traps during September, some taken every year; young at the surface and along the shores of Vineyard Sound, during summer and fall. - Smith. Orie at Menemsha, August I, Igo8, one in Buzzards Bay trap, Woods Hole, July 29, I908. Nantucket.Sharp and Fowler.

Food: Amphipods, copepods, seaweed.-Linton. Parasites: Distomum vibzx.-Linton.

Canthidermis sobaco Poey. Sobaco, trigger-fish.

H. M. Smith, I898, p. 104 (C. asperrimus); Jordan and Evermann, 1898, p. I705; Kendall, I908, p. II3.

Vineyard Sound, off Great Harbor; one specimed taken in floating gulfweed, July 24, I897.

\section{Family MONACANTHIDE.}

Monacanthus hispidus (Linnæus). Foolfish, filefish.

Storer, I867 (Monacanthus massachusettensis); Baird, I873 (Stephanolepis setifer); Bean, I884; H. M. Smith, 1898, p. I04; Jordan and Evermann, I898, p. I7×5; Linton, I899; Kendall, I908, p. II 4 .

Eel Pond, Buzzards Bay, Vineyard Sound, Katama Bay, Great Harbor, Tisbury Pond.-Ed$a$ What is now believed to be the young of this species was described by Smith as a new species, Chatodon bricei. 
Monacanthus hispidus-Continued.

wards. Of variable abundance, sometimes very common, occurring under gulfweed or in eelgrass or rockweed. One specimen dredged in Vineyard Sound, at Fish Hawk station 7778 . This fish occurs locally from July to November. Only small specimens are taken, the maximum size being about 4 inches.

Food: Hydroid stems.-Linton.

Alutera schoepfii(Walbaum). Orange filefish, foolfish.

Baird, I873 (Alutera cuspicauda and Ceratacanthus aurantiacus); Verrill and Smith, I873, p. 520 (Ceratacanthus aurantiacus); H. M. Smith, I898, p. I04; Jordan and Evermann, 1898, p. I718; Linton, 1901, p. 464; Kendall, I908, p. II 5 .

Buzzards Bay, Eel Pond, Quisset Harbor, Tisbury Great Pond.-Edwards. Rather common during summer, being recorded from July to November ro. This fish frequents shores, especially near eelgrass, and is taken in traps (large specimens), seines (small ones); also in fyke nets.

Food: One specimen in August was found to have eaten a large quantity of Pennaria.Verrill and Smith. Algæe eaten in captivity.Smith. Hydroid stems.-Linton.

Parasites: Cestodes (Linton) Dibothrium aluterce, D. sp. (larvæ), Otobothrium crenacolle (cysts), Rhynchobothrium bulbifer (cysts). Trematodes (Linton)-Distomum pallens, D. valdeinflatum, D. sp. Copepods (Rathbun)Lencolophus sultanus.

Alutera monoceros (Linnæus).

Jordan and Evermann, I898, p. I720; Smith, I898a, p. 544, I899, I899a, т900; Kendall, I908, p. II 5 .

One taken with seine at Woods Hole on August 221898 , a second in trap at Menemsha Bight August I, I899.-Smith.

\section{Family OstracIDAE.}

Lactophry's triqueter (Linnreus). Trunkfish.

Jordan and Evermann, I898, p. I722; H. M. Smith, 1899, I900; Kendall, I908, p. II5.

Several specimens taken in $1899^{\circ}$ also in $I 897$ and perhaps earlier; those collected previous to I899 had been identified as L. trigonus.Smith. Taken seining; in one case washed ashore-Edwards.
Lactophry's trigonus (Linnæus). Trunkfisli.

Storer, I867, p. 236 (Lactophrys yalei); Gill, I873, p. 793; Baird, I873 (after Storer); H. M. Smith, I898, p. I04; Jordan and Evermann, I 898 , p. $x_{723}$; Kendall, I908, p. II 5 .

Vineyard Haven.-Gill. Quisset Harbor, Great Harbor, Eel Pond.-Edwards. Young (maximum $x$ inch long) not uncommon, occurring under gulfweed or among eelgrass from July to October.-Smith. Taken in tow nets or seines.

Lactophry's tricornis (Linnæus). Trunkfish, cowfish.

Jordan and Evermann, I898, p. I724; H. M. Smith, I900, I901a; Kendall, I908, p. II6.

Katama Bay, several small specimens taken in September, I899; two on October 4, I900; one ( $5_{5} \mathrm{r} / 2$ inches long) washed ashore at Cuttyhunk November 6, 1899.-Smith.

\section{Family TETRAODONTIDF.}

Lagocephalus lavigatus (I,innæus). Smooth puffer. Storer, r867, p. 225 (Tetrodon lavigatus); Baird, 1873 (Tetrodon levigatus); H. M. Smith, 1898, p. I04; Jordan and Evermann, I898, p. 1728; Sherwood and Edwards, I90I; Linton, I901, p. 464; Kendall, igos, p. II6.

Buzzards Bay, Vineyard Sound, Woods Hole, Cedar Tree Neck, Menemsha Bight.-Edwards. Not very common, perhaps a half dozen each year, mostly during September and October.-Smith. Several specimens in 1900.-Sherwood and Edwards. Two in 1908. Taken in traps.

Parasites (Linton): Nematodes-Ascaris sp. (immature). Cestodes-Dibothrium sp. (larvæ), Scolcx polymorphus (larva). TrematodesDistomum sp.

Spheroides spengleri(Bloch). . Southern puffer.

H. M. Smith, I898, p. I04; 1899; Jordan and Evermann, I898, p. I732; Kendall, I908, p. II7.

Woods Hole, Katama Bay, taken with seine, very rare. Taken in 1899 . - Smith. Again in I900.-Edwards. Recorded for September and October.

Sphcroides maculatus (Bloch \& Schneider). Swellfish, puffer. [Chart 203.]

Storer, I867, p. 224 (Tetrodon turgidus); Baird; I873 (Chilichthys turgidus); Bean, I884 (Tetrodon turgidus); H. M. Smith, 1898 , p. r04; Jordan and Evermann, I898, p. 1733; Bumpus, 
Spheroides maculatus-Continued.

I898a, p. 59; Linton, I90I, p. 464; Sharp and Fowler, I904, p. 510; Kendall, x908, p. II7.

Abundant everywhere in local waters, occurring from about May 20 to cold weather. Enormously abundant in 1903 , when perhaps several thousand were taken in one set of the trap. Young puffers are seined throughout the summer. Occasionally specimens were dredged by the Survey throughout Vineyard Sound and Buzzards Bay.

Fish Hawk stations: 755 I (I large), 7554 (I), 7602 (I small), 76 I9 (several small), 7633 (I), 7634 (I), 7654 (I), 7656 (I),

Phalarope and Blue Wing stations: 5I (I small), I 58 (I small).

Spawns from June I to Io.-Smith. The eggs have been artificially fertilized in the laboratory. Small young abound in summer. Young taken in tow from June to August, chiefly in July.-Towing records of $V$. N. Edwards.

Food: Various Crustacea (crabs, hermit crabs, amphipods, shrimps), annelids, seaweed, various mollusks (bivalve and univalve).-Linton .

Parasites: Acanthocephala (Linton).-Echinorhynchus acus. Nematodes (Linton)-Ascaris habena. Cestodes (Linton)-Dibothrium sp. (larvæ), Phyllobothrium loliginis (immature), Rhynchobothrium bulbifer (cysts), R. tumidulum (cysts), R. sp. (cysts), Scolex polymorphus (larvæ), Tetrarhynchus bisulcatus (cysts), T. sp. (cysts). Trematodes (Linton)-Distomum valdeinflatum, D. vibex, D. vitellosum. Copepods (Wilson)-Tucca corpulentus.

Spheroides testudineus (Linnæus). Tambor, globefish.

Cope, I87o, (Tetraodon geometricus); Jordan and Evermann, 1898, p. I734; Kendall, I908, p. II 7 .

Newport.-Cope.

Spheroides trichocephalus (Cope).

Cope, 1870 (Tetraodon trichocephalus); Jordan and Evermann, 1898, p. 1737; Kendall, I908, p. II 8.

Newport.-Cope:

\section{Family DrodonTIDE.}

Diodon hystrix Linnxus. Porcupine-fish.

Smith and Kendall, IS98; H. M. Smith, r898, p. I04; Jordan and Evermann, I898, p. I745; Kendall, rgo8, p. rr8.

One specimen, 9 inches long, taken in trap in Buzzards Bay, near Wcods Fole station, August I2, I895.
Chilomycterus schoepfi (Walbaum). Burrfish, porcupine-fish, rabbit-fish.

Baird, 1873 (Chilomycterus geometricus); H. M. Smith, 1898, p. I05; Jordan and Evermann, I898, p. I748, I749; Linton, I901, p. 455; Kendall, i908, p. I18

Buzzards Bay, Menemsha Bight, Great Harbor, Muskeget, Tisbury Pond-E-Edwards. Of irregular occurrence, but generally rare; more numerous than usual during summer of 1906 . Present during September, October, and November. Taken in traps and seines.

Parasites: Nematodes (Linton)-Ascaris neglecta. Cestodes (Linton)-Ligula sp. (larva). Copepods (C. B. Wilson)-Tucca impressus.

Chilomycterus antillarum Jordan \& Rutter. Burrfish.

Jordan and Evermann, I898, p. I749; Smith, I899; (not listed by Kendall).

Quisset Harbor, one specimen seined September 7, I897.-Smith. Katama Bay, September I, 1899, one small specimen; Great Harbor, Woods Hole, November 2, rgro, one full-sized specimen taken in fyke net; Menemsha, September I6, I9II, one specimen. (Last three identified with fair certainty by F. B. Sumner).

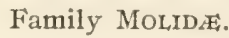

Mola mola (Linnæus). Sunfish.

Baird, I873 (Mola rotunda); Bean, I884 (Mola rotunda); H. M. Smith, 1898, p. I05; Jordan and Evermann, I898, p. I753; Linton, r9or, p. 465; Sharp and Fowler, rgo4, p. 5II; Kendall, I 908 , p. I I 9 .

Vineyard Sound; said to be much rarer now than formerly. Dr. Smith states that formerly 8 or Io were commonly seen in a season, but in recent years seldom more than one. On July II, I900, a sunfish weighing about 250 pounds was harpooned by Dr. Bumpus in Vineyard Sound. Several were reported in local waters in 1908 , though none of these were captured. Nantucket, rare.-Sharp and Fowler. They appear during July and August and are sometimes captured with a harpoon.

Food: Salpæ, small amphipods.-Linton. Large jelly fish.-C. W. Stone.

Parasites: Acanthocephala (Linton)-Echinorhynchus acus. Immature rematodes. Cestodes (Linton)-Dibothrium microcephalum, Tetrarhynchus elongatus. Trematodes (Linton)-Distomum contortum, $D$. foliatum, $D$. fragile, D. macrocotyle, D. arigroflavum, Tristomum mole. Copepods (Rathbun)-Cecrops latreilli, Lepeophtheirus normanni (C. B. Wilson)-Anthosoma crassum, Penella filosa. 


\section{Family SCORPAEIDA:}

Sebastes marinus (Linnæus). Rosefish, red perch. Bean, r884; H. M. Smith, I898, p. 105; Jordan and Evermann, I898, p. I760; Kendall, I908, p. IIg.

Great Harbor, December 20, I895; several specimens stranded by the tide.-Smith.

Scorpana plumieri Bloch. Scorpion-fish.

Jordan and Evermann, I898, p. I848; H. M. Smith, I899, I900, I901a; Kendall, I908, p. I20.

Woods Hole, 20 specimens during August, September, and October, $1899 ; 2$ in 1900.-Smith.

Scorpana grandicornis Cuvier \& Valenciennes. Scorpion-fish, lionfish.

Jordan and Evermann, I908, p. I850; H. M. Smith, I899, I900; Kendall, I908, p. I20.

Katama Bay, one specimen seined September 29, 1899. -Smith.

\section{Family COTTIDA:}

Myoxocephalus aneus (Mitchill). Sculpin, grubby. [Chart 204.]

Baird, I873 (Cottus mitchilli); Bean, I884 (Cottus aneus); Bumpus, 1898 , p. 485 (Acanthocottus aneus); Mead, I898, p. 702 (A. aneus); H. M. Smith, I898, p. 105 (A. ceneus); Jordan and Evermann, I898, p. I972; Linton, I90I, p. 466; Kendall, I908, p. I2I.

Shores and deeper waters everywhere, very common throughout the year. Taken with the seine and fyke net. Dredged by the Survey with considerable frequency throughout Vineyard Sound and along the eastern shore line of Buzzards Bay, in waters 2 to $5_{5}$ fathoms deep.

Fish Hawkstations: 7522 (I small), 7524 (I small), 7524 bis ( 2 very small), 7528 (I), 7530 (I), 7536 (2 small), 7543 bis (I small), 7547 bis ( 3 small), 7549 bis (2), 7653 (I), 7699 ( $I$ young), 770 o ( $\mathrm{I}$ young), 7704 (I), 7722 (I small), 7739 (I), 7740 (2), $7760(4), 776$ I (I small), 7762 (many small), 7767 (many small), 7777 (3 small).

Phalarope and Blue Wing stations: 8 (2), I4 (I), 20 (I small), 24 (I), 27 (I), 29 (I), 32 (I very small), 34 (I), 36 (I), 38 (I), 44 (3), 50 (many small), 52 (few), 53 (many), 55 (I), 56 (I), 58, 59,64 (I ?), 69 (I), 73 (I), 74 (I), 79, 83, 100

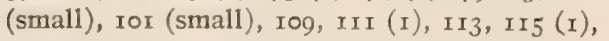
II 7 (I), I29 (I), I3I (2), I34 (I), I4I (I).

Spawns all through the winter.-Edwards. Eggs taken from nets and seaweed in March.Bumpus. Observed hatching April 27, 1898.Mead. Young of sculpin (probably for the
Myoxocephalus aneus-Continued. most part of this species) taken from January to May; most abundantly in March and April; a few recorded in October.-Towing records of V. N. Edwards.

Food: Annelids, copepods, shrimps, and young fish (flounders).-Linton. Also crabs (Cancer and Pagurus) and Zostera.-I. A. Field.

Parasites: Acanthocephala (Linton)-Echinorhynchus acus. Nematodes (Linton)-Ascaris clavata, A. habena, A.sp. Cestodes (Linton)Dibothrium punctatum, D. sp. (larvæ), Rhynchobothrium bulbifer (cysts), $R$. imparispine (cysts). Trematodes (Linton)-Distomum $a p$ pendiculatum, D. sp. Copepods (C. B. Wilson)-Argulus laticauda, A. megalops.

Myoxocephalus gronlandicus (Cuvier \& Valenciennes). Daddy sculpin.

Storer, 1867 , p. 26 (Acanthocottus variabilis); $\mathrm{H}$. M. Smith, 1898, p. I05 (Acanthocottus granlandicus); Jordan and Evermann, I8g8, p. I974; Kendall, Ig08, p. I22.

Common from October to December or January, the occurrence being similar to that of the next species.

Spawn in November and December.

Myoxocephalus octodecimspinosus (Mitchill). Eighteen-spined sculpin, long-spined sculpin.

Baird, I873 (Cothus octodecim-spinosus); Bean, I884 (Cottus octodecimspinosus); H. M. Smith, I898, p. I05 (Acanthocottus octodecimspinosus); Jordan and Evermann, I898, p. 1976; Sharp and Fowler, I904, p. 5II; Kendall, Igo8, p. 123.

Shores and deeper water everywhere; very abundant from October to December or January. A few taken during the Survey dredging in Vineyard Sound and at Crab Ledge, in July August, and September.

Fish Hawk stations: 7556 (I), 7608 (4), 7718 (3). Phalarope station I9.

Spawns in November and December; eggs often come ashore by the bucketful on Nobska Beach.-Smith.

Parasites (Linton): Acanthocephala-Echinorhynchus acus. Nematodes-Ascaris clavata, A. habena. Cestodes-Dibothrium punctatum, Rhynchobothrium imparispine (cysts). Trematodes-Distomum sp.

At times this sculpin may be a pest to fishermen, taking bait intended for other fish.-Edwards. 
Hemitripterus americanus (Gmelin). Sea raven.

Baird, 1873 (Hemitripterus acadianus); Bean, I884; H. M. Smith, 1898, p. I05; Jordan and Evermann, 1898, p. 2023; Linton, r9or, p. 467 ; Kendall, r908, p. 125 .

Great Harbor, Katama Bay, Great Pond, off Nantucket.-Edwards. Common in October and November.-Smith. Seined in May,-Edwards. Occasionally dredged in the western part of Vineyard Sound during July and August.-Survey.

Fish Hawk stations: 7680 (I small), 7703 (I small), 7718 (3), 773 (I).

Parasites (Linton): Acanthocephala-Echinorhynchus acus. Nematodes-Ascaris sp. Cestodes-Dibothrium punctatum, Phyllobothrium loliginis (immature), Rhynchobothrium imparispine (cysts). Trematodes-Distomum simplex.

\section{Family CyCLOPTERIDAE.}

Cyclopterus lumpus Linnæus. Lumpfish, lump sucker.

Baird, r873; Bean, 1884; Bumpus, r898a, p. 59; H. M. Smith, I898, p. I05; Jordan and Evermann, I898, p. 2096; Sharp and Fowler, I904, p. 5 I 1 ; Kendall, Ig08, p. I25.

Buzzards Bay, Vineyard Sound, Great Harbor, Eel Pond. Adults common in spring when they are taken in traps, fyke nets, and seines; young found among driftweed throughout the summer till November. Two small specimens taken in tow net, June 5, I905.-Edwards. One young fish dredged near Gay Head at Blue Wing station 48.

Spawns in April.-Smith, Bumpus.

Parasites: Caligus rapax.-C. B. Wilson.

\section{Family LIPARIDIDA.}

Neoliparis atlanticus Jordan \& Evermann. Sea snail.

H. M. Smith, 1898, p. I05 (Neoliparis montagui); Jordan and Evermann, 1898, p. 2 I07 (sp. nov.); Kendall, I908, p. I26.

Fyke net at mouth of Little Harbor, in December.-Edwards. Vineyard Sound, in August.--Survey. Apparently rare locally.

Fish Hawk stations: 7536 (one, about I inch long, identified by B. W. Evermann), $772 \mathrm{I}$ (one, identified by R. C. Osburn).

Liparis liparis (Linnæus). Sea snail.

Bean, 1884 (Liparis lineatus); H. M. Smith, I898, p. I05; Jordan and Evermann, r898, p. 2rr6; Kendall, I908, p. 127.
Liparis liparis-Continued.

Woods Hole, at mouth of both harbors, on rocky bottom; common in winter, occasional in summer.-Edwards.

Found full of spawn in December and January.Smith. Two with spawn, March 26.-Edwards.

Parasites: Undetermined cestode.-Linton.

$$
\text { Family TrIGLIDAE. }
$$

Prionotus carolinus (Linnæus). Sea robin, com mon gurnard. [Chart 205.]

Storer, I867, p. 18 (Prionotus palmipes); Baird, 1873; Verrill and Smith, 1873, p. 516; Goode, I884a, p. $255^{-2} 5^{8}$ (Prionotus palmipes); Bean, 1884; H. M. Smith, I898, p. I06; Jordan and Evermann, I898, p. 2156; Bumpus, I898a; Linton, I901, p. 470; Sharp and Fowler, I904, p. 5II; Kendall, I908, p. I27.

Common everywhere in local waters, both inshore and at greater depths. About $I, 000$ taken in a trap in one day (May, I898).Bumpus. Present from May or June till October or later.-Smith. Dredged by the Survey throughout Vineyard Sound and the lower end of Buzzards Bay, in water 5 to $I 7$ fathoms deep (mainly young specimens).

Fish Hawk stations: 7542 (? I small), 7547 (I small), $755^{\circ}$ ( 2 very small), 7553 (I very small), 7554 (many; all small but one), 756r (I), 7562 (I), 7563 bis (I small), 7569 (2 small), 7574 (I), $757^{8}$ (I small), $75^{80}, 759^{8}$ (I very small), 76 I 7 ( 2 young, $3 / 4$ inch?), 7653 ( 1 young), 7656,7657 (I), 7660, 7663 (I small), 767 I (I), 7673 (2), 7675 (several), 7733 (2 small), 7740 (2), $774 \mathrm{I}$ (3), 7760 ( s small), 776r (many small), 7766 (few small), 7769 (many small), 7770 (I small), 7772 (I), 7774 (I), 7775 (I), 7776 (I small), 7779 (I).

Phalarope station 55 (I).

Spawns in June and July and perhaps later. Bumpus reports that they were not yet in spawning condition May 16, I $898 ;$ F. R. Lillie (Marine Biological Laboratory card catalogue) records having "stripped" them on July 25 , 1890. Goode reported "nearly ripe eggs" as late as August 12. Young, $35 \mathrm{~mm}$. long, taken August 5, r8gr.-Lillie. Young common in Waquoit Bay; occasionally taken in tow at Woods Hole, from May till August.-Edwards. Food: Crago septemspinosus, a small flounder, amphipods, Panopeus sayi, Cancer irroratus, and several small fishes.-Verrill and Smith. Crabs, shrimps, and small fishes.-Goode. Shrimps in large numbers, amphipods and 
Prionotus carolinus-Continued.

other small crustacea, squid, lamellibranch mollusks, annelids, seaweed, young clams (Mya), fish (young winter flounder and herring.)-Linton.

Parasites: Acanthocephala (Linton)-Echinorhynchus acus. Nematodes (Linton)-Ascaris habena, immature nematodes. Cestodes (Linton)-Tetrarhynchus bisulcatus (cysts). Trematodes (Linton)-Diplostomum sp., Distomum appendiculatum, D. vitellosum, D. sp. Copepods (C. B. Wilson)-Argulus megalops.

Prionotus strigatus (Cuvier \& Valenciennes). Striped sea robin, red-winged sea robin.

Storer, I867, p. I6 (Prionotus lineatus); Baird, I873 (Prionotus evolans); Bean, I884 (Prionotus evolans); H. M. Smith, I898, p. 106; Jordan and Evermann, r898, p. 2167 ; Bumpus, I898a, p. 59; Kendall, I908, p. I28.

Common everywhere, but less so than $P$. carolinus. Adults taken during May and June; young till November.-Edwards. Caught in traps and with the seine.

Spawns in summer. Ovaries enlarged, but not ripe, May I3.-Bumpus. Young $3 / 4$ inch long and upward common throughout the summer.-Smith.

Parasites (Linton) - Acanthocephala-Echinorhyncus acus. Cestodes-Rhynchobothrium imparispine (cysts), $R$. longispine (cysts), Tetrarhynchus bisulcatus (cysts). Trematodes-Distomum sp.

\section{Family CePHal,ACANTHida,}

Cephalacanthus volitans (Linnæus). Flying robin, flying gurnard.

Storer, 1867, p. 22 (Dactylopterus volitans); Baird, I873 (Dactylopterus volitans); H. M. Smith, I898, p. I06; Jordan and Evermann, 1898, p. 2183 ; Kendall I908, p. 129.

Buzzards Bay and Vineyard Sound, late in the fall; a few every year, but not so common as formerly; Waquoit Bay, August 28, I899, one specimen; Katama Bay, September r, 1899, two specimens.-Smith. Hadley Harbor.Edwards. Taken in traps; sometimes washed ashore.

\section{Family Gobmde.}

Gobius stigmaticus (Poey). Goby.

Jordan and Evermann, I898, p. 2224.

Tisbury Pond, one specimen seined October 4, 1906 (taken by V. N. Edwards, identified by H. M. Smith).
Gobiosoma bosci (Lacépède). Goby.

Bean, I884; H. M. Smith, I898, p. I05; Jordan and Evermann, I898, p. 2259; Kendall, I908, p. 129 .

Common throughout the summer in Buzzards Bay, at Scraggy Neck, Pocasset Harbor, and Quisset Harbor.-Edwards. Mouth of Wareham River, at Phalarope station I58, one specimen.-Survey. Taken with the seine or by dredge.

\section{Family ECHENEIDIDE,}

Echeneis naucrates Linnæus. Shark sucker, remora.

Baird, 1873 (Leptecheneis naucrates and L. naucrateoides); Bean, I884; H. M. Smith, 1898 , p. Io6 (Echeneis naucrates and $E$. naucrateoides); Jordan and Evermann, I898, p. 2269 (Echeneis naucrates); p. 2270 (E. naucrateoides); Sharp and Fowler, I904, p. 5I I; Kendall, Igo8, p. I30 (Echeneis naucrates and E. naucrateoides).

Buzzards Bay, in the Bureau's fish trap, not uncommon, several being taken nearly every summer. One caught in July, 1897, on hook and line, baited with clam.-Smith. Nantucket, rare.-Sharp and Fowler.

Remora remora (Linnæus). Remora.

Baird, I873 (Echeneis remora); H. M. Smith, I898, p. I06; Jordan and Evermann, I898, p. 227 I Linton, I90I, p. 473; Kendall, I908, p. I3I.

Buzzards Bay. Included by Baird in 1873 list. Rare and usually attached to large sharks. One taken September 14, 1898.- Smith.

Food: Fish, squid.-Linton.

Parasites: Cestodes (Linton)-Rhynchobothrium speciosum (cysts). Trematodes (Linton)Distomum lageniforme, D. monticellii. Copepods (C. B. Wilson)-Caligus rapax.

Remora brachyptera (Lowe). Swordfish sucker.

Storer, 1867, p. 217 (Echeneis quatuordecimlaminatus); Baird, 1873 (Remoropsis brachyptera); Gill, 1873 (Remoropsis brachyptera); Bean, 1884 (Echeneis brachyptera); H. M. Smith, r898, p. I06; Jordan and Evermann, I898, p. 2272; Kendall, I908, p. I3I.

Vineyard Haven.-Gill. North side of Naushon.-Edwards. Listed as "rare" by Smith, but no data given.

Parasites: Dionchus agassizi. Linton.

Rhombochirus osteochir (Cuvier). Spearfish remora.

Baird, I873, H. M. Smith, I898, p. Io6; Jordan and Evermann, 1898, p. 2273; Kendall, I908, p. I3I.

Included by Baird in 1873 list. A specimen taken in trap at Quisset Harbor August 6, 1886. - Smith. No other records. 


\section{Family MalacantHids.}

Lopholatilus chamcleonticeps Goode \& Bean.a Tilefish.

Collins, I884; Goode, r884a, p. 360; Bean, I884; Goode and Bean, r895, p. 284; Jordan and Evermann, I898, p. 2278; Bumpus, I899; Linton, I90I, p. 47 I.

Southeast of No Mans Land on border of Gulf Stream, where it was originally discovered in 1879. Common at depths of 80 to 250 fathoms.-Goode. Abundant before 1882 , in the March and April of which year over a billion, according to estimate, died as a result of unusual temperature conditions. Not taken again until 1892 , after which time they apparently began to be more abundant. Taken on trawl lines.

Spawns in July.

Food: Preeminently a crab-eater, the intestines being sometimes filled with these; also found to have eaten squid, spiny dogfish (Squalus acanthias), menhaden, and other fish, Salpæ, mollusks, annelids, holothurians, actinians.Linton.

Parasites (Linton): Acanthocephala-Echinorhynchus $\mathrm{sp.} \mathrm{Immature} \mathrm{nematodes.} \mathrm{Ces-}$ todes-Scolex polymorphus (larvæ), Tetrarhynchus bisulcatus (cysts). Trematodes-Distomum focundum, D. ocreatum.

A fair food fish, though no market for it has thus far been developed.

\section{Family BATRACHOIDIDAz.}

Opsanus tau (Linnæus). Toadfish.

Verrill and Smith, 1873 , p. 5 I6 (Batrachus tau); Baird, I873 (Batrachus tau); Bean, I884 (Batrachus tau); Rider, r886, p. 77 (Batrachus tau); Clapp, I89I, p. 494 (Batrachus tau); H. M. Smith, 1898, p. I05; Jordan and Evermann, I898; p. 23r5; Linton, r9or, p. 468; Kendall, I 908 , p. I32.

Common everywhere in shallow waters, under stones and among weeds; a resident fish, taken throughout the year. Ordinarily obtained with the seine.

Spawns in June. Reported to be spawning as early as June 3, by Bumpus; as late as the middle of July by Ryder. In 1906 the spawning period, so far as observed by Dr. J. T. Patterson, extended from June I2 to June 25; the young fish were found to break the capsule on the 26 th day after fertilization, and to become
Opsanus tau-Continued.

entirely free on the $42 \mathrm{~d}$ day. One or both parents guard the eggs until hatched. Two females were taken by Mr. Edwards in December having their ovaries filled with large, seemingly mature eggs. We know of no other evidence, however, that this fish spawns in winter.

Food: One specimen taken locally in July contained Cancer irroratus.-Verrill and Smith. Mollusks (Littorina, Ilyanassa, Tritia, Urosalpinx, Crepidula, Pecten) Crustacea (Cancer, Palcmonetes, Pagurus); bones and fragments of fish, including other toadfish, found in stomach.-Linton. In order of frequency: Pagurus longicarpus in Littorina shells, Cancer irroratus, Panopeus depressus, Ovalipes, Palcemonetes, Crepidula, small fish (Fundulus, Tautogolabrus, Menidia), teleost eggs.-I. A. Field.

Parasites (Linton): Acanthocephala-Echinorhynchus acus, E. clavæceps, E. fusiformis. Nematodes-Ascaris habena. Cestodes-Rhynchobothrium tumidulum (scolices), Scolex polymorphus (larvæ). Trematodes-Distomum tenue, D. tornatum, D. valdeinflatum, D. sp., Monostomum vinal-edwardsii.

\section{Family PHOLIDIDE.}

Pholis gunnellus (Linnæus). Gunnel, rock eel. [Chart 206.]

Storer, I867 (Gunnelus mucronatus); Baird, I873 (Murcnoides mucronatus); Bean, I884 (Murcenoides gunnellus); H. M Smith, I898, p. I06; Jordan and Evermann, 1898, p. 2419; Kendall, I908, p. I32.

Abundant along shores in early spring, when it may be seined; at other times found only in deeper water. Dredged by the Survey during July and August in waters of 3 to $I_{3}$ fathoms, at scattered stations in Vineyard Sound; only twice in Buzzards Bay. Young taken in tow from April to July, chiefly in April.-Towing records of V. N. Edwards.

Fish Hawk stations: $75^{24}$ bis (I), $75^{25}$ bis (I), 7553 (I), 7555 (2), 7556 (several), 7564 (3), 7573 (few), 7760 (I medium), 7762 (2), 7764 (I).

Phalarope and Blue Wing stations: 2 I (I), 24 (2), 93, I23 (I).

Parasites: Acanthocephala (Linton)-Echinorhynchus acus. Copepods (C. B. Wilson)-Argulus laticauda. (Wilson lists this parasite for "a blenny." Pholis is the only blenny taken at all frequently in this region.)

$a$ This fish does not properly belong to the Woods Hole fauna, but has been included here on account of its biological interest. For history of our knowledge of the tilefish see Collins, 1884 , and Bumpus, 1899 .

$$
\text { I6269 } 9^{\circ} \text {-Bull. } 3 \mathrm{r}, \mathrm{pt} 2-\mathrm{I} 3-\mathrm{I}_{5}
$$




\section{Family STICHAIDA.}

Ulvaria subbifurcata (Storer).

Bean, I884 (Eumesogrammus subbifurcatus. Locality not stated, and perhaps not actually taken within region); Jordan and Evermann, I898, p. 2440 ("North Atlantic, south to Cape Cod; very rare"); Kendall, I908, p. I34 (not recorded for local waters).

Western portion of Vineyard Sound, only four living specimens recorded. These were taken during July and August, in the course of the Survey dredging, at depths of 5 to 12 fathoms. Mr. Edwards reports having found several (perhaps 1o or 12) of these fishes in the crop of a sheldrake shot near Robinsons Hole, December, I907, or January, I908.

Fish Hawk stations: $7555 \bar{\ddagger}$ (one, $6 \mathrm{~cm}$. long), $7556 \ddagger$ (one, $8.5 \mathrm{~cm}$. long), $7697 \dagger$.

Phalarope station $53 \dagger$ (one, $4 \mathrm{~cm}$. long).

\section{Family CRIPTACANTHODIDE.}

Cryptacanthodes maculatus Storer. Wrymouth, ghostfish.

H. M. Smith, I898, p. I06; Smith and Kendall, 1898 (Cryptacanthus maculatus); Jordan and Evermann, 1898, p. 2443; Biological Notes, No. I (I900); Kendall, I908, p. I34.

Woods Hole Harbor, in 1875 ; again in December, I896, in a fyke net.-Smith. Edgartown, January, I900, a specimen II inches long.Edwards. Dr. Smith reports having seen several small specimens (an inch or less, in length) from Woods Hole.

\section{Family ANARHICHADIDEE.}

Anarhichas lupus Linnæus. Wolffish, catfish.

H. M. Smith, I898, p. Ic6; Jordan and Evermann, I898, p. 2446; Kendall, I908, p. I35.

Vineyard Sound, in traps and on cod lines, quite rare.-Smith. None seen for several years.Edwards.

\section{Family ZOARCIDA.}

Zoarces anguillaris (Peck). Eel pout.

Bean, I884; H. M. Smith, I8g8, p. I06; Jordan and Evermann, I898, p. 2457; Kendall, I908, p. I35.

Off Gay Head and Cuttyhunk, caught while fishing for cod, during fall; occasionally in Vineyard Sound, off Great Harbor. Abundant formerly, now less so.-Edwards. At Fish Hawk station 773 I (repeated July 30, I907) a small specimen was taken, which was referred to this species with tolerable certainty.
Lycodes reticulatus Reinhardt. Eel pout.

Goode and Bean, 1895, p. 305; H. M. Smith. I898, p. Iо6; Jordan and Evermann, I898, p. 2465 ; Kendall, I908, p. $3_{3} 6$.

Vineyard Sound, taken by the Fish Hawk.-Goode and Bean. Not common.

\section{Family OPHDIDE.}

\section{Leptophidium sp. ${ }^{a}$}

Sumner, 1909, p. 984 .

A fish which belongs with little doubt to thi: genus was found by Mr. Edwards in the body cavity of a large hake (Urophycis tenuis), taken in Woods Hole Harbor, May, I908. The stranger was enveloped by a covering of peri toneum. It measured $25 \mathrm{~cm}$. in length and was extremely hard and shrunken, having the consistency of dried cod, though darker in color There were no traces of scales, or even of skin. in most places, while the fin rays were wanting except at the caudal end, where some shreds remained. The chief distinguishing character was the frontal spine proper to the genus. The hake had a seemingly unimpaired stomach, filled at the time with a fair-sized whiting. The Leptophidium had doubtless been swallowed by the hake (probably at some distant point, in deeper water) and had forced its way out from the stomach of the latter fish into the body cavity, becoming encysted as above described.

\section{Family MERLUCCUDE.}

Merluccius bilinearis (Mitchill). Silver hake, whiting.

Baird, I873 (Merlucius bilineatus); Bean, 1884; H. M. Smith, 1898, p. 107; Jordan and Evermann, 1898, p. 2530; Linton, I90I, p. 473; Sharp and Fowler, 190.4, p. 5II; Kendall, I908, p. 137 .

Buzzards Bay, Woods Hole, Vineyard Sound; abundant during fall, some years common in summer. Taken in traps at Menemsha Bight, constituting at times the greater part of the catch. Young specimens dredged by the Survey at the western cnd of Vineyard Sound, in waters $I_{3}$ to 16 fathoms deep.

Fish Hawk stations: $7575,75^{82}, 75^{83}, 75^{86}$ (one, Io inches long), 7592,7598 .

Food: Fish, small crustacea, many crabs ( $P$ qnoperes).-Linton.

Parasites (Linton): Acanthocephala-Echinorhynchus acus, E. proteus. Nematodes-Ascaris clavata. Cestodes-Dibothrium angustatum, D. crassiceps, Phyllobothrium sp. (imma- 
Merluccius bilinearis-Continued.

ture), Rhynchobothrium bulbifer (cysts), $R$. imparispine (cysts), Scolex polymorphus (larvæ). Trematodes-Distomum ocreatum, $D$. vitellosum.

Not valued by local fisherman, except for bait.

$$
\text { Family GADIDÆ:. }
$$

Pollachius virens (Linnæus). Pollock.

Baird, 1873 (Pollachius carbonarius); H. M. Smith, I898, p. I07; Jordan and Evermann, $x 898$, p. 2534; Sherwood and Edwards, I90x; Linton, I901, p. 474; Sharp and Fowler, rgo4, p. 5II; Kendall, Igo8, p. ${ }_{37}$

Vineyard Sound, Eiel Pond, Great Harbor, Menemsha Bight, Buzzards Bay. Common formerly; only a few adults now taken in the Sound, young numerous.-E,dwards. Adults appear in May, departing when water reaches temperature of 60 to 65 degrees; no regular line fishing for these, though many are caught in the traps.-Smith.

Spawns [at Gloucester] from the end of October to the end of December. Young fish $I / 2$ inches long appear in April.-Smith. Young taken in the tow net from January to May, most abundant in April.-Towing records of V. N. Edwards. Larger young, 7 or 8 inches long, are taken in February and March; a similar run of fish of this size in the fall.-Smith.

Parasites: Acanthocephala (Linton)-Echinorhynchus acus. Nematodes (Linton)-Ascaris clavata, immature nematodes. Cestodes (Linton)-Rhynchobothrium imparispine (cysts). Trematodes (Linton)-Dactylocotyle denticulatum, Distomum ocreatum. Copepods (C. B. Wilson)-Alebion gracile, Caligus curtus, $C$. mutabilis, C. rapax, Lerncea branchialis.

Microgadus tomcod (Walbaum). Tomcod, frostfish.

Baird, 1873 (Microgadus tomcodus); Verrill and Smith, 1873, p. 519; Bean, I884 (Gadus tomcodus); H. M. Smith, I898, p. I07; Jordan and Evermann, I898, p. 2540; Sherwood and Edwards, Igor; Linton; Igor, p. 475; Kendall, I908, p. I38.

Everywhere in the harbors, near shore, abundant in winter, though taken throughout the year. Taken with fyke net or seine or on hook and line.

Spawns in December. Young taken from January till April, most frequently in March and April.-Towing records of V. N. Edwards. Attempts at artificial propagation of this fish have been unsuccessful at Woods Hole, though this has been carried on in some other places.
Microgadus tomcod-Continued.

Food: Local specimens taken in March and April contained Crago septemspinosus, Hippolyte zostericola, Palcmonetes vulgaris, Gammarus annulatus, G. natator, Calliopius laviusculus, Microdeutopus minax, Gammarus ornatus, $G$. mucronatus, Elasmopus lavis, Pontogenia inermis, Ptilocheirus pinguis, Caprella, Nereis virens, various small fishes.--Verrill and Smith. Annelids, shrimps, amphipods, and other small crustacea.-Linton.

Parasites: Acanthocephala (Linton)-Echinorhynchus acus. Nematodes (Linton)-Ascaris clavata, A.sp., Ichthyonemasp. Cestodes (Linton)-Dibothrium rugosum, Rhynchobothrium bulbifer (cysts), R. imparispine (cysts), Scolex polymorphus (larvx). Trematodes (Linton)Distomum appendiculatum, $D$. ocreatum, $D$. simplex, D. vitcllosum, D. sp. Copepods (C. B. Wilson)-Argulus laticauda, A. megalops, Caligus curtus (chalimus stage).

Gadus callarias Linnæus. Cod.

Storer, 1867, p. I66 (Morrhua americana); Baird, 1873 (Gadus morrhua); Bean, I884 (Gadus morrhua); H. M. Smitis, I8g8, p. I06; Jordan and Evermann, r898, p. 254I; Bumpus, I898, p. 486; Linton, I9or, p. 475; Sherwood and Edwards, I90I; Sharp and Fowler, I904, p. 5II; Kendall, I908, p. I39.

Vineyard Sound, Great Harbor, few in Buzzards Bay; keeping to deep water in winter and summer, but coming to shores in fall and spring.-Edwards. Abundant and apparently not decreasing. The cod appears in Vineyard Sound, April I, and remains till about May ${ }_{5} 5$; makes a second visit from October till wintry weather.-Smith.

Spawns from the middle of November till the middle of March. Young $1 / 2$ inch or more in length taken in surface tow in March, April, and May.

Food: Worms, herring, lants, crabs.-Smith. Young observed feeding on copepods.Bumpus.

Parasites: Acanthocephala (Linton)-Echinorhynchus acus. Nematodes (Linton)-Ascaris capsularia, A. clavata, A. habena, Heterakis foveolata. Cestodes (Linton)-Dibothrium rugosum, Rhynchobothrium bulbifer (cysts), $R$. imparispine (cysts). Trematodes (Linton)Distomum ocreatum, D. rachion, D. sp., Nitzschia papillosa, undetermined trematodes. Copepods (C. B. Wilson)-Caligus curtus, C. rapax, Lerncea branchialis. 
Melanogrammus aglefinus (Linnæus). Haddock. Verrill, 1873 , p. 518; Baird, I873; Bean, r884; H. M. Smith, I898, p. I07; Jordan and Evermann, I898, p. 2542; Linton, I9or, p. 476; Sharp and Fowler, I904, p. 5II; Kendall, rgo8, p. I40.

Common 6 or 7 miles off Gay Head and on the ocean side of Marthas Vineyard; at Lamberts Cove, 4 or 5 specimens, weighing 8 or 9 pounds, were taken May I4, I 898 ; a few others in Vineyard Sound during the same spring.--Smith. Taken in March and April on hook and line, baited with herring or clam.

Spawns in March.-Edwards.

Food: "A complete list of the animals devoured by the haddock would doubtless include all species belonging to this fauna." - Verrill and Smith.

Parasites: Acanthocephala (Linton)-Eclinorhynchus acus. Nematodes (Linton)-Ascaris acanthocaudata, A. clavata, Heterakis foveolata, immature nematodes. Cestodes (Linton)-Dibothrium rugosum, Rhynchobothrium imparispine (cysts), Scolex polymorphus (larvæ). Trematodes (Linton)-Distomum rachion, D. sp. Copepods (C. B. Wilson)-Caligus curtus, C. rapax, Lernca branchialis.

Urophycis regius (Walbaum). Codling, king hake.

H. M. Smith, r898, p. 106 (Phycis regius); Jordan and Evermann, I898, p. 2553; Kendall, I908, p. I4I.

Vineyard Sound, Buzzards Bay, scarce. Woods Hole; one specimen taken November $6 \ddagger$, another November $7 \ddagger$, IgIr. Taken in the seine late in the fall.-Smith. Dredged in August.-Survey.

Fish Hawk Stations: $7627 \dagger(1), 7654 \dagger(2), 7657 \dagger$ (I).

Urophycis tenuis (Mitchill). Squirrel hake, white hake.

Bean, 1884; Bumpus, I898a, p. 60; H. M. Smith, 1898, p. 106 (Phycis tenuis); Jordan and Evermann, I898, p. 2555; Linton, I90r, p. 477 (Phycis tenuis); Kendall, I908, p. I42.

Abundant and of general distribution. A bottom-living fish, frequenting muddy bottoms. Fishes of $I$ to $I / 2$ pounds weight abundant in October and November; many then enter the Eel Pond; young common throughout the summer when they are sometimes taken at the surface under celgrass and gulfweed.-Smith. Occasional specimens dredged by the Survey in Buzzards Bay, one in Vineyard Sound.
Urophycis tenuis - Continued.

Fish Hawk stations: 7592 (? 2 large and I small), 7617 (2), 7624 (x small), 7656 (I), 7662 (I), 7663 (I), 7673 (r).

Phalarope station 22 (I small).

Taken with ripe eggs in July.

Food: Worms have been found in stomach.Edwards.

Parasites: Acanthocephala (Linton)-Echinorhynchus acus. Nematodes (Linton)-Ascaris habena, A.sp., Ichthyonema sp. Cestodes (Linton)-Dibothrium rugosum, Phyllobothrium loliginis (immature), Rhynchobothrium imparispine (cysts). Trematodes (Linton)-Distomum hispidum. Copepods (C. B. Wilson)Caligus curtus, C. rapax.

Urophycis chuss (Walbaum). Hake, squirrel hake.

Baird, I873; Bean, I884; H. M. Smith, r898, p. I07 (Phycis chuss); Jordan and Evermann, I898, p. 2555; Linton, Igor, p. 478 (Phycis chuss); Kendall, I908, p. I43.

Abundant in May and June, again in October and November.-Smith. Dredged by the Survey in July and August at the western end of Vineyard Sound.

Fish Hawk stations: $75^{8} \mathrm{I}^{*}$ (one 2 incles long), $7592^{*}$ (one 3 inches long), $7599 \dagger$ (I large), $7682 \dagger(1), 7702 \dagger(2), 7706 \dagger(1), 7707 \dagger(1), 7709 \dagger$ (2), $77 \times 9 \dagger(I)$.

Found with nearly ripe spawn in July; young hake (perhaps $U$. chuss) taken in tow from February till October; most abundant from March till July.-Edwards.

Food: Shrimps, amphipods, and other small crustacea, small fish.-Linton.

Parasites: Acanthocephala (Linton)-Echinorhynchus acus. Nematodes (Linton)-Ascaris habena, Heterakis foveolata. Cestodes (Linton)-Dibothrium punctatum, Phyllobothrium loliginis (immature), Rhynchobothrium bulbifer (cysts), R. imparispine (cysts), R. longispine (cysts), Scolex polymorphus (larvæ), Tetrarhynchus bisulcatus (cysts). Trematodes (Linton)-Distomum appendiculatum, D. ocreatum. Copepods (C. B. Wilson)-Caligus rapax.

Gaidropsarus argentatus (Reinhardt).

Jordan and Evermann, I898, p. 2559; Kendall, I 908 , p. I43.

Vineyard Sound.-Goode, cited by Kendall.

Rhinonemus cimbrius (Linnæus). Four-bearded rockling.

Bean, I884; Goode and Bean, r895, p. $384 ;$ H. M. Smith, I898, p. I07; Jordan and Evermann, 
Rhinonemus cimbrius - Continued.

I898, p. 2560; Linton, I899; Sherwood and Edwards, I9or; Kendall, I908, p. I44 (Enchelyopus cimbrius).

Buzzards Bay, near Penikese.-Goode and Bean. Great Harbor, one taken in winter in a fyke net. One ro inches long speared in Little Harbor in January, I889; young in tow during June and July, I9oo.- Sherwood and Fdwards. About ten, I I $/ 2$ inches long, taken in tow net at end of Bureau of Fisheries pier, April I7, I906.Edwards.

Food: Shrimps, amphipods, bivalve mollusks.Linton.

Parasites (Linton): Acanthocephala-Echinorhynchus acus. Trematodes-Distomum sp.

Brosmius brosme (Müller). Cusk, ling.

H. M. Smith, I898, p. I07; Jordan and Evermann, I8g8, p. 256 I (Brosme brosme); Linton, I90I, p. 479; Kendall, 'I908, p. I44.

Vineyard Sound; formerly not uncommon in April and May, when it was caught along with cod; now very rare, though taken occasionally.-Smith.

Parasites: Ascaris sp.-Linton.

\section{Family MACrourIDAs.}

Macrourus bairdii Goode \& Bean. Baird's grenadier, rat-tail.

Bean, 1884; Goode and Bean, 1895, p. 393; H. M. Smith, I898, p. Io7; Jordan and Evermann, I898, p. 2583; Linton, I9oI, p. 480; Kendall, I908, p. I45.

Vineyard Sound, August 26, I882; dredged by the Fish Hawk at a depth of 9 fathoms.Goode and Bean.

Parasites (Linton): Acanthocephala-Echinorhynchusacus. Nematodes-Ascaris sp. (immature).

\section{Family PLEURONECTIDE:}

Hippoglossus hippoglossus (Linnæus). Halibut.

Baird, I873 (Hippoglossus americanus); H. M. Smith, I898, p. I08; Jordan and Evermann, ז898, p. 26II; Sherwood and Edwards, I90I; Sharp and Fowler, 1904, p. 512; Kendall, 1908, p. 145 .

Vineyard Sound; now very rare within the region, not having been taken for some years; formerly not uncommon, a few large sized specimens being taken annually during April.Smith.

Parasites: Acanthocephala (Linton)-Echinorhynchus acus. Nematodes (Linton)-Ascaris clavata, Hcterakis foveolata. Cestodes (Lin-
Hippoglossus hippoglossus-Continued. ton)-Dibothrium crassiceps, D. punctatum, Scolex polymorphus (larvæ). Trematodes (Linton)-Epibdella hippoglossi. Copepods (C. B. Wilson)-Brachiella rostrata, Caligus curtis.

Hippoglossoides platessoides (Fabricius). Sand dab, rusty flounder.

Bean, I884; H. M. Smith, I898, p. I08; Jordan and Evermann, 1898, p. 2614; Linton, r9or, p. $48 \mathrm{I}$; Kendall, $x_{908}$, p. 146.

Great Harbor, Woods Hole, and adjacent inshore waters, not common, though specimens are occasionally taken on lines in February, and one year some were caught in a fyke.-Smith.

Parasites: Nematodes (Linton)-Ascaris incurva, Ichthyonema sp. Copepods (C. B. Wilson)Argulus megalops.

Paralichthys dentatus (Linnæus). Summer flounder. [Chart 20\%.]

Verrill and Smith, 1873 , p. 5I9 (Chonopsetta ocellaris); Baird, 1873 (Chanopsetta ocellaris); Bean, I884; H. MI. Smith, 1898, p. I08; Jordan and Evermann, I898, p. 2629; Linton, I90I, p. 48I; Sharp and Fowler, I904, p. 512; Kendall, I908, p. I46.

Abundant throughout local waters, particularly on sandy bottoms. Taken from May io to October 15.--Smith. Caught in large numbers in local fishtraps and by hook and line. Dredged by the Survey at scattered stations in Vineyard Sound and Buzzards Bay, 5 to I7 fathoms.

Fish Hawk stations: 7543 bis (several), 755 I (I large), 7554 (I), 756I (I large), 7562 (about 6), 7574 (about 6), 7612 (I small), 7638 (I), 7643 (I), 7676 ( 1 about 2 feet long), 7686 ( 1 ).

Food: One taken in June contained 26 Yoldia limatula, numerous Nucula proxima, Tellina tenera and Tritia trivittata, also Ampelisca; other specimens contained Cancer irroratus, Pinnixa sayana, Crago septemspinosus, Loligo pealii, Tellina tenera, Nucula proxima, Echinarachnius parma.-Verrill and Smith. Squid (I8 from single stomach), hermit crab, fish, crustaceans.-Linton.

Parasites: Acanthocephala (Linton)-Eclinorhynchus acus, E. lateralis, E. proteus, E. sagittifer. Nematodes (Linton)-Ascaris sp. (immature), Ichthyonema sanguineum. Cestodes(Linton)-Dibothrium punctatum, Otobothrium crenacolle (cysts), Phyllobothrium loliginis (immature), Rhynchobothrium bulbifer (cysts), $R$. heterospine (cysts), R. imparispine (cysts), $R$. longispine (cysts), R. speciosum (cysts), 
Paralichthys dentatus-Continued.

Scolex polymorphus (larvx), Synbothrium filicolle (cysts), Tetrarhynchus bicolor (cysts), $T$. bisulcatus (cysts), T. robustus (cysts). Trematodes (Linton)-Diclidophora affinis, Distomum appendiculatum, D. dentatum, D. grandiporum, $D$. monticellii, $D$. pudens, $D$. vitellosum, $D$. sp. Rhynchobdellida: a leech. Copepods (C. B. Wilson)-Argulus alose, $A$. laticauda, $A$. megalops, Chondracanthus galeritus, Lepeophtheirus eduardsi.

Paralichthys oblongus (Mitchill). Four-spotted flounder. [Chart 208.]

Baird, I873 (Chanopsetta oblonga); Bean, I884; Goode and Bean, I895, p. 436; Bumpus, I898a, p. $60 ;$ H. M. Smith, I898, p. Io8; Jordan and Evermann, I898, p. 2632 ; Linton, I9or, p. 483 ; Sharp and Fowler, 1904, p. 512; Kendall, I908, p. 147 .

Common everywhere, though less so than preceding species. Taken in May and June, being scarce at other times; most abundant about June I.-Smith. Dredged by the Survey at scattered stations in the outer portions of Vineyard Sound and Buzzards Bay; 7 to 17 fathoms, sand and mud.

Fish Hawk stations: 7543 bis (several), 7554 (I small), 7602 (I small), 7654 (I), 7656 (I), 766I (I large), $7673{ }^{\prime}$ (3 small), 7676 (4), 7686 (I), 7706 (I).

Spawns in May; incubation lasts about eight days.-Smith; Bumpus.

Food: Shrimps, amphipods, small crabs (Cancer), annelids, mollusks, small crustacea, small fish.-Linton.

Parasites: Acanthocephala (Linton)-Echinorhynchus acus. Immature nematodes. Cestodes (Linton)-Dibothrium punctatum, Phyllobothrium loliginis (immature), Scolex polymorphus (larvæ), Tetrarhynchus bisulcatus (cysts). Trematodes (Linton)-Distomum vitellosum, D. sp. Copepods (C. B. Wilson)Caligus rapax, Lepeophtheirus edwardsi.

Limanda ferruginea (Storer). Rusty dab, rusty flatfish.

Baird, I873 (Myzopsetta ferruginea); Bean, r884; Goode and Bean, I895, p. 427; H. M. Smith, I898, p. I08; Jordan and Evermann, I898, p. 2644; Linton, x901, p. 484; Kendall, I908, p. 147 .

Vineyard Sound and Buzzards Bay; very common throughout the year, at depths of Io to I2 fathoms; a few taken in Great Harbor in fyke nets during winter.-Smith. Dredged by the Survey at occasional stations in the western end of Vineyard Sound; 7 to 17 fathoms, sand.
Limanda ferruginea-Continued.

Fish Hawk stations: $770 \mathrm{r}$ (2 young) †, 7703 (2 young), 7704 (several small) $†, 7717$ (I young), 77 I8 (I young), 77 I9, $7724 \dagger, 773$ I (I)†.

Food: Enormous numbers of crustacea (amphipods, shrimps, schizopods, small crabs, $\mathrm{Ca}$ prella and Squilla), annelids, bivalve and univalve mollusks, small fishes.-Linton.

Parasites (Linton): Acanthocephala-Echinorhynchus acus. Immature nematodes. Cestodes-Dibothrium punctatum, Rhynchobothrium imparispine (cysts), Scolex polymorphus (larvæ). Trematodes-Distomum simplex, $D$. vitellosum, D. sp.

Pseudopleuronectes americanus (Walbaum). Flatfish, winter flounder. [Chart 209.]

Baird, I873; Verrill and Smith, I873, p. 520; Bean, 1884 (Pleuronectes americanus); Bumpus, r898, p. 485 ; H. M. Smith, I898, p. ro8; Jordan and Evermann, I898, p. 2647 ; Linton, I9or; Sherwood and Edwards, I90I; Sharp and Fowler, I904, p. 5I2; Kendall, I908, p. I48.

Vineyard Sound, Buzzards Bay, Great Harbor, Waquoit Bay; abundant throughout the year. Caught in traps, fyke nets, and seines or by hook and line. Dredged by the Survey throughout Buzzards Bay; in Vineyard Sound taken only at the eastern and western ends; 4 to $I 7$ fathoms, almost exclusively on bottoms of sand or mud or mixtures of the two.

Fish Hawk stations: $75^{24}$ ( $\mathrm{I}, 7$ inches long), $75^{26}$ ( 1,8 inches long), $75^{82}$ (I), 7602 (2 small), $76 \mathrm{r}_{3}$ (I small), 7616 (I small), 7620 (I small), 7622 (2), 7643 (I), 7644 (I), 7656 (3), 7657 (I), 766c (several small), $766 \mathrm{I}$ (4), 7663 (several small), 767 I (several), 7673 (i small), 7676 (3 small), 7678 ( I small), 7679 (several), 7680 ( 2 small), 768 I (several), 7685 (I), 7686 (I), 7687 (2), 7688 (I), 7689 (2), 7702 (I), 7707 (I), 7710 (I), 7721 (I), 7724 (2), 7725 (I small), 7728 (3), 7729 (3), $7730(3), 773 I(2), 7762$ (many medium sized and small), 7764 (several small), $778 \mathrm{I}$ (I small). Phalarope stations: 53 (many small), 78 ( small), 79 (I small), Io9, I29 (I young).

Spawns from February to April or May. Young in tow, April, May, and June; most abundant in May.-Towing records of $\mathrm{T}$. N. Edwards. For breeding habits, see Sherwood and Edwards (Igor).

Food: One specimen in August contained large numbers of Haminea solitaria.-Verrill and Smith. Shrimps and other small crustacea, annelids, mollusks, red seaweed, fish.-Linton.

Parasites: Acanthocephala (Linton)-Echinorhynchus acus. Nematodes (Linton)-Ascaris habena, A. sp., Ichthyonema sp. Cestodes (Lir- 
Pseudopleuronectes americanus-Continued.

ton)-Dibothrium punclatum, Rhynchobothrium imparispine (cysts), R. sp. (cysts), Tetrarhynchus bisulcatus (cysts), T. sp. (cysts). Trematodes (Linton)-Distomum appendiculatum, $D$. areolatum, D. globiporum, D. grandiporum, $D$. vitellosum, $D$. $\mathrm{sp}$. Protozoa-Sporozoa (cysts). Copepods (C. B. Wilson)-Argulus laticauda, A. megalops, Caligus rapax, Lepeophtheirus edwardsi.

One reversed specimen reported. Individuals occasionally found with pigment on lower side (V. N. Edwards, in "Biological Notes," No. I).

Lophopsetta maculata (Mitchill). Sand dab, windowpane. [Chart 2 Io.]

Storer, r867, p. 205 (Pleuronectes maculatus); Bean, I884; H. M. Smith, I898, p. I08 (Bothus maculatus); Jordan and Evermann, I898, p. 2660; Linton, r9or, p. 484 (Bothus maculatus); Sharp and Fowler, I904, p. 512 ; Kendall, Ig08, p. I50; Sumner, I910, fig. II.

Common everwhere on sandy bottoms, both in shallow and deep water. Dredged frequently by the Survey in Vineyard Sound, chiefly in the western half; 5 to I 7 fathoms, almost exclusively on sandy bottom; none taken in Buzzards Bay. Present from April till late autumn.-Smith.

Fish Hawk stations: 7540 (I small), 7543 bis (few), 7546 ( 2 very small), 7553 (I small), 7554 (r small), 7562 (4), 7567 (3, I large), 7568 (few small), 7569 (I large), 7574 (3), 7575 (several small), 7576 (few small), 7577 (I small), 7579 (I small), $75^{84}$ (I), $75^{85}$ (I small), 7589 (I small), 7590 (I), 759 I (several, 2 large), 7596 (I large), 7598 (I large), 7600 (I small), 7601 (I small), 7676 (2), 7677 (2), 7686 (I), 7698 (I small), 7701 (r large), 7702 (several), 7703 (few), 7705 (I medium), 7707 (2), 7726 (2 small), 7727 (several small), 7728 (2), 7729 (3), 773 I (2).

Full of spawn about June I.-Smith. Young taken in tow from May till July, especially in June.-Towing records of V. N. Edwards.

Food: Specimens brought into the laboratory often regurgitated Ammodytes americanus.Sumner.

Parasites: Acanthocephala (Linton)-Echinorhynchus acus. Nematodes (Linton)-Ascaris habena. Cestodes (Linton)-Dibothrium punctảtum, Rhynchobothrium imparispine (cysts). Trematodes (Linton)-Distomum vitellosum. Copepods (C. B. Wilson)-Argulus megalops.
Platophrys ocellatus (Agassiz).

Jordan and Evermann, I898, P. 2663 ("Long Island to Rio Janeiro ").

Several specimens seined by Mr. Lidwards in 'Tisbury Great Pond, October 4, 16, and 20, 1906 (identified by H. M. Smith).

\section{Family SOLEIDE.}

Achirus fasciatus Lacépède. Hog choker.

Storer, 1867, p. 207 (Achirus mollis); Baird, r873 (Achirus lineatus); Bean, I884 (Achirus lineatus); H. M. Smith, I898, p. I08; Jordan and Evermann, I898, p. 2700; Bumpus, I898, p. 60 ; Linton, I90I, p. 487; Kendall, I908, p. I50.

Tashmoo Pond.-Storer. Vineyard Sound (occasional in traps), Wareham River (abundant), Buzzards Bay, Quisset Harbor, Eel Pond, Waquoit Bay, Great Pond, Tisbury Pond.Smith, Edwards. Taken throughout the year.

Eggs apparently ripe the latter part of May.Bumpus.

Food: In August, vegetable débris (Fucus and eelgrass).-Linton.

Parasites: Distomum appendiculatum, D. sp.Linton.

Gymnachirus nudus Kaup.

Jordan and Evermann, I898, p. 2703 (listed only for Brazil); Kendall, I9II, p. 202.

One small specimen, taken by V. N. Edwards at Tisbury Pond, October I6, I906.

\section{Family LOPHIIDAs.}

Lophius piscatorius Linnæus. Goosefish, angler, fishing frog.

Storer, 1867 , p. 102 (Lophius americanus); Baird, I873 (Lophius americanus); Verrill and Smith, I873, p. 516; Bean, I884; H. M. Smith, I898, p. Iog; Jordan and Evermann, 1898, p. 2713 ; Sherwood and Edwards, I9or; Linton, I9or, p. 487; Sharp and Fowler, I904, p. 512; Kendall, Igo8, p. I5 I.

Distribution general, individuals even entering the "basin" of the local pier. Large specimens common in summer and fall, in the traps at Menemsha Bight. Late in the fall they are often seen in Woods Hole Harbor, sometimes allowing themselves to become stranded in shallow water near shore. On such occasions they do not turn back, but push on until completely grounded. A large specimen taken in the beam trawl during the Survey dredging at Crab Ledge (Fish Hawk station 7608). 
Lophius piscatorus-Continued.

Nantucket, about 50 at one time.-Sharp and Fowler.

Spawns in May and June.-Edwards. Spawn laid in clusters, which are often found attached to fish traps or floating in the Sound.

Food: Six coots found by Capt. Leonard West, of Chilmark, in the stomach of one goosefish.Storer. A local specimen in June contained Cancer irroratus and Loligo pealii.-Verrill and Smith. Mollusks, annelids, small crustacea, winter flounder.-Linton. In order of frequency: Squid (Loligo), skates (Raja erinacea), flounders (Paralichthys, Lophopsetta, Pseudopleuronectes), lady crabs, Ammodytes, squeteague, sea robin, butterfish, Anguilla chrysypa.-I. A. Field.

Parasites: Acanthocephala (Linton)-Echinorhynchus acus, E. lateralis, E. pristis, E. sp. Nematodes (Linton)-Ascaris increscens, A. rigida, Heterakis foveolata. Cestodes(Linton)Dibothrium sp. (larvæ), Rhynchobothrium imparispine (cysts), R. speciosum (cysts), R. sp. (cysts), Scolex polymorphus (larvæ), Tetrarhynchus bisulcatus (cysts), T. sp. (cysts). Trematodes (Linton)-Distomum nigrescens. Copepods (C. B. Wilson)-Argulus megalops, Lepcophtheirus thompsoni.

\section{Family ANTENNARIDAE.}

Pterophryne histrio (Linnæus). Sargassum-fish, mousefish (a senseless name!), marbled angler. Storer, 1867, p. 105 (Chironectes levigatus); $\mathbf{H}$. M. Smith, I898, p. I09; Jordan and Evermanı, I898, p. 27I6; Kendall, I908, p. I52.

Vineyard Sound, among floating Sargassum, which it apparently seldom leaves; occasionally straying into harbors such as Vineyard Haven and Quisset Harbor. This straggler from southern waters was first recorded locally by Storer in 1867 . During many seasons it is not observed at all. An especially large number were taken in 1897 (see Smith, I898); a few in 1906 and r907; none since the last date (I 9 I I note). It does not appear till July, but specimens have been taken as late as November. They are collected by means of dip nets along with the gulfweed.

The sargassum fish has deposited unfertilized spawn on several occasions in laboratory aquaria. This is laid in jelly masses, similar to those of Lophius.

Parasites: Distomum sp.-Linton.

The marvelous and undoubtedly protective coloration and configuration of this fish render it one of the most striking objects which appear on our coast.

\section{Class REPTILIA.}

\section{Family DERMOCHELIDAE.}

Dermochelys coriacea (Linnæus). Leather-jacket. Henshaw, I904, p. I.

Buzzards Bay, near Woods Hole. Mr. Edwards states that a specimen was taken in a fish trap about 20 years ago, by Mr. I. S. Spindell, which weighed $I, 400$ pounds. Very few have been seen in neighborhood of Woods Hole in recent years, however. Near Newport.Henshaw.

\section{Family CHELONIIDF.}

Caretta caretta (Linnæus). Loggerhead turtle.

Hensinaw, I904, p. 4 (Thallassochelys caretta. No local records).

Menemsha Bight in traps; a number of specimens, usually about 2 feet in length, taken every year.-V. N. Edwards. Howard Ayers records (Marine Biological Laboratory card catalogue) the taking of one specimen in a fish trap on Uncatena Island in July, $\mathbf{1 8 9 2 . ~ T w o ~}$ individuals (one weighing 35 pounds) were brought to the Woods Hole station during the summer of 1908 .
Eretmochelys imbricata (Linnæus). Hawks-bill turtle.

Sumner, I909, p. 984 .

Menemsha Bight in traps; a number of specimens, usually about 18 inches in length, taken every year.-V. N. Edwards. This species, according to Mr. Edwards, is more common locally than the preceding. A specimen, under 6 inches long, in the local museum, bears the label "Woods Hole, August 20, 1903"; another small example was taken among gulfweed during the summer of I908. (Both identified by F. B. Sumner from descriptions and figures furnished by Dr. L. Stejneger). Mr. Edwards likewise reports having seen "hawk-bill" turtles in Long Island Sound as late as Thanksgiving Day. They were then exhausted by the cold.

\section{Family CHELYDRIDAE.}

Chelydra serpentina (Linnæus). Snapping turtle. Henshaw, I904, p. I (no local records).

Sometimes found in salt marshes connected with Great Pond.-V. N. Edwards. 


\section{Family TESTUdinides.}

Malaclemmys centrata concentrica (Shaw). Diamond-back terrapin (northern variety).

J. A. Allen, 1870, p. 260 (Malacoclemmys palustris); True, I884, p. I56 (Malacoclemmys palustris); Bangs, I896, p. 159 (Malaclemmys terrapin); Henshaw, I904, p. 3 (Malacoclemmys terrapin); Hay, I905, pp. I-9.

Nantucket (?) and New Bedford.-Allen, True. Wareham.-Allen. Buzzards Bay.-Bangs, Hay. Wareham River, common; Acushnet River, near New Bedford, occasional; may be
Malaclemmys centrata concentrica-Continued. taken scining.-V. N. Edwards. A fair-sized specimen taken in Wareham River by Dr. E. D. Congdon in 1908 .

Bangs states that prior to 1895 , or thereabouts, this tortoise was "common in the creeks and salt marshes of Buzzards Bay," it being "no unusual sight to see six or eight fine terrapin sunning themselves on a single rock." The animal has become comparatively scarce, however, owing to its being caught for the market.

\section{Class AVES.}

\section{Family COLYMBID我.}

Colymbus holboellii (Reinhardt). Holböll's grebe. Howe and Allen, Igor, p. 20.

Bristol County, probably an uncommon winter visitant; Nantucket, rare.-H. \& A. Vicinity of Woods Hole, fairly common as a winter resident; most abundant in November.Edwards. Male and female specimens in Mr. Edwards's collection dated December I and December 2I, I8go.

Colymbus auritus Linnæus. Horned grebe.

Howe and Allen, Igor, p. 20.

Bristol County, common winter visitant to coast; Nantucket, common.-H. \& A. Vicinity of Woods Hole, common as a winter resident; present from November till May.-Edwards. Male and female specimens in Mr. Edwards's collection dated December I and December 12, 1890 .

Podilymbus podiceps(Linnæus). Pied-billed grebe.

Howe and Allen, r9or, p. 20.

Bristol County, rather uncommon transient visitor--H. \& A. Woods Hole.-V. N. Edwards, L. Jones, I. A. Field. Present from fall till May.-Edwards. Male specimens in Mr. Edwards's collection dated November 12 and December 6, 1902, (former shot in the Eel Pond).

$$
\text { Family Gavid }
$$

Gavia immer (Brünnich). Loon.

Howe and Allen, rgor, p. 21 .

Of general distribution throughout the region; very common in winter, less so in summer. Living birds occasionally taken in the fishtraps and kept in the "shark pool" of the Woods Hole station, where they speedily become very tame. Specimens in Mr. Edwards's collection dated March 17,1888 , and January I4, I893.
Gavia stellata (Pontoppidan). Red-throated loon.

Howe and Allen, igor, p. 2 I.

Bristol County, uncommon winter visitor along coast; Nantucket, common.-H. \& A. Vineyard Sound, in summer.-L. Jones, I. A. Field. Common locally as a migrant, but not common in winter.-Edwards. Specimens of both sexes in Mr. Edwards's collection dated February 28, and March 27, I889, and April 10, I894.

Family Alcid 巵.

Fratercula arctica (Linnæus). Puffin.

Woods Hole, rare.-Edwards. Specimens in Mr. Edwards's collection dated January I8, I902, and January, I904.

Cepphus grylle (Linnæus). Black guillemot.

Howe and Allen, Igor, p. 24.

Nantucket, scarce,-H. \& A. Woods Hole and Hadley Harbor, in winter, rare.-Edwards. Specimens in Mr. Edwards's collection dated February ro, 189 (both sexes), December r9, I8g8 (male).

Uria lomvia (Linnæus). Brünnich's murre.

Howe and Allen, I90r, p. 24.

Bristol County, a winter visitor; Nantucket, common.-H. \& A. Woods Hole, in winter, common.-Edwards. Specimens in Mr. Edwards's collection dated January 18,1890 , and December 2I, I89I (both sexes).

Alca torda Linnæus. Razor-billed auk.

Howe and Allen, I9cr, p. 23.

Nantucket, scarce.-H. \& A. Woods Hole, usually common in winter; abundant during season of 1908-9.-Edwards. Specimen in Mr. Edwards's collection dated December I2, I889, and December 2I, ISg8 (both sexes). 
Alle alle (Linnæus). Little auk.

Howe and Allen, I901, p. 23. (No local references.)

Woods Hole, in winter, common, a hundred sometimes being seen in a flock.-Edwards. Male and female specimens in Mr. Edwards's collection dated December Io, I895, and December 8,10 , and 12,1898 .

\section{Family STERCORARIIDE.}

Megalestris skua (Brünnich). Skua.

Howe and Allen, rgor, p. 31; G. M. Allen, r909, p. 9 .

Pollock Rip, one female, September ro, I884.

Stercorarius pomarinus (Temminck). Pomarine jaeger.

Howe and Allen, rgor, p. 3 r.

Buzzards Bay.-H. \& A. Woods Hole, Buzzards Bay, Vineyard Sound; common in summer and fall.-V.N. Edwards, L. Jones, I. A. Field. A female specimen in Mr. Edwards's collection dated August 2, r888; a male dated October 29, 1890 .

Stercorarius parasiticus (Linnæus). Parasitic jaeger.

Howe and Allen, I90r, p. 31 .

Buzzards Bay.-H. \& A. Woods Hole; Buzzards Bay; Vineyard Sound.-V. N. Edwards, L. Jones, I. A. Field. Present in spring, summer and fall. Male specimens in Mr. Edwards's collection dated August 12 and August 29, 1888.

Stercorarius longicaudus Vieillot. Long-tailed jaeger.

Howe and Allen, r9or, p. 31 .

Nantucket, occasional.-H. \& A. Woods Hole in spring and fall.-Edwards. Specimens in Mr. Edwards's collection dated August I2, I888 (female), October I3, I894.

\section{Family LARIDAE.}

Pagophila alba (Gunnerus). Ivory gull.

G. M. Allen, I909, p. ro.

Monomoy Island, December I, I886; "accidental winter visitor."

Rissa tridactyla (Linnæus). Kittiwake gull.

Howe and Allen, Igor, p. 30.

Bristol County, uncommon winter visitant of the coast; common in fall; Nantucket, common.-H. \& A. Woods Hole, sometimes common in November and December.-Edwards. Specimens in Mr. Edwards's collection dated November 29 , I888 (both sex ss), November 20 , I 890 (female).
Larus leucopterus Faber. Iceland gull.

Woods Hole, in winter, generally rare, though common during the season of $1908-9$. - Edwards.

Larus marinus Linnæus. Black-backed gull.

Howe and Allen, I9or, p. 29.

Bristol County, rather common winter visitor off the coast; Nantucket, common.-H. \& A. Woods Hole, a fairly common winter resident.-Edwards. A male specimen in Mr. Edwards's collection dated January Io, I896.

Larus argentatus Pontoppidan. Herring gull.

Howe and Allen, I90I, p. 29; G. M. Allen, I909, p. I3.

Bristol County, abundant winter visitant; Nantucket, common.-H. \& A. Vicinity of Woods Hole, common in winter, occasional in summer. Most of them come in September and leave in May.-Edwards. This gull nested at Weepecket Island in I882,-Mackay, cited by Allen. Male and female specimens in Mr. Edwards's collection dated February 27, I889, and February 4, I90I.

Larus delawarensis Ord. Ring-billed gull.

Howe and Allen, I901, p. 30 (no local records).

Woods Hole, in late summer and autumn, fairly common.-L. Jones, I. A. Field. Mr. Edwards has only seen this gull in winter. A male specimen in Mr. Edwards's collection dated January 17,1893 .

Larus atricilla Linnæeus. Laughing gull.

Howe and Allen, rgor, p. 29; G. M. Allen, rgog, p. 15 .

Nantucket, common; breeding on Muskeget.H. \& A. The latter colony, according to Dr. Jones, consisted of about 500 individuals in 1904. The average number of eggs in a nest is about three; and the young are fed on $\mathrm{Am}$ modytes, just as young terns are; likewise on insects, etc. The laughing gull comes after the terns appear, and disappears about the same time as the latter.-Edwards. Male specimens in Mr. Edwards's collection dated September, I900 and August 10, 1906; a female dated August 8, I895.

Larus philadelphia (Ord). Bonaparte's gull.

Howe and Allen, Igor, p. 28.

Bristol County, common on migrations; Nantucket, common.-H. \& A. Woods Hole, fairly common in fall as a migrant. - Edwards. Specimens in Mr. Edwards's collection dated November 20, I89o (female), December I2, I894 (both sexes), December I, I895 (male). 
Sterna caspia Pallas. Caspian tern.

Howe and Allen, Igor, p. 25.

Nantucket, taken several times in September. H. \& A. Woods Hole, rare-Edwards. A female specimen in Mr. Edwards's collection dated September 20, I89x.

Sterna maxima Boddaert. Royal tern.

Howe and Allen, I90r, p. 27; G. M. Allen, I909, p. 17 .

Nantucket, a pair taken July, 1874.-H. \& A. Chatham, July 29, I889.-Allen. Seen by Mr. Edwards at Muskeget several different summers.

Sterna sandvicensis acuflavida (Cabot). Cabot's tern.

G. M. Allen, I909, p. I7.

Chatham, August, I865; Monomoy Island, October 2 , I 888 ; an " accidental visitor."

Sterna hirundo Linnæus. Common tern.

Howe and Allen, I901, p. 26; Jones, I906, p. 35; G. M. Allen, r910, p. 19 .

This tern is extremely abundant throughout the region from May I or earlier to the middle of September. Mr. Edwards states that young birds sometimes linger till January I. Two winter records (January $\Upsilon_{7}$ and February 20) cited by Allen. The local nesting grounds are situated at Penikese, Weepecket Islands, the Muskeget group, Katama Bay (on ocean side) and probably at No Mans Land.--Jones. From a consideration of these, Dr. Jones estimated the number of common terns present locally in 1904 as being somewhere in the neighborhood of 100,000 . The average number of eggs in one nest is three (two to six). These are laid in the sand or among driftweed, but no regular nests are constructed. The young are fed principally upon the sand launce (Ammodytes americanus), of which they may eat as many as ro in one day. This fish likewise appears to form the principal article of diet for the adult. (See account by Jones, I906.)

Sterna paradisea Brünnich. Arctic tern.

Howe and Allen, Igor, p. 26.

Nantucket, not very common.-H. \& A. Woods Hole, occasiona1.-Edwards. Weepeckets, August 4, I903.-Jones.

Sterna dougalli Montagu. Roseate tern.

Howe and Allen, I901, p. 27; Jones, I906, p. 43.

Abundant throughout the region from May to September. In 1904, Dr. Jones estimated the number present in this region as approximately 40,000. He found nesting places at Penikese,
Sterna dougalli-Continued.

Weepecket and Muskeget Islands. The average number of eggs found in a nest was two (rarely three), and these were nearly always laid among vegetation. As in the case of $S$. hirundo; the young are fed upon Ammodytes.

Sterna antillarum (Lesson). Least tern.

Howe and Allen, Igor, p. 28.

Nantucket, fairly common.-H. \& A. Katama Bay is the nesting place of a small colony.Jones. Reported as nesting likewise at Penikese and Muskeget, but Dr. Jones found no evidence of this. A female specimen in Mr. Edwards's collection dated September I4, I893; a male, July 20, I894. Formerly much more common than at present.-Edwards.

Sterna fuscata Linnæus. Sooty tern.

G. M. Allen, I909, p. 20.

Chatham, September, 1877; Newport, 1877. "Accidental visitor."

Hydrochelidonnigrasurinamensis (Gmelin). Black tern.

Howe and Allen, I9or, p. 25.

Nantucket, "not very abundant, August usually."-H. \&. A. Woods Hole, fairly common in fall as a migrant.-Edwards.

Rhynchops nigra Linnæus. Black shimmer.

Howe and Allen, r9or, p. 28; G. M. Allen, rgog, p. 22 .

Falmouth and Woods Hole: 2 records.-H. \& A. Weepecket Islands, July I6, I903.-Jones. "Said to have bred about 1830 at Muskeget Island."-Allen. Formerly common at Nantucket; likewise seen in Vineyard Sound; none seen lately.-Edwards.

\section{Family PROCELLARIIDEE.}

Puffinus borealis Cory. Cory's shearwater.

Howe and Allen, rgor, p. 22.

Nantucket, fairly common some years; Buzzards Bay, abundant during the fall of $1886 .-$ H. \& A. Vicinity of Woods Hole.-V. N. Edwards, L. Jones, I. A. Field. Summer and fall; "generally seen on the ocean or near it in the Sound."-Jones. Male specimens in Mr. Edwards's collection dated August 20, I885, and August 29, I888.

Puffimus gravis (O'Reilly). Greater shearwater. Male specimens in Mr. Edwards's collection dated September 2, I888, and October I3, I894. 
Puffinus griseus (Gmelin). Sooty shearwater.

Howe and Allen, I9or, p. 23 (P. fuliginosus).

Buzzards Bay, a few in the fall of 1886; Nantucket, once noted.-H. \& A. Vicinity of Woods Hole.-V. N. Edwards, L. Jones, I. A. Field. Present during summer and fall; "generally seen in the ocean or near it on the Sound."-Jones. A male specimen in Mr. Edwards's collection dated August 20, I890.

Oceanodroma leucorhoa (Vieillot). Leach's petrcl. Howe and Allen, rgor, p. 2 r.

"One June record from Marthas Vineyard Island."-H. \& A. Dr. Jones and Mr. Edwards have both observed this bird locally in summer and fall; " "generally seen in the Sound or on the ocean, feeding. It is possible that it breeds in the vicinity." - Jones. Dr. G. M. Allen states, on the contrary, that this bird is not known to breed south of Maine.

Oceanites oceanicus (Kuh1). Wilson's petrel.

Howe and Allen, I9or, p. 22.

Nantucket, common,-H. \& A. Vicinity of Woods Hole in summer.-V. N. Edwards, L. Jones, I. A. Field. "Usually seen in the Sound or on the ocean, feeding." A male specimen in Mr. Edwards's collection, dated July I 5, I 886 .

\section{Family SULIDAE.}

Sula bassana (Linnæus). Gannet.

Howe and Allen, I90r, p. 59.

Nantucket, not very common. H. \& A. Woods Hole, rare in spring, common in fall.-Edwards. A female specimen in Mr. Edwards's collection, dated October Io, I888; a male dated September 20,1889 .

\section{Family PHALACROCORACIDAE.}

Phalacrocorax carbo (Linnæus). Common cormurant.

Howe and Allen, I901, p. 59.

Bristol County, rather common visitant along the coast; Nantucket, scarce--H. \& A. Woods Hole, fairly common as a spring and fall migrant; occasionally seen in winter and in summer as late as July.-Edwards. Female specimens in Mr. Edwards's collection, dated November 28, I888, and December I5, I 898 .

Phalacrocorax auritus (I.esson). Double-crested cormorant.

Howe and Allen, I9or, p. 59 (no local records).

Woods Hole, common as a spring and fall migrant.-Edwards. A male specimen in Mr. Edwards's collection, dated June 16, I89I.
Family PELECANIDE.

Pelecanus occidentalis (Linnæus). Brown pelican. Howe and Allen, I90I, p. 60 (P. fuscus); G. M. Allen, I909, p. 28 .

Nantucket, a flock of $I_{3}$ seen by S. C. Martin about I867.-H. \& A. One specimen seen at Robinsons Hole, May, Igor.-Edwards.

\section{Family FiregATID}

Fregata aquila (Linnæus). Frigate bird.

Howe and Allen, 190I, p. 60; G. M. Allen, I909, p. 29 .

New Bedford, one shot October I7, I893. ("Record not confirmed."-Allen.)

\section{Family ANATIDE.}

Mergus americanus Cassin. American merganser. Vicinity of Woods Hole, tolerably common; sometimes abundant at Waquoit Bay.-Edwards. Quisset.-Field. Specimens in Mr. Edwards's collection, dated February 12, I887 (female), November 23, I887 (male), March Io, I902 (both sexes).

Mergus serrator Linnæus. Red-breasted merganser, sheldrake.

Howe and Allen, igor, p. 58 (Merganser serrator). Bristol County, common winter visitor along the coast; Nantucket, common.-H. \& A. Woods Hole.-V. N. Edwards, I. A. Field. Abundant as a migrant and winter resident.-Edwards. Male and female specimens in Mr. Edwards's collection, dated April 2, I8go, and April Io, r8gr.

Lophodytes cucullatus (Linnæus). Hooded merganser.

Howe and Allen, I90I, p. $5^{8}$.

Nantucket, scarce.-H. \& A. Woods Hole, during migrations and in winter, scarce.-Edwards. A female specimen in Mr. Edwards's collection dated November 2,1887 .

Anas platyrhynchos Linnæus. Mallard duck.

Howe and Allen, Igor, p. 50 (A. boscas).

Bristol County, uncommon transient visitor: Nantucket, not unusual.-H. \& A. Woods Hole, during migrations and through the winter-Edwards.

Anas rubripes (Brewster). Black duck.

Howe and Allen, Igor, p. 50 (Anas obscura).

Bristol County, uncommon summer resident and very common winter resident; Nantucket, common.-H. \& A. Common as a migrant and during winter and summer. "Evidentiy 
Anas rubripes-Continued.

breeding at Muskeget."-L. Jones, I. A. Field. A male specimen in Mr. Edwards's collection dated February 24, 1889 , a female February 20 , I894.

Mareca americana (Gmelin). American widgeon.

Howe and Allen, 1901, p. 52; G. M. Allen, 1909, p. 33 .

Nantucket, not very abundant.-H. \& A. Formerly present during migrations, but none seen for a number of years.-Edwards.

Nettion crecca Linnæus. European teal.

Howe and Allen, rgor, p. 52; G. M. Allen, rgog, p. 34 .

Muskeget, male, March 16 , 1890.

Nettion carolinensis (Gmelin). Green-winged teal.

Woods Hole, formerly fairly common; now less so.-Edwards. A female specimen in Mr. Edwards's collection dated September 2 , I888.

Querquedula discors (Linnæus). Blue-winged teal.

Howe and Allen, I9or, p. 52 .

Bristol County, uncommon transient visitor; may winter; Nantucket, scarce.-H. \& A. Woods Hole, during migrations, formerly common, now scarce.-Edwards. A female specimen in Mr. Edwards's collection dated September 20,1887 .

Spatula clypeata (Linnæus). Shoveller duck.

Howe and Allen, I90r, p. 53.

Nantucket, I record.

Dafila acuta (Linnæus). Pin-tail duck.

Howe and Allen, I9or, p. 52 .

Bristol County, rather common transient visitor; Nantucket, scarce; young birds occasional.H. \& A. Formerly fairly common in Buzzards Bay during migrations, now rare; a specimen shot at Weepecket February 4, I909.-Edwards.

Marila americana (Eyton). Red-headed duck.

Howe and Allen, I9or, p. 53 (Nyroca americana). Bristol County, rare transient visitor; Nantucket, fairly common.-H. \& A. Specimens in Mr. Edwards's collection dated December ro, I900 (male), January 5, I908 (female).

Marila vallisneria (Wilson). Canvasback duck.

Howe and Allen, I9or, p. 53 (Nyroca vallisneria). Nantucket, rare.

Marila marila (Linnæus). American scaup duck. Howe and Allen, rgor, p. 54 (Nyroca marila).

Bristol County, common in migrations; Nantucket, common.-H. \& A. Waquoit, common during migrations.-Edwards. Specimens in Mr. Edwards's collection dated April 6, r888 (male), December 6, r89 (both sexes).
Marila affinis (Eyton). Lesser scaup duck.

Howe and Allen, Igor, p. 54 (Nyroca affinis).

Nantucket, not uncommon.-.H. \& A. Woods Hole.-I. A. Field. Common during migrations only. A female specimen in Mr. Edwards's collection dated April 6, I888.

Clangula clangula americana (Bonaparte). American golden-eye duck.

Howe and Allen, Igor, p. 54.

Bristol County, very common winter visitor along coast; Nantucket, common.-H. \& A. Male specimens in Mr. Edwards's collection dated March 8, 1890, and February I2, I894.

Charitonetta albeola (Linnæus). Buffle-head duck, dipper.

Howe and Allen, I901, p. 55.

Bristol County, uncommon winter visitant; Nantucket, not uncommon.-H. \& A. Woods Hole, occasional in migrations, less so in winter.-Edwards. A male specimen in Mr. Edwards's collection dated March 8, I89o; a female, dated January 2 I, I89.3.

Harelda hyemalis (Linnæus). Old squaw, longtailed duck.

Howe and Allen, x9or, p. 55.

Bristol County, abundant winter visitant along coast; Nantucket, common.-H. \& A. Woods Hole, abundant during migration and all winter.-Edwards. Male and female specimens in Mr. Edwards's collection dated January 4, I889, and March 6, I89o.

Histrionicus histrionicus (Linnæus). Harlequin duck.

A male specimen in Mr. Edwards's collection dated December I8, I895. This was killed at Weepecket Island.

Somateria mollissima borealis (Brehm). Northern eider.

Howe and Allen, rgor, p. 57.

Nantucket, rare.-H. \& A. Woods Hole, January 2 I, I893, I female.-Edwards.

Somateria dresseri Sharpe. American eider.

Howe and Allen, I9or, p. 57.

Bristol County, common winter visitant along the coast; Nantucket, common.-H. \& A. Woods Hole, common during migrations and in winter.-Edwards. Male and female specimens in Mr. Edwards's collection dated February 27,1890 , February 6 and February 21 , I893, and February II, I894. 
Somateria spectabilis (Linnæus). King eider.

Howe and Allen, rgor, p. 57.

Nantucket, in winter, rare--H. \& A. Woods Hole, in winter, rare-Eidwards. A female specimen in Mr. Edwards's collection dated January 21, I893; a male, January 20, x894.

Oidemia americana Swainson. American scoter.

Howe and Allen, I901, p. 56.

Bristol County, common winter visitor along coast; Nantucket, common.-H. \& A. Woods Hole, common during migrations and in the winter.-Edwards. Male and female specimens in Mr. Edwards's collection dated February 16,1899 .

Oidemia deglandi Bonaparte. White-winged scoter (commonly called "coot").

Howe and Allen, rgor, p. 56.

Bristol County, abundant winter visitor along coast.-H. \& A. Woods Hole and vicinity.V. N. Edwards, I. Jones, I. A. Field. Present throughout the year, being especially abundant in winter, when great flocks are seen in Buzzards Bay. Not known to breed here.-Edwards. Specimens in Mr. Edwards's collection dated January I, I89o, January I 5, I890, and January 9, I892.

Oidemia perspicillata (Linnæus). Surf scoter

Howe and Allen, I90I, p. 56.

Nantucket, common.-H. \& A. Woods Hole and vicinity, abundant during migrations, common in winter.-Edwards. One seen at Quicks Hole, July 30, I904.-Jones. Specimens in Mr. Edwards's collection dated December 20,1890 (male), January 6, I89I (both sexes).

Erismatura jamaicensis (Gmelin). Ruddy duck.

Howe and Allen, Igor; G. M. Allen, Igog, p. 46. Nantucket, rare; Buzzards Bay, common.-H. \& A. Woods Hole and vicinity, common during migrations.-Edwards. Specimens in Mr. Edwards's collection dated December I, I 890 (female), December 4, I8go (male), November 20, I89r (both sexes).
Branta canadensis (Linnæus). Canada goose.

Howe and Allen, I901, p. 49.

Bristol County, common transient visitor; Nantucket, not uncommon.-H. \& A. Woods Hole and vicinity, common as a migrant.-Edwards. A male specimen in Mr. Edwards's collection dated January I9, 1893 .

Brantabernicla glaucogastra (Brehm). Brant.

Howe and Allen, Igor, p. 50 (Branta bernicla) G. M. Allen, igog, p. 50 .

Nantucket, common.-H. \& A. Woods Hole and vicinity, formerly common as a migrant, rarely wintering; recently uncommon,-Edwards. A female specimen in Mr. Edwards's collection dated April Io, I89r.

Branta nigricans (Lawrence). Black brant.

G. M.:Allen, I909, p. 5 I.

Chatham, in spring of $188_{3}$ : "accidental visitor."

Olor columbianus (Ord). Whistling swan.

Howe and Allen, I901, p. 47; G. M. Allen, I909, p. $5^{2}$

Nantucket, I shot, March, 1878 .

Family PIIALAROPODIDÁ.

Phalaropus fulicarius (Linnæus). Red phalarope.

Howe and Allen, I90I, p. 43 (Crymophilus fulicarius).

Nantucket, common.-H. \& A. Penikese, July 21, 1901.-L. Jones, I. A. Field. Present locally only during migrations; sometimes quite common.-Edwards. A male specimen in Mr. Edwards's collection dated June I5, I882.

Lobipes lobatus (Linnæus). Northern phalarope.

Howe and Allen, I9or, p. 43 (Phalaropus lobatus).

Bristol County, rather uncommon transient visitor; Nantucket, common.-H. \& A. Of general distribution; sometimes common, occurring on migrations and during summer.-Edwards. A male specimen in Mr. Edwards's collection dated August II, 1886.

Steganopus tricolor Vicillot. Wilson's phalarope. Howe and Allen, rgor, p. 43.

Nantucket, I specimen, August, I889--H. \& A. A male specimen in Mr. Edwards's collection dated May 30, I893.

Class MAMMALIA.

Family BALENIDE.

Balcena glacialis Bonnaterre. North Atlantic right whale, black whale.

G. M. Allen, Ig04, p. I. True, I904, p. 244 (no local records).
Balana glacialis-Continued.

Nantucket.-Allen. Mr. Edwards wrote to Prof. Baird, May I, I886: "I hear to-day that the right whales are plenty back of Nantucket and that they have killed three this week and towed them ashore and stripped them." 
incgaptera nodosa (Bonnaterre). Humpback whale.

G. M. Allen, I904, p. 2; True, I904, p. 2 II. (No local records given by either writer.)

Were formerly seen in Vineyard Sound; none for many years.-V. N. Edwards.

Balcnoptera phy'salus (Linnxus). Common finback whale.

G. M. Allen, I904, p. 2; True, I904, p. Io7. (No local records given by either writer.)

Whales of this species were formerly seen in Vineyard Sound, the last one in 1903 or $1904 .-$ V. N. Edwards. Mr. Edwards states that two specimens, which were believed at the time to be sulphur-bottom whales ( $B$. musculus), were taken many years ago during the month of May at Tuckernuck and Smiths Island, respectively. They liad drifted ashore, after being shot. The skeleton of one of these was sent to the National Museum. Dr. True informs us that no sulphur-bottom whales have been received at the museum, but only specimens of the fin back. He therefore regards the foregoing records as applying to the finback, and regards any records of the occurrence of the sulphurbottom whale in the Woods Hole Region as being questionable.

? Balanoptera musculus (Linnæus). Sulphur-bottom whale.

Goode, I884, p. 27 (Sibbaldius borealis); G. M. Allen, I904, p. 3 (no local records).

According to Goode, Prof. Baird obtained a fine skeleton of this whale at Nantucket in 1875 ; but Mr. Edwards believes that reference is here made to one of the two specimens mentioned in our discussion of the preceding species. As stated above, Dr. True questions the reliability of any records of the occurrance of the sulphur-bottom whale in local waters.

Balanoptera acuto-rostrata Lacépède. Little piked whale.

G. M. Allen, I904, p. 2 (no local records); True, I904, p. 192 .

Monomoy Point Lighthouse, July II, I883, a young specimen picked up and towed into Harwichport; the skeleton was received by the National Museum from the U. S. Fish Commission.-True.

\section{Family PhysetERIDAE}

Physeter macrocephalus Linnæus. Sperm whale. Jackson, I842, p. I37; Goode, I884, p. 7 ; G. M. Allen, I904, p. 3.

"Vineyard Sound, about I 5 miles from New Bedford, on the $29^{\text {th }}$ of March, 1842 ", a specimen
Physeter macrocephalus-Continued.

r6 feet long.-Jackson. Siasconset, Nantucket, August 26, 1897, a young (apparently new born) specimen obtained by Dr. Harrison Allen and presented by him to the National Museum.-True.

Mesoplodon bidens (Sowerby).

G. M. Allen, I904, p. 4 .

Nantucket, a specimen 16 feet in length.-Agassiz. (Note in Proceedings of the Boston Society of Natural History, November 6, I867.)

Family DELPHINIDA:

Globiocephala melas (Traiil). Blackfish.

Goode, I884, p. II; G. M. Allen, 1904, p. 5 (no local records); True, I889, p. I33 (no local records).

"Occasionally run ashore at Nantucket." Goode. Vineyard Sound and Buzzards Bay, appearing in schools; formerly common.V. N. Edwards. Dr. True informs us that various skeletons and skulls of this species, which had been collected by Mr. Edwards, were received by the National Nuseum in 1875,1877 , and 1884 . Forty-five were driven ashore at Monument Beach, Buzzards Bay, on September 30,1907 , these being only a fraction of the total school.

Phocana phocana (Linnæus). Puffing pig, snuffer, harbor porpoise, herring hog.

True, I889, p. II8 (Phocœna communis; no local records); G. M. Allen, I904, p. 6 (no local records).

Taken in traps at Menemsha Bight, and formerly in Buzzards Bay (when trap fishing was allowed); ascends the "river" as far as New Bedford, feeding upon alewives; appears in June and July.-V. N. Edwards. Dr. True informs us that odd bones, sent by Mr. Edwards from Woods Hole, are stored in the National Museum (entered in 1874).

Lagenorhynchus acutus (Gray). Striped porpoise, skunk porpoise.

True, I889, p. 85 ; G. M. Allen, I904, p. 6 (no local records).

Woods Hole (specimen figured by True, I889, pl. xxirr). Dr. True likewise supplies us with records of specimens taken in I 888 in neighboring parts of the ocean, somewhat beyond the limits of the region as defined in this report. Buzzards Bay; schools frequently seen in August and September.-V. N. Edwards. One taken at Menemsha Bight in fish trap October 7. 1901 . 
Delphinus delphis Linnæus. Common dolphin.

G. MI. Allen, I904, p. 7 (no local records).

Dr. True furnishes the following record: "Woods Hole, Mass., September 29, I884. Male and female. Skeletons in U. S. National Museum, received from U. S. Fish Commission. (These may have merely been brought into Woods Hole from some other place)." He also cites several captures of this species in adjacent parts of the ocean, beyond the limits of this region, strictly speaking.

\section{Family MURIDA.}

Fiber zibethicus (Linnæus). Muskrat.

G. M. Allen, I904, p. I7 (no local records).

Lackeys Bay, in marsh; Great Pond; Waquoit Bay; Tisbury Pond; Chilmark Pond; Herring Pond (at Edgartown).-V. N. Edwards.

Builds nests from dead eelgrass, marsh grass, etc., at first forming a solid heap, which is then excavated. These animals are trapped throughout the winter.

\section{Family PHOcID瓜.}

Phoca vitulina Linnæus. Harbor seal.

H. M. Smith, I900, G. M. Allen, r904, p. 20 (no local records).

Scraggy Neck; Lackeys Bay; Woods Hole Harbor; common some years, a herd of Ioo or more

\section{Phoca vitulina-Continued.}

being sometimes seen in Buzzards Bay. Appear in middle of October or first of Novermber and continue till April or May; never seen in summer. Caught in fyke nets or gill nets; in the former case they drown; in the latter case they are frequently caught alive, 2 I specimens being thus taken by Mr. Edwards within two weeks during January, I887.-Smith. A specimen was shot by Mr. E. F. Locke within the "basin" of the local pier on December 24, I907.

? Cystophora cristata (Erxleben). Hooded seal, crested seal.

G. M. Allen, r904, p. 2 I (no local records).

To this species perhaps belongs a seal said by Mr. V. N. Edwards to be several times as large as the harbor seal and seen by him during more than one season in Lackeys Bay.

\section{Family MusteLIDEE.}

Putorius vison lutreocephalus (Harlan). Little brown mink.

G. M. Allen, r904, p. 25 (no local records).

Nonamesset Island, in gutters and salt sands.V. N. Edwards. Devils Foot Island, in Woods Hole Harbor.-F. B. Sumner.

\section{BIBLIOGRAPHY FOR FAUNAL CATALOGUE.}

(Restricted almost wholly to papers recording the occurrence of species within the region comprised by the present report.)

Adams, C. B.

1839. Observations on some species of the marine shells of Massachusetts, with descriptions of five new species. Boston Journal of Natural History, vol. II, p. 262-288, pl. v.

1840. Descriptions of thirteen new species of New England shellś. Ibid., vol. III, p. 3r8-332,

Agassiz, A.

$$
\text { pl. III. }
$$

I865. North American Acalephæ. Illustrated Catalogue of the Museum of Comparative Zoology at Harvard College, no. 2, 1865, p. xiv +234 . Cambridge.

Agassiz, L.

I860-I862. Contributions to the natural history of the United States, vol. III and IV. Little, Brown

ALLEN, G. M.

$$
\text { \& Co., Boston. }
$$

I904. Fauna of New England. 3. List of the Mammalia. Occasional Papers of the Boston Society of Natural History, VII, no. 3 , p. I-35.

I909. Fauna of New England. II.-List of the Aves. Ibid., vII, no. II, p. I-230.

ALLEN, J. A.

I870. Notes on Massachusetts reptiles and batrachians. Proceedings of the Boston Society of Natural History, vol. ${ }_{3}$, p. 260-263.

1878. A list of the birds of Massachusetts, with annotations. Bulletin of the Essex Institute, vol. Io, p. 3-37. Salem, Mass. 
ANDREWS, E. A.

1892. On the eyes of polychætous annelids. Journal of Morphology, vol. vII, I69-222, p1. IX-xn. Boston.

BAIRD, S, F.

1873. List of fishes collected at Woods Hole. Report U. S. Fish Commission I87 I -72, p. $823-827$. Washington.

BANGS, O.

1896. An important addition to the fauna of Massachusetts. Proceedings of the Boston Socicty of Natural History, vol. xxvi, p. I59-16r.

BARTSCH, PaUl.

1909. Pyramidellidæ of New England and the adjacent region. Proceedings of the Boston Socicty of Natural History, vol. Xxxrv, no. 4, p. 67-II3, pl. II-I4.

rgoga. More notes on the family Pyramidellidæ. The Nautilus, vol. xxin, no. 4, p. 54-59. Boston.

BEAN, B. A.

I909. The proper name of the American eel Anguilla rostrata (Le Sueur). Science, n. S., vol. xxix, p. 871, 872. New York.

BEAN, T. H.

r884. List of fishes collected by the U.S. Fish Commission at Woods Hole, Mass., during the summer of 1881. Report of the U. S. Fish Commission 1882, p. 339-344. Washington.

BENEDICT, J. E.

I90I. The hermit crabs of the Pagurus bernhardus type. Proceedings of the U. S. National Museum, vol. Xxir, p. 451-466. Washington.

Benedict, J. E., ANd Rathbun, M. J.

r89r. The Genus Panopeus. Proceedings of the U. S. National Museum, vol. xiv, p. 355-385, pl. XIX-XXIv. Washington.

BERGH, R.

I885. Beiträge zur Kenntniss der Éolidiaden, VIII,-Verhandlungen der k. k. zoologisch-botanischen Gesellschaft in Wien, Jg. I885, p. 3-62, taf. I-VIr.

BIGELOW, M. A.

1902. The early development of Lepas. Bulletin of the Museum of Comparative Zoology, vol. $\mathrm{XL}, \mathrm{p} .60-\mathrm{I} 4 \mathrm{I}, \mathrm{pl}$. I-I2. Cambridge.

Biological, Notes, No. I.

1900. Bulletin of the U. S. Fish Commission, vol. xIx, I899, p. 305-3ro. Washington. (Notes by H. M. Smith, H. C. Bumpus, V. N. Edwards, E. E. Hahn, A. D. Mead, and G. M. Gray).

Biological Notes, No. 2 .

rgor. Bulletin U. S. Fish Commission, vol. xxI, r9or, p. 27-33. Washington. (Notes by G. H. Sherwood, V. N. Edwards, and H. M. Smith.)

Bumpus, H. C.

r898. The breeding of animals at Woods Holl during the month of March, r8g8. Science, n. s., vol. vir, no. I7 r, Apr. 8, r898, p. 485-487. New York.

I898a. The breeding of animals at Woods Holl during the month of May, I898. Ibid., vol. virI, no. $\mathrm{I}_{5}$, July $\mathrm{I}_{5}, \mathrm{I} 898$, p. $5^{8-6}$.

1898b. The breeding of animals at Woods Holl during the months of June, July, and August, 1898 . Ibid., vol. virI, no. 207 , Dec. I6, I898, p. 850-858.

I899. The reappearance of the tilefish. Bulletin U. S. Fish Commission, vol. xvir, I8gS, p. 32 I-333. Washington.

Bush, K. J.

I909. Notes on the family Pyramidellidæ. American Journal of Science and Arts, vol. xxvir, June, rgog, p. 475-484. New Haven.

CALkins, G. N.

1902. Marine protozoa from Woods Hole. Bulletin of the U. S. Fish Commission, vol. xxr, rgor, p. 4I3-468. Washington.

I62 $69^{\circ}-$ Ball. 3 I, pt $2-\mathrm{r} 3-\mathrm{I} 6$ 
Calman, W. T.

1912. The Crustacea of the order Cumacea in the collection of the U. S. National Museum. Proceedings U. S. National Museum, vol. XI, p. 603-676, II2 text fig. Washington.

Clapp, CORNELIA M.

I89 I. Some points in the development of the toadfish (Batrachus tau). Journal of Morphology, vol. V, p. 494-501. Boston.

ClARK, H. I.

1899. The Synaptas of the New England coast. Bulletin of the U. S. Fish Commission, vol. XIx, I899, p. 2I-3I, pl. Io. Washington.

I904. The echinoderms of the Woods Hole region. Ibid., vol. XxI, I902, p. 547-576, pl. I-XIV.

1905. Fauna of New England. 4. List of the Echinodermata. Occasional papers of the Boston Society of Natural History, VII, I905, p. I-I3.

1908. A brittle star new to the Woods Hole fauna. Science, n. s., vol. xxvir, no. 682, Jan. 24, Ig08, p. I47. New York.

COE, W. R.

I895. Descriptions of three new species of New England palæonemerteans. Transactions of the Connecticut Academy of Science and Arts, vol. IX, p. 5 $55^{-522}$. New Haven.

1899. Notes on the times of breeding of some common New England nemerteans. Science, n. s., vol. Ix, February 3, I899, p. I67-I69. New York.

1902. Nemertean parasites of crabs. American Naturalist, vol. xxxvi, no. 426, p. $431-450$. New York.

COLE, L. J.

Igor. Notes on the habits of pycnogonids. Biological Bulletin of the Marine Biological Laboratory at Woods Hole, vol. 2 , no. 5, p. 195-207.

1906. Feeding habits of the pycnogonid Anoplodactylus lentus. Zoologischer Anzeiger, bd. xxix, nr. 24, p. 740,74 I. Leipzig.

I9I0. Peculiar habitat of a pycogonid (Endeis spinosus) new to North America, with observations on the heart and circulation. Biological Bulletin of the Marine Biological Laboratory at Woods Hole, vol. xvir, . no. 4, p. I93-203.

Colitins, J. W.

I884. History of the tilefish. Report U.S. Fish Commission I882, p. 237-294, 2 pl. Washington.

ConkLin, E. G.

I\$97. The embryology of Crepidula. Journal of Morphology, vol. I3, p. I-226. Boston.

COPE, E. D.

I870. Observations on some fishes, new to the American fauna, found at Newport, R. I., by Samuel Powell. Proceedings of the Academy of Natural Sciences of Philadelphia, vol. xx, p. II 8 -I 2 r.

COWLES, R. P.

1903. Notes on the rearing of the larvæ of Polygordius appendiculatus and on the occurrence of the adult on the Atlantic coast of America. Biological Bulletin of the Marine Biological Laboratory at Woods Hole, vol. IV, no. 4, p. $125^{-128}$.

Cushman, J. A.

1906. Marine Ostracoda of Vineyard Sound and adjacent waters. Proceedings of the Boston Society of Natural History, vol. 32 , no. 1o, p. $359-385$, pl. $27-38$.

1908. Foraminifera of the Woods Hole region. Ibid., vol. 34 , no. 2, p. 2 I-34, pl. 5 -

DALL, W. H.

I889. A preliminary catalogue of the shell-bearing marine mollusks and brachiopods of the southeastern coast of the United States. Bulletin of the U. S. National Museum, no. 37, 2 I8 p., 74 pl. (Reprinted with $2 \mathbf{I}$ additional plates in I903.)

DAVENPORT, C. B.

I89r. Observations on budding in Paludicella and some other Bryozoa. Bulletin of the Museum of Comparative Zoology, Harvard College, vol. xxm, no. I, p. I-II4, pl. I-XII. Cambridge. 
DESOR, i.

1848. [Notes in report of meeting.] Proceedings of the Boston Society of Natural History, vol. III, p. 65-68 (meeting of Oct. I8, 1848).

EHLERS, ERNST.

1864-68. Die Borstenwürme (Annelida Chætopoda) nach systematischen und anatomischen Untersucliungen. 4to. Leipzig.

FAxoN, W.

1879. On some young stages in the development of Hippa, Porcellana, and Pinnixa. Bulletin of the Museum of Comparative Zoology, Harvard College, vol. v, no. I , p. 253-268, pl. I-V, Cambridge.

FEWKES, J. W.

I880. Contributions to a knowledge of the tubular jellyfishes. Bulletin of the Museum of Comparative Zoology, Harvard College, vol. vi, p. I27-I46, pl. I-III. Cambridge.

I88I. Studies of the jellyfishes of Narragansett Bay. Ibid., vol. virr, no. 8, I88I, p. I4I-I82, pl. I-IX.

I882. On the Acalephæe of the east coast of New England. Ibid., vol. IX, no. 8, p. 29I-3Io, p1. I.

I883. On the development of certain worm larvæ. Ibid., vol. XI, no. 9, p. I67-208, pl. I-vin.

FIELD, I. A.

1907. Unutilized fishes and their relation to the fishing industries. Bureau of Fisheries doc. no. 622 , 50 p., I pl.; also in Report of the Commissioner of Fisheries for I906 and Special Papers. Washington.

I9II. The food value of sea mussels. Bulletin of the Bureau of Fisheries, vol. xxıx, I909, p. 87-I28, p1. xvin-Xxv. Washington. (Issued separately as Bureau of Fisheries doc. no. 742.)

GaNong, W. F.

1886. Is Littorina litorea introduced or indigenous? American Naturalist, vol. xx, p. 931-940. New York.

1889. The cconomic Mollusca of Acadia. St. John, New Brunswick, I889, II6 p. (Reprinted from Bulletin no. vin of the Natural History Society of New Brunswick.)

GARDINER, E. G.

1895. The early development of Polychœrus caudatus Mark. Journal of Morphology, vol. xI, p. I55-x 7 I. Boston.

GeROULD, J. H.

1904. The development of Phascolosoma. (Preliminary note.) Archives de Zoologie Expérimentale et Générale [4], t. XI, Notes et revue, no. 2, p. I-XII. Paris.

I906. The development of Phascolosoma. (Notes on the embryology of Sipunculidæ, II.) Zoologischer Jahrbücher, Abtheilung für Anatomie, bd. 23, heft I, p. 77-162, taf. 4-II. Jena.

1908. A comparison of the cephalic organs in certain sipunculids. Report of meeting of American Society of Zoologists. Science, n. s., vol. xxvII, p. 488. New York.

GILL, THEODORE:

1873. Catalogue of the fishes of the east coast of North America. Report U. S. Fish Commission, I871-72, p. $779-822$. Washington.

GOODE, G. B.

1879. The occurrence of Belone latimanus in Buzzards Bay, Massachusetts. Proceedings of the U. S. National Museum, vol. I, p. 6, 7. Washington.

I879a. A history of the menhaden. Report of the U. S. Fish Commission I877, p. I-527, p1. I-XxxI. Washington.

I883. Materials for a history of the swordfish. Ibid., I880, p. 289-387, p1. I-xxiv. Washington. 1884. Natural history of useful aquatic animals. Part I.-The whales and porpoises. The Fisheries and Fishery Industries of the United States, sec. I, pt. I, p. $7-32$. U. S. Fish Commission, Washington.

1884a. Same. Part III.-Fishes. Ibid., sec. I, p. I63-682, pl. 35-252. 
GOODE, G. B. AND BEAN, T. H.

r895. Oceanic ichthyology. Special Bulletin of the U. S. National Museum, vol. I, p. I-553, vol. II, pl. I-cxxir. Washington.

Goto, S.

I900. Notes on some exotic species of ectoparasitic trematodes. Journal of the College of Science, Imperial University of Tokyo, I898-I900, p. 263-295, pl. Xx, XXI.

GouL, D, A. A.

I84r. Report on the Invertebrata of Massachusetts, comprising the Mollusca, Crustacea, Annelida, and Radiata. 373 p., I5 pl. Cambridge.

1870. Report on the Invertebrata of Massachusetts. Second edition, comprising the Mollusca. Edited by W. G. Binney. 524 p., xxvir pl. Boston.

GRAFF, L. vON.

rgrr. Acœla, Rhabdocœla und Allœcœla des Ostens der Vereinigten Staaten von Amerika. Zeitschrift für wissenschaftliche Zoologie, bd. xcrx, hft. I, p. 32 I-428, pl. I-VI.

GURLEY, R. R.

1893. On the classification of the Myxosporidia, a group of protozoan parasites infesting fishes. Bulletin of the U. S. Fish Commission, vol. XI, I89I, p. 407-420. Washington.

1894. The Myxosporidia, or psorosperms of fishes, and the epidemics produced by them. Report of the U. S. Fish Commission, I892, p. $65-304+v$, pl. I-47. Washington.

HARGER, O.

1873. (In Report upon the invertebrate animals of Vineyard Sound, p. 567-573. See Verrill and Smith.)

i879. Notes on New England Isopoda. Proceedings of the U. S. National Museum, vol. II,

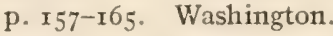

I880. Report on the marine Isopoda of New England and adjacent waters. Report of the U. S. Fish Commission 1878 , p. 297-462, pl. r-XII. Washington.

HARGITT, C. W.

I900. A contribution to the natural history of Pennaria tiarella McCrady. American Naturalist, vol. Xxxiv, no. 40, p. $387-406$, pl. I-IV. New York.

Igor. Synopses of North American invertebrates. XIV.-The Hydromedusæ, pt. I. Ibid', vol. xxxv, no. 412, April, I901, p. 301-315.

Igora. Synopses of North American invertebrates. XIV.-The Hydromedusæ, pt. Ir. Ibid., vol. xxxv, no. 4I3, May, Igor, p. 379-395.

Igorb. Synopses of North American invertebrates. XIV.-The Hydromedusæ, pt. Ir. Ibid., vol. $\mathrm{xxxv}$, no. 4r5, July, igor, p. 575-595.

1902. Notes on a few medusæ new to Woods Hole. Biological Bulletin of the Marine Biological Laboratory at Woods Hole, vol. II, no. I, P.I3-23, I902.

I902a. Notes on the coelenterate fauna of Woods Hole. American Naturalist, vol. xxxvi, no. 427, July, I902, p. 549-560. New York.

I903. Synopses of North American invertebrates. XIV.-The Scyphomedusæ, pt. IV. Ibid., vol. XxxviI, no. 437 , p. $331-345$.

1904. The medusæ of the Woods Hole region. Bulletin of the Bureau of Fisheries, vol. xxiv, I904, p. 2 I-79, pl. I-VII. Washington.

I906. Experiments on the behavior of tubicolous annelids. Journal of Experimental Zoology, vol. III, no. 2, p. 295-320. Philadelphia.

1908. Notes on a few cœlenterates of Woods Hole. Biological Bulletin of the Marine Biological Laboratory at Woods Hole, vol. xIv, no. 2, p. 95-120.

r909. New and little-known hydroids of Woods Hole. Ibid., vol. xvir, no. 6, p.369-385.

I9rI. A further note on Keratosum complexum. Ibid., vol. Xx, no. 3, p. I87-I 89 .

HAY, W. P.

1905. A revision of Malaclemmys, a genus of turtles. Bulletin of the Bureau of Fisheries, vol. XXIV, I904, p. 3-I9, pl. I-XIr. Washington. 
HENSHAW, S.

1904. Fauna of New England. I. List of the Reptilia. Occasional papers of the Boston Society of Natural History, vII, p. I-I3.

HERRICK, F. H.

I8g6. The American lobster. Bulletin of the U. S. Fish Commission, vol. xv, I895, p. I-252, pl. I-54. Washington.

1902. The reproductive period in the lobster. Ibid., vol. XXI, I90I, p. I6I-I66.

I9r. Natural history of the American lobster. Ibid., vol. xxIx, I909, p. I49-408, pl. xxxmxivir. (Issued separately as Bureau of Fisheries document no. 747.)

HOLMES, S. J.

rgor. Observations on the habits and natural history of Amphithoë longimana Smith. Biological Bulletin of the Marine Biological Laboratory at Woods Hole, vol. II, p. I65-193.

1903. Synopses of North American invertebrates. xvin. The Amphipoda. American Naturalist, vol. xxxvir, p. 267 .

1905. The Amphipoda of southern New England. Bulletin of the Bureau of Fisheries, vol. xxIv, I904, p. 457-529, pl. I-XIII.

HowE, R. H., AND ALLEN, G. M.

1901. The birds of Massachusetts. I54 p. Cambridge.

HYATT, A.

1877. Revision of the North American Poriferæ; with remarks upon foreign species. Part II. Memoirs of the Boston Society of Natural History, vol. II, pt. IV, p. I I-84, pl. I5-I 7.

1878. Article “Sponges"' in Johnson's New Universal Cyclopædia, Appendix, p. x667-r67o. (Figure of "Tethya gravata Hyatt (N. S.)" on p. I668.)

Jackson, J. B. S.

1845. Dissection of a spermaceti whale, and three other cetaceans. Boston Journal of Natural History, vol. v, p. I37-I 7 I.

JONES, L.

I906. A contribution to the life history of the common (Sterna hirundo) and roseate (S. dougalli) terns. Wilson Bulletin, vol. xvmI, n. s. no. 2, p. 35-47. Oberlin, Ohio.

Jordan, D. S., AND EvERMANN, B. W.

1896-rgoo. The fishes of North and Middle America. Bulletin of the U. S. National Museum,

JUDD, S. D. no. 47 , IV pt., I-33 3 p., I-cccxcir pl. Washington.

1896. Descriptions of three species of sand fleas (amplipods) collected at Newport, R. I. Proceedings of the U. S. National Museum, vol. XvII, p. 593-603. Washington.

KENDALL, W. C.

1902. Notes on the silversides of genus Menidia of the east coast of United States, with descriptions of two new subspecies. Report U. S. Fish Commission I90r, p. 241-267. Washington.

1908. Fauna of New England. 8. List of the fishes. Occasional Papers of the Boston Society of Natural History, vol. vII, no. 8, p. I-I 52 .

I9II. Notes upon two rare flatfishes (Gymnachirus fasciatus Günther and G. nudus Kaup). Proceedings U. S. National Museum, vol. 40, p. 20I-203. Washington.

KENDALL, W. C., AND SMiTH, H. M.

I895. Extension of the recorded range of certain marine and fresh-water fishes of the Atlantic coast of the United States. Bulletin U.S. Fish Commission, vol. xrv, r894, p. I 5 ${ }^{-2}$. Washington.

KINGSLEY, J. S.

1897. On a new genus and two new species of macrurous Crustacea. Bulletin of the Essex Institute, vol. xxvir, p. 95-99, pl. III. Salem, Mass.

L,EFEVRE, G.

I898. Budding in Perophora. Journal of Morphology, vol. xIV, no. 3, p. 367-424, pl. XxIx-xxxI. Boston.

L.EIDY, J.

1855. Contributions toward a knowledge of the marine invertebrate fauna of the coasts of Rhode Island and New Jersey. Journal of the Academy of Natural Sciences of Philadelphia, vol. III, 2 d ser., p. $3^{-18}$, p1. $\mathrm{x}, \mathrm{xI}$. 
LEWTS, MARGARET.

I899. Clymene producta sp. nov. Proceedings of the Boston Society of Natural History, vol. XXVIII, P. III-II5, pl. I, 2.

LirTON, E.

1889. Notes on entozoa of marine fishes of New England, with descriptions of several new species. Report of the U. S. Fish Commission I886, p. 453-5II, pl. I-VI. Washington.

I890. Notes on entozoa of marine fishes of New England, with descriptions of several new species. Part II. Ibid., I887, p. 719-899, pl. I-XV.

I89r. Notes on entozoa of marine fishes, with descriptions of new species. Part III.-Acanthocephala. Ibid., r 888 , p. 523-542, pl. IIII-LX.

I8gra. On the anatomy of Thysanocephalum crispum Linton, a parasite of the tiger shark. Ibid., I8S8, p. 543-555, pl. LXI-LXVII.

I 8 I b. On certain wart-like excrescences on the short minnow, Cyprinodon variegatus, due to psorosperms. Bulletin of the U. S. Fish Commission, vol. Ix, x889, p. 99-102, pl. xxxrv. 1897. Notes on larval cestode parasites of fishes. Proceedings of the U. S. National Museum, vol. xIx, p. $787-824$, pl. I-vil. Washington.

I $897 \mathrm{a}$. Notes on cestode parasites of fishes. Ibid., vol. xx, p. 423-456, pl. XxvII-Xxxiv.

I 898 . Notes on trematode parasites of fishes. Ibid., vol. Xx, p. 507-548, pl. XL-LIV.

I900. Fish parasites collected at Woods Hole in I898. Bulletin of the U. S. Fish Commission, vol. XIX, I899, p. 267-304, pl. XxxmI-XIIII. Washington.

I901. Parasites of fishes of the Woods Hole region. Ibid., vol. Xrx, I899 p. 405-492, pl. I-xxxrv.

1905. Notes on cestode cysts, Tænia chamissonii, new species, from a porpoise. Proceedings of the U. S. National Museum, vol. xxvir, p. 819-822, pl. xxxv. Washington.

1907. A cestode parasite in the flesh of the butterfish. Bulletin of the Bureau of Fisheries, vol. XXVI, I906, p. III-I32, pl. I and II. Washington.

1907a. Notes on Calyptrobothrium, a cestode genus found in the torpedo. Proceedings of the U. S. National Museum, vol. xxxir, p. 275-284. Washington.

rgro. On a new rhabdocœle commensal with Modiolus plicatulus. Journal of Experimental Zoology, vol. IX, no. 2, p. $37 \mathrm{I}-384$, pl. I-4.

LINVILLE, H. R.

I903. Natural history of some tube-forming annelids. Mark Anniversary Volume, p. $225^{-2} 35$. New York.

MARK, E. I.

r892. Polychœrus caudatus, n. g. and sp. of turbellarians. (Acæla, fam. Aphanostomida). Festschrift z. Geburtstage R. Leuckarts, p. 298-309, pl. xxxi. Leipzig.

MAYER, A. G.

1900. Descriptions of new and little-known medusæ from the western Atlantic. Bulletin of the Museum of Comparative Zoology, Harvard College, vol. Xxxvir, no. I, p. I-9, pl. I-6. Cambridge.

rgor. The variations of a newly arisen species of Medusa. Science Bulletin, Museum of the Brooklyn Institute of Arts and Sciences, vol. I, no. I, p. I-27, pl. I, II.

I9ı. Medusæ of the world. Publication No. Iog of the Carnegie Institution, vol. I, II, III; 735 p., p1. I-76. Washington.

MAYER, $P$.

1903. Die Caprellida der Siboga-Expedition. Siboga-Expeditie, XxxIV, p. I-I60, pl. I-IO. Leiden.

MEAD, A. D.

1897. The early development of marine annelids. Journal of Morphology, vol. xiI, no. 2, p. 227326 , pl. X-xix. Boston.

1898. The breeding of animals at Woods Holl during the month of April, r898. Science, n. s., vol. vIr, no. I77, May 20, I898, p. 702-704. New York.

r900. The natural history of the starfish. Bulletin of the U. S. Fish Commission, vol. xıx, I899, p. 203-224, pl. 23-26. Washington.

MENSCI, P. C.

I900. Stolonization in Autolytus varians. Journal of Morphology, vol. xvI, no. 2, p. 269-322, pl. xiII, xiv. Jena.

METCALF, M. M.

Ig00. Notes on the morphology of the Tunicata. Zoologischer Jahrbücher, bd. xmI, heft 4. p. 495-6o2, pl. 34-40. Jena. 
Montgomery, T. H.

1897. Descriptions of new metamemerteans. Zoologischer Jahrbücher, Syst. Abth., bd. X, p. I-I4. Jena.

MOORE, ANNE.

rgoo. Dinophilus gardineri (sp. nov.) Biological Bulletin of the Marine Biological Laboratory at Woods Hole, vol. I, p. I5-18.

MOORE, J. P.

r898. The leeches of the U.S. National Museum. Proceedings of the U. S. National Miuseum, vol. $\mathrm{xxI}, \mathrm{p} .543-563, \mathrm{pl}$. XL. Washington.

I903. Descriptions of two new species of Polychæta from Woods Hole, Mass. Proceedings of the Academy of Natural Sciences of Philadelphia for November, I903, p. $720-726, \mathrm{pl}$. XL.

rgo3a. Some pelagic Polychæta new to the Woods Hole fauna. Ibid., I903, p. 793-80r, pl. LV.

1905. A new species of sea mouse (Aphrodita hastata) from eastern Massachusetts. Ibid., I905, p. 294-298.

I905a. Some marine Oligochæta of New England. Ibid., I905, p. 373-399, pl. xxxIr, xxxmr.

1906. Descriptions of new species of Polychæta from the southeastern coast of Massachusetts. Ibid., Ig06, p. 501-508, pl. XIX.

I907. Descriptions of new spioniform annelids. Ibid., I907, p. I95-207, p1. XV, XVI.

1907a. Description of a new species of annelid from Woods Hole. Ibid., I907, p. 448-45I.

Morgan, T. H.

I89r. The growth and metamorphosis of Tornaria. Journal of Morphology, vol. v, p. 407-458. Boston.

I8gra. A contribution to the embryology and phylogeny of the pycnogonids. Studies from the Biological Laboratory of Johns Hopkins University, vol. v, no. I, p. I-76, pl. I-vIIr. Baltimore.

MURBACH, L.

I895. Preliminary note on the life history of Gonionemus. Journal of Morphology, vol. XI, p. 493-496. Boston.

1898. Hydroids from Woods Hole, Mass. Quarterly Journal of Microscopical Science, vol. 42, p. $34 \mathrm{I}-360, \mathrm{pl} .34$. London.

NICKERSON, W. S.

I898. Preliminary notice of a new species of endoproct, Loxosoma davenporti, from the Massachusetts coast. Science n. s., vol. vII, p. 220. New York.

I899. Notes on Loxosoma davenporti. Ibid., vol. IX, p. 368.

Igor. On Loxosoma davenporti, sp. nov. Journal of Morphology, vol. xvir, p. 35I-380. Boston.

Nutring, C. C.

I900. American hydroids. Part I. -The Plumularidæ. Special Bulletin of the U. S. National Museum, I900, p. I-285, pl. I-XXXIV. Washington.

190I. The hydroids of the Woods Hole region. Bulletin of the U. S. Fish Commission, vol, xIx, I899, p. 325-386. Washington.

1904. American hydroids. Part II.--The Sertularidæ. Special Bulletin of the U. S. National Museum, I904, p. I-325, pl. I-XLI. Washington.

OSBURN, R. C.

1912. The Bryozoa of the Woods Hole region. Bulletin of the Bureau of Fisheries, vol. xxx, Igro, p. 203-266, pl. XvIII-XXXI. (Issued separately as Bureau of Fisheries doc. 760.) Washington.

PARKER, G. H.

1902. The reactions of copepods to various stimuli and the bearing of this on daily depth migrations. Bulletin of the U. S. Fish Commission, vol. xxI, I9or, p. 103-123. Washington.

1902a. Notes on the dispersal of Sagartia luciæ Verrill. American Naturalist, vol. xxxvi, no. 426, p. 491-493. New York.

Patterson, J. T.

rgr2. Early development of Graffilla gemellipara-a supposed case of polyembryony. Biological Bulletin of the Marine Biological Laboratory at Woods Hole, vol. xxIr, no. 3, p. 173-204, pl. I-VI. 
PECK, J. I.

I894. On the food of the menhaden. Bulletin of the U. S. Fish Commission, vol. xm, I893, p. I13-I26, p1. I-VIII. Washington.

I896. The sources of marine food. Ibid., vol. XV, I895, p. 35I-368, pl. 65-7I.

PERKINS, H. F.

1902. The development of Gonionema murbachii. Proceedings of the Academy of Natural Sciences of Philadelphia, I902, p. 750-790, pl. XXI-Xxxiv.

PILSBRY, H. A.

I907. The barnacles (Cirripedia) contained in the collections of the U. S. National Museum. Bulletin 60, U. S. National Museum, p. I-I22, p1. I-II. Washington.

PRATT, H. S.

I900. Synopses of North American invertebrates. XII.-The trematodes. American Naturalist, vol. Xxxiv, p. 645-662. New York.

RATHBUN, M. J.

1892. Catalogue of the crabs of the family Periceridx in the U. S. National Museum. Proceedings of the U. S. National Museum, vol. Xv, p. $23^{I-277}$, pl. Xxvm-XL. Washington.

1893. Catalogue of crabs of the family Maiidx in the U. S. National Museum. Ibid., vol. xvi, p. 63-I03, pl. III-VIII.

I905. Fauna of New England. 5.-List of the Crustacea. Occasional Papers of the Boston Society of Natural History, viI, p. I-II7.

Rathbun, R.

1884. Natural history of useful aquatic animals. Part V.-Crustaceans, worms, radiates, and sponges. Y.-The Crustacea. The fisheries and fishery industries of the United States, sec. I, pt. v, p. $763-830$. U. S. Fish Commission, Washington.

I884a. Annotated list of the described species of parasitic copepods (Siphonostoma) from American waters contained in the U.S. National Museum. Proceedings of the U.S. National Museum, vol. vil, p. 483-492. Washington.

1886. Descriptions of parasitic copepods belonging to the genera Pandarus and Chondracanthus. Ibid., vol. $1 \mathrm{x}, \mathrm{p} .3$ I0-324, pl. v-XI.

1887. Descriptions of new species of parasitic copepods belonging to the genera Trebius, Perissopus, and Lernanthropus. Ibid., vol. $\mathrm{x}, \mathrm{p} .559-57 \mathrm{I}, \mathrm{pl}$. $\mathrm{xxIx}-\mathrm{xxxv}$.

Richardson, H.

I901. Key to the isopods of the Atlantic coast of North America, with descriptions of new and little-known species. Proceedings of the U. S. National Museum, vol. xxII, p. 493-579. Washington.

1904. Contributions to the natural history of the isopods. Ibid., vol. xxvir, p. I-89.

I905. Monograph of the isopods of North America. Bulletin of the U. S. National Museum, no. 54, I905, p. I-727. Washington.

RYDER, J. A.

I884. On a skin parasite of the cunner (Ctenolabrus adspersus). Bulletin of the U. S. Fish Commission, vol. IV, 1884 , p. 37-42. Washington.

1886. The development of the toadfish. American Naturalist, vol. 20, p. 77-80. New York.

Sharp, B., AND FoWLER, H. W.

I904. The fishes of Nantucket. Proceedings of the Academy of Natural Sciences of Philadelphia, vol. LVI, p. 504-512.

Sharpe, R. W.

I9I0. Notes on the marine Copepoda and Cladocera of Woods Hole and adjacent regions, including a synopsis of the genera of the Harpacticuida. Proceedings U. S. National Museum,

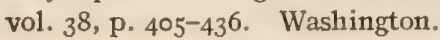

SHERWOOD, G. H., AND EDWARDS, V. N.

I90x. Notes on migration, spawning, abundance, etc., of certain fishes in I900. In: Biological Notes, No. 2, Bulletin U. S. Fish Commission, vol. xxr, Igor, p. 27. Washington. 
SMITI, F.

1895. Notes on species of North American Oligochæta. Bulletin of the Illinois State Laboratory of Natural History, IV, p. 289-292. Urbana.

SмIтн, H. M.

1898. Fishes found in vicinity of Woods Hole. Bulletin U. S. Fish Commission, vol. XvII, I89; p. 85-III, pl. 3. Washington.

I898a. Fishes new to the fauna of southern New England recently collected at Woods Hole. Science, n. s., vol. virI, no. I99, Oct. 21 , I898, p. 543, 544. New York.

1899. Fish fauna of the Woods Hole region. Ibid., vol. $x$, no. 259, December I5, 1899, p. 878-881.

I899a. Notice of a filefish new to the fauna of the United States. Bulletin U. S. Bureau of Fisheries, vol. xvir, I898, p. 273-278, pl. 64, 2 text cuts. Washington.

1900. Additions to the fish fauna in I899. In: Biological Notes, No. I, Ibid., vol. XIX, I899 p. $309,310$.

I90I. Additions to the fish fauna in 1900. In: Biological Notes, No. 2, Ibid., vol. XxI, Igor, p. 3I.

I9ora. Notes on the subtropical fishes observed in 1900 . In: Biological Notes, No. 2, ibid., vol. XXI, 1901, p. 32, 33.

SMith, H. M., AND KENDALI, W. C.

1898. Notes on the extension of the recorded range of certain fishes of the United States coasts. Report U. S. Fish Commission, 1896, p. 169-176. Washington.

Sмiтн, S. I.

1879. The stalk-eyed crustaceans of the Atlantic coast of North America, north of Cape Cod. Transactions of the Connecticut Academy of Arts and Sciences, vol. v, p. 27-r 38, pl. viII-XII. New Haven.

1879a. Occurrence of Chelura terebrans, a crustacean destructive to the timber of submarine structures, on the coast of the United States. Proceedings of the U. S. National Museum, vol. II, p. 232-235. Washington.

188I. Preliminary notice of the Crustacea dredged, in 64 to 325 fathoms, off the south coast of New England, by the United States Fish Commission in 1880 . Ibid., vol. III, p. 4I $3-55^{2}$.

1882. On the species of Pinnixa inhabiting the New England coast, with remarks on their early stages. Transactions of the Connecticut Academy of Arts and Sciences, vol. Iv, pt. 2 p. 247-253. New Haven.

r882a. Occasional occurrence of tropical and subtropical species of decapod Crustacea on the coast of New England. Ibid., vol. IV, pt. 2, p. 254-267.

I882b. On the amphipodous genera, Cerapus, Uniciola, and Lepidactylis, described by Thomas Say. Ibid., vol. IV, pt. 2, p. $268-284$.

1884. Report on the decapod Crustacea of the Albatross dredgings off the east coast of the United

Stimpson, W. States in 1883 . Report of the U. S. Fish Commission I882, p. 345-426, pl. I-X. Washington.

1851. Shells of New England. A revision of the synonomy of the testaceous mollusks of New England, with notes on their structure and on their geographical and bathymetric distribution, 58 p., 2 pl. Boston.

STORER, D. H.

1867. A history of the fishes of Massachusetts. Reprinted from the Memoirs of the American Academy of Arts and Sciences, 1867,287 p., 39 pl. Cambridge and Boston.

SUMNER, F. B.

1908. The biological laboratory of the Bureau of Fisheries at Woods Hole, Mass.: Report of work for the season of 1907. American Naturalist, vol. XLII, no. 497, p. 317-340. New York.

1909. The biological laboratory of the Bureau of Fisheries at Woods Hole, Mass.: Report of the past year's work, and announcement for the coming season. Science, n. s., vol. xxrx, no. $75^{6}$, June 25,1909, p. $983^{-}-987$. New York.

1909a. On the occurrence of the littoral bamacle, Chthamalus stellatus (Poli) at Woods Hole, Mass. Ibid., vol. $\mathrm{xxx}, \mathrm{p} .373-374$.

I910. An intensive study of the fauna and flora of a restricted area of sea bottom. Bulletin of the Bureau of Fisheries, vol. xxviI, I908 (Proceedings of the Fourth International Fisheries Congress), p. I225-1263. (Issued separately as Bureau of Fisheries doc. no. 716). 
Tirompson, M. T.

1899. The breeding of animals at Woods Holl during the month of September, I898. Science, n. S., vol. IX, no. 225, Apr. I4, I899, p. $5^{8} \mathrm{I}-5^{8} 3$. New York.

1902. A new isopod parasitic on the hermit crab. Bulletin of the U. S. Fish Commission for Igor, p. 53-56, pl. 9, 10. Washington.

I903. A rare thalassinid and its larva. Proceedings of the Boston Society of Natural History, vol. 3 I, no. I, P. I-2I, pl. I-3.

I903a. The metamorphoses of the hermit crab. Ibid., vol. 3I, no. 4, p. I47-209, p1. 4-ro.

TREADWELL, A. L.

Igor. The cytogeny of Podarke obscura. Journal of Morphology, vol. xvI, p. 399-486, p1. xxxVI-XI. Boston.

TRUE, F. W.

I884. The useful aquatic reptiles and batrachians of the United States. The Fisheries and Fishery Industries of the United States, sec. I, pt. I, p. I37-I62. U. S. Fish Commission, Washington.

I889. Contributions to the natural history of the cetaceans, a review of the family Delphinidæ. Bulletin No. 36, U. S. National Museum, p. I-I9I, pl. I-XLvin. Washington.

1904. The whalebone whales of the western North Atlantic. Smithsonian Contributions to Knowledge, vol. 33, no. I4I4, p. I-VII, I-332, pl. I-50. Washington.

VAN NAME, W. G.

19ro. Compound ascidians of the coasts of New England and neighboring British Provinces. Proceedings of Boston Society of Natural History, vol. 34, no. II, p. 339-424, pl. 34-39.

I912. Simple ascidians of the coasts of New Englaud and neighboring British Provinces. Proceedings of the Boston Society of Natural History, vol. 34, no. 13, p. 439-6r9, pl. 43-73.

VERRILL, A. E.

I871. Descriptions of some imperfectly known and new ascidians from New England. American Journal of Science and Arts, 3d ser., vol. I, p. 54-58, 93-100, 2 II-212, 288-293, 443-446. New Haven.

I87ra. On the distribution of marine animals on the southern coast of New England. Ibid., 3d ser., vol. II, p. $357-362$.

1872. Recent additions to the molluscan fauna of New England and the adjacent waters, with notes on other species. Ibid., 3d ser., vol. III, p. 209-2I4, $28 \mathrm{I}-290$.

1874. Explorations of Casco Bay by the U. S. Fish Commission in 1873. Proceedings American Association for the Advancement of Science, Portland meeting, p. 340-395. Washington.

1875. Results of dredging expeditions on the New England coast in 1874. American Journal of Science and Arts, $3 \mathrm{~d}$ ser., vol. IX, p. 4I2-4I5. New Haven.

$1875^{\mathrm{a}}$. Same title as the preceding. Ibid., vol. $\mathrm{x}, \mathrm{p} .3^{6-43}$.

I875b. On the post-pliocene fossils of Sankaty Head, Nantucket Island. Ibid., 3d ser., vol. $\mathbf{x}$, p. $364-375$.

1878. Notice of recent additions to the marine fauna of the eastern coast of North America. Ibid., 3 d ser., vol. $\mathrm{XVI}, 1878$, p. $207-215$.

1879. Notice of recent additions to the marine Invertebrata of the northeastern coast of America, with descriptions of new genera and species and critical remarks on others. Part I. Proceedings of the U. S. National Museum, vol. II, p. 165-205. Washington.

1880. Synopsis of the Cephalopoda of the northeast coast of America. American Journal of Science and Arts, 3d ser., vol. xIx, p. 284-295; pl. xII-XvI. New Haven.

I880a. Rapid diffusion of Littorina littorea on the New England coast. Ibid., 3d ser., vol. xx, p. 25 I.

r88ob. Occurrence of Ciona ocellata (Ascidia ocellata Agassiz) at Newport, R. I. Ibid., 3d ser., vol. $\mathrm{xx}$, p. $25 \mathrm{I}$.

I880c. Notice of recent additions to the marine Invertebrata of the northeastern coast of America, with descriptions of new genera and species and critical remarks on others. Part II.Mollusca, etc. Proceedings of the U. S. National Museum, vol. II, p. 356-409. Washington.

I88r. The cephalopods of the northeast coast of North America. Transactions of the Connecticut Academy of Arts and Sciences, vol. v, p. I77-446, pl. xxvI-I,VI. New Haven. 
VERRILI, A. E.-Continued.

1882. Report of the cephalopods of the northeast coast of America. Report of the U. S. Fish Commission, I879, p. 2II-455, pl. I-XLVI. Washington.

1882a. Notice of recent additions to the marine Invertebrata of the northeastern coast of America, etc. Part IV. Proceedings of the U. S. National Museum, vol. v, p. 355-343. Washington.

I882b. New England Annelida. Part I.-Historical sketch, with annotated lists of the species hitherto recorded. Transactions of the Connecticut Academy of Arts and Sciences, vol. Iv, pt. 2, p. 285-324, pl. III-XII. New Haven.

I882c. Catalogue of marine Mollusca added to the fauna of the New England region during the past Io years. Ibid., vol. v, p. 447-587, pl. XLIII-XLVIII.

1882d. Notice of the remarkable marine fauna occupying the outer banks of the southern coast of New England (no, 7), and of some additions to the fauna of Vineyard Sound. American Journal of Science and Arts, 3 d ser., vol. Xxiv, p. 36o-37I.

1884. Notice of the remarkable marine fauna occupying the outer banks off the southern coast of New England; and some additions to the fauna of Vineyard Sound. Report of the U. S. Fish Commission r882, p. 64r-669. Washington.

1884a. Second catalogue of Mollusca recently added to the fauna of the New England coast and adjacent parts of the Atlantic, consisting mostly of deep-sea species, with notes on others previously recorded. Transactions of the Connecticut Academy of Arts and Sciences, vol. vi, p. I39-294, pl. xxviI-xxxrr. New Haven.

1885. Notice of recent additions to the marine Invertebrata of the northeastern coast of America, with descriptions of new genera and species and critical remarks on others. Proceedings of the U.S. National Museum, vol. viII, p. 424-448. Washington.

1885a. Third catalogue of Mollusca recently added to the fauna of the New England coast and adjacent parts of the Atlantic, consisting mostly of deep-sea species, with notes on others previously recorded. Transactions of the Connecticut Academy of Arts and Sciences, vol. vi, p. 395-452, pl. LII-LIV. New Haven.

I892. The marine nemerteans of New England and adjacent waters. Ibid., vol. vIII, p. $382-456$, p1. xxxir-xxxix.

r892a. Dinophilidæ of New England. Ibid., vol. virr, p. 457-458.

r892b. Marine planarians of New England. Ibid., vol. virI, p. 459-520, pl. XI,-XLIV.

I895. Supplement to the marine nemerteans and planarians of New England. Ibid., vol. Ix, p. 523-534.

I895a. Distribution of the echinoderms of northeastern America. American Journal of Science and Arts, ser. 3, vol. XLIX, p. I27-I4I, I99-2I2. New Haven.

I898. Descriptions of new American actinians, with critical notes on other species. Ibid., 4th ser., vol. vi, p. 493-498.

VerRLLL, A. E., AND BUSh, K. J.

I8g8. Revision of the deep-water Mollusca of the Atlantic coast of North America, with descriptions of new genera and species. Proceedings of the U. S. National Museum, vol. xx, p. 775-901, pl. LXXI-XCVII. Washington.

VERRILL, A. E., AND SMITH, S. I.

I873. Report upon the invertebrate animals of Vineyard Sound and the adjacent waters. Report WARD, H. B. of the U. S. Fish Commission, $187 \mathrm{I}-72$, p. 295-778, pl. I-Xxxvm. Washington.

I892. On Nectonema agile Verrill. Bulletin Museum of Comparative Zoology, Harvard College,

WEBSTER, H. E. vol. Xxin, no. 3 , p. I35-I87, pl. I-VIII. Cambridge.

r878. Annelida Chrtopoda of the Virginian coast. Transactions of the Albany Institute, vol. Ix (advance separate, p. $\mathrm{x}-72, \mathrm{pl}$. $\mathrm{I}-\mathrm{XI}$ ). Albany.

WHEELER, W. M.

I894. Syncœlidium pellucidum, a new marine triclad. Journal of Morphology, vol. Ix, no. 2, p. r67-r94. Bosion.

I894a. Planocera inquilina Wheeler, a polyclad inhabiting the branchial chamber of Sycotypus canaliculatus Gill. Ibid., vol. IX, p. I95-202.

Igoo. The free-swimming copepods of the Woods Hole region. Bulletin of the U. S. Fish Commission, vol. XIX, I899, p. I57-192. Washington. 
WILHELMI, J.

1908. On the North American marine triclads. Biological Bulletin of the Marine Biological Laboratory at Woods Hole, vol. xv, no. I, P. I-6.

WILLIAMS, L. W.

1906. Notes on marine Copepoda of Rhode Island. American Naturalist, vol. xL, no. 477, p. 639660. New York. (The territory covered by Williams does not properly belong to the region considered in this report.)

Wilson, C. B.

1902. North American parasitic copepods of the family Argulidæ, with a bibliography of the group and a systematic review of all known species. Proceedings of the U. S. National Museum, vol. $\mathrm{xxV}$, p. $635^{-742}$, pl. vIII-XXvir. Washington.

1905. The fish parasites of the genus Argulus found in the Woods Hole region. Bulletin of the Bureau of Fisheries, I904, p. II 7-I3I. Washington.

I905a. North American parasitic copepods belonging to the family Caligidæ. Part I. The Caliginæ. Proceedings of the U. S. National Museum, vol. XxvIII, p. 479-672, p1. v-XxIX. Washington.

rgo5b. New species of parasitic copepods from the Massachusetts coast. Proceedings of the Biological Society of Washington, vol. XVII, p. I27-I3I.

1907. North American parasitic copepods, belonging to the family Caligidx. Part 2. The Trebinæ and Euryphorinæ. Proceedings of the U. S. National Museum, vol. xxxI, p. 669$720, \mathrm{pl} . \mathrm{xv}-\mathrm{xx}$. Washington.

1907a. Additional notes on the development of the Argulidæ, with description of a new species. Ibid., vol. XXXII, p. 4II-424, pl. XXIX-XXXII.

Igo7b. North American parasitic copepods, belonging to the family Caligidæ. Parts 3 and 4 . A revision of the Pandarinæa and the Cecropinæ. Ibid., vol. xxxII, p. 323-490, pl. XVII-XLII.

I9I1. North American parasitic copepods belonging to the family Eirgasilidæ. Ibid., vol. xxxIx, p. $263-400$, pl. $41-60$.

Wrison, E. B.

1878. Descriptions of two new genera of Pycnogonida. American Journal of Science and Arts, $3 \mathrm{~d}$ ser., vol. $\mathrm{xv}$, p. 200-203.

r878a. Synopsis of the Pycnogonida of New England. Transactions of the Connecticut Academy of Arts and Sciences, vol. v, p. I-26, pl. I-vir.

r880. Report on the Pycnogonida of New England and adjacent waters. Report of the U. S. Fish Commission, 1878 , p. 463-506, pl. I-vII.

I892. The cell lineage of Nereis: A contribution to the cytogeny of the annelid body. Journal of Morphology, vol. vi, p. $36 \mathrm{I}-480, \mathrm{pl}$. xm-xx.

WILson, H. V.

I89I. Notes on the development of some sponges. Journal of Morphology, vol. V, p. 5II-5I9.

r8gra. The embryology of the sea bass (Serranus atrarius). Bulletin U. S. Fish Commission, vol. IX, I889, p. 209-277, pl. LxxxvIII-cvII. Washington.

WINKLEY, H. W.

r908. A new Cæcum. The Nautilus, vol. xxu, no. 6, p. 54. Boston.

I909. New England Pyramidellidx, with description of a new species. Ibid., vol. xxm, no. 3 , p. 39,40 . 


\title{
Section IV.-A CATALOGUE OF THE MARINE FLORA OF WOODS HOLE AND VICINITY.
}

\author{
* \\ BY BRADLEY MOORE DAVIS.
}

This list is based chiefly on the general field studies of the writer for some eight summers, while in charge of the department of botany of the Marine Biological Laboratory, and the special botanical operations of the biological survey of the Bureau of Fisheries for the summers of 1903, 1904, 1905, and 1907. A six weeks' sojourn at Woods Hole in April and May, 1907, extended materially the information relating to the spring algal flora and seasonal habits of a number of species. There are included also records and references of earlier collectors, W. G. Farlow, W. A. Setchell, W. J. V. Osterhout, C. P. Nott, and others, and the more recent observations of F. S. Collins and Miss Lillian $\mathrm{J}$. MacRae. The records on the distribution of the algæ are known personally to the writer except where specific statement is made on the authority of another.

The regions covered by this list comprise: (I) The immediate waters of Woods Hole, (2) the deeper waters of Buzzards Bay, and (3) the deeper waters of Vineyard Sound from the westerly entrance to a line drawn between East Chop and Falmouth Heights. A few references to localities outside of the regions described above have been included for certain species of especial interest.

The dredging stations are given in two groups:

I. Buzzards Bay, divided by a line drawn from the west end of Naushon (Robinsons Hole) to Round Hill Point into $(a)$ an upper and $(b)$ a lower portion.

2. Vineyard Sound, divided into three regions, $(a)$ the westerly portion from the entrance at Gay Head to a line drawn from the west end of Naushon (Robinsons Hole) to Kopeecon Point (Cape Higgon), (b) the narrow portion from this line to one connecting Nobska Point and West Chop, $(c)$ the easterly portion from the latter line to one drawn between Falmouth Heights and East Chop. In both groups the stations that skirt the coast are collected and introduced by the word "Inshore." The inshore stations were dredged for the purpose of determining the conditions in relatively shallow water, from I to 5 fathoms in depth.

The inshore stations are almost wholly those designated by the lower numbers I-I 67, and were chiefly dredged by the Phalarope and Blue Wing (summers of 1904, I905, and 1907). The stations in the deeper regions of Buzzards Bay and Vineyard Sound have the high numbers $7521-7602$ (Vineyard Sound, summer of 1903), 7610-7675 (Buzzards Bay, summer of 1904), and 7676-7783 (Tineyard Sound, summer of 1905); they were dredged chiefly from the Fish Hawk. Numbers followed by the word "bis" 
refer to stations, selected from those of the corresponding number in Vineyard Sound, that were redredged in the following summer (1904). A few numbers followed by the date (1907) refer to selected stations redredged in the summer of that year. In addition to the numbered stations plotted upon the maps there are records for several special trips of the author on the Genevicve of the Marine Biological Laboratory and the Bluc Wing. These were (I) off Devils Bridge, Gay Head, August I7, I903 (Blue Wing), (2) Lobsterville Cove, Menemsha Bight, August 9, 1904 (Blue Wing), (3) Menemsha Bight, July I7, 1905 (Genevieve), and (4) cove west of Cuttyhunk Neck, July 27, I905 (Genevicue). For detailed information on the situation of the stations, dates of dredgings, depths, character of the bottom, etc., the reader is referred to the "Description of dredging stations occupied during the present Survey," section I, p. 20I-2 I 8.

The strong tidal currents of Vineyard Sound and Buzzards Bay carry large amounts of algal débris, which is widely distributed along the bottom, frequently in stations utterly foreign to the life habits of the species. The dredge very often brings up fragments of this algal drift, which can generally be recognized by their water-worn appearance and frayed ends. However, it is sometimes very difficult to be certain whether such fragments are algal drift or have been torn from their attachment by the dredge. We have endeavored to separate critically all clear evidence or probability of algal drift from the records of growth in situ. The former will appear at the ends of the lists of stations for certain species under the heading "Drifted fragments," and these records must be understood to mean that the species does not, so far as we know, grow at that station.

The species are arranged alphabetically in the genera, which are grouped in families following closely the classification presented in Engler and Prant1, "Die natürlichen Pflanzenfamilien." The assembling into orders differs in important particulars from the arrangement in the above treatment. Four classes are recognized, the Cyanophyсеæ, Chlorophyceæ, Phæophyceæ, and Rhodophyceæ.

The list aims to include all specific references in literature and published sets of algæ to the occurrence of the species within the limits of the survey. In this list, only the author's name and date of publication appear, the full titles of the papers being given in the bibliography at the end of the catalogue. P. B.-A. stands for the Phycotheca Boreali-Americana of Collins, Holden, and Setchell; A. A. B. Ex. for the Algxe Americanæ Boreales Exsiccatæ of Farlow, Anderson, and Eaton; A. A. D. Ex. for the Algæ Aquæ Dulcis Exsiccatæ of Wittrock and Nordstedt. The authorities for the specific names are, with few exceptions, those given in the Phycotheca BorealiAmericana and in "Preliminary Lists of New England Plants: V. Marine Algæ" by Frank S. Colinns (Rhodora, vol. II, p. 4I-52, I900).

We are greatly indebted to Mr. Collins for a number of determinations and for his kindly criticism of the manuscript. 


\title{
Division THALLOPHYTA.
}

\author{
Subdivision ALGAE. \\ Class CYANOPHYCEA:
}

Order COCCOGONALES.

\section{Family CHroococcaceis.}

\section{Chroococcus turgidus Nägeli.}

Common, in salt marshes, on wet earth and rocks, mixed with Calothrix, Lyngbya, Microcoleus, Vaucheria, etc.

Woods Hole: Little Harbor, Penzance. Quisset salt marshes. Hadley Harbor.

Spring, summer, undoubtedly at other seasons.

Glococapsa crepidinum Thuret.

Abundant, on woodwork and rocks at high-water mark.

Woods Hole.

At all seasons.

Polycystis elabens Kützing.

Common, in salt marshes, forming slimy masses on decaying algæ and on Zostera, frequently mixed with Lyngbya, Microcoleus, etc.

Woods Hole: Penzance. Quisset. Hadley Harbor.

Summer.

Farlow, I88I, p. 28 (Polycystis elabens Kützing), Woods Hole.

\section{Family Chamasiphonacere.}

Dermocarpa prasina (Reinsch) Bornet \& Thuret.

Common, on Polysiphonia fastigiata.

Woods Hole, off Juniper Point.

Spring, early summer.

On Polysiphonia fastigiata, which in turn grows on Ascophyllum nodosum.

Hyella caspitosa Bornet \& Flahault.

Abundant wherever old shells are found in quiet waters.

Woods Hole.

Spring, summer, undoubtedly at all seasons.

Boring into clam and other shells.

Pleurocapsa fuliginosa Hauck.

Common, on harbor walls and rocks near highwater mark, forming a dark stain.

Woods Hole.

At all seasons.

\section{Order HORMOGONALES.}

\section{SUBORDER HOMOCYSTEE⿸⿻一丿工厶.}

\section{Family Oscillatoriace,}

SUBFAMILY VAGINARIEAA.

Hydrocoleum glutinosum (Agardh) Gomont.

Common, on Zostera.

Woods Hole.

Summer.

Farlow, I88x, p. 35, 36 (Lyngbya nigrescens var. major Farlow), Woods Hole; A. A. B. Ex., fas. $\mathrm{I}$, no. 47 (Lyngbya nigrescens var. major Farlow), Woods Hole (W. G. Farlow).

Hydrocoleum lyngbyaceum Kützing.

Occasional, on Ascophyllum nodosum.

Harbor of Woods Hole.

Summer.

P. B.-A., fas. V, no. 204 (Hydrocoleum lyngbyace$u m$ var. $A$, Gomont), Woods Hole, August I4, I894 (W. A. Setchell).
Microcoleus chthonoplastes (Flora Danica) Thuret.

Common, in salt marshes and brackish pools, mixed with Lyngbya and other algæ.

Woods Hole: Eel Pond, Penzance. Quisset. Hadley Harbor.

Summer, undoubtedly at other seasons.

Farlow, I88I, p. 33, 34 (Microcoleus chthonoplastes Thuret), Woods Hole; Farlow, r88r, p. 33 (Oscillaria subtorulosa Brebisson), Woods Hole; A. A. B. Ex., fas. v, no. 227, Woods Hole, August, 1877 (W. G. Farlow); P. B.-A., fas. IV, no. I 53 , Woods Hole, July I7, I895 (W. J. V. Osterhout).

Microcoleus tenerrimus Crouan.

Occasional, in salt marshes and brackish pools, mixed with Microcoleus chthonoplastes, Lyngbya, and other algæ.

Woods Hole: Penzance, Eel Pond.

Summer.

Found by F. S. Collins, summer of 1904. 
SUBFAMILY LYNGBYEAE.

Lyngbya astuarii (Mertens) Liebman.

Common, salt marshes and brackish pools, on stones and mud between tide marks, also on wharves.

Woods Hole: Penzance, Eel Pond. Salt marshes of Quisset and Hadley Harbor,

Summer, undoubtedly throughout the year.

Lyngbya confervoides Agardh.

Occasional, in salt marshes and pools.

Woods Hole: Penzance.

Summer.

Farlow, 188I, p. 35 (Lyngbya luteo-fusca J. Agardh), Woods Hole; A. A. B. Ex., fas. I, no. 48 (Lyngbya" luteo-fusca J. Agardh), Woods Hole (W. G. Farlow).

Lyngbya Lagerheimii (Möbius) Gomont.

In brackish waters.

Little Pond of Falmouth Heights.

Known only from specimen in herbarium of the Marine Biological Laboratory collected by W. A. Setchell and W. J. V. Osterhout.

Lyngbya majuscula (Dillwyn) Harvey.

Occasional, attached to Zostera, and sometimes found floating in large quantities in sheltered situations.

Woods Hole: Great Harbor. Vineyard Haven. Vineyard Sound east end of Naushon. Menemsha Bight.

Summer.

Farlow, 1873, p. 293, Woods Hole, Naushon, Edgartown; Farlow, I875, p. 380, Woods Hole; A. A. B. Ex., fas. v, no. 228 , Vineyard Haven, September, 1883 (W. G. Farlow); P. B.-A., fas. v, no. 202, Woods Hole, August 16, 1894 (W. A. Setchell).
Lyngbya semiplena (Agardh) J. Agardh.

Common, in salt marshes, brackish pools and ditches, mixed with Microcoleus, Lyngbya, etc.

Woods Hole: Ditches of Penzance.

Summer, undoubtedly at other seasons.

\section{Oscillatoria amphibia Agardh.}

Common, on woodwork of wharves, frequently mixed with Oscillatoria latevirens.

Woods Hole.

Summer, undoubtedly at other seasons.

Found by F. S. Collins, summer of 1904 .

Oscillatoria latevirens Crouan.

Common, on woodwork of wharves, frequently mixed with Oscillatoria amphibia.

Woods Hole.

Summer, undoubtedly at other seasons.

Found by F. S. Collins, summer of 1904 .

Phormidium persicinum (Reinke) Gomont.

Rare, appearing during the winter in a jar of salt water (G. M. Gray).

Woods Hole.

P. B.-A., fas. Xxix, no. I40I, Woods Hole, May, ${ }_{907}$ (B. M. Davis).

Spirulina subsalsa Oersted.

Common in salt marshes and brackish pools, mixed with Lyngbya, Microcoleus, etc.

Woods Hole: Penzance. Quisset. Hadley Harbor.

Summer, probably at all seasons.

Farlow, I88I, p. 3 I (Spirulina tenuissima Kützing), Woods Hole.

\section{SUBORDER HETEROCYSTEE.}

\section{Family NosTOCACE, 瓜.}

Anabcena torulosa Lagerheim.

Abundant, on decaying algæ and Zostera, from whence it frequently rises and floats in quiet waters.

Woods Hole: Zostera patches in E,el Pond, Little Harbor, Ram Island. Similar situations Quisset Harbor, Hadley Harbor, Tarpaulin Cove.

Summer.

Farlow, 1876, p. 715 (Spharozyga Carmichaelli Harvey), Woods Hole; Farlow, I881, p. 30 (Sphørozyga Carmichaelli Harvey), Woods Hole.
Microchcte grisea Thuret.

Common, on pebbles and shells with Isactis.

Woods Hole: Eel Pond. West Falmouth (Collins).

Summer, undoubtedly at other seasons.

Collins, r884, p. r3o, old pecten shell, West Falmouth.

Nodularia Harveyana (Thwaites) Thuret.

Common, in brackish water mixed with Lynghya, Microcoleus, etc.

Woods Hole: Eel Pond.

Summer. 


\section{Family StrgonemaCEIE.}

Mastigocoleus testarum Lagerheim.

Common, wherever old shells are found in quiet waters.

Woods Hole.

Boring into clam and other shells.

Spring, summer, undoubtedly at all seasons.

P. B.-A., fas. v, no. 2r3, Quisset, July, 1893 and r895 (W. A. Setchell).

\section{Family SCYTONEMACEA}

Plectonema calothrichoides Gomont.

Common, on woodwork of wharves.

Woods Hole: Eel Pond, wharves of Bureau of Fisheries.

Spring.

\section{Family RIVUr,ARIACE,AE.}

Amphithrix violacea (Kützing), Bornet \& Flahault. Common, on shells of Turritella.

Woods Hole: Eel Pond.

Summer.

Found by F. S. Collins, summer of 1904.

Brachytrichia Quoyi (Agardh) Bornet \& Flahault. Common in its localities, attached to Fucus.

Woods Hole: Quisset Harbor. Hadley Harbor. Hog Island Harbor (F. S. Collins).

Summer.

Farlow, 1876, p. 7 I5 (Rivularia nitida (Agardh?), Woods Hole; Farlow, I881, p. 39 [Hormactis Quoyi (Agardh) Bornet, in litt.], Woods Hole, Falmouth; Collins, 189o, p. 175, Buzzards Bay shore of Woods Hole, Quisset, and Hog Island Harbors; A. A. B. Ex., fas. I, no. 45 (Hormactis Farlowii Bornet), Woods Hole (W. G. Farlow); A. A. D. Ex., fas. 25, no. II97, Quamquisset Harbor, August, I89r (W. A. Setchell); P. B.-A., fas. I, no. 8, Quamquisset Harbor, Falmouth, August I, r89o (W. A. Setchell).

Probably introduced by ships that formerly brought guano to Woods Hole from islands in the Pacific.

Calothrix ceruginea (Kützing) Thuret.

Common, on woodwork of wharves, frequently mixed with Oscillatoria.

Woods Hole.

Summer, undoubtedly at other seasons.

Found by F. S. Collins, summer of 1904.

Calothrix confervicola (Dillwyn) Agardh.

Common, on larger algæ in quiet, shallow waters. Dredged by the Survey in Vineyard Haven, 3 to 4 fathoms.

$$
\text { I6269 }- \text { Bull. } 3 \text { I, pt } 2-\mathrm{r} 3-\mathrm{I} 7
$$

Calothrix confervicola-Continued.

Woods Hole: Great Harbor, Eel Pond, Little Harbor. Vineyard Haven: at station 72 on Sphacelaria cirrhosa.

Summer, undoubtedly at other seasons.

Farlow, 1873, p. 293, Woods Hole; Farlow, r881, p. 36 , Woods Hole; A. A. B. Ex., fas. v, no. 225, Woods Hole (W. G. Farlow); P. B.-A., fas. I, no. 9, Woods Hole, July 12, 1892 (W. A. Setchell).

Calothrix crustacea Thuret.

Common, on larger algæ and rocks between tide marks.

Woods Hole: Great Harbor, Eel Pond, Little Harbor. Black Rock.

Summer, undoubtedly at other seasons.

Farlow, 1881, p. 36, Woods Hole; A. A. B. Ex., fas. I, no. 49, Woods Hole (W. G. Farlow).

Calothrix fusco-violacea Crouan.

Common, on old Punctaria plantaginea, Zostera, and larger algæ.

Woods Hole: Grassy Lredge, Little Harbor.

Early summer.

Setchell, 1896, p. 87 , Woods Hole, summer of 1896; P. B.-A., fas. v, no. 217 , Woods Hole on Punctaria plantaginea (Roth) Greville (C. P. Nott).

Calothrix parasitica (Chauvin) Thuret.

Common, on Nemalion multifidum, occasionally on Castagnea and other loose tissued algæ.

Woods Hole: Juniper Point, Grassy Ledge. Cuttyhunk.

Summer.

A. A. B. Ex., fas. v, no. 224, Woods Hole (W. G. Farlow); P. B.-A., fas. III, no. I I I, Woods Hole, July 29, I895 (C. P. Nott).

Calothrix pulvinata (Mertens) Agardh.

Common, forming patches resembling honeycomb on wharves and stones.

Woods Hole: Wharves and harbor walls.

Summer, undoubtedly at other seasons.

Farlow, 1881, p. 37, Woods Hole; A. A. B. Ex., fas. I, no. 5o, Woods Hole (W. G. Farlow).

Calothrix scopulorum (Weber \& Mohr) Agardh.

Common, forming patches on rocks and piles near high-water mark.

Woods Hole: Grassy Ledge. Tarpaulin Cove. Piles of wharf at Gay Head.

Summer, undoubtedly at other seasons.

Farlow, 1881, p. 37, Woods Hole. 
Isactis plana (Harvey) Thuret.

Common, on Punctaria, Fucus, Ascophyllum, rocks and old shells.

Woods Hole: Grassy Ledge. Along Buzzards Bay shore. Cuttyhunk (Setchell).

Summer, probably at all seasons.

A. A. B. Ex., fas. v, no. 222, Woods Hole (W. G. Farlow); P. B.-A., fas. Iv, no. I56a, Cuttyhunk, August 3, I894 (W. A. Setchell).

Rivularia atra Roth.

Common, on rocks, stones, and barnacles, between tide marks.

Woods Hole: Juniper Point, Grảssy Ledge. Black Rock.

Summer, probably at all seasons.
Rivularia atra-Continued.

Farlow, I873, p. 293, Woods Hole; A. A. B. Ex., fas. V, no. $22 \mathrm{I}$, Woods Hole in part (W. G. Farlow).

Rivularia nitida Agardh.

Common, on mud and roots of Spartina in salt marshes, between tide marks.

Quisset Harbor.

Summer, undoubtedly at other seasons.

Farlow, I88x, p. $3^{8}$ (Rivularia plicata Carmichael), Woods Hole; P. B.-A., fas. vi, no. 260 b, Quamquisset Harbor, Falmouth, July and August, r89I (W. A. Setchell).

Rivularia polyotis (J. Agardh) Bornet \& Flahault. Cohasset Narrows (Farlow).

Farlow, I88I, p. 38, 39 (Rivularia hospita 'Thuret). Cohasset Narrows.

\section{Class CHLOROPHYCE, 无。}

\section{Order PROTOCOCCALES.}

\section{Family PALMELLACEA.}

Glococystis zostericola (Farlow) Collins.

Common, on Zostera, forming slimy patches mixed with other microscopic algæ.

Woods Hole: Eel Pond. Quisset Harbor (Setchell).

Summer.
Farlow, 1882, p. 67, 68 (Glococapsa zostericola Farlow), Woods Hole, August, r88r; A.A.B. Ex., fas. v, no. 230, [Gloocystis chrysophthalma (Montagne) Farlow], Woods Hole (W. G. Farlow); P.B.-A., fas. v, no, 219 , I896 [Glococystis chrysophthalma (Montagne) Farlow], Quisset, July, I893 (W. A. Setchell).

\section{Order ULOTRICHALES.}

\section{Family ULOTRICHACEA:}

Ulothrix flacca (Dillwyn) Thuret.

Common, on woodwork of wharves, stones, Fucus, etc., above low water.

Woods Hole: Great Harbor, Grassy Ledge.

Summer, undoubtedly at other seasons.

Ulothrix implexa Kützing.

Occasional, on rocks, above low water.

Woods Hole: Grassy Ledge.

Spring and early stummer.

\section{Family UlvaCEA}

Enteromorpha clathrata (Roth) Greville.

Abundant, in quiet water and pools, attached to stones, Zostera, larger algæ, or floating in masses, frequently in brackish water. Dredged by the Survey, Vineyard Haven in 3 to 4 fathoms, over a shelly and muddy bottom.

Woods Hole: Eel Pond, ditches of Penzance. Marshes of Quisset Harbor and Hadley Harbor. Vineyard Haven, station 72, few.

Summer, undoubtedly at other seasons.

Farlow, I873, p. 292, Woods Hole.

P.B.-A., fas. D, no.-Lxxvir, Eel Pond, Woods Hole, August r6, 1904 (F. S. Collins).
Enteromorpha crinita (Roth) J. Agardh.

Common, in pools and ditches of salt marshes.

Woods Hole: Pools of Penzance.

Summer.

Enteromorpha erecta (Lyngbye) J. Agardh.

Occasional.

Woods Hole (Holden).

Known only from specimens in the herbarium of the Marine Biological Laboratory, collected by, Isaac Holden.

Enteromorpha intestinalis (Linnæus) Greville.

Abundant, in quiet waters, attached to woodwork of wharves, stones, shells, etc., between tide marks. Dredged once by the Survey off Marthas Vineyard (station 6I) in 5 fathoms, over a sandy bottom.

Woods Hole: Eel Pond, Little Harbor, Grassy Ledge. Quisset Harbor. Hadley Harbor. Tarpaulin cove.

Vineyard Sound: Inshore-Marthas Vineyard, station $6 \mathrm{I}, \mathrm{few}$.

Summer, ndoubtedly at other seasons 
Enteromorpha linza (Linnxus) J. Agardh.

Common, attached to stones and woodwork of wharves, near low-water mark and below.

Woods Hole: Great Harbor, Little Harbor. Black Rock.

Summer.

Enteromorpha minima Nägeli.

Common, attached to rocks near high-tide mark. Woods Hole: Stone harbor walls, Grassy Ledge. Summer.

Enteromorpha percursa (Agardh) J. Agardh.

Common, in pools and ditches, floating in large masses frequently mixed with other species of Enteromorpha.

Woods Hole: Eel Pond, brackish pools and ditches of Penzance.

Summer.

Enteromorpha plumosa Kützing.

Common, in quiet waters, attached to Zostera.

Woods Hole.

Summer.

Synonym: Enteromorpka Hopkirkii McCalla of Collins' ( I900) list.

Enteromorpha prolifera (Flora Danica) J. Agardh.

Common, in pools and ditches of salt marshes, in floating masses mixed with Cladophora, also on rocks. Dredged once by the Survey, Hog Island Harbor (station I35) in $3 \frac{3}{4}$ to 5 fathoms, over sand and gravel.

Woods Hole: Ditches of Penzance. Black Rock

Buzzards Bay: Inshore-Hog Island Harbor, station 135 , few.

Vineyard Sound: Inshore-Gay Head, stations 50 and 5 I, many on rocks.

Summer.

Ilea fulvescens (Agardh) J. Agardh.

Occasional, on stones at low-water mark.

Woods Hole: Little Harbor (Setchell).

July 31, I895.

Known only from specimens in the herbarium of the Marine Biological Laboratory collected by W. A. Setchell.

Monostroma crepidinum Farlow.

Occasional, on piles of wharves between tide marks.

Woods Hole: Government wharves Little Harbor (Farlow). Head of Vineyard Haven (Setchell).

August (Farlow), August I4, I892 (Setchell).

Farlow, I88r, p. 42, Government wharf, Woods Hole; A. A. B. Ex., fas. IV, no. I74, Woods Hole (W. G. Farlow); P. B.-A., fas. v, no. 220 , head of Vineyard Haven, August I4, I892 (W. A. Setchell).
Monostroma Grevillei (Thuret) Wittrock.

Abundant, on stones and larger algæ near lowwater mark.

Woods Hole: Little Harbor.

Spring.

Protoderma marinum Reinke. (Taxonomic position uncertain.)

Very common, on pebbles, especially in quict waters, forming a green coating.

Woods Holc. Quisset. Tarpaulin Cove.

At all seasons.

Ulva Lactuca Linnæus. Sea-lettuce.

Common, attached to rocks, wharves, and algx, above and below low water.

Woods Hole.

Buzzards Bay: Drifted fragments, stations 76.45 , 84, I6r, I65.

Vineyard Sound: Drifted fragments, stations 49, 60.

At all seasons.

Ulva Lactuca var. latissima (Linnæus) De Candolle.

Common, floating in quiet, shallow water.

Woods Hole: Little Harbor, Eel Pond, ditches on Penzance.

Summer

P. B.-A., fas. D, no. Lxxvi, Eel Pond, Woods Hole, August I6, I904 (F. S. Collins).

Ulva Lactuca var, rigida (Agardh) Le Jolis.

Common, on rocks exposed to the action of waves, above low-water mark.

Woods Hole: Harbor walls, Grassy Ledge, Juniper Point, Government wharves Little Harbor. Black Rock.

Buzzards Bay: Drifted fragments, stations 7629 , II 3 .

Vineyard Sound: Gay Head, stations 50 and 5 I, many.

At all seasons.

\section{Family Ch.ETOPHORACEE:}

Acrochate repens Pringsheim.

Common, epiphytic in base and middle regions of Chorda filum, among the paraphyses and sporangia.

Woods Hole.

Summer.

Collins, 1906a, p. I24, Woods Hole, September I, r905; P. B.-A., fas. Xxvi, no. 1279, Woods Hole, September I, Ig05 (F. S. Collins).

Bulbocoleon piliferum Pringsheim.

Common, on Leathesia and Chordaria.

Woods Holc.

Summer.

Farlow, I88I, p. 57, Woods Hole. 
Endoderma perforans Huber.

Probably common, growing in the tissue of faded and dead leaves of Zostera.

Mattapoisett (Collins).

September, I906 (Collins).

P. B.-A., fas. xxxur, no. r625, Mattapoisett, September 9, 1906 (F. S. Collins).

Endoderma viride (Reinke) Lagerheim.

Occasional, growing in the cell wall of Seirospora Griffithsiana.

Falmouth (Collins).

September, 1883 (Collins).

Collins, I906a, p. I23, 124, Falmouth, September, 1883.

Pilinia Reinschii (Wille) Collins.

Common, on shells of Turritella.

Woods Hole: Along Buzzards Bay (Collins).
Pilinia Reinschii-Continued.

Summer of I905 (Collins).

Synonym, Acroblaste Reinschii Wille of Collins' (1900) list.

Pringsheimia scutata Reinke.

Occasional, on Zostera and larger algæ.

Waquoit Bay, Falmouth (Setchell).

July 2r, I8go (Setchell).

Specimen in herbarium of Marine Biological Laboratory, collected by W. A. Setchell.

Tellamia contorta Batters.

Common, forming a thin superficial coating on shells of living Littorina palliata.

Woods Hole.

Summer, undoubtedly at other seasons.

Found by F. S. Collins, summer of 1905.

Order SIPHONOCLADIALES.

\section{Family Cladophorace,}

Chetomorpha area (Dillwyn) Kützing.

Occasional, on rocks.

Woods Hole: Off Juniper Point. Gay Head.

Summer, probably at all seasons.

Farlow, I873, p. 293, Gay Head.

Chetomorpha Linum (Flora Danica) Kützing.

Common, unattached, in wiry masses over muddy or sandy bottoms in shallow water. Dredged by the Survey in 5 fathoms, over mud.

Woods Hole: Off Juniper Point. Nobska. Gay Head.

Buzzards Bay: Inshore-Cuttyhunk, station roo, few; Nashawena, station 79, fragment.

Vineyard Sound: Inshore-Menemsha Bight July ${ }_{77}$, 1905, haul 3 , few.

Summer, probably at all seasons.

Farlow, 1873, p. 293 (Chetomorpha sutoria Berkeley), Gay Head; Farlow, r873, p. 293 (Chetomorpha litoria Harvey), Gay Head; probably refers to Chetomorpha Linum.

Chøtomorpha melagonium (Weber \& Mohr) Kützing. [Chart 228.]

Common, on rocks and stones in fairly deep water off the exposed points of Gay Head and Cuttyhunk. Dredged by the Survey over sand, gravel, and stones in 4 to 9 fathoms. Frequently washed ashore at Gay Head and Cuttyhunk.

Vineyard Sound: Inshore-Cuttyhunk, stations 32,33 , and 34 , few; Sow and Pigs 37 , few; Gay Head 44, 45, 56, 57, 58, and 60, few; also off Devils Bridge August 17, 1903, hauls 3 and 4, many; Marthas Vineyard 65 and 74 , few. Drifted fragments, 7719,7721 .

Summer, winter, undoubtedly all seasons.
Chatomorpha melagonium-Continued.

Farlow, 1873, p. 293 (Chatomorpha Picquotiana Montagne), Gay Head; Farlow, 1881, p. 47 [Chcetomorpha Picquotiana (Montagne) Kütz= ing], Gay Head.

Cladophora albida (Hudson) Kützing.

Common, on rocks below low water.

Woods Hole: Off Juniper Point.

Summer.

P. B.-A., fas. $x x v$, no. I227, Juniper Point (Butlers Point), Woods Hole, August 14, I904 (F. S. Collins).

Cladophora albida var, refracta (Wyatt) Thuret.

Common, on rocks, stones, and larger algæ below low water.

Woods Hole: Juniper Point, Buzzards Bay.

Buzzards Bay: Drifted fragments, station 7668 .

Vineyard Sound: Gay Head, stations 50 and 51, many.

Summer.

Cladophora arcta (Dillwyn) Kützing.

Abundant, on wharves and stonework below low water.

Woods Hole: Wharves and harbor walls.

Spring, summer.

Cladophora expansa (Mertens) Kützing.

Common, in brackish ditches and pools.

Woods Hole: Salt marsh pools of Penzance.

Summer.

A. A. B. Ex., fas. v, no. 2 ro, Woods Hole (W. G. Farlow).

Cladophora flexuosa (Griffiths) Harvey.

Common, attached to rocks below low water.

Woods Hole.

Summer. 
Cladophora flexuosa-Continued.

Farlow, 1873, p. 293, Woods Hole Government wharf; Farlow, I881, p. 54, Woods Hole; A. A. B. Ex., fas. v, no. 206, Woods Hole (W. G. Farlow).

Cladophora fracta (Flora Danica) Kützing.

Rare, in brackish water.

Woods Hole: Eel Pond Creck (Setchell).

August, Ig04 (Setchell).

Farlow, r873, p. 293, Woods Hole; A. A. B. Ex. fas. v, no. 208, Falmouth, I88 I (W. G. Farlow); specimens in the herbarium of the Marine Biological Laboratory collected by W. A. Setchell.

Cladophora glaucescens (Griffiths) Harvey.

Common, attached to rocks and woodwork of wharves below low water.

Woods Hole: Harbor wharves, Juniper Point; Government wharf Little Harbor, Gut of Canso.

Summer.

A. A. B. Ex., fas. v, no. 205 , Woods Hole, August, I88I (W. G. Farlow).

Cladophora gracilis (Griffiths) Kützing.

Abundant, attached to wharves and stones below low-water mark, sometimes on Zosterc. Dredged by the Survey over sand and gravel in 2 to $5 \frac{1}{2}$ fathoms.

Woods Hole: Harbor walls, basins of Bureau of Fisheries, Grassy Ledge, Juniper Point.

Buzzards Bay: Inshore-Cuttyhunk, station ro4, few; Nashawena 79, few; Uncatena II7, few.

Vineyard Sound: Inshore-Tarpaulin Cove, station I 7, few on Zostera; Robinsons Hole 20 and 2 , few; Pasque 24 and 25, few. Drifted fragments, 7543 bis and 7570 .

Summer.

Farlow, I88I, p. 55, Woods Hole; A. A. B. Ex., fas. v, no, 209, Falmouth, r88I (W. G. Farlow).

\section{Cladophora hirta Kützing.}

Occasional, on rocks below low water.

Woods Hole: Juniper Point.

Summer.

Cladophora lanosa (Roth) Kützing.

Occasional, attached to larger algæ below lowwater mark, floating in Vineyard Sound attaclied to Ascophyllum nodosum and goose barnacles (Lepas).

Woods Hole: Steamboat wharf, Grassy Ledge, Juniper Point.

At all seasons.
Cladophora lanosa var. uncialis (Flora Danica) Thuret.

Common, on stones and rocks, above and below low-water mark.

Woods Hole: Grassy Ledge (Miss MacRae). Vineyard Sound.

December, 1904, April and May, rgo5 (Miss MacRac, Grassy Ledge). Summer (Vineyard Sound).

Cladophora refracta (Roth) Areschoug.

Abundant, attached to stones near low-water mark.

Woods Hole.

Summer.

A. A. B. Ex., fas. v, no. 207, Woods Hole, August, I88 I (W. G. Farlow).

Cladophora Rudolphiana (Agardh) Harvey.

Abundant, attached to stones and Zostera, below low-water mark.

Woods Hole: Little Harbor.

Summer.

Farlow, I873, p. 292, Woods Hole; I'arlow, I88I, p. 54,55 , Woods Hole.

Cladophora rupestris (Linnæus) Kützing.

Occasional, attached to rocks below low-water mark.

Woods Hole: Nobska Point. Gay Head.

Early summer.

Farlow, I873, p. 292, Gay Head, Vineyard Sound.

Rhizoclonium Kerneri Stockmayer.

Occasional.

Woods Hole (Setchell).

August, I894.

Known only from specimen in herbarium of the Marine Biological Laboratory collected by W. A. Setchell.

Rhizoclonium riparium (Roth) Harvey.

Common, on sand and rocks between tide marks, woodwork of wharves.

Woods Hole: Grassy Ledge, Government wharf Little Harbor.

Summer.

Farlow, I88I, p. 49, Woods Hole; A. A. B. Ex., fas. v. no. 213, Woods Hole (W. G. Farlow).

Rhizoclonium tortuosum Kützing.

Occasional, growing over other algæ in quiet waters.

Woods Hole.

Summer.

Farlow, I873, p. 293 (Chatomorpha tortuosa Dillwyn), Woods Hole. 
Order SIPHONALES.

Codiolum gregarium A. Braun. (Taxonomic position uncertain.)

Common in its localities, attached to rocks and barnacles (Balanus).

Woods Hole: Outermost rocks of Grassy Ledge, Summer.

P. B.-A., fas. IV, no. I65, Woods Hole, July, 1895 (C. P. Nott),

\section{Family BRYOPSIDACEAE.}

Bryopsis hypnoides Lamouroux.

Occasional.

Woods Hole: Entrance of Eel Pond. Wharves, New Bedford (G. M. Gray). Mattapoisett (Collins).

Spring.

Collins, I906a, p. I24, Mattapoisett, May, I905.

P. B.-A., fas. XXvi, no. I286, Mattapoisett, May 28, 1905 (F. S. Collins).

Bryopsis plumosa (Hudson) Agardh.

Occasional, on stones and in sand, on woodwork of wharves.

Woods Hole: Grassy Ledge, entrance of Eel Pond, Gut of Canso, Government wharves Little Harbor.

Summer.

Farlow, 1873, p. 292, Woods Hole.

\section{Family DerRestace.}

Derbesia vaucheriaformis (Harvey) J. Agardh. Rare.

Woods Hole: Entrance to Eel Pond (Farlow), Edgartown (Jernegan).

May, 1876 (Farlow), December, I895 (Jernegan).

Farlow, I881, p. 6o, Woods Hole.

P. B.-A., fas. VII, no. 318, Edgartown, December, I895 (M. W. Jernegan).

\section{Family VAUCHERTACER:}

Vaucheria litorea Agardh.

Common, over gravel near low-water mark.

Woods Hole: Juniper Point.

Summer.

Farlow, 1876, p. 712 (Vaucheria piloboloides Thuret), Woods Hole (?); Farlow, I881, p. 105, Woods Hole.

Vaucheria Thuretii Woronin.

Common, on mud between tide marks or below. Dredged once by the Survey, in Cuttyhunk Harbor (station 104), 23/4 to 3 fathoms, over muddy sand.

Woods Hole: Eel Pond. Salt marshes Quissett and Penzance.

Buzzards Bay: Cuttyhunk Harbor, station I04, many.

Summer.

\section{Class PHAOPHYCEA}

\section{Order PHAEOSPORALES.}

\section{Family ECTOCARPACE,}

Ascoclyclus orbicularis (J. Agardh) Magnus.

Occasional, on Zostera.

Woods Hole: Little Harbor (Setchell).

July 25, I895 (Setchell).

P.B.-A., fas. IV, no. I73, Little Harbor, Woods Hole, July 25, I895 (W. A. Setchell).

Ectocarpus acidioides Rosenvinge.

Abundant, on old Laminaria.

Woods Hole: Grassy Ledge, entrance to Elel Pond.

Spring.

Ectocarpus confervoides (Roth) Le Jolis.

Very common, attached to Scytosiphon, Chordaria, and other larger algæ, Zostera, and to woodwork of wharves. Dredged by the Survey in 3 to 6 fathoms at several scattered stations, over sandy and stony bottoms.
Ectocarpus confervoides-Continued.

Woods Hole: Great Harbor, Eel Pond, Grassy Ledge, Little Harbor.

Buzzards Bay: Inshore-Gull Island, station II6, many; Naushon 87 , few. Drifted fragments, 105.

Vineyard Sound: Westerly portion-7735, few on Rhodomela subfusca. Inshore-Marthas Vineyard stations 64 and 67 , many on Zostera; 69 , few on Zostera; 73 and 75 , very many on Zostera. Drifted fragments, 7706 and 7710 on Chorda filum.

Spring, summer, probably at all seasons.

Ectocarpus elegans Thuret.

Occasional, attached to larger algæ.

Edgartown, on muddy bottom attached to various algæ, at 2 meters depth (Jernegan).

December, 1896 (Jernegan).

P.B.-A., fas. VII, no. 320, Edgartown, December, I896 (M. W. Jernegan). 
Ectocarpus fasciculaius Harvey.

Common, attached to Chordaria, Chorda, Laminaria, and other larger algx. Dredged by the Survey, 5 to 8 fathoms, over sandy and stony bottoms.

In the summer off exposed points as at Gay Head and Sow and Pigs, probably common in the winter and spring at Woods Hole.

Woods Hole: Grassy Ledge (MacRae). Nobska (Farlow).

Buzzards Bay: Lower portion- 7656 , many on Chorda filum.

Vineyard Sound: Inshore-Sow and Pigs station 37, few; Gay Head stations 50 and $5 \mathrm{I}$, many on algæ; also off Devils Bridge, August 17 , Ig03, haul 5, many on Laminaria.

Spring Igo+ (MacRae), summer, probably at all seasons.

Farlow, 1873, p. 286, Gay Head, Nobska.

Ectocarpus granulosus (English Botany) Agardh.

Occasional, attached to Sargassum and other algre.

Woods Hole: Grassy Ledge (MacRae).

Summer, December 30, 1904 (MacRae).

Ectocarpus granulosis var. tenuis Farlow.

Occasional.

Woods Hole. Gay Head (Farlow).

Farlow, I873, p. 286 (Ectocarpus Durkeei Harvey), Gay Head; Farlow, 1876, p. 7 ro (Ectocarpus Durkeei Harvey), Woods Hole; Farlow, I88I, p. 70, Woods Hole.

\section{Ectocarpus lutosus Harvey.}

Occasional, attached to Fucus.

Woods Hole.

Summer.

Farlow, 188r, p. 72, Woods Hole.

\section{Ectocarpus Mitchelle Harvey.}

Occasional, on woodwork, goose bamacles (Lepas) and on Chorda.

Floating in Vineyard Sound attached to timber and goose barnacles. Near Edgartown (Jernegan).

Summer, November, 1896 (Jernegan).

Farlow, 1876, p. 7 10; Farlow, 1879, p. 72, 73 , Nantucket; Collins, I89r, p. 337, 338, near Edgartown (Jemegan); P. B.-A., fas. vir, no. $32 \mathrm{I}$, Edgartown, on Chorda attached to an old wreck, November, 1896 (Jernegan).

Ectocarpus ovatus Kjellman.

Occasional, on mussel shells (Mytilus).

Woods Hole: Grassy Ledge (MacRae). Edgartown (Colt).
Ectocarpus ovalus-Continued.

April 22, I904 (MacRae); February, I892 (Colt).

Collins, I896b, p. 459, Edgartown, F'ebruary, I $89_{2}$ (Colt).

Ectocarpus penicillatus J. Agardh.

Occasional, attached to larger algx, and Zastera.

Woods Hole: Grassy Ledge (MacRae).

Spring, Igoł (MacRac).

Ectocarpus siliculosus (Dillwyn) Agardh.

Very common, attached to Scytosiphon and other algx, Zostera, on stones, and woodwork of wharves. Dredged by the Survey in 3 to 5 fathoms, occasionally in deeper water ( 7 to $r_{3}$ fathoms), over sandy and stony bottoms. In the summer common in the lower portions of Buzzards Bay and Vineyard Sound.

Woods Hole: Grassy Ledge, Little Harbor.

Buzzards Bay: Inshore-Cuttyhunk, station I00, very abundant; ror and 102 , few; I03, many; I04, very abundant; Pasque 82 , few. Drifted fragments, $76_{57}$ and $766_{3}$.

Vineyard Sound: Westerly portion- $77 I 7$ and 7728 , few on Polysiphonia nigrescens. Narrow portion- $75^{2} 5$ bis, I on Sargassum. InshoreRobinsons Hole, station $2 \mathrm{I}$, few on algæ, Quicks Hole 29, many on Zostera; Cuttyhunk 38, many on algæ; Gay Head 50, 5I, 44, and 45, few on algæ; also off Devils Bridge August I7, 1903 , haul 3 , few; 4 , many on algæ; Menemsha Bight, August 9, 1904, very many on Zostera; Marthas Vineyard 63 , few on stones. Spring, summer, probably at all seasons.

Farlow, I873, p. 286 (Ectocarpus viridis Harvey), Woods Hole; P. B.-A., fas. vir, no. 319a, Edgartown, November, I896 (M. W. Jernegan).

Ectocarpus siliculosus var. hiemalis (Crouan) Kuckuck.

Common, on stones, woodwork, and algæ.

Woods Hole: Great Harbor, Grassy Ledge, Little Harbor. Edgartown (Jernegan).

Summer, December (Jernegan).

Farlow, I88I, p. 7 I (Ectocarpus confervoides var. hiemalis Kjellman), Woods Hole (?); P. B.-A., fas. vir, no. 372 , Edgartown, December, 1896 (M. W. Jernegan).

Ectocarpus tomentosus (Hudson) Lyngbye.

Occasional, attached to Fucus and other algx.

Woods Hole: Grassy Ledge (MacRae).

Summer, December 30, Ig04 (MacRae).

Pylaiella littoralis (Linnæus) Kjellman.

Occasional, attached to wharves and larger algæ. Woods Hole: Grassy Ledge, Eel Pond, Little Harbor. Gay Head.

Spring; summer. 
Sorocarpus uvaformis Pringsheim.

Rare, on mussel shells (Mytilus).

Woods Hole: Grassy Ledge (MacRae). Marthas Vineyard (Colt).

Spring, I904 (MacRae).

Collins, I896b, p. 459, Marthas Vineyard, I892 (Colt).

Streblonema Chordarice (Farlow) De Toni.

Common, endophytic in Mesogloia divaricata and Leathesia difformis.

Woods Hole: Great Harbor, Grassy Ledge, Little Harbor.

Summer.

Farlow, I88x, p. 69, Woods Hole.

Streblonema oligosporum Strömfelt.

Occasional, endophytic in' Desmarestia viridis.

Robinsons Hole (I. F. Lewis).

August, 1907.

Collins, 1908, p. 134, Robinsons Hole, August, I907.

Streblonema parasiticum (Sauvageau) De Toni.

Occasional, endophytic in Cystoclonium purpurascens.

Woods Hole: Grassy Ledge (Collins).

September 2, 1905 (Collins).

Collins, I906a, p. 125, Woods Hole.

Family SPHACELARIACEA.

Cladostephus spongiosus (Lightfoot) Agardh.

Occasional, on stones in fairly deep water. Vineyard Sound, washed ashore at Nobska.

Summer.

Cladostephus verticillatus (Lightfoot) Agardh. [Chart 229.]

Common, on stones in fairly deep water. Dredged by the Survey in 2 to ${ }_{3} 3$ fathoms, over sandy and stony bottoms. Scattered throughout Vineyard Sound.

Woods Hole: Off Nobska. Frequently washed ashore at Nobska, Gay Head, Cuttyhunk.

Vineyard Sound: Westerly portion-station 7717 , many; 7598 and 7734 , few. Narrow portion7744, few; 7753, large plant; $75^{25}$ bis, few. Easterly portion-7760, 7771, 7779, one each. Inshore-Robinsons Hole 2I, Marthas Vineyard 62 , one; 69 and 73 , few.

Summer.

Farlow, 1873 , p. 286, Gay Head, No Mans Land.

Sphacelaria cirrhosa (Roth) Agardh.

Common, attached to Fucus, Ascophyllum, Sargassum, occasionally Zostera, and stones. Dredged by the Survey in 3 to 8 fathoms, over
Sphacelaria cirrhosa-Continued.

sandy and stony bottoms. At scattered stations chiefly in the easterly portion of Vineyard Sound in and near Vineyard Haven.

Woods Hole: Juniper Point, Grassy Ledge. Weepecket Islands (Farlow). Black Rock.

Vineyard Sound: Easterly portion-7760 and $777^{2}$, many on Sargassum. Inshore-Marthas Vineyard station 76 , few on stones; 73 , few; 69, few on stones; $776 \mathrm{r}$, many on Sargassum; Vineyard Haven 72 , many on Zostera. Drifted fragments, 7749,7751 .

Summer.

Farlow, I873, p. 286, Weepecket Islands.

Sphacelaria radicans (Dillwyn) Agardh.

Common, attached to stones, shells, and mudcovered rocks. Dredged by the Survey in 3 to 5 fathoms, over sandy, stony, and muddy bottoms. At scattered stations chiefly in and near Vineyard Haven.

Woods Hole: Little Harbor near Juniper Point. Black Rock.

Buzzards Bay: Inshore-Cuttyhunk, station ro2, few on shells.

Vineyard Sound: Inshore-Marthas Vineyard, station 69, many; 73, few; Vineyard Haven $7 x$, many; 72 , few.

Summer.

Farlow, 188r, p. 76, Woods Hole.

\section{Family ENCEI,IACE, E.}

Asperococcus echinatus (Mertens) Greville.

Rare, attached to rocks, Ascophyllum and Fucus.

Woods Hole: Grassy Ledge.

Spring, early summer, after which it goes out of season.

Desmotrichum balticum Kützing.

Common, on Zostera, occasionally on larger algæ, and on rocks. Dredged by the Survey off Marthas Vineyard (station 67 ) on Zostera, in 4 fathoms, over sand.

Woods Hole: Grassy Ledge, Little Harbor.

Vineyard Sound: Inshore-Marthas Vineyard, station 67 , few on Zostera.

Spring, summer.

Usually in company with Desmotrichum undulatum; much more delicate than the latter, being I to 3 cells broad.

Desmotrichum undulatum (J. Agardh) Reinke.

Common, on Zostera, occasionally on larger algæ, and on rocks. Dredged by the Survey in 3 to 6 fathoms, on Zostera, over sandy and stony bottoms.

Woods Hole: Grassy Ledge, Eel Pond, Little Harbor. 
Desmotrichum undulatum-Continued.

Vineyard Sound: Inshore-Quicks Hole, station 29, many; Gay Head 50 and 5I, few; Marthas Vineyard 64, few; 67, many; 69, few.

Spring, summer.

Farlow, 1873 , p. 285 (Punctaria tenuissima Greville), Woods Hole.

Phyllitis fascia (Flora Danica) Kützing.

Common, on rocks near low-water mark. Dredged by the Survey in Robinsons Hole at $3 \frac{1}{2}$ fathoms, over gravel.

Woods Hole: Grassy Ledge, Juniper Point, Devils Foot Island, entrance to Eel Pond.

Vineyard Sound: Inshore-Robinsons Hole 22, few; Gay Head 50 and 5I, on rocks near lowwater mark.

Winter, spring, early summer, after which it goes out of season.

Pogotrichum fliforme Reinke.

Rare, on Zostera, in company with Desmotrichum, Giraudia, and various small species (Schuh).

Woods Hole, October, I899 (G. W. Gray). Oak Bluffs, January, I895 (R. E. Schuh).

Autumn, winter.

Schuh, I900b, p. 206, 207, Oak Bluffs (Cottage City), January, I895.

Punctaria latifolia Greville.

Common, attached to Zostera and the larger alga. Woods Hole: Grassy Ledge, Eel Pond, Little Harbor.

Spring, summer.

Punctaria plantaginea (Roth) Greville.

Common, attached to rocks and larger algæ.

Woods Hole: Grassy Ledge, Little Harbor, off Juniper Point.

Spring, summer.

Farlow, 1873 , p. 285, Woods Hcle; Farlow, 188r, p. 64 , Woods Hole.

Rhadinocladia Farlowii Schuh.

Occasional, on Zostera and Chorda. Dredged by the Survey in Vineyard Haven in 4 fathoms on Zostera, over stony and muddy bottoms.

Vineyard Haven station 69, many on Zostera; 70 (few on Zostera).

Stimmer.

Schuh, rgooa, p. III, II2, growing on Chorda and washed ashore at Vineyard Haven, August 27, 1892; Schuh, I901, p. 218, a more complete descripion of the genus than the reference above,

Scytosiphon lomentarius (Lyngbye) J. Agardh.

Common, rocks and stones near low-water mark.

Woods Hole: Grassy Ledge, Little Harbor off Juniper Point, Devils Foot Island, Ram Island, Gut of Canso.
Scytosiphon lomentarius-Continued.

Vineyard Sound: Gay Head at stations 50 and $5 \mathrm{I}$, many.

Winter, spring, early summer, after which it goes out of season except in favorable situations.

Family Striariace, E.

Striaria altenuata Greville.

Rare.

Woods Hole: Washed ashore Little Harbor and Nobska Beach. Edgartown (King).

Summer, January (King).

Farlow, 1882 , p. 64, 66, material found by J. D. King at Edgartown in January, supposed by Mr. King to have grown at the mouth of Edgartown harbor.

\section{Family Desmarestiace,}

Arthrocladia villosa (Hudson) Duby. [Chart 230.] Occasional, on stones and shells in fairly deep water. Dredged by the Survey in 4 to $\mathrm{I}_{3}$ fathoms, over sand and gravel bottoms. A scattered distribution in Buzzards Bay and Vineyard Sound.

Woods Hole: Washed ashore Little Harbor, Nobska Beach. Falmouth Heights (Collins). Robinsons Hole.

Buzzards Bay: Upper portion- $76_{53}$, few. Inshore-Cuttyhunk I00, I0I, and I03, few; cove west of Cuttyhunk Neck July 27, 1905, great quantities, Hog Island Point I34, two.

Vineyard Sound: Westerly portion-stations 7725,7728 and 7729 , few; 7734 , many. Narrow portion- 7732 , few; 7733 , many; 39 , one. Easterly portion-7755, one. Inshore--Cuttyhunk 38 , few; Gay Head 56, many; Menemsha Bight 53 and 54, many; Marthas Vineyard 65 and 73 , few.

Summer.

Farlow, 188r, p. 183, Falmouth Heights (F. S. Collins); Hervey, I882, p. I26, I27, Menanhant, East Falmouth; Peters, $188_{5}$, p. 62, Woods Hole; A. A. B. Ex., fas, v, no. I94, Falmouth, August, I883 (G. W. Perry); P. B.-A., fas., D, no. Xxx, cove west of Cuttyhunk Neck, July 27, I905 (B. M. Davis and Miss L. J. MacRae).

Desmarestia aculeata (Linnæus) Lamouroux. [Chart 23I.]

Common, off exposed shores on stones and over sand. Dredged by the Survey in $I / 2$ to $I 4$ fathoms, over sandy and stony bottoms. Confined almost entirely to the lower portion of Buzzards Bay and the westerly portion of Vineyard Sound. 
Desmarestia aculeata-Continued.

Buzzards.Bay: Upper portion -7653 and 7655 , few. Lower portion $-7656,7657,7662$ and 7671 , few. Inshore-Sow and Pigsiı , many; Cuttyhunk 100, 102, and 103, few; cove west of Cuttyhunk Neck, July 27, x905, many; Penikese II3, many; II4, few; Pasque 82 , few; 83 , many; Robinsons Hole 86, many. Drifted fragments, $7664,7665,8 \pi$.

Vineyard Sound: Westerly portion-7718, many; 7719,2 large plants; 7720, 2 large plants; 7730, few; 7701, 2 large plants; 7566, 7588, 7595, and 7596, few. Narrow portion-7739, many. Inshore-Robinsons Hole 20, many; 21; 22, and 23. few; Pasque 24, many; 26, few; Quicks Hole 27 and 29, many; Nashawena 30, few; Cuttyhunk 33, 34, and 38, many; Gay Head $46,47,48$, and 56 , few; 57 , many; 59 and 60 , few; 773I, several large plants; Marthas Vine yard 65 , few. Drifted fragments, $758_{3}, 7707$, 7738 .

Summer.

Farlow, 1873 , p. 285 , Woods Hole.

Desmarestia viridis (Flora Danica) Lamouroux. [Chart 232.]

Common, on stones and algæ below low-water mark. Dredged by the Survey in 2 to ${ }_{5}$ fathoms, over sandy and stony bottoms. In the lower portion of Buzzards Bay chicfly, but rather generally distributed throughout Vineyard Sound.

Woods Hole: Grassy Ledge, entrance to Eel Pond.

Buzzards Bay: Upper portion- 7653 , many; 7654 , few. Lower portion- 7665 , few. InshoreSow and Pigs II I, few; Cuttyhunk ı०o, many; ror and I02, few; Nashawena 78 and 80, few; Pasque 82 , few. Drifted fragments, $76 \mathrm{ro}$, 76 I 1,765 I (I907), 79, 81

Vineyard Sound: Westerly portion-7720, one on Chondrus; 7725 , one; 7728 and 7730 , few on Polysiphonia nigrescens; $7677,7678,7706$, and 7707, few; 7710, one on Phyllophora; 7734, few. Narrow portion-7522 bis, one; 7524 bis, one; $75^{25}$ bis, many; 7543 bis, and 7549 bis, few. Inshore-Nonamesset 8, few: Naushon 6, few; 9, two; IO, II, I2, I5, one each; Tarpaulin Cove I7, many; July I8, I903, haul 2, one; Robinsons Hole 20, few; 22, many; 23, few; Pasque 24, one; Quicks Hole 27, few; Cuttyhunk 32 and 33 , few; Gay Head 46, few; 57 and 58, many; 59, few; 7731, many; 773x (1907) many; Menemsha Bight, July $x$, I905, hauls $x$, one; 2 , many; 3 , few. Drifted fragments 7698 .

Spring, summer.

\section{Family Dictyostphonace,}

Dictyosiphon fœniculaceus (Hudson) Greville.

Occasional, on Chordaria, Scytosiphon and larger algæ below low-water mark.

Woods Hole: On piles steamboat wharf, Eel Pond, Little Harbor. Naushon (Farlow).

Spring.

Farlow, I873, p. 285, Naushon; Farlow, I88r, p. 66, Woods Hole.

Dictyosiphon hippuroides (Lyngbye) Areschoug. [Chart 233.]

Common, on stones and in sand below low-water mark. Dredged by the Survey in 3 to ro fathoms, over sandy and stony bottoms. Scattered distribution in Buzzards Bay and Vineyard Sound.

Woods Hole: Grassy Ledge.

Buzzards Bay: Lower portion-7656, many. Inshore-Cuttyhunk ror, few; Penikese II3 and II4, few; Gull Island II 5, few; Pasque 82, many; Quisset r29, few; Gunning Point r3 few.

Vineyard Sound: Westerly portion -7676 , one; 7725 , many; 7729 , one; 7730 , one. Easterly portion-7760, one. Inshore-Cuttyhunk 38 , few; Devils Bridge Gay Head, August I7, I903, hauls 3, few; 4, many; Marthas Vineyard 74, 75 and $776 \mathrm{r}$, few; Vineyard Haven 7762 , few. Summer.

To Dictyosiphon hippuroides we have referred the common species of the summer, which compares well with material and descriptions of this form. It is, however, a puzzling species which should be studied at other seasons of the year to make certain its affinities. It seems possible that this form may be a late seasonal condition of Dictyosiphon faniculaceus, very common in this region in the spring.

\section{Family MYRIOTRICHIACEAE.}

Myriotrichia filiformis Harvey.

Common, on Scytosiphon and Sargassum.

Woods Hole: Entrance to Eiel Pond, Juniper Point.

Summer.

\section{Family ELACHISTACEA}

Elachista fucicola (Velley) Fries.

Abundant, attached to Fucus and Ascophyllum.

Woods Hole: Grassy Ledge, Juniper Point. Black Rock

Buzzards Bay: Drifted fragments, 7617 .

Vineyard Sound: Drifted fragments, 7523, 29.

Summer.

Farlow, I873, p. 286, Woods Hole. 
Elachista stellaris var. Chorde Areschoug.

Occasional, on Stilophora rhizodes.

Falmouth (Collins).

September (Collins).

Collins, r801, pp. 339,340 , on Stilophora rhizodes, Falmouth, in September.

Giraudia sphacelarioides Derbès \& Solier.

Rare, on Zostcra, intermingled with Punctaria, Ectocarpus, and various small species.

Vineyard Haven (Schuh) and Oak Blufis (Cottage City, Schuh).

August, I892, January, I895.

Schuh, I906b, p. 206, Vineyard Haven, August, I892, Oak Bluffs (Cottage City), January, I895.

\section{Family ChORDARIACEA}

Castagnea virescens (Carmichael) Thuret.

Occasional, on rocks, algæ, and Zostera, below low-ivater mark.

Woods Hole: Great Harbor, Little Harbor. Washed ashore at Nobska.

Spring, early summer.

Farlow, I876, p. 708, Woods Hole; Farlow, I88r, pp. 85,86 , Woods Hole.

Castagnea Zosterce (Mohr) Thuret.

Common, attached to Zostera.

Woods Hole: Grassy Ledge, Little Harbor.

Late summer.

Farlow, I876, p. 708, Woods Hole; Farlow, I88I, p. 86, Woods Hole.

Chordaria flagelliformis (Flora Danica) Agardh.

Common, on stones, wharves, and larger algæ below low-water mark. Dredged by the Survey in 3 to Io fathoms, over sandy, shelly, and gravelly bottoms. A scattered distribution in Buzzards Bay and Vineyard Sound.

Woods Hole: Grassy Ledge, Gut of Canso. Nobska. Black Rock.

Buzzards Bay: Upper portion- -7653 and 7654 , few. Lower portion -7656 , many on stones; 7667 , few on stones.

Vineyard Sound: Narrow portion-7524, one; $75^{2} 5$, few. Inshore-passage of Woods Hole I 8 , few on Chondrus; Quicks Hole 29, few; Gay Head 50 and 5 , thick patches on rocks; Marthas Vineyard $52,61,68,76$, and 7761 , few on stones. Drifted fragment, 60 , one.

Spring, summer.

Farlow, 1873 , p. $28_{5}$, Nobska, Gay Head.

Hecatonema maculans (Collins) Sauvageau.

Occasional, on Zostera, Rhodymenia palmata.

Woods Hole: (Collins). No Mans Land.

Summer. May 2, I005 (Collins).
Leathesia difformis (Linnæus) Areschoug.

Abundant, attached to larger algæ, Ascophyllum, Fucus, etc. Dredged by the Survey off Cuttyhunk and in Robinsons Hole, 2 to 5 fathoms over sandy and muddy bottoms.

Woods Hole: Grassy Ledge, Little Harbor.

Buzzards Bay: Inshore-roo, few on Phyllophora.

Vineyard Sound: Inshore-Robinsons Hole 20, few on Chondrus; 29, few on stones. Drifted fragments, 7688,83 .

Summer.

Farlow, 1873 , p. 286 (Leathesia tuberiformis S. F. Gray), Buzzards Bay; P. B.-A. fas. III, no. I30, Woods Hole, August I4, 1894 (W. A. Setchell).

Mesogloia divaricata (Agardh) Kützing.

Abundant in quiet water, attached to larger algx and stones below low-water mark. Dredged by the Survey in 3 to 6 fathoms, over sandy and stony bottoms.

Woods Hole: Great Harbor, Grassy Ledge, Little Harbor. Black Rock.

Buzzards Bay: Inshore-near Gunning Point, station I 30 , many.

Vineyard Sound: Narrow portion-7548, few. Inshore-Marthas Vineyard 73, many. Drifted fragments, $768 \mathrm{I}, 7688$, I6r.

Summer.

Farlow, 1873, p. 286 (Chordaria divaricata Agardh), Woods Hole; A. A. B. Ex., fas.v, no. I98, Woods Hole (W. G. Farlow).

Myriactis pulvinata Kützing, var. minor Farlow.

Common, parasitic in the cryptostomata of Sargassum Filipendula.

Woods Hole: Entrance to Eel Pond, off Juniper Point.

Summer.

Farlow, r881, pp. 81, 82, Woods Hole; P. B.-A., fas. v, no. 23 I, Woods Hole, August I3, I 895.

Myrionema corunne Sauvageau.

Common, on Laminaria.

Woods Hole: Grassy Ledge (Collins).

December 30, I904 (Collins).

Collins, I906b, p. 158, Woods Hole, on Laminaria.

Myrionema vulgare Thuret.

Common, on Zostera, Rhodymenia palmata.

Woods Hole. Washed ashore at Gay Head.

Spring, summer.

Farlow, 1876, p. 709 (Myrionema strangulans Greville), Woods Hole; Farlow, I876, p. 709 (Myrionema Leclancherii Harvey), Gay Head; P. B.-A., fas. VI, no. 2 So [Myrionema Leclancherii (Chauvin) Harvey], on Rhodymenia palmata, Gay Head, August Io, I89o (W. A. Setchell). 
Family STILOPHORACEA,

Stilophora rhizodes (Turner) J. Agardh.

Occasional, attached to the base of Zostera below low-water mark. Dredged by the Survey in $21 / 2$ to 5 fathoms, over sandy and stony bottoms at stations 130 and $I_{3} \mathrm{I}$ off the east shore in the upper portion of Buzzards Bay.

Washed ashore at Nobska, Waquoit (Farlow).

Buzzards Bay: Inshore-Gunning Point, I 30 and I3 I many on dark-colored dead Zostera.

Summer.

Farlow, 1873, p. 285, Waquoit.

\section{Family RALFSIACEA}

\section{Ralfsia clavata (Carmichael) Farlow.}

Abundant, on stones and shells at low-water mark. Dredged by the Survey in 3 to 12 fathorns, over sandy, shelly, and gravelly bottoms. Widely scattered at the inshore stations in Buzzards Bay and Vineyard Sound.

Woods Hole: Grassy Ledge, Eel Pond, Ram Island, Little Harbor. Buzzards Bay shore. Tarpaulin Cove.

Buzzards Bay: Lower portion- 7671 , few. Inshore-Cuttyhunk IO2 and IO3, few; Gull Island $I_{15}$ and II6, many; Weepeckets I08, few; Uncatena II7, few on shells; Penzance 123, few; Quisset 128, many; Gunning Point I3I, many; West Falmouth I32, many; I37, one; Hog Island Point I34, many; Sconticut Neck 163, few; Mishaum Point 167, many.

Vineyard Sound: Narrow portion $-75^{24}$ bis, one. Easterly portion-7780, few. Inshore-Gay Head 56, few; 57 , many; $5^{8}$ and 59 , few; also off Devils Bridge August I7, 1903, many; Menemsha Bight July I7, I905, haul 3, few; Marthas Vineyard 52,6r, 62, and 63, few; 65, many; 66 and 68 , few; $69,73,74,76$ and 77 , many.

Summer.

Farlow, I88ז, p. 88, Woods Hole.

Ralfsia verrucosa (Areschoug) J. Agardh.

Common, on stones near low-water mark.

Woods Hole: Grassy Ledge, Little Harbor. Tarpaulin Cove.

Summer.

\section{Family LAMINARIACE}

Agarum Turneri Postels \& Ruprecht.

Occasional.

Washed ashore at Gay Head.

Summer.

A laria esculenta (Linnæus) Greville.

Occasionally washed ashore at Gay Head.

Summer.
Chorda fllum (Linnæus) Stackhouse. [Chart 234.]

Common, on stones and shells below low-water mark. Dredged by the Survey in 2 to $\mathrm{I}_{4}$ fathoms, over sandy bottoms. A scattered distribution in Buzzards Bay and Vineyard Sound.

Woods Hole: Great Harbor, Grassy Ledge, entrance to Eel Pond, Little Harbor off Juniper Point. Black Rock.

Buzzards Bay: Lower portion-7656, one. Inshore-Cuttyhunk Ioo, Ior, and I02, few; Gull Island I16, many; Naushon $9 \mathrm{r}$ and 96, few; Weepeckets roS, few; Gunning Point I3 1 , few.

Vineyard Sound: Westerly portion-757I, 7567 and $759 \mathrm{r}$, few. Narrow portion -7542 bis, one; 755 I, 7557 and 7559 , few. Inshore-Robinsons Hole 2I, many; 22, few; Quicks Hole 29, many; Gay Head 50 and $5 \mathrm{I}$, patches in shallow water; 47 and 49, few; Menemsha Bight 53 and 54, few; Marthas Vineyard 73, few. Drifted fragments, $7573,7676,7688,7706,7710$, 7730, 7731, 7733, 7754 .

Summer.

Chorda tomentosa Lyngbye.

Common, on piles of wharves, stones, and shells below low-water mark.

Woods Hole: Piles of steamboat wharf, entrance to Eel Pond, Grassy Ledge.

Spring.

Laminaria Agardhii Kjellman. Kelp, devils apron. [Chart 235.]

Common, on wharves, stones, and shells below low-water mark. Dredged by the Survey in 2 to $I 7$ fathoms, over sandy, shelly, and stony bottoms. Chiefly in the lower portion of Buzzards Bay, but widely distributed through Vineyard Sound.

Woods Hole: Great Harbor, entrance to Eel Pond, off Grassy Ledge in ship channel. Wharf at Gay Head.

Buzzards Bay: Upper portion- -7653 and 7654 , few. Lower portion- 7656 and 7657 , many; 7660 , one; 7662 , two; $766_{3}$, few. InshoreCuttyhunk Ior and I04, few; Gull Island II5 and 116 , few. Drifted fragments, 7617,7619 , $7637,7638,7672,(1907), 78,79,80,82,99$.

Vineyard Sound: Westerly portion-758I (I907), one; $75^{82}, 75^{83}, 75^{84}, 75^{88}, 75^{89}, 759^{2}, 7593$, 7595 and 7599 , few; $7677,7702,7703,7706$, one each; 7718 , very many; 7719 , one; 7728 , few. Narrow portion- 7524 bis, one; $75^{2} 5$ bis, many; 7532 bis, 7533 bis, 7536,754 I, one each; 7557 , few; 7732, one; 7739, few; 7740, few; 7749, few. Easterly portion- 7755 , one; 7767 , few; 7775 , one; 7776 , one. Inshore-Woods Hole 
Laminaria Agardhii-Continued. passage I2I, many; Tarpaulin Cove July I8, I903, haul I and 3, few; Robinsons Hole 22, few; Pasque 24, many; 26, few; Quicks Hole 28, one; Cuttyhunk 32, 33, and 34, few; 38 , many; Gay Head 50 and $5 \mathrm{r}$, few, $44,45,46,47$, $49,57,59$, and 60, few; $773 \mathrm{I}$, one; also off Devils Bridge, August 17, 1903, haul 5, many; Menemsha Bight July I7, 1905, hauls 1,2 , and 3 , few; Marthas Vineyard 65 , one; 7761 , one. Drifted fragments, $7530,757^{2}, 75^{8} 5,75^{8} 9,7676,7710$, $7720,7736,7753,7760,7762,7766,7780$.

At all seasons.

Farlow, 1873, p. 285 (Laminaria saccharina Lamouroux), Gay Head, Woods Hole; P. B.-A., fas. D, no. LXxxIr (Laminaria Aghardii forma normalis Setchell), Woods Hole, May, I905 (Miss L. J. MacRae).

Laminaria Agardhii var. vittata Setchell. [Chart 236.]

Common, attached to stones, wharves, etc., below low-water mark. Dredged in 2 to 17 fathoms, over sandy, shelly, and stony bottoms. Largely restricted to the lower portion of Buzzards Bay and the westerly portion of Vineyard Sound.

Woods Hole: Great Harbor steamboat wharves.

Buzzards Bay: Iower portion- $766_{4}$, one; $766_{5}$, two; 7666,7667 , and 7671 , few; 7670 , many. Inshore-Sow and Pigs I I 1 , many; Cuttyhunk I00, few; II2, many; cove west of Cuttyhunk Neck July 27, 1905, many. Drifted fragments, 7669 .

Vineyard Sound: Westerly portion $-75^{82}$, I on Phyllophora; $75^{8} 3$, few; $7679,7680,7681$, one each; 7701, 7704, and 7706 , few; 7707 , one; 77 r9, one; 7720 , few on Chondrus; 7723 and 7724 , few. Narrow portion-755 I, few; 7549, one. Inshore-Robinsons Hole 21, many; Pasque
Laminaria Agardhii var. vittata-Continued. 24, many; 26, few; Quicks Hole 27 many; Nashawena 30, few; Cuttyhunk 32, 33, 34, and 38 , few; Sow and Pigs 36 and 37 , few; Gay Head 44,45 , and 47 , few; 57 , many; 59 and 60 , few; 7731, many; Marthas Vineyard 65, many. Drifted fragments, $7554,7686,7688,7709$.

Spring, summer, probably at all seasons.

Laminaria digitata (Linnæus) Lamouroux. Kelp, devil's apron. [Chart 237.]

Occasional, attached to stones and rocks off exposed points. Dredged by the Survey off Gay Head in 3 to 13 fathoms, over sandy and stony bottoms.

Wharf at Gay Head.

Buzzards Bay: Drifted fragment, 7639 .

Vineyard Sound: Westerly portion -7593 , few; 7722 , one. Inshore-Gay Head 44, 48; 50, and $5 \mathrm{I}$, few; also off Devils Bridge August I 7, I903, haul 5 , many.

Summer, probably at all seasons.

Farlow, 1873, p. 285, Gay Head; Farlow, I881, p. 94, Gay Head; Setchell, r9oo, p. I44 (Laminaria digitata forma typica Foslie), Gay Head.

\section{Family TILOPTERIDACE $z$.}

Haplospora globosa Kjellman.

Rare.

Edgartown (King).

January (King).

Collins, I899, p. 126, found at Edgartown by J. D. King.

Scaphospora Kingii Farlow.

Rare.

Washed ashore Edgartown (King).

January, 1882 (King).

Farlow, 1882, p. 67, found at Edgartown, January, 1882, by J. D. King.

\section{Order CYCLOSPORALES.}

Family FUCACE王.

Ascophyllum nodosum (Linnæus) Le Jolis. Rockweed.

Common, attached to rocks near low-water mark.

Woods Hole: Great Harbor, Grassy Ledge, Ram Island, Juniper Point, Little Harbor. Buzzards Bay shore. Black Rock.

Buzzards Bay: Drifted fragments, 7615,7617 , $7620,7622,7629,7630,7634,7635,7639,765^{2}$, $7663,7670,7672,78,80,82$, I3I, I46, I 48 , x 5 r,

Vineyard Sound: Drifted fragments, $7537,755^{\circ}$ bis, 7551, 7570, 7576, 7599, 7720, 7759, I, 26. At all seasons, fruiting during Nay.
Fucus evanescens Agardh.

Common, attached to rocks.

Woods Hole: Harbor walls, entrance to Eel Pond, Red Ledge, Gut of Canso. Gay Head. Vineyard Sound: Drifted fragment, 773r. spring, early summer.

Fucu platycarpus Thuret. Occasional, attached to rocks. Woods Hole: Entrance to Eel Pond. Summer.

Fucus vesiculosus Linnæus. Rockweed. Abundant, on stones, harbor walls, and wharves. 
Fucus vesiculosis-Continued.

Woods Hole: Great Harbor, Grassy Ledge, Ram Island, Devils Foot Island, Juniper Point, Little Harbor. Gay Head 50 and 5I (large form without bladders). Black Rock.

Buzzards Bay: Drifted fragments, 7629,7636 , 765 I (1907), 82.

Vineyard Sound: Drifted fragments, 7523, 7525 bis, $7588,7728,7730,7749,29$.

At all seasons.

Fucus vesiculosus var. laterifructus Greville.

Common, on stones between tide marks.

Woods Hole: Devils Foot Island.

At all seasons.

Fucus vesiculosus forma limicola Collins.

Common, on muddy shores and flats near high water mark.

Woods Hole: Little Harbor, Devils Foot Island, Ram Island. Mattapoisett (Collins).

Spring, summer.

P. B.-A., fas. xxuI, no. II 33 , Mattapoisett, September I4, I902 (F. S. Collins).

Fucus vesiculosus var. spharocarpus Farlow.

Occasional, on flat rocks well above low-tide mark.

Woods Hole. Gay Head at stations 50 and 5I, on flat rocks. Black Rock.

Spring, summer.

Fucus vesiculosus var. spiralis Farlow.

Occasional, above low-water mark, frequently unattached over muddy or grassy bottom.

Woods Hole: Little Harbor.

Spring, summer.

Sargassum bacciferum (Turner) J. Agardh.

Occasional, floating in Vineyard Sound.

Summer.

This plant is believed to come from the Gulf Stream, being carried into the waters of Vineyard Sound after heavy storms.

Sargassum Filipendula Agardh. [Chart 238.]

Common, attached to rocks and stones below low-water mark. Dredged by the Survey in $2 \frac{1}{2}$ to ${ }_{5}$ fathoms, over sandy, shelly, and stony bottoms. Common in the upper portion
Sargassum Filipendula-Continued.

of Buzzards Bay along the easterly shore, and widely distributed throughout the narrow and easterly portion of Vineyard Sound.

Woods Hole: Entrance to Eiel Pond, off Juniper Point. Hadley Harbor. Black Rock.

Buzzards Bay: Upper portion- 7630 ( 1907 ), few, $76_{32}$, one; 7639 and 7654 , few. Lower portion7657 , few. Inshore - Gull Island II6, few; Uncatena II7, many; Penzance 123, many; Quissct I28 and I29, few; I30, many; Gunning Point I3I, many on sulphur sponges; West Falmoutil I32, one; Hog Island Point I34, many; Hog Island Harbor I35, few; North Falmouth 136 , few; 137, many; I3 8 , two; Nyes Neck 141 , many; Cataumet Harbor I42, few; Scraggy Neck I45, few; Bassetts Island I46, few; Wings Neck 147 and I48, few. Drifted frag. ments, 7621 ( 1907 ), 7626, 7627, $7628,7629,7633$, $7634,7636,7638,766$ I, I50, I $51, I_{52}, I_{59}, 165$.

Vineyard Sound: Narrow portion $-75^{2} 5$ bis and 7533 bis, few; 7537 , one; 7554,7555 and 7557 , few; 7740, two; 7742, 7744, 7749, 7750, 7753, one each. Easterly portion-7755, one; 7760 , few; 7761 (I907), few; 7763, 7764, 7766, and 7767 , few; $7772,7775,7776,7778$, one each; 7780,7781 and 7783 , few. Inshore-passage of Woods Hole I2I, few; Nonamesset I, one; 8 , one; Menemsha Bight July I7, I905, haul I, one; Marthas Vineyard 73 and 77 , few; Vineyard Haven 7761 , many; 7762 , few. Drifted fragments, $75^{23}, 7532,7546,755^{\circ}$ bis, 7581, 7599, $7701,7728,7729,7730,7733,7751,7759,7782$, Ir 8 .

At all seasons, but most luxuriant in the summer when it fruits abundantly.

Farlow, 1873 , p. 283,284 , (Sargassum vulgare Agardh), Woods Hole; Farlow, I875, p. 353 (Sargassum vulgare), Woods Hole; P. B.-A., fas. D, no. XCvir, Juniper Point (Butlers Point), Woods Hole, August -I5, I904 (F. S. Collins)

Sargassum Filipendula var. subedentatum J. Agardh Occasional, attached to stones below low-water mark.

Woods Hole.

Summer. 


\section{CLASS RHODOPHYCE $A$ E.}

\section{Order BANGIALES.}

\section{Family BANGIACEA:}

Bangia fusco-purpurca (Dillwyn) Lyngbye.

Common, attached to stones and woodwork of wharves between tide marks.

Woods Hole: Harbor walls and wharves, Grassy ledge on rocks along ship channel, Little Harbor on Government wharves, Juniper Point.

Spring, summer.

Farlow, 1873 , p. 292, Woods Hole; P. B.-A., fas. II, no. 87, Juniper Point (Butlers Point), Woods Hole, July, I893 (W. A. Setchell).

Erythrotrichia ceramicola (Lyngbye) Areschoug.

Common, on Zostera in company with Chantransia virgatula, occasional on Desmarestia viridis.

Woods Hole: Grassy Ledge, Ëel Pond, Little Harbor. Robinsons Hole (I. F. Lewis).

Spring, summer.
Erythrotrichia ceramicola-Continued.

Farlow, 1876, p. 707, Buzzards Bay; Collins, I908, p. I34; Robinsons Hole, August, 1907.

Porphyra laciniata (Lightfoot) Agardh.

Common, attached to stones and woodwork of wharves near low-water mark.

Woods Hole: Entrance to Eel Pond, Bureau of Fisheries wharves, harbor walls, Grassy Ledge.

At all seasons.

Farlow, I873, p. 292 (Porphyra vulgaris Agardh), Woods Hole.

Porphyra leucosticta Thuret.

Common, on Zostera and larger algx.

Woods Hole: Great Harbor, Little Harbor. Oak Bluffs (Cottage City, King).

Spring.

Collins, I884, pp. I3I, I32, Oak Bluffs (Cottage City, J. D. King).

\section{Order NEMALIONALES.}

\section{Family NeMALIONACEAS.}

Acrochatium Dasyce Collins.

Occasional, on Dasya elegans.

Woods Hole (Collins).

September 2, I905 (Collins).

Collins, Igo6c, p. I9I, Woods Hole, September 2, I905, on Dasya elegans. P. B.-A., fas. Xxvir, no. 1342 , Woods Hole, September 2, 1905 (F.S. Collins).

Acrochatium Daviesii (Dillwyn) Nägeli.

Occasional, on Desmarestia viridis.

Robinsons Hole (I. F. Lewis).

August, 1907.

Collins, rgo8, p. I34, Robinsons Hole, August, 1907 .

Synonym, Chantransia Daviesii (Dillwyn) Thuret, P. B.-A., fas. Xvili, no. 880.

Acrochatium minimum Collins.

Occasional, on Desmarestia viridis.

Robinsons Hole (I. F. Lewis).

August, 1907 .

Collins, I908, p. 133, Robinsons Hole, August, I907.

Acrochatium secundatum (Lyngbye) Nägeli.

Common, attached to Zostera, Ceramium rubrum, Porphyra laciniata, etc.

Woods Hole: Grassy Ledge, Juniper Point.

Summer, winter, probably at all seasons.

Synonym, Chantransia secundata (Lyngbye) Thuret, P. B.-A., fas. XxII, no. Io88, not no. 236.
Acrochetium virgatulum (Harvey) Bornet

Abundant, fringing Zostera, and occasionally on Ceramium rubrum.

Woods Hole: Eel Pond, Grassy Ledge, Little Harbor.

Summer, probably at other seasons.

Synonym, Trentepohlia virgatula var. secundata (Farlow, I88I, p. Iog).

Chantransia efflorescens var. Thuretii Bornet.

Occasional, attached to Ceramium rubrum and Cystoclonium purpurascens.

Woods Hole: Off Juniper Point at a depth of from I to 3 meters (Nott). Gay Head (Farlow).

Summer, July, I895 (Nott).

Farlow, 1876, p. 705 (Chantransia Daviesii Thuret), Gay Head; Farlow, I88r, p. Iog 'Trentepohlia Daviesii, Harvey), Gay Head, on (ystoclonium purpurascens; Collins, I896a, p. 5 (Chantransia corymbifera Thuret), Woods Hole, on Ceramium rubrum and Cystoclonium purpurascens (C. P. Nott); P. B.-A., fas. IV, no. I92 (Chantransia corymbifera Thuret), Woods Hole, July i 5 to 20,1895 (C. P. Nott).

Nemalion multifidum (Weber \& Mohr) J. Agardh.

Common, attached to rocks between tide marks.

Woods Hole: Juniper Point, Grassy Ledge. Cuttyhunk. Penikese. Gay Head. Black Rock.

Summer, probably at other seasons. 
Nemalion multifidum-Continued.

P. B.-A., fas. IV, no. I93b, Juniper Point (Butlers Point), Woods Hole, July, x895 (Mrs. R. A. Esten).

\section{Family ChestangIACE}

Scinaia furcellata ('Turner) Bivona.

Occasional, attached to stones and shells below low-water mark. Dredged by the Survey off Gay Head and Cuttyhunk in $1 / 2$ to 9 fathoms, over sandy and stony bottoms.

Woods Hole: Dredged in the Hole in previous years. Washed ashore at Nobska and Gay Head.

Buzzards Bay: Inshore-Cuttyhunk, station I03, one; cove west of Cuttyhunk Neck July 27 , rgo5, few.

Vineyard Sound: Inshore-Robinsons Hole, station 2 1, many; Gay Head 57, few.
Scinaia furcellata-Continued.

Summer.

Farlow, 1873, p. 290, Gay Head; Farlow, I875, p. 367, Gay Head; Farlow, 1876, p. 699, Gay Head; Farlow, I881, p. I18, Devils Bridge off Gay Head on shells of Mytilus; P. B.-A., fas. IV, no. I94, floating off Cuttyhunk, August I3, I895 (C. P. Nott).

\section{Family Gelidiaceas.}

Gelidium crinale ('Tumer) J. Agardh.

Occasional, attached to rocks and stones near low-water mark.

Woods Hole: Along the shore of Buzzards Bay. Black Rock.

\section{Summer}

Farlow, 1876, p. 697 (Gelidium corneum var. crinale), Woods Hole; Farlow, 1881, p. I58, Woods Hole.

\section{Order CERAMIALES.}

\section{Family Ceramiace}

Antithamnion americanum (Harvey) Farlow.

Occasional, on wharves and larger algæ.

Woods Hole: Harbor wharves (MacRae). Washed ashore at Nobska.

Spring, 1904 (MacRae). Summer.

Antithamnion cruciatum (Agardh) Nägeli. [Chart 239.]

Common, attached to stones, larger algæ, and Zostera, below low-water mark. Dredged by the Survey in 3 to 15 fathoms, over sandy, shelly, and stony bottoms, frequently attached Phyllophora, Chondrus, and Polyides. Generally distributed inshore along the Elizabeth Islands and Marthas Vineyard, and in the easterly portion of Vineyard Sound. Black Rock.

Buzzards Bay: Lower portion-767I, few. Inshore-Sow and Pigs III, many; Cuttyhunk II2, many; I0O, IOI and I02, few; Penikese II3, many; Gull Island $x 16$, few; Nashawena $78,79,80$, and $8 \mathrm{r}$, few; Pasque 82, many; 84 , few; Naushon 86, many; 87 and 90, few; 9 I, many; Weepeckets ro8, few on shells: Nyes Neck I 40 , few on sulphur sponges.

Vineyard Sound: Westerly portion-7566, 757 , 7690 , and 7720 , few; 7724 , many; 7730 , few; 7734 , few on Cladostephus; 7735, many. Narrow portion-752I bis, $75^{22}$ bis, $75^{2} 3$ bis, 7533 bis, and $754 \mathrm{I}$ bis, few; 7543 bis, many on Diopatra tubes; 7554 bis, many; 7732, 7744, and 7745 , few. Easterly portion-7757, few on shells; 7760 , few; 7764 , many; 7765 and 7766 , few; 7768 , many on Chondrus: 7770 , many on
Antithamnion cruciatum-Continued.

Phyllophora; 7771 , few; $777^{2}$, many on Chondrus; 7773, many; 7774, few; 7775, many on Phyllophora; 7779 and 7780, few. Inshore--Great Ledge, Woods Hole 4, few; Nonamesset I, many; 2 and 3 , few; 8 , many; Naushon 9, ro, II, I2, 6 and 7 , few; I4, one; I6, many attached to Phyllophora; Tarpaulin Cove 17 , many on Zostera; Robinsons Hole 22 and 23, many on Phyllophora; Pasque 25, many; Gay Head 56, few; Menemsha Bight July 17, I905, haul x, many; Marthas Vineyard 52,6r, and 62, few; 63 and 64 , many; 65, few; 69, many; 70 and 73 , few; 74 , many; 77 , few. Drifted fragments, 775 I.

Summer.

Farlow, 1873, p. 292 (Callithamnion cruciatum Agardh), Weepecket; Farlow, I881, p. 122 (Callithamnion crucialum Agardh), Woods Hole, Vineyard Sound.

Antithamnion cruciatum var, radicans J. Agardh.

Occasional, on piles of wharves.

Woods Hole: Piles of Government wharf in Little Harbor (Setchell).

July I7, I89o (Setchell).

Collins, 1899, p. 125, Woods Hole (W. A. Setchell).

Antithamnion plumula (Ellis) Thuret.

Occasional, attached to stones, shells, and larger algæ below low-water mark. Dredged by the Survey in 2 to 9 fathoms (once in $12 \mathrm{r} / 2$ fathoms), over sandy and stony bottoms. A scattered distribution in the lower portion of Buzzards Bay and westerly portion of Vineyard Sound. 
Antithamnion plumula-Continued.

Buzzards Bay: Inshore-Cuttyhunk 103, few; Pasque 84 , few attached to shells. Drifted fragments, 7624 .

Vineyard Sound: Westerly portion -7678 , one. Inshore-Tarpaulin Cove I7, on Zostera; Gay Head 57 and 58 , few on larger algx; Menemsha Bight, July I 7 , I905, hauls I and 2, few.

\section{Summer.}

Farlow, 1873, p. 292 (Callithamnion Plumula Lyngbye), Devils Back Gay Head; Farlow, I875, p. 376 (Callithamnion Plumula Lyngbye) Gay Head; Farlow, 1876, p. 704 (Callithamnion Plumula Lyngbye), Gay Head; Farlow, I88 I, p. I24 (Callithamnion Plumula Lyngbye), Gay Head; Farlow, I882, p. 68 (Callithamnion Plumula Lyngbye), Gay Head, an antheridial plant collected in September.

Anthithamnion Pylaisci (Montagne) Kjellman.

Rare, on wharves and algæ below low-water mark.

Woods Hole (Farlow).

Farlow, I88r, p. I23 (Callithamnion Pylaisci Montagne), Woods Hole.

\section{Callithamnion Baileyi Harvey.}

Common, on rocks, stones, wharves, larger algæ, and Zostera. Dredged by the Survey in 3 to 13 fathoms, frequently attached to Desmarestia, Chondrus, Phyllophora, and Cystoclonium, over sandy and stony bottoms. A scattered distribution inshore along the Elizabeth Islands, Gay Head, and in the easterly portion of Vineyard Sound.

Woods Hole: Steamboat wharves, Grassy Ledge, Government wharves Little Harbor, Juniper Point. Black Rock.

Buzzards Bay: Upper portion- 7653 , few on Desmarestia. 'Lower portion-7656, many on Desmarestia. Inshore-Pasque 82, many; 90 and 9I, few on Phyllophora; Weepeckets ro8, few on Phyllophora.

Vineyard Sound: Narrow portion $-75^{23}$, few on Cystoclonium; 7547 bis, two; 7739 (I907), few. Easterly portion- 7768 and $777^{2}$, many on Phyllophora; 7778 , one. Inshore-Nonamesset I, few; Tarpaulin Cove 17, few; July I8, r9o3, hauls I, 3 , and 4 , few; Pasque 24 and 25, many on Phyllophora; 26, few on Phyllophora; Quicks Hole 27 , many on Desmarestia; Gay Head 50 and $5 \mathrm{I}$, many on Chondrus. Drifted fragments, 7755 .

Summer.

I62 $69^{\circ}-\mathrm{Bull}$. $3 \mathrm{I}$, pt $2-\mathrm{I} 3-\mathrm{I} 8$
Callithamnion Baileyi var. laxum Farlow.

Common, with the typical form, on stones, larger algx, and Zostera.

Woods Hole.

Summer.

Farlow, r875, p. 376 (Callithamnion Dietzice Hooper), Woods Hole; Farlow, I893, p. 107, 108, (Callithamnion Dietzice Hooper), Woods Hole.

Callithamnion byssoideum Arnott.

Common, attached to Zostera, and larger algæ. Dredged by the Survey in 3 to 6 fathoms, over sandy and stony bottoms. A scattered distribution along the easterly shore of the upper portion of Buzzards Bay.

Woods Hole: Grassy Ledge, Little Harbor. Weepecket (Farlow).

Buzzards Bay: Inshore-Quisset $\mathrm{I} 29$ and $\mathrm{I}_{30}$, many on dark-colored dead Zostera; West Falmouth I33, one; North Falmouth 137 , many.

Summer.

Farlow, 1873, p. 292, Woods Hole, Weepecket.

Callithamnion corymbosum (English Botany) Agardh.

Occasional, attached to Zostera, and larger algæ. Dredged by the Survey in 2 to 4 fathoms, over sandy and stony bottoms at three widely separated stations.

Woods Hole: Grassy Ledge, Little Harbor, Gay Head and Weepecket (Farlow).

Buzzards Bay: Wings Neck, station I 50 , few on Agardhiella.

Vineyard Sound: Inshore-Marthas Vineyard 69 , few; Vineyard Haven 7o, few on Zostera, and larger algæ.

Summer.

Farlow, 1873 , p. 292, Woods Hole, Gay Head, Weepecket; Farlow, I8SI, pp. I28, I29, Woods Hole.

Callithamnion roseum (Roth) Harvey.

Common, on stones, shells, Zostera, and larger algæ. Dredged by the Survey in 3 to $I_{3}$ fathoms, frequently attached to Zostera, Phyllo. phora, Chondrus, and Sargassum, over sandy, shelly, and stony bottoms. A scattered distribution inshore along the Elizabeth Islands and Marthas Vineyard, abundant in the easterly portion of Vineyard Sound.

Woods Hole: Grassy Ledge, dredged in the Hole in previous years. Black Rock. Washed ashore at Nobska, Cuttyhunk, and other points.

Buzzards Bay: Inshore-Cuttyhunk ror, ro2, and I03, few; Gull Island II6, few; Pasque 83 , few; Naushon 87, few; Weepeckets ro8, few; Scraggy Neck 145 , few. 
Callithamnion roseum-Continued.

Vineyard Sound: Westerly portion-7725, few. Narrow portion-752I bis, few on stones; 7744 , few on Phyllophora; 7754, few. Easterly portion-7756, few; 7759 , few; 7764 , many; 7766 , few; 7767 , abundant on Chondrus and Sargassum; 7768, few; 7769, many on Chondrus and Phyllophora; 7770, many on Phyllophora; 7771, many unattached; 7772, many; 7773, few; 7774, many on Phyllophora; 7775, many; 7776 , many on mussel shells; 7778 , few; 7779 , few; 7780 , few; $778 \mathrm{I}$, few; 7782 , few. Inshore-Naushon I6, many, Gay Head 57 , few on stones and rocks; Menemsha Bight, July 17, I905, haul 2, few; Marthas Vineyard 61 , few; 63 , very many; 65 , few; 69 , many on larger algæ and Zostera; 76 , few on larger algæ; $776 \mathrm{I}$, many.

Summer.

Farlow, I88I, p. 125, I26, Woods Hole.

Callithamnion tetragonum (Withering) Agardh.

Occasional, on stones and algæ near low-water mark. Dredged by the Survey in 5 to $13 \frac{1}{2}$ fathoms, over sandy and stony bottoms, at three stations in the easterly portion of Vineyard Sound.

Woods Hole: Grassy Ledge. Robinsons Hole.

Vineyard Sound: Easterly portion-7764, many; 7765 and 7766 , few.

Summer.

Farlow, 1873 , p. 291, Woods Hole, Marthas Vineyard.

Ceramium botryocarpum Griffiths.

Occasional.

Penikese (Esten), probably along the shores of the Elizabeth Islands.

July $25, \mathrm{I} 896$.

Known from specimen in the herbarium of the Marine Biological Laboratory collected by Mrs. R. A. Esten.

Ceramium capri-cornu (Reinsch) Farlow.

Rare.

Cuttyhunk.

Summer.

Ceramium fastigiatum Harvey.

Common, on Zostera, and larger algæ. Dredged by the Survey in 2 to 7 fathoms, attached to Zostera, Phyllophora, etc., occasionally on stones, over sandy and stony bottoms. A widely scattered distribution at inshore stations in both Buzzards Bay and Vineyard Sound.

Woods Hole: Grassy Ledge. Weepecket (Farlow). Black Rock.
Coramium fastigiatum-Continued.

Buzzards Bay: Inshore-Naushon 87, one; 90 , few on Phyllophora; Quisset I3o, many; Gunning Point I3I, many; North Falmouth I36 and I37, many on Zostera; I38, few, I39, one; Nyes Neck $1_{4} \mathrm{I}$, many. Drifted fragments, $76 I_{5}$, 7626 .

Vineyard Sound: Narrow portion-7542, one; 7548, few. Inshore-Tarpaulin Cove July I8, I903, haul I, few; Robinsons Hole 20, many on stones, Cuttyhunk 33, 34, and 38, few; Gay Head 44 , few on rocks and stones.

Summer.

Farlow, 1873 , p. 291, Woods Hole, Weepecket.

Ceramium pedicellatum $\mathrm{J}$. Agardh.

Occasional.

No Mans Land, probably along the shores of the Elizabeth Islands.

Summer, July 20, I904.

Ceramium rubrum (Hudson) Agardl. [Chart 240.]

Very common, on stones, woodwork of wharves, Zostera, and larger algæ. Dredged by the Survey in $\mathrm{I}$ to Ig fathoms, attached to stones, Zostera, and larger algæ such as Chorda, Chondrus, and Phyllophora, over sandy, shelly, and stony bottoms. Distribution very general throughout Vineyard Sound and scattered in the lower portion of Buzzards Bay.

Woods Hole: Great Harbor, Grassy Ledge, entrance to Eel Pond, Little Harbor. Black Rock. Alongshore, Penikese, Cuttyhunk, Gay Head, Tarpaulin Cove.

Buzzards Bay: Lower portion -7656 , many on Chorda; 7665 and 7670 , few on stones. Inshore-Cuttyhunk 100 and I04, few on Phyllophora; Nashawena 79, few; Pasque 82, few. Drifted fragments 86.

Vineyard Sound: Westerly portion-757 I, few on Chorda; 7575, few; 7576, few on Champia; $75^{8} 3,75^{89}, 7593,7676$, and 7680 , few; 7701 , one; 7704, one; 7710,7717 , and 7719 , few; 7721 , many on Chondrus; 7722, many; 7734, few. Narrow portion- $75^{24}, 75^{2} 5,7538$, and $754 \mathrm{I}$ bis, few; 7542 bis, many on Chorda; 7548, few; 755I, many on Chorda; 755I (I907), few; 7554, few; 7557 , many on Chorda; $7559,7560,75^{6} 5$ bis, 7732,7733 , and 7739 , few; 7746 , one, 7749 , one. Easterly portion-7755, many; 776I (I907), many. Inshore-passage of Woods Hole II8, few); Great Ledge Woods Hole 4, I on stone; Tarpaulin Cove July I8, I903, hauls I and 3, few; haul 4, few; Robinsons Hole 20, few; $2 \mathrm{I}$ and 22, many; Sow and Pigs 37, few, Gay Head 50 and 5 , many on Chondrus; $44,45,46$, 
Ceramium rubrum-Continued.

47 and 48 , few on Chondrus and larger algx; 57, many; 59, few; 773I, many on larger algæ; 773 I (1907), few; also off Devils Bridge August $I_{7}, I_{90}$, hauls 3 and 4 , many on larger algæ; Menemsha Bight, July I7, 1905, haul 2, few; Marthas Vineyard 55 , few on algæ; 64 few on stones; 73 , few on algæ. Drifted fragments, $7537,7546,7588,7547$ bis, 7678 , $7682,7699,7706,775 \mathrm{I}, 7754$.

At all seasons.

Ceramium strictum (Kützing) Harvey.

Common, on Zostera, larger algæ, and sometimes on stones. Dredged by the Survey in 2 to $15 \frac{1}{2}$ fathoms, over sandy, shelly, and stony bottoms. A scattered distribution, chiefly in the easterly portion of Vineyard Sound.

Woods Hole: Grassy Ledge, Little Harbor, off Juniper Point, frequently washed ashore in Little Harbor. Black Rock.

Vineyard Sound: Narrow portion-7746, one. Easterly portion- $-776_{3}$, one; 7764 , few. Inshore-Robinsons Hole 20, few on stones; Marthas Vineyard 6I, many on Zostera; Vineyard Haven 7o, few on stones. Drifted fragments, 49

Summer.

Farlow, 1873, p.29I (Ceramium diaphanum Roth), Woods Hole, Weepecket; this reference is probably to Ceramium strictum; Farlow, I88r, p. 136, Little Harbor Woods Hole.

Ceramium tenuissimum (Lyngbye) J. Agardh.

Common, on Zostera, larger algæ, and occasionally on stones. Dredged by the Survey in 3 to I5 fathoms, over sandy and stony bottoms. Common at inshore stations along Marthas Vineyard, but distribution scattered along the Elizabeth Islands and easterly shore of Buzzards Bay.

Woods Hole: Grassy Ledge, Little Harbor, off Juniper Point. Black Rock.

Buzzards Bay: Upper portion-7652, few on Zostera. Inshore-Hog Island Point I34, few; Bassetts Island 146, many; Wings Neck 147 , few. Drifted fragments, I38, I4I.

Vineyard Sound: Westerly portion-7724, 7725, and $77^{26}$, many; 7730 , few. Narrow portion7530 bis and $754 \mathrm{x}$ bis, few; 7542 bis, many on Chorda; 7554 bis, many; 7559 and 7565 bis, few. Easterly portion- 7777 , many on Zostera; $778 \mathrm{x}$, few; 7783 , many. Inshore-Sow and Pigs 35, few; Menemsha Bight 53 and 54, few on algx; Marthas Vineyard 6I and 62, few; 67, many on
Ceramium tenuissimum-Continued.

Zostera; 69, 73, 74, 75, and 76, many on Zostera and larger algx; 77 , few; Vineyard Haven $7 n$, few on Zostera.

Summer.

Farlow, 1873 , p. 291 [Ceramium arachnoideum (?) Agardh], Woods Hole.

Griffthsia Bornetiana Farlow. [Chart 24I.]

Common, on larger algx below low-water mark. Dredged by the Survey in 2 to $r_{5}$ fathoms (most plentiful between 3 and 6 fathoms), frequently attached to Phyllophora and Chondrus, over sandy and stony bottoms. Distribution scattered inshore along the east side of Buzzards Bay and in the easterly portion of Vineyard Sound.

Woods Hole: Juniper Point. Nobska. Tarpaulin Cove. Weepecket Islands (Farlow).

Buzzards Bay: Inshore-Gull Island i16, many on Phyllophora; Naushon 87, few; Uncatena II7, many on Phyllophora; Weepeckets I08, many on Phyllophora; Penzance r23, many, and I24, few, on Phyllophora and Chondrus; Quisset I28, many on Phyllophora; I29 and I3o, many; Gunning Point I3I, many; Hog Island Point I34, many; Hog Island Harbor 135, few; North Falmouth I37, few; Nyes Neck I4I, many; Cataumet Harbor I42, many. Drifted fragments, $7626,7627,126,127, I_{3} 8$.

Vineyard Sound: Narrow portion -7533 bis, few on stones; 7749 , one; 7754 , one. Easterly portion- 7755 , few; 7778 , one; 7782 , one. Inshore-passage of Woods Hole I22, few; Nonamesset 8, one; Marthas Vineyard 52, few; 7761 , one. Drifted fragments, 7537.

Summer.

Farlow, 1873, p. 29 I (Griffithsia corallina Agardh), Buzzards Bay, Woods Hole, Weepecket Islands; A. A. B. Ex., fas. II, no. 88, Woods Hole in part (IV. G. Farlow); P. B.-A., fas. vi, no. 295, Little Harbor Woods Hole, July 20, 1893 (W. A. Setchell).

Griffithsia tenuis Agardh. [Chart 242.]

Common, on stones and over sand in sheltered waters. Dredged by the Survey in 2 to 4 fathoms, loosely attached over sandy and muddy bottoms. Distribution restricted to the extreme upper portion of Buzzards Bay.

Buzzards Bay: Upper portion- $-63^{2}$, I on stone. Inshore-Wings Neck I50, many loosely attached on sandy bottom; Tobys Island I52, few; Monument Beach I53, few.

Summer. 
Pleonosporium Borreri (English Botany) Nägeli.

Common, on wharves and larger algæ below lowwater mark. Dredged by the Survey in I to $6 \frac{1}{2}$ fathoms, over sandy, stony, and muddy bottoms. A scattered distribution, chiefly in the lower portion of Buzzards Bay and westerly portion of Vineyard Sound.

Woods Hole: Great Harbor (occasional).

Buzzards Bay: Lower portion, 7675, few.

Vineyard Sound: Inshore-Naushon 7, one; Pasque 24 and 25, many on Phyllophora; 26, few on Phyllophora; Cuttyhunk 33, many on Phyllophora; 38, few; Gay Head 50 and 5 I few, at base of larger algæ.

Summer.

Farlow, 1873, p. 291 (Callithamnion Borreri Agardh), Woods Hole; Farlow, r881, p. I24, I25 (Callithamnion Borreri Agardh), Woods Hole; A. A. B. Ex., fas. v, no. I93 (Callithamnion Borreri Agardh), Woods Hole (W. G. Farlow).

Plumaria elegans (Bonnemaison) Schmitz. [Chart 243.]

Common, on rocks and alga below low-water mark off exposed points and reefs. Dredged by the Survey in 3 to $I_{7}$ fathoms, frequently attached to Chondrus and Phyllophora, over sandy and stony bottoms. Distribution restricted to the vicinity of Gay Head and Sow and Pigs.

Off reefs of Devils Bridge, Gay Head and Sow and Pigs. Attached to large rocks at and below low-water mark on west side of Penikese. Between Gay Head and No Mans Land (Farlow).

Vineyard Sound: Westerly portion-7584, few; 7719, few on old Phyllophora; 7720, many; 7728, few. Inshore-Sow and Pigs 36, few, and 37 , many, on Chondrus and Phyllophora; Gay Head 44, few; 57,58 , and 59 , many on Chondrus and Phyllophora; also off Devils Bridge August I7, 1903 , hauls 3 and 4 , many on rocks and larger algæ, such as Chondrus and Phyllophora.

Summer, probably at all seasons.

Farlow, 1873 , p. 282 , 29 I (Ptilota elegans Bonnemaison), between Gay Head and No Mans Land; Farlow, 188r, p. I33 (Ptilota elegans Bonnemaison), Gay Head.

Rhodochorton membranaceum Magnus.

Occasional, on Bryozoa, sertularian hydroids, and shells. Dredged by the Survey at station 65 in $3 \frac{1}{2}$ to 6 fathoms, over gravel.

Vineyard Sound: Inshore-Marthas Vineyard 65 (many on Crisia eburnea).

Summer.
Rhodochorton Rothii (English Botany) Nägeli.

Occasional, attached to rocks between tide marks.

Woods Hole: Juniper Point.

Summer.

Seirospora Griffithsiana Harvey.

Common, on stones, shells, Zostera, and larger algx below low-water mark. Dredged by the Survey in 3 to $101 / 2$ fathoms, over sandy, shelly, and stony bottoms. A scattered distribution in both Bay and Sound.

Woods Hole: Grassy Ledge. Frequently washed ashore in abundance at exposed points.

Buzzards Bay: Lower portion-7660, few on stones. Inshore-Cuttyhunk I04, few; Gull Island Ir6, few; Pasque 84, one; Naushon 90, one; Quisset I30, few.

Vineyard Sound: Westerly portion-7728, many; 7729 , few. Inshore-passage of Woods Hole I22, one; Nonamesset 2, one; 8 , few on larger algæ; Tarpaulin Cove July 18, I903, haul I, many on Zostera; Gay Head 49, few on larger algæ; Menemsha Bight July I7, I905, hauls I, 2 and 3 , few; Marthas Vineyard 52 , many on larger algæ.

Summer.

Farlow, 1873, p. 292 (Callithamnion seirospermum Griffiths), Menemsha, Gay Head; Farlow, I882, p. 68 (Callithamnion versicolor), Woods Hole; P. B.-A., fas. viII, no. 39I, Edgartown, July 3I, I897 (M. W. Jernegan).

Spermothannion Turneri (Mertens) Areschoug. [Chart 244.]

Common, on larger algæ. Dredged by the Survey in $I$ to $I 7$ fathoms, frequently attached to Chondrus, Phyllophora, Polyides, and Sargassum, over sandy, shelly, stony, and muddy bottoms. Widely distributed in Vineyard Sound and inshore along the Elizabeth Islands in Buzzards Bay.

Woods Hole: Frequently washed ashore at Nobska and in Little Harbor.

Buzzards Bay: Inshore-Cuttyhunk roo, many on Chondrus; I02, few on Chondrus; II2, many; Penikese II3, many; Gull Island II6, many; II5, few; Pasque 82, few; Naushon 9o, few, and 96, many, on Phyllophora.

Vineyard Sound: Westerly portion- 7585,7588 , $75^{89}$ and 7598, few; 7717 and 7719, few on Phyllophora. Narrow portion-752I bis, few, and $75^{25}$ bis, many, on Phyllophora; 7524, $75^{26}$ (1907), few; 7530 bis, few, and 7533 bis, many, on Phyllophora; $7537,7542,7548,755^{1}, 7553$, and 7560 , few; 7562 , few on Chondrus; 7739, few on Phyllophora and Chondrus; 774I, few; 7749, many on Phyllophora and Sargassum; 
Spermothamnion Turneri-Continued.

7751, few on Polyides; $775^{2}$ and 7754 , few on Phyllophora. Easterly portion-7755, on base of Sargassum; 7759, 7760, and 7763 , few; 7764 , many; 7770,7772 and 7775 , many on Phyllophora; $777 \mathrm{I}$, many unattaclied; 7774 and 7777 , few, 7779, few on Chondrus; 7780, 7781, and 7782 , few. Inshore-Robinsons Hole 20, many; Quicks Hole 27 and 28, few, and 29, many, on Phyllophora; Nashawena 30 , many on Phyllophora; Cuttyhunk $32,33,34$, and 38 , many on Phyllophora and Chondrus; Sow and Pigs 35, few on algæ; Gay Head 44, 45, and 46, many, and 47 and 49, few, on Chondrus and Phyllophora; 50 and $5 \mathrm{I}$, many on Chondrus; 56,57 , and 58 , many, and 59, few, on Chondrus and Phyllophora; also Devils Bridge August I7, I903, hauls 3 and 4, many on Phyllophora and Plumaria; Marthas Vineyard 55, few, and 64,65 , 66, 67, and 68, many, on Chondrus, Phyllophora, and Zostera; 61 and 63 , many, and 62 , few, on Chondrus and other algæ; 69, many on Phyllophora; 74, many, and 75, 76, and 77, few, on larger aigæ; $776 \pi$, many; Vineyard Haven 72 , many on Phyllophora; 7762, few. Drifted fragments, $775^{8}, \mathrm{I}_{3}$.

Summer, winter, undoubtedly at all seasons.

Farlow, 1873, p. 292 (Callithamnion Turneri Agardh), Vineyard Sound; P. B.-A., fas. IV, no. 197, floating off Gay Head and Cuttyhunk, August, I895. (C. P. Nott.)

Spyridia filamentosa (Wulfen) Harvey. [Chart 245. 1

Common, on stones and shells, Zostera, and larger algæ. Dredged by the Survey in 3 to 55 fathoms (most plentiful in from 4 to ro fathoms), over sandy, shelly, stony, and muddy bottoms. Widely distributed inshore along
Spyridia filamentosa-Continued.

the east side of Buzzards Bay and along Marthas Vineyard; scattered throughout Vineyard Sound and inshore along the Elizabeth Islands.

Woods Hole: Grassy Ledge, Juniper Point. Weepecket (Farlow). Black Rock. Frequently washed ashore at Nobska.

Buzzards Bay: Lower portion -7656 , few at base of Laminaria; $767 \mathrm{I}$, many; 7675 , few on Zostera. Inshore-Cuttyhunk 103,2 on Phyllophora; Gull Island II6, few; Naushon 90, 2 on Phyllophora; Uncatena II7, few; Quisset I29, few; I30, many on pebbles; West Falmouth I32, many, and $\mathrm{I}_{33}$, few, on pebbles; North Falmouth $I_{3} 6$ and $I_{37}$, many on pebbles, I $_{3} 8$, few; Hog Island Point I34, few on pebbles; Cataumet Harbor I42, few; Scraggy Neck I45, few; Bassetts Island I46, few; Wings Neck I47, few; Cromeset Neck 158 , many. Drifted fragments, $7636,150, I_{51}, I_{52}, I_{53}$.

Vineyard Sound: Westerly portion-7571, 7572, and 7588 , few; 7720 , I on Chondrus; 7724 , many; $77^{25}$, many entangled with other algæ; 7726 , many entangled with Polysiphonia irigrescens; 7735, many. Narrow portion-7530 bis, fev; 7533 bis, I on stone; $7542,7559,7562$ and 774I, few; 7749, one. Easterly portion-7759 and 7760 , few; 7763 , few on shells; 7763 (igo7), few; 7776 and 7783 , many. Inshore-Menemsha Bight 53 and 54, many on stones; also July 17, I905, haul I, few; Marthas Vineyard 52, many on stones; $55,61,64,68,69,73$, and 76 , few on stones; 67 , many on stones; Vineyard Haven 7762 , few.

Summer.

Farlow, I873, p. 29I, Woods Hole, Weepecket; A. A. B. Ex., fas. IV, no. I5I, Woods Hole (W. G. Farlow); P. B.-A., fas. vir, no. 393, Edgartown, July I7, I897 (M. W. Jernegan).

\section{Order RHODOMELALES}

\section{Family RHODOMELACEA}

Chondria dasyphylla (Woodward) Agardh.

Common, on rocks and larger algæ, sometimes Zostera, in shallow water below low-tide mark. Dredged by the Survey in 4 to ro fathoms, over sandy and stony bottoms. Restricted chiefly to the easterly portion of Vineyard Sound.

Woods Hole: Grassy Ledge, Juniper Point, Buzzards Bay shore. Tarpaulin Cove.

Buzzards Bay: Drifted fragment, I5I.

Vineyard Sound: Easterly portion-7755, one; 7774 , one; 7777,7781 , and 7782 , few; 7783 , one. Inshore-Marthas Vineyard 6I, I on stone; 73 , few on pebbles.
Chondria dasyphylla-Continued.

Summer.

Farlow, 1873, p. 286 (Chondria littoralis Agardh), Woods Hole; Farlow, 1875, p. 359 (Chondria littoralis), Woods Hole; A. A. B. Ex., fas. v, no. I86, Woods Hole in part (W. G. Farlow); P. B.-A., fas. III, no. I42, Buzzards Bay, Woods Hole, August 7, 8894 (W. A. Setchell).

Chondria sedifolia Harvey.

Occasional, on stones, Zostera, and larger alga below low-water mark.

Woods Hole: Little Harbor off Iuniper Point. Summer.

Farlow, I873, p. 286 (Chondria dasyphylla var. sedifolia), Woods Hole. 
Chondria tenuissima (Goodenough \& Woodward) Agardh.

Very common, on rocks and larger algæ below low-water mark. Dredged by the Survey at station 73 , in $2 \frac{1}{2}$ to 5 fathoms, over a stony bottom.

Woods Hole: Grassy Ledge, Juniper Point, Buzzards Bay shore. Nobska. Tarpaulin Cove. Black Rock.

Vineyard Sound: Inshore-Marthas Vineyard 73, few on stones.

Summer.

Chondria tenuissima var. Baileyana (Harvey) J. Agardh.

Common, on stones and larger alga below lowwater mark.

Woods Hole: Grassy Ledge, Little Harbor off Juniper Point.

Summer.

Farlow, 1873, p. 286 (Chondria Baileyana Harvey), Woods Hole; A. A. B. Ex., fas. v, no. r87, Woods Hole (W. G. Farlow).

Dasya elegans (Martens) Agardh.

Common, in quiet waters on Zostera, larger algæ, and occasionally stones. Dredged by the Survey in 2 to $r_{3}$ fathoms, over sandy and stony bottoms. A wide and scattered distribution in both Bay and Sound.

Woods Hole: Grassy Ledge, Little Harbor. Black Rock.

Buzzards Bay: Upper portion- 7632 , I on stone. Lower portion -7674 and 7675 , few on Zostera; 7656 , one, and 7666 , one, on stones. InshoreGunning Point I30, one; Great Hill I 54 , I on stone. Drifted fragments, 7626,7653 .

Vineyard Sound: Westerly portion-7734, few. Narrow portion-7733, few; 7751, one; 7753 , few. Easterly portion-7755, 7768, and 7770 , few; 7775, many; $7777,7778,7779,7780,778 \mathrm{I}$, 7782 and 7783 , few. Inshore-passage of Woods Hole 122, one; Robinsons Hole 2I, few on stones; Marthas Vineyard 55 , few on algx; $6 \mathrm{r}$, many, and 69, few, on Zostera; 73,75 , and 76 , many on Zostera. Drifted fragments, 7556 bis, $7717,7749,7759$.

Summer.

Polysiphonia atrorubescens (Dillwyn) Greville.

Occasional, on stones in fairly deep water. Dredged by the Survey in 2 to 8 fathoms, over sandy and stony bottoms. A scattered distribution at inshore stations off the Elizabeth Islands in the lower portion of Buzzards Bay and off Marthas Vineyard in the westerly portion of Vineyard Sound.
Polysiphonia atrorubescens-Continued.

Washed ashore on exposed points as at Gay Head, Cuttyhunk, and No Mans Land.

Buzzards Bay: Inshore-Sow and Pigs in , few; Pasque 82 , few. Drifted fragments, 7622 .

Vineyard Sound: Inshore-Gay Head 56, many on stones; Menemsha Bight July I 7 , 1905, haul 2 , few.

Summer.

Farlow, 1873, p. 287, Gay Head, Menemsha Bight; Farlow, 188I, p. I74, Gay Head.

Polysiphonia elongata (Hudson) Harvey. [Chart 246.]

Common, on stones and rocks in fairly deep water. Dredged by the Survey in 2 to 17 fathoms (most plentiful from 5 to $I_{3}$ fathoms), over sandy, shelly, and stony bottoms. Widely distributed throughout Vineyard Sound and the lower portion of Buzzards Bay.

Washed ashore on exposed points as at Nobska, Cuttyhunk, and Gay Head.

Buzzards Bay: Lower portion- 7656 , one; 7662 (I907) and 7665 , few; 7675 , one. Inshore-Sow and Pigs III, many; Cuttyhunk 100 and I02, few; Iог, many; cove west of Cuttyhunk Neck 27, I905, many; Penikese II4, few.

Vineyard Sound: Westerly portion-758I (I907), few; 7678 , three; 7685 , many; 7686 , one; 7698 , one; 7701, many; 7702, 7706, 7709, one each; 7717 , few; 7723 , many; 7724 , one; 7725 , few; $77^{26}$, many; $77^{27}$, one; 7728 and 7730 , few; 7734 , many. Narrow portion-7557, 7733, one; and 7739, few; 7751, 7752, 7754, one each. Easterly portion- 7760 and 7766 , few; 7772,7780 , few on Phyllophora. Inshore-Robinsons Hole 23, one; Quicks Hole 29, one; Cuttyhunk 33 and 34, many; 38 , few; Gay Head 44 and 45 , many; $46,47,48$ and 49 , few; 56 and 59 , many; 60 , few; 773I, many; 773I (I907), few; also off Devils Bridge August 17, 1903, hauls I and 2, few; Menemsha Bight July I7, I905, hauls 2 and 3 , many; Marthas Vineyard 55, 64, 65, 68 and 73 , few; Vineyard Haven 7762 , few. Drifted fragment, 78 .

Summer.

Farlow, 1873 , p. 287, Gay Head, Menemsha Bight; Farlow, I88I, p. I72, Woods Hole, Gay Head; A. A. B. Ex., fas. v, no. 182, Gay Head, (W. G. Farlow); P. B.-A., fas. I, no. 44, Gay Head, August 22, I892 (W. J. V. Osterhout).

Polysiphonia fastigiata (Roth) Greville.

Occasional, attached to Ascophyllum nodosum.

Woods Hole: Grassy Ledge, Juniper Point, Buzzards Bay shore. Nobska. Black Rock.

Spring, early summer.

Farlow, 1873 , p. 287 , Woods Hole. 
Polysiphonia fibrillosa (Dillwyn) Greville.

Common, on rocks and larger algx at and below low-tide mark. Dredged by the Survey in 2 to $x$ I fathoms, over sandy, and stony bottoms. At several scattered stations chiefly in Vineyard Sound.

Woods Hole: Grassy Ledge, Juniper Point. Nobska. Black Rock.

Buzzards Bay: Inshore-Cuttyhunk 104, one. Drifted fragments, 76 ro, 82 .

Vineyard Sound: Easterly portion-7759, few. Inshore-Robinsons Hole 20, few; Quicks Hole 29, few; Menemsha Bight July 17, I905, haul 2, few. Drifted fragments, 13 .

Summer.

Farlow, 1876, p. 693, Woods Hole; Farlow, I88I, pp. I72, I73, Woods Hole; A. A. B. Ex., fas. v, no. r8I, Woods Hole (W. G. Farlow); P. B.-A., fas. xxv, no. I244, Juniper Point (Butlers Point), Woods Hole, August, 1904 (B. M. Davis and Miss I. J. MacRae).

Polysiphonia Harveyi Bailey.

Common, on Zostera in quiet waters. Dredged by the Survey in 5 to ro fathoms, over sandy, shelly, stony, and muddy bottoms. At a few scattered stations in Buzzards Bay and the easterly portion of Vineyard Sound.

Woods Hole: Eel Pond, Little Harbor.

Buzzards Bay: Lower portion-7663, many on Zostera. Inshore-Uncatena $\mathbf{I} 7$, few on Zostera. Drifted fragments, I5o, I5I and ${ }_{5} 8$ on Zostera.

Vineyard Sound: Easterly portion $-7778,7779$, 7780 and 7781 , few on Zostera; 7782 , one; 7783 , few on Zostera. Inshore-Vineyard Haven 72, few on Zostera.

Summer.

Farlow, 1873 , p. 287 , Woods Hole; A. A. B. Ex., fas. IV, no. I33, Woods Hole (W. G. Farlow),

Polysiphonia nigrescens (Dillwyn) Greville. [Chart 247.]

Common, in fairly deep water on stones and shells and over muddy bottom. Dredged by the Survey in I to ${ }_{5}$ fathoms (most plentiful in 5 to Io fathoms), over sandy, shelly, stony, and muddy bottoms. Very widely distributed in both Bay and Sound.

Woods Hole: Entrance to Eel Pond. Black Rock.

Buzzards Bay: Upper portion-7610, 7615,7636 , $7637,76_{3} 8$ and 7639 , few; 7648 , many; 7649 , few; 7654 and 7655 , many. Lower portion $-76_{56}$,
Polysiphonia nigrescens-Continued.

few; 7659 , many; $7664,7666,7668$ and 7672 , few. Inshore-Sow and Pigs III, few; Cuttyhunk IO2 and II2, few; Penikese II3 and II4, few; Gull Island II5, many; Nashawena 80 and 81 , few; Pasque 82 , few; 83 , many; 84 , few; Naushon 86, 90 and $9 \mathrm{r}$, few; Weepecket ro8, I09, and I Io, few; Penzance I22, one; Sconticut Neck $16_{3}$ and $16_{4}$, few; Mishaum Point 167 , few. Drifted fragments, $7614,7618,7626$, 7645,7650, Ioo.

Vineyard Sound: Westerly portion-758I (1907), few; 7717 , few; 7718 , one; $77^{24}$ and 7725 , many; 7726 , few; 7728, 7729, 7730 and 7734 , many. Narrow portion-7523 bis, one; 7549 (1907), few; 755I (I907), few; 7751, one; $775^{2}$, many. Easterly portion-7760, one; 7763 (1907), few. Inshore-Nonamesset $x$, one; Naushon 5,6 , and 7 , few; 9, one; Ir, one; Tarpaulin Cove 18 , many; I9, one; Robinsons Hole 20 and 22, few; Nasha. wena 3 , two; Cuttyhunk 33, few, 34, many; Gay Head 47, few; 49, many; 50 and 51 , few; 59, few; 60, many; $75^{8 \mathrm{I}}$ bis, few, $773 \mathrm{I}$, many, 773I (r907), few; Menemsha Bight 53 and 54 , many; also July $I_{7}$, I905 hauls 1,2 , and 3, many; Marthas Vineyard 52, many; 55,62 , 76 and 77 , few; $776 \mathrm{r}$, few. Drifted fragments, 7532 bis, 7533 bis, 7775 , I4, I 5 .

Spring, summer.

Farlow, I873, p. 287, Woods Hole, Gay Head.

Polysiphonia nigrescens var. fucoides Harvey.

Occasional, in fairly deep water on stones and over mud. Dredged by the Survey in 5 to $5 \frac{1}{2}$ fathoms, over gravel and mud at station 33 .

Weepecket and No Mans Land (Farlow).

Vineyard Sound: Inshore-Cuttyhunk 33 (few). Summer.

Farlow, r873, p. 287, Weepecket (on Fucus), No Mans Land (ro fathoms).

Polysiphonia Olneyi Harvey.

Common, on Zostera in quiet waters. Dredged by the Survey at stations 73 and 127 , in 2 to 5 fathoms, over sandy, stony, and muddy bottoms.

Woods Hole: Eel Pond, Little Harbor. Quisset Harbor.

Buzzards Bay: Inshore-Quisset Harbor 127, few on Zostera. Drifted fragments, I23.

Vineyard Sound: Inshore-Marthas Vineyard 73, many on Chorda filum.

Summer.

Farlow, 1873 , p. 287 , Woods Hole. 
Polysiphonia urceolata (Lightfoot) Greville.

Common, on stones and wharves in the spring. Dredged by the Survey in 2 to I 9 fathoms, over sandy, stony, and muddy bottoms. Probably widely distributed in both Bay and Sound in the spring, but in the summer only found in the lower portion of Buzzards Bay and westerly portion of Vineyard Sound.

Woods Hole: Wharves and harbor walls, entrance to Eel Pond, Grassy Ledge, Little Harbor.

Buzzards Bay: Lower portion- 7670 , few; 7673 , one; and 7675 , I on stone. Inshore-Sow and Pigs II , few; Gull Island II 5 , few on stones. Drifted fragments, $8_{3}, 8_{4}$.

Vineyard Sound: Inshore-Cuttyhunk 32 , I on stone.

Spring, passing out of season in early summer.

Farlow, I873, p. 286, Woods Hole, Government wharf.

Polysiphonia variegata (Agardh) Zanardini. [Chart 248.]

Common, on stones, Zostera, and larger algæ, frequently growing unattached over sand and mud. Dredged by the Survey in 3 to 6 fathoms, over sandy, shelly, stony, and muddy bottoms. In the upper portion of Buzzards Bay, at inshore stations, chiefly along the easterly shore.

Woods Hole: Wharves and harbor walls, Little Harbor, over sand and mud in quiet water. Weepecket (Farlow). Black Rock.

Buzzards Bay: Upper portion-7632, one; Inshore--Naushon 9I, one; Weepecket I08, few, Penzance I23, few; West Falmouth I33, one; Hog Island Point I34, many; Hog Island Harbor I35, few; North Falmouth I36, few; 137 , many; I38, one; Nyes Neck I39, one: I40, one, I4I, few; Scraggy Neck 145, many; Bassetts Island I46, few; Wings Neck I47, few.

Vineyard Sound: Drifted fragments, 7554 bis.

Summer.

Farlow, 1873, p. 287, Woods Hole, Weepecket Islands; P. B.-A., fas. v, no. 245a, Woods Hole, August 15, 1895 (W. A. Setchell).

Polysiphonia vestita J. Agardh.

Rare.

Marthas Vineyard (Jernegan).

Collins, $1896 \mathrm{~b}$, p. 462, Marthas Vineyard (M. W. Jernegan).
Polysiphonia violacea (Roth) Greville.

Common, on stones and larger algæ below lowwater mark. Dredged by the Survey in I to I3 fathoms, over sandy and stony bottoms. A scattered distribution in both Bay and Sound.

Woods Hole: Wharves and harbor walls, entrance to Eel Pond, Grassy Ledge, Juniper Point, Gut of Canso. Black Rock.

Buzzards Bay: Lower portion-7664, one very dark in color, on stone. Inshore-Nashawena 79, few; Pasque 82, few; West Falmouth 129 and I 30 , few; North Falmouth I36, I37, few.

Vineyard Sound: Westerly portion-7681, 7704, 772 I, one each. Narrow portion $-75^{23}$ bis, I on stone. Easterly portion- 7780 , one. Inshore-Gay Head 50 and $5 x$, few on rocks, 45, one; 48, few; Marthas Vineyard 64, few.

Summer.

Farlow, 1873 , p. 287, Gay Head, Menemsha.

\section{Rhodomela Rochei Harvey.}

Common, on stones, Phyllophora and other large algæ below low-water mark. Dredged by the Survey in 3 to 8 fathoms, over sandy and stony bottoms. Probably widely distributed in the spring in both Bay and Sound, but in the summer only found at scattered stations.

Woods Hole: Washed ashore at Nobska and at other points.

Buzzards Bay: Inshore-Gull Island II5, few; Pasque 82, few; Naushon 89, one; Weepeckets 105, 108, and 109, few; passage of Woods Hole I22, few; Penzance I23, few; Quisset I28, many on Phyllophora; Hog Island Point I34, many; Hog Island Harbor I35, few; North Falmouth 136 , few; I37, many; Nyes Neck I4I, many on Phyllophora; Mishaum Point I67, I large plant.

Vineyard Sound: Inshore-Gay Head 7731 (1907), one.

Spring, passing out of season in the summer. The plants dredged were chiefly old basal portions.

Farlow, r88I, p. I69, Woods Hole; P. B.-A., fas. Xxvi, no. I296, Woods Hole, April 23, 1905 (F. S. Collins).

Rhodomela subfusca (Woodward) Agardh.

Occasional, on stones and over sand and mud, below low-water mark. Dredged by the Sur. vey in 3 to I 2 fathoms, over sandy, stony, and muddy bottoms. Probably widely distributed in the spring in both Bay and Sound, but in the summer only found at scattered stations. 
Rhodomela subfusca-Continued.

Woods Hole: Washed ashore at Nobska and along the Buzzards Bay shore. Wharf at Gay Head. Black Rock.

Buzzards Bay: Upper portion-7639, one; $76_{52}$, one. Lower portion -7656 , one; 7667 , one. Inshore-Pasque $8_{3}$, one; Naushon 9r, one; 96 , few. Drifted fragments 7626 .

Vineyard Sound: Westerly portion-7735, one. Narrow portion-7554 bis, one. InshoreQuicks Hole 29, 2 on stones; Gay Head 56, few on stones; Marthas Vineyard 6r, I on a stone. Drifted fragments, 20 .
Rhodomela subfusca-Continued.

Spring, passing out of season in the summer, the plants dredged being well past their prime.

Farlow, 1873, p. 286, Gay Head, Vineyard Sound; Farlow, I88I, p. I63, Woods Hole; A. A. B. Ex., fas. v, no. I84, Gay Head (W. G. Farlow).

Rhodomela virgata Kjellman.

Rare.

Marthas Vineyard (Jemegan).

Collins, I896b, p. 46I, 462, Marthas Vineyard (M. W. Jernegan).

\section{Order GIGARTINALES.}

\section{Family GigartinACEAE.}

Actinococcus aggregatus Schmitz.

Occasional, epiphytic on Gymnogongrus Griffithsic.

Back River near Monument Beach (A. W. Evans).

July 27, I 896 (Evans).

Specimen in herbarium of Bureau of Fisheries.

Actinococcus peltaformis Schmitz.

Rare, epiphytic on Gymnogongrus norveqicus. Dredged by the Survey in 7 fathoms off Gay Head at station 56 , over sand and gravel.

Vineyard Sound: Gay Head 56, few on Gymnogongrus norvegicus.

Summer.

Actinococcus subcutaneus (Lyngbye) Schmitz.

Common, epiphytic on Phyllophora Brodici. Dredged by the Survey in 4 to ${ }_{5}$ fathoms, over sandy and stony bottoms. Distribution scattered in Vineyard Sound, but may be expected in both Bay and Sound wherever Phyllophora Brodici occurs.

Vineyard Sound: Westerly portion $-75^{83}$ and 7595, few. Narrow portion-752I bis, many; $75^{22}$ bis, few; $75^{24}$ bis, few; $75^{25}$ bis, many. Inshore-Nonamesset 8, few; Naushon 9 and Io, few; Cuttyhunk 32,33 , and 34 , many; Marthas Vineyard 61,62 , and $6_{3}$, many.

Summer.

Ahnfeldtia plicata (Turner) Fries. [Chart 249.]

Common, on stones and loose over the bottom in fairly deep water. Dredged by the Survey in I to $I_{4}$ fathoms (most plentiful in 7 to $I_{3}$ fathoms), over sandy, shelly, and stony bottoms. Distribution chiefly in lower portion of Buzzards Bay and westerly portion of Vineyard Sound, and also off East and West Chop.

Woods Hole: Near Devils Foot Island. Nobska, Cuttyhunk. Black Rock.
Ahnfeldtia plicata-Continued.

Buzzards Bay: Lower portion-7638, few; 7656 . few. Inshore-Sow and Pigs IIr, few; Cuttyhunk II2, few; Gull Island II6, many. Drifted fragments, 79, 82 .

Vineyard Sound: Westerly portion-7593, 7598, and 7599 , few; 77 I 8 , one; 7720 , few; 7721 , one; 7724 and 7725 , few. Narrow portion- 7524 bis and $75^{2} 5$ bis, few. Easterly portion -7760 , one. Inshore-Robinsons Hole 2 I and 22, few; Sow and Pigs 36 , few; Gay Head 50 and 51 , considerable; 44 and 46 , few; 47 , many; 48 , few; 49 , considerable; 6o, few; also off Devils Bridge August I7, I903, hauls I and 2, few; Marthas Vineyard 55, few; 69, two.

Spring, summer, probably at all seasons.

Farlow, 1873, p. 290, Gay Head.

Chondrus crispus (Linnæus) Stackhouse. Irish moss. [Chart 250.]

Very common, on stones and rocks at low-water mark and below. Dredged by the Survey in I to I9 fathoms (most plentiful in 4 to 12 fathoms), over sandy, shelly, and stony bottoms. Widely distributed throughout Vineyard Sound and in the lower portion of Buzzards Bay; less plentiful in the upper portion of the Bay.

Woods Hole: Wharves and harbor walls, Grassy Ledge, Juniper Point, Buzzards Bay shore. Nobska. Tarpaulin Cove. Black Rock.

Buzzards Bay: Upper portion-76ro, few. Lower portion- 7656 and 7659 , many; $766_{3}, 766_{5}$, few; 7668 , one; 7670 , few; 7672 , one; 7673 , one. Inshore-Sow and Pigs III, many; Cuttyhunk 100 and I12, many; I02, few; Gull Island II6, many; Nashawena 79 and 80, few; Naushon 87. few; Weepeckets ro8, few; Penzance I23, many; Gunning Point I 30 , one. Drifted fragments, $765^{2}$. 
Chondrus crispus-Continued.

Vineyard Sound: Westerly portion-7566, 758 I (1907), 7582,7583,7584,7585,7589,7591, and 7596, few. Narrow portion-752I ( 1907 ), many; $75^{23}$ bis, $75^{24}$ bis, and $75^{2} 5$ bis, few; 7533 bis, many; 7536 , one; 7537 , one; 7542 bis, few; 7546 , one; $7553,7554,7554$ bis, $7560,7561,75^{62}, 773^{2}$, 7739, and 7746, few; 7749, many. Easterly portion-7759, few; 7760 , one; 7763 (r9o7), few; 7764 , very many; 7765 , few; 7766 , many; 7767 , few; 7768, many; 7769, 7770, 777 I, 7772 and 7777 , few; 7779 and 7781 , few; Inshore-passage of Woods Hole II8, few; I2I, many; Great I.edge, Woods Hole 4, few; Nonamesset I and 2, many; 3 and 8, few; Naushon 5, one; Robinsons Hole 20, 21, 22, and 23, many; Pasque 24, ferv; 25 and 26, many; Quicks Hole 29, few; Nashawena 30 and 31 , few; Cuttyhunk 32 and 34 , many; 38 , few; Sow and Pigs 35 and 36 , few; Gay Head 50 and 5 I, very abundant; $44,45,46$, $47,48,49,56,57$, and 58 , many; $59,60,75^{8} \mathrm{I}$ bis, and $773 \mathrm{I}$ bis, few; also Devils Bridge August I 7 , I903, hauls 3 and 4, many; Menemsha Bight August 9, r904, few; Marthas Vineyard 62, 63 , and 64 , few; 67 , many; 68 , few, 76 , few; 776 I (1907), few. Drifted fragments, 7570,770 , $7774, I_{3}, I_{4}, I_{5}$.

At all seasons.

Farlow, 1873, p. 290, Gay Head, Woods Hole.

Gymnogongrus Griffithsice (Turner) Martius.

Occasional, on stones.

Back River near Monument Beach (A. W. Evans).

July 27,1896 . (Evans.)

Specimen in herbarium of Bureau of Fisheries.

Gymnogongrus norvegicus (Turner) J. Agardh.

Rare. Dredged by the Survey off Gay Head at station 56 in 7 fathoms; attached to stones over a sandy bottom.

Vineyard Sound: Westerly portion-Gay Head 56 , few on stones.

Summer.

Phyllophora Brodici (Turner) J. Agardh. [Chart, 25r.]

Common, on stones well below low-water mark, frequently growing in sand and mud. Dredged by the Survey in $I_{1} / 2$ to $I_{5}$ fathoms (most plentiful in 4 to ro fathoms), over sandy, shelly, and stony bottoms, occasionally over mud. Very widely distributed throughout both the Bay and Sound.

Buzzards Bay:-Upper portion-76ro, 7611,7613 , $761_{4}, 761_{5}, 7617,7618,7627$, and 7654 , few. Lower portion-7656, many; 7663,7672 , and
Phyllophora Brodici-Continued.

7673 , few. Inshore-Sow and Pigs III, many; Cuttyhunk 100, I0I, and I03, few; II2, many; cove west of Cuttyhunk Neck July 27, 1905, many; Penikese II3, many; II4, few; Gull Island II5, few; II6, many; Nashawena 80, few; Pasque 82,83 , and $8_{5}$, few; Naushon 86 and $9 \mathrm{I}$, many; Uncatena II7, many; Weepeckets I08, few; rog, one; I Io, few; Penzance I22, one; Scraggy Neck I44, many; I45 and I 47 , few. Drifted fragments, $7621,7622,7629$.

Vineyard Sound: Westerly portion $-75^{8} 3,75^{8} 4$, $759 \mathrm{I}, 7595,7596$, and 7598, few. Narrow portion- $75^{2} \mathrm{I}$ bis, many; $75^{22}$ bis, few; $75^{23}$ and $75^{24}$, many; $75^{24}$ bis and $75^{2} 5$, few; $75^{2} 5$ bis, many; 7526 (I907), many; 7530, one; 7532, one; 7533 bis, many; 7534 , few; 7535 , one; 7536 , one; 7536 bis, $7537,7541,7542$ (I907), 7547, 7547 bis, 7548 and 7739 , few; 7744 , one; 7749 , few. Easterly portion-7763 (1907) and 7766, few. Inshore-Great Ledge 4, few; Nonamesset, I many; 2, 3, and 8, few; Naushon 5, 7, 9, and 10, few; I2, one; I6, many; Robinsons Hole 20, 21 , and 22, many; Quicks Hole 27, many; Nashawena 30 and 31 , many; Cuttyhunk 32,33 , and 34, many; 38 , few; Sow and Pigs 35 , few; 36 , many; $3 \%$, few; Gay Head 44, few; 45, many, $46,47,48$, and 49 , few; 56,57 , and 58 , many; 59 , few; also off Devils Bridge August I7, I903, hauls $I$ and 2, few; 3 and 4, many; Menemsha Bight July I 7, I 905, haul 2, few; Marthas Vineyard 52 and 55 , few; 61 and 62 , few; 63 , many; 65 and 66 , few; 69, many; 71 , many; $73,74,76$, and 77 , few. Drifted fragments, $7582,75^{88}$.

Summer, winter, undoubtedly at all seasons.

Farlow, I873, p. 290, Gay Head; Farlow, I88I, p. I45, Woods Hole.

Phyllophora Brodicei var. catenata (Lyngbye) Areschoug.

Occasional. Dredged by the Survey off Nobska at station $752 \mathrm{I}(\mathrm{Ig07})$ in 8 to ro fathoms, over coarse sand.

Vineyard Sound: Narrow portion-7521 (1907), many.

August 9, r907.

Phyllophora membranifolia (Goodenough \& Woodward) J. Agardh. [Chart 252.]

Common, on stones, well below low-water mark, frequently growing over sand. Dredged by the Survey in 3 to 17 fathoms (most plentiful in 4 to ro fathoms), over sandy, shelly, stony, and muddy bottoms. Very widely distributed throughout both the Bay and Sound. 
Phyllophora membanifolia-Continued.

Buzzards Bay: Upper portion-7610 (I907), $762 \mathrm{I}$ (1907), 7630, 7630 (1907), 7631 and 7632 , few; 7635 , many; 7639 (1907), few. Lower portion7657 , few; 7659, many; 7660 , few; 7662 , many on holdfasts of Laminaria; 7663 (I907), 7664 , 7666,7672 (I907), and 7675 ; few. InshoreSow and Pigs III, many; Cuttyhunk I00, many; IOz and I03, few; II2, many; Penikese, II3 many; Gull Island II5, few, II6, many; Nashawena 79 and $8 \mathrm{r}$, few; Pasque $82,83,84$, and 85 , few; Naushon 86 and 87 , many; 89 , one; 90 , one; 91 , many; 92 , few; 96 , many; Uncatena II7, many; Weepeckets I08, many; 109, one; IIo, few; Penzance I23, many; I24, few; Quisset I26, few); I28, many; I30, few; Hog Island Point $\mathrm{I}_{34}$, many; Hog Island Harbor I35, few; North Falmouth I37, many; Nyes Neck I40, one; I4I, many; Sconticut Neck 163, few; off Apponaganset Bay 165 , few; Mishaum Point 167 , few. Drifted fragments, $76 \mathrm{r} 8,7633,7634$, $765 \mathrm{r}, 78$.

Vineyard Sound: Westerly portion-7706, one; 77 10, few; 77 19, one; 7722 , one; 7725 , few; 7729 , few. Narrow portion-752x bis, many; $75^{23}$ bis, few; $75^{24}$ bis, few; $75^{2} 5$ bis, very many; 7530 bis, few; $753 \mathrm{I}$ bis and 75.33 bis, many; 7542 bis, 7543 (I907) and 7549 (I907), few; 7739 and 7740 , many; 7741 , few; 7742 , many; 7743 , two; 7744, many; 7745 , few; 7749, many; $775^{2}$, few; 7754, one. Easterly portion-7755, one; $7759,7760,7764,7765,7766,7768$, and 7769 , few; 7770 , many; 7772 and 7774 , few; 7775 , many; 7780 , one; 7782 , few; 7783 , one. Inshore-Robinsons Hole 22 and 23, many; Pasque 24, 25, and 26, many; Nashawena 30 , many; Cuttyhunk 33, many; Gay Head 56, 57 , and 58 , many; 60, few; Marthas Vineyard 64 , 65 and 66 , few; 67 , many; 68, few; 69, many; 74 and 77 , few; 7761 , many; Vineyard Haven 7762 , few. Drifted fragments, 7682,7779, I3.

Summer, winter, undoubtedly at all seasons.

Farlow, 1873, p. 290, Gay Head.

Sterrocolax decipiens Schmitz. (Taxonomic position uncertain).

Occasional, parasitic on Ahnfeldtia plicata.

Woods Hole. Washed ashore at Nobska. Spring, summer.
Family RHODOPHYLLIDACEAE.

Agardhiella tenera (J. Agardh) Schmitz. [Chart 253.]

Common, on stones and shells in fairly deep water. Dredged by the Survey in 2 to $I_{5}$ fathoms (most plentiful in 4 to Io fathoms), over sandy, shelly, stony, and muddy bottoms. Very widely distributed throughout both Bay and Sound.

Woods Hole: Entrance to Eel Pond, off Grassy Ledge in ship channel. Black Rock.

Buzzards Bay: Upper portion- $761_{5}, 2$ on sulphur sponges; 7632 , one; 7645 , one; 7648 , many on shells; 7649 and 7650 , few. Lower portion7661 , one. Inshore - Cuttyhunk roo and ro3, few; Penikese II $_{3}$, few; Gull Island Ir6, few; Uncatena II7, many; Weepeckets I08, few; Penzance I23 and I24, few; Quisset I28, few; 129 and I3o, many; West Falmouth I 32 , many; I33, few; Hog Island Point I34, many; Hog Island Harbor I35, few; North Falmouth ${ }_{13} 6$ and I37, many; Nyes Neck I4I, many; Cataumet Harbor I42, many; Scraggy Neck 145, many; Bassetts Island $I_{4} 6$, very many on shells, Wings Neck 147, many; I48, three; 150 , few; Great Hill I54, few; Cromeset Neck 158, many; Wareham River $1_{55}, I_{56}$, and $\mathrm{I}_{57}$, few; Sconticut Neck 163 and r64, few; Mishaum Point 167 , few. Drifted fragments $7612,761_{4}$, 76 I6, 7646 .

Vineyard Sound: Westerly portion-7728, one; 7730 and 7734 , few; 7735, one. Narrow portion7525 bis, many; 7533 , one; 7533 bis, few on sulphur sponges and stones; 7535 , one; 7536 , one; 7537 and 7540 , few; 754 I, one; 754 I bis and 7542 , few; 7543 bis, one; 7553 , few; 7559 , one; 7562 and 7733 , few; 7744, 7751, 7753, 7754, one each. Easterly portion- 7755 , one; 7758 , one; 7760 , 7763,7763 (I907), 7764 and 7765 , few; 7766 , few on shells; 7766 (ז907), 7771, 7772, 7775 and 7777 , few; 7778 , many on stones and shells; 7779 , $7780,7781,7782$, and 7783 , few. Inshore-passage of Woods Hole I2I, many; Nonamesset I, two; 8 , many; Naushon 7 , two; 9 , three; Tarpaulin Cove I7, few; also July I8, I903, haul 2, few; Quicks Hole 28, two; Nashawena 30, two; Cuttyhunk 33 and 38 , few; Menemsha Bight 53 and 54, many; August 9, 1904, few; July I7, I905, haul 1 , many; Marthas Vineyard 52, many; 55 , few; 6r, 62, 65, and 68, few; 69, many; 73 
Agardhiella tenera-Continued.

and 74, few; 77, many; 776r, many; Vineyard Haven $70,71,72$ and 7762 , many. Drifted fragments, 7548 .

Summer, undoubtedly at other seasons.

Farlow, 1873 , p. 289 (Solieria chordalis J. Agardh), Woods Hole; A. A. B. Ex., fas. IV, no. I43, (Rhabdonia tenera J. Agardh), Woods Hole (W. G. Farlow).

Cystoclonium purpurascens (Hudson) Kützing. [Chart 254.]

Common, attached to stones in fairly deep water. Dredged by the Survey in $2 \frac{1}{2}$ to 13 fathoms (most plentiful in 4 to ro fathoms), over sandy, shelly, and stony bottoms, occasionally over mud. A scattered distribution through Vineyard Sound and in the lower portion chiefly of Buzzards Bay.

Woods Hole: Entrance to Eel Pond, Grassy Ledge, Juniper Point. Nobska.

Buzzards Bay: Upper portion- $-76_{53}$ and 7654 , few. Lower portion-7656, 7659, and 7680 , few. Inshore-Cuttyhunk 104, one. Drifted fragments, 7616 .

Vineyard Sound: Westerly portion-7720, one; 7729 , few. Narrow portion- $75^{24}$ bis, two; $75^{2} 5$ bis, 7542 (I907) and 7549 (I907), few. Easterly portion- 7760 , one. Inshore-passage of Woods Hole Ir8, few; Nonamesset 8, many; Robinsons Hole 20 and 22, many; Pasque 25, many; Quicks Hole 29, few; Nashawena 30 , one; Cuttyhunk 33 and 34, many; Gay Head 44, 49, 56, 57,58 , and 59, many; 6o, few; Marthas Vineyard 52,62 , and $6_{3}$, few.

Summer.

Farlow, r873, p. 290, Gay Head, Woods Hole.

Cystoclonium purpurascens var. cirrhosum Harvey. [Chart 255.]

Common, on stones and larger algæ i, fairly deep water. Dredged by the Survey in $\mathrm{I}$ to 17 fathoms (most plentiful in 4 to 12 fathoms), over
Cystoclonium purpurascens var. cirrhosum-Con. sandy, shelly, and stony bottoms, occasionally over mud. Distribution chiefly in the lower portion of Buzzards Bay and westerly portion of Vineyard Sound.

Buzzards Bay: Upper portion -7639 and 7653 , few. Lower portion-765I (rgo7), 7656, 7659, 7662 (I907), $7663,7664,7666,7672$, and 7673 , few. Inshore-Sow and Pigs III, many; Cuttyhunk I00, many; I02, few; II2, many on Phyllophora; Cove west of Cuttyhunk Neck July 27, I905, many; Penikese II3, many; Gull Island II5, few; II6, many; Nashawena 8o, few; Pasque 82 and 85 , few; 83 , many; Naushon 86, many. Drifted fragments, 7665 . Vineyard Sound: Westerly portion-758r (1907), $75^{8} 5,7601,7676$, and 7678 , few; 7686 , one; 7692 and 7693 , few; 7703, I on Rhodymenia; 7706, one; 7707 , many; 77I 7 , few; 7718, many; 7719, one; 7722 , one; 7730 , many. Narrow portion $-75^{23}$, few; 7534, one; 7740, one; 39, few. InshoreNonamesset I, one; 8 , few; Robinsons Hole 20 and 22, many; Pasque 24 and 25 , many; Quicks Hole 27, few; Cuttyhunk 32, 33, and 34, many; Sow and Pigs 35 , one; 36 and 37 , few; Gay Head 50 and $5 \mathrm{I}$, considerable on bottom; $44,45,46$, $47,48,49,5^{6}, 5^{8}$, and 59 , many; $60,75^{8}$ I (r907) and $773 \mathrm{I}$, few; 773I ( 1907 ), many; also Devils Bridge August I7, 1903, haul I, few; hauls 2, 3 , and 4, many; Menemsha Bight 53 and 54, few; August 9, I904, few; July I7, 1905, haul 2, many; Marthas Vineyard $5_{2}$ and 63 , few. Drifted fragments, $7572,7677,7700$.

Summer.

Euthora cristata (Linnæus) J. Agardh.

Rare, on stones in 8 to Io fathoms off Gay Head (Farlow).

August and September I, I873 (Farlow).

Farlow, I876, p. 698, dredged off Gay Head; Farlow, I88I, p. I53, I54, Gay Head in 8 or 10 fathoms.

\section{Order RHODYMENIALES.}

\section{Family SPHAEROCOCCACE正.}

Gracilaria confervoides (Linnæus) Greville.

Occasional, on muddy shores.

Mattapoisett (Collins).

September I4, I902 (Collins).

Collins, 1903, p. 232, Mattapoisett; P. B.-A., fas. xxI, no. I04I, in dense tufts, floating, Mattapoisett, September I4, I902 (F. S. Collins).
Gracilaria multipartila (Clementi) Agardh.

Occasional, on stones, sandy and muddy bottoms. Dredged by the Survey in 2 to $I_{4}$ fathoms (most plentiful in 4 to Io fathoms), over sandy and stony bottoms. Distribution chiefly at inshore stations in the narrow portion of Vineyard Sound.

Woods Hole: Entrance to Eel Pond. Hadley Harbor (W. G. Farlow). 
Gracilaria multipartita-Continued.

Buzzards Bay: Inshore-Pasque 84, one; Quisset Harbor 127. one.

Vineyard Sound: Narrow portion -7554 bis, one. Easterly portion - 7766, one. Inshore-passage of Woods Hole I2 I, many; Great Ledge, Woods Hole 4, few; Nonamesset I, few; 2 , many; 3 , few; 8, many; Naushon 5, 9, and ro, few; I2, one; Devils Bridge, Gay Head August I7, 1905, hauls 3 and 4, few; Marthas Vineyard 61, 62, 63 , and 68 , few.

Summer.

Farlow, I873, p. 289, Woods Hole, Hadley Harbor.

Gracilaria multipartita var. angustissima Harvey. Occasional, on sandy and muddy bottoms.

Woods Hole: Entrance to Eel Pond, Little Harbor.

Summer.

Hypnea musciformis (Wulfen) Lamouroux.

Occasional, in fairly deep water.

Woods Hole: Off Juniper Point on rocky bottom at a depth of 3 to 4 fathoms (Nott). Black Rock. Frequently washed ashore in Little Harbor, at Nobska, and along the Falmouth shore.

Summer.

Farlow, r873, pp. 283, 289, Woods Hole, Nobska, Falmouth shore; Farlow, 1875, p. 366, Woods Hole; Farlow, 1876, p. 697, Woods Hole; A. A. B. Ex., fas. rv, no. I44, Woods Hole (W. G. Farlow); P. B.-A., fas. IV, no. I96, off Juniper Point (Butlers Point), Woods Hole, August 26, 1895 (C. P. Nott).

\section{Family RHodymeniace.}

Champia parvula (Agardh) Harvey. [Chart 256.] Common on stones, Zostera, and larger algæ, frequently lying loosely on the bottom. Dredged by the Survey in I to I 9 fathoms (most plentiful in 4 to I2 fathoms), over sandy, shelly, stony, and muddy bottoms. Very widely distributed throughout both Bay and Sound.

Woods Hole: Grassy Ledge, Juniper Point. Nobska. Tarpaulin Cove. Black Rock.

Buzzards Bay: Upper portion-76ro (1907), many; 7648, few on algæ; 765 I (I907), few; 7653 and 7654 , many on algæ; 7630 ( I 907 ), few. Lower portion -7656 and 7657 , few; $766 \mathrm{r}$, many; 7662 and 7663 , many; 7664 , few; 7668 , one; 7670 , one; 7671 , few; 7672 , one. Inshore-Cuttyhunk 100, few; Gull Island i16, many; Naushon 96, one; Uncatena Ir 7 , many on Phyllophora; Weepeckets ro9, one; Penzance 123, many; Quisset I28, many on Phyllophora; I29, few; I30, many;
Champia parvula-Continued.

Gunning Point $\mathrm{I}_{3} \mathrm{I}$, many; Hog Island Point I34, many; Hog Island Harbor 135, many; North Falmouth $\mathrm{r}_{3} 6$ and $\mathrm{I}_{37}$, many; $\mathrm{r}_{3} 8$, one; I39, one; Nyes Neck I4I, few; Cataumet Harbor 142, few; Scraggy Neck 144, one; Wings Neck I48, few; I5o, one; Cromeset Neck I58, few; off Apponaganset Bay 165, few. Drifted fragments, $7627,7658,166$.

Vineyard Sound: Westerly portion-7566, 7567, 7568,7569 , and 7571 , few; 7572 , many; 7574 , $7575,7576,7578,7588$, and 7676 , few; 7703 , one; 7724 , many; 7725 , few; 7728,7729 , and 7734 , few. Narrow portion-7521, one; 752 I ( 1907 ), few; $75^{23}$ bis, one; $75^{25}, 75^{25}$ bis, 7526 ( 1907 ), and 7533 bis, few; 7534 , one; $754 \mathrm{I}$, one; $754 \mathrm{I}$ bis, 7542,7542 (I907), 7543 ( 1907$), 7546$ and 7547 , few; 7549 bis, one; 7549 ( 1907$)$, many; 755I, 755 I ( 1907$), 7553,7554,7554$ bis, 7557 , $7559,7560,75^{62}$, and 7565 bis, few; $773^{2}$ and 7733, many; 7739, few on Phyllophora; 7741, few; 7745 , many; 7746 , few; 7749 , many; $775^{2}$, many on Phyllophora; 7753, few; 7754, many. Easterly portion-7756, 7757, 7758, 7759, 7760, 7763 , and 7763 (1907), few; 7764 , many; 7765 , $7766,7767,7769,7770$, and 7771 , few; 7772 , one; 7774 one; 7775, many on Phyllophora; 7776 , many; $7777,7778,7779,7780,7780$ (I907), $7781,7782,7783$, and 7783 (1907), few. Inshore-passage of Woods Hole I22, few; Nonamesset I, one; 8, one; Naushon 6, one; Tarpaulin Cove July 18, I903, haul I, few; Robinsons Hole 20, 2I, and 22, few; Cuttyhunk 38, few; Gay Head $5^{\circ}$ and 5 , few on bottom; 44, 46, and 47 , few; 49, many; also off Devils Bridge August 17, 1903, hauls I and 2, few; Menemsha Bight July 17 , I905, haul 3 , few; Marthas Vineyard $61,62,6_{3}$, and 64, few; 67 and 68 , many on Zostera and large algæ; 73, many; 74, 75, 76 , and 77 , few; $776 \mathrm{r}$, many; Vineyard Haven 70,71 , and 72 , many, some on Crepidula shells; 7762 , many. Drifted fragments, $753^{\circ}, 7677$, 7736 .

Summer.

P. B.-A., fas. vr, no. 290, Little Harbor, Woods Hole, July, 1893 (W. A. Setchell); P. B.-A., fas. XII, no. 592, Edgartown, August, 1897 (M. W. Jernegan).

Lomentaria rosea (Harvey) Thuret. [Chart 257.]

Occasional, on stones, shells, and larger algæ in deep water off exposed points. Dredged by the Survey in 4 to 13 fathoms, over sandy, shelly, and stony bottoms. Distribution restricted in the summer to the westerly portion of Vineyard Sound, chiefly off Gay Head and Sow and Pigs. 
Lomentaria rosea-Continued.

Vineyard Sound: Westerly portion-7593, few; 7708, one; 7709, one. Inshore-Sow and Pigs 37 , few on Phyllophora; Gay Head 45, few on Phyllophora and other algæ; 56 , few; 57 and 58, many; 59, few.

Summer.

Farlow, 1873, p. 291 (Chylocladia rosea Harvey), Devils Back, Gay Head, 8 to ro fathoms; Farlow, 1875 , p. 37 I (Chylocladia rosea Harvey), Gay Head; Farlow, I876, p. 698, Gay Head; Farlow, 188I, p. 155, Gay Head; A. A. B. Ex., fas. I, no 17 , Gay Head (W. G. Farlow); P. B.-A., fas. XXV, no. I24I, off Gay Head in 7 to I2 fathoms, August I5, I904 (B. M. Davis and Miss L. J. MacRae).

Lomentaria uncinata Meneghini. (Chart 258.]

Common, on stones, wharves, frequently growing loosely over sand, below low-tide mark and in fairly deep water. Dredged by the Survey in $I^{1 / 2}$ to 15 fathoms (most plentiful in 4 to 10 fathoms), over sandy, shelly, and stony bottoms. Distribution scattered in the upper portion of Buzzards Bay and the narrow and easterly portions of Vineyard Sound.

Woods Hole: Entrance to Eel Pond, Grassy Ledge, Little Harbor. Weepecket (Farlow), Black Rock.

Buzzards Bay: Upper portion $-76_{32}$ and 7653 , few. Lower portion- $767 \mathrm{I}$ and 7675 , few. Inshore-Gull Island in6, few; Weepecket ro8, few; Gunning Point 13 $_{3}$, many; West Falmouth I32, few; I33, one; Hog Island Point I34, many; Hog Island Harbor 135, few; North Falmouth I36, few; 137, many; 138, one; Nyes Neck I4I, few; Scraggy Neck I44, few; I45, many; Bassetts Island 146 , many; Wings Neck 147 and I48, few; I50, many; off Aucoot Cove I60, few; Mishaum Point 167 , few. Drifted fragments, 7628.

Vineyard Sound: Westerly portion- 7734 and 7735 , few. Narrow portion- 7537 and 7548 , few; $755^{1}$, one; 7557 and 7733 , few; 7751 , one. Easterly portion-7757, one; 7759 , few; 7760 , many; $7763,7764,7766,7777,7778,7781$, and 7782 , few. Inshore-passage of Woods Hole $I 18$, few; Robinsons Hole 21 and 22, few; Pasque 24, one; Marthas Vineyard 6r and 64, few; 69, many; 76 , few on larger algæ; 7761 , many; Vineyard Haven 70,71 , and 72 , many; 7762 , many.

Summer.

Farlow, 1873 , p. 290 (Chylocladia Baileyana Harvey), Woods Hole, Buzzards Bay, Weepecket.
Rhodymenia palmala (Linnæus) Greville. Dulse. [Chart 259.]

Common, on stones and larger algæ in fairly deep water off exposed points. Dredged by the Survey in I to I9 fathoms (most plentiful in 4 to I2 fathoms), over sandy, shelly, and stony bottoms. Distribution chiefly in the lower portion of Buzzards Bay and westerly portion of Vineyard Sound.

Wharf at Gay Head.

Buzzards Bay: Upper portion- 7653 , few; 7656 , one. Lowrer portion- $7664,7665,7666,7667$, 7670 , and $767 \mathrm{I}$, few. Inshore-Sow and Pigs III, few on mussel shells; Cuttyhunk II 2 , few on mussel shells. Drifted fragments, 7654, I04.

Vineyard Sound: Westerly portion-7567, 7569, $7578,75^{82}, 75^{84}, 75^{8} 5,7588$, and 7591 , few; 7593 , few on Laminaria; 7595, 7701, 7703, and 7708, few; 7718, many on Desmarestia; 7719, one; 7720, I on Chondrus; 7723, few; 7724, one; 7728 and 7729 , few. Narrow portion-7530 bis, few. Easterly portion--7755, one. Inshore-Robinsons Hole 21 and 22, many; Pasque 25 and 26, few; Quickes Hole 27, many; Sow and Pigs 36 , few; Gay Head 50 and $5 \mathrm{r}$, few; 44, few; 45,46 , and 47 , many; 48 , few; 59 , many; 60 , few: 773I (1907), few; also off Devils Bridge, August 17 , rgo3, hauls 3 and 4, many; Marthas Vineyard 52, few; 776r, one. Drifted fragments, $755 \mathrm{I}, 7717,15$.

Spring, summer, undoubtedly at all seasons.

Farlow, 1873 , p. 290, Gay Head, Woods Hole.

\section{Family DELESSERIACEAE.}

Delesseria sinuosa (Goodenough \& Woodward) Lamouroux. [Chart 260.]

Occasional, on larger algæ and sometimes stones, in fairly deep water off exposed points. Dredged by the Survey in $I \frac{1}{2}$ to 17 fathoms (most plentiful in 4 to 12 fathoms), over sandy, shelly, and stony bottoms. Distribution practically restricted to the lower portion of Buzzards Bay and westerly portion of Vineyard Sound.

Buzzards Bay: Lower portion- 7664 , few. Inshore-Sow and Pigs Ir , few; Cuttyhunk roo, few on Phyllophora; Penikese Ir 3 , few.

Vineyard Sound: Westerly portion-7582, 759r, 7593 , and 7595, few; 7690,7692 , and 7693 , few; 7701, many; 7703, few; 7709, one; 7719, many on Phyllophora; 7720, many; 7721, 2 o. Phyl. lophora. Narrow portion-39, few. InshoreCuttyhunk 32 and 33, many on Phyllophora; 
Delesseria sinuosa-Continued.

34, few on Phyllophora; Sow and Pigs 35 and 36 , considerable; Gay Head 45, many; 46, few; 56,57 , and 58 , many; 773 I, one; also off Devils Bridge August 17, 1903, haul I, few; hauls 2 and 3 , many.

Summer, probably at other seasons.

Farlow, I873, P. 289, Gay Head, No Mans Land.

Grinnellia americana (Agardh) Harvey. [Chart 26I.]

Common, on stones, shells, and wharves below low-water mark. Dredged by the Survey in 2 to 19 fathoms (most plentiful in 4 to I 2 fathoms), over sandy, shelly, stony, and muddy bottoms. Very widely distributed throughout both the Bay and Sound.

Woods Hole: Govermment wharves Little Harbor. Black Rock.

Buzzards Bay: Upper portion-76I5, 2 on sulphur sponges; 7621 , many; 7624 and 7625 , few; 7628 and 7629 , many; $7630,7632,7634,7635$, and 7639 , few; 7648 , many; 7649 and 7653 , few; Lower portion- 7660 and 7661 , few; 7663 , many; 7670 , one; 7671 , many; 7675 , few. InshoreCove west of Cuttyhunk Neck July 27, I905, many; Penikese II4, few; Gull Island Ir6, many; Nashawena 8o, many on Crepidula shells; Pasque 84 , many; 85 , few; Naushon 9o, few on Phyllophora); Uncatena II7, few on Phyllophora; Weepeckets I08, many on Phyllophora; Penzance I23, many; I24, one; Quisset I26, one; I30, few; Gunning Point I3I, few; West Falmouth $\mathrm{I}_{32}$ and $\mathrm{I} 33$, few; Hog Island Point I34, many; Hog Island Harbor 135 , few; North Falmouth I36, many; I37, few; Scraggy Neck I44, few; Bassetts Island r46, few; Wings Neck I47, few; I48, many; I50,
Grinnellia americana-Continued.

two; Great Hill I54, few; Cromeset Neck I58, many; Wareham River $\Upsilon_{55}$ and 156 , few Sconticut Neck 163 and I64, few; Mishaum Point 167 , few. Drifted fragments, 7620 , $7645,7647,145$.

Vineyard Sound: Westerly portion $-7575,7576$, and 7589 , few 7724 , one; 7725 , few; 7727 , one; 7729 , few; 7730 , one; 7734 and 7735 , many; 7736 ; one. Narrow portion-7521, one; 7521 (1907), and $75^{2} 5$ bis, few; $75^{2} 7$, few on sulphur sponges; $753 \mathrm{I}$ bis and 7536 , few; $7537,7539,7540$, one each; 754I, few; 7542, many; 7546 and 7547 , few; 7549 , one; $755 \mathrm{I}, 7553,7554,7556$ bis, 7557 , $7559,7560,7562$ and 7732 , few; 7733 , very many; 7737, one; 7741, one; 7753, few. Easterly portion-7755, few; 7756 , one; $775^{8}$, one; 7759 , $7760,7763,7764,7766,7767,7768,7771,7772$, 7774 , and 7775 , few; 7776 , one; $7777,7778,7779$, $7780,7781,7782$, and 7783 , few. Inshore-passage of Woods Hole I22, few; Great Ledge, Woods Hole 4, two; Nonamesset I, 2 , and 3 , few; 8, many; Naushon 5 and 7 , many; 9, few; Tarpaulin Cove I7, few; also July I8, I903, haul, I few; Pasque 25, few; Cuttyhunk 33, few; Gay Head 49, one; 56, many; 758I, one; also off Devils Bridge August $\mathrm{I}_{7}, \mathrm{I}_{9} \mathrm{O}_{3}$, haul 3 , few, haul 4, many; Menemsha Bight 53 and 54, few; Marthas Vineyard 55 and $6 \mathrm{I}$, few; 63 , many; 64 , few; 65 , many; 66 and 67 , few; 77 , many; 7761 , few; Vineyard Haven 70 and 71 , many; 72 , few; 7762 , many on shells. Drifted fragments $7544,7548,756 \mathrm{r}$.

Summer.

Farlow, 1873, p. 288, Woods Hole, Edgartown, Buzzards Bay; A. A. B. Ex., fas. II, no. 64 , Woods Hole (W. G. Farlow).

\section{Order CRYPTONEMIALES.}

Family GLoiosiphoniace,

Gloiosiphonia capillaris (Hudson) Carmichael.

Occasional.

Mattapoisett (F. S. Collins).

May 30, 1905 (Collins).

\section{Family NEMASTOMACE,}

Nemastoma Bairdii Farlow.

Rare. Known only from a single specimen washed ashore at Gay Head in August, 1871 (Farlow).

Farlow, 1873, p. 290 (Nemalion multifidum J. Agardh), "a specimen bearing tetraspores picked up at Gay Head"; Farlow, I875, p. 372 (Nemastoma? Bairdii n. sp.), Gay Head; Farlow, 1876, p. 702 (? Nemastoma Bairdii Farlow), Gay Head; Farlow, I88I, p. I42 (Nemastoma? Bairdii Farlow), Gay Head.

\section{Family RHIZOPHYLLIDACEA.}

Polyides rotundus (Gmelin) Greville. [Chart 262.] Common, on stones in fairly deep water. Dredged by the Survey in $\mathrm{I}^{1} / 2$ to 15 fathoms (most plentiful in 4 to ro fathoms), over sandy, shelly, and stony bottoms, occasionally over mud. A scattered distribution in both Bay and Sound, but not present in the extreme upper portions of Buzzards Bay.

Buzzards Bay: Lower portion- 7659 , many; 7660 and 7666 , few. Inshore-Cuttyhunk 100 and Ior, few; Penikese Ir3, many; I14, few; Gull Island II5, few; I16, many; Nashawena 78 , 79, and 8I, few; Pasque 82, few; 83 , many; 84 and 85 , few; Naushon 86 and 9I, many; Weepeckets 108, few; I09, one; Hog Island Point 134 , one. Drifted fragments 7613,7652 . 
Polyides rotundus-Continued.

Vineyard Sound: Westerly portion-7701, one; 7717 , few. Narrow portion-7526 (1907), few; 7532 bis, one; 7533 bis, few; 7536 , one; 754 I bis, few; 7548 , one; 7560 , few; 7749 , one; 7751 , one; 7752 , many. Easterly portion $-7759,7766$ and $75^{81}$ ( 1907 ), few. Inshore-Nonamesset $x$ and 3, few; Pasque 24, many; 25, few; Nashawena 30 and 31 , many; Cuttyhunk 32,33 , and 34 , many; $3^{8}$, few; Gay Head 44 , few; 46,47 , and 48 , many; $56,57,5^{8}$ and 60 , few; $75^{8}$ I (I907), few; also off Devils Bridge August I7, I903, hauls I and 2, few; Marthas Vineyard 55, 62, 68, 69, 73, 74, and 77 , few; 7761 , one.

Summer.

Farlow, I873, p. 290, Gay Head.

\section{Family SouAMARIACEE.}

Rhododermis Georgii (Batters) Collins. (Taxonomic position uncertain).

Abundant, on Zostera in company with Myrionema vulgare, Hecatonema maculans, etc.

Woods Hole: Little Harbor (Collins).

April 23, Ig05 (Collins).

Collins, r9o6b, p. I60, Woods Hole.

P. B.-A., fas. Xxvi, no. I299, Woods Hole, April 23, I905 (F. S. Collins).

Family CoRAlimace,

Corallina officinalis Linnæus. [Chart 263.]

Common, on stones and rocks below low-tide mark and in fairly deep waters. Dredged by the Survey in 2 to $13 \frac{1}{2}$ fathoms (most plentiful in 4 to ro fathoms), over sandy, shelly, and stony bottoms. Distribution chiefly in the lower portion of Buzzards Bay and westerly portion of Vineyard Sound.

Woods Hole: Juniper Point, Buzzards Bay shore. Nobska. Black Rock.

Buzzards Bay: Lower portion $-766_{3}$, many. Inshore-Sow and Pigs III, many; Cuttyhunk I00, I0r, and II2, few; Penikese II3, few; Gull Island II6, many; Weepecket Io8, few. Drifted fragments, $8_{2}, 83,99$.

Vineyard Sound: Westerly portion $-7566,75^{8} 3$, and 7596, few. Narrow portion-753I bis, many. Inshore-Robinsons Hole 20, two; 21 , few; Quicks Hole 29, few; Nashawena 30 , many; Cuttyhunk 32,34 , and 38 , many; Sow and Pigs 35, few; 36, many; 37, few; Gay Head 44 and 45 , few; 47 , many; 48 , few; 56 and 57 , many; $5^{8}$ and 6o, few; $75^{81} \mathrm{I}$, few; also off Devils Bridge August 17, I903, hauls I and 2, few; Marthas Vineyard $5_{2}$ and 63 few. Drifted fragments, 39,7726 .

Summer, winter, undoubtedly at all seasons.

Farlow, I873, p. 288, Woods Hole, Gay Head.
Hildenbrandia prototypus Nardo. (Taxonomic position uncertain.) [Chart 264.]

Common, on stones and rocks near low-tide mark and in fairly deep water. Dredged by the Survey in $1 / 2$ to 14 fathoms (most plentiful in 4 to ro fathoms), over sandy, shelly, and stony bottoms. A scattered distribution in both Bay and Sound, chicfly at inshore stations.

Woods Hole: Grassy Ledge, Juniper Point, Buzzards Bay shore. Nobska. Tarpaulin Cove. Black Rock.

Buzzards Bay: Inshore-Sow and Pigs III, many; Cuttyhunk го2, few; Gull Island Iı6, many: Pasque 82, few; Naushon 9r, few; Hog Island Point 134, many; Cataumet Harbor I42, few.

Vineyard Sound: Narrow portion -7533 bis, few; 7544 bis, 7546 bis, and 7547 bis, many; 7747 , few. Easterly portion- $7757,7759,7760,7766$, 7777,7778 , and 7780 , few. Inshore-Robinsons Hole 2 I and 22, many; Quicks Hole 28, few; Gay Head $5^{8}$ and 59, many; also off Devils Bridge August I7, I903, hauls 3 and 4, many; Menemsha Bight July I7, I905, haul I, one; haul 3 , few; Marthas Vineyard 62 and 63 , few; 65 , many; 66, few; 69, many; 73 , many; 74 and 77 , few; Vineyard Haven 7o, few.

Summer, undoubtedly at all seasons.

Farlow, 1873 , p. 290 (Hildenbrandtia rubra Meneghini), Woods Hole.

Lithothamnion polymorphum (Linnæus) Areschoug. [Chart 265.]

Common, on stones and shells in fairly deep water. Dredged by the Survey in 2 to 15 fathoms (most plentiful in 4 to ro fathoms), over sandy, shelly, and stony bottoms. A scattered distribution in both Bay and Sound.

Buzzards Bay: Upper portion-762I, one. Lower portion-7659, few. Inshore-Sow and Pigs III, many; Gull Island II6, many; Nashawena $8 \mathrm{r}$, one; Pasque 85 , one; Weepeckets 108 , few; Penzance 123 , many; Quisset I28, many; West Falmouth $\mathrm{I}_{32}$, many; Hog Island Point 134 , many; Mishaum Point 167 , many.

Vineyard Sound: Narrow portion-7524 bis, 7525 bis, 7533 bis, many; 7534 , few; 7534 bis and 7535 bis, many; 7539 and 7539 bis, few; 7544 bis, many; 7752, few. Easterly portion-7757, few; 7760 , many; 7763 (1907), $7764,7766,7767,7769$, 7772 , and 7778 , few. Inshore-Nonamesset 3 , few; Naushon 5, one; Robinsons Hole 2r, many; Quicks Hole 28, one; Sow and Pigs 35, few; Gay Head 57, 58, 59, and 60, many; Marthas Vineyard 52 , few on shells; $62,63,65,66$, $69,73,74$, and 77 , few; Vineyard Haven zo few. Summer, winter, undoubtedly at all seasons. 
Melobesia farinosa Lamouroux.

Common, on Fucus vesiculosus, Chondrus, Phyllophora, and Zostera, at low-tide mark and in fairly deep water. Dredged by the Survey in $3 \frac{I}{2}$ to II I $/ 2$ fathoms, over sandy and stony bottoms. A scattered distribution at inshore stations along Marthas Vineyard.

Woods Hole: Juniper Point. Nobska. Gay Head.

Vineyard Sound: Inshore, Gay Head 57 and $5^{8}$, many on Chondrus and Phyllophora; Marthas Vineyard 69,75 , and 76 many on Zostera.

Summer.

Farlow, 1881, p. 180, 18ז, Woods Hole; P. B.-A., fas. IV, no. 200, Woods Hole, August I3, I 895 (W. A. Setchell and W. J. V. Osterhout).

Melobesia Lejolisii Rosanoff.

Very common, on Zostera both in shallow and fairly deep water. Dredged by the Survey in 2 to $I 2 \frac{1}{2}$ fathoms, over sandy, stony, and muddy bottoms. A scattered distribution in Vineyard Sound where Zostera is found, undoubtedly also present along the shore of Buzzards Bay.

Woods Hole: Grassy Ledge, Eel Pond, Little Harbor. Quisset Harbor. Tarpaulin Cove.

Vineyard Sound: Westerly portion-7728 and 7729 , many. Narrow portion $-75^{2} 5$ bis, many. Easterly portion- 7777 and 7779 , many; 7780 and 7782 , few. Inshore-Great Ledge, Woods Hole, 4, many; Quicks Hole 29, many; Menemsha Bight, August 9, I904, abundant; Marthas Vineyard 6r, 62, and 63, many; 64 , few; 67, 60, 73,75 , and 76 , many; 77 , few; Vineyard Haven 70 and 72 , few. Drifted fragments, 7543 bis, 7565 bis, $7737,57,59$.

Summer.

Farlow, r88 r, p. I80, Woods Hole.

Melobesia membranacea (Essper) Lamouroux.

Occasional, on Chondrus and Phyllophora in fairly deep water. Dredged by the Survey in
Melobesia membranacea-Continued.

$3^{x} / 2$ to 10 fathoms, over sandy and stony bottoms. Distribution chiefly in the lower portion of Buzzards Bay and westerly portion of Vineyard Sound.

Buzzards Bay: Lower portion -7672 , many on Chondrus. Inshore-Sow and Pigs III, many on Chondrus and Phyllophora; Cuttyhunk roo, many on Phyllophora; ro3, few.

Vineyard Sound: Narrow portion-7739, few on Phyllophora. Inshore-Gay Head 56, 57, and 58, many on Chondrus and Phyllophora; Marthas Vineyard 63 and 65 , few on Phyllophora.

Summer.

Melobesia pustulata Lamouroux.

Common, on Ascophyllum, Chondrus, and Phyllophora, at low-tide mark and in fairly deep water. Dredged by the Survey in $I \frac{1}{2}$ to $I 4$ fathoms, over sandy, shelly, and stony bottoms. Distribution chiefly off Cuttyhunk, Sow and Pigs, and Gay Head, but also in the easterly portion of Vineyard Sound.

Woods Hole: Little Harbor. Tarpaulin Cove. Weepecket (Farlow).

Buzzards Bay: Inshore-Cuttyhunk II2, many. Vineyard Sound: Westerly portion-7582, many on Chondrus. Easterly portion -7764 and 7765 , few; 7768 and 7770 , many on Chondrus. Inshore-Cuttyhunk 32, 34, and 38, many on Chondrus; Sow and Pigs 36 , many on Chondrus; Gay Head 44, few; 45, 46, 47, and 49, many on Chondrus and Phyllophora; 57, few on Chondrus and Phyllophora; also off Devils Bridge, August I7, I903, hauls 3 and 4 , many on Chondrus.

Summer.

Farlow, 1873, p. 288, Woods Hole, Gay Head, Weepecket; P. B.-A., fas. vI, no. 300 , I.ittle Harbor, Woods Hole, July 3I, I895 (W. A. Setchell).

DISTRIBUTION OF ZOSTERA MARINA IN THE DEEPER WATERS OF BUZZARDS BAY AND VINEYARD SOUND.

Zostera marina Linnæus. Eelgrass. [Chart 266.]

Abundant, in quiet shallow waters along the shore. Dredged by the Survey in 2 to 13 fathoms, over sandy, stony, and muddy bottoms. Distribution in the deeper waters chiefly at inshore stations along Marthaś Vineyard, but scattered in other portions of Vineyard Sound, and also in Buzzards Bay.

Woods Hole: Shallow water of Great and Little Harbors, Eel Pond, Grassy Ledge, Ram Island, Devils Foot Island. Hadley Harbor. Quisset Harbor. Tarpaulin Cove. Menemsha Bight. Cuttyhunk Harbor.

Buzzards Bay: Lower portion-7663, much; 7674 and 7675 , few. Inshore-Cuttyhunk Harbor I04,

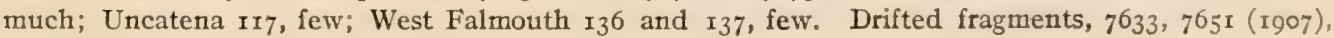
$7653,7657,745^{8}, 79$, I $_{5}, \mathrm{I}_{50}, \mathrm{I}_{5} \mathrm{I}, \mathrm{I}_{52}, \mathrm{I}_{53}, \mathrm{I}_{5} 6, \mathrm{I}_{5} 8, \mathrm{I} 6 \mathrm{r}$.

$$
\text { r } 6269^{\circ}-\text { Bull. } 3 \mathrm{I}, \text { pt } 2-\mathrm{r} 3-\mathrm{rg}
$$


Vineyard Sound: Westerly portion -7728 and 7729 , few. Narrow portion -7525 bis, few. Easterly portion- $7777,7778,7779,7780$ and 7781 , much; 7782 and 7783 , few. Inshore-Great Ledge, Woods Hole 4, few; Tarpaulin Cove I7, few; also July I8, r903, haul I, much; Quicks Hole 29, few; Marthas Vineyard 61,62, and 63, much; 64, few; 65, much; 66, few; 67, much; 68, 69, 70, 72, 73, 74, 75, 76, and 77 , few. Menemsha Bight August 9, I904, much. Drifted fragments 7543 bis, 7546, 7547, 7548, $755^{1}$ $7557,7562,7565$ bis, 7588,773 x, 7733, $7737 \cdot 7740,7775,57,59$.

Summer, the creeping stems living throughout the winter.

MARINE ALGE WHICH MAY BE EXPECTED IN THE WATERS OF WOODS HOLE AND VICINITY.

There is given below a list of marine algæ which have been reported sufficiently near to the region covered by this survey, and under sufficiently similar life conditions, to indicate that they are likely to be found sooner or later in the waters of Woods Hole or vicinity.

CYANOPHYCEA:

Dermocarpa violacea Crouan.

Lyngbya lutea (Agardh) Gomont.

Lyngbya subtilis Holden.

Nodularia spumigena var. litorea (Kützing) Bornet \& Thuret.

Plectonema terebrans Bornet \& Flahault.

Rivularia Biasolettiana Meneghini.

Spirulina Meneghiniana Zanardini.

CHLOROPHYCEA:

Chlorocystis Cohnii (Wright) Reinhart.

Enteromorpha marginata J. Agardh.

Entoderma Wittrockii (Wille) Lagerheim.

Monostroma latissimum (Kützing) Wittrock.

Urospora penicilliformis (Roth) Areschoug.

PHAOPHYCEA:

Eclocarpus dasycarpus Kuckuck.

Halothrix lumbricalis (Kützing) Reinke.

Myriotrichia claveformis Harvey.

Rhadinocladia cylindrica Schuh.

RHODOPHYCE A:

Bangia ciliaris Carmichael.

Melobesia Corallince Crouan.

\section{BIBLIOGRAPHY FOR FLORAL CATALOGUE.}

The following is a list of references in the Catalogue to the occurrence of marine plant species at Woods Hole and vicinity.

Collins, I. S.:

I884. Notes on New England marine algæ, IV. Bulletin of the Torrey Botanical Club, vol. xI, p. 130. New York.

1890. Brachytrichia Quoyii (Ag.) Bornet and Flahault. Ibid., vol. xvII, p. 175 .

1891. Notes on New England marine algæ, V. Ibid., vol. XviII, p. 335.

I8g6a. Notes on New England marine algæ, VI. Ibid., vol. XXIII, p. I.

1896b. Notes on New Ėngland marine algæ, VII. Ibid., vol. Xxim, p. $45^{8}$.

I899. To seaweed collectors. Rhodora, vol. I, p. I2r. Boston.

I900. Preliminary lists of New England plants. V. Marine algæ. Ibid., vol. II, P. 4I.

1903. Notes on algæ, VI. Ibid., vol. v, p. 23r.

I906a. Notes on algæ, VII. Ibid., vol. vIII, p. I22.

1906b. Notes on algæ, VIII. Ibid., vol. vin, p. I57.

igo6c. Acrochætium and Chantransia in North America. Ibid., vol. vili, p. 189.

1908. Two new species of Acrochætium. Ibid., vol. $x$, p. 133 . 
FARLOW, W. G.:

1873. List of the seaweeds or marine algx of the south coast of New England. Report U. S. Commission of Fish and Fisheries, $187 x-72$, p. 28x. Washington.

1875. List of the marine algx of the United States. Proceedings American Academy of Arts and Sciences, vol. $\mathrm{x}, \mathrm{p} .35 \mathrm{I}$. Boston.

1876. List of the marine algæ of the United States. Report U. S. Commission of Fish and Fisheries, $1874-75$, p. 691 . Washington.

1881. The marine algæ of New England. Ibid., I879, p. I-210, pl. I-XV.

1882. Notes on New England algæ. Bulletin of the Torrey Botanical Club, vol. Ix, p. 65. New York.

1893. Notes on some algæ in the herbarium of the Long Island Historical Society. Ibid., vol. $\mathrm{xx}, \mathrm{p} .107$.

HERVEY, A. B.:

1882. Arthrocladia villosa, Duby. Bulletin of the Torrey Botanical Club, vol. Ix, p. 126. New York.

PeTERS, J. E.:

1885. Arthrocladia villosa, Duby. Bulletin of the Torrey Botanical Club, vol. xir, p. 62. New York.

ScHü, R. E.:

Ig00a. Rhadinocladia, a new genus of brown algæ. Rhodora, vol. II, p. III. Boston.

1900b. Notes on two rare algæ of Vineyard Sound. Ibid., vol. 11, p. 206.

1901. Further notes on Rhadinocladia. Ibid., vol. III, p. 218.

SETCHELL, W. A.:

1896. Notes on Cyanophyceæ. I. Erythea, vol. IV, p. 87.

1899. Notes on Cyanophycex. III. Ibid., vol. vir, p. 45.

1900. Critical notes on the New England species of Laminaria. Rhodora, vol. II, p. II 5 and 142. Boston.

PUBLISHED SETS OF ALGE.

Colins, F. S., Holden, I., ANd Setchell, W. A.

Phycotheca Boreali-Americana. Malden.

Farlow, W. G., ANDERson, C. L., and Eaton, D. C.

Algæ Americanæ Boreales Exsiccatæ. Cambridge.

WITTROCK, V., AND NORDSTEDT, O.

Algæ Aquæ Dulcis Exsiccatæ. Lund. 

[Synonyms in italics.]

Abictinaria abietina

Page.

Abudcfduf saxatilis.

Acanthias americanus.

Acanthobothrium coronatum.

Acanthobothrium paulum.

Acanthocephala

Acanthocheilus nidifex.

Acanthocottus ancus.

Acanthocottus grondlandicus..

A canthocotius octodecimspinosus.

Acanthocottus variabilzs.

Acanthodoris pilosa.

Acartia tonsa

Achirus fasciatus.

Achirus lineatus.

Achirus mollis.

Achrochate repens

Acilius fraternus.

Acineta divisa.

Acineta tuberosa

Acinetida.

Acipenser brevirostris.

Acipenser brevirostrum.

Acipenseridæe

Acipenser oxyrhynchus.

Acipenser sturio.

Acmæa alveus.

Acmrea testudinalis.

Acmridx.

Acroblaste Reinschii.

Acrochretium Dasyæ.

Acrochatium Daviesii.

Acrochætium minimum. .

Acrochatium secundatum

Acrochætium virgatulum.

Acrocirrus leidyi.

Acteonida.

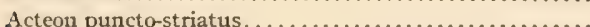

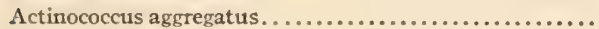

Actinococcus peltæformis.

Actinococcus subcutaneus

Actinophrys sol. .

Actinopoda.

Actinozoa.

Adelochorda.

Egina longrcornis.

AE ginella longicornis.

Eginclla longicornus

Flurehthys marnus . .

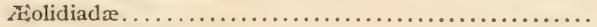

Aiolidia papillosa. . . . . . . . . . . . . . . . . . . . . .

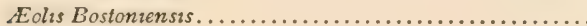

Eolis despecta.

Eolis gymnota.

Eolis papillosa.

Eolis pilata. .

Eolis salmonacea.

Eiquorea albida.

Equoreida.

Aischna

Atea anguina.
Fage.

Fteidx

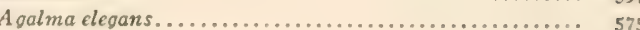

Agalmidx.

Agamonema capsularia....................... 592

Agamonema papilligerus....................... 592

Agardhiclla tenera........................... 825

Agarum Turueri............................ $8 \mathrm{rc}$

Aglantha conica.............................. 574

Aglantha digitalis.......................... 574

Aglaophenia arborea........................... 574

Aglaophenia minuta...................... 573

Aglaophenia struthionoides....................... 574

Aglaurida................................. 574

Ahnfeldtia plicata............................. $8_{23}$

Alaria esculcnta............................ 810

Albula vulpes............................. 741

Albulidx......................................

Alca torda............................... 775

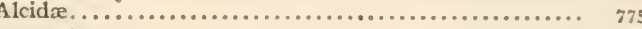

Alcyoniidx.................................. 576

Alcyonidiidx............................... 605

Alcyonidium gelatinosum...................... 606

Alcyonidium hirsutum......................... 606

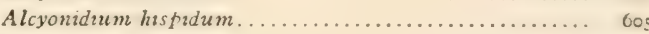

Alcyonidium mytili.............................. 606

Alcyonidium parasiticum.................... 6... 609

Alcyondium ramosum.......................... 605

Alcyontdium rubrum.......................... 606

Alcyonidium verrilli.......................... 605

Alcyonium carneum........................ 576

Alderia harvardiensis..........................

Alebion glaber.................................. 642

Alebion glabrum................................ $6_{42}$

Alebion gracile................................. $6_{42}$

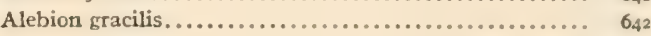

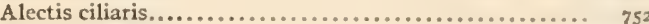

Alectryonidx.............................. 708

Alexia myosotis............................ 706

Algæ....................................... 797

Aligena elevata.............................. $6 \varepsilon_{9}$

Alle alle.................................. $\quad 776$

Allorchestes littoralis........................ 648

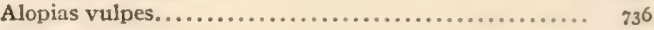

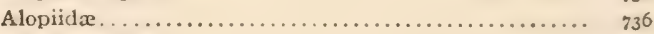

4 losa menhaden............................. 742

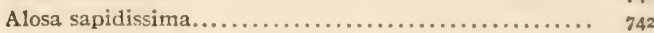

Alteutha depressa................................. $6_{39}$

Alutera cuspicauda............................ $76_{2}$

Alutera monoceros........................... $7 \mathbf{7 6}_{2}$

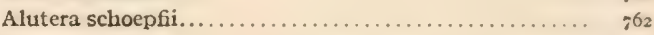

A mage pusilla............................... $6{ }_{2} \mathrm{~S}$

A marccium constellatum....................... $\quad 733$

A marccum pallidum ...................... 732

A maracium pellcidum ...................... 732

A niarcium stellatum ........................ 733

Amaroucium glabrum......................... ${ }_{233}$

A maroucum pallidum . .................... 732

Amaroucium pellucidum................... 732

Amaroucium pellucidum constellatum............ $\quad 733$

Amaroucium stellatum ...................... 733

Amathia dichotoma.......................... 606

Ammochares artifex......................... 626 
Ammocharidæ.

Page.

Ammodytes americantus

Ammodytes dubius.

Ammodytidx

Ammotheidx.

Ammotrypane fimbriata.

Amobra.

Amocba guttula. .

Amouroucium constellatum.

A mouroucium stellatum.

Ampelisca agassizi.

Ampelisca compressa .

Ampelisca macrocephala.

Ampelisca spinipes.

Ampcliscidx.

A mpharete gracilis...

Ampharete setosa.

Ampharetidx. .

Amphictenidx.

Amphidinium operculatum.

Amphineura.

Amphinome pallasii

Amphinomidx...

Amphioplus abdita

Amphipholis elcgans.

Amplipholis squamata

Amphipoda...

Amphiporidr.

Amphiporus bioculatus.

Amphiporus cruentatus.

Amphiporus glutinosus

Amphiporus ochraceus..

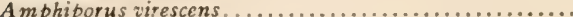

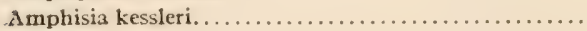

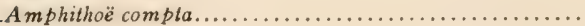

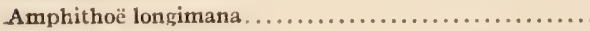

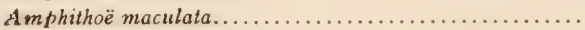

Amphithoë rubricata.

Amphithuë zalida...

Amphithrix violacea .

Amphitrite attenuata

Amphitrite cirrata.

Amphitrite ormata.

Amphiurida

Anabæna torulosa......................... ${ }_{79} 8$

Anachis avara............................... 710

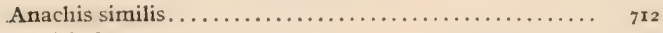

Anaitis formosa............................ 616

Anaitis picta............................. 616

Anaitis speciosa............................... 616

Anaperus gardineri. ...................... $\quad 58 \mathrm{r}$

Anaphia.................................. $6_{77}$

Anarhichadidx............................. 768

Anarhichas lupus.......................... $\quad{ }_{768}$

Anas boscas.................................. ${ }_{778}$

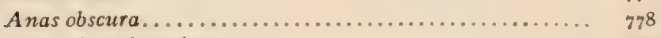

Anas platyrhynchos...................... $\quad 778$

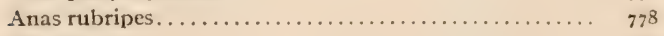

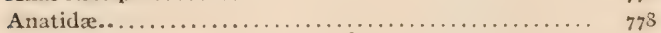

A nalina papyracea........................... 699

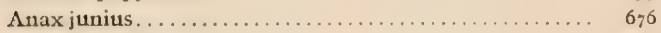

Anchorella uncinata.

Anchovia argyrophanus.

Anchovia brownii.

Anchovia mitchilli.

Ancmonia sagassensis.
Page

A nouilla chrysypa............................ 740

Anguilla rostrata...................... 740

Anguillidæ.............................. 740

Anguinella palmata......................... 606

Angulus modeslus......................... 694

Angulus tenellus................................... 694

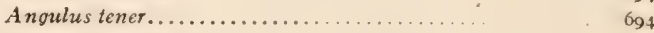

Anisonema vitrea...................... 553

Annulata......................... $6 \mathbf{r}_{5}$

Anomalocera pattersonii...................... $6_{3} 8$

Anomia aculeata........................... $6{ }_{79}$

A nomia electrica............................ 678

A nomia ephippium..................... 678

A nomia glabra..................... 678

Anomia simplex.......................... 678

Anomiidæ....................... 678

Anonyx nobilis................................ 649

Anonyx nugax..................... 648

Anoplobranchus sanguincous................. 628

Anoplodactylus lentus...................... 677

Anoplophrya branchiarum................... 554

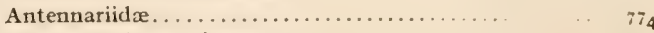

Antennularia americana................ 573

Antenntalaria antennina.................. . 573

Antheacherida......................... 643

Antheidæ............................... 577

Anthobothrium laciniatum .................. 585

Anthobothrium pulvinatum.................. 585

Anthocephalum gracile......................... ${ }_{585}$

Anthophysa formosa....................... 575

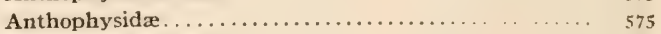

Anthosoma crassum. ....................... 643

Anthostoma acutum.......................... $6_{23}$

Anthostom a fragile............................. 624

Anthostoma robustum....................... 624

Anthura branchiata......................... $6{ }_{5} 8$

Anthura brunnea.......................... ${ }_{5} 8$

Anthura polita................................ 658

Anthura tenuis............................... 658

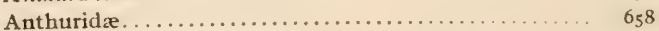

Antithamnion americanum................... $8 \mathrm{r} 4$

Antithamnion cruciatum ................... $8 \mathbf{1}_{4}$

Antithamnion cruciatum var, radicans............ $8 \mathbf{r} 4$

Antithamnion plumula .................... $8 \mathbf{1}_{\mathbf{4}}$

Antithamnion pylaisai ..................... $8 \mathbf{1 5}$

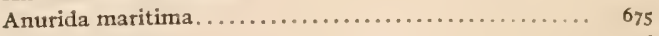

A peltes quadracus. ............................ 746

Aphanostoma aurantiacum ................... ${ }_{5} 80$

A phanostoma diversicolor. ..................... ${ }_{580}$

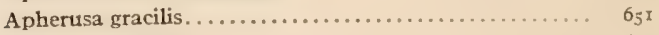

Aphrodita aculeata. ......................... 619

Aphrodita hastata.......................... 619

Aphroditidæ........................... 6ro

Aplidium pallidum..................... $\quad 732$

A plysia willcoxi........................ 704

Aplysidiæ................................. 704

A pogon americanus............................ 755

A pogon imberbus............................. 755

A pogon maculatus. ........................... $\quad 755$

Appendicularia............................ 734

Appendiculariidx......................... 734

A rabella opalina ............................ 622

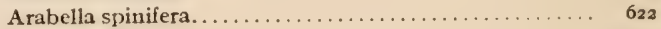

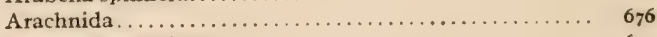

Arbacia punctulata.......................... $6 \mathrm{II}$

Arbaciidæ. .............................. $6 \mathbf{r}$

Arca campechiensis pexata.................... 685 
Page

Arca pexala....

Arca ponderosa.

Arca transversa.

Archosargus probatocephalus.

Arcidre.................

Arcularia vibex.

Arenaus cribrarius. .

Arenicola cristata. .

Arenicola marina.

Arenicolidie..

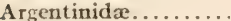

Argina pexala

Argulidx.

Argulus alosæ.

Argulus fund vil.

Argulus laticauda..

Argulus latus

Argulus megalops.

Aroyreiosus capillaris.

A ricia ornata.

Ariciidæe. .

Artacolax saetiger.

Artemia grzilis

Arthrocladia villosa.

Arthropoda. .

Ascaris acanthocaudata

Ascaris adunca.......

Ascaris brevicapitata

Ascaris capsularia. .

Ascaris clavata . . . . . . . . . . . . . . . . . . . . . . .

Ascaris habena.

Ascaris increscens. .

Ascaris incurva.

Ascaris inquies.

Ascaris neglecta. .

Ascaris rigida. .

Ascaris rotundata.

A scidia carnea....

Ascidia complanata.

Ascidia manhattensis.

Ascidia tenella.

Ascoclyclus orbicularis.

Asconidx. .

Ascophyllum nod

Ascortis f ragilis.

Asperococcus echinatus .

Aspidisca hexeris.

Aspidisca polystyla.

Assiminea grayana

Assiminea modesta

Assimineida..

Astarte castanea

Astarte quadrans.

Asturle sulcala.

Astarte undata.

A starte uniata lutea.

Astartidxe. .

Astasia contorta .

Astasiidæ.

Asterias arenicola.

Asterias austera.

Asterias tenera......................................

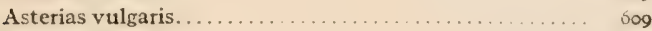

Asteriidx.

Asteroidea.

Astræidae.

Astrangia danx.

l'age.

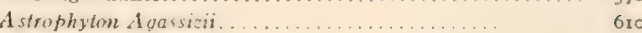

Astrorhiza limicrla................ . . .

Astrorhizidx................. . . . . . 549

Astyris lunata ...............

Astyris rosacea......................

Astyris zonalis............... . . . . .

Atherinidx................. . 747

Athlennes hians . . . . . . . . . . . . . .

Atylidx................. 652

Aurelia flavidula ................. . 575

Auriculidæ............................. 706

Autolytus cornutus . . . . . . . . . . . . . . . . .

A utolytus emertoni................... 516

Autolytus mirabilis............................ 615

Autolytus ornatus. ................... 616

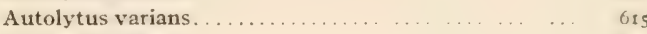

Autonoë smithi...................................... 653

Auxis thazard ......................... . $\quad 749$

Aves................................

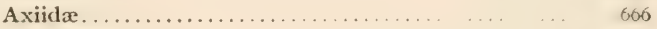

Axius serratus . . . . . . . . . . . . . . . . . 666

Balæna glacialis. . . . . . . . . . . . . . . . . . . . . .

Balænidæ................................ $7_{80}$

Balænoptera acuto-rostrata.................... $78 x$

Balænoptera musculus.... . . . . . . . . .

Balzenoptera physalus...................... $-3 t$

Balanidæ............................... 6.4

Balanoglossus aurantiacus . . . . . . . . . . . . . . . . . $7_{2} 8$

Balanoglossus Kowalevskii...................... ${ }_{728}$

Balanus amphitrite ........... $6+4$

Balanus balanoides. . . . . . . . . . . . . . . . . . . 646

Balanus crenatus. . . . . . . . . . . . . . . . . . 646

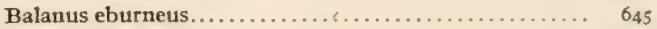

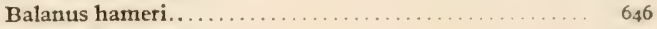

Balanus porcatus. ............................ 646

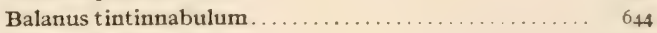

Baliste carolinensis..................... 76 I

Balistes forcipatus. . . . . . . . . $76 \ldots \ldots \ldots \ldots \ldots \ldots \ldots$

Balistes poiselli........................... ${ }_{76 \mathbf{r}}$

Balistes vetula.......................... $76 \mathrm{r}$

Balistidæ................................ $76 \mathrm{r}$

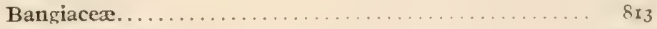

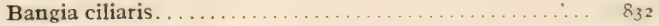

Bangia fusco-purpurea ........................ $8 \mathbf{I}_{3}$

Bangiales............................... 813

Barentsia discreta.........................

Barentsia major......................... 596

Barnea costata............................ Tor

Barnca truncata.......................... ;or

Batea secunda........................... $65 \mathrm{r}$

Bateidre . . . . . . . . 6 .

Bathyluca solaris . . . . . . . . . . . . . . . . 575

Batrachoididæ.......................

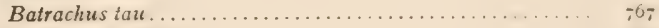

Bdelloura candida. ...................... 580

Bdelloura propinqua....................... 5 \$o

Bdellouridx............................

Bela harpularia .......................

Bela pleurotomaria..........................

Bela plicafa............................

Belone latimanus.......................... 745

Belone longirosiris........... . . . . . . .

Belone truncata.......................... 744

Beroë cucumis . . . . . . . . . . . . . . . . . . 579

Beroë ovata........................ 579

Beroidz................................ 579

578 Berosus peregrinus........................... 676 
Bicellaria ciliata

Bicellariidæ

Bidessus discretus.

Biloculina elongata.

Biloculina ringens.

Biloculina ringens striatella.

Biloculina tubulosa

Bittium alternatum.

Bittium grecnii.

Bittium nionum.

Blepharichthys crinitus.

Bodo caudatus. .

Bodo globosus.

Bodonida.

Bodotriidx

Bolina alata

Bolinidx.

Bolivina punctata.

Boltenia burkhardti.

Boltenia ovifera..

Bomolochus teres...

Bopyridre.

Boreoscala grœnlandica.

Bostrichobranchus molguloides

Bothus maculalus

Botryllidx.

Botryllus gouldii.

Botryllus schlosseri.

Bougainvillia autumnalis

Bougainvillia carolinensis.

Bougainzillia gibbsi.

Bougainvillia superciliaris

Bougainvilliidæ.

Bowerbankia gracilis

Bowerbankia gracilis caudata

Brachiclla ramosa..

Brachiclla rostrata. ...

Brachiella thynni.

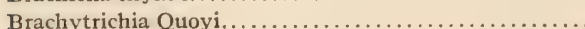

Brada setosa.

Brama raii.

Branchellion ravenclii.

Branchiobdella rancuelii....

Branchipodidx.

Branta bernicla glaucogastra......................

Branta canadensis..............................

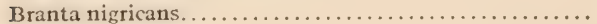

Brevoortia menhaden .............................

Brevoortia tyrannus............................

Brosme brosme ...................................

Brosmius brosme...............................

Bryopsidacex...............................

Bryopsis hypnoides.............................

Bryopsis plumosa..............................

Bryozoa......................................

Buccinidx...................................

Buccinum cincreum .............................

Buccinum undatum..............................

Buccinum vibcx.................................

Bugula avicularia...............................

Bugula cucullifera...............................

Bugula fiabellata..

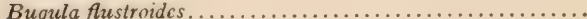

Bugula gracilis uncinata .........................

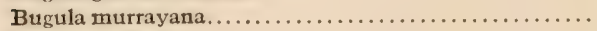

Bucula turrita.....

Bulbocoleon piliferum

Page.

598

598

676

550

$55^{\circ}$

550

$55^{\circ}$

$7 \times 7$

717

717

752

553

552

$55^{2}$
$66 \mathrm{x}$

579

579

$55 \mathrm{x}$

$73 \circ$

730

640

$66 \mathrm{I}$

754

729

773

$73 \mathrm{I}$

73 I

$73 \mathrm{I}$

563
Buliminidx

(20)

Bulla solitaria............................... $7^{04}$

Bullidæ..................................... $77_{4}$

Bursaridæ................................ 554

Busycon canaliculatum........................ $\quad 707$

Busycon carica............................... 708

Byblis agassizi.................................. $6_{50}$

Byblis serrata................................. $6_{50}$

Caberea ellisii................................ 598

Cæcidæ........................................ 718

Cæcum cooperi............................... 718

Cacum costatum............................ ${ }_{71} 8$

Cæcum johnsoni............................. 718

Cæcum pulchellum........................, ${ }_{71} 8$

Calanidæ.................................... $6_{3} 8$

Calanus finmarchicus........................... $6_{3} 8$

Calappa flammea............................... $6_{69}$

Calappa marmorata............................. 669

Calappidx................................... $65_{9}$

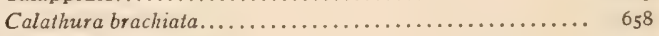

Calathura branchiata............................ 658

Caligidæ.................................. $64 \mathrm{I}$

Caligodes megacephalus......................... $6_{42}$

Caligus belones................................ 64

Caligus bonito ............................... $6_{4 I}$

Caligus chelifer............................... 64

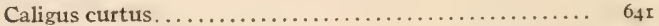

Caligus mutabilis.............................. $6_{4} \mathrm{I}$

Caligus pelanydis.......................

Caligus rapax.................................. $6_{44}$

Caligus rufimaculatus............................ $6_{4} \mathrm{r}$

Caligus schistonyx............................ $6_{44}$

Callianassa stimpsoni............................ 666

Callianassidx.................................. 666

Callinectes hastatus............................ $6_{772}$

Callinectes sapidus.......................... $6_{72}$

Calliobothrium eschrichtii...................... ${ }_{585}$

Calliobothrium verticillatum..................... $\quad 585$

Calliopiidx................................ $65 \mathrm{I}$

Calliopius læviusculus.......................... $6_{51}$

Calliopius rathkei............................... $65 \mathrm{I}$

Callista convexa ................................. $6_{92}$

Callithamnion Baileyi......................... 815

Callithamnion Baileyi var, laxum................. 815

Callithamnion Borreri.......................... $8 x 8$

Callithamnion byssoideum...................... 815

Callithamuion corymbosum.................... 8I5

Callithamnion cruciatum......................... $8 \mathrm{r}_{4}$

Callithamnion Dietzice.......................... $81_{5}$

Callithamnion plumula.......................... $8 \mathrm{r} 4$

Callithamnion Pylaisai.......................... $81_{5}$

Callithamnion roseum....................... 815

Callithamnion seirospermum...................... 818

Callithamnion tetragonum...................... 816

Callithamnion Turneri.......................... $8 \mathbf{1 8}$

Callithamnion versicolor......................... $8 \mathbf{8} 8$

Callocardia morrhuana........................... 692

Calothrix æruginea........................... 799

Calothrix confervicola............................ 799

Calothrix crustacea............................. 799

Calothrix fusco-violacea.......................... ${ }^{7} 799$

Calothrix parasitica............................. 799

Calothrix pulvinata............................... 799

Calothrix scopulorum............................ 799

Calycella nuttingi. ................................. 575

Calycella syringa............................ $57 x$ 
Calyptospadix cerulea

Page.

Calyptræidx...

Calyptrobothrium minus

Calyptrobothrium occidentale.

Campanularia amphora.

Campanularia angulata.

Campanularia calceolifera.

Campanularia edwardsi.

Campanularia fexuosa.

Campanularia hincksii

Campanularia minuta.

Campanularia neglecta.

Campanularia poterium.

Campanularia verticillata

Campanularia volubilis.

Campanulariidæ.

Campanulinidx.

Caucer borealis.

Cancer irroratus.

Cancridx.

Canthidermis asperrimus.

Canthidermis sobaco.

Capitella gracilis.

Capitellidx....

Caprella acutifrons

Caprella geometrica. .

Caprella linearis.

Caprellidæ.

Carangida.

Carangus bartholomæi

Carangus cry'sos. . .

Carangus hippos.

Caranx bartholomai.

Caranx chrysus.

Caranx crysos.

Caranx hippos.

Carcharhinus limbatus.

Carcharhinus milberti.

Carcharhinus obscturus.

Carcharias littoralis.

Carcharias obscurus.

Carchariidæ..

Carcharodon atweodi.

Carcharodon carcharias.

Carcinides mænas.

Carcinonemertes carcinophila .....................

Carcinonemertidæ. .

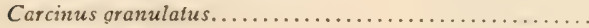

Carcinus manas.

Cardita borcalis.............................. 68

Carditid $x \ldots \ldots \ldots \ldots \ldots \ldots \ldots \ldots \ldots \ldots \ldots \ldots, 68_{7}$

Cardium ciliatum.................................... $6_{9 g}$

Cardium pinnulatum......................... 690

Caretta caretta.............................. $\quad 774$

Carinella pellucida.......................... 590

Carinellidx............................. 5590

Carinogammarus mucronatus.................. $6_{52}$

Carinoma tremaphoros........................ 590

Carinomidæ............................... 590

Castagnea virescens......................... Sog

Castagnea Zosteræ............................. 8o9

Caudina arenata ............................. 6I

Cavolina gymnota............................ 705

Cavolina tridentata........................ $\tau_{703}$

Cazolina trispinosa........................ 703

Cavolinidx.............................. $7_{703}$

Cecrops atreillii $\ldots \ldots \ldots \ldots \ldots \ldots \ldots \ldots \ldots \ldots \ldots \ldots, \quad 643$
Cellepora ramulosa........................................

Cellepora scabra

Cellularia peachii ............................. $5 g^{*}$

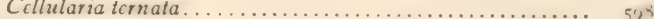

Ccllularia turrita............................. 5 ,

Cellulariidx................................ $59^{3}$

Centrolophide............................. 754

Centrolophus niger............................

Centrolophus pompilus......................... ist

Centropages hamatus........................... 6,8

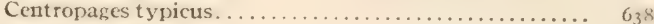

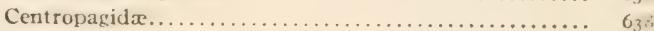

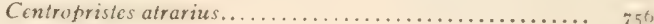

Centropristes striatus. . . . . . . . . . . .

Cenlrotristes zarius..............................

Centropristis fucus..........................

Centropristis nigricans.........................

Cephalacanthidx............................ 760

Cephalacanthus volitans....................... 766

Cephalopoda................................ $\quad 727$

Cephalothrix linearis......................... 590

Cephalotrichidæ............................. 590

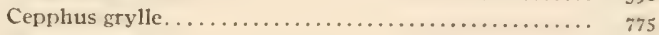

Ceramiaceæ..................................... $8_{I_{4}}$

Ceramiales.................................... $8_{I_{14}}$

Ceramium arachnoidcum........................... $8_{817}$

Ceramium botryocarpum ........................ 816

Ceramium capri-cornu.......................... $8_{16}$

Ceramium diaphanum........................... $S_{17}$

Ceramium fastigiatum........................ $8 \mathrm{n} 6$

Ceramium pedicellatum ...................... 816

Ceramium rubrum............................. 816

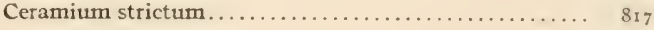

Ceramium tenuissimum........................... $8_{17}$

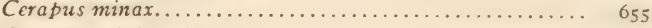

Cerapus rubricornis............................ 655

Cerapus tabularis............................... 655

Cerapus tubularis............................ 655

Ceratacanthus aurantiacus...................... $\quad 762$

Ceratium fusus. . . . . . . . . . . . . . . . . . . . . . . $\quad{ }_{553}$

Ceratium tripos............................. $\quad 553$

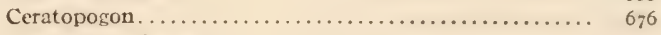

Cerebratulusfuscus............................ $59 \mathrm{I}$

Cerebratulus lacteus........................... 59I

Cerebratulus leidyi............................ 590

Cerebratulus luridus......................... 591

Cerebratulus marginatus....................... 591

Cerianthidx.............................. $55_{576}$

Cerianthus americanus....................... 576

Cerithiidæ.............................. ${ }_{717}$

Cerithiopsidæ............................

Cerithiopsis emersonii....................... 717

Cerithiopsis greenii......................... $i^{117}$

Ccrithiopsis terebralis.......................... $7_{717}$

Cerithium greenii............................ $\quad 717$

Cerithium terebrale.......................... $\quad 717$

Ceronia arctata................................. $69 \mathrm{~s}$

Cestidx................................... 579

Cestoda..................................... ${ }_{585}$

Cestus veneris . . . . . . . . . . . . . . . . . . . . . $\quad 579$

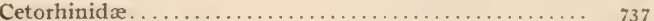

Cetor hinus maximus......................... 737

Chanopsetta oblonga........................ 7772

Chanopsetta ocellaris......................... $77 x$

Chætangiaceæ............................ $88_{14}$

Chætinopoma greenlandica...................... $6_{3}$ 
Chatobranchus sanquineous.

Chætodipterus faber.

Chatodon bricei

Chretodon capistratus.

Chrtodon ocellatus.

Chcetodon striatus.

Chatodontidx.

Chrtognatha.

Chatomorpha xea.

Chatomorpha Linum.

Chertomorpha litoria.

Chxtomorpha melagonium

Chatomor phe Picquotiana.

Chatomorpha sutoria.

Chatomorpha tortuosa.

Chatophoracex.

Chxtopleura apiculata.

Chatopoda.

Chatopteridze.

Chxtopterus pergamentaceus.

Chalina arbuscula.

Chalina oculata.

Chamæsiphonaceæ.

Champia parvula.

Chantransia corymbifera.

Chantransia Daviesii.

Chantransia efflorescens var. Thuretii.

Chantransia secundata.

Charitonetta albeola.

Charybdea verrucosa.

Charybdeidæ.

Cheilodipteridæ.

Cheloniida

Chelura terebrans.

Cheluridx...........

Chelydra serpentina.

Chelydridæ.

Chernes oblongus.

Childia spinosa.

Chilichthys turgidus.

Chiliferidæ..

Chilodon cucullulus.

Chilomycterus antillarum.

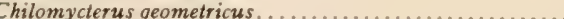

Chilomycterus schoepfi.

Chiridotea creca.

Chiridotea tuftsii.

Chironectes lavigatus...

Chironomus halophilus

Chirostoma notata.

Chiton apiculatus .

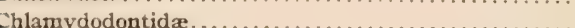

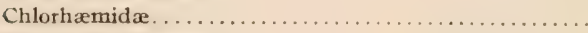

Chloridella empusa.

Chloridellid $x$.

Chlorocystis Cohnii

Chlorophycex. .

Choanoflagellata.

Chondracanthidse.

Chondracanthus galeritus. . . . . .

Chondracanthus merluccii . . . . . . . . . . . . . . . .

Chondracanthus phycidis. . . . . . . . . . . . . . . . . . .

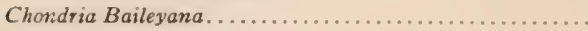

Chondria dasyphylla. .

Chondria dasyphylla var. sedifolia.....................

Chondria littoralis.
Page.
Page.

Chondria sedifolia...................... 8 I9

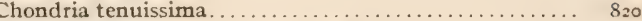

Chondria tenuissima var. Baileyana ............. 830

Chondrus crispus . . . . . . . . . . . . . . . . . . . . 823

Chorda filum.............. 8 ro

Chorda tomentosa . . . . . . . . . . . . . . . . . . 810

Chordariacex ............................. 809

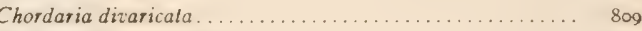

Chordaria flagelliformis. ..................... 809

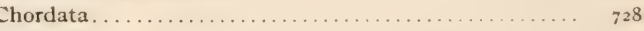

Chroococcacex.............................. 797

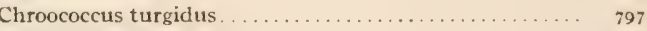

Chrysodomus decemcostatus ................. 708

Chthamalus stellatus . . . . . . . . . . . . . . . . . ${ }_{646}$

Chylocladia Baileyana ........................ $8_{2} 8$

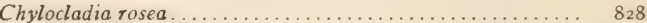

Ciliata . . . . . . . . . . . . . . . . . . . . . . 554

Cingula aculeus ............................... ${ }_{720}$

Cingula minuta ........................ $\quad 720$

Ciona intestinalis.......................... 730

Ciona ocellata.............................. 730

Ciona tenella ............................. 730

Cirolana concharum ...................... 658

Cirolanidæ................................. 658

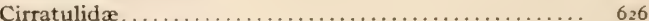

Cirratulus cirratus . . . . . . . . . . . . . . . . . $6_{2} 6$

Cirratulus grandis . . . . . . . . . . . . . . . . . . . $66_{26}$

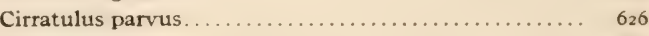

Cirratulus tenuis............................. $6_{26}$

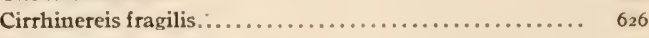

Cirrhinereis phosphorea $\ldots \ldots \ldots \ldots \ldots \ldots \ldots \ldots \ldots . \ldots \ldots$

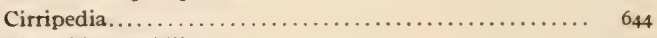

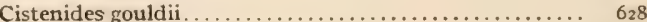

Cladocoryne floccosa sargassensis................ $\quad 560$

Cladocorynidæ............................. 560

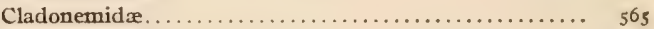

Cladophora albida. ........................... 802

Cladophora albida var, refracta................. 802

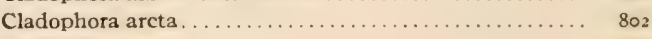

Cladophoraceæ........................... 802

Cladophora expansa...................... 802

Cladophora flexuosa . . . . . . . . . . . . . . . 802

Cladophora fracta ....................... $80_{3}$

Cladophora glaucescens .................... 803

Cladophora gracilis . . . . . . . . . . . . . . . $80_{3}$

Cladophora hirta......................... 803

Cladophora lanosa . . . . . . . . ............. 803

Cladophora lanosa var. uncialis ................. 803

Cladophora refracta........................ 803

Cladophora Rudolphiana..................... 803

Cladophora rupestris......................... $8 \mathrm{~S}_{3}$

Cladostephus spongiosus. . . . . . . . . . . . . . . 806

Cladostephus verticillatus..................... 806

Clangula clangula americana............... 779

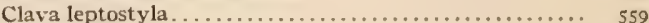

Clavella uncinata. ........................... $6_{44}$

Clavidæ. . . . . . . . . . . . . . . . . . . . . . . 559

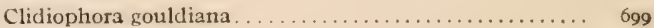

Clidiophora trilineaia ....................... 699

Cliona celata........................ 557

Cliona sulphurea......................... $\quad . \ldots 57$

Clione limacina............................ 703

Clione papillonacea........................ 703

Clionidæ................................ $\quad 357$

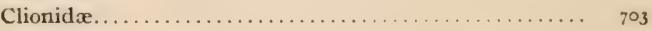

Clitellio arenarius................................. $6_{34}$

Clitellio irrorata. ........................ 634

Clupanodon pseudohispanicus.................. 745 
Clupea elongeto.

Page.

Clupea harengus.

Clupea pseudohispanica.

Clupeidx.

Clymenc producla.

Clymenella torquata.

Clytia bicophora.

Clytia cylindrica.

Clytia folleata.

Clytia grayi.

Clytra johnstoni

Clytia noliformis

Clytia volubilis.

Cncmidotus muticus.

Coccogonales.

Cochlodesma leanum

Codiolum gregatium

Codonella.

Codoniidx.

Codonoeca gracilis.

Codonoecidxe.

Codonosiga botryt is.

Colenterata.

Coleoptera.

Colpidium colpoda

Columbella avara.

Columbella lunata.

Columbella rosacea.

Columbellidx.

Colymbidre...

Colymbus auritus..

Colymbus holboellii. .

Conchoderma auritum

Conchoderma virgatum.

Condylostoma patens

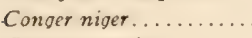

Conger occanica.

Conilera concharum.

Conorhynchus macrocephalus.

Convolutida.

Cupepoda

Corillinaceæ

Corallina officinalis.

Corambidx

Corbula contracta.......

Corbulidx.

Cordylophora lacustris.

Corixa burmeisterii

Corixa harrissii.

Corolla calceola.

Coronula diadema

Coronulidx

Corophiidas

Corycæidæe.

Corymorpha pendula.

Corymorphidxe.

Coryne mirabilis...

Coryne producta.

Corynidæ.

Corynitis linvillei.

Coryphana hippurus.

Coryphænidæ.

Coryphella gymnota.

Coryphella mananensis.

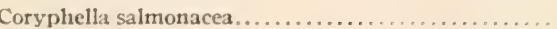

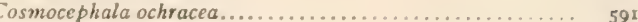

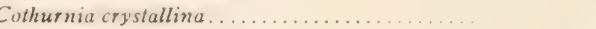

Cothurnia imberbis curvula........................ 555

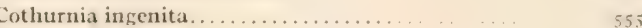

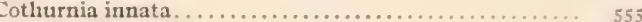

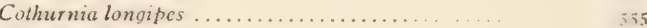

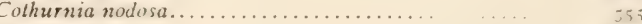

Cottidx................................. $7^{\sigma_{4}}$

Cottus aneus..........................................

Cottus mitchilli...........................

Cottus octodecimspinosus. . . . . . . . . . . . . . 76.

Couthouyella striatula .....................

Crago septemspinosus................... 66.

Cragonidx.

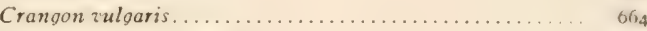

Crassinella mactracea........................ 688

Cratena gymnota. .......................

Cratena pilata.............................

Crenella glandula.......................... $68_{3}$

Crepidula convexa......................... $7_{22}$

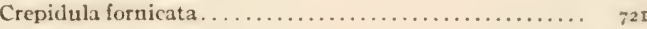

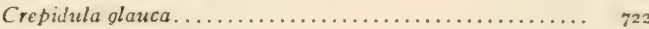

Crepidula plana........................... $7^{23}$

Crepidula unguiformis...........................

Cribrella sanguinolenta.......................... $60 \%$

Cribrilina annulata ............................ $60 \mathrm{r}$

Cribrilina punctata ................................. $60 \mathrm{r}$

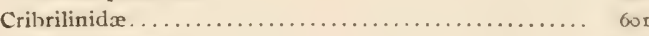

Crisia cribraria........................... 597

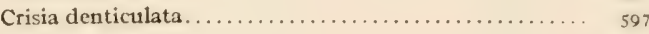

Crisia eburnea........................... 596

Crisiidæ............................... 596

Crossobothrium angustum. .................... ${ }_{5} \mathrm{~S}_{5}$

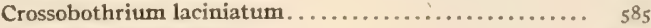

Crucibulum striatum . . . . . . . . . . . . . . . .

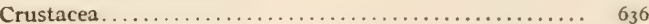

Crymophilus fulicarius..................... 780

Cryptacanthodes maculatus..................... ${ }_{768}$

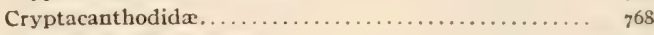

Cryptacanthus maculatus...................... ${ }_{768}$

Cryptodon gouldii.......................... 690

Cryptodon obesus............................... 690

Cryptonemiales ............................ 829

Clcnolabrus adspersus. ....................... ${ }_{759}$

Ctenophora................................ 579

Cucullanus globosus......................... 593

Cucumaria frondosa......................... $6 \mathrm{r}_{3}$

Cucumaria pulcherrima..................... $6 \mathrm{r}_{3}$

Cucumariidx.............................. $6 \mathbf{6}_{3}$

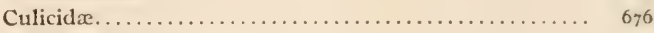

Cumacea.................................. 66

Cumingia tellinoides..................... 696

Cunanthidre.............................. 574

Cunina discoides......................... 574

Cupulita cara................................ 575

Cyanea arctica............................ 575

Cyanca capillata, var. arctica................. 575

Cyanea fulra............................ 575

Cyaneidx...................... . . 575

Cyanophycex............................... 797

Cyathura carinata................ 658

Cybium maculatum........................... 750

Cybium regale ...................... 750

Cyclas dentata............................. 690

Cyclas islandica......................... $69 x$

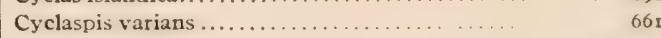

Cyclocardia borealis.............................. 687 
Page.

Cyclocardia novanolice.

Cyclopidx.

Cyclopterida

Cyclopterus lumpus. ....

Cyclosporales.

Cylichna alba.

Cylichna oryza. ...

Cylichnella oryza.

Cylindrocidx

Cylindroleberis marix

Cylista leucolena.

Cymbulia calceolus

Cymbuliidx.

Cymothoidx.

Cynoscion regalis.

Cynthia carnea.

Cynthia echinata...

Cynthia partita.

Cynthiidæ.

Cyphosus boscii.

Cypridæ.

Cypridinidx

Cyprina islandica.

Cyprinodon variegatus.

Cypselurus furcatus. .

Cypselurus gibbifrons.

Cypselurus heterurus.

Cyrtodaria siliqua.

Cystoclonium purpurascens

Cystoclonium purpurascens var. cirrhosum

Cystophora cristata.

Cytherca convexa.

Cythere dawsoni.

Cythereis albomaculata.

Cythereis arenicola. . . .

Cythereis canadensis.

Cythereis concinna.

Cythereis dunelmensis

Cythereis emarginata.

Cythereis phalaropi.

Cythereis tuberculata.

Cythereis villosa

Cythereis vineyardertsis.

Cytheridx.

Cytheridea americana

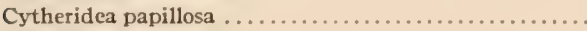

Cytheridea punctillata

Cytheridea rubra....

Cytheridea seminuda

Cytherideis fasciata.

Cytherois zostericola.

Dacnitis hians.

Dacritis sphærocephala..

Dactylocotyle denticulatum

Dactylometra quinquecirra.

Dactyloblcrues volitans.

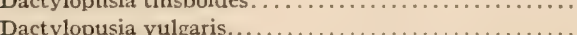

Dafila acuta

Dalyellia dodgei.

Dalyellia mohicana. .

Dalyellia rossi. .

Dasyatidæ...

Dasyatis centrura.

Dasyatis hastata.

Decapoda.

Decapterus macarellus.
Page.

Decapterus punctatus. ........................ $\quad 752$

Delesseriacex................................. $8_{2} 8$

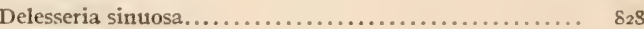

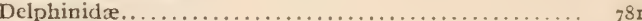

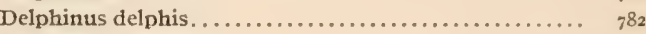

Dendronotidx................ 704

Dendronotus arborescens. . . . . . . . . . . . . . 70.

Dendronotus robustus. . . . . . . . . . . . . . . . . .

Dendrosomidx............................. ${ }_{55} 6$

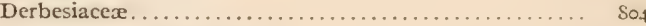

Derbesia vaucheriæeformis..................... 804

Dermocarpa prasina........................ 797

Dermocarpa violacea............................ $8_{32}$

Dermochelida................................ 774

Dermochelys coriacea ............................. 774

Dermocystis ctenolabri. ..................... ${ }_{58} \mathrm{~S}_{2}$

Desmacidonidx.................................. 559

Desmacidon palmata....................... 559

Desmarestia aculeata....................... 807

Desmarestiacex......................... 807

Desmarestia viridis. ........................... 808

Desmotrichum palticum..................... 806

Desmotrichum undulatum..................... 806

Dexamine thea ............................. $66_{51}$

Diacria trispinosa............................ ${ }^{0}$

Diastopora patina............................. 597

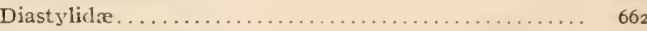

Diastylis abbreviata . . . . . . . . . . . . . . . . . . . . 662

Diastylis abbreriatus........................ $66_{2}$

Diastylis polita. . .............................. 662

Diastylis politus............................. $66_{2}$

Diastylis quadrispinosa ..................... 662

Diastylis quadrispinosus...................... 662

Diastylis sculpta........................... $66_{2}$

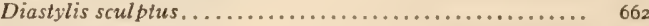

Dibothrium aluterx. . . . . . . . . . . . . . . . . . . . . ${ }_{5} 85$

Dibothrium angustatum ..................... ${ }_{5} \delta_{5}$

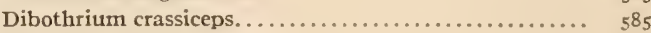

Dibothrium ligula........................ ${ }_{5} \mathrm{~S}_{5}$

Dibothrium manubriforme. . . . . . . . . . . . ${ }_{5} 86$

Dibothrium microcephalum................... 586

Dibothrium plicatum...................... $\quad{ }_{586}$

Dibothrium punctatum..................... ${ }_{58} 86$

Dibothrium restiforme..................... ${ }_{5} 56$

Dibothrium rugosum . . . . . . . . . . . . . . . . . . ${ }_{5} 56$

Dichelesthium sturionis........................ 643

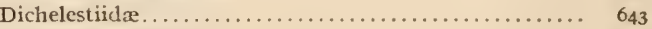

Diclidophora affinis......................... ${ }_{5} \mathrm{~S}_{2}$

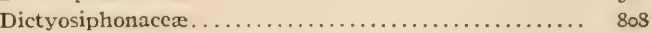

Dictyosiphon foniculaceus.................... 808

Dictyosiphon hippuroides.................. 808

Didemnidx............................ 73 I

Didemnum lutarium. .................... 73 I

Dinabothrium septaria..................... ${ }_{5} 86$

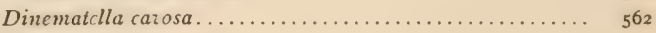

Dinematura latifolia....................... $6_{42}$

Dinoflagellata........................... 553

Dinophilea............................... 595

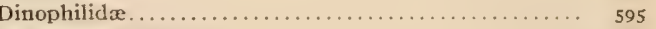

Dinophilus gardineri...................... 595

Dinophilus pygmæus......................... 595

Dinophilus simplex....................... 595

Dinophysidæ............................... 554

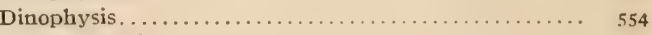

Dicdon hystrix.............................. $7^{6}$

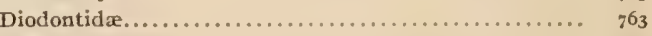

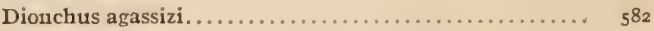

Diopatra cuprea ...................... $66_{2}$ 


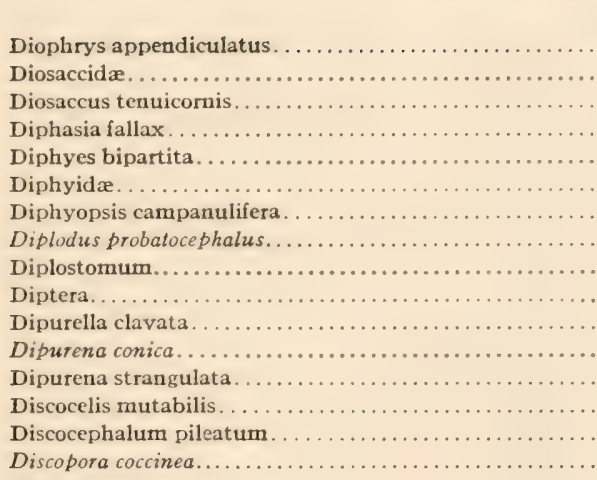

Page.

Discopora coccinea.

Discopora nitida.

Discorbina rosacea

Dissodactylus mellitæ.

Distephanus speculum

Distomum appendiculatum.

Distomum areolatum.

Distomum bothryophor

Distomum clavatum.

Distomum contortum .

Distomum dentatum.

Distomum fenestratum

Distomum focundum .

Distomurn foliatum.

Distomum fragile. .... .

Distomum globiporum

Distomum grandiporum .

Distomum gulosum.

Distomum hispidum .

Distomum lageniforme.

Distomum macrocotyle

Distomum monticellii.

Distomum nigrescens.

Distomum nigroflavum

Distomum nitens

Distcmum ocreatum.

Distomum pallens

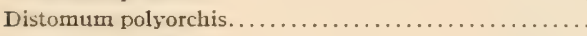

Distomum pudens.

Distomum pyriforme. . . . . . . . . . . . . . . . . .

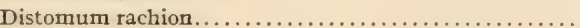

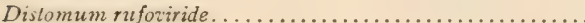

Distomum simplex. . . . . . . . . . . . . . . . . . .

Distomum tenue.

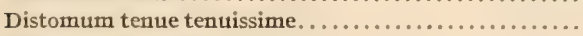

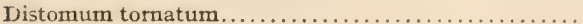

Distomum valdeinflatum . . . . . . . . . . . . . . . .

Distomum veliporum . . . . . . . . . . . . . . . . . . .

Distomum vibex. . . . . . . . . . . . . . . . . . . .

Distomum vitellosum.........................

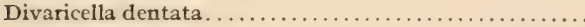

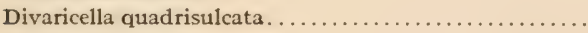

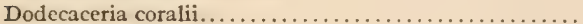

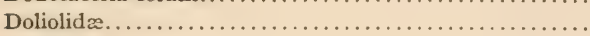

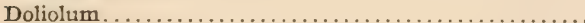

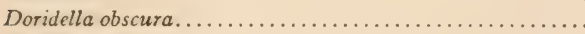

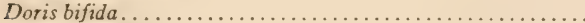

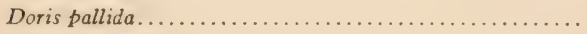

Doto coronata . . . . . . . . . . . . . . . . . . . . . . . .

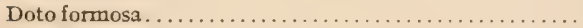

Dotonidx.

Drillia

Drilonereis longa.
Dimamena pumila

Dysmor phosa fulourans............................

Eysteria lanccolata. . . . .

Echeneibothrium variabile. . . . . . . . . . . . . . ${ }_{596}$

Echeneidid $x$.

Echeneis brachyptera ...................... $; 60$

Echeneis naucrateodides....................... $\rightarrow$. . . .

Echeneis naucrates. . . . . . . . . . . . . .

Echeneis quatuordecimlaminatus................... 760

Echeneis remora. ...............................

Echinarachnius parma..................... 6ra

Echinasteridx............................. $60_{7}$

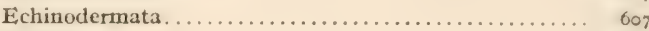

Ėchinoidea. 621

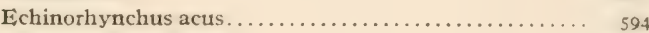

Echinorhynchus agilis...........................

Echinorhynchus attenuatus. . . . . . . . . . . . . . . 594

Echinorhynchus aurantiacus................... 595

Echinorhynchus carchariz................. 59.

E,chinorhynchus clavæceps........................ 594

Echinorhynchus fusiformis. . . . . . . . . . . . . . 59

Echinorhynchus globulosus....................... 594

Echinorhynchus incrassatus. ...................... 59

Echinorhynchus lateralis. . . . . . . . . . . . . . . . 59.

Echinorhynchus pristis..................... 594

Echinorhynchus proteus................... 594

Echinorhynchus sagittifer.................... 595

Echinorhynchus serrani...................... 595

Echinorhynchus thecatus................... 595

Echthrogaleus coleoptratus.................. 642

Echthrogaleus denticulatus . . . . . . . . . . . . . . 642

Echthrogaleus torpedinis. . . . . . . . . . . . . . . $\sigma_{42}$

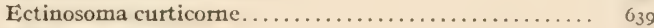

Ectinosomidæ.............................. $6_{39}$

Ectocarpacex............................ 804

Ectocarpus æcidioides ........................ So 4

Ectocarpus confervoides.................... So.

Ectocarpus confervoides var. hiemalis................. 805

Ectocarpus dasycarpus. . . . . . . . . . . . . . . . $8_{32}$

Ectocarpus Durkeci. . . . ...................... Sos

Ectocarpus elegans.......................... 804

Ectocarpus fasciculatus. .................... 805

Ectocarpus granulosus..................... So

Eictocarpus granulosus var. tenuis................ 805

Ectocarpus lutosus. . . . . . . . . . . . . . . . . . 805

Ectocarpus Mitchellæe......................... 805

Ectocarpus ovatus......................... 805

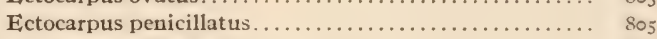

Ectocarpus siliculosus......................... 805

Ectocarpus siliculosus var. hiemalis.................. So $_{5}$

Ectocarpus tomentosus........................... Sos

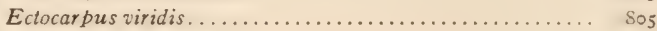

Ectopleura dumorticri....................... ${ }_{56 \mathrm{I}}$

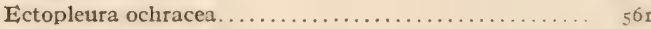

Ectopleura prolifica........................ 561

Edotea acuta . . . . . . . . . . . . . . . . . . . . . . 660

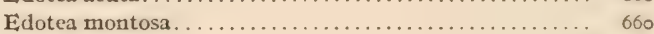

Edotea triloba............................... 660

Edwardsia elegans. . . . . . . . . . . . . . . . . . . $5 ; 6$

Edwardsia farinacea . . . . . . . . . . . . . . . . . . . $5: 6$

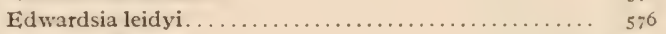

Edwardsia lineata . . . . . . . . . . . . . . . . . . 577

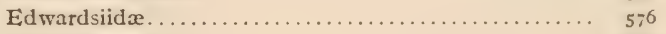

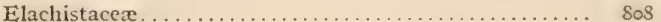

Elachista fucicola ......................... 808

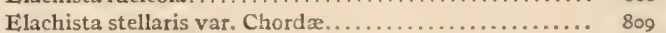

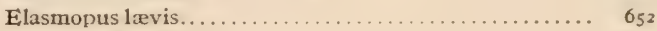

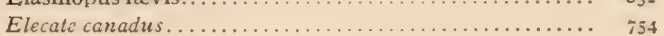


Page

Eloact is producta......

Elopida

Elops saurus.

Elysia chlorotica.

Filysiella catula

Embletonia pallida

Eimerita talpoida.

Enchelinida.

Enchelyopus cimbrius.

Enchytræidx.

Enchytræus albidus.

Enchytraus triventralopectinatus.

Encoeliaceæ. . .

Endeid $x$

Endeis spinosus.

Endoderma perforans.

Endoderma viride.

Engraulididæ

Ensatella americana.

Ensis americana.

Ensis directus.

Enteromorpha clathrata.

Enteromorpha crinita.

Enteromorpha crecta

Enteromerpha Hopkirkii.

Enteromorpha intestinalis

Enteromorpha linza.

Enteromorpha marginata

Enteromorpha minima. .

Enteromorpha percursa.

Enteromorpha plumosa.

Enterumorpha prolifera.

Entoderma Wittrockii.

Eolis bostoniensis....

Eolis papillosa.

Eprlys montosus.

Epelys trilobus.

Epenthesis folleata.

Ephclota coronata.

Ephippidæe.

Ephyrida.

Épibdella bumpusii.

Epibdella hippoglossi.

Epiclintes retractilis

..................... 555

Epinephelus adscensionis..................... 755

Epincphelus morio .......................... $\quad 756$

Epinephelus niveatus....................... ${ }_{756}$

Epitonium dallianum ........................ 714

Epitonium lineatum........................ 714

Epitonium multistriatum ...................... 714

Epizoanthus americanus...................... 576

Eretmochclys imbricata....................... 774

Ergasilidæ............................... $6_{40}$

Ergasilus labracis........................... 640

Ergasilus manicatus.......................... 640

Erichsonella attenuata. . . . . . . . . . . . . . . . . . . . 660

Erichsonella filiformis........................... 660

Erichsonia attenuata........................... 660

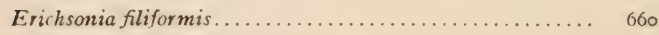

Ericthonizes difformis.......................... 655

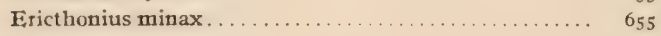

Ericthonius rubricomis...................... 655

Ėrismatura jamaicensis

Eristalis.

Erythrotrichia ceramicola

Escharella variabilis.
Escharidæ..................................... 603

Escharina pediestoma......................... 603

Escharina porosa............................. 60.4

Escharipora punctata............................

Esocidx..................................... ${ }_{744}$

Esperella fibrexilis ............................ 559

Esperella modesta.......................... 559

Eteone robusta. .................... 6I0

Eteone setosa............................. $0_{16}$

Elrumeus sadina............................ ${ }_{741}$

Etrumeus teres...........................

Eucheilota duodecimalis...................... ${ }_{56} 6_{7}$

Eucheilota vent ricularis...................... ${ }_{567}^{67}$

Euchone elegans ........................... $6_{30}$

Eucinostomus gula........................ $\quad{ }_{758}$

Eucope diaphana............................ . 509

Eucope polygena........................... $\quad 55^{50}$

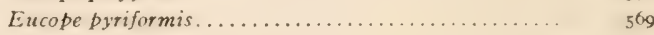

Ėucopidx................................ ${ }_{507}$

Eucratea chelata ......................... 597

Eucrateidæ.............................. 597

Eudactylina nigra ........................... $0_{443}$

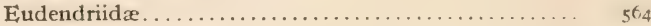

Eudendrium album....................... 556

Eudendrium capillare....................... $5_{505}^{50}$

Etudendrium carneum....................... 505

Eudendrium dispar. . . . . . . . . . . . . . . . . . . . 50.4

Eudendrium ramosum...................... 504

Eudendrium tenue . . . . . . . . . . . . . . . . . . . $5_{505}$

Eudorella hispida........................... 601

Eudorella pusilla ............................ $60 x$

Eudorella truncatula.......................... on

Eudorellopsis deformis................... . . of

Euglycera dibranchiata........................ $0_{23}$

Eugomphodus littoralis........................ . $\quad 730$

Eugyra glutinans........................... $\quad j 29$

Eugyra pilularis............................. $; 29$

Eulalia annulata.............................

Eulalia gracilis ..............................

Fulalia pistacia.......................... 617

Eulamia milberti............................. $\quad{ }^{335}$

Eulamia obscura ........................... 735

Fuleptorhamphus velox...................... 745

Eulima conoidea......................... 755

Etulima olcacea........................... 714

Eulimidæ................................. $7_{714}$

Eumesogrammus subbifurcatus...................... 768

Fumidia americana.........................

Eumidia papillosa.................................. or

Eumidia vivida............................... 617

Eunicidx....................................

Eunoë oerstedi.................................. OT

Eupagurus annulipes......................... 068

Eupagurus bernhardus........................ $\quad 667$

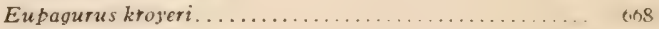

Eupagurus longicar pus...................... $\quad 067$

Eupagurus pollicaris......................... 006

Eupagurus pubescens............ . . ons

Eupanopeus herbstii................. 073

Euphausiidæ................ $\quad 063$

Euphysa virgulata............ 560

Eupleura caudata.............. $7 \times 3$

Euplotes charon.................. 555

Euplotes harpa......................... 555

Fuplotidx........................... . $\quad 555$

Ėupomacentrus leucostictus. ..................... $\quad 759$

Eurylepta maculosa......................... 580 
Page.

Euryleptidx

Eurypanopeus depressus. ..................... 6

Eurytemora herdmani. ............................. 638

Firytemora hirumbides

Eustylochus ellipticus.

Eusyllis fragilis

Eusullis tencra.

Euthemisto bispinosa...

Futhemisto compressa.

Futhora cristata.

Eutima limpida.

Eutima mira.

Fivadne nordmanni. .

Eixocotidx.

Exocutus furcatus.

Exocotus gibbifrens.

Erocatus heterurus.

Exocatus melanurus.

Exocotus rondelettii

Exocoetus volitans

Exuvialla lima

Exuvixlla marina.

Fabricialcidyi.

Fabricia stellaris.

Facelina bostoniensis.

Farella familiaris.

Fasciolariidx

Fiber zibethicus.

Filaria rubra.

Filograna implexa.

Fiona marina.

Fiona nobilis.

Fistularia serrato.

Fistularia tabacaria.

Fistulariidæ

Flustrella hispida.

Tiustrellidx

Foraminifera . . . . . . . . . . . . . . . . . . . .

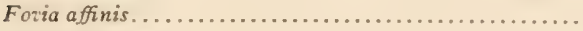

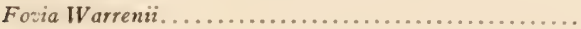

Fratercula arctica. . . . . . . . . . . . . . . . . . . . .

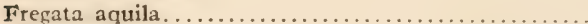

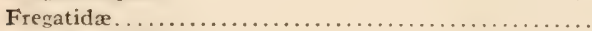

Frontonia leucas.

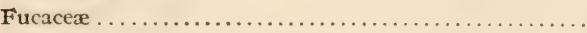

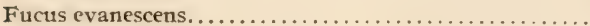

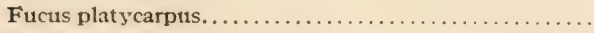

Fucus vesiculosus. . . . . . . . . . . . . . . . . . .

Fucus vesiculosus var. laterifructus. . . . . . . . . . . . .

Fucus vesiculosus forma limicola

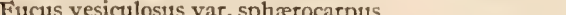

Fucus vesiculosus var. spiralis . . . . . . . . . . . . . . 8 II $_{2}$

Fulgur canaliculata.

Fulgur carica. .

Fundulus diaphanus.

Fundulus heteroclitus.

Fundulus majalis

Fundulus multifasrialus.

Fundulus pisculentus.

Fusus dccemcostatus.

Fusus islandicus.

Gadidæ.

Gadus callarias.

Gadus morrhua.

Gadus tomcodus.

Gaidropsarus argentatus

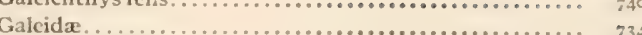

Gammarellis an:"uloums.

Gammarida . . . . . . . . . . . . . .

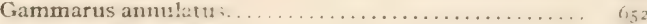

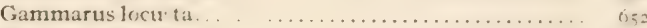

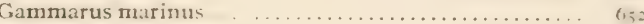

Gammarus musunatus........................

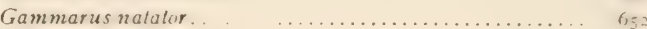

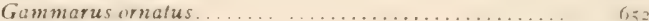

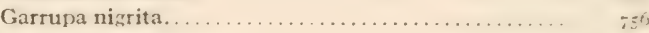

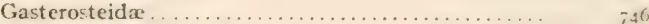

Gasterosteus aculeatus.................. ; 74

Gastcrestcus biaculcatus........................

Gasterosteus bispinosus.................

Gasterosteus gladiunculus....................... 746

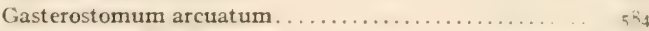

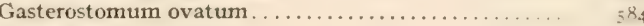

Gastropoda.............................. 70,3

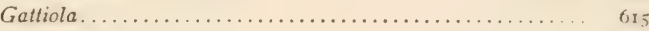

Gavia immer . . . . . . . . . . . . .

Gavia stellata............................

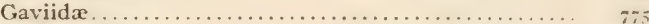

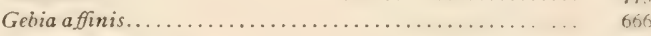

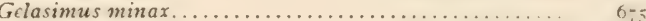

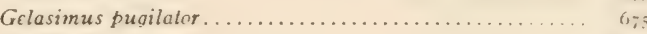

Gclasimus pugnax..........................

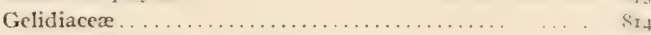

Gelidium corneum var. crinale.................. 814

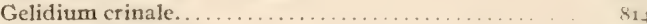

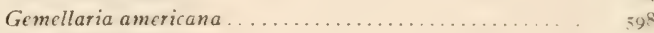

Gemellaria loricat $a \ldots \ldots \ldots \ldots \ldots \ldots \ldots \ldots \ldots \ldots \ldots$

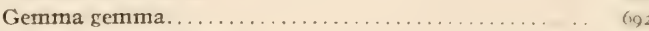

Gemmaria cladophora....................

Gemmaria gemmosa. .......................

Germo alalunga....................... $; 49$

Gerres argenteus...................... 758

Gerridæ................................. ${ }_{75}$

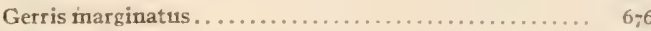

Geryonidæ.............................. 574

Gi

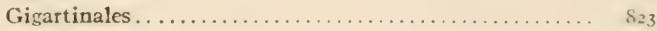

Giraudia sphacelarioides..................... Son

Glandula arenicola...........................

Glenodinium cinctum . . . . . . . . . . . . . . . . 553

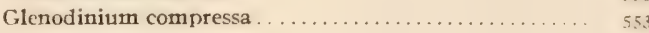

Globiocephala melas.................. $7_{8}$

Glœecapsa crepidinum ..................... 797

Glcocapsa costericola.......................... S 800

Gloocystis chrysophthalma ..................... 800

Gloocystis zostericola . ..........................

Gloiopotes ornatus. ........................ 642

Gloiosiphonia capillaris.................... $8_{29}$

Gloiosiphoniacex. .................. \&

Glossocodon tenuirostris ... . . . . . . . $5 . \ldots \ldots$

Glycera capitata ........................

Glyceridx. ........................ $60_{23}$

Glycinde gracilis....................... 623

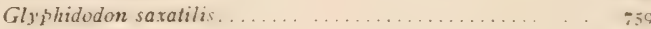

Gobida........................ $=60$

Gobiomurus aronorii.... ...................... $75 t$

Gobiosoma bosci........................... 766

Gobius stigmaticus. . . . . . . . . . . . . . . . . 766

Goniadida . . . . . . . . . . . . . . . . . . . 623

Gonionema murtiochii .................... 574

Gonionemus murbachii. . . . . . . . . . . . . . . $5: 4$ 
Gonionemus vertens.

Page.

Gonothyrza loveni

Gorgonidx

Gorgonocephalidx.

Gorgonocephalus agassizii. .

Gouldia mactracea.

Gracilaria confervoides

Gracilaria multipartita

Gracilaria multipartita var. angustissima

Graffilla gemellipara.

Grantia ciliata

Grapsida

Gregarina gigantea..

Griffithsia Bornetiana.

Griffithsia corallina.

Griffithsia tenuis

Grinnellia americana.

Gromia lagenoides.

Gromidx.

Grubea websteri.

Grubia compta.

Grubiosyllis websteri

Gunnclus mucronatus.

Gymnachirus nudus.

Gymnodinium gracile spherica.

Gymnogongrus Griffithsix.

Gymnogongrus norvegicus.

Gymnosarda alleterata..

Gymnosarda pelamis.

Gyratrix hermaphroditus maculatus.

Gyrinus.

Hæmulidæ.

Halatractus zonatus.

Halecidx.

Halecium articulosum

Halecium beani...

Halecium gracile.

Halecium halecinum.

Halecium tenellum.

Halichondria caduca. .

Halichondria panicea.

Haliplus ruficollis .

Halocampa producta.

Halocynthia echinata.

Halodrillus littoralis. .

Halothrix lumbricalis.

Haminea solitaria.

Haplospora globosa.

Harelda hyemalis...

Harmothoë imbricata.

Harpacticida. .

Harpacticus chelifer.

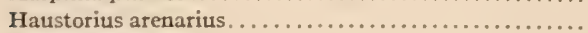

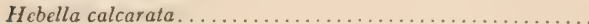

Hebella pygmxa. .

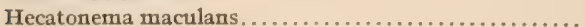

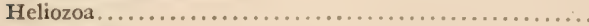

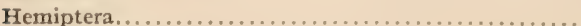

Hemiramphidæ. . . . . . . . . . . . . . . . . . . . .

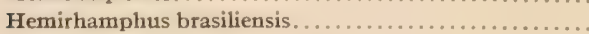

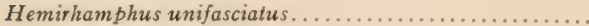

Hemitripterus acadianus..

Hemitripterus americanus. ........................

Hemiurus crenatus.......

Henricia sanguinolenta.

Hermæa cruciata.
Hermæidx $\quad$ Page

Hermellidx

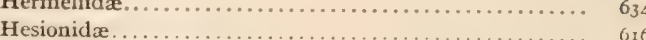

Heterakis foveolata. . .

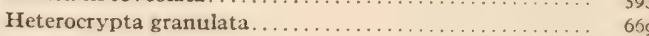

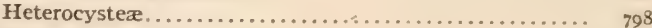

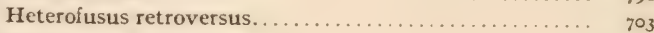

Heteromastus filiformis................... $6_{29}$

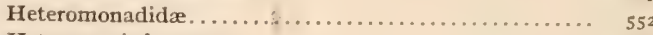

Heteromysis formosa....................... $66_{3}$

Heterophrys myriapoda................... 552

Hexacotyle thynni...................... ${ }_{584}$

Hexanematichlhys felis....................... 740

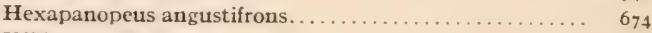

Hildenbrandia prototypus.............. 830

Hildenbrantia rubra ...................... $8_{30}$

Hippa talpoida........................... 666

Hippidx. . . . . . . . . . . . . . . . . . . . . . 666

Hippocampus heptagonus....................... 746

Hippocampus hudsonius. . . . . . . . . . . . . . . 746

Hippoglossoides platessoides...................... $77 \mathrm{I}$

Hippoglossus americanus..................... $77 \mathrm{r}$

Hippoglossus hippoglossus..................... 77 I

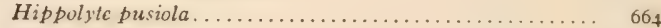

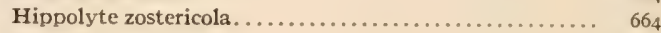

Hippolytidæ. . . . . . . . . . . . . . . . . . . . . . 664

Hippomedon serratus. . . . . . . . . . . . . . . . . . . . $66_{49}$

Hipponoë gaudichaudi........................ 6 rg

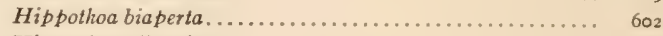

Hippothoa divaricata........................ $66_{3}$

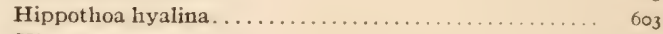

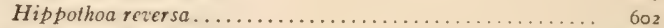

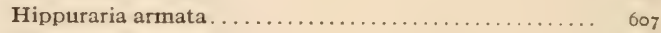

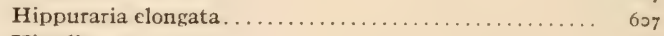

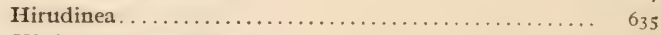

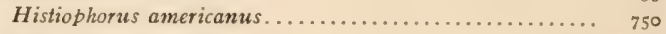

Histiophorus gladius...................... 750

Histrionicus histrionicus................... 779

Holocentridæ........................ 748

Holocentrus ascensionis...................... 748

Holocentrus tortugre....................... ${ }_{748}$

Holot hurioidea........................ $6 \mathrm{r}_{3}$

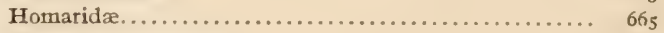

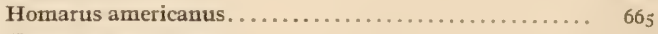

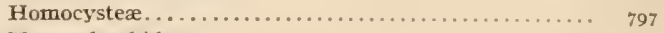

Homorrhaphidæ.......................... ${ }_{55} 8$

Hoplonyx cicada........................... 649

Hormactis Farlowii ......................... 799

Hormactis Quoyi. . . . . . . . . . . . . . . . . . . . . 799

Hormogonales............................. 797

Hyalea trispinosa...................... 703

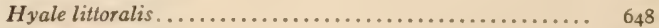

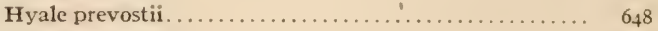

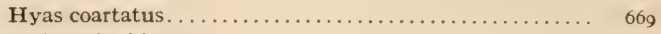

Hybocodonidæ............................ ${ }_{56} \mathrm{r}$

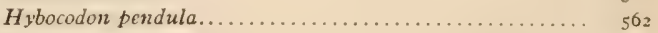

Hybocodon prolifer...................... ${ }_{56}$

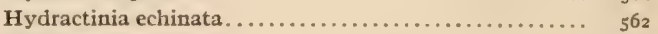

Hydractinia polyclina....................... ${ }_{562}$

Hydrallmania falcata....................... 573

Hydrargyra majalis............................ ${ }_{743}$

Hydrichthys mirus...................... ${ }_{56} \mathbf{I}$

Hydroceratinidx............................ ${ }_{570}$

Hydrochelidon nigra surinamensis............. $\quad 777$

Hydrocoleum glutinosum.................... 797

Hydrocoleum lyngbyaceum. . . . . . . . . . . . $\quad 797$

Hydroides dianthus. . . . . . . . . . . . . . . $\sigma_{31}$

Hydroporus................................. 676 
Page.

Hydrozoa..

Hyella cæspitos

Hyperia galba.

Hyperia medusarum

Hyperiidx.....

Hyperoche abyssorum

Hypnea musciformis

Hypolytus peregrinus

Hyporhamphus roberti.

Hyporhamphus unifasciatus.

Hyporthodus flavicauda.

Ianthina fragilis.

Ichthyobdella funduli

Ichthyobdella rapax.

Ichthyobdellidæ...

Ichthyonema globiceps.

Ichthyonema sanguineum .

Idalia modesta.....

Idaliella modesta.

Idotea carca.

Idotea irrorata.

Idotea marina.

Idotea phosphorea.

Idotea robusia.

Idotea Tuftsii. . .

Idothea baltica. . .

Idothea marina.....

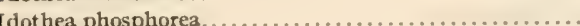

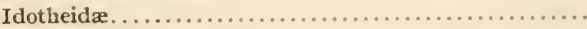

Idya furcata . . . . . . . . . . . . . . . . . . . . . . . . . .

Idvia roseola. . . . .

Idyidæx.

Ilea fulvescens.

Ilyanassa obsoleta.

Ilyanthidæ.

Ilyopsyllidæ..................

Ilyopsyllus sarsi.

Imogine oculifera

Inachidx

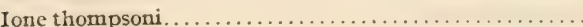

Isactis plana.................................

Ischnochitonidæ.

Ischy rocerus anguipes.

Isodictya palmata.

Isogomphodon maculipinnis,

Isopoda

Istiophoridx

Istiophorus nigricans. . . . . . . . . . . . . . . . . . . .

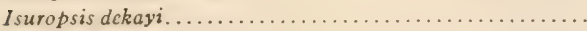

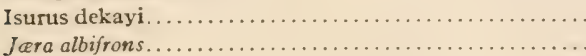

Jare copiosa .

Jæra marina.................................. 660

Jaminia producta.......................... $7_{15}$

Jaminia seminuda........................... ${ }_{716}$

Janiridæ

Janthina fragilis........................... $7^{14}$

Janthinidæ.............................. 714

Jassa marmorata ............................. 655

Kellia planulata................................. 689

Kelliopsis elevata.............................. 689

Keratosum complexum....................... 570

Kyphosidæ............................... ${ }_{75} 8$

Kyphosus incisor ........................... ${ }_{758}$

Kyphosus sectatrix......................... $\quad 758$

Labidocera æstiva.
Page.

Labrax lineatus.................. 755

Labridx.................................

Lacophilus maculosus. . ......................... 676

Lacrymaria coronata. . . . . . . . . . . . . . . . . . 554

Lacrymaria lagenula ............................... 554

Lactophrys tricornis......................... $\quad-662$

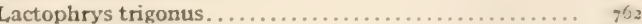

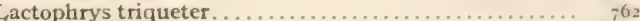

Lactophrys yalei ............................. $;_{i j 2}$

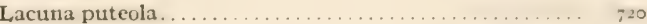

Lacuna vincta........................... $\quad 7=0$

Lamargus muricalus.................................... 69

Lævicardium mortoni ........................... $\sigma_{9 x}$

Lafoxa calcarata................................. ${ }^{5 b^{67}}$

Lafoea dumosa............................ $\quad{ }_{570}$

Lafoea gracillima................................ $55^{\circ}$

Lafœidæ................................. 570

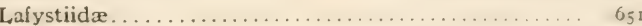

Lafystius sturionis . . . . . . . . . . . . . . . . . .

Lagenorhynchus acutus . . . . . . . . . . . . . . . 78

Lagocephalus lævigatus............................

Lagodon rhomboides........................ $75^{3}$

Lamellidoris muricata........................

Lamellidoris pallida .........................

Laminaria Agardhii ............................ 8 8

Laminaria A gardhii forma normalis................ $81 \mathrm{~s}$

Laminaria Agardhii var. vittata ................. $s_{i 1}$

Laminariacex........................ 810

Laminaria digitata. ........................... $8 \mathrm{ir}$

Laminaria digitata forma typica.................. 8I

Laminaria saccharina........................... $S_{\mathrm{Ir}}$

Lamna cornubica........................... ${ }_{73}$

Lamnidx................................. ${ }_{736}$

Laodicea calcarata........................... $5_{567}$

Laodicea cruciata .............................. ${ }_{56}$

Laomedea a mphora ............................. ${ }_{568}$

Leomedea divaricata............................ 570

Laophonte longicaudata...................... $6_{39}$

Laophontidx................................. $6_{39}$

Laridx.................................

Larimus fasciatus........................... $\quad 750$

Larus argentatus.......................... 776

Larus atricilla ............................

Larus delawarensis . . . . . . . . . . . . . . .

Larus leucopterus...........................

Larus marinus........................... $\pi_{7 \rightarrow 0}$

Larus philadelphia.........................., $\pi_{i \rightarrow 0}$

Latreutes ensiferus............................ $66_{4}$

Leathesia difformis . .......................... So so

Leathesia tuberiformis........................... Son

Lecanicephalum peltatum....................... ${ }_{5} 56$

Lecanocephalus annulatus.................... $\quad 593$

Leda tenuisulcata.............................

Ledidx................................... 685s

Leiostomus xanthurus........................... $; 5$

Lembus elongatus............................ 554

Lembus infusionum........................... 554

Lembus pusillus.............................. 5

Lepadidx................................... 646

Lepas anatifera ............................... $6_{477}$

Lepas anserifera............................. 647

Lepas fascicularis............................... $6 \sigma_{q} 6$

Lepas fasciculatus.............................. 646

Lepas hilli....................................

Lepas pectinata............................. 646

Lepeophtheirus edwardsi....................... $\sigma_{4}$

Lepeophtheirus nordmannii.................... $\sigma_{42}$

Lepeophtheirus thompsoni....................... $\sigma_{4,2}$ 
Lepidastylus arenarius...

Lcpidactylus dytiscus.

Lepidametria commensalis.

Lepidonotus squamatus

Lepidonotus sublevis .

Lepræa rubra.

Lepralia americana.

Lepralia pallasiana.

Lepralia pertusa.

Lepralia serrata..

Leptasterias compta.

Leptasterias tenera.

Leptecheneis naucrateoides.

Leptecheneis naucrates.

Leptocephalidæ.

Leptocephalus conger

Leplochelia algicola.

Leptochclia dubia.

Leptochelia savignyi..

Leptochiton apiculatus.

Leptochiton rubcr.

Leptoclinum albidum.

Leptoclinum lutcolum

Leptocuma minor.

Leptonidæ..

Leptophidium...

Leptoplana folium...

Leptoplana variabilis.

Leptoplanidx..

Leptosynapia girardii.

Leptosynapta inhærens.

Leptosynapta roseola

Lernæa branchialis.

Lernaenicus radiatus.

Lernxidx. .

Lernæolophus sultanus

Lerncenema radiata.

Lernæopodidx...

Lernanthropus brevoortix

Lernanthropus pomatomi.

Lesueuria hyboptera...

Lesueuriidx.

Leuconacia incerta..

Ieuconidæ..............

Leucosolenia bolryoides.

Libinia canaliculata.

Libinia dubia

Libinia emarginata

Lichenopora verrucaria

Lichenoporid $x$.

597

Lichnophora auerbachii.................... 555

Lichnophora macfarlandi.................... 555

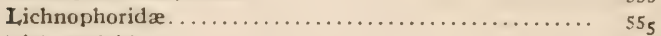

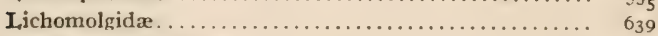

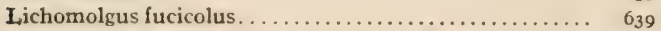

Ligula chylomyctcri.............................. ${ }_{586}$

Ligyda oceanica. . . . . . . . . . . . . . . . . . . . . . 66 I

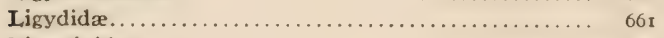

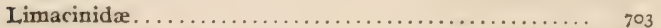

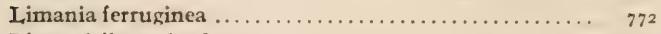

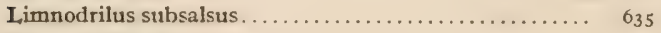

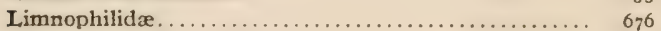

Limnoria lignorum. . . . . . . . . . . . . . . . . . . ${ }_{65} 8$

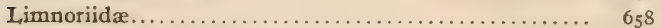

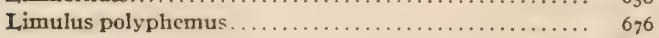

Lineidx................................ 590

Lineus bicolor.

Lincus communis $\quad$ Page.

Lineus socialis . . . . . . . . . . . . . . . . . . . . . . $59{ }_{590}$

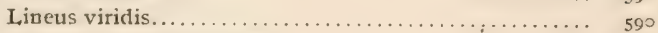

Lincus viridis sanguineus.................. 590

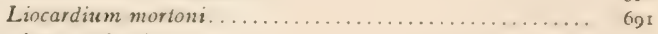

Lionotus fasciola......................... 554

Liostomus obliquus....................... $\quad 759$

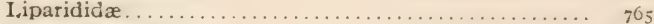

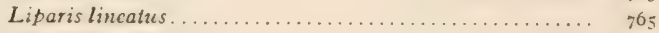

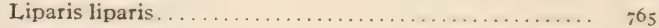

Liriope scutigera............................. 57.4

Lirus perciformis.......................... 754

Lissoflagellata ....................... 552

Lithothamnion polymorphum ................ $8_{30}$

L.itiupa bombix.......................... $7_{720}$

Litiopa melanostoma. ....................... $\quad 7=0$

Litiopidæ.............................. $7 \neq 0$

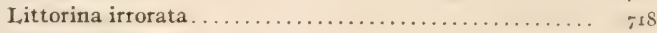

Littorina litorea. ......................... 719

I,ittorina palliata......................... 719

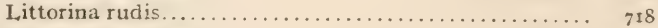

Littorina tenebrosa...................... 718

Littorinclla minuta . . . . . . . . . . . . . . . . . . .

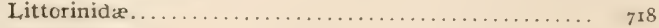

Lituolidæ............................... 549

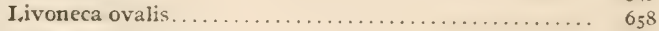

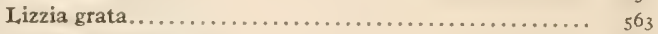

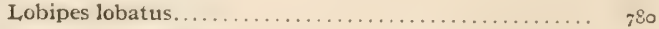

Lobotes surinamensis . . . . . . . . . . . . . . ${ }_{756}$

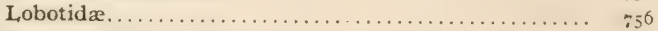

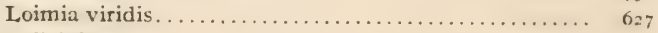

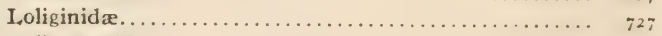

Loligo pealii........................... 727

Loligo punctata . . . . . . . . . . . . . . . . . . .

Lomentaria rosea . . . . . . . . . . . .

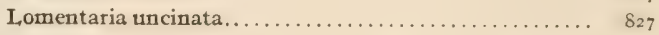

Lophiidæ............................. 773

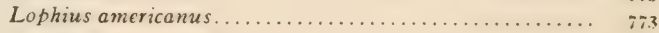

Lophius piscatorius...................... 73

Lophodytes cucullatus................... $77^{8}$

\$.opholatilus chamæleonticeps................. 767

Lophopsetta maculata .................... 773

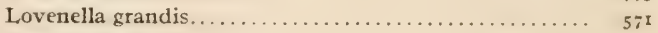

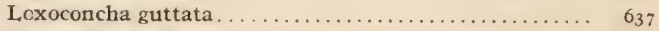

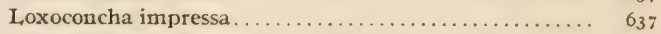

I.oxophyllum setigerum ..................... 554

Loxophyllum setigerum var. armalum.............. 554

I.oxosoma davenporti....................... 595

Loxosoma minuta ........................ 595

Loxosomidx . . . . . . . . . . . . . . . . . . . . 595

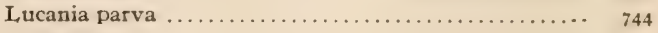

Lucina dentata.............................. 690

Lucina filosa............................... 690

Lucinidæ............................... 690

Luconacia incerta.......................... 656

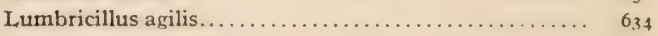

Lumbriconereis fragilis ....................... 623

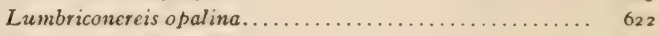

Lumbriconcreis tenus. . . . . . . . . . . . . . . . . . . 623

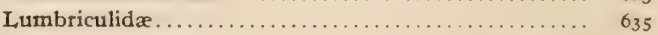

L.umbriculus limosus . . . . . . . . . . . . . . . . . . . 635

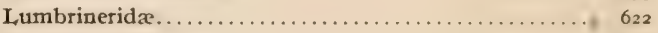

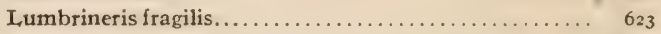

Lumbrineris hebes........................ $66_{23}$

Lumbrineris tenuis. . . . . . . . . . . . . . . . . 623

Lunatia heros......................... 725

Lunatia immaculata.......................... 727 


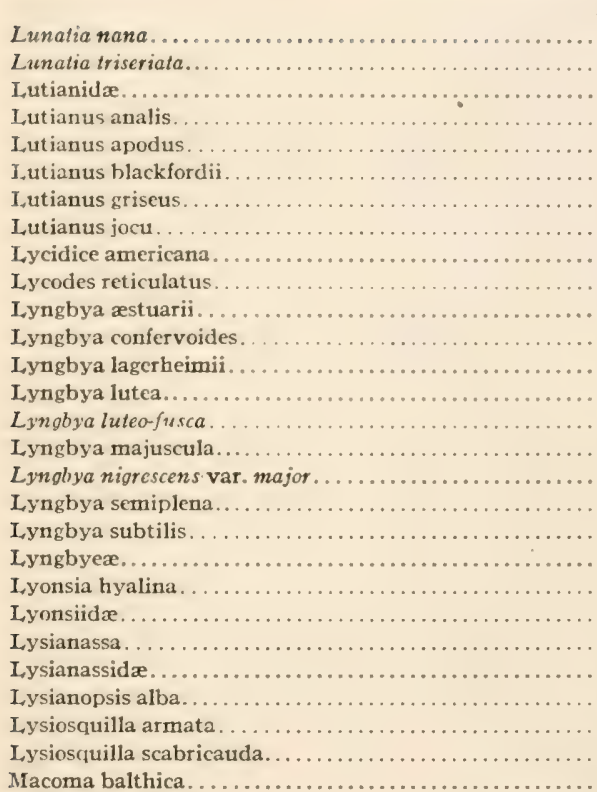

Macoma balthica.

Macoma fragilis.

Macoma fusca.

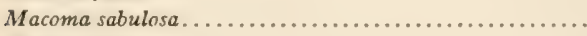

Macoma tenta.

Macrouridæ. .

Macrourus bairdii.

Tacrurus bairdic.

Mactra lateralis.

Mactra solidissima.

Mactrida.

Magaptera nodosa

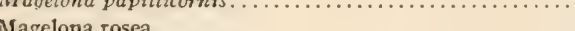

Magelonid $x$.

Malacanthidæ.

Malaclemmys centrata cor

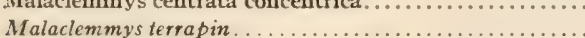

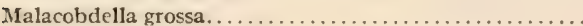

Malacobdella obesa.

Malacobdellida

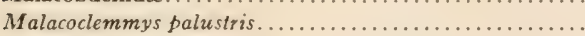

Malacoclemmys terrapin.

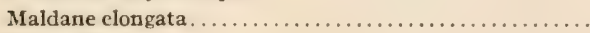

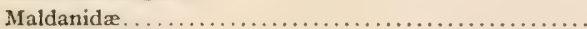

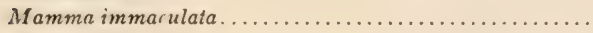

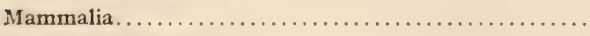

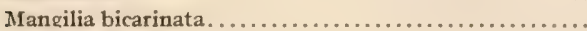

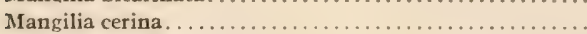

Mangilia plicosa . . . . . . . . . . . . . . . . . . . .

Mareca americana.

Margarita obscura. .

Margarites obscurus

Margarites undulatus

Margelis rarolinensis

Marila affinis.

Míarila americana.

Marila marila.

Marila vallisneria

Page. Marsipobranchii

Mastigamœba simplex.........

Mastigocoleus testarum.............. ;

Maurolicidæ.................

Maurolicus borcalis............................ 743

Maurolicus pennanti.................... it

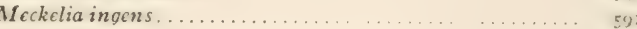

Meckelia lactea............ $59 \mathrm{I}$

Meckclia lurida................................

Meckelia rosea..................................... 500

Megalestris skua ............................

Meganyctiphanes norvegica.................... $66_{3}$

Melampus bidentatus............................ $7_{706}$

Melampus !ineatus.... . . . n

Melanogrammus æelefinus........

Melicertum campanula.......................... ${ }_{567}$

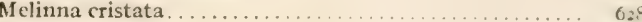

Melinna maculata............................ $6_{28}$

Melita dentata............................... $6_{52}$

Melita nitida............................... $65_{52}$

Melita parvimana.......................... $6_{52}$

Mcllita pentapora........................... $6 \mathrm{r}_{3}$

Mellita quinquesperforata..................... $6_{13}$

Mcllito testudinaria........................... $6_{13}$

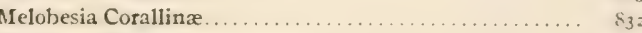

Melobesia farinosa. . ........................ $\delta_{31}$

Melobesia Lejolisii.............................. $8_{3}$

Melobesia membranacea....................... $\delta_{3 x}$

Melobesia pustulata .......................... $\delta_{3}$

Membranipora arctica.......................... 601

Membranipora arctica armifera.................. 601

Membranipora aurita.......................... 608

Membranipora craticula ........................... $6_{00}$

Membranipora cymbæformis..................... 599

Membranipora flemingii ....................... for

Membranipora lacroixii ......................... 600

Membranipora lineata........................ $6_{\infty}$

Membranipora monostachys.................... 600

Membranipora pilosa.......................... 590

Membranipora tehuelcha..................... 60

Membranipora tenuis.......................... $66_{\infty}$

Membranipora unicomis...................... $t_{\infty}$

Membraniporidæ............................ 599

Menidia beryllina............................. $\quad{ }_{447}$

Menidia beryllina cerea........................ itit

Menidia gracilis............................ it

Menidia menidia notata...................... $\quad 747$

Menidia notata.............................. 547

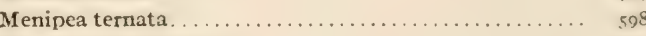

Menticirrhus nebulosus........................... $\quad 759$

Menticirrhus saxatilis........................ 759

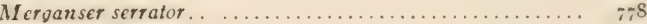

Mergus americanus.......................... $\quad ; 8$

Mergus serrator........................... $\quad ; ; 8$

Metlucciidx............................. $7_{768}$

Merluccius bilinearis........................... $; 68$

Merlucius bilinealus......................... $; 68$

Mertensia ovum......................... 579

Mertensiidæ................................ 579

Mesodesma arctatum . . . . . . . . . . . . . . . . . . 69

Mesodesmatidx.............................. 698

Mesodinium cinctum........................ 554

Mesogloia divaricata........................ $\delta_{0}$

Mesoplodon bidens........ . . . . . . . . . . . $78 \mathrm{z}$

Mesovelia bisignata.......................... $6 ; 6$

Metridia hibernica............................ $\sigma_{3} 8$

Metridia lucens............................... $6_{3} 8$ 
Metridium dianthus

Melridium marginatum.

Michtheimysis stenolepis.

Microchæte grisca..

Microciona prolifera.

Microcoleus chthonoplastes.

Microcoleus tenerrimus.

Microcotyle hiatulx.

Microcotyle longicauda...

Microcotyle pomatomi

Microcotyle stenotomi

Microdeutopus danmonensis

Microdeutopus gryllotalpa.

Microdeutopus minax.

Microgadus tomcod.

Microgadus tomcodus.

Micropogon undulatus

Microporella ciliata.

Microporella ciliata stellata.

Microporellidæe.

Microstomum davenporti.

Micrura affinis

Micrura cæca.

Micrura leidyi.

Miliolina bicomis.

Miliolina boueana

Miliolina circularis.

Miliolina oblonga .

Miliolina seminulum.

Miliolina venusta.

Miliolinidæ.

Mnemiidx

Mnemiopsis leidyi.

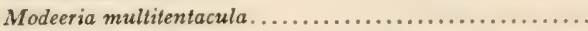

Modiola modiolus.

Modiola plicatula.

Modiolaria corrugata.

Modiolaria discors. .

Modiolaria lævigata.

Modiolaria nigra.

Modiolus demissus. .

Modiolus hamatus.

Modiolus modiolus.

Mora lævis.

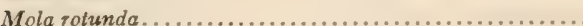

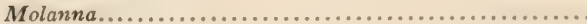

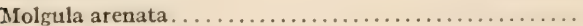

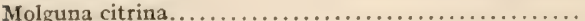

Molguna koreni.

Molgula manhattensis.

Molgula pannosa.

Molgula papillosa.

Moloula pilularis ...........

Molgula producta

Molgulidæ.

Molidæ

Mollia hyalina.

Mollusca

Molluscoida

Molpadia oölitica.

Molpadiidæ.

Monacanthidx.

Monacanthus hispidus.

Monacanthus massachusettensis.

Monas sp.

Monocelis fusca
Page.

577
Page.

$5^{82}$

Monoculodes edwardsi........................ $6_{5 x}$

Ionoophorum triste ............................. ${ }_{582}$

.

Monopylephorus glaber........................ $66_{35}$

Monopylephorus parvus....................... $6_{35}$

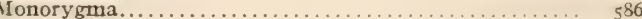

Monosiga fusiformis........................ 553

Monosiga ovata .............................. ${ }_{553}$

Monostæchas quadridens..................... 573

Monostomum orbiculare. .......................... ${ }_{53}$

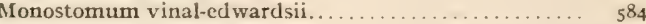

Monostroma crepidinum..................... $80 \mathrm{r}$

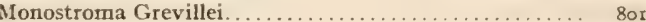

Monostroma latissimum...................... $8_{32}$

Montacuta bidentata............................ 639

Montacuta elevata............................. 689

Montacuta percompressa....................... 689

Montagua pilata............................ 705

Morone americana........................ 755

Morrkua americana........................... 760

Mucronella nitida ....................... 604

Mucronella pavonella.......................... 604

Mucronella peachii............................. 604

Mucronella ventricosa.......................... 604

Mrugil cephalus.............................. $\quad{ }_{747}$

Mugil curema ...................................... 5477

Mugilidæ............................... $\quad 747$

Mugil linealus.............................. $\quad 7_{77}$

Mugil trichodon............................. 747

Mulinia lateralis........................... 698

Mullidæ................................. ${ }_{748}$

Mullus auratus.......................... ${ }_{748}$

Muræna retifera............................. $\quad 740$

Murænidx................................ $7_{740}$

Murønoides gunnellus......................... ${ }_{767}$

Muranoides mucronatus........................... $\quad 767$

Muricidx................................. $7_{713}$

Muridx................................. $7_{782}$

Irustelidx............................ $7_{782}$

Mustelus canis............................. ${ }^{734}$

Mya arenaria.............................. 70 r

Myacidx..............................

MIycoideacex............................ 7or

Mycteroperca bonaci............................ 756

Mycteroperca interstitialis..................... $\quad 756$

Mycteroperca venenosa........................... $\quad 756$

Myliobatidx............................... $\quad 739$

Myliobatis freminvillei.......................... 739

Myoxocephalus æneus......................... $\quad 764$

Myoxocephalus grondlandicus.................... $\quad 764$

Myoxoephalus octodecimspinosus ................. 764

Myriactis pulvinata............................. 809

Myrionema corunnæ............................. 809

Myrionema Leclancherii............................ 80. 809

Mfyrionema strangulans........................ Sog

Myrionema vulgare ........................... 809

Myriotrichiaceæ............................. 808

Myriotrichia clavæformis.................... $88_{32}$

Myriotrichia filiformis........................ 803

Myriozoidx............................... 602

Myrmeciplana elegans...................... " ${ }_{s 8 z}$

Mysidx................................... $66_{3}$

Mysis americana.............................. $6_{63}$

Mysis stenolepis............................. $6_{3}$

Mytilidx . . . . . . . . . . . . . . . . . . .

Mytilus edulis............................... $68 \mathrm{x}$

Myxicola steenstrupii............................. $6_{3} 0$ 


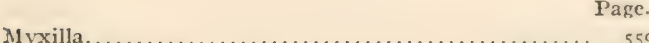

Myxine glutinosa.

Myxinida.

Myxobolida

Mryobolus lintoni

Myzopsetla ferrugines.

Naiidxe.

Nanmoia cara...

Naraganscta coralii.

Narcobatida. .

Nassa obsoleta..

Nassa trivittata.

Nassa zibex.

Nassula microstome

Nassula nofata.

Natica clausa.

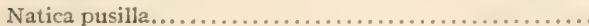

Naticidx.

Naucrates ductor

Naushonia crangonoides

Nautilograpsus minutus.

Nectonema agile.

Nectonema agilis.

Nectonercis megalops.

Nemalionaceæ.

Nemalionales

Nemalion multifidum.

Nemastoma Bairoii.

Nemastomacex...

Nemathelminthes. .

Nematobothrium .

Nematoda.

Nemertes socialis.

Nemertes viridis.

Nemertinea. .

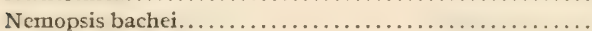

Neoliparis atlanticus.

Neoliparis montagui.

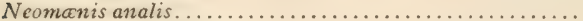

Neomanis apodus

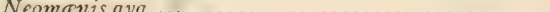

Neomanis blackfordi.

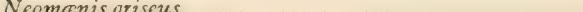

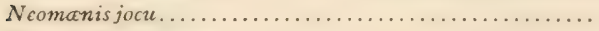

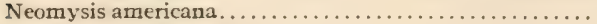

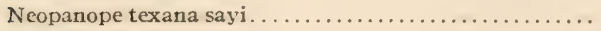

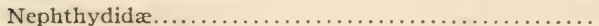

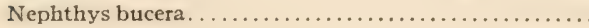

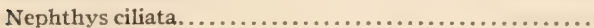

Nephthys incisa. . . . . . . . . . . . . . . . . . . . . .

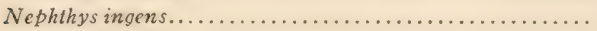

Nephthys picta...............................

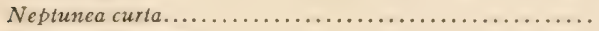

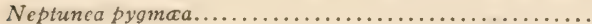

Neptunus sayi. ....

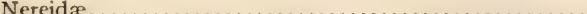

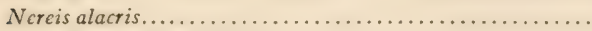

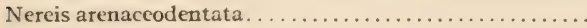

Nercis dumerilii.

Nercis limbata.

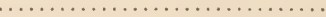

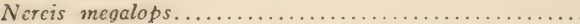

Nereis pelagica.

Nereis virens.

Nerocila munda.

Nesippus alatus.

Nettion carolinensi.

Nettion crecea.

Neuroptera.
Nererita duplicato

Nicolea simplex........................... $6_{27}$

Nicomache dispar............................. $\sigma_{29}$

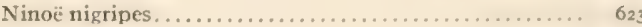

Nitzschia elegans.............................. ${ }_{58}$

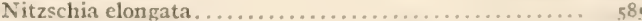

Nitzschia papillosa........................... ${ }_{58}$

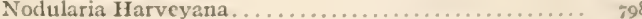

Nogagus Latrcillii....................................

Nomeus gronovii ................................... ${ }^{754}$

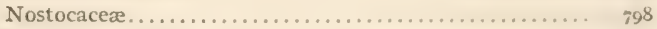

Nothria conchylegia ......................... $6_{22}$

Notomastus filiformis........................ . $\sigma_{229}$

Notomastus luridus.......................... $G_{22}$

Notonecta undalata.......................... 6

Nucula delphinodonta.......................... 686

Nucula proxima. ..........................

Nucula proxima ovata......................... 686

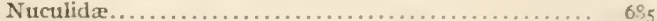

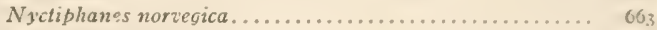

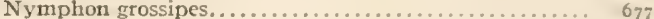

Nymphonidx.............................

Nyroca afflnis.................................

Nyroca americana............................ 779

Nyroca marila................................. $77_{79}$

Nyroca vallisneria............................. $\quad 779$

Obelia bicuspidata............................. 570

Obelia bidentata.................................. 5570

Obclia conmissuralis........................ $\quad s 09$

Obelia congdoni............................. 5,5

Obelia diaphana............................ 569

Obelia dichotoma............................... ${ }_{569}$

Obclia divaricala .............................. $\quad 550$

Obelia flabellata............................... 569

Obelia gelatinosa.............................. 570

Obelia geniculata............................ 566

Obelia longissima.......................... $5{ }_{570}$

Obclia plana .............................. $55_{5}$

Obelia polygena.............................. ${ }_{570}$

Obelia pyriformis............................. 570

Oceania languida.............................. ${ }_{56}$

Oceania singularis........................... ${ }_{568}$

Oceanites oceanicus.................................

Oceanodroma leucorhoa.......................... $\quad 778$

Octobothrium denticulatum....................... ${ }_{582}$

Octocotyle major .............................. ${ }_{585}$

Octocotyle scombri............................... ${ }_{5} \delta_{5}$

Octoplenum affine................................ ${ }_{582}$

Octopus granulatus............................. $\quad i_{28}$

Ocypoda arenaria................................. $6_{75}$

Ocypode albicans............................. 675

Ocypude quadrato............................... 675

Ocypodidx..................................... $6_{75}$

Ocyurus chrysurus........................... $\quad{ }_{557}$

Odonata.................................... 676

Odontomya................................... 676

Odontosyllis lucifera........................... $61_{5}$

Odostomia bisuturalis....................... is

Odostomia bushiana........................ $7_{116}$

Odostomia dealbata......................... $7_{717}$

Odostomia fusca .............................. it

Odostomia hendersoni........................ 716

Odostomia impressa..........................., 716

Odostomia modesta.......................... $\quad ; 17$

Odostomia producta............................. 715

Odostomia seminuda ......................... ${ }_{716}$

Odostomia trifida............................ 716

EEdiceridx................................ 
Page

idemia american.

Oidemia deglandi.

Oidemia perspicillata.

Oithona similis.

Oligochxta. .

Oligoplites saurus.

Olor columbianus. .

Ommastrephes illecebrosa

Ommastrephes sagiltatus.

Onchidoris pallida. .

Onchobothrium uncinatum.

Oniscidæ. .

Onuphidx.

Opalinidx...

Opercularella pumila.

Ophelia denticulata.

Opheliidx.

Ophidiidæe.

Ophioderma brevispina.

Ophioglycera gigantea.

Ophinglyphia robustc..

Ophiolepididx.

Ophiopholis aculeata.

Ophiura brevispina.

Ophiura olingcea..

Ophiura robusta.

Ophiuridæ..

Ophiuroidea. .

Ophisthonema oglinum.

Opsanus tau........

Orbicella acroposa. .

Orbicellidx......

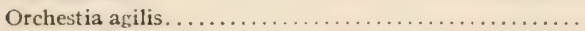

Orchestia palustris...

Orchestiidx. .

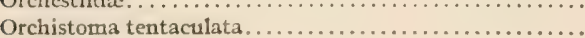

Orcymus allitcratus.

Orcynus secundi-dorsalis.

Orcynus thunning.

Orcynus thynnus...

Orthagoriscicola muricata.

Orthopristis chrysopterus. . .

orthopyris caliculato.......

Orygmatobothrium angustum

Orygmatobothrium crenulatum................ 586

Orygmatobothrium paulum................... ${ }_{5} 86$

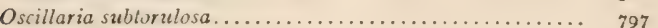

Oscillatoria amphibia....................... 798

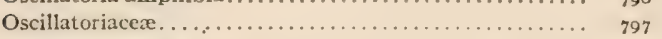

Oscillatoria læetevircus..................... 798

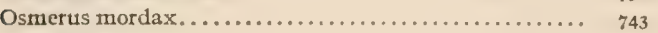

Ostraciidx................................. $7_{762}$

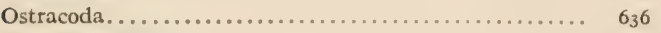

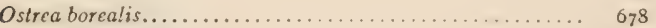

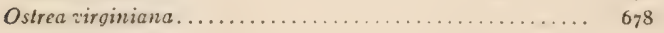

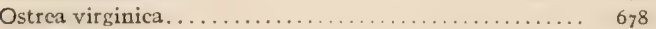

Ostreidx................................ 673

Otobothrium crenacolle........................... ${ }_{586}$

Otobothrium dipsactmm.................... ${ }_{5} \$ 6$

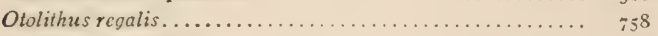

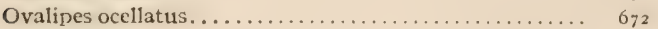

Oxycephalidx................................6. 648

Oxycephalus clausi............................ 648

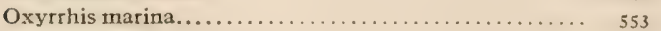

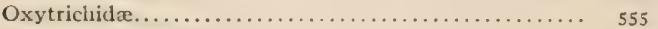

Oxyurostylis smithi. . . . . . . . . . . . . . . . . 662

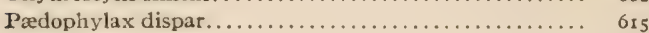

P๕dophylax longiceps........................... 6r.
Page.

.

Pagrus argyrops............................. $\quad 757$

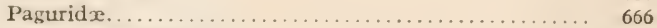

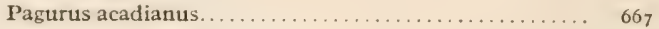

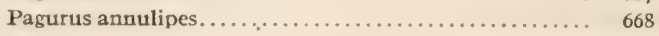

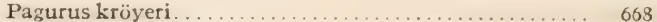

Pagurus longicarpus. . . . . . . . . . . . . . . 667

Pagurus politus. . . . . .... 668

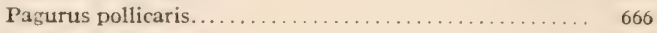

Pagurus pubescens. ........................... 668

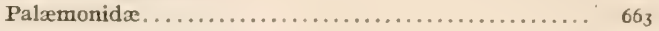

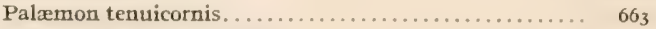

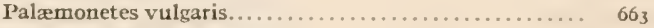

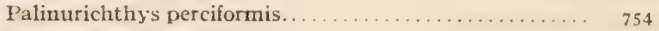

Palinuris perciformis......................... 754

Palio lessonii. . . . . . . . . . . . . .

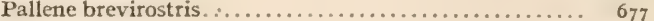

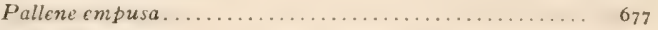

Pallenidx.............................. 677

Palmellaceæ........................... 800

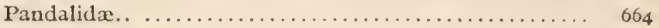

Pandalus annulicornis...................... 664

Pandalus leptocerus......................... $66_{4}$

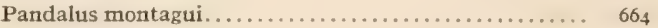

Pandarus cranchii . . . . . . . . . . . . . . . . . . $66_{42}$

Pandarus sinuatus. . . . . . . . . . . . . . . . $6 . \ldots .6$

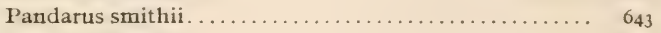

Pandora trilineata ................................ 699

Pandoridx. ............................... 699

Panopous angustifrons...................... 674

Panopeus depressus........................ $6_{73}$

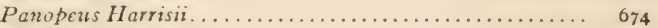

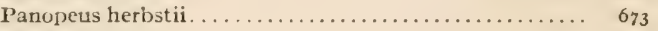

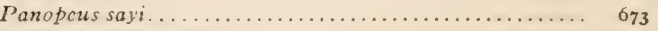

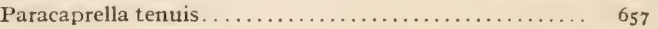

Paralichthys dentatus...................... 771

Paralichthys oblongus................... $\quad 773$

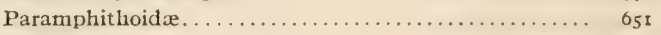

Paranais littoralis........................... $6_{34}$

Paranthura branchiata...................... $6_{5} 8$

Paraphoxus spinosus. . . . . . . . . . . . . . . . . . . 649

Parapolia aurantiaca....................... 590

Parasabella microphthalmia................. $66_{30}$

Parasira catenulata........................ $7_{22}$

Paratania medusia......................... 587

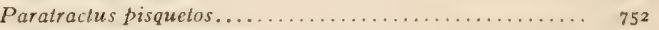

Parexocoetus mesogaster.................... 745

Parthenopidæ................................ 669

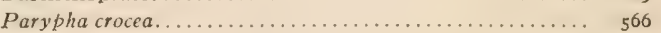

Pastinara hastata............................ 739

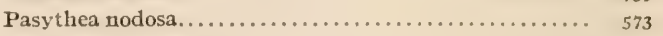

Patellina corrugata.......................... $55 \mathrm{x}$

Pecten gibbus borealis........................ 680

Pecten irradians...................... 0.50

Pecten islandicus. .............................. oso

Pecten magellanicus. ...................... . 6779

Pecten tenuicostatus. ....................... 6 6 6

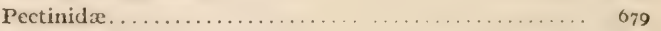

Pedicellina cernua. ....................... $\$ 95$

Pedicellina Americana. . . . . . . . . . . . . . . . . 595

Pedicellinidæ.............................. 595

Pelagia cyanella........................ 576

Pclagiidx............................. 576

Pelamys sarda. .......................... $\quad 749$

Pclecanidx. .......................... $77^{8}$

Pelecanusfuscus.......................... $77^{8}$

Pelecanus occidentalis. ........................... 778

Pelecypoda................................. $67^{8}$ 
Page.

Pelia mutica............................. 670

Peltidiicla

Peneidx...

Pencus brasiliensis.

Peneus brasiliensis.

Pennaria tiarella.

Pennariidx..........

Pennella costai.

Pennella filosa.

Penlamera pulcherrima..

Peprilus paru.

Peranemidx.

Peridinidx.

Peridinium digitale

Peridinium divergens

Peridinium furca.

Perigonimus minutus.

Periploma papyracea.

Periplomatidæ.

Perissopus communis.

Peritromidæ.

Peritromus emmae.

Perophora viridis

Perophorida.

P:tasida

Petricola pholadiformis.

Pet ricolida

Petromyzon americanus.

Petromyzonida

Petromyzon marinus

Phacoides filosus.

Ph:eophycex

Phæosporales

Phalacrocoracidx.

Phalacrocorax auritus

Phalacrocorax carbo.

Phalaropodidæe.

Phalaropus fulicarius.

Phalaropus lobatus.

Phascolion strombi.

Phoscolosoma comentarium

Phascolosoma gouldii

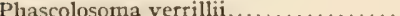

Phialidium languidum. .

Phialium duodecimale.

Philhydrus perplexus.

Philichthys xiphixe.

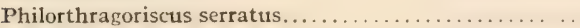

Philoscia vittata...

Phocæna phocæna.

Phoca vitulina.

Phocidæ.

Pholadide.

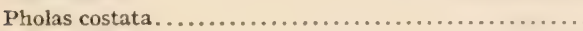

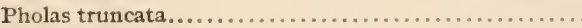

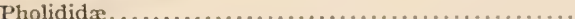

Pholis gunnellus.

Phonorhynchus helgolandicus.

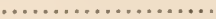

Phoreiobothrium triloculatum . . . . . . . . . . . . . . . . .

Phormidium persicinum . .......................

Photidæ.

Phoxichilidiidx.

Phoxichilidium maxillare.

Phoxichilus spinosus.
Phoxocephalidx................

Page.

Phoxocephalus hollowlit

Phozus Kreseri.

Phronima allantica.

Phronima sedentaria

Phronimidic.

Phryxus abdominalis

Phycis chuss.

Phycis regius.

Phycis tenuss.

Phyllitis fascia.

Phyllobothrium foliatum.

Phyllobothritum loliginis.

Phyllobothrium thysanocephalums....

Phyllodoce catenula.

Phyllodocidx.

Phyllophora Brodizi.

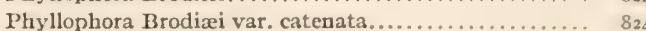

Phyllophora membranifolia......................

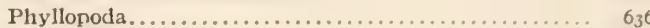

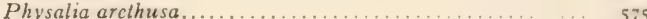

Physalia pelagica...........................

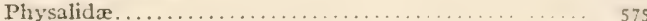

Physeteridx................... $78 \ldots \ldots \ldots$

Physeter nacrocephalus. ..................... $z^{3}$

Phytomastigophora ...................... 553

Pilinia Reinschii. ........................ $\varepsilon_{02}$

Pimelepturus boscia..........................

Pinnixa chætopterana........................ 674

Pinnixa cylindrica.............................. 674

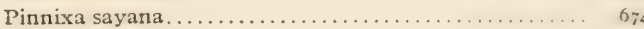

Pinnotheres maculatus....................... 674

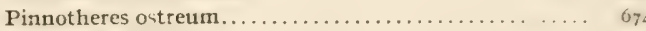

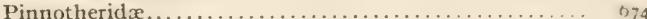

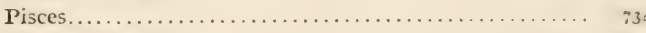

Piscicola rapar............................. 035

Pista intermedia........................ $55_{27}$

Pista palmata................................ $6_{27}$

Placobranchus catulus.......................

Plagiostomum morgani. ....................... $5_{582}$

Plagiostomum stellatum .................... 582

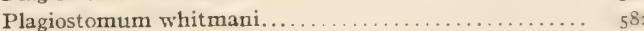

Plagiostomum wilsoni. . . . . . . . . . . . . . . . . 58

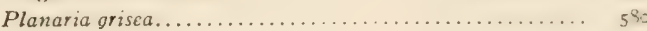

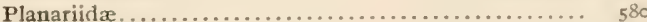

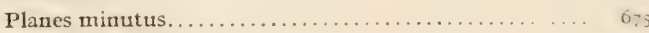

Planocera inquilina......................... .

Planocera ncbulosa...................... $5.5^{80}$

Planocerida..............................

Platophrys ocellatus.................... $7 ; 3$

Platybothrium cervinum..................... 58 .

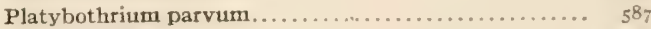

Plat yhelminthes............................

Piatynereis megalops. . . . . . . . . . . . . . . . . . . .

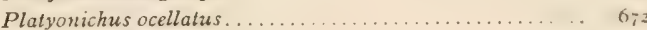

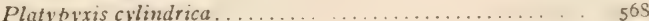

Plectonema calothrichoides. . . . . . . . . . . . . . . . 799

Plectonema tercbrans.......................... $8_{32}$

Pleonosporium Borreri ...................... $8 \mathrm{r} 8$

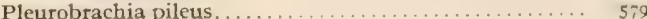

Pleurobrachia rhododactyla.................... $\quad 579$

Pleurobrachiidæ................................ 579

Pleurobranchrea tarda ...........................

Pleurobranchidæ............................ jo,

Pleurocapsa fuliginosa ......................... 797

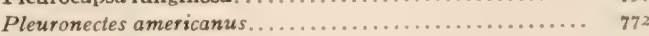

Pleuronectes maculatus............................. 773 
Pleuronectida.

Page.

Pleurcnema setigera.

Pleuronemida.

Pleurotoma bicarinata.

Pleurotoma bicarinatis $m$

Pleuroloma cerinum

Plcurotoma plicato...

Plumaria elegans.

Plumularia tenella.

Plumulariidxe.

Podarke obscura.

Podilymbus podiceps

Podoceridie

Podoceropsis nitida

Podocerus falcatus.

Podoccrus fucicola

Podocerus marmoralus.

Podocoryne carnea

Podocoryne fulgurans

Podon leuckarti

Podophrya gracilis.

Podophryida.

Poeciliida.

Pogonias cromis.

Pogotrichum filiforme

Polina glutinosa.

Pollachius carbonarius.

Pollachius virens.

Polycera Lessonii.

Polycerella emertoni

Polyceridæ. .

Polychoerus caudatus

Polychæta...........

Polycirrus eximeus

Polycirrus phosphoreus.

Polycystidx...

Polycystis elabens.

Polydactylus octonemus

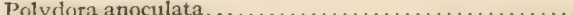

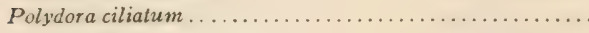

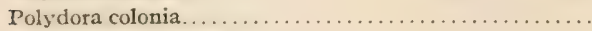

Polydora concharum . . . . . . . . . . . . . . . . . . .

Polydora littorea . . . . . . . . . . . . . . . . . . . . .

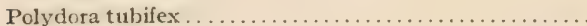

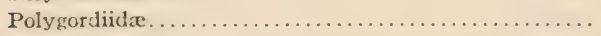

Polygordius ............................... 629

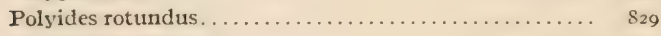

Polymastia robusta....................... ${ }_{557}$

Polymastidre........................... 557

Polymorphina concava...................... $55 \mathrm{I}$

Polymorphina lactea ......................... 55 I

Polymorphina rotundata.................. 551

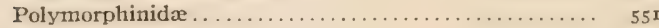

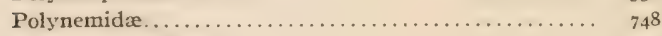

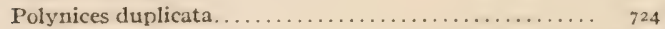

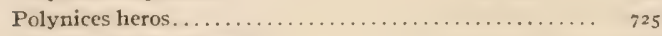

Polynices immaculata...................... 727

Polynices nana........................ 727

Polynices triseriata......................... $\quad 7_{226}$

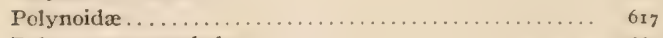

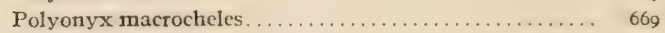

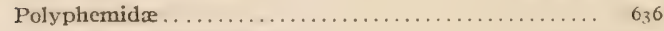

Polysiphonia atrorubescens. ................. 820

Polysiphonia elongata ...................... 820

Polysiphonia fastigiata . . . . . . . . . . . . . . . 820

Polysiphonia fibrillosa...................... $82 x$

Polysiphonia Harveyi.. yiphonia nigrescens...................... 821

Polysiphonia nigrescens var. fucoides............. $S_{21}$

Polysiphonia Olneyi......................... $8_{2 I}$

Polysiphonia urceolata...................... $88_{22}$

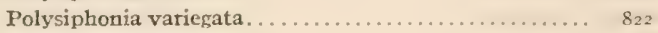

Polysiphonia vestita.................... $8 z 2$

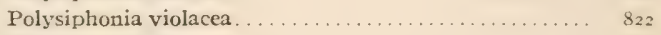

Polystomella crispa...................... 552

Polystomella striatopunctat $2 \ldots \ldots \ldots \ldots \ldots \ldots \ldots \ldots .552$

Polystomellidæ.......................... 552

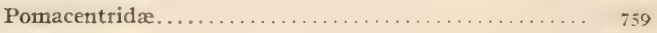

Pomatomidæ........................... $\quad 753$

Pomatomus saltatrix..................... 753

Pomolobus æstivalis.................... 742

Pomolobus mediocris. . . . . . . . . . . . . $74 \mathrm{I}$

Pomolobus pseudoharengus. . . . . . . . . . . . 742

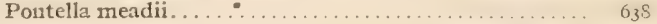

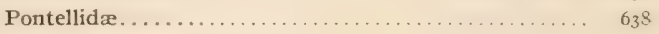

Pontobdella rapax......................... 635

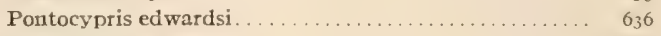

Pontogenia inermis.......................... $6_{5} \mathrm{I}$

Pontonema marinum ....................... 59.4

Poutonema vacillatum . . . . . . . . . . . . . . . . . 594

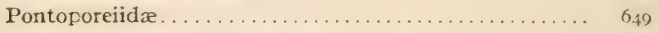

Porcellana (Polyonyx) macrocheles................... 669

Porcellanidæ............................ 669

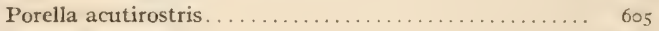

Porella concinna......................... 605

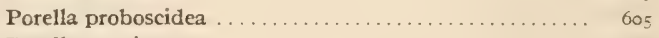

Porella propinqua ......................... 605

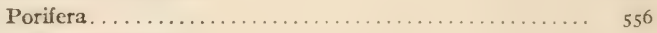

Porina tubulosa......................... 601

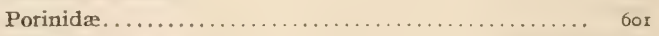

Poronotus triacanthus....................... 554

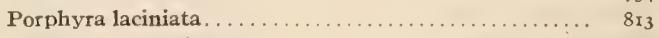

Porphyra leucosticta..................... 813

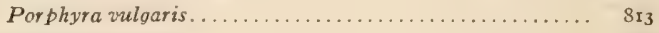

Porpita linnæana........................ 574

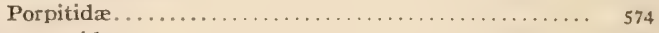

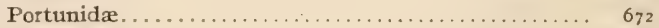

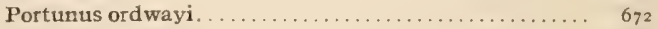

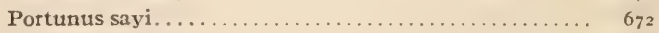

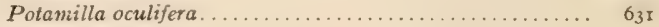

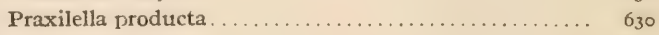

Praxilella tricirrata . ....................... 630

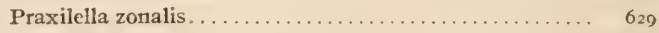

Priacanthidæ........................... 757

Priacanthus altus. . . . . . . . . . . . . . . . $\quad 757$

Priacanthus arenatus................... 757

Pringsheimia scutata..................... So

Prionace glauca. . . . . . . . . . . . . . . . . . 735

Prionospio heterobranchia .................. 624

Prionospio tenuis . . . . . . . . . . . . . . . . . .

Prionotus carolinus . . . . . . . . . . . . .

Prionotus evolans........................ $; 66$

Prionotus lineatus......................... $; 66$

Prionotus palmipes........................ 765

Prionotus strigatus . . . . . . . . . . . . .

Probopyrus palamoncticola.................... $66 \mathrm{r}$

Probopyrus pandalicola..................... $66 \mathrm{r}$

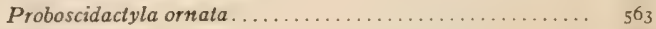

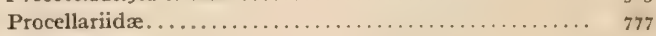

Procerodes ulva ........................... 580

Procerodes watrenii. . . . . . . . . . . . . . . . . ${ }_{580}$

Procerodes wheatlandi...................... 580

Promesostoma marmoratum nudum............. $58 \mathrm{r}$

Promicropterus decoratus . ......................... ${ }_{756}$

Prorhynchus stagnalis....................... $5^{8 \mathrm{I}}$ 
Page.

Prorocentridae

I'rothiostomidx.

Prothiostomum gracile

Pruliara burcalis.

Protiara haeckeli.

Protococcales.

Protoderma marinum.

Protozoa.

Protula.....

I'roxenetes modestus

Psammobiidæ.

Pseudocytheretta ed wardsi.

Pseudodiaptomus coronatus

Pseudopleuronectes americanus

?'scudopotamilla oculifera.

Pscudopriacanthus altus

I'terogorgia gracilis.

Pterophryne histrio.

Pteroplatca maclura.

Pieropoda.

Pterosyllis cincinnata.

Ptilanthura tenuis.

Ptilochcirus pingtis

Ptiluta elcoans.

Puffints borealis

Puffinus fuliginosus.

Puffinus gravis

Puffinus griseus

Pulvinulina lateralis

Pulvinulina tumida.

Punctaria latifolia

Punctaria plantaginea.

Punclaria tenuissima.

Pungitius pungitius.

Purpura lapillus.

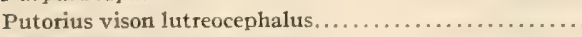

Pycnogonida.

Pycnogonididx

Pycnogonum littorale...................... 67

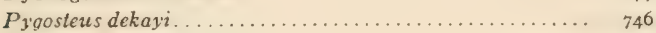

Pygosteus pungitius......................... ${ }_{746}$

Pylaiella littoralis.......................... 805

Pyramidella bartschi........................ $7 \mathbf{7 5}$

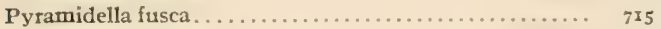

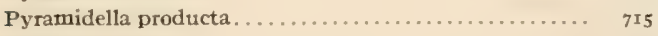

Pyramidellidæ............................. $7_{715}$

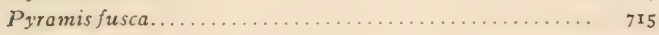

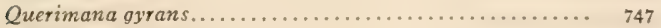

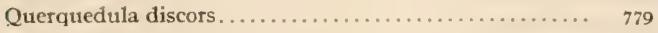

Rachycentridx........................... 754

Rachycentron canadus........................ 754

Raia diaphana.............................. ${ }_{73} 8$

Raia eglanteria .............................. 738

Raja eglanteria........................... ${ }_{73} 8$

Raja erinacea.......................... 737

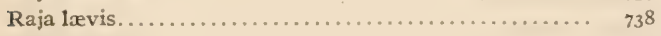

Raja ocellata.............................. 738

Raja radiata.............................. ${ }_{73} 8$

Rajidæ................................... 737

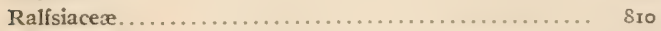

Ralisia clavata............................ 810

Ralfsia verrucosa .......................... 810

Ranclla caudaia ............................ $71_{3}$

Ralhkea octopunctata, var. grate................. ${ }_{563}$

Remora brachyptera....................... ;66

Remora remora.......................... 766

Rcmoropsis brachyptera..................... ${ }_{766}$

Reniera............................... $55^{8}$ tentaliniformis.

54

酒

Rhadinocladia cylindrica..... ............ $\varepsilon_{32}$

Rhadinocladia Farlowii...................... . . . . . . .

Rhamphostomella bilaminata................. 605

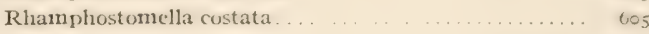

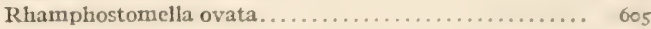

Rhermatedes tenuis..................... 571

Rhinebothrium cancellatum ............... . . $5 . \ldots$

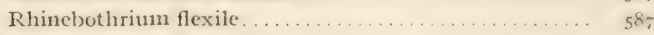

Rhinebothrium longicolle................... 587

Rhinebothrium minimum .................. $58 \mathrm{j}$

Rhinonemus cimbrius. . . . . . . . . . . . . . . . 770

Rhinoptera bonasus...................... 739

Rhinoptera quadribba....... .. ........... 723

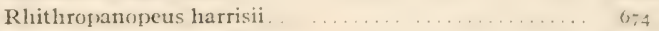

Rhizoclonium Keneri. ................... \&

Rhizoclonium riparium. .................... $\varepsilon_{2}$

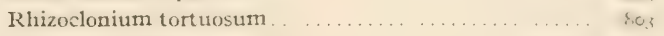

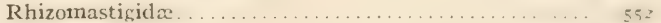

Rhizophyllidacex . . . . . . . . . . . . . . . $8 \geq 0$

Rhizopoda.......................... 5

Rhoda inermis.......................... $60_{33}$

Rhodine attenuata......................

Rhodochorton membrauaceum. ............. 818

Rhodochorton Rothii ................... 818

Rhododermis Georgii. .................... $8_{30}$

Rhodomelacex. ......................... 819

Rhodomelales.......................... $\delta_{19}$

Rhodomela Rochei...................... $\delta_{22}$

Rhodomela subiusca. . . . . . . . . . . . . . . . . $\delta_{22}$

Rhodomela virgata...................... $8_{23}$

Rhodophycex.......................... $\mathrm{SI}_{3}$

Rhodophyllidace $\ldots \ldots \ldots \ldots \ldots \ldots \ldots \ldots \ldots \ldots \ldots \ldots, \delta_{25}$

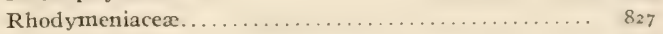

Rhodymeniales............................ 826

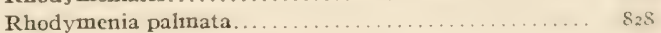

Rhombochirus osteochir ................... 7 tio

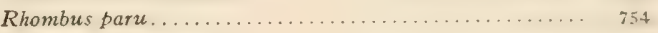

Rhombus triacanthus...................... 754

Rhopalonema typicum.................... 574

Rhopalonema velatum.......................... 574

Rhynchobolus americanus.................. 623

Rhynchobolus dibranchiatus.................... 623

Rhynchobothrium agile.................... ${ }_{587}$

Rhynchobothrium attenuatum. ................ 587

Rhynchobothrium bisulcatum . . . . . . . . . . . . . ${ }_{5} \&_{9}$

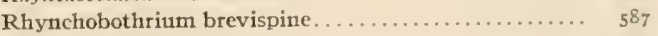

Rhynchobothrium bulbifer. ................. 587

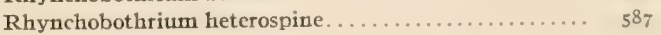

Rhynchobothrium hispidum. ................ 587

Rhynchobothrium imparispine. . . . . . . . . . . . 588

Rhynchobothrium lomentaceum............... ${ }_{5} 58$

Rhynchobothrium longicorne................ ${ }_{5}^{88}$

Rhynchobothrium longispine................. $\quad 588$

Rhynchobothrium speciosum................. 588

Rhynchobothrium tenuicolle ..................... ${ }_{5} \delta_{7}$

Rhynchobothrium tenuispine................. ${ }_{5} 88$

Rhynchobothrium tumidulum. . . . . . . . . . . . . 588

Rhynchobothrium wageneri................. 588

Rhynchops nigra. . . . . . . . . . . . . .

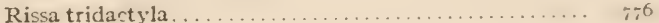

Rissoa aculcus.......................... $\quad 720$

Risson arenaria........................... $\quad 720$

Rissoa exarata .......................... 720

Rissed minuta........................... $i 20$

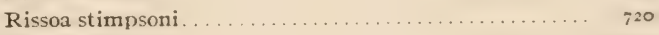

Rissoida.............................. $; 20$ 
Rivularia atra

Rivularia Biasolettiana.

Rivulariaceae.

Rivularia hospita.

Rivularia nitida

Rivularia plicata.

Rivularia polyotis.

Roccus lineatus.

Rochfortia planulata.

Rotalia beccarii.

Rotalidx.

Rypticus bistrispinus

Sabrlla microphthalmia.

Sabellaria vulgaris.

Sabellidæ.

Sabellides pusilla.

Sagartia leucolena.

Sagartia lucize.

Sagartia modesta.

Sagartiidx. .

Sagitta elegans.

Salmonidxe.

Salmo salar.

Salpa caboti.

Salpa caboti var. cyanea.

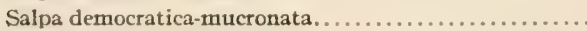

Salpa zonaris-cordiformis

Salpidæ.

Salvelinus fontinalis.

Sapphirina gemma.

Sarda pelomys.

Sarda sarda

Sargassum bacciferum.

Sargassum Filipendula.

Sargassum Filipendula var. subed

Sargassum zulgare

Sargus ovis.

Sarothrodus maculocinctus

Sarsia hargitti.

Sarsia tubulosa var. mirabilis

Sarsiella americana.

Sarsiella zostericola. . . . . . . . . . . . . . . . . . . . . . .

Saxicava arctica. .

Saxicavidæ.

Scala granlandica

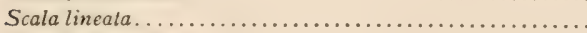

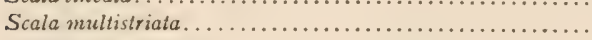

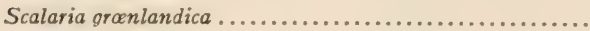

Scalaria lineata....

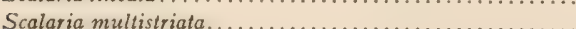

Scalibregma brevicauda...

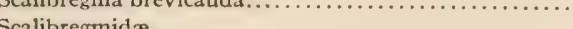

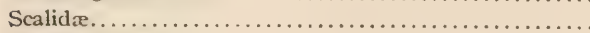

Scaphandridx.

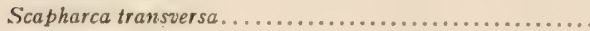

Scaphospora Kingii.

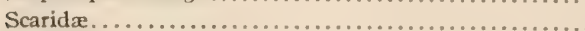

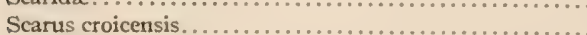

Scelide.

Schizopoda.

Schizoporella auriculata.

Schizoporella biaperta.

Schizoporella hyalina. .

Schizoporella unicornis

Schizotricha tenella

Sciænidae.

Sciænops ocellatus.

800

832

799

800

800

$8 \infty$

800

755

689

$55^{2}$

$55 \mathrm{t}$

756

630

634

630

628

577

577

577

577

595

743

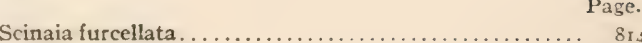

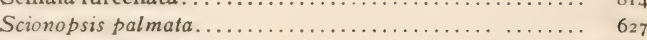

Scolecolepis cirrata............................. $6_{24}$

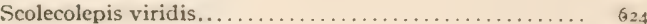

Scolex polymorphus......................... $s_{58}$

Scoloplos acutus ............................... $6_{23}$

Scoloplos fragilis.................................. $\sigma_{24}$

Scoloplos robustus............................ 624

Scomber colias................................ $\quad 749$

Scomber japonicus..............................

Scomber scombrus............................. $74^{9}$

Scomber vernalss................................

Scombercsox scutellatus......................... 745

Scomberomorus cavalla......................... 750

Scomberomorus maculatus..................... $\quad 750$

Scomberomorus regalis......................... $75^{\circ}$

Scombresocidæ............................... 745

Scombresox saurus............................ 745

Scombridæ.................................. ${ }_{748}$

Scorpæna grandicornis........................ $7_{76}$

Scorpæna plumieri............................ $7_{76}$

Scorpæidæ................................. $\quad 762$

Scruparia clavata............................. 598

Scrupocellaria scabra......................... 598

Scutellidx................................... $6 \mathrm{r}_{2}$

Scylløa edwardsii.............................. 704

Scyllæa pelagica............................. 70.4

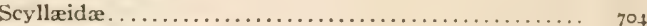

Scyphacella arenicola............................ $66 \mathrm{I}$

Scyphacidæ............................... $66 \mathrm{r}$

Scyphozoa................................... 575

Scytonemaceæ............................ $\quad 799$

Scytosiphon lomentarius...................... 807

Sebastes marinus............................ $77_{4}$

Seila terebralis............................ $7_{717}$

Seirospora Griffithsiana......................... 818

Selene argentea.............................. ${ }_{753}$

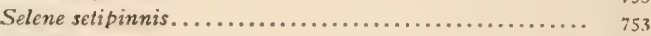

Selene vomer................................ 753

Semelidæ.................................... 696

Seriola dumerili.............................. $\quad 7_{751}$

Seriola lalandi................................ $75 \mathrm{I}$

Seriola zonata............................... ${ }_{751}$

Serpula dzanthus............................. $6_{3} \mathrm{I}$

Serpulidx................................ $6_{31}$

Serranidx................................ $\quad 755$

Serranus atrarius............................. $\quad{ }_{756}$

Sertularella abietina............................ $\quad{ }_{573}$

Sertularella gayi .............................. $\quad 573$

Sertularella polyzonias......................... $\quad{ }_{573}$

Sertularella tricuspidata......................... 573

Sertularia argentea.......................... ${ }_{572}$

Sertularia complexa........................... 572

Sertularia cornicina......................... ${ }_{572}$

Scriularia cupressina............................. 573

Sertularia gracilis........................... 572

Sertularia pumila ........................ $57^{2}$

Sertularia versluysi........................ 572

Sertulariiclx........................... 573

Scsarma recticulata............................ $6_{75}$

Sesarma reticulatum......................... 675

Sibbaldius borealis................................

Sigalionidæ............................. $6{ }_{18} 8$

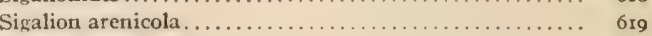

Siliqua costata............................ 695

Siluridæ................................. $7_{740}$

Sipho islandicus...... $\quad \ldots \ldots \ldots \ldots \ldots \ldots \ldots .70 \%$

Sipho pygmaus............................. . ; 
Sipho stimpsoni.

Siphonales.

Siphonocctes cuspidatus.

Siphonœcetes smithianus.

Siphonorbis pygaxxus

Siphostoma fuscum.

Sipunculida.

Sipunculidxe. .

Skenea planorbis.

Slabberia strangulata.

Smittia porifera.

Smittia trispinosa

Smittia trispinosa nitida

Solariella obscura

Solaster endeca.

Solasterid $x$.

Solecurtus divisus.

Solecurius gibbus.

Soleidx.

Solemya borealis

Solemya velum.

Solen ensis.

Solcnida. .

Solcnomya borealis.

Solenomya velum.

Solenomyida.

Somateria dresseri

Somateria mollissima borealis.

Somateria spectabilis.

Sorocarpus uvaformis

Sparida.

Sparisoma flavescens.

Spatula clypeata

Spermothamnion Turneri

Sphacelariacere.

Sphacelaria cirrhosa.

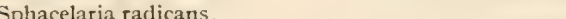

Spharifer lintoni.

Sphærococcaceæ.

Spharoma quadridentatum.

Sphæromidx

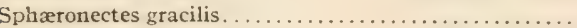

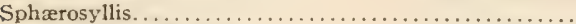

Spharozyga Carmichaelii. .

Spheroides maculatus.

Spheroides spengleri.

Spheroides trichocephalus. . . . . . . . . . . . . . .

Sphyræena barracuda.

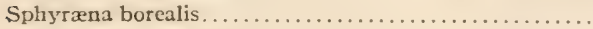

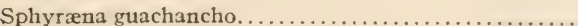

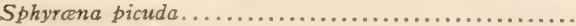

Sphyrna zygæna

Spiochætopterus oculatus.

Spionidz.

Spio robuste.$\cdots$

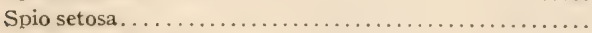

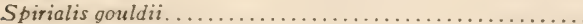

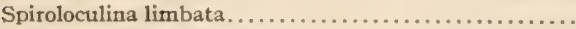

Spirontocaris grcenlandica.

Spirontocaris liljeborgii.

Spirontocaris pusiola.

Spiroptera pectinifer

Spirorbis borealis.

Spirorbis fewkesii.
Page. 70.9

304

655

655

$70 \mathrm{~B}$

635

535

721

560

\section{Spirorbis lucidus.}

Sirurbis porrecta.

Spirorbis quadrangularis

Spirorbis spirillum .

ipirorbis spirorbis

Spirorbis stimpsoni

isirorbis tubeformis.

Spirula frayilis.

Spirula peronii

Spirulidx.

Spirulina Meneghiniana.

Spirulina subsalsa.

Spirulina tinuissima.

Spisula solidissima. . .

Spongia sulphurea.

Spongiobothrium variabile.

Sporozoa .

Spyridia filamentosa

Squalid $x$.

Srutualus acant!1ias

Squalus americunus.

quamariacex

Siruatina dumerili.

Squatina squatina.

Squatinidx

Squilia empusa

Staurophura laciniata.

Staurophora mertensii.

Staurostoma laciniata.

Steenstrupia aurata.

Steenstrupia virgulata.

Steganopus tricolor

Stegocephalida

Stegocephalus inflatus

Page.

0.33

633

6,33

633

1) 32

633

632

727

727

727

832

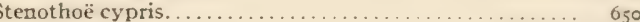

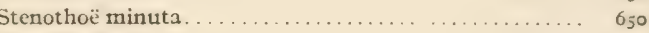

Stenothoidæ....................... 650

Stenotomus argyrops....................... 757

Stenotomus chrysops....................... 757

Stenotomus gardeni........................ 757

Stenotomus zersicolor...................... 757

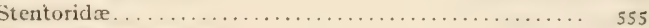

Stephanolepsis sctifer ..................... 761

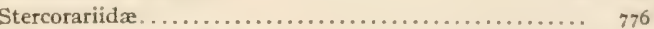

Stercorarius longicaudus.................... $7 ; 6$

Stercorarius parasiticus. . . . . . . . . . . . . . . . . . 776

Stercorarius pomarinus.................. 70

Stereoderma unisemita............................... $6 \mathrm{r}_{4}$

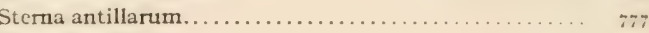

Sterna caspia............................

Sterna dougalli. .......................... 777

Sterna fuscata . . . . . . . . . . . . . . .

Sterna hirundo........................... 777

Sterna maxima. ........................ $; \% 7$

Sterna paradisea ........................... 777

Stema sandvicensis acuflavida............... 777

Sternaspidx. . . . . . . . . . . . . . . . . . . . . . . . 630

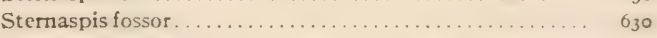

Sternaspis scutata......................... 630

Sterrocolax decipiens. ...................... 825

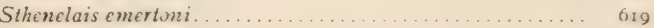

Sthenelais gracilis. . . . . . . . . . . . . . . . . . . . . 619

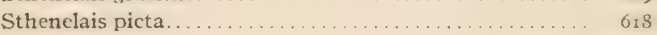

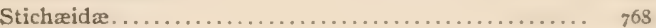

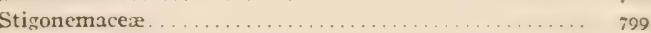

Stilifer stimpsoni. . . . . . . . . . . . . . . . . . . 75 
Stilophoracex

Stilophora rhizodes.

Stolephorus argyrophanus.

Stole phorus broacnii . . .

Stole phorus mitchilli.

Stomatopoda

Stomatopora diastoporoides.

Stomobrachium tentaculatum . .

Stomotoca apicata

Stomotica direme.

Stomotoca rugosa

Streblonema Chordaria.....

Streblonema oligosporum.

Streblonema parasiticum.

Striaria attenuata.

Striariaceze

Stromatcidie.

Stromatcus iriacanthus

Strombidium caudatum

Strongylocentrotidx

Strongylocentrotus droebachiensis.

Styela partita.

Stylact is hooperi

Stylifer Stimpsoni.

Styliola vitrea

Stylochopsis littoralis.

Stylochus zebra...

Suberites compacta

Suberitidx.

Suctoria

Sula bassana.

Sulidx.

Sunamphitoë pelagica

Syconidx.

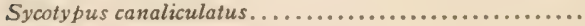

Syllidx.

Syllides setosa

Sy!lides verrilli

Syllis pallida

Sympetrum

Sympleustes glaber.

Sympleustes latipes.

Synafta inharcns...

Synapta roseola.

Synapticlx.

Synbothrium filicolle.

Syncolidium pellucidum.

Syncoryne mirabilis.

Syncoryne producta.

Syndesmobothrium filicolle.

Synguathidx.

Syngnathus fuscus.

Syngnalhus peckianus.

Synodontidx

Synoicidx.

,

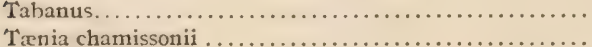

Trenia dilatata..

Tæniosomidx.

Tagclus divisus.

Tagelus gibbus. .

Talorchestia longicomis.

Tanaicla.

Tanais cavolinii . .

Tanais filum.

Tanats viltalus...

Pafe. sio

743

742
Page.

Tnystylum orbiculare............................ $66_{77}$

Tarpon atlanticus.................................

Tautoga onitis ............................ 760

Tautogolabrus adspersus...................... $\quad 759$

Tealia crassicornis........................... 577

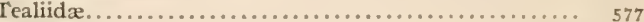

Tectura alveus................................ ${ }_{727}$

Tcctura testudinalis........................... ${ }_{727}$

Tedania...................................... ${ }_{55} 8$

Tellamia contorta............................. 802

Tellimiya elevata............................... $6 \mathrm{Sg}$

Tellimy a ferruginosa............................ $68_{\mathrm{s}}$

Tellina tenella................................. 694

Tellina tenera.................................. 697

Tellina tenta................................... $6_{095}$

Tellinidx.................................. 694

Temnodon sallator................................. ${ }_{753}$

Temora longicornis........................... 63

Terebellidæ.................................. 620

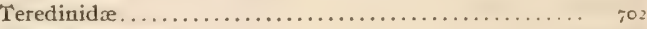

Teredo megotara.............................. $7^{02}$

Teredo navalis..................................

Teredo thomsoni................................ ;0z

Tergipes despectus............................ 70

Testudinidx.................................. $\quad 775$

Tetanocera................................. $6{ }^{n} 6$

Tethya gravata................................. ${ }_{55} 8$

Tethya gravida.............................. $55_{58}$

Tethyidx................................. ${ }_{558}$

Tethys willcoxi............................. 704

Tetradidemnum albidum......................... ${ }_{73}$ I

Tetraglene agilis.............................. 6 615 $_{5}$

Tetragonuridæ............................. $\quad 755$

Tetragonurus cuvieri........................... $\quad 755$

Tetraodon geomtricus.............................. $7_{763}$

Tetraodon trichocephalus......................... $\quad 7_{63}$

Tetraodontidx............................. $\quad 7_{62}$

Tetrapterus albidus........................... $\quad 750$

Tetrapterus imperator......................... $\quad 750$

Tetrarhynchus bicolor........................ ${ }_{589}$

Tetrarhynchus bisulcatus......................... ${ }_{5}^{589}$

Tetrarhynchus elongatus. . . . . . . . . . . . . . . . . . 559

Tetrathynchus erinaceus............................ ${ }_{589}$

Tetrarhynchus lintoni......................... $\quad 5^{89}$

Tetrarhynchus robustus. ......................... ${ }_{589}$

Tetrarhynchus tenue........................... ${ }_{589}$

Tetrastemma candidum........................ 592

Tetrastemma dorsale......................... 592

Tetrastemma elegans......................... 592

Tetrastemma vermiculus....................... 592

Tetrastemma vittatum........................ 592

Tetrastemmatidx............................. ${ }_{592}$

Tetrodon larigatus............................ $\quad 762$

Tetrodon turgidus............................... $\quad 762$

Tetronarce occidentalis........................ $\quad 739$

Teuthididx............................... $7_{76}$

Teuthis bahianus............................ $76 x$

Teuthis cæruleus.............................. $76 \mathrm{r}$

Teuthis hepatus........................... $76 \mathrm{x}$

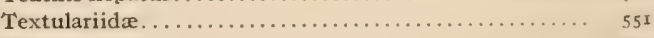

Thais lapillus............................... $77_{4}$

Thalassochelys caretta......................... 7774

Thalestridx.................................. $\sigma_{39}$

Thalestris gibba...................................

Thallophyta................................ $\quad 797$

Thamnocnidia tenella......................... $\quad 566$

Thaumantiidæ........................... 567

Thelepus cincinnatus....................... 627 
Thracia conradi.

Page.

Thracia septentrionalis . . .

Thracia truncata.

Thraciida.

Thuiaria argentea.

Thuiaria cupressina..

Thuiaria tluuja.

Thunnus thynnus

Thyasira gouldii.

Thyasira trisinuata.

Thyone briareus

Thyone fusus.

Thyone scabra

Thyone unisemita

Thyropus.

Thysanocephalum crispum

Thysanocephalum ridiculum.

Thysanoëssa incrmis.

Thysanopoda inermis.

Thysanopoda norvegica.

Tiarida.

Tiarina fusus. . . . .

Tiaropsis diademata.

Tilopteridaceæ.

Tima formosa.

Tintinnidæ.

Tintinnopsis beroidea compressa.

Tintinnopsis beroidea plagiostoma

Tintinnopsis davidoffi.

Tintinnus.

Tomopteridæ.

helgolandica.....

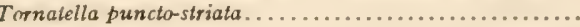

Tornatina canaliculata.

Tornatinidx

Torpedo occidentalis.

Tortanus bumpusii. .

Tortanus discaudata.

Tottenia gemma.

Tottenia manhattensis.

Trachelinidæ. .

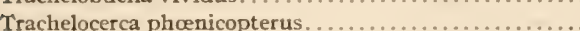

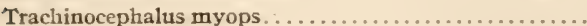

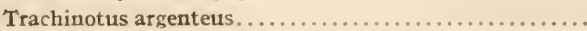

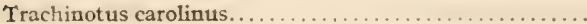

Trachinotus falcatus.

Trachinotus goodei.

Trachinotus ovatus.

Trachurops crumenophthalmus.

Trachurus trachurus.

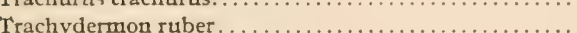

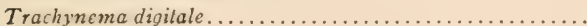

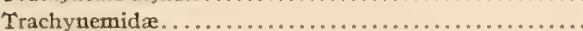

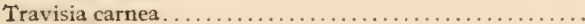

Trebius tenuifurcatus.

Trematoda.

Trentepohlia daviesii.

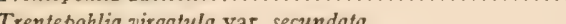

Trichiurida

Trichiurus lepturus

Trichophrya salparum.

Trichosphærium sieboldi.

Triforidae.

Triforis nigrocinctus.

Triglidx.

Trigonoporus folium.

Trigonostomum matki.
Trilocularia gracilis. . . . . . .

Tristomum coccineum ........................ $5 . \ldots$

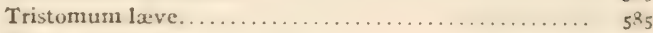

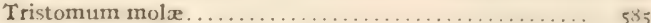

Tristomum papillosum...................... $5 . \ldots \ldots$

Tristomum rudolphianum ......................

Tritia trivittata ......................... 7

Triticellidx................... 607

Tritonof usus curtus. . . . . . . . . . . . . . . . . . 703

Tritonofusus islandicus . . . . . . . . . . . . . . . . .

Tritonolusus stimpsoni . . . . . . . . . . . . . . . .

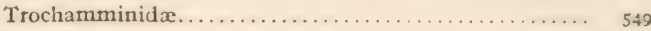

Trochidx..............................

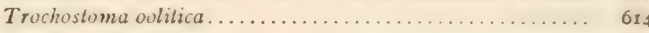

Trophonia affinis. . . . . . . . . . . . . . $630 \ldots \ldots \ldots$

Tropisternus glaber................................. 676

Tropisternus nimbatus...................... 676

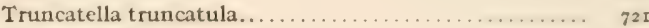

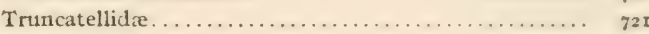

Truncatulina lobatula . . . . . . . . . . . . . . . .

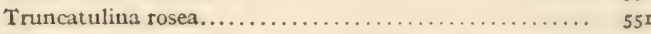

Trygon cenlrura.............................. 739

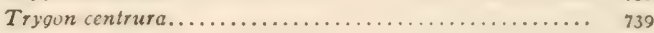

Trypanosyllis.................................. 6rs

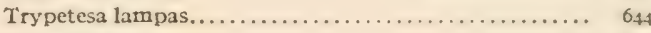

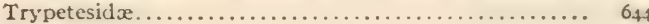

Tryphosa pinguis............................. 649

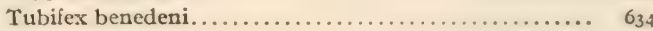

Tubifex hamatus........................... 634

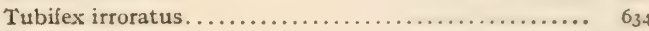

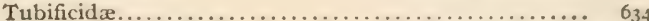

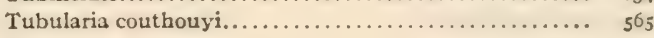

Tubularia crocea.......................... 566

Tubularia laryux........................ 566

Tubularia parasitica..................... $56 \%$

Tubularia spectabilis....................... 566

Tubularia tenella......................... 566

Tubulariidx............................ 565

Tubulipora atlantica.......................... 597

Tubulipora flabellaris........................ 597

Tubulipora liliacea........................... 597

Tubuliporidx............................ 597

Tucca corpulentus......................... 6.40

Tucca impressus........................... 6.40

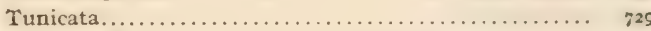

Turbellaria. .............................. 579

Turbonilla xqualis........................ 715

Turbonilla areolata......................... 715

Turbonilla buteonis.......................... 716

Turbonilla costulata....................... 716

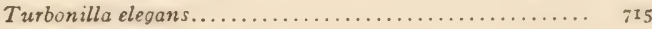

Turbonilla elegantula ...................... 715

Turbonilla equalis............................. 715

Turbonilla interrupta........................ 715

Turbonilla mighelsi....................... $;$ it

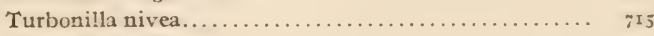

Turbonilla rathbuni....................... $; 16$

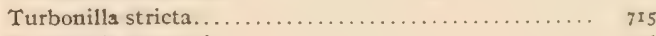

Turbonilla sumneri....................... $; 16$

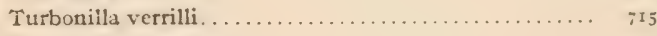

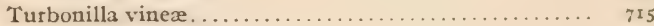

Turbonilla winkleyi. . . . . . . . . . . . . . . . .

Turbonilla winkleyi senilis.................... $7_{116}$

Turris episcopalis................................. 562

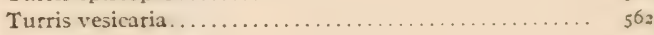

Turritella intermpta....................... 75

Turritidx................................

Turritopsis uutricula....................... 56 z 
Tylocephalum pingue........... Page.

Tylosurus acus

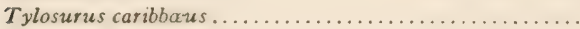

Tylosurus marinus.

Uca minax .

Uca pugilator.

Uca pugnax

Ulmaridax

Ulothrix flacca

Ulothrix implexa

Ulotrichaceæ

Ulotrichales

Ulvacex.

Ulva Lactuca

Ulva Lactuca var, latissima.

Ulva Lactuca var. rigida. . .

Ulvaria subbifurcata.

Unciola irrorata

Upogebia affinis

Uria lomvia.

Urochorda. . . . . .

Uronema marina.

Uronychia setigera.....

Uronychia transfuga . .

Urophycis chuss. ...............................

Urophycis regius. . . . . . . . . . . . . . . . . . . . . . . . .

Urophycis tenuis. . . . . . . . . . . . . . . . . . . . . . . .

Urosalpinx cincrea.

Urosalpinx cinereus

Urospora penicilliformis

Urothoë.

Utriculus canaliculatus

Vaginarieæ.

Valkeria uva.

Vaucheriacex

Vaucheria litorea

Vaucheria piloboloides

Vaucheria Thurctii.

Velella mutica.

Velellidx.

Velutin halioidea......................................

Velutina zonata.................................

Venericardia borealis.

Venericardia borealis nov-anglia.
Page.

Veneridæ................................. $69 z$

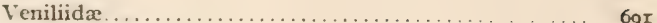

Venus mercenaria ............................. $6_{92}$

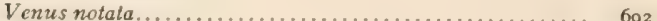

Vermetidx.............................. 718

Vermetus radicula............................ 718

Vermicularia spirata......................... $\eta_{118}$

Verneuilina polystropha....................... ${ }_{55}$

Vesicularia armata........................... 607

Vesicularia cuscata .............................. 606

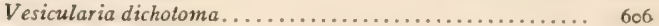

Vesicularia familiaris........................... 606

Vesiculatia gracilis................................. 606

Vesiculariidx............................... 606

Vibilia viatrix................................. $6_{47}$

Vibiliidæ................................. 647

Virbius zostcricola............................ 664

Vomer curtus................................ $\quad 753$

Vomer setipinnis.............................. 753

Vorticella marina............................ 555

Vorticella patellina........................... ${ }_{555}$

Vorticellidæ...................................... 555

Webbina hemispherica....................... 549

Willia ornata............................. $56_{3}$

Woodsholia lilliei ............................ $5_{8}^{8 \mathrm{I}}$

Xanthidæ................................... $6_{73}$

Xestolebris depressa........................... $6_{36}$

Xiphias gladius............................. 751

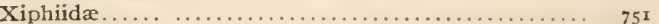

Xiphosura ...................................... $66_{7} 6$

Yoldia limatula................................ 686

Yoldia myalis................................. 686

Yoldia sapotilla ................................. 686

Yoldia thraciæformis......................... 68

Zanclea cladophora............................. ${ }_{565}$

Zanclea gemmosa............................... ${ }_{565}$

Zirphæa crispata........................... ;OI

Zoanthidæx.................................. $\quad 576$

Zoarces anguillaris......................... ${ }_{768}$

Zoarcidx............................................ 78

Zoomastigophora........................... 552

Zoothamnium elegans......................... 555

Zostera marina................................ $8_{31}$

Zygcana malleus.................................. ${ }_{736}$

Zygeupolia rubens............................ 590

Zygodactyla gronlandica..................... 571

Zygonemertes virescens....................... 591 







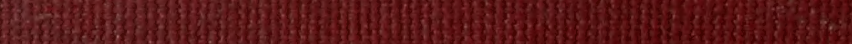

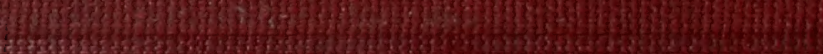

-

1030

(3)

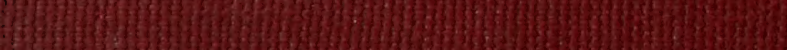

Q

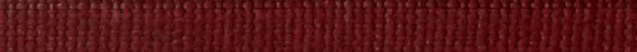

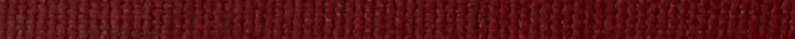

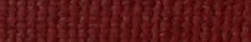

32.

16.

13)

Wing 